UNIVERSIDADE DE SÃO PAULO

FACUDADE DE FILOSOFIA, LETRAS E CIÊNCIAS HUMANAS DEPARTAMENTO DE LETRAS MODERNAS

PROGRAMA DE PÓS-GRADUAÇÃO EM ESTUDOS LINGUÍSTICOS, LITERÁRIOS E TRADUTOLÓGICOS DO FRANCÊS

PRISCILA AGUIAR MELÃO

O gênero textual anúncio publicitário no ensino do FLE: o desenvolvimento da capacidade discursiva "argumentar" por meio de recursos verbais e visuais

VERSÃO CORRIGIDA 


\title{
O gênero textual anúncio publicitário no ensino do FLE: o desenvolvimento da capacidade discursiva "argumentar" por meio de recursos verbais e visuais
}

\author{
Dissertação apresentada ao \\ Programa de Pós-Graduação em Estudos \\ Linguísticos, Literários e Tradutológicos \\ em Francês do Departamento de Letras \\ Modernas da Faculdade de Filosofia, Letras \\ e Ciências Humanas da Universidade de \\ São Paulo, para a obtenção do título de \\ Mestre em Letras, Língua e Literatura \\ Francesa. \\ Orientador: Profa. Dra. Eliane Gouvêa \\ Lousada
}

Aprovada em:

Banca Examinadora

Prof. Dr. Instituição:

Julgamento: Assinatura:

Prof. Dr. Instituição:

Julgamento: Assinatura:

Prof. Dr. Instituição:

Julgamento: Assinatura:

\section{VERSÃO CORRIGIDA}

São Paulo 
Aos meus pais, Pedro Melão Filho e Maria Graciete Aguiar Melão, pelo amor incondicional e pela vitória ao conseguir educar os seus três filhos. Não tiveram a oportunidade aos estudos e, entretanto, priorizaram a nossa educação. Agradeço à minha mãe, também, pelo bom-humor diário, pelas risadas contagiantes em todos os momentos da vida, por sua força e por estar sempre ao meu lado. Ao meu pai, pelo caráter, pelas madrugadas de trabalho, por estar ao meu lado para me ouvir e me aconselhar, sempre com amor. 


\section{Agradecimentos}

À Profa. Dra. Eliane Gouvêa Lousada, pela orientação e dedicação. Agradeço por estar no meu caminho, por ser disponível e por acreditar em mim. Muito obrigada pela amizade, paciência, pelos puxões de orelha e por sempre me orientar com amor. Sou o que sempre desejei e posso afirmar que hoje sou melhor, como pessoa e como profissional, por ter o seu exemplo e ouvir os seus conselhos.

Ao CNPq (Conselho Nacional de Pesquisa e Desenvolvimento Científico e Tecnológico), pelo apoio financeiro que possibilitou esta pesquisa.

À Profa. Dra. Cristina Moerbeck Casadei Pietraróia, não só pelas importantes sugestões no exame de qualificação, mas por participar da minha formação, na Graduação e na Pós-Graduação, sempre feliz e dedicada.

À Profa. Dra. Anise D’Orange Ferreira pelas preciosas contribuições no exame de qualificação.

À minha grande amiga, Natália Appezzato Pinazza, minha sincera gratidão. Sua companhia desde a Graduação foi especial, pois você sempre me incentivou, não só no caminho pessoal, mas, sobretudo, no caminho da academia. Sua sabedoria e dedicação são inspiradoras. Agradeço por participar da minha vida.

Às minhas amigas Suélen Maria Rocha e Luiza Guimarães Santos pela cumplicidade na vida acadêmica e pessoal. É muito bom saber que existe amizade na academia e, sobretudo, trabalho em conjunto. A minha conquista é, também, de vocês.

Ao Prof. Dr. Paulo Massaro e à Profa. Dra. Eliane Gouvêa Lousada por acreditarem em mim durante a entrevista dos Cursos Extracurriculares de Francês da FFLCH. Passar por um processo seletivo tão importante, ao chegar de um intercâmbio, significa ter sido acolhida e receber as boas-vindas ao país natal.

Aos colegas dos grupos de estudos ALTER-AGE e FLEPE pelas reflexões, pelo aprendizado e pela contribuição acadêmica. Em especial aos colegas: Luzia Bueno, Juliana Bacan Zani, Renata Correa Rocha, Luciano Tocaia, Thiago Jorge Santos, Mariana Casemiro Barioni, Renata Añez, Emily Silva, Marcos da Costa Menezes, Simone Dantas, Ana Paula Silva, Jéssica Lima, Jaci Brasil, Flávia Fazion, Lygia Rachel Torelli.

Ao meu marido, Vinícius, a quem amo e com quem rio, choro, brigo e faço planos. Agradeço por me acompanhar desde a Graduação, por me fazer atravessar a fronteira com os seus sonhos. Orgulho-me de sua bravura, desde a infância, e de sua perseverança nos últimos anos. Você é o meu exemplo de coragem e obstinação.

Aos meus irmãos mais velhos, por torcerem pela irmã caçula e pelo amor incondicional. À minha irmã, Rita, especialmente pela cumplicidade, amizade, pelo incentivo nos últimos anos, pelo carinho e por nos dar o melhor presente: Malu. Ao meu 
irmão, Dimas, especialmente pela companhia e pelas brincadeiras da infância, também, pelos ensinamentos em exatas, na fase do vestibular, na qual a minha ansiedade era também a sua. Sua sabedoria é inspiradora.

À minha avó, Gumercinda de Jesus, com amor, pelo exemplo de coragem ao desbravar os mares e ao lutar para manter a sua família.

À família Abreu, pelos finais de semana familiares, fartos e divertidos. Em especial, à minha sogra, Veronilda, por acreditar em mim, sempre me incentivando e me apoiando nos estudos. E, também, ao Eduardo Henrique, pela convivência familiar e pelas mensagens de texto incentivadoras.

A meus educadores, em especial, às professoras que foram exemplo na minha vida escolar e que me inspiraram nesta viagem dentro da educação. À profa. Valéria, pelo ensino fundamental e à profa. Flora, pelo ensino médio.

À Maria Helena, prima querida, que alegrava as minhas férias escolares ao presentear-nos, aos meus irmãos e a mim, com caixas de livros. Agradeço por me incentivar e por me mostrar o meio editorial.

À Cida, muito querida, agradeço pelos chocolates que adoçaram a minha infância e pela paciência ao me ensinar matemática. Você muito contribuiu para a minha formação.

Aos amigos da república Terebi, pelo convívio, pelos desabafos, pela escala da limpeza e, sobretudo, pela amizade: Samara, Filipe, Jaqueline, Raquel, Aline, Marcela, Brunela, Cris e Miku.

Aos amigos que, em algum momento, tiveram presença na minha vida nos últimos anos. Àqueles que me incentivaram, ajudaram-me ou, simplesmente, ouviramme. Em especial, ao grupo Mônica, Néia e Alê, pela companhia e pelas risadas. Vocês fizeram deste período mais leve. Também agradeço ao grupo Thaís, Fernando, Miguel e Luli, pela diversão e pelos desabafos, mas, principalmente, pelo Miguel, motivo de espairecimento e carinho. Ele alegrou grande parte deste percurso. Ao Demetriu e ao Roger, que fizeram do meu caminhar mais tranquilo através das conversas, viagens, risadas e, sobretudo, através da motivação. Ao grupo do Sanfra: Siomara Molina, Fabiana Machado, Jussara Goes, Rosana Longrova e Patrícia Dib, pelo interesse no meu trabalho, pela prática pedagógica compartilhada e pelo apoio na reta final.

Aos colegas de faculdade, por tornarem mais fácil e divertida esta caminhada universitária: Melina, Sandra, Fernanda, Mário, Colega, Rogério, Lilian.

Aos meus ex-alunos, aos meus alunos atuais e aos meus futuros alunos, vocês são a inspiração e o motivo para o meu desenvolvimento acadêmico.

A Deus, pois sem o seu iluminar, não haveria sabedoria emocional, e sem a minha fé, não haveria conquista. 
"Na vida superior a teoria e a prática completam-se. Foram feitas uma para a outra." (Fernando Pessoa) 


\section{RESUMO}

Esta dissertação, que se insere na linha Estudos linguísticos e didáticos, tem por objetivo estudar o ensino-aprendizagem de língua estrangeira através da elaboração de uma sequência didática e da produção de textos pertencentes ao gênero textual anúncio publicitário por alunos de FLE. Para tanto, visamos a apresentar a análise desse gênero textual e suas contribuições para as práticas de ensino de língua estrangeira e, sobretudo, buscamos colaborar para as reflexões sobre o desenvolvimento das capacidades de linguagem dos alunos na aprendizagem de FLE através de gêneros textuais. Porém, pretendemos dar especial atenção ao desenvolvimento da capacidade de argumentar, por meio de textos verbais e visuais, característicos do anúncio publicitário. Para isso, apoiamo-nos no quadro teórico-metodológico do interacionismo sociodiscursivo (ISD), tal como é apresentado por Bronckart (1999, 2003, 2006, 2008), no que se refere à compreensão do agir humano através da atividade de linguagem. Servimo-nos também do modelo de análise de textos do ISD destinado, principalmente, ao estudo de textos verbais e das propostas para o ensino de línguas por meio dos gêneros textuais (SCHNEUWLY; DOLZ, 2004). Inspiramo-nos, também, na união das categorias da Gramática do Design Visual (GDV), desenvolvida por Kress e Van Leeuwen (2006), para nos auxiliar na análise de textos não verbais, à perspectiva do ISD, assim como foi proposta por Leal (2011). Essa união das teorias possibilita a análise dos gêneros textuais multimodais como os anúncios publicitários, pois, esse gênero combina textos verbais e não verbais. Baseamo-nos, ainda, em outros teóricos do ISD para a elaboração do material didático através da noção de gênero textual (SCHNEUWLY; DOLZ, 2004; CRISTOVÃO, 2005; MACHADO, 2005; DIONÍSIO, 2005; LOUSADA, 2005) e para analisar o desenvolvimento das capacidades relacionadas ao "argumentar" (PLANTIN, 2008; KOCH, 2004). Dessa forma, construímos o modelo didático do gênero textual anúncio publicitário, elaboramos uma sequência didática e a aplicamos, de modo a coletarmos as produções textuais iniciais e finais dos alunos de FLE. Posteriormente, analisamos as produções através do modelo de análise proposto neste estudo, observando a apropriação do gênero textual anúncio publicitário pelos alunos e, portanto, sua aprendizagem no que diz respeito aos efeitos argumentativos produzidos pela combinação do texto verbal e visual. Os resultados 
desta dissertação apresentam o gênero textual como megainstrumento (SCHNEUWLY; DOLZ, 2004), visto que ele contribui para o desenvolvimento das capacidades de linguagem dos alunos em língua estrangeira e, sobretudo, da capacidade que permite ao aluno argumentar, valendo-se de elementos verbais e visuais, ou seja, agir socialmente por meio da linguagem. 


\section{RESUMÉ}

Ce mémoire, qui s'insère dans la ligne de recherce Etudes linguistiques et didactiques, vise à étudier l'enseignement-apprentissage des langues étrangères à travers l'élaboration d'une séquence didactique et la production de textes appartenant au genre textuel «publicité » par les étudiants de FLE. À cette fin, nous souhaitons présenter l'analyse de ce genre textuel et ses contributions aux pratiques d'enseignement de langue étrangère et, surtout, nous visons à contribuer aux discussions sur le développement des capacités langagières des élèves dans l'apprentissage du FLE par les genres textuels. Cependant, nous cherchons à nous concentrer sur le développement des capacités discursives liées à l'argumentation à travers les textes verbaux et visuels, qui sont des caractéristiques du genre textuel «publicité ». Pour cela, nous nous appuyons sur le cadre théorique et méthodologique de l'interactionnisme socio-discursif (ISD), comme le propose Bronckart (1999, 2003, 2006 , 2008), en ce qui concerne la compréhension de l'agir humain à travers l'activité langagière. Nous nous servons aussi du modèle d'analyse de textes de l'ISD destiné, principalement, aux études des textes verbaux et aux propositions pour l'enseignement de langues à travers les genres textuels (SCHNEUWLY; DOLZ, 2004). Nous nous inspirons également de l'union des catégories de la Grammaire du Design Visuel (GDV), développées par Kress et Van Leeuwen (2006), pour nous aider à l'analyse des textes non verbaux et du cadre théorique et méthodologique de l'ISD, comme il a été proposé par Leal (2011). Cette union des théories permet l'analyse des genres textuels multimodaux comme les publicités, car ce genre combine les textes verbaux et les textes non verbaux. Nous comptons également sur d'autres théoriciens de l'ISD pour l'élaboration du matériel didactique à travers la notion de genre textuel (SCHNEUWLY; DOLZ , 2004; CRISTOVÃO, 2005; MACHADO, 2005; DIONÍSIO, 2005; LOUSADA, 2005 ; et d'autres) et pour analyser le développement des capacités liées à l'argumentation (PLANTIN , 2008; KOCH , 2004) . De cette manière, nous avons construit le modèle didactique du genre textuel publicité, nous avons élaboré une séquence didactique et nous l'avons appliquée, afin de recueillir les productions textuelles initiales et finales des étudiants de FLE. Par la suite, nous avons analysé les productions à travers le modèle d'analyse proposé dans cette étude, en observant l'appropriation du genre 
textuel publicité par les élèves et leur apprentissage en ce qui concerne les effets argumentatifs produits par la combinaison du texte verbal et visuel. Les résultats de ce mémoire montrent le genre textuel comme un instrument (SCHNEUWLY; DOLZ , 2004), car il contribue au développement des capacités langagières des élèves en langue étrangère et, surtout, de la capacité qui permet à l'élève d'argumenter, en se servant des éléments verbaux et visuels, c'est-à-dire, en agissant socialement à travers le langage. 


\begin{abstract}
This thesis, which belongs to the research project linguistic and didactic studies, aims to study the teaching and learning of foreign language through the development of a didactic sequence and production of texts belonging to the textual genre advertisement by FLE students. In order to achieve this goal, we aim to present the analysis of this textual genre and its contributions to the practices of foreign language teaching and, above all, we seek to contribute to the discussions on the development of students' language capacities when learning FLE through textual genres. However, we intend to focus in particular on the development of the capacities to argue, through verbal and visual texts, which are characteristic of the advertisement texts. In order to do so, we rely on the theoretical and methodological framework of socio-discursive interactionism (SDI), as shown by Bronckart (1999, 2003, 2006, 2008), regarding the understanding of human activity through language activity. Moreover, we employ the model of text analysis of the SDI intend, primarily to the study of verbal texts and proposals for teaching languages through text genres (SCHNEUWLY; DOLZ, 2004). Furthermore, we are inspired by the union of the categories of Grammar of Visual Design (GVD), developed by Kress and Van Leeuwen (2006), to assist in the analysis of non-verbal texts, in the prospective of SDI, as proposed by Leal (2011). This union of theories enables the analysis of multimodal textual genre as advertisements, because this genre combines verbal and nonverbal texts. We also rely on other SDI theorists for the preparation of didactic material through the notion of genre (SCHNEUWLY; DOLZ , 2004; CRISTOVÃO , 2005; MACHADO, 2005; DIONÍSIO, 2005; LOUSADA, 2005) and to analyze the development of capacities related to " argue " (PLANTIN , 2008; $\mathrm{KOCH}, 2004)$. Thus, we built the didactic model of the textual genre advertisement, we developed a didactic sequence and then applied it in order to collect the initial and final textual productions by FLE students. Subsequently, we analyzed the productions within the framework proposed in this study, observing the appropriation of the textual genre advertisement by students and, therefore, their learning in terms of argumentative effects produced by the combination of verbal and visual texts. The outcomes of this thesis show the genre as a mega instrument (SCHNEUWLY; DOLZ , 2004), since it contributes to the development of student's language capacities in a foreign language
\end{abstract}


and, above all, student's ability to argue, using verbal and visual aspects and acting in the social world through language. 


\section{Sumário}

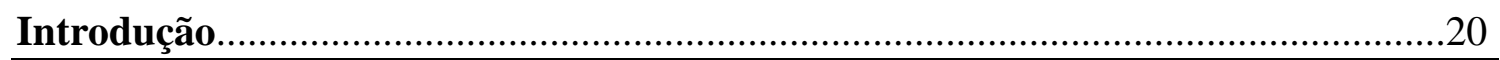

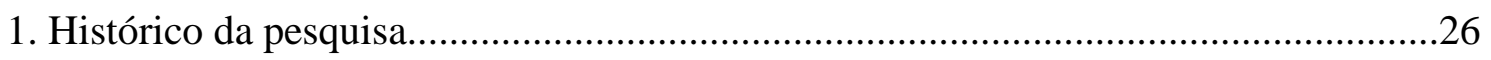

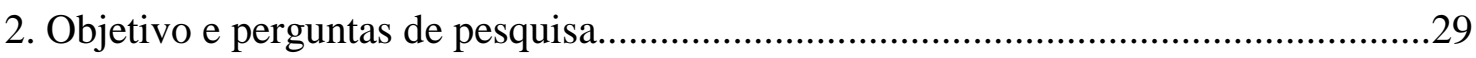

Capítulo I - Fundamentação Teórica.......................................................................................32

1. Interacionismo social e interacionismo sociodiscursivo...........................................33

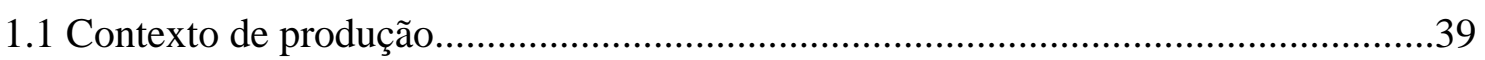

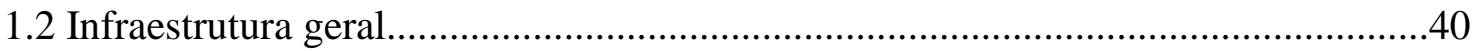

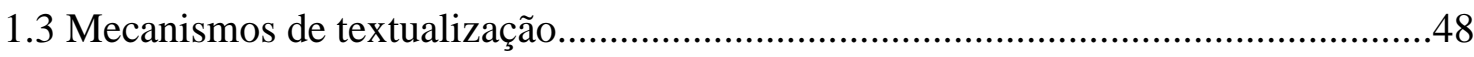

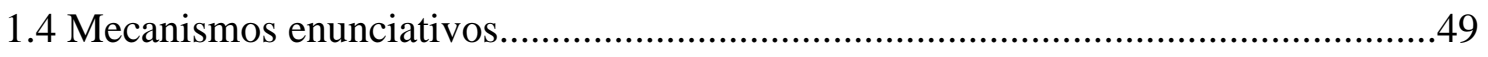

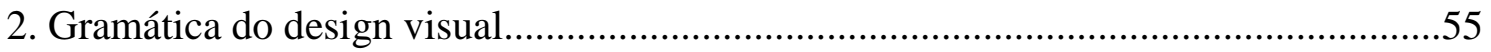

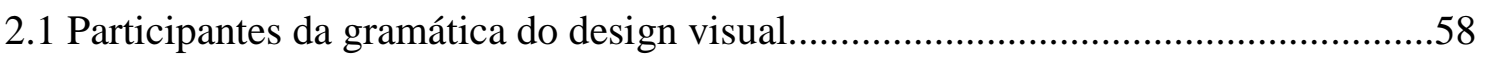

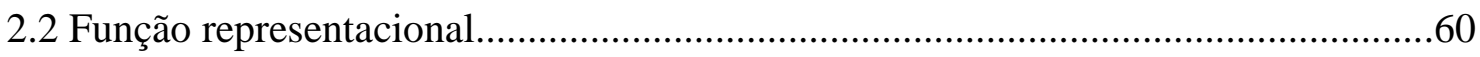

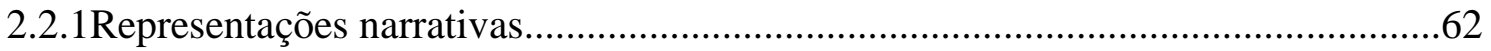

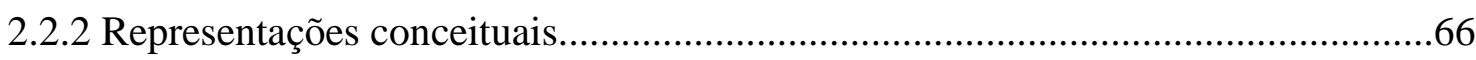

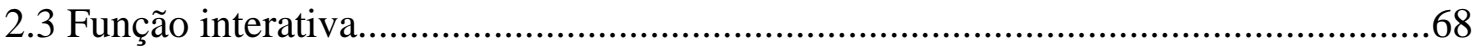

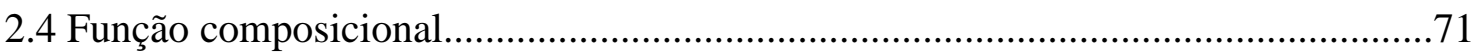

3. União do Interacionismo sociodiscursivo e da Gramática do design visual...............75

3.1 Contexto de produção, de recepção e conteúdo temático..........................................75

3.2 Arquitetura interna dos textos multimodais....................................................... 77

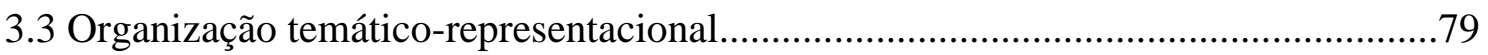

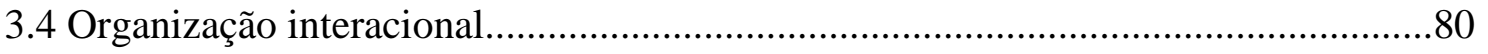

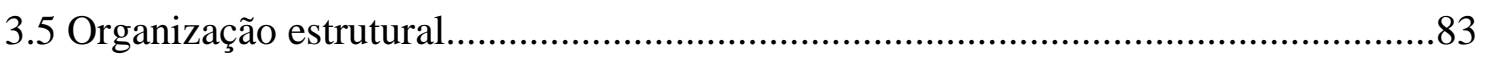

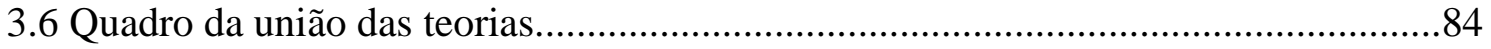

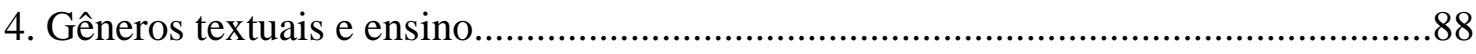

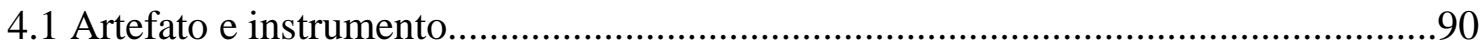

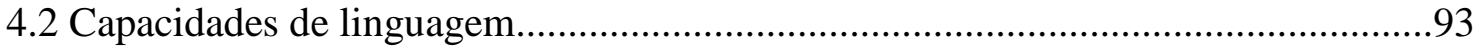

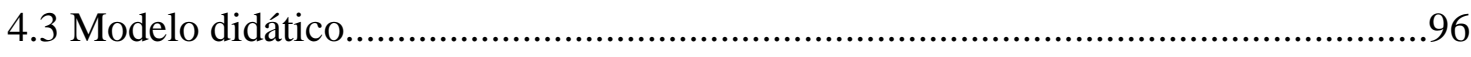

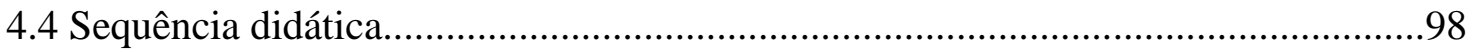




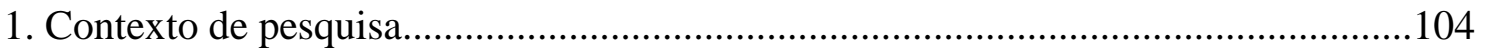

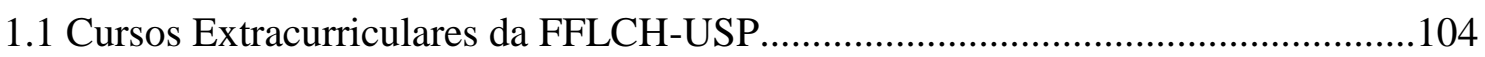

1.2 Os alunos participantes dos Cursos Extracurriculares da FFLCH-USP..................108

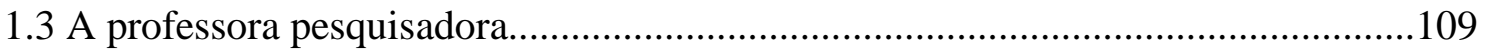

2. Procedimentos para a elaboração do modelo didático.............................................110

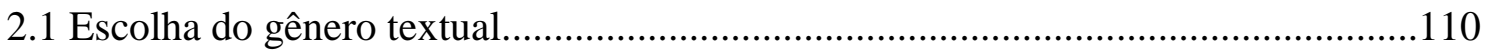

2.2 Escolha dos jornais Direct Matin e Direct Soir....................................................111

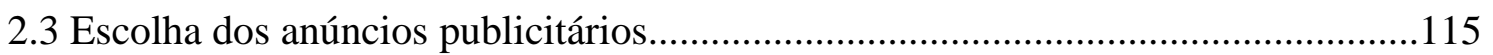

2.4 O modelo didático do gênero anúncio publicitário................................................120

3. Procedimentos de coleta e produção de dados.........................................................137

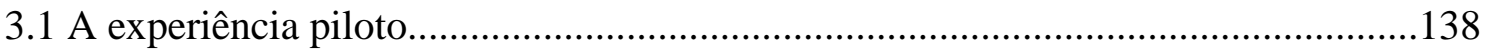

3.1.1 Elaboração da sequência didática piloto............................................................138

3.1.2 Os alunos participantes da produção piloto........................................................159

3.1.3 Aplicação da sequência didática piloto e reflexões.............................................161

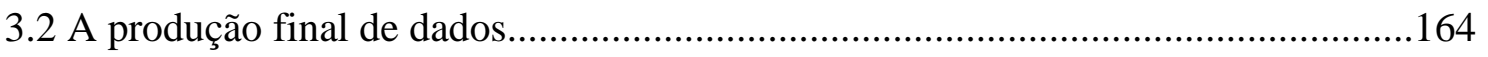

3.2.1 A elaboração da segunda sequência didática......................................................164

3.2.2 Os alunos participantes da segunda turma......................................................171

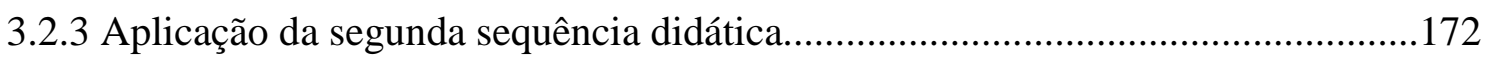

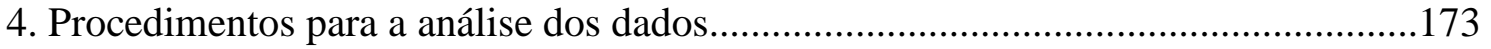

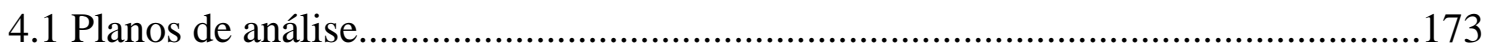

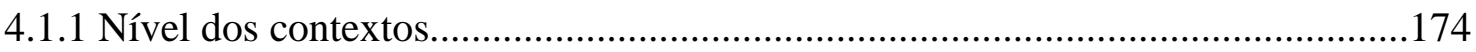

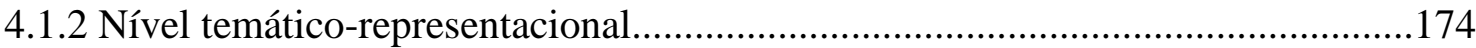

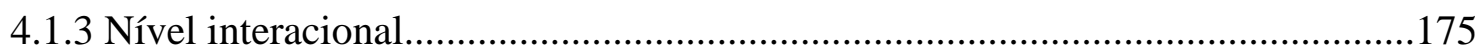

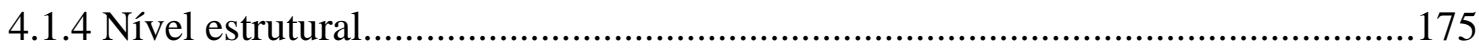

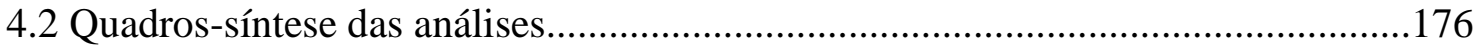

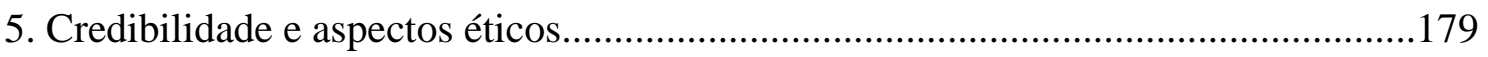

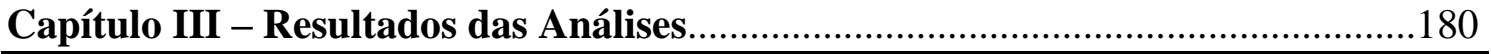

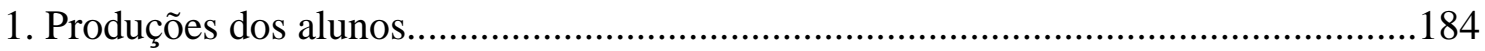




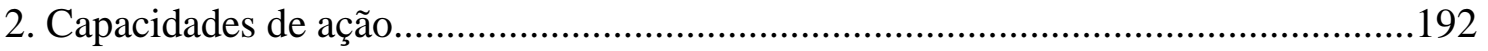

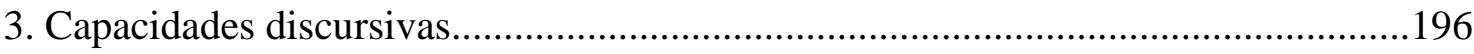

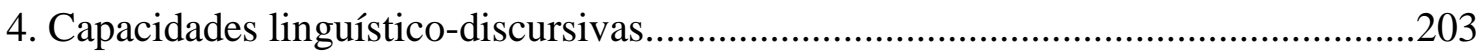

5. Síntese das análises e o efeito argumentativo das produções....................................213

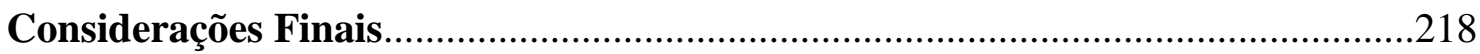

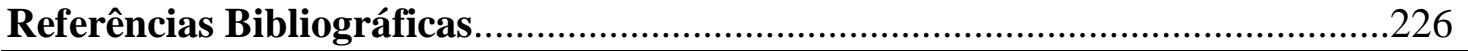

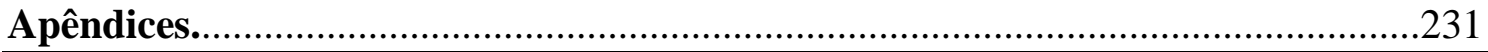




\section{Lista de Quadros}

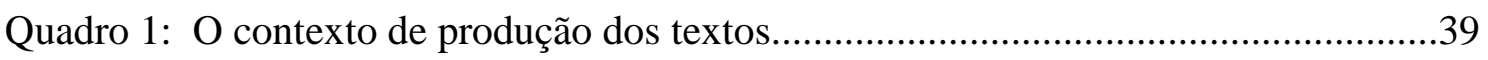

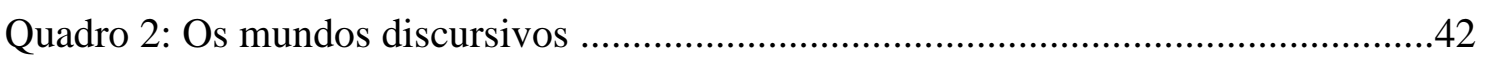

Quadro 3: Os três níveis da arquitetura textual..........................................................50

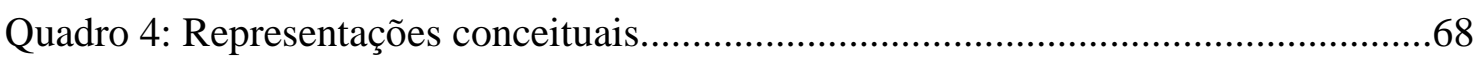

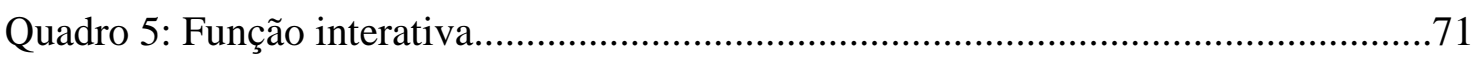

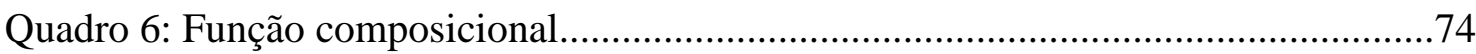

Quadro 7: Os contextos de produção e de recepção.....................................................76

Quadro 8: Formação da semiótica sócio interacional proposta por Leal (2011).............78

Quadro 9: Organização temático-representacional......................................................80

Quadro 10: Organização interacional verbal e não verbal............................................82

Quadro 11: Organização estrutural........................................................................... 83

Quadro 12: Quadro global de análise (Leal, 2011): união do ISD com a GDV..............85

Quadro 13: Capacidades de linguagem dominantes..................................................95

Quadro 14: O contexto de produção dos jornais virtuais Direct Matin e Direct Soir.113

Quadro 15: Quadro-síntese para a análise das produções textuais dos alunos...............162

Quadro 16: Quadro-síntese para a análise das capacidades de linguagem dos

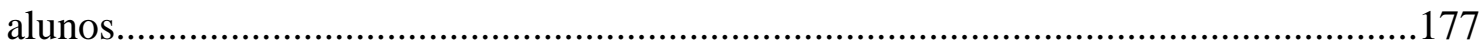

Quadro 17: Quadro de análise das capacidades de linguagem - capacidade de

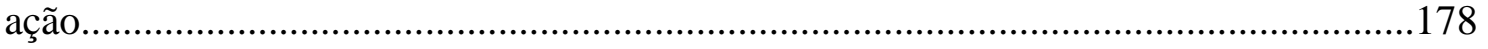

Quadro 18: Quadro de análise das capacidades de linguagem - capacidade

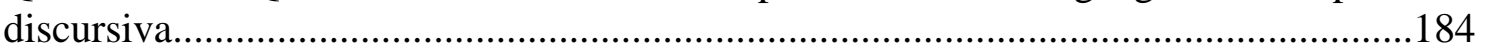

Quadro 19: Quadro de análise das capacidades de linguagem - capacidade linguístico

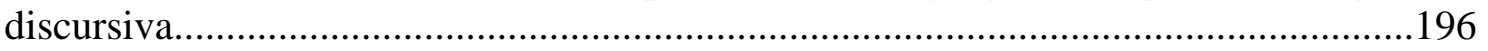

Quadro 20: Quadro de análise das capacidades de linguagem - capacidade

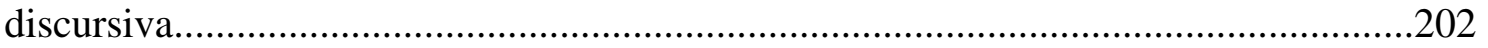

Quadro 21: Quadro de análise das capacidades de linguagem - capacidade linguístico-

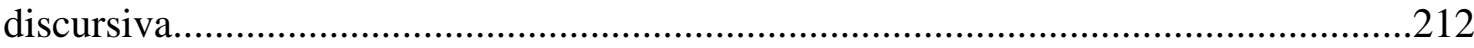

Quadro 22: síntese geral do desenvolvimento da argumentatividade..........................214 


\section{Lista de Figuras}

Figura 1: anúncios publicitários do Guaraná Antártica............................................22

Figura 2: anúncio publicitário do metrô de Paris.............................................................27

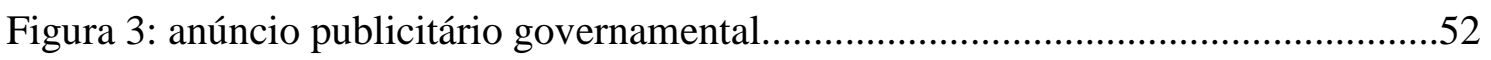

Figura 4: Shannon and Weaver's communication model (1949)......................59

Figura 5: imagens das representações narrativa e conceitual........................................61

Figura 6: anúncio publicitário da ERDF..................................................................63

Figura 7: imagens dos personagens da animação Toy Story........................................63

Figura 8: anúncio publicitário da empresa Total...........................................................64

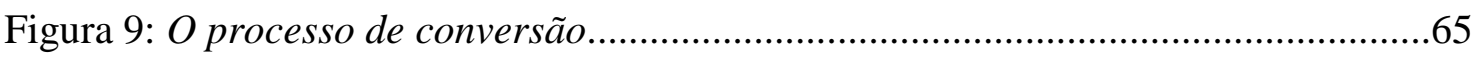

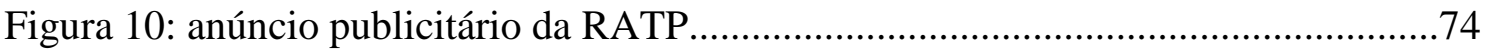

Figura 11: Logotipo com nome da loja "O melhor bolo de chocolate do

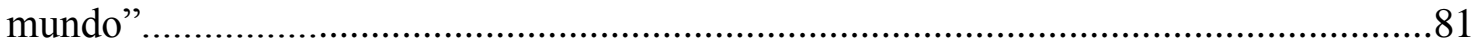

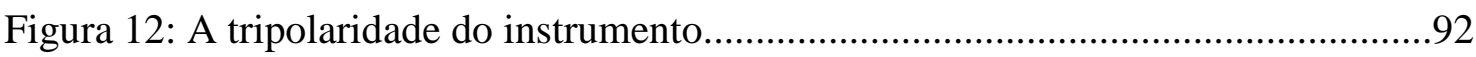

Figura 13: Esquema da sequência didática..................................................................99

Figura 14: gráfico do crescimento anual de turmas e alunos dos Cursos Extracurriculares de Francês da FFLCH-USP ...........................................................106

Figura 15: A proporção dos diferentes anúncios publicitários.....................................116

Figura 16: A recorrência dos tipos de anúncios publicitários dos jornais Direct Matin e

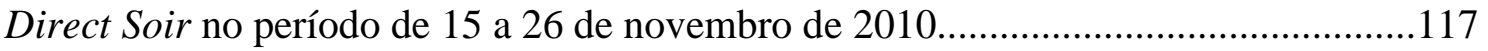

Figura 17: Anúncio publicitário de vídeo - M6....................................................... 123

Figura 18: Anúncio publicitário de vídeo - Toy Story 3.............................................124

Figura 19: Anúncio publicitário de transporte - BMW ...............................................124

Figura 20: Anúncio publicitário de transporte - RATP............................................125

Figura 21: Anúncio publicitário de transporte - Renault............................................125

Figura 22: Anúncio publicitário de vídeo - M6.......................................................127

Figura 23: Anúncio publicitário de transporte e governamental - BMW e Total.........128

Figura 24: Anúncio publicitário de transporte - Renault..............................................128

Figura 25: Anúncio publicitário de vídeo - Direct Star..............................................129

Figura 26: Anúncio publicitário governamental - Service Civique..............................130 
Figura 27: Anúncio publicitário de vídeo - Direct Star................................................131

Figura 28: Anúncio publicitário de vídeo - Le nom des gens......................................132

Figura 29: Anúncio publicitário de vídeo - Toy Story 3.............................................132

Figura 30: Anúncio publicitário de vídeo - Chevaliers du Fiel....................................133

Figura 31: Parte do anúncio publicitário de vídeo - Toy Story 3................................134

Figura 32: Parte do anúncio publicitário de vídeo - Le nom des gens..........................134

Figura 33: Anúncio publicitário de vídeo - Toy Story 3.............................................135

Figura 34: Anúncio publicitário de transporte - Peugeot..............................................136

Figura 35: Anúncio publicitário de transporte - RATP............................................136 


\section{Lista de Siglas}

ALTER - Grupo de pesquisa para Análise de Linguagem, Trabalho Educacional e suas Relações

ALTER-AGE - Grupo de pesquisa para Análise de Linguagem, Trabalho Educacional e suas Relações - Aprendizagem, Gêneros Textuais e Ensino

$\mathrm{CNPq}$ - Conselho Nacional de Desenvolvimento de Pesquisa científica e tecnológica FFLCH - Faculdade de Filosofia, Letras e Ciências Humanas

FLE - Francês língua estrangeira

GDV - Gramática do Design Visual

ISD - Interacionismo Sociodiscursivo

LE - Língua estrangeira

LM - Língua Materna

MD - Modelo Didático

PCN - Parâmetros Curriculares Nacionais

QECR - Quadro Europeu Comum de Referência

SD - Sequência Didática

USP - Universidade de São Paulo 


\section{Introdução}

“Toda manhã vocês se levantavam e saíam para o trabalho. Na verdade, porém, vocês nunca estiveram de fato acordados. Pode ser que vocês tenham visto o sol, a lua e as estrelas no céu, e também tudo o que existe e se move sobre a terra...mas vocês nunca viram todas essas coisas como elas realmente são" (Jostein Gaarder) 
Esta pesquisa tem por objetivo estudar o ensino-aprendizagem do francês língua estrangeira através da produção feita pelos alunos, de textos pertencentes ao gênero anúncio publicitário. Ela se insere na linha Estudos Linguísticos e didáticos e é fruto dos trabalhos que o Grupo ALTER-AGE/CNPq ${ }^{1}$ tem desenvolvido no campo do ensino de línguas por meio de gêneros textuais e do trabalho do professor de línguas. O contexto específico em que realizamos nossa pesquisa é composto por alunos de nível $\mathrm{V}^{2}$ ou A2 que estudam nos Cursos Extracurriculares de Francês.

Para desenvolver nossa pesquisa, apoiamo-nos no quadro teórico-metodológico do interacionismo sociodiscursivo (BRONCKART, 2003, 2006, 2008), que sugere uma abordagem para a compreensão do agir humano através da atividade de linguagem ao desenvolver um modelo de análise de textos destinado, principalmente, ao estudo de textos verbais, com conceitos e propostas para o ensino de línguas por meio dos gêneros textuais. No entanto, por estudarmos justamente o gênero anúncio publicitário, que se constrói a partir de textos verbais e de textos visuais, julgamos necessária a complementação do modelo do interacionismo sociodiscursivo (ISD), no que diz respeito à análise das imagens que compõem os anúncios. Por isso, apoiaremo-nos também na gramática do design visual (GDV), proposta por Kress e van Leeuwen (2006) e também utilizada por outros pesquisadores que se propuseram a analisar textos verbais e visuais a partir do ISD, como é o caso de Leal (2011).

A escolha de nosso objeto de pesquisa se justifica se levarmos em consideração que o mundo, no qual agimos por meio da linguagem, hoje, é permeado por textos verbais e visuais. Por isso, não há sentido em analisar apenas os textos verbais, especialmente se abordarmos o gênero anúncio publicitário que, na maioria das vezes, combina o texto verbal e o não verbal. Esse gênero, é um dos mais influenciados pela imagem, ou seja, pelo texto não verbal, como podemos observar na evolução dos anúncios publicitários a seguir, que compara anúncios do mesmo produto, o Guaraná, em diferentes épocas.

\footnotetext{
${ }^{1}$ O Grupo ALTER-AGE (Análise de Linguagem, Trabalho Educacional e suas Relações - Aprendizagem, Gêneros e Ensino) surgiu em 2011, através do interesse da professora doutora Eliane Gouvêa Lousada em filiar as pesquisas em andamento na sede da FFLCH-USP a um grupo maior e de repercussão nacional e internacional: o Grupo ALTER. O grupo de pesquisa ALTER-AGE é sediado na USP e é cadastrado no CNPq: http://dgp.cnpq.br/buscaoperacional/detalhegrupo.jsp?grupo=00678018KT1AMW

${ }^{2}$ Os alunos devem ter concluído com sucesso o nível IV dos Cursos Extracurriculares de Francês ou devem ter um nível A2 de acordo com o Quadro Comum Europeu de Referência para as Línguas (QCERL). A escolha dos níveis para o curso será apresentada, mais adiante, na seção de metodologia.
} 


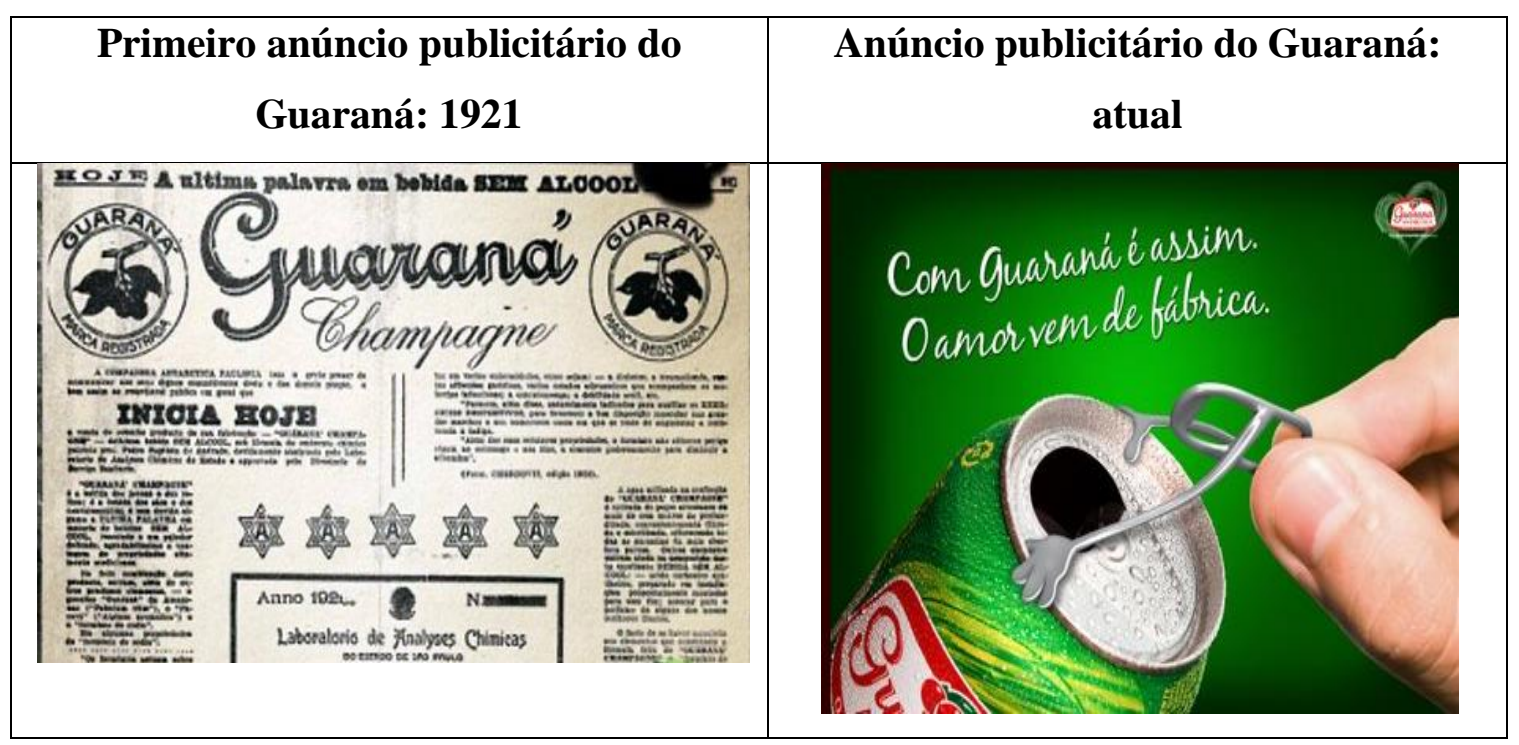

Figura 1: anúncios publicitários do Guaraná Antártica

Ao ver os textos acima, observamos que, em 1921, o anúncio publicitário do Guaraná Antártica era majoritariamente verbal. Apesar de o anúncio da década de 20 ser o primeiro do Guaraná e ter, também, um propósito informativo, o seu objetivo é de divulgar a marca e o novo produto somente através do texto verbal. No entanto, no anúncio publicitário atual, observamos o oposto dos anúncios das décadas de 20 e 30 , pois há a inserção da imagem colorida e a diminuição do texto verbal.

Logo, para entender o anúncio publicitário do início do século XX era necessário compreender o texto verbal, mas, para entender o anúncio publicitário atual, para o destinatário deve compreender as múltiplas simbioses, ou seja, os textos multimodais. Dessa forma, podemos inferir que, para desenvolver uma postura crítica em relação ao poder persuasivo dos anúncios, é necessário exercitar a compreensão do ponto de vista verbal e visual.

Embora Kress e Van Leeuwen (2006) afirmem a possibilidade de analisar os textos multimodais (ou seja, que combinam múltiplas semioses, no caso aspectos verbais e visuais) separadamente, por formarem sistemas semióticos independentes, também demonstraremos, nesta pesquisa, que nos anúncios publicitários, o efeito argumentativo (KOCH, 1996) é, justamente, produzido pela união do verbal e do não verbal. Ou seja, para compreendermos o gênero textual anúncio publicitário, podemos analisar os textos verbal e visual separadamente, mas, é somente através da sua união que conseguiremos analisar o poder de persuasão do gênero textual em questão. Por exemplo, na figura 1, no anúncio publicitário mais recente do Guaraná, só compreendemos o efeito argumentativo do jogo de palavras sobre o amor, quando 
observamos o abridor da lata se agarrando para não ser destacado, ou seja, a intenção de persuadir o leitor leva o produtor a mostrar que nem a própria lata quer se ver longe do guaraná.

Abordaremos, nesta pesquisa, não só o enfoque da língua por ela mesma, ou o fato de existir uma interação social através dela, mas a sua capacidade argumentativa (KOCH, 1996) que vai além do texto verbal. Segundo Koch (1996), se somos dotados de razão e de vontade, logo, avaliamos, julgamos e criticamos algo ou alguém através do discurso. Ainda para a autora $(\mathrm{KOCH}, 1996)$, o discurso é dotado de intencionalidade, ou seja, tenta persuadir, influir sobre o comportamento do outro.

Mais especificamente no caso do anúncio publicitário, podemos dizer que seu objetivo é justamente o de persuadir, influir sobre comportamentos, o que não acontece somente através das estruturas verbais, mas de toda a apresentação da imagem aos olhos do leitor. Portanto, podemos dizer que compreender os aspectos não verbais dos anúncios pode contribuir para desenvolver o poder de argumentação, tanto para o criador do anúncio publicitário, que tem como objetivo convencer o seu público, quanto para o público que deve: julgar, criticar e avaliar o que está sendo divulgado em um anúncio.

Mas, para compreendermos o papel do gênero textual anúncio publicitário nesta pesquisa, que se insere na área da Didática, apresentaremos o papel dos gêneros textuais no ensino-aprendizagem de línguas estrangeiras e, consequentemente, do francês como língua estrangeira (FLE), expondo, de forma sucinta, as orientações mais recentes para o ensino de línguas em geral e para o ensino de línguas estrangeiras.

No campo da didática das línguas estrangeiras, nas últimas décadas, a língua passou a ser vista como um meio de ação no mundo, o que acabou por se refletir nos documentos oficiais como o QCERL (Quadro Comum Europeu de Referência para as Línguas), publicado em 2001. No âmbito do ensino de língua materna, esse pressuposto também faz parte das orientações oficiais e dos materiais didáticos para o ensino da língua portuguesa, no Brasil, e francesa, na Suíça francófona, todos pela questão dos gêneros textuais (SCHNEUWLY E DOLZ, 2004).

Com efeito, no Brasil, a questão do ensino da língua materna como meio de ação no mundo tem sido preocupação constante desde a publicação dos Parâmetros Curriculares Nacionais (PCN), tendo dado origem a reflexões teóricas e transposições didáticas sobre o ensino de gêneros textuais (MACHADO, 2005; MEURER e MOTTAROTH, 2002). Em relação à língua estrangeira, o ensino da língua com o objetivo de 
agir socialmente surge, no Brasil, como uma decorrência dos $\mathrm{PCN}$, ressaltando a importância do ensino por meio dos gêneros textuais (CRISTOVÃO, 2005; LOUSADA, 2008).

No âmbito internacional de ensino de línguas, o Quadro Comum Europeu de Referência (Conseil de l'Europe, 2001:41) sintetiza mais de uma década de discussões sobre o ensino de línguas na Europa, propondo, assim, a perspectiva acional no campo da Didática das línguas estrangeiras. Segundo esse documento, para que o aprendiz aja como um ator social, ele deve incluir em sua aprendizagem textos de diferentes domínios, como: o domínio pessoal (receitas, instruções, romances, jornais, revistas, correio pessoal, e também publicidades), público (aviso ao público, etiqueta, embalagem, regulamentos, e também anúncios) e profissional (carta de negócios, relatórios, descrição de funções, material publicitário), além do domínio escolar (livros de leitura, cadernos de exercícios, dicionários, documentos autênticos). Como podemos constatar, o QCER apresenta, assim, uma série de gêneros textuais, divididos em áreas/domínios, mostrando-os como essenciais para a aprendizagem das línguas estrangeiras.

Baseando-nos nessas questões que permeiam o ensino-aprendizagem de línguas nas últimas décadas, bem como nas teorias, dentro do campo das ciências da linguagem, que veem a língua como um meio de ação no mundo, escolhemos textos pertencentes ao gênero do domínio pessoal anúncio publicitário para a realização de nossa pesquisa. Sendo assim, para estudar o ensino-aprendizagem do francês através da produção de textos dos alunos, propomos a elaboração de uma sequência didática por meio do gênero textual anúncio publicitário, visando ao desenvolvimento das capacidades de linguagem, nas quais se insere o efeito argumentativo, dos alunos aprendizes da língua francesa.

Compreender e/ou criar um anúncio publicitário é uma forma de agir no mundo, e, por isso, permite a união da perspectiva acional (QECR, 2001) com a perspectiva de ensino por meio de gêneros textuais (BRONCKART, 2003; SCHNEUWLY e DOLZ, 2004). Para Lousada (2008), trabalhar os gêneros textuais em sala de aula, quando relacionados à compreensão/recepção e à produção, pode ser um viés para alcançar os objetivos propostos pelo Quadro Europeu Comum de Referência. Nessa perspectiva, o gênero anúncio publicitário pode ser um instrumento importante na aprendizagem do FLE. 
Segundo Schneuwly e Dolz (2004), a capacidade de interação social está diretamente ligada à representação que temos sobre o gênero em questão, independentemente da língua. Para esses autores, o desenvolvimento das capacidades de linguagem pode ser observado pelo mecanismo de reprodução dos modelos de práticas de linguagem disponíveis no meio social, ou seja, o desenvolvimento acontece quando os membros da sociedade dominam esses modelos e adotam estratégias explícitas para que os aprendizes possam também se apropriar desses modelos (SCHNEUWLY e DOLZ, 2004: 52). O gênero anúncio publicitário foi escolhido pois pode ser um instrumento desenvolvedor das capacidades de linguagem individuais (SCHNEUWLY e DOLZ, 2004) e, mais especificamente, as capacidades ligadas à argumentação por meio de formas verbais e visuais.

Outro fator importante para a escolha do gênero textual anúncio publicitário é a sua autenticidade, pois se trata de um texto real, que se transforma constantemente com o passar do tempo, sendo, portanto, rico em aspectos sociais, históricos e culturais. Logo, esse gênero textual possibilita uma grande exploração pedagógica, tanto no que diz respeito a aspectos linguísticos, como, por exemplo, o acréscimo de vocabulário, o estudo da sintaxe, como também a compreensão das ambiguidades, veiculadas por meio do encontro entre o texto verbal e o visual e, ainda, a inserção do aluno no cotidiano francófono atual. Dessa forma, o anúncio publicitário pode permitir ao aluno entrar em contato com os hábitos alimentares, a vida familiar, os lazeres etc., criando a possibilidade, para o aluno, de traçar um paralelo entre a cultura francófona e a sua. Além do contato socio-histórico cultural, o gênero anúncio publicitário pode, também, preencher a lacuna gerada pelo fato de que muitos livros para o ensino do francês contêm material fabricado quase que exclusivamente para fins didáticos ${ }^{3}$.

Porém, para que o gênero possa vir a ser um instrumento de ensinoaprendizagem, o professor precisa conhecê-lo de forma a identificar suas características ensináveis. Para tanto, o professor deve construir o modelo didático do gênero, a partir do qual ele poderá criar diferentes sequências didáticas visando ao desenvolvimento das capacidades de linguagem dos alunos. É através da sequência didática que os alunos poderão se apropriar do gênero textual e aumentar suas capacidades para agir no meio social (SCHNEUWLY e DOLZ, 2004).

\footnotetext{
${ }^{3}$ É o caso, por exemplo, dos seguintes livros didáticos de francês como língua estrangeira, publicados atualmente (Echo, 2010) e há alguns anos (Campus, 2002), ou mesmo de alguns materiais que misturam materiais autênticos e fabricados (Alter Ego, 2006).
} 
Como expusemos, para o gênero textual anúncio publicitário, existe a necessidade não só da compreensão verbal, mas também da compreensão visual, para compreender o efeito argumentativo do texto. Portanto, a sequência didática a ser apresentada nesta pesquisa tem como objetivo sensibilizar os alunos aos efeitos argumentativos produzidos pela combinação do texto verbal e visual nos anúncios. Para tanto, optamos por trabalhar tanto a compreensão quanto a produção de anúncios publicitários com os alunos, pois acreditamos que o fato de deslocar o aluno do papel de apenas destinatário dos anúncios ao papel de produtores dos anúncios poderia contribuir para que eles conhecessem e aprendessem as estratégias de persuasão que ocorrem pelo confronto do texto verbal e do visual. Além disso, tivemos a intenção de mostrar aos alunos que a produção de um anúncio publicitário - unindo o verbal e o visual contribui não só para a aprendizagem de uma língua estrangeira, mas também para que eles se tornem cidadãos mais críticos e conscientes sobre o poder de persuasão de um texto multimodal, seja ele em língua estrangeira ou em língua materna.

Partindo da apresentação do objetivo geral desta dissertação e da delimitação de nosso objeto de estudo, propomos, na seção seguinte, a apresentação de como a pesquisa se constituiu, além de seus objetivos mais específicos e das perguntas que o direcionaram.

\section{Histórico da Pesquisa}

O tema desta pesquisa surgiu de uma experiência vivida ainda como estudante de francês língua estrangeira, em 2008, durante um intercâmbio em Paris, na França, onde conheci os jornais gratuitos Direct Matin e Direct Soir, utilizados nesta pesquisa. A leitura diária desses jornais fez-me perceber uma lacuna na aprendizagem do francês, visto que, apesar de ter estudado a língua francesa na graduação durante quatro anos, não conseguia compreender muitas partes dos jornais e, principalmente, os anúncios publicitários neles publicados. Esse fato contribuiu para que eu formulasse a hipótese de que, além dos obstáculos linguísticos, a dificuldade de compreensão desses textos vinha do fato de os anúncios publicitários não serem compostos somente por um texto verbal, mas terem seu sentido construído a partir das ambiguidades geradas pela união entre texto verbal e visual. Além disso, eu não conseguia recorrer ao intertexto, ou seja, recorrer a algum texto, fato, imagem ou cena que eu já tivesse lido, escutado, visto ou 
vivido, por exemplo, para interpretá-los. Muitas vezes os implícitos culturais inseridos em um anúncio são apresentados através do plano não verbal e devemos recorrer ao intertexto para compreendê-lo, como é o caso do anúncio a seguir.

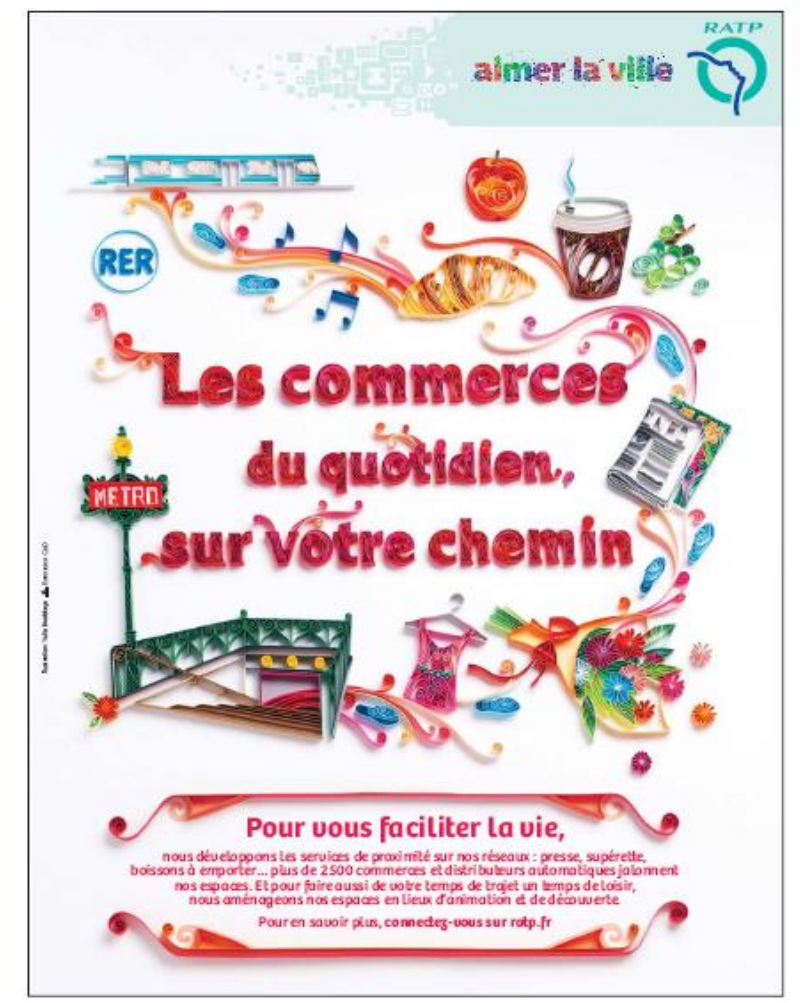

Figura 2: anúncio publicitário do metrô de Paris

Podemos observar tal importância argumentativa através do anúncio acima, no qual o texto verbal não é suficiente para apresentar a riqueza cultural que ele veicula. A partir da imagem, conhecendo o movimento "art nouveau" e o fato de que um de seus expoentes, Hector Guimard, foi o responsável pela arte visual que decora as entradas de metrô de Paris, podemos realmente compreender o desenho dos "caminhos" do comércio que é encontrado nos metrôs de Paris. Assim, o anúncio, que mostra objetos relacionados a diferentes comércios e ligados pelas linhas que simbolizam o movimento art nouveau, chegando à entrada do metrô de Paris, só pode ser plenamente compreendido se tivermos essas informações culturais que são veiculadas, neste caso, pela imagem presente no texto. Ao deslocarmos o local de leitura desse anúncio, aqueles que nunca conheceram essa arte, não poderão recorrer ao intertexto e não compreenderão onde este anúncio foi divulgado. 
Essa lacuna, mais do que me parecer apenas um problema pessoal de aprendizagem, gerou a curiosidade de estudar o papel desses textos autênticos na aprendizagem do francês, como uma maneira de preparar melhor os alunos para compreender não apenas as estruturas linguísticas, mas também o conhecimento cultural e cotidiano francófonos, veiculados através deles. Portanto, diante dessa constatação, pude repensar na minha aprendizagem e perceber que embora os livros didáticos trouxessem, muitas vezes textos multimodais, as atividades propostas exploravam apenas o ensino de estruturas verbais, portanto; a imagem e seu poder argumentativo não eram relevantes na aprendizagem de uma língua.

No ano de 2009, retornei ao Brasil para dar continuidade à minha formação na Licenciatura do francês da USP, a fim de preparar-me para a carreira como professora; ao mesmo tempo, durante o intercâmbio, havia produzido um esboço de um projeto sobre o ensino de língua francesa através de anúncios publicitários, pois pretendia dar início à pesquisa acadêmica.

No mesmo ano, apresentei-me para o processo seletivo dos Cursos Extracurriculares de Francês da Faculdade de Filosofia, Letras e Ciências Humanas da Universidade de São Paulo, local onde eu poderia conhecer as práticas de ensinoaprendizagem do FLE e colocar em prática o meu objetivo de trabalhar com os documentos autênticos, anúncios publicitários, para o ensino da língua francesa. No início de 2009, comecei a participar das reuniões pedagógicas dos Cursos Extracurriculares, organizadas e guiadas por textos teóricos sobre a didática de línguas, escolhidos pela coordenadora ${ }^{4}$ e por todos os monitores ${ }^{5}$, de acordo com as necessidades e problemas encontrados na prática do professor e na aprendizagem dos alunos. Esses textos teóricos e a orientação da coordenadora nos ajudavam a conhecer diferentes materiais didáticos e a desenvolver um olhar mais crítico sobre o que poderia ser feito para desenvolver as diferentes habilidades dos alunos de língua francesa.

Em julho de 2009, tornei-me monitora nos cursos extracurriculares e comecei a aprender o trabalho do professor de francês como língua estrangeira. Apesar do desejo de trabalhar com documentos autênticos, com vistas a melhorar o ensino de língua estrangeira, eu ainda não sabia criar atividades e encadeá-las de forma a contribuir para a aprendizagem dos alunos. Entretanto, a cada reunião pedagógica eram discutidas

\footnotetext{
${ }^{4}$ A coordenadora, desde 2009, é a Profa. Dra. Eliane Gouvêa Lousada, que em 2010 começaria a orientar este estudo.

${ }^{5}$ Nos Cursos Extracurriculares de Francês, os professores são "monitores" da Universidade, ou seja, são alunos já graduados ou fazendo pós-graduação que ministram as aulas.
} 
atividades baseadas em textos autênticos, o que facilitava minha aprendizagem. Aos poucos, fui desenvolvendo um olhar de professora e compreendendo que a elaboração de um material didático a partir de documentos autênticos poderia melhorar a aprendizagem dos alunos de FLE.

Apresentei, em 2010, o esboço do meu projeto à coordenadora dos Cursos Extracurriculares de francês da FFLCH que, posteriormente, orientou-me a desenvolvêlo para, então, ingressar no mestrado. Após o meu ingresso, no início de 2011, minha orientadora e eu continuamos com o desenvolvimento do projeto de ingresso "O gênero anúncio publicitário no ensino de francês língua estrangeira" e com a busca de teorias que pudessem guiar esse estudo. A escolha do gênero textual se deu por todos os motivos apresentados até o momento e, também, pelo fato de o anúncio publicitário estar presente em diferentes meios de comunicação, sendo, portanto, um forte instrumento de exploração pedagógica, visto que se insere temporalmente, culturalmente e socialmente no mundo.

As disciplinas cursadas no primeiro semestre de 2011 puderam dar forma e base ao projeto, pois o curso de "Metodologia de Pesquisa em Didática e EnsinoAprendizagem de Línguas Estrangeiras" ajudou-me a estruturar este estudo, a identificar os objetivos a serem alcançados e a descobrir onde seria a aplicação desta pesquisa. O local de aplicação escolhido foi os Cursos Extracurriculares de Francês, visto que eu já era monitora naquele contexto e contribuiria diretamente para o meu trabalho.

\section{Objetivo e perguntas de pesquisa}

Como mencionamos inicialmente, é objetivo desta pesquisa estudar o ensinoaprendizagem do francês língua estrangeira através da produção, pelos alunos, de textos pertencentes ao gênero anúncio publicitário. Como objetivo específico, pretendemos verificar como os alunos mobilizam suas capacidades de linguagem para produzir textos que combinem elementos verbais e visuais, procurando criar um efeito argumentativo a partir deles. Para tanto, analisaremos o gênero textual anúncio publicitário e verificaremos como esse documento autêntico pode contribuir para desenvolver as capacidades de linguagem dos alunos de FLE, além de possibilitar suas ações como atores sociais e inseri-los na cultura francófona. 
Para tanto, fizemos, primeiramente, uma análise de textos pertencentes ao gênero anúncio publicitário, com o objetivo de construir seu modelo didático (DOLZ, PASQUIER e BRONCKART, 1993), fator primordial para a elaboração da sequência didática (SCHNEUWLY e DOLZ, 2004). Em seguida, após a elaboração da sequência didática, pudemos aplicá-la e verificamos, nos textos produzidos pelos alunos, se houve desenvolvimento de suas capacidades de linguagem, mobilizadas pela escrita dos anúncios, dando especial atenção para o uso de elementos verbais e visuais, procurando criar um efeito argumentativo.

Além disso, como o gênero textual anúncio publicitário apresenta categorias de análise específicas de textos multimodais, propusemos a união do ISD (BRONCKART, 1999, 2003) com algumas categorias da GDV (KRESS e VAN LEEUWEN, 2006), partindo da proposta inicial de Leal (2011), que uniu as duas teorias com o objetivo de analisar os cartoons $^{6}$ divulgados nos jornais portugueses. Entretanto, diferentemente de Leal (2011), analisaremos o gênero textual anúncio publicitário e esperamos, assim, contribuir também para enriquecer o modelo de análise textual do ISD. Portanto, serviremo-nos do quadro de união criado por Leal (2011), mas almejamos contribuir para o ISD através da análise do texto multimodal anúncio publicitário, que difere dos cartoons analisados por Leal (2011), sobretudo por seu caráter argumentativo, já que, como apontamos, o maior objetivo de um anúncio publicitário é o de persuadir o seu leitor. De fato, o texto verbal assim como o texto não verbal desse gênero textual, possuem um caráter argumentativo que não se encontra no gênero cartoon. Esta pesquisa visa, dessa forma, a verificar como acontece a argumentação nesse gênero textual, não apenas a partir do texto verbal, mas a partir do texto não verbal; e visa, portanto, a preencher uma lacuna nos estudos do ISD.

Desse modo, para atingir nossos objetivos, este estudo visa responder às seguintes perguntas de pesquisa:

1. Quais características do gênero textual anúncio publicitário podem ser consideradas ensináveis aos alunos de FLE e, portanto, podem constituir seu modelo didático?

2. A sequência didática proposta por nós pode ser considerada como um instrumento pertinente para o desenvolvimento das capacidades de linguagem dos alunos de FLE? Por quê?

\footnotetext{
${ }^{6}$ Em sua pesquisa, Leal (2011) nomeia como cartoons as histórias em quadrinhos (HQs) ou as charges dos jornais portugueses.
} 
3. Quais são os elementos das capacidades de linguagem dos alunos de FLE, no plano verbal e no plano visual, que se destacam em suas produções finais?

4. Qual o desempenho dos alunos em relação ao "efeito argumentativo" dos anúncios produzidos na comparação das produções inicial e final? 


\section{Capítulo I - Fundamentação Teórica}

"Quando finalmente eu conseguia decorar o que cada carta me dizia, começava outra fase do jogo: eu tentava embaralhar as cartas para que cada frase que elas diziam se juntasse a fim de formar um todo coerente." (Jostein Gaarder) 
Este capítulo tem como objetivo apresentar as linhas teóricas em que nos baseamos para o desenvolvimento desta pesquisa. Para isso, começaremos pelas bases principais: o interacionismo social e uma de suas correntes, o interacionismo sociodiscursivo (BRONCKART, 2003, 2006). Posteriormente, complementaremos o quadro teórico da pesquisa, com o apoio da gramática do design visual de Kress e Van Leeuwen (2006). Optamos por esses autores, pois o interacionismo sociodiscursivo não possui categorias que possibilitem a análise de imagens, necessárias, em nosso caso, pois trataremos do gênero textual anúncio publicitário.

Este capítulo será dividido em quatro seções, organizadas como apresentamos a seguir. Na primeira seção, discorreremos sobre o ISD como uma corrente do interacionismo social, definiremos gênero textual e texto e apresentaremos o modelo de análise de textos do interacionismo sociodiscursivo a partir de seus diferentes níveis de estudo: contexto de produção, infraestrutura geral dos textos, mecanismos de textualização e mecanismos enunciativos.

Em seguida, apresentaremos a gramática do design visual de Kress e Van Leeuwen (2006), detalhando os conceitos de participante, função representacional, representação narrativa, representação conceitual, função interativa e função composicional, com o objetivo de dar pistas para a compreensão geral da imagem.

Na terceira seção, baseando-nos em Leal (2011), proporemos a união das teorias do interacionismo sociodiscursivo e da gramática do design visual, apresentando o contexto de produção, de recepção e o conteúdo temático. Posteriormente, apresentaremos a nova arquitetura interna dos textos com a junção do não-verbal, a organização interacional e a organização estrutural.

Finalmente, na quarta seção, apresentaremos a questão dos gêneros textuais no ensino de língua e desenvolveremos os conceitos de artefato e instrumento, de capacidades de linguagem, de modelo didático e de sequência didática.

\section{Interacionismo social e interacionismo sociodiscursivo}

A teoria do interacionismo social surgiu no início do século $\mathrm{XX}$ e foi desenvolvida através de diferentes pensadores, como, Hegel (1947) no estudo do desenvolvimento da atividade e do psiquismo humano, Marx e Engels (1951) com o 
papel dos instrumentos, da linguagem e do trabalho na construção da consciência e Vigotski com sua definição de linguagem como instrumento de mediação simbólica (BRONCKART, 2003). Oposto à linguística estrutural behaviorista ou neonativista, o interacionismo social investigou a formação de organizações sociais particulares e de caráter semiótico através da interação social, ou seja, essa teoria considerou a conduta humana como uma conduta socialmente contextualizada.

O interacionismo sociodiscursivo foi construído progressivamente ao longo da formação de Bronckart (2006, p. 12), tendo sido consolidado a partir de uma preocupação didática que emergiu de uma situação concreta: adaptar modelos teóricos e resultados de pesquisa à realidade das salas de aula, preocupação com a qual se confrontou ao dar um curso de Linguística para formadores e professores em Genebra. Para a construção do projeto do ISD, Bronckart contou com vários colaboradores, dentre eles Schneuwly e Bain (BRONCKART, 2006, p.13).

Antes de chegar às bases do ISD, Bronckart (2006) estudava Psicologia em Liège, tendo entrado em contato com diversas teorias, inclusive o behaviorismo de Skinner, o construtivismo de Piaget e o estruturalismo de Chomsky. Porém, foram as lacunas nessas teorias que o fizeram perceber a necessidade de um quadro textual global, em que a interação social ocupasse papel primordial e o levaram a estudar as teorias vigotskianas. Com efeito, como aponta Bronckart (2003, p. 24), Vigotski (1998), em sua perspectiva sociointeracionista, analisou o desenvolvimento humano através da interação social mediada por uma ferramenta técnica e semiótica. Em outras palavras, segundo a teoria vigotskiana, uma criança se apropria das unidades de significação da língua de seu meio fazendo com que seu psíquico comece a funcionar e a organizar suas ideias para interagir no mundo. Segundo Bronckart (2003, p.28), para Vigotski (1998), o desenvolvimento humano não é passivo ou ativo, ele é interativo, acontece através das intervenções das pessoas nesse meio. Vigotski (1998, p. 73) ainda acrescenta a essa ideia de interagir no meio, "os meios artificiais", ou seja, a atividade mediada que é capaz de mudar, fundamentalmente, todas as operações psicológicas, como, por exemplo: o uso de instrumentos que "amplia de forma ilimitada a gama de atividades em cujo interior as novas funções psicológicas podem operar". Dentre os instrumentos mencionados por Vigotski (1998), temos a linguagem, considerada um instrumento psicológico, já que é capaz de transformar as operações psicológicas e pode permitir ao homem, não apenas agir sobre os objetos, como ocorre com as ferramentas técnicas, mas agir sobre si mesmo. Dada a importância da linguagem como instrumento que atua 
no desenvolvimento, como demonstra Vigotski (1998), Bronckart (2006, p. 13) passou a estudar concomitantemente a análise dos discursos, com os trabalhos de Culioli (1990) e Jean-Michel Adam (1990) e a obra de Bakhtin ${ }^{7}$.

Outro teórico fundamental no qual Bronckart (2006) se baseou para a construção da teoria do ISD foi Saussure $(1975)^{8}$. A partir da análise de Saussure (1975) sobre o signo, relacionando a linguagem, a língua e o pensamento humano, Bronckart (2003, p. 69) observou que esse autor já apontava o sistema da língua como instável diacronicamente ou estável se considerado sincronicamente. Pois, se o tempo e as variações do uso da língua fossem considerados, perceberíamos que a língua só poderia ser apreendida através de produções verbais em diferentes situações de comunicação, ou seja, a língua só poderia ser apreendida através de textos.

Ao analisar as bases do ISD, percebemos que, para seu fundador, embora a língua aparente esteja dentro de um sistema baseado em regras, só conseguimos analisála a partir dos infinitos textos encontrados no mundo. Com isso, abordaremos um outro aporte teórico para o interacionismo sociodiscursivo: a ciência dos textos/discursos. Os textos/discursos podem ser orais ou escritos, servem para comentar as infinitas atividades cotidianas e recebem suas características de acordo com as diversas mídias de interação comunicativa, sendo que essas atividades cotidianas e mídias são formadoras dos infinitos gêneros (BRONCKART, 2005a).

Para compreender a noção de gênero para o ISD, faz-se necessário abordar autores fundadores do conceito: Bakhtin (1997) e Volochinov (1977). Para Bakhtin, a utilização da língua ocorre em forma de enunciados orais ou escritos, sendo que "qualquer enunciado considerado isoladamente é, claro, individual, mas cada esfera de utilização da língua elabora seus tipos relativamente estáveis de enunciados" (BAKHTIN, 1997, p.280). São esses enunciados relacionados à determinada atividade humana que o autor denomina de gênero do discurso. Bakhtin (1997, p.282) opõe-se ao formalismo que ignora "a natureza do enunciado e as particularidades de gênero que assinalam a variedade do discurso em qualquer área do estudo linguístico" e acredita na inesgotável variedade virtual da atividade humana. Para ele (BAKHTIN, 1997, p.280).,

\footnotetext{
${ }^{7}$ A influência da obra de Bakhtin para o ISD é discutível atualmente, pois Bronckart reviu recentemente esse posicionamento de seus primeiros estudos (BRONCKART e BOTTA, 2010) e adota a perspectiva de Volochinov (1977). Neste estudo, por nos basearmos em várias obras de Bronckart desde 1999, guardamos as referências das publicações iniciais, por um efeito de coerência da constituição dos conceitos.

${ }^{8}$ Bronckart (2006) toma os estudos de Saussure em relação aos signos que foram recentemente redescobertos, não se baseando no Curso de Linguística Geral de 1916.
} 
"cada esfera dessa atividade comporta um repertório de gêneros do discurso que vai diferenciando-se e ampliando-se à medida que a própria esfera se desenvolve e fica mais complexa".

Para Volochínov (1977), filósofo do círculo de Bakhtin (1997) e um dos fundadores do conceito "gênero", o fenômeno da linguagem seria uma prática de um meio social. Segundo ele (VOLOCHINOV, 1977, p. 73),

\begin{abstract}
"L’unicité du milieu social et celle du contexte social immédiat sont des conditions tout à fait indispensables pour que le complexe physico-psyco-physiologique que nous avons défini puisse être relié à la langue, à la parole, puisse devenir un fait de langage. “9
\end{abstract}

Essa reflexão sobre gênero textual e linguagem foi extensa também na obra de Bakhtin (1997), na qual o autor evidenciou a riqueza e a variedade dos gêneros, ou seja, a inesgotável variedade potencial da atividade humana. Para esse autor (BAKHTIN, 1997), cada esfera da atividade humana admite um conjunto de gêneros do discurso que "vai diferenciando-se e ampliando-se à medida que a própria esfera se desenvolve e fica mais complexa" (1997, p.279). Ainda no campo das ciências da linguagem, Bakhtin (1997) serviu de base para muitas outras reflexões, como podemos ver em Bronckart (2005b), ao definir arquitexto (BRONCKART, 2005b, p.234) através da organização da variedade virtual da atividade humana:

“[...] mesmo que a identificação e a classificação dos gêneros continuem sendo sempre problemáticas, o fato é que os gêneros de textos existem, ou melhor, coexistem no ambiente linguageiro e que se acumulam historicamente em um subespaço dos pré-construtos humanos, que denominamos, retomando essa noção, o arquitexto de uma determinada comunidade verbal"

\footnotetext{
9 A singularidade do meio social e do contexto social imediato são condições absolutamente indispensáveis para que o complexo físico-psico-fisiológico, que nós definimos, possa ser relacionado à língua, à fala e possa se tornar um fato de linguagem (Tradução nossa).
} 
Logo, o arquitexto é o conjunto de gêneros de textos, modelos de ação de linguagem que permitem o funcionamento da dimensão física, social e subjetiva das práticas da linguagem.

Como observamos no parágrafo anterior, Bronckart (2006) também acredita na variedade inesgotável da atividade humana e, portanto, dos gêneros do discurso, mas, nomeia-os de gêneros de textos. Segundo esse autor, o termo discurso "poderia levar a pensar que a linguagem se manifesta de outra maneira que não seja na prática" (BRONCKART, 2006, p.141), por isso o emprego do termo atividade discursiva de Bakhtin aparecerá como atividade de linguagem na obra de Bronckart (BRONCKART, 2006, p.140).

O autor (BRONCKART, 2003, p.72) explica, ainda, que os textos são produtos da atividade humana e "estão articulados às necessidades, aos interesses e às condições de funcionamento das formações sociais no seio das quais são produzidos", ou seja, os textos são produções de linguagem. Segundo ele (BRONCKART, 2006, p.143):

“(...) os textos são produtos da operacionalização de mecanismos estruturantes diversos, heterogêneos e por vezes facultativos. Esses mecanismos se decompõem em operações também diversas, facultativas e/ou em concorrência, que, por sua vez, se realizam explorando recursos linguísticos geralmente em concorrência".

Segundo Bronckart (2006, p.143), os gêneros de textos são produtos de linguagem com configurações de escolhas relativas à seleção e à combinação dos mecanismos estruturantes, das operações cognitivas e de suas modalidades de realização linguística, mas que se encontram momentaneamente "cristalizados" ou estabilizados pelo uso. Logo, os gêneros de texto mudam com o tempo e com as diferentes formações sociais de linguagem, podendo se desprender das suas finalidades originais, servindo a outras finalidades, pois "o resultado atual de um gênero é geralmente um misto, dependente das decisões originais de uma formação social de linguagem ou de processos posteriores de recuperação ou de mascaramento" (BRONCKART, 2006, p.144). Por isso, assim como para outros autores, inclusive Bakthin (1997), não existe a possibilidade de uma classificação estável e definitiva dos gêneros. 
Segundo Bronckart (2003), o texto possui um contexto de produção, ou situação de ação de linguagem, e é composto por um folhado ou arquitetura textual em três camadas: a infraestrutura geral do texto, os mecanismos de textualização e os mecanismos enunciativos. Para esse autor, o contexto de produção é constituído de parâmetros objetivos (emissor, co-emissor, e espaço/tempo de ação) e parâmetros sociossubjetivos (quadro social de interação, papel do enunciador, papel dos destinatários e objetivo), além de outras representações da situação de ação ou dos conhecimentos disponíveis no agente/pessoa.

A definição dos parâmetros da situação de ação de linguagem suscetíveis de terem uma influência no texto a ser produzido foi proposta por Bronckart (2003) após um estudo sobre diferentes teorias de cunho enunciativo, como por exemplo as de Benveniste, Culioli, Ducrot, entre outras. Para tanto, Bronckart (2003) não propõe categorias novas, mas opta por recuperar as categorias que dizem respeito ao contexto físico, sabendo que elas não podem, em nenhuma instância, serem dissociadas do contexto sociossubjetivo em que encontramos a posição social dos participantes e local da interação. Portanto, Bronckart (2003) propõe que se pense sempre no produtor físico (emissor) que assume o papel de enunciador em determinada situação de ação de linguagem (e que poderia assumir o papel de outro enunciador em outra situação de ação de linguagem, mesmo sendo considerado o mesmo emissor físico). O mesmo ocorre com o receptor, físico, e seu papel social, o de destinatário: embora o receptor físico seja sempre o mesmo, para Bronckart (2003), seu papel social pode mudar segundo a situação de ação de linguagem, o que lhe confere o papel de destinatário, interlocutor ou co-enunciador. Vale ressaltar que, para esse autor, as expressões são equivalentes e dizem respeito ao papel social ocupado pelos participantes, variável segundo cada interação (e no interior de uma mesma interação, como no caso de um diálogo).

A arquitetura textual é composta de três níveis (BRONCKART, 2003, p.119 e BRONCKART 2006, p.146): "a infraestrutura geral do texto" composta do plano global dos conteúdos temáticos, tipos de discursos e eventuais sequências; os mecanismos de textualização, que asseguram a "coerência temática" do texto, compostos pelos mecanismos de conexão, coesão nominal e coesão verbal; e os "mecanismos enunciativos", que asseguram a "coerência pragmática" do texto e que são compostos pelos mecanismos de gestão das vozes e modalizações. Vejamos, na seção a seguir, o contexto de produção em detalhe, além de cada um desses níveis de análise dos textos. 


\subsection{Contexto de produção}

Para produzir um texto, segundo Bronckart (2003, p.92), o agente deve mobilizar as representações sobre os mundos - físico, social e subjetivo - no contexto de produção e no conteúdo temático ou referente. A análise do contexto de produção, ou seja, da situação de interação ou de comunicação em que o produtor e o destinatário se encontram, pode nos ajudar a entender as razões que determinam a forma como um texto é organizado.

Quadro 1: O contexto de produção dos textos

\begin{tabular}{|l|l|l|}
\hline \multicolumn{2}{|c|}{ Ação de linguagem no contexto de produção } \\
\hline 1. Parâmetros objetivos & $\begin{array}{l}\text { Emissor } \\
\text { Espaço } \\
\text { Tempo }\end{array}$ \\
\hline 2. Parâmetros sociossubjetivos & $\begin{array}{l}\text { Quadro social de interação } \\
\text { Papel do enunciador } \\
\text { Papel dos destinatários } \\
\text { Objetivos }\end{array}$ \\
\hline $\begin{array}{l}\text { 3. Outras representações da situação e dos } \\
\text { conhecimentos disponíveis na pessoa }\end{array}$ & $\begin{array}{l}\text { Escolha do modelo de gênero pertinente } \\
\text { ao contexto da situação de ação. } \\
\text { Adaptação do modelo em função das } \\
\text { propriedades da situação de ação. }\end{array}$ \\
\hline
\end{tabular}

(BRONCKART, 2003, p.92)

De acordo com o quadro acima, o contexto de produção, tal como é apresentado por Bronckart (2003, p.93; 2006, p.146), é organizado em três elementos: os parâmetros objetivos da ação da linguagem, os sociossubjetivos e outras representações da situação e dos conhecimentos disponíveis na pessoa que produz. Os parâmetros objetivos (2006) ou o mundo físico (2003) dizem respeito ao conjunto do "comportamento verbal concreto" (2003, p. 93) e são divididos em: lugar de produção: o lugar físico onde o texto é produzido, momento de produção: o período durante o qual o texto é produzido, emissor (2003 e 2006) ou um possível coemissor (2006), ou seja, o produtor físico do texto e receptor, ou seja, as pessoas que percebem ou recebem o texto. 
Por outro lado, desconectado desses parâmetros objetivos, existe o mundo sociossubjetivo (2003) ou os parâmetros sociossubjetivos (2006) da ação da linguagem, ou seja, esses parâmetros sociossubjetivos nos apresentam o quadro social de interação, isto é, a interação comunicativa em um local social, como, por exemplo, a instituição escolar; o papel social do enunciador, ou seja, o estatuto do emissor; e o papel social dos destinatários, ou seja, o estatuto dos receptores; além do objetivo do texto, ou do ponto de vista do enunciador, os efeitos que o enunciador deseja produzir nos destinatários. Outro fator importante na análise da ação de linguagem são as outras representações da situação e dos conhecimentos disponíveis no agente. Elas são referentes à temática que será expressa no texto, ou seja, "as macroestruturas semânticas elaboradas sobre um determinado domínio de referência e disponíveis na memória" (BRONCKART, 2006, p.146). Segundo Bronckart (2006, p.147), “o agente dispõe de um conhecimento pessoal do arquitexto de sua comunidade verbal e dos modelos de gêneros nele disponíveis, modelos que podem ser apreendidos não só em função de suas propriedades linguísticas objetivas, mas também em função das etiquetagens e das classificações das quais eles se tornaram o objeto e em função das indexações sociais das quais são portadores”. Por isso, o agente, ao adotar um modelo de gênero pertinente aos seus objetivos, deve adaptá-lo de acordo com as suas propriedades particulares.

Vimos que os parâmetros apresentados permitem levantar hipóteses sobre o contexto de produção, que tem grande influência na produção textual. Veremos, a seguir, as três camadas do folhado textual, ou seja, a infraestrutura geral dos textos, os mecanismos enunciativos e os mecanismos de textualização.

\subsection{Infraestrutura geral}

A infraestrutura geral dos textos compreende três elementos do plano global dos textos, ou seja: a organização geral dos conteúdos, os tipos de discursos e as sequências textuais. Segundo Bronckart (2003, p.153), a organização geral dos conteúdos é a identificação temática visível no processo de leitura como, por exemplo, a temática social, política, histórica, entre outras e a maneira pela qual esses conteúdos estão dispostos no texto.

A categoria dos tipos de discurso foi proposta por Bronckart (1999) à luz dos estudos de Benveniste (1966) e Weinrinch (1973) e é uma das grandes contribuições do 
ISD para a análise de textos, por combinar duas grandes formas de organização discursiva: a oposição discurso e história, proposta por Benveniste (1966) e a diferença entre mundo comentado e mundo narrado, proposta por Weinrich (1973). Sendo assim, os tipos de discurso se organizam a partir de dois mundos: o mundo da ordem do narrar e o mundo da ordem do expor.

O mundo da ordem do expor pode ser dividido entre implicado ou autônomo. O mundo da ordem do expor implicado dá origem ao discurso interativo. Nele podemos encontrar uma interação verbal, mesmo que seja em um monólogo. É possível encontrar turnos de fala, frases não declarativas, unidades que remetam a objetos, a espaço ou tempo de uma interação, os dêiticos espaciais e temporais. Ainda no discurso interativo, podemos encontrar nomes próprios, verbos, pronomes e adjetivos na $1^{\mathrm{a}}$ ou $2^{\mathrm{a}}$ pessoa do singular ou plural - eu, nós, você, vocês, a gente - anáforas nominais, auxiliares de modo ou de valor pragmático, como: poder, querer, dever, ser preciso. Esse mundo é caracterizado por sua densidade verbal, diferentemente do mundo do expor autônomo, que tem como característica a densidade sintagmática.

O mundo do expor autônomo está relacionado ao discurso teórico, ou seja, o discurso monologado, escrito sem frases declarativas ou referência espaço-temporal. Além disso, geralmente não encontramos nomes próprios ou pronomes que façam referência às pessoas do discurso, ou seja, da interação, mas há frases passivas e anáforas pronominais e nominais. Como se trata de um discurso teórico, podemos encontrar diversos organizadores lógico-argumentativos e a presença do auxiliar de modo poder.

Segundo Bronckart (2003), o mundo da ordem do narrar também pode ser dividido em dois: o narrar implicado e o narrar autônomo. O mundo do narrar implicado refere-se ao relato interativo, o qual pode ser situado em referência ao espaço e ao tempo do mundo dos agentes. Nesse mundo, o narrar implica personagens e acontecimentos: encontramos unidades linguísticas referentes ao agente-produtor, organizadores temporais, como advérbios, sintagmas preposicionais, coordenativos, subordinativos, entre outros. O narrar implicado é semelhante ao discurso interativo quanto à quantidade de verbos, sendo eles em predominância pertencentes ao passado composto (correspondente ao pretérito perfeito da língua portuguesa) e pretérito imperfeito, e às vezes são associados às formas do pretérito mais-que-perfeito, futuro simples ou futuro do pretérito. O relato interativo está inserido no mundo do narrar implicado e pode ser monologado ou desenvolvido em situação de interação real 
(originalmente oral) e de interação irreal, como por exemplo, através o gênero escrito: romance ou peça de teatro.

E, finalmente, o discurso também pode ser classificado em um mundo do narrar autônomo, referente à narração. Nele, nenhuma unidade linguística se refere diretamente ao agente/produtor ou aos personagens em cena. As indicações de tempo ou de local podem aparecer no decorrer do discurso ou podem ser indeterminadas como nos contos de fadas, em que encontramos, era uma vez, em um lugar longínquo.

Quadro 2: Os mundos discursivos

\begin{tabular}{|l|l|l|}
\hline & $\begin{array}{l}\text { O mundo do expor: relacionado ao } \\
\text { presente conjunto, ou seja, conjunto } \\
\text { ao mundo ordinário, }\end{array}$ & $\begin{array}{l}\text { O mundo do narrar: não está } \\
\text { relacionado ao presente, mas a algo } \\
\text { que já pode ter acontecido, por isso é } \\
\text { disjunto ao presente. }\end{array}$ \\
\hline Implicado & Discurso interativo & Relato interativo \\
\hline Autônomo & Discurso teórico & Narração \\
& & \\
\hline
\end{tabular}

(BRONCKART, 2003, p.157)

Além da análise dos conteúdos temáticos e dos tipos de discursos, as sequências textuais (BRONCKART, 2003, p.153) completam a infraestrutura geral dos textos. Para abordar a questão das sequências, Bronckart (2003, p. 218) baseia-se nos estudos de Adam (1990, 1992), porém ressaltando seu estatuto dialógico, ou seja, orientado pelas representações que o agente produtor do texto tem sobre seu destinatário e sobre seus objetivos. Nesse sentido, a escolha da organização do texto provém de decisões interativas, o que justifica seu caráter dialógico.

Para Bronckart (2003), as sequências são os modos de planificação textual ou os modos de planificação de linguagem, ou seja, são organizações locais que estão divididas em: sequências narrativas, explicativas, argumentativas, descritivas, dialogais e injuntivas. As sequências possuem fases de realização. Por exemplo, a sequência 
narrativa, geralmente, é planificada em situação inicial, desenvolvimento da situação, complicação da situação narrativa, clímax e conclusão da complicação.

Nesta pesquisa, enfocaremos apenas a sequência argumentativa, já que ela é a mais importante para a compreensão e produção do gênero textual anúncio publicitário. Portanto, não detalharemos as outras sequências textuais e suas fases, pois procuraremos aprofundar os estudos sobre argumentação, que darão sustentação às nossas análises.

Bronckart (2003) baseia-se em Adam (1990, 1992) e nos estudos de alguns teóricos sobre a argumentação, para explicar as fases da sequência argumentativa, que funcionam como um protótipo, ou seja, um modelo abstrato, composto de fases. $\mathrm{O}$ protótipo da sequência argumentativa é composto por quatro fases (BRONCKART, 2003, p.226):

- a fase de premissas ou dados: em que se propõe uma constatação de partida;

- a fase de apresentação de argumentos: em que elementos são expostos para orientar uma conclusão provável, podem ser lugares comuns, regras gerais, exemplos, entre outros.

- a fase de apresentação de contra-argumentos: em que apresentam restrições em relação à apresentação de argumentos e também podem ser lugares comuns, regras gerais, exemplos, entre outros.

- a fase de conclusão ou de uma nova tese: apresenta os efeitos dos argumentos e dos contra-argumentos.

Apesar da existência de quatro fases, segundo Bronckart (2003, p.227), o protótipo da sequência argumentativa pode ser reduzido ou complexo, ou seja, pode passar diretamente da premissa à conclusão, o que deixaria implícita as outras duas fases, ou poderia explicitar a tese, entrelaçar argumentos e contra-argumentos, desenvolver os dois últimos e concluir. Um dos exemplos de sequência argumentativa exposto por Bronckart (2003,p. 227) é um texto publicitário, no qual a sequência argumentativa se reduz a uma série de argumentos que conduzem à uma conclusão que pode ser implícita ou explícita.

O próprio Bronckart (2003, p. 218) ressalta, portanto, que os protótipos das sequências são apenas construtos teóricos, que podem desempenhar um papel de modelo para o agente produtor de um texto, mas que, no fundo, são mobilizados pela experiência do intertexto pelo produtor do texto. Em outras palavras, os modelos de sequência estão disponíveis no intertexto, mas dependem de decisões do produtor do 
texto em função da situação de ação de linguagem em que se encontra, de seu destinatário e de seus objetivos. Portanto, em função desse estatuto dialógico, não se pode esperar que as sequências sejam sempre organizadas a partir das mesmas fases já pré-estabelecidas, mas que elas sejam reorganizadas e funcionem de forma diferente para cada situação de ação de linguagem. Em nosso trabalho, consideramos que os objetivos do produtor do texto e os efeitos que quer produzir em seu destinatário são o que chamaremos de "efeito argumentativo".

Por essa razão, ao trabalharmos com o anúncio publicitário, pareceu-nos essencial compreender que o efeito argumentativo alcançado por esse gênero textual não poderia decorrer apenas de uma sequência argumentativa com fases definidas, tal como apresentada por Adam (1990, 1992). Utilizando, assim, as próprias considerações de Bronckart (2003), procuramos outros autores que pudessem dar conta da compreensão de como se dá a argumentação quando ela ocorre por outros meios que não são as fases descritas no protótipo. Sendo assim, consultamos alguns autores que falam da argumentação em geral, como Koch (1996); do discurso midiático no que diz respeito ao efeito de verdade que se quer produzir (CHARAUDEAU, 2007); e, finalmente, Plantin (2008), que parece levar em conta o estatuto dialógico das sequências e o empréstimo ao intertexto. Com isso, visamos a complementar a proposta de Bronckart (2003) na análise da sequência argumentativa.

Segundo Koch (1996, p.19), por exemplo, a interação social por intermédio da língua é caracterizada, fundamentalmente, pela argumentatividade (KOCH, 1996, p.19):

\footnotetext{
"como ser dotado de razão e vontade, o homem, constantemente, avalia, julga, critica, isto é forma juízos de valor. Por outro lado, por meio do discurso - ação verbal dotada de intencionalidade - tenta influir sobre o comportamento do outro ou fazer com que compartilhe determinadas de suas opiniões."
}

Logo, se a argumentatividade está inscrita no uso da linguagem, a argumentação é a sustentação de todo o discurso $(\mathrm{KOCH}, 1996$, p.23). Ainda segundo a autora (KOCH, 1996), a persuasão é composta pela intencionalidade no discurso e pela argumentação. Ambos, a intencionalidade e o discurso argumentativo, têm como objetivo a persuasão. Desta forma, o gênero anúncio publicitário é um texto que tem 
como objetivo maior influir sobre o comportamento do leitor, ou seja, persuadi-lo. Para isso, o produtor de um anúncio publicitário deve ter certas intenções e o leitor deve apreendê-las. Segundo Koch (1996, p.24), "toda atividade de interpretação presente no cotidiano da linguagem fundamenta-se na suposição de que quem fala tem certas intenções, ao comunicar-se".

Portanto, o destinatário do anúncio precisa apreender a intencionalidade do produtor, para realmente compreender esse gênero textual. Porém, no caso do anúncio publicitário, a intencionalidade do produtor não se constrói somente através do texto verbal, mas, também, através do texto visual, do qual trataremos mais a frente.

Para Charaudeau (2007), em Discurso das mídias, o discurso não está voltado às regras de uso da língua, ou seja, o discurso não é a língua, mas ele é a união das circunstâncias em que se fala ou escreve com a maneira pela qual se fala ou escreve. Logo, é a união das condições extradiscursivas e das realizações intradiscursivas que produz sentido (2007, p.40). No âmbito da informação, Charaudeau (2007) afirma que, além das condições extradiscursivas e das realizações intradiscursivas, existem dois polos para construir um sentido: a natureza do saber que é transmitido e o efeito de verdade que pode produzir no receptor.

A natureza do saber, com base em Charaudeau (2007, p.47), é o resultado de uma construção humana que pode se voltar para o mundo, através da categoria saberes de conhecimento, ou pode se voltar para si mesmo, através da categoria saberes de crença. Portanto, a natureza do saber pode ser racional ou subjetiva.

Já o "efeito de verdade" não pode ser confundido com o "valor de verdade", pois valor de verdade se baseia na evidência, enquanto o efeito de verdade se baseia na convicção. Charaudeau (2007, p.49) explica, portanto, que o efeito de verdade faz parte de um dispositivo enunciativo de influência psicossocial, no qual cada um dos parceiros da troca verbal tenta fazer com que o outro adira a seu universo de pensamento e de verdade. Logo, o que se observa no efeito de verdade não é a busca de uma verdade, mas a busca de "credibilidade". Esse conceito é importante para nossas análises do gênero textual anúncio publicitário, pois veremos que ele busca produzir um "efeito de verdade", já que almeja a credibilidade do produto ou da marca, porém não parece ter compromisso com o "valor de verdade".

Plantin (2008) retoma os modelos argumentativos de Toulmin (2006), Ducrot (1990), Grize (1990) Doury (1997), entre outros, para mostrar que eles não levam em conta algo essencial para a argumentação: os afetos, as emoções. É, justamente, por 
estarmos analisando anúncios publicitários que nos parece fundamental observar como as emoções afetam os destinatários dos anúncios publicitários, o que nos permite compreender seu efeito argumentativo.

Dessa forma, Plantin (2008) critica o modelo da coerência argumentativa proposto por Toulmin (2006) que define o discurso argumentativo como um composto de seis elementos: um dado, ou seja, uma informação; uma lei de passagem, que significa uma garantia ou argumento; um suporte, portanto, um argumento que consolide a lei de passagem; um modalizador, ou seja, um advérbio conector que pode concluir ou restringir algo; uma conclusão, que através de um modalizador pode encerrar uma ideia; e uma refutação, também introduzida através de um modalizador para contrapor outra ideia.

Plantin (2008, p. 31) se apoia em Ducrot (1990) ao criticar o modelo argumentativo de Toulmin (2006), pois, para Ducrot (1990), Toulmin tinha uma visão "ingênua" ou "tradicional" da argumentação, acreditando em uma língua científica perfeita, sem analisar a concepção semântica do discurso. Plantin (2008, p.63) propõe, assim, um modelo dialogal, influenciado pelos estudos sobre as interações e com base em Hamblin (1970) e na perspectiva da lógica do diálogo. Segundo Plantin (2008, p.65), a abordagem dialogal "visa levar em consideração a insatisfação decorrente dos modelos puramente monologais da argumentação que surgiu pelo menos desde os anos 1980”.

O modelo dialogal, proposto por Plantin (2008, p.118), analisa a argumentação dialogada, o desacordo conversacional e argumentativo, a pergunta argumentativa, os papeis argumentativos, o ônus da prova, os lugares, os roteiros, a contradição ou a refutação e a conclusão do discurso. No entanto, para a análise dos anúncios publicitários, daremos apenas destaque à argumentação dialogada, no que diz respeito à polifonia e à intertextualidade, e aos afetos, pois são estes que nos parecem importantes para nossos objetivos.

Para Plantin (2008), o diálogo significa a relação face a face, ou seja, a linguagem oral e a presença física de interlocutores, além da contínua sequência de réplicas relativamente breves. No entanto, Plantin (2008, p.65) afirma que os conceitos de polifonia e de intertextualidade permitem aplicar à concepção dialogada da argumentação ao discurso monolocutor, já que a própria teoria da polifonia se construiu a partir do reconhecimento de um espaço dito dialógico, no qual "uma proposição é atribuída a uma "voz", diante da qual o locutor se situa" (Plantin, 2008, p.65). Com 
essas reflexões, podemos compreender que há um diálogo interior, independente do face a face presencial, o que se enquadra à perspectiva apresentada pelo ISD e, portanto, pode nos ser útil para a análise do gênero textual anúncio publicitário, que, em nosso caso, diz respeito apenas aos anúncios publicados em jornais.

Além desses conceitos, Plantin (2008) apresenta o estudo da argumentação dialogada como intertextual. Ou seja, para Ducrot (1990) "o locutor polifônico" se reconhece em uma atividade, como um encenador, o locutor polifônico escolhe quais são suas identificações. Com essa versão de Ducrot (1990), Plantin (2008) coloca a noção de intertextualidade acima do locutor, visto que ele se torna uma instância de reformulação de discursos que já aconteceram.

Assim como citamos anteriormente, outro fator importante para essa pesquisa no modelo dialogal é a importância dos afetos. A ideia dos afetos no discurso surgiu há muito tempo na teoria retórica de Cícero (1928), Quintiliano (1977) e Aristóteles (1931), e nessa teoria afirma-se ser impossível estudar a argumentação omitindo as emoções que estão sempre vinculadas às situações argumentativas de base, como no debate político e nas disputas judiciais. À vista disso, Plantin (2008, p.124) conclui que os afetos são importantes nas modernas teorias da argumentação pois:

\footnotetext{
"os locutores aderem a seus discursos, seus valores e interesses estão em jogo, eles duvidam, ressentem-se do estresse provocado por uma questão aberta que seria preciso regular, da irritação contra posições antagônicas, têm um sentimento de triunfo ("vencemos as eleições"), ou raiva e humilhação ("eles não entenderam nada"). Se admitirmos que todos os discursos não são argumentativos, que os discursos argumentativos não estão no mesmo patamar dos outros discursos, se não identificarmos o argumentativo com o emocional, então será necessário admitir que o modelo das emoções no discurso argumentativo depende de um modelo de emoções no discurso em geral, deixando escancarada a questão da especificidade do papel da emoção na argumentação."
}

Refletindo sobre o que acabamos de expor, podemos dizer que, para Plantin (2008), a argumentação não ocorre apenas através de modelos pré-estabelecidos, como o de Toulmim (2006), mas, ao contrário, tem base nas relações dialógicas. Nesse 
sentido, encontramos semelhanças com o que afirma Bronckart (2003) sobre o estatuto dialógico das sequências, inclusive a argumentativa e compreendemos que não podemos nos prender à identificação da sequência argumentativa para analisar os anúncios publicitários. Dessa forma, concluímos que o efeito argumentativo não se constroi apenas no âmbito da infraestrutura textual, circunscrito no interior da sequência argumentativa, mas pode se desenvolver ao longo de todos os níveis do modelo de análise do ISD, sobretudo nos mecanismos enunciativos, como veremos mais a frente.

Após o estudo da organização geral dos conteúdos do texto, temos a análise dos mecanismos de textualização que explicitam de que forma se deu a organização temática do texto.

\subsection{Mecanismos de textualização}

Nos recentes estudos de Bronckart (2006, p.148), os mecanismos de textualização foram nomeados de coerência temática, pois contribuem para dar a coerência linear através dos processos isotópicos de conexão, de coesão nominal e de coesão verbal. Os processos isotópicos ou mecanismos articulam a progressão temática do texto através de conjunções, advérbios, da introdução de temas ou personagens novos, retomando-os ou substituindo-os por pronomes pessoais, relativos, demonstrativos e possessivos.

Os mecanismos de conexão marcam a progressão temática, organizam o texto e podem ser conjunções, advérbios, locuções adverbiais, grupos preposicionais, grupos nominais e segmentos de frases. A organização temática é feita por organizadores lógicos (logo, portanto, então, por isso etc), espaciais (nesta seção, aqui, no capítulo II etc), e temporais (há algum tempo, depois disso, antes, durante etc).

O mecanismo de coesão nominal introduz o tema ou os personagens do texto e é responsável pela retomada desses elementos. Por isso, a coesão nominal é encontrada através das anáforas, como, por exemplo, a retomada do autor Bronckart nesta pesquisa, pois podemos fazer uso de: “o autor", "o pesquisador", “ele”, “o teórico”, entre outros. As anáforas podem ser encontradas através de pronomes pessoais, sinônimos, pronomes relativos, entre outros.

Outro articulador da progressão é a coesão verbal, capaz de organizar o tempo, os acontecimentos e as ações realizadas de forma temporal ou hierárquica que são 
verbalizadas no texto; logo, verbos do passado possuem valor de anterioridade, verbos no presente possuem valor de simultaneidade e, no futuro, de posteridade. Essa temporalidade acontece no momento da produção do texto em relação ao momento descrito. Além dos verbos, a coesão verbal pode aparecer com marcadores de valor temporal, como, os advérbios (organizadores textuais) ou grupos preposicionais (BRONCKART, 2003, 2006).

\subsection{Mecanismos enunciativos}

Os mecanismos enunciativos ou coerência pragmática são as regras para os posicionamentos de enunciação, expressas pelas modalizações e pela gestão das vozes e não estão diretamente ligados à progressão temática.

As modalizações são as avaliações formadas sobre alguns elementos ou aspectos do conteúdo temático. Em outras palavras, elas servem para explicitar julgamentos e avaliações que partem de uma instância e se dirigirem a algum conteúdo semiotizado no texto (BRONCKART, 2006, p.149).

Segundo Bronckart ${ }^{10}$ (2008), as modalizações podem ser classificadas em:

- lógicas: consistem em julgamentos sobre o valor de verdade das proposições enunciadas e são expressas por certeza, possibilidade, probabilidade, improbabilidade, entre outros (por exemplo: “deve ter existido", "sem dúvida", "poderia existir"); -apreciativas: consistem em julgamentos mais subjetivos, e apresentam os fatos como bons, estranhos, ruins (por exemplo: "o melhor de todos", "você gosta", "você odeia");

- deônticas: consistem em julgamentos que avaliam o que é enunciado à luz dos valores sociais, atribuem um valor de obrigação social (por exemplo: “é necessário", “é preciso", "você deve").

Outro elemento que faz parte dos mecanismos enunciativos é a distribuição das vozes no texto, pois elas devem mostrar as responsabilidades por aquilo que está sendo expresso, dito, visto, pensado (2006, p.149). As vozes podem ser identificadas como as vozes do autor empírico, as vozes sociais e as vozes de personagens, podendo ser elas implícitas ou explícitas (BRONCKART, 2003, 2006).

\footnotetext{
${ }^{10}$ Bronckart (1999 [2003]) havia selecionado quatro tipos de modalizações: as lógicas, as deônticas, as apreciativas e as pragmáticas, mas, recentemente (BRONCKART, 2008), classificou-as em três: as lógicas, as deônticas e as apreciativas.
} 
Os mecanismos enunciativos não estão diretamente ligados à progressão temática, por isso são mais superficiais comparados aos outros níveis da arquitetura textual. Os níveis da arquitetura textual que apresentamos podem ser sintetizados no quadro abaixo.

Quadro 3: Os três níveis da arquitetura textual

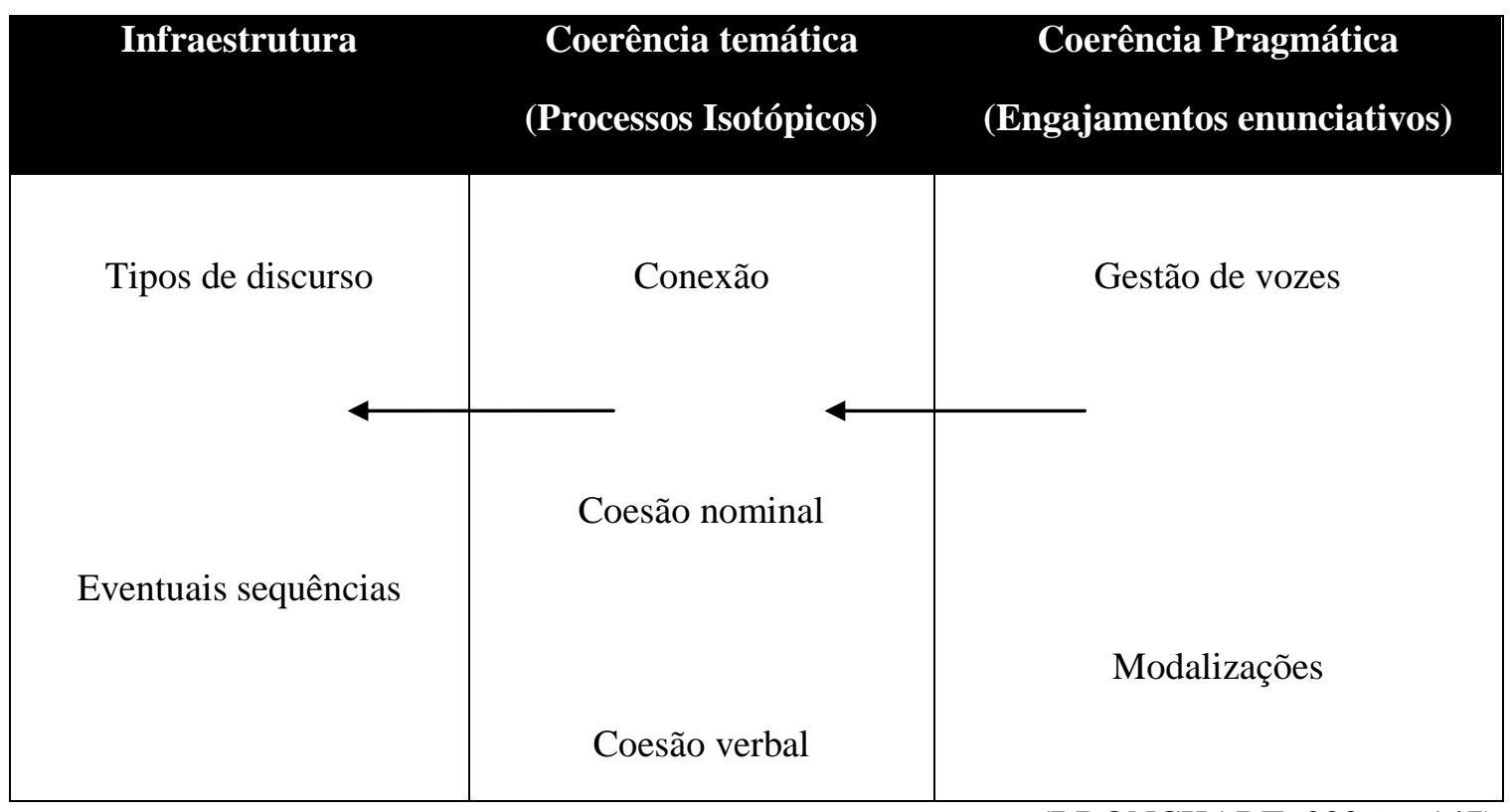

(BRONCKART, 2006, p.147)

Para exemplificar o que vimos até agora, apresentaremos a análise de um anúncio publicitário, que nos servirá para mostrar os conceitos teóricos, aplicados ao mesmo texto No anúncio abaixo, assim como afirmamos anteriormente, podemos compreender o discurso argumentativo do gênero textual anúncio publicitário através dos recursos verbais e não verbais. Para expor como esses recursos se alternam, provocando um efeito argumentativo que visa a persuadir o destinatário, propomos mostrar uma rápida análise dos elementos não verbais, que serão apresentados em detalhe na seção 2, apenas para ilustrar nosso propósito. Em um segundo momento, mostraremos a análise do que acabamos de expor; dando continuidade, ao final de cada exposição de um nível de análise do ISD, mostraremos como os conceitos se aplicam ao mesmo anúncio.

Ao analisarmos os recursos não verbais desse anúncio, ou seja, a organização do não verbal, baseada em Kress e Van Leeuwen (2006), observamos um processo de reação transacional, isto é, existe uma transação entre o participante da figura e o leitor, visto que os integrantes da família da foto queimada lançam seus olhares para nós, 
leitores, interpelando-nos para observarmos o ocorrido. Além disso, encontramos a representação conceitual, ou seja, a imagem composta por atributos, como, por exemplo, a imagem dos fios de um pisca-pisca natalino, um objeto comum familiar no final do ano. E, através desta representação, podemos inferir que esta seja a época de maior índice de incêndio na França. O plano em close-up dos membros da família é um outro recurso não verbal que nos aproxima da cena das pessoas retratadas e da cena do incêndio.

Outro fator importante nos planos da imagem é a fotografia aparecer no chão da casa incendiada. Portanto, estamos observando a imagem do alto, o que nos dá superioridade e a certeza de que se a estamos observando aquela cena, um incêndio ainda não aconteceu no nosso lar, logo, devemos tomar cuidado.

Além disso, a imagem que apresenta ao leitor a gravidade de um incêndio e suas consequências, persuade o leitor de forma imediata. Logo, houve uma intenção do destinatário em informar algo importante para aquele contexto para o leitor e, visualmente, isso só foi possível através da argumentação do não verbal para persuadir o leitor. 


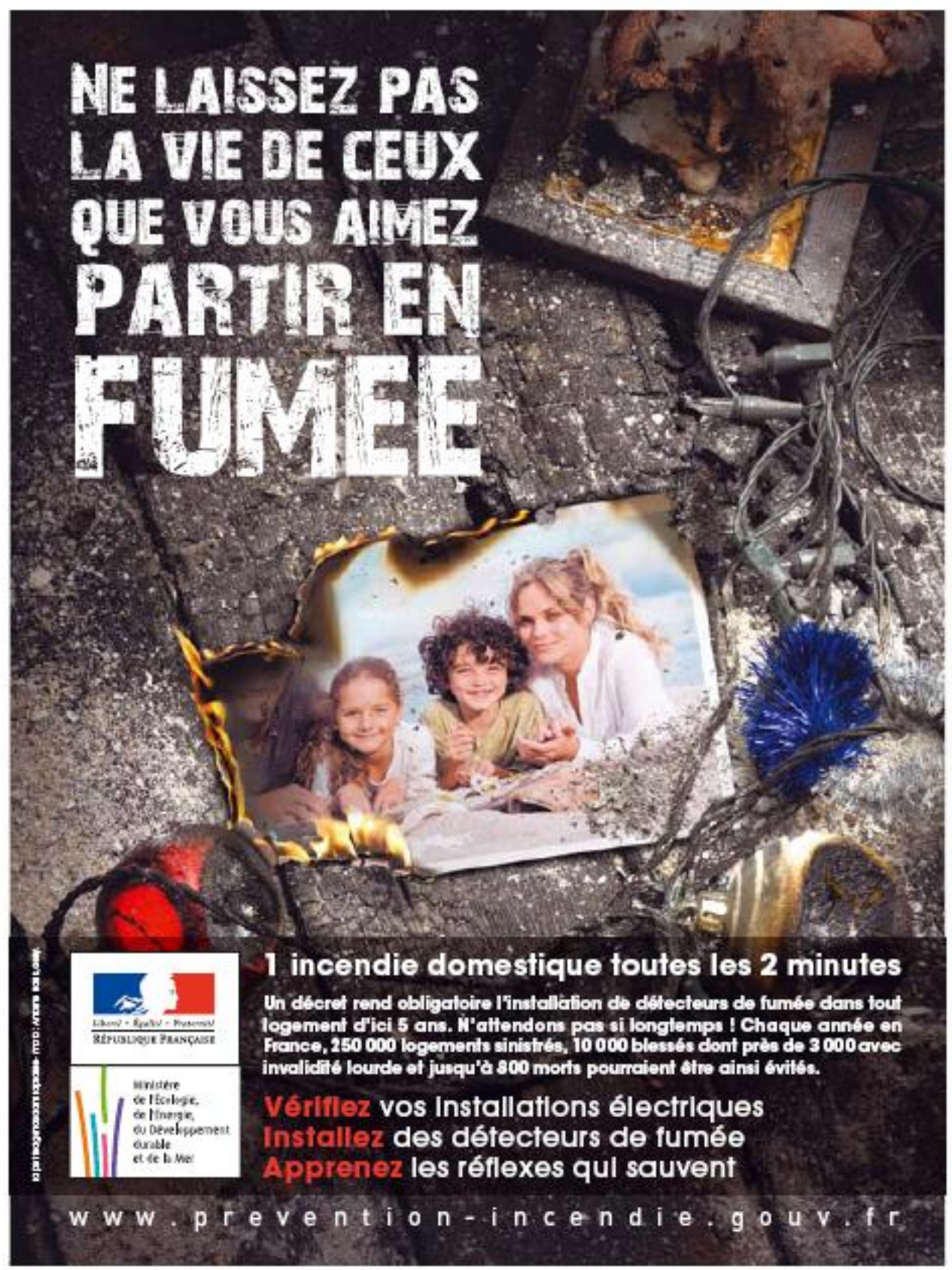

Figura 3: anúncio publicitário governamental

No entanto, o gênero anúncio publicitário também é produzido através de elementos verbais e, ao observarmos todos os elementos desse anúncio publicitário governamental, percebemos que existe também um efeito argumentativo causado pelo texto verbal. No anúncio acima, o efeito argumentativo se realiza na infraestrutura geral do texto, ou seja, no discurso e nas eventuais sequências e pode ser melhor analisado 
através dos mecanismos de textualização e dos mecanismos enunciativos que serão retomados a seguir.

No que diz respeito aos mecanismos de textualização, se observarmos o anúncio publicitário governamental do tópico anterior, encontramos os organizadores lógicos de vários tipos e com diferentes funções, que estabelecem a conexão: em "dont" (que); espaciais, em "tous les logements" (todas as moradias) e temporais, em "longtemps" (muito tempo).

Quanto à coesão nominal, encontramos, no anúncio: a) "en fumée” (em fumaça) para não utilizar duas vezes a palavra "incêndio"; b) "la vie de ceux que vous aimez" (a vida daqueles que você ama), uma expressão que é subentendida como a vida dos familiares, se conectarmos os elementos verbais aos não verbais.

Finalmente, no caso do anúncio que analisamos, a coesão verbal acontece de forma hierárquica ao utilizar o imperativo negativo em "ne laissez pas la vie de ceux que vous aimez partir en fumée" (não deixe a vida daqueles que você ama partir em fumaça), seguido de: "vérifiez...installez...apprenez" (verifique...instale...aprenda), que estão também ressaltados em vermelho.

No que diz respeito aos mecanismos enunciativos, no caso do anúncio governamental que analisamos, podemos dizer que eles são, junto com o texto não verbal, os grandes responsáveis pelo efeito argumentativo do texto, o que se enquadra no que aponta Plantin (2008) sobre o modelo dialogal da argumentação. Vejamos, portanto, alguns dos efeitos argumentativos, causados pelos mecanismos enunciativos, como as vozes, que explicitam a relação com o intertexto e as modalizações que, como dissemos, permitem revelar, de alguma forma, a questão dos afetos:

- a inserção da voz social, por meio do jogo de palavras e frases prontas, já ditas, presentes no intertexto: ne laissez pas... partir en fumée. Nesse caso, vemos a expressão "partir en fumée" sendo retomada pelo produtor do anúncio, visando a causar um efeito de argumentação

- a inserção de uma voz social, que apresentam um argumento de autoridade, já que: a) são citadas estatísticas, verossímeis, pois os números geralmente não mentem; b) é mencionado um decreto, que veicula a voz do governo para falar da obrigatoriedade da instalação do detector de fumaça.

- as modalizações deônticas, realizadas por meio do modo imperativo (que, aliás, aparecem em vermelho) para dar um conselho ou uma ordem à população para que tomem cuidado com a possibilidade de um incêndio doméstico. 
É importante salientar que o uso do imperativo ganha força, pois vem depois das estatísticas alarmantes e do discurso de autoridade, e sem essas inserções de vozes, o uso de modalizações deônticas seria enfraquecido.

Com esse exemplo, podemos compreender de que forma se dá a argumentação no anúncio apresentado, a partir do texto verbal, do texto visual e dos elementos do intertexto que eles mobilizam.

Em resumo, podemos fazer uma síntese sobre a maneira como estamos considerando a questão da argumentação nos anúncios publicitários, partindo de Bronckart (2003, 2006), mas acrescentando outros autores. Como vimos, parece-nos importante não analisar a argumentação apenas a partir da categoria da sequência argumentativa, mas considerar, também, algumas categorias linguístico-discursivas, que permitem compreender o efeito argumentativo produzido pelos anúncios, como por exemplo:

- no plano da infraestrutura textual: análise dos conteúdos temáticos, dos tipos de discurso e presença de algumas fases da sequência argumentativa; análise do efeito de verdade (CHARAUDEAU, 2007), da intertextualidade (PLANTIN, 2008) e da persuasão, composta pela argumentação e pela intencionalidade (KOCH, 1996). Com isso, visamos a identificar o efeito argumentativo global, gerado pelo anúncio;

- no plano da coerência temática, temos por objetivo por analisar o que propõe Bronckart (2003, 2006): coesão verbal, coesão nominal e conexão;

- no plano da coerência pragmática, analisaremos as modalizações, pois elas nos parecem mais apropriadas para veicular as emoções de que nos fala Plantin (2008) e as vozes, pois, no modelo dialogal proposto por Plantin (2008), elas têm grande importância para a argumentação. Temos, então, as seguintes categorias:a) a inserção de vozes, que pode ser uma categoria para analisar o empréstimo ao intertexto, como fator para argumentar. Podemos encontrar: voz do autor (provem diretamente da pessoa que produz o texto), vozes sociais (provém de outras pessoas ou de instituições humanas que se tornam vozes de autoridade) e vozes de personagens (pessoas que estão diretamente implicadas no conteúdo temático). Todas as vozes podem aparecer através de discurso direto, indireto, ou outros índices como palavras entre aspas, discurso "segundo" etc.;

b) as modalizações, que, ao nosso ver, podem ser uma categoria para a compreensão das emoções na argumentação, de que nos fala Plantin (2008): a) deônticas que consistem em julgamentos que avaliam o que é enunciado à luz dos valores sociais, atribuem um 
valor de obrigação social (por exemplo: "é necessário", “é preciso", "você deve”); modalizações apreciativas que consistem em julgamentos mais subjetivos, e apresentam os fatos como bons, estranhos, ruins (por exemplo: "o melhor de todos", "você gosta", "você odeia"). Em alguns casos, podemos ter também as modalizações lógicas, que expressam um valor de verdade, certeza, possibilidade etc.

Portanto, para compreender de que forma o gênero textual anúncio publicitário persuade o leitor, é necessário analisar a intenção e a argumentação na interação social (KOCH, 1996; BRONCKART, 2003; PLANTIN, 2008), por intermédio dos recursos linguísticos, mas, também, dos recursos visuais (KRESS; VAN LEEUWEN, 2006), conjuntamente. Recorremos aos estudos de Kress e Van Leeuwen (2006), pois, embora o modelo de análise textual do ISD tenha sido construído a partir da análise de centenas de textos empíricos, como nos aponta Bronckart (2006), como o próprio autor nos mostra, ele foi construído principalmente a partir de textos verbais. Por isso, a análise da imagem, presente em diversos gêneros textuais escritos, como folders, anúncios publicitários, manuais de instrução, gibis, charges, além dos gêneros de texto orais, não pode ser feita apenas a partir das categorias propostas pelo ISD. Por essa razão, nossa análise dos anúncios publicitários, que contém muitas imagens, será complementada através de outra base teórica, proposta por Kress e Van Leeuwen (2006), que propõem estudos sobre a gramática do design visual. A junção é pertinente, pois ela se baseia em alguns pressupostos comuns, que já foram delineados por Leal (2011).

\section{Gramática do design visual}

Como já salientamos, o fato de termos escolhido o anúncio publicitário como foco de nossa pesquisa nos levou a construir um quadro teórico coerente com esse objeto de estudo, o que implicou na complementação do modelo do ISD com uma vertente teórica que propõe a análise de textos multimodais.

Para tanto, escolhemos os estudos de Kress e Van Leeuwen (2006), pois os pressupostos que embasam o trabalho desses autores não são conflitantes com os estudos do ISD, tendo sido, inclusive, reunidos no trabalho de Leal (2011) que teve a preocupação de centrar sua pesquisa na relação entre o texto verbal e o não verbal. 
Kress e Van Leuween (2001) justificam a necessidade de uma análise que leve em conta também elementos não verbais, pois mostram que cada vez mais a monomodalidade dá lugar à multimodalidade, em todos os setores, não apenas na esfera artística. Segundo os autores Kress e Van Leeuwen (2001, p.01):

\begin{abstract}
"More recently this dominance of monomodality has begun to reverse. Not only the mass media, the pages of magazines and comic strips for example, but also the documents produced by corporations, universities, government departments etc, have acquired colour illustrations and sophisticated layout and typography. And not only the cinema and the semiotically exuberant performances and videos of popular music, but also the avant-gardes of the 'high culture' arts have begun to use an increasing variety of materials and to cross the boundaries between the various art, design and performance disciplines, towards multimodal gesamtkunstwerke, multimodal events, and so on"11.
\end{abstract}

Kress e Van Leeuwen (2001) nos apresentam a multimodalidade como os novos textos dessa era digital e afirmam que até os documentos do governo tornaram-se multimodais com a inserção de cores e layouts sofisticados.

Leal (2011, p.342), em sua tese, afirma que não é possível ignorar a enorme presença da imagem na organização textual, sobretudo no caso do gênero textual com o qual trabalhou: as histórias em quadrinhos. Por isso, diante da necessidade de encontrar elementos de estudo capazes de formularem um quadro metodológico que pudesse aprofundar esse fenômeno da sociedade global, Leal (2011) conseguiu unir as categorias de análise do ISD e da GDV em um quadro metodológico o qual o nomeou de semiótica sociointeracional.

\footnotetext{
11 "Mais recentemente, esse domínio de monomodalidade começou a mudar. Não só os meios de comunicação, as páginas de revistas e as histórias em quadrinhos, por exemplo, mas também os documentos produzidos por empresas, universidades, departamentos do governo e etc adquiriram ilustrações a cores e layout e tipografia sofisticados. E não só o cinema e as performances semioticamente exuberantes e os vídeos de música popular, mas também os vanguardista das artes de "alta cultura" começaram a usar uma crescente variedade de materiais e cruzar as fronteiras entre várias artes, design e disciplinas de performance, em direção ao multimodal gesamtkunstwerke, eventos multimodais, e assim por diante." (Tradução nossa) (2001, p.01)
} 
Para os autores supracitados, Kress e Van Leeuwen (2006), a imagem também possui uma gramática, ou seja, assim como as palavras, a imagem possui suas regras e pode ser, por exemplo, conotativa, denotativa, irônica. Para justificar tal afirmação, Kress e Van Leeuwen (2006, p.01) apoiam-se no linguista Halliday para demonstrar a semelhança entre imagem e léxico:

\begin{abstract}
“"Grammar goes beyond formal rules of correctness. It is a means of representing patterns of experience (...) it enables human beings to build a mental picture of reality, to make sense of their experience of what goes on around them and inside them.' (HALLIDAY, 1985, p.101) The same is true for the 'grammar of visual design'.",
\end{abstract}

$\mathrm{Ou}$ seja, como as estruturas linguísticas, as estruturas visuais possuem uma interpretação particular sobre as experiências e as formas da interação social.

Além disso, Kress e Van Leeuwen (2006, p. 02) afirmam que, apesar das diferentes maneiras de representar as "coisas", tais representações estão ligadas a uma cultura e a uma história específicas: "And the way some things can, for instance, be 'said' either visually or verbally, others only visually, again others only verbally, is also culturally and historically specific" ${ }^{13}$.

Krees e Van Leeuwen (2006, p.42) adotaram pressupostos da Linguística Sistêmico-Funcional proposta por Michael Halliday (1985) para analisar o componente visual de um texto, baseando-se no conceito de metafunção: as metafunções ideacional, interpessoal e textual. Para os autores, assim como para Halliday (1985), o mundo é semioticamente representável e as metafunções são capazes de representar os objetos e suas relações no mundo. A metafunção ideacional, por exemplo, pode ser representada por vetores que explicitam o envolvimento entre dois objetos, ou seja, evidenciam o processo de interação. A metafunção interpessoal pode apresentar a relação entre o

\footnotetext{
12 A gramática vai além das regras formais de correção. É um meio de representar os padrões de experiência (...) que permite ao ser humano a construção de uma imagem mental da realidade, para dar sentido a sua experiência, sobre o que acontece ao redor e dentro dela. '(HALLIDAY, 1985, p.101).O mesmo é verdadeiro para a "gramática do design visual" (2006, p.01) (Tradução nossa).

${ }^{13} \mathrm{E}$ a forma como algumas coisas podem, por exemplo, ser 'ditas' tanto visualmente quanto verbalmente, outras podem ser 'ditas' somente visualmente e outras somente verbalmente, é também culturalmente e historicamente específica. (Tradução nossa).
} 
produtor e o recebedor de um sinal, ou seja, essa metafunção trata da relação entre o produtor e o meio social, pois estabelece um papel comunicativo. Por outro lado, a metafunção textual representa a relação entre texto e imagem, ou seja, trata-se da realidade semiótica, das significações das relações entre direita e esquerda, ou seja, do posicionamento dos textos não verbais e dos textos verbais no gênero textual.

Portanto, como já salientamos, temos como base o ISD, estudo que foi construído principalmente a partir da análise de textos verbais, com objetivos didáticos. No entanto, por trabalharmos com o gênero textual anúncio publicitário, necessitamos de uma base teórica que leve em conta textos multimodais. Por isso, optamos por utilizar a GDV, já que outros estudiosos do ISD já haviam proposto uma união das teorias, também com fins didáticos (LEAL, 2011).

Segundo a GDV, as relações entre texto verbal e imagem podem acontecer semanticamente, ou seja, um gênero textual como o anúncio publicitário pode ser compreendido ao relacionar o texto escrito do anúncio à imagem, através de uma relação de complementaridade. Essa é a perspectiva que adotam alguns teóricos. No entanto, a GDV propõe que as relações entre texto verbal e imagem sejam compreendidas semioticamente através das representações dos objetos desse anúncio e suas relações no mundo. Essas representações só podem ser compreendidas através da relação entre os participantes e os objetos das imagens. Por isso, para analisar o texto não verbal, trataremos o termo "participante", escolhido por Kress e Van Leeuwen (2006), e suas relações com os outros elementos da imagem.

\subsection{Participantes da Gramática do Design Visual}

Na seção anterior, explicamos que podemos analisar semanticamente as relações entre texto escrito e imagem. Mas, os elementos encontrados na imagem devem ser analisados semioticamente, pois as pessoas, os objetos e/ou os lugares envolvidos no ato comunicativo (KRESS; VAN LEEUWEN, 2006, p.47) podem produzir diferentes representações. Eles são chamados de participantes. 
Para Kress e Van Leeuwen (2006), o ato comunicativo pode conter dois tipos de participantes: os representados e os interativos. Os participantes representados são seres animados ou inanimados, apresentados no interior dos textos visuais, enquanto que os participantes interativos são o produtor e o receptor de um texto oral ou escrito, são aqueles que falam, ouvem, escrevem e leem o texto. Leal (2011, p.177), com base em Kress e Van Leeuwen (2006), afirma que os participantes representados, aqueles que são interpretados pelas imagens, são o assunto mais importante durante a análise do "ato semiótico"; contudo, a relação entre os dois tipos de participantes pode ser mais complexa, ou seja, os participantes interativos - produtores e receptores - podem eles mesmos ser representados pela imagem.

Esses participantes aparecem em imagens estáticas ou não dinâmicas, como em uma fotografia, e em imagens dinâmicas, como em um filme. Como escolhemos o gênero textual anúncio publicitário, trabalharemos somente com imagens estáticas e não dinâmicas.

A partir dos tipos de participantes, podemos encontrar três tipos de relações que serão apresentadas nas seções a seguir: a função representacional - entre participantes representados, a função interacional - entre participantes interativos, e a função composicional - entre participantes interativos e representados. Mas, antes de apresentarmos cada tipo de função, é importante expor o modelo de comunicação proposto por Shannon e Weaver (1949) e utilizado inicialmente por Kress e Van Leeuwen (2006) para explicar as bases da análise dos participantes e dos processos que acontecem em cada tipo de relação.

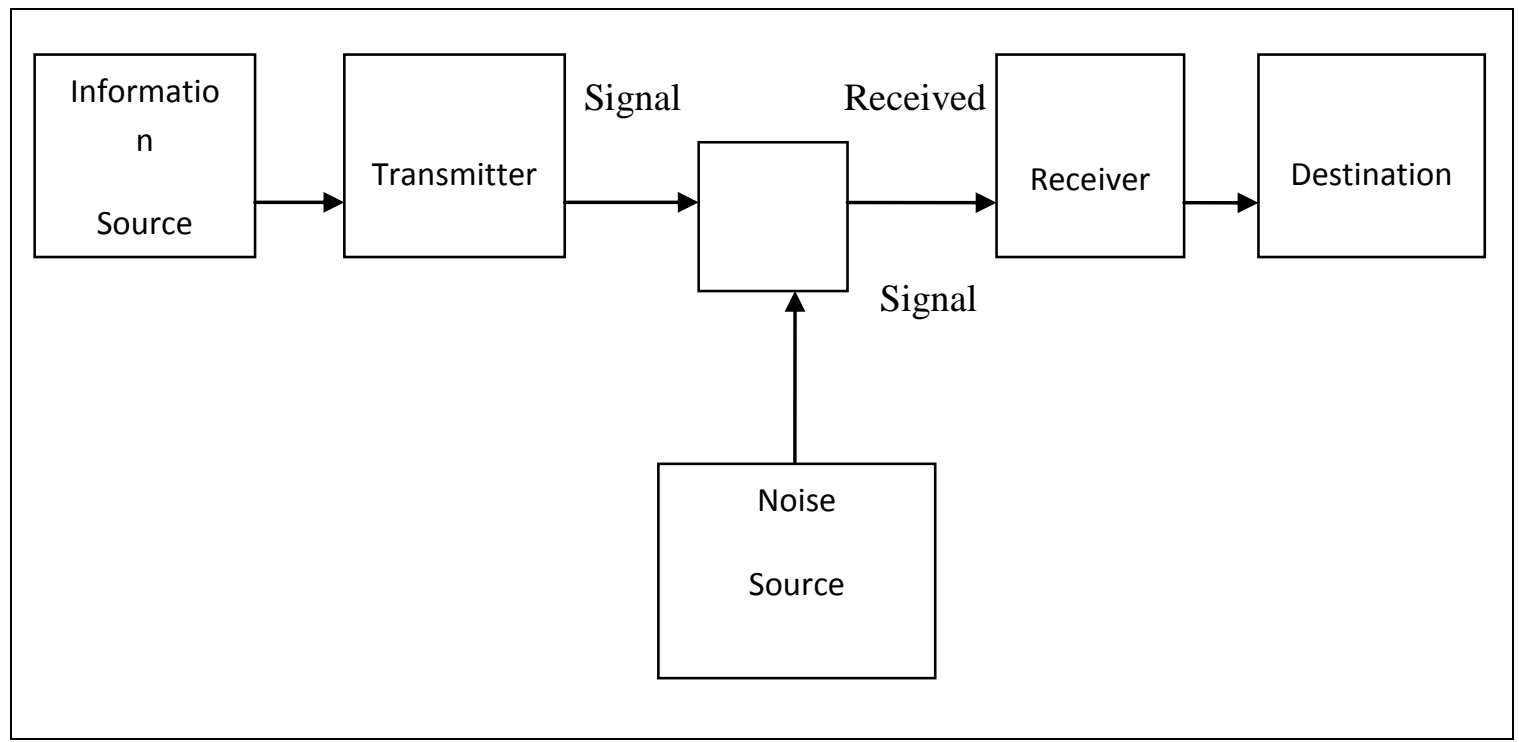

Figura 4: Shannon and Weaver's communication model (1949) (Reproduzido de KRESS; VAN LEEUWEN, 2006, p.48) 
Segundo Kress e Van Leeuwen (2006, p.48), as caixas apresentadas no esquema acima, no papel de emissor/receptor, representam os participantes - pessoas e/ou objetos - enquanto que as setas representam os processos de relação entre os participantes, ou seja, as setas representam a direção da ação comunicativa. $\mathrm{Ou}$, ainda, se pensarmos em um texto escrito, as caixas podem ser consideradas "os nomes" e as setas "os verbos" - pois realizam os processos: enviar/transmitir.

Esse famoso modelo de Shannon e Weaver (1949), para a análise da comunicação, é limitado, como já foi demonstrado por inúmeros autores. Kress e Van Leeuwen (2006) também expõem essa limitação ao justificarem que a análise de uma imagem naturalista ou um diagrama não seria possível somente com esse modelo, assim como não o é um texto verbal.

Sendo assim, para complementar esse modelo de análise, Kress e Van Leeuwen (2006, p.49) se basearam, também, nas teorias de Arnheim (1974, 1982), na qual os participantes são considerados como massas e os processos como vetores, e na semiótica funcional, de Halliday $(1978,1985)$, que nomeia o participante como um ator e a ação como um objetivo.

Leal (2011) também salienta que Kress e Van Leeuwen (2006) fazem uma analogia com a língua, através do modelo proposto por Shannon e Weaver (1949), para esclarecer que as caixas seriam consideradas como os nomes, enquanto as setas seriam os verbos (que realizam os processos de enviar/transmitir), sendo que a junção desses dois elementos formaria a oração. O mesmo processo seria semelhante nas imagens.

Da mesma forma que construímos as orações através de verbos e nomes, observaremos nas próximas seções a construção das ações comunicacionais, através de funções compostas por participantes e/ou objetos: funções representacional, interacional e composicional.

\subsection{Função representacional}

A função representacional, citada anteriormente como uma relação entre os participantes representados, funcionará como indicadora daquilo que está sendo apresentado na cena comunicativa, das relações construídas entre os elementos apresentados e das circunstâncias de como esses elementos são apresentados. Kress e Van Leeuwen (2006) relacionam a função representacional à metafunção ideacional de 
Halliday (1994), já que, por meio dessa função, o falante e o ouvinte conseguem organizar e trazer para a língua as suas experiências do mundo real; isso também inclui o mundo psicológico, ou seja, é por meio da metafunção ideacional que conseguimos expressar nossas percepções do mundo.

Leal (2011, p.179) define a função representacional de Kress e Van Leeuwen (2006) como uma habilidade do sistema semiótico de uma imagem que serve para representar os objetos e as suas relações no mundo através de um sistema representacional dividido em dois tipos: as representações narrativas (2.2.1) e as representações conceituais (2.2.2).

Podemos observar, nas duas imagens abaixo, que em uma delas existe uma ação, algo acontece, um participante indica com as suas mãos que existe um movimento na cena, ou seja, trata-se de uma representação narrativa. Enquanto que, na outra imagem, é possível identificar um conceito através de um objeto, sem que existam vetores indicativos de ações, ou seja, trata-se de uma representação conceitual, como podemos identificar através do trem do metrô ou de sua entrada.
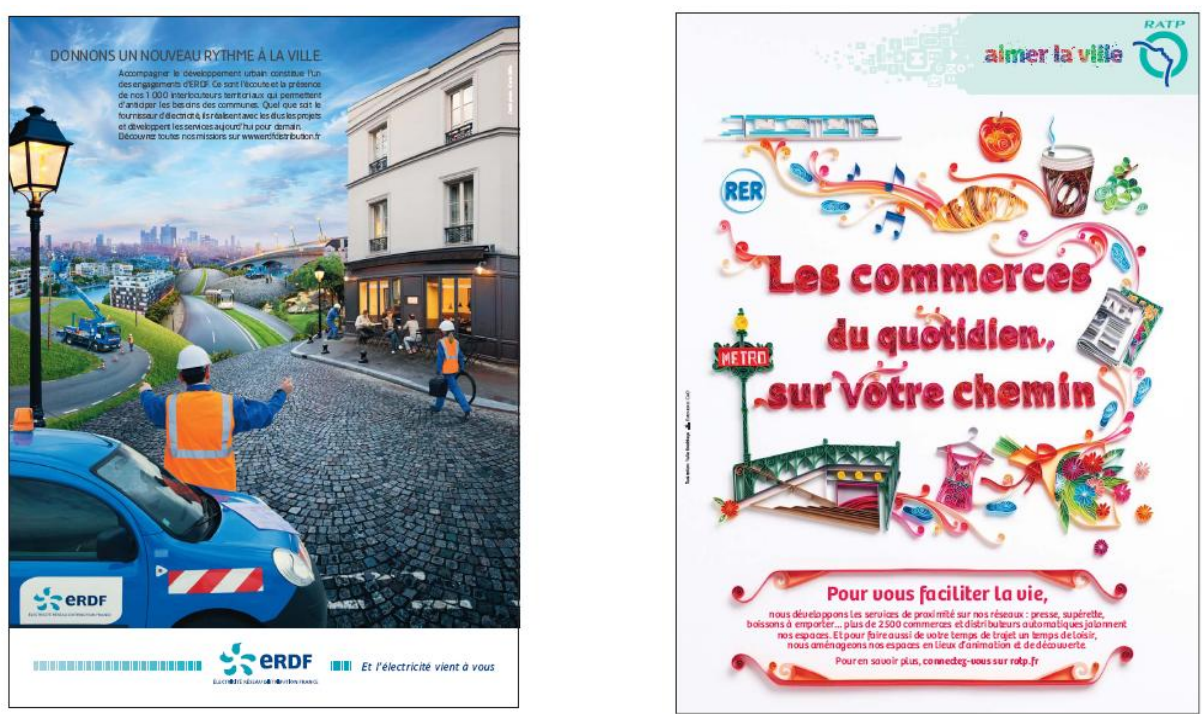

Figura 5: imagens das representações narrativa e conceitual

Para analisar as representações, seguindo Kress e Van Leeuwen (2006), identificaremos os participantes, atores e objetivos da seguinte forma:

a) participantes - se deles não emanar o vetor;

b) atores - se deles emanar o vetor;

c) objetivos - se do participante não emanar um vetor, mas o receber. 


\subsubsection{Representações narrativas}

As representações narrativas são identificadas pelas setas, segundo Kress e Van Leeuwen (2006, p.59), pois, "when participants are connected by a vector, they are represented as doing something to or for each other" ${ }^{\prime 14}$, ou seja, os vetores que emanam de um participante apontam para algum objeto ou outro participante, por isso funcionam como verbos que indicam uma ação na imagem.

Os vetores podem ser simbolizados por linhas que emanam de objetos, de extremidades (como um dedo ao apontarmos um objeto) ou de um olhar e atingem um objetivo ou meta. Portanto, a partir do vetor, podemos descobrir a quantidade de participantes, a direção da ação e o objetivo dessa ação. Segundo Kress e Van Leeuwen (2006, p.74), as representações narrativas podem ser divididas entre processos - de ação, de reação, verbal, mental e de conversão - e circunstâncias - cenário, significação e acompanhamento.

Os autores classificaram o processo de ação em transacional e não transacional, sendo transacional quando houver pelo menos um ator e qualquer vetor que não emane do olhar, mas que alcance um objetivo. O processo de ação transacional pode ser unidirecional quando há um só ator ou pode, ainda, com dois atores, ser classificado em bidirecional e, nesse caso, eles fazem o papel de interatores.

A figura a seguir é um anúncio publicitário da $\operatorname{ERDF}^{15}$ e servirá como exemplo de representação narrativa classificada em processo de ação transacional unidirecional, pois os braços do participante em primeiro plano são os vetores que indicam o trabalho da ERDF nas ruas francesas.

\footnotetext{
14 “Quando os participantes são conectados por um vetor, eles são representados fazendo alguma coisa para ou por cada um” (Tradução nossa).

${ }^{15}$ ERDF é a sigla para "Électricité Réseau Distribution France ». Portanto, trata-se do anúncio publicitário da rede de distribuição de eletricidade na França.
} 


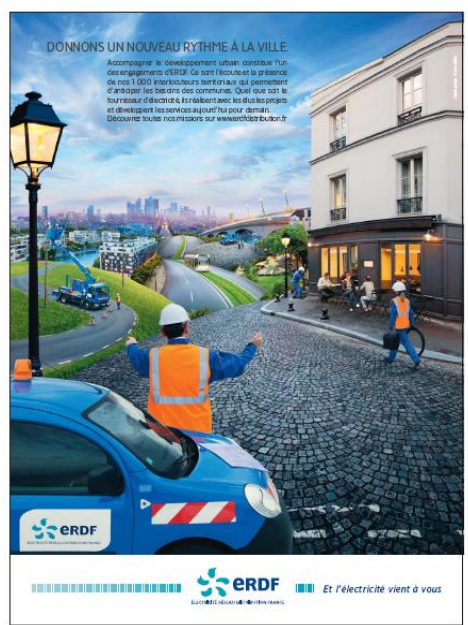

Figura 6: anúncio publicitário da ERDF

O processo de ação não transacional acontece quando a imagem apresentar um só ator, sem que consigamos identificar o objetivo na cena, ou seja, quando a chegada do vetor não é direcionada a outro participante, mas a qualquer elemento que não esteja em cena. Outro tipo de processo de ação não transacional é a presença do objetivo e/ou dos participantes sem que possamos visualizar o ator e, portanto, seu vetor. Esse processo de ação não transacional da imagem pode ser equivalente aos verbos intransitivos da linguagem verbal ${ }^{16}$.

Um exemplo de processo de ação não transacional aparece através dos personagens da animação Toy Story, pois não conseguimos identificar o objetivo da cena, todos estão olhando para algo não identificável.

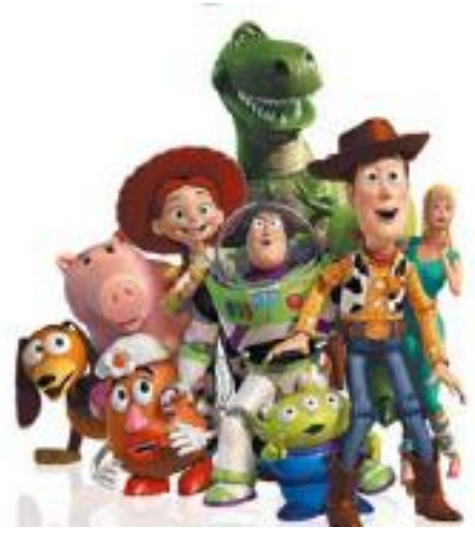

Figura 7: imagens dos personagens da animação Toy Story

\footnotetext{
${ }^{16}$ Essa semelhança é citada por Kress e Van Leeuwen (2006) que acreditam facilitar o entendimento do processo na imagem, mas, sempre com base em Halliday (1994 [1985]) que ressalta a possibilidade de um verbo intransitivo do inglês se tornar transitivo em outra língua.
} 
Os processos de reação acontecem quando a ação da imagem é manifestada a partir do olhar de um participante para outro Neste caso, se imaginarmos dois participantes, chamaremos de reator o participante do qual emana um vetor do olhar por isso esse participante deve ser necessariamente animal ou humano - e de fenômeno esse olhar que atinge um objetivo humano ou animal, pois esse objetivo também deve possuir uma expressão facial.

Da mesma forma que o processo de ação, o processo de reação pode ser transacional, quando o olhar do reator nos possibilita de visualizar o fenômeno ou não transacional quando não conseguimos ver o fenômeno da reação.

$\mathrm{Na}$ imagem a seguir podemos observar uma representação narrativa através de um processo de reação transacional, pois existem dois vetores "olhar", sendo o primeiro vetor do homem, que está trabalhando nas novas energias, e o segundo vetor da mulher, que recebe essa nova energia e a coloca em sua empresa. Ambos os participantes apresentam a reação através de seus olhares entre si e apresentam o objetivo dessa interação através dos vetores "mãos", ou seja, as mãos dos participantes pegam um bambu, uma nova forma de energia para os empresários.

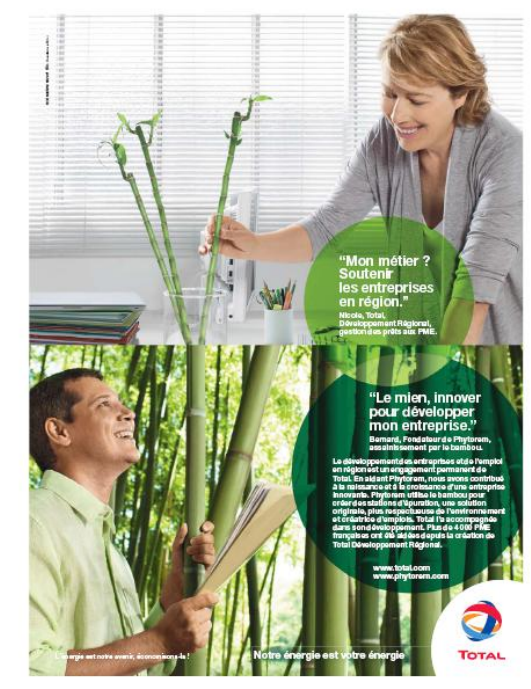

Figura 8: anúncio publicitário da empresa Total

Outro processo identificado por Kress e Van Leeuwen (2006) é o processo verbal, que ocorre através de balões de fala ou de pensamento, como podemos encontrar em histórias em quadrinhos. Este processo precisa de falas e o participante é chamado de dizente, enquanto sua fala é chamada de enunciado. 
O processo mental é parecido com o processo verbal, em que podemos encontrar balões de pensamentos, mas o processo mental não apresenta enunciado, pois são os sentimentos advindos do pensamento, classificado como fenômeno, e expressados pelo participante chamado de experienciador. Kress e Van Leeuwen (2006, p.77) designam alguns processos e alguns verbos referentes ao processo mental: o processo de percepção - ver, ouvir; o processo de afeição - gostar, desejar; e o processo de cognição - saber, pensar, acreditar, entre outros.

Por fim, o processo de conversão acontece quando um dos participantes, durante o processo de ação, é conjuntamente ator e objetivo (meta) de outro ator. Ainda no processo de reação, podemos encontrar o processo de conversão, ou seja, quando um dos participantes é, ao mesmo tempo, o reator e o fenômeno de um outro participante. Neste caso, o participante que recebe o vetor, também o transmite, ou seja, o participante possui duas funções, como por exemplo, o que acontece nos ciclos aprendidos em biologia em que o homem é, ao mesmo tempo, hospedeiro e transmissor. Essa dupla função pode ser visualizada, no esquema proposto por Kress e Van Leeuwen (2006, p.69), a seguir:

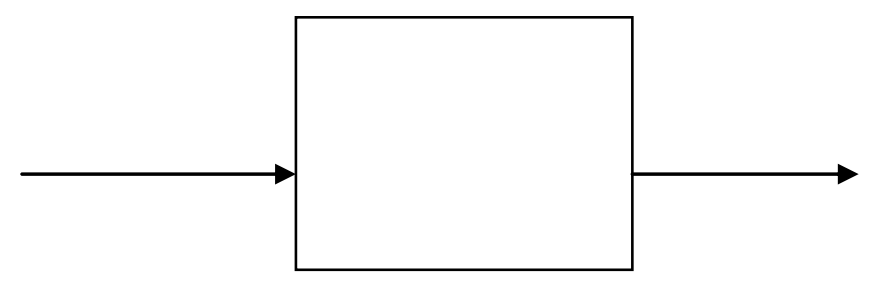

Kress e Van Leeuwen (2006, p.69)

Figura 9: $O$ processo de conversão

As representações narrativas também podem ser encontradas em imagens que contém outros elementos, como por exemplo, participantes secundários. Essas imagens são conhecidas como circunstâncias, quando participantes que não entram no esquema principal da ação, dos quais não emanam vetores, servem para algumas representações da cena, ou seja, para fornecer informações adicionais. As circunstâncias podem ser reconhecidas a partir do cenário, ou seja, através da ambientação da imagem, quando há um contraste entre o primeiro plano e o plano de fundo. O cenário pode ser considerado quando os participantes estão em um primeiro plano e sobrepõem-se à ambientação; quando existe a visualização do cenário com poucos detalhes, portanto, sem ser o foco 
principal; quando não há cenário, ou seja, o fundo é totalmente de uma cor; ou quando o cenário é totalmente evidente, como em uma fotografia.

Além do cenário, outro tipo de circunstância que pode aparecer no processo de ação, ou seja, na representação narrativa, é alguma ferramenta que transmita um significado. Por exemplo, em uma imagem com dois participantes conversando, consideramos o diálogo como a ação e as circunstâncias são os gestos que fazemos ao manter uma conversação, ou seja, os gestos são significativos no processo de ação.

Por fim, o acompanhamento é considerado como outra circunstância e ocorre quando qualquer participante, que não seja o ator e que não tenha relação vetorial com outros participantes, aparece na imagem. Esse participante não pode ser considerado um atributo simbólico, pois aparece em cena como um figurante.

\subsubsection{Representações conceituais}

As representações conceituais são as caracterizações dos participantes em relação a sua classificação, a sua estrutura e a sua simbologia. Logo, não presenciamos vetores nesse campo. Elas podem ser classificadas como classificacional, analítica e simbólica.

A representação conceitual classificacional diz respeito ao grupo do qual o participante faz parte, ou seja, os participantes são definidos de acordo com as características do seu grupo. Segundo Kress e Van Leeuwen (2006), a classificação pode ser chamada de taxionômica fechada, quando há mais de um elemento na imagem e quando há simetria entre eles, ou seja, quando os elementos ocupam espaços simétricos e estão estruturados verticalmente ou horizontalmente. Portanto, não há nenhum elemento que apresente algum tipo de hierarquização, os participantes aparecem dispostos simetricamente e sem contraposição entre bem e mal ou melhor e pior, por exemplo. No entanto, a classificação taxionômica aberta é uma estrutura na qual os objetos são colocados de forma a serem classificados hierarquicamente, como em um pódio ou em uma estrutura de árvore. Por exemplo, quando construímos uma árvore genealógica, apresentamos os elementos de mesmo tamanho e de forma organizada como na taxionomia fechada, entretanto, neste caso, existe uma única ordem ou classificação para a construção dessa árvore (filhos, pais, avós, bisavós, tataravós). 
Geralmente, o fundo da imagem, de ambas as taxionomias, é neutro, pois não interfere na ordem ou classificação existente no esquema.

O processo analítico é a representação da relação entre os participantes do processo e pode envolver dois tipos de participantes, o portador, ou seja, o participante que representa o todo; e os participantes com atributos possessivos, ou seja, aqueles que representam a parte. Por exemplo, a imagem de um homem vestido comumente poderia ser qualquer homem, portanto, esse participante seria o portador, pois representa todos os homens. Mas, se o homem da imagem estivesse vestido com um jaleco e possuísse um estetoscópio, significa que o participante tem atributos possessivos e ele representa parte do todo, pois se trata de um médico ou de um enfermeiro.

Além da relação entre os participantes, o processo analítico pode ser considerado estruturado ou desestruturado. O processo analítico estruturado acontece quando encontramos descrições que especificam as relações entre as partes e o todo, como no exemplo do homem de jaleco com um estetoscópio, pois ambos objetos rotulam o participante. Além das marcas de um grupo, as marcas podem ser rótulos temporais ou espaciais. No entanto, o processo analítico desestruturado acontece quando não há especificidade quanto às relações entre as partes e o todo, como no exemplo de uma imagem com dois homens comuns, pois ambos participantes nos fará percorrer diferentes caminhos para relacionar o processo analítico e o portador.

O processo simbólico pode ser apresentado ou identificado através da análise do realce ou da nuance do posicionamento dos participantes no texto não verbal. Logo, o realce encontrado na simbologia pode ser analisado a partir do exagero ao retratar o tamanho de um participante, o olhar diferente ou um gesto do mesmo, que possa representar valores culturais, por exemplo. E, a nuance encontrada na simbologia pode ser analisada através da sugestão da imagem, que pode ser um simples contorno no portador ou um traço que possamos identificá-lo como portador. No entanto, seja através do realce ou da nuance, é nesse processo simbólico que identificamos o portador em sua essência, ou seja, identificamos a sua identidade.

No quadro abaixo, vemos uma síntese das representações conceituais, como explicamos nos parágrafos anteriores. 
Quadro 4: Representações conceituais

Representações Conceituais $\left\{\begin{array}{l}\text { Classificacional } \\ \text { Analítico } \\ \text { Simbólico }\end{array}\right.$

\subsection{Função interativa}

A função interativa, como a representativa, analisa as interações. Mas, enquanto a função representativa analisa as interações entre pessoas e coisas encontradas em uma imagem, a função interativa analisa as interações entre o produtor e o observador da imagem. Assim como a metafunção interpessoal permite ao falante expressar sua opinião, ou seja, ser participante de uma ação comunicacional criando e mantendo as relações sociais, a função interativa expressa uma opinião, a visão de mundo dos produtores.

Da mesma forma que a metafunção interpessoal apresenta três fatores linguísticos, envolvimento, valoração e negociação, a função interativa apresenta três fatores não verbais: o contato, a distância social e a perspectiva. Além disso, Kress e Van Leeuwen (2006) acrescentaram um quarto fator: a modalidade, que será discutida adiante.

O contato de uma estrutura não verbal pode ser dividido em exposição/oferta e interpelação/demanda. A exposição/oferta é analisada através do olhar do ator, desde que o ator não olhe para o leitor, como se fosse um filme. A interpelação/demanda também é analisada através do olhar, mas acontece quando o participante olha para o leitor, ou seja, quando o leitor é convidado a interagir através de uma relação imaginária: - "The participant's gaze (and the gesture, if present) demands something from the viewer, demands that the viewer enter into some kind of imaginary relation with him or her"17 (KRESS; VAN LEEUWEN, 2006, p.118) - sendo esta relação analisada através da expressão do participante: caso a expressão seja rude, o leitor pode imaginar que fez algo errado ou que deve ficar distante, por exemplo.

17 “O olhar do participante (e o gesto, se presente) exige algo do espectador, exige que o espectador entrar em algum tipo de relação imaginária com ele ou ela" (tradução nossa) 
Portanto, o contato através da interpelação/demanda ou exposição/oferta pode sugerir diferentes graus de envolvimento, seja como em um filme, em que somos espectadores, ou como em um jornal televisivo, em que somos colocados na interação, pois o vetor do olhar do jornalista nos encontra diretamente.

O contato também pode ser analisado através da distância social. Kress e Van Leeuwen (2006, p.125) justificam a análise da distância social com base nas nossas relações pessoais, pois a distância que nós mantemos das outras pessoas depende totalmente da nossa relação social com essas pessoas. Assim, a distância social depende da relação social e é identificado por três planos: plano fechado, plano médio e plano geral.

O plano fechado é o de menor distanciamento, aquele mais próximo do leitor como acontece em imagens close-ups. Em seguida, o plano médio possui um maior distanciamento e pode ser chamado de plano americano por causa do corte da imagem na altura da cintura ou do joelho do participante. Ao mostrar um plano como um todo, uma imagem pode ser totalmente impessoal, o que Kress e Van Leeuwen (2006) chamam de plano geral.

O terceiro fator da função interativa apresentado por Kress e Van Leeuwen (2006) é a perspectiva. Esse fator analisa o envolvimento e o poder do participante em relação ao observador e pode ser explicado pelos inúmeros ângulos de uma imagem. A perspectiva pode ser classificada como subjetiva ou objetiva.

A perspectiva subjetiva é identificada através dos ângulos horizontais - pelos quais identificamos o envolvimento entre participante e observador - e dos ângulos verticais - que identificam a relação de poder. Os ângulos horizontais são divididos em dois: ângulo frontal - ângulo de maior envolvimento, pois ele apresenta a igualdade entre participante e observador, como se ambos fizessem parte do mesmo mundo - e ângulo oblíquo - de maior distanciamento, ou seja, aquilo que é visto não faz parte do mundo do observador. Os ângulos verticais são divididos em três tipos: ângulo alto em que o observador detém o poder, como se esse fosse o olhar de Deus, ou seja, de cima para baixo; ângulo baixo - a partir do qual o participante detém o poder, pois ele está acima do observador -; e o ângulo do nível do olhar, no qual encontramos a igualdade de poder, o participante e o observador interagem de igual para igual.

Kress e Van Leeuwen (2006) explicam que, na perspectiva subjetiva, pode existir uma imagem e dois ângulos, como, um ângulo frontal e oblíquo, pois o envolvimento do participante e do observador é variável. 
Enquanto a perspectiva subjetiva apresenta ângulos, a perspectiva objetiva não os apresenta. E, de forma organizada e estrutural, a perspectiva objetiva exibe uma a ação como, por exemplo, podemos citar os pictogramas, ou seja, as placas de trânsito e os manuais com os "modos de fazer". Ou, ainda, podemos citar os mapas e os diagramas, que não são orientadores de uma ação como a placa de trânsito, mas direcionam para o conhecimento em uma perspectiva objetiva.

O quarto fator da perspectiva interacional é a modalidade, ou seja, a confiança do observador na verdade representada pela imagem. A modalidade pode ser analisada por seis marcadores: a cor, a contextualização, a representação, a profundidade, a iluminação e o brilho.

Sendo o marcador cor correspondente à utilização da cor - observação da saturação das cores seja ela máxima ou mínima, como o preto e o branco -, a diferenciação das cores - se existe uma diversidade de cores -, e a modulação dela escala que inicia na sombra e vai até a cor plena. O segundo marcador, a contextualização, é o marcador da cena visual, ou seja, a observação se há ausência de cenário ou se o cenário é bem definido e detalhado. A representação avalia os detalhes pictóricos que funcionam em uma escala entre abstração total e máxima representação. O quarto marcador, a profundidade, pode ser escalonado entre perspectiva máxima de profundeza ou ausência total dela - achatamento. A iluminação pode ser grande ou ausente e se a iluminação de uma imagem não acontecer totalmente, mas em uma parte da imagem, o produtor faz uso desse marcador para destacar o seu objetivo. O brilho é o último marcador da modalidade da cor e diz respeito à variação dos tons de cinza, através da qual também pode colocar em destaque uma parte da imagem, assim como observamos no marcador iluminação.

O quadro a seguir demonstra a função interativa através de um esquema para a análise das interações entre o produtor e o observador da imagem. 
Quadro 5: Função interativa

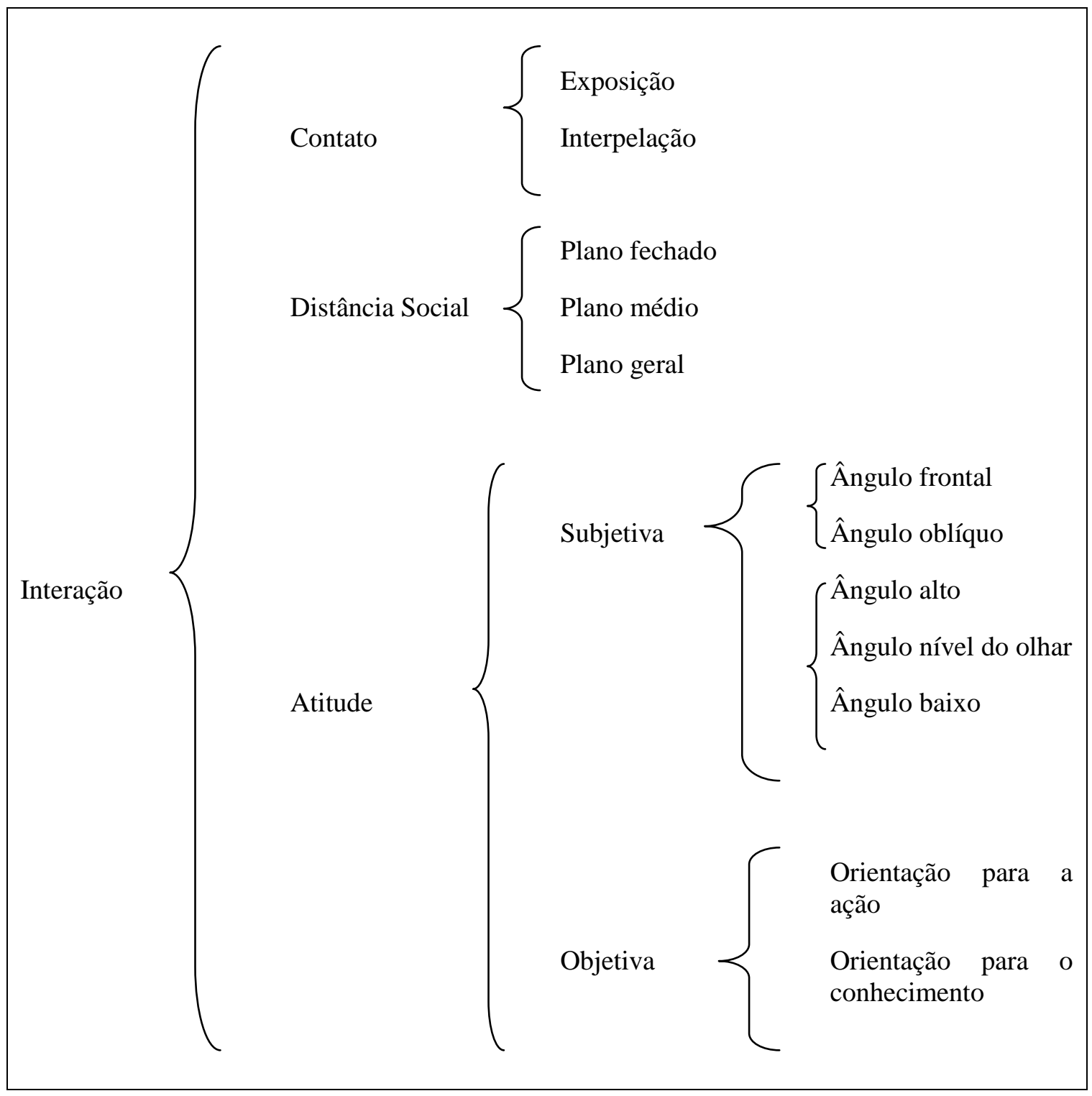

(Adaptado de KRESS; VAN LEEUWEN, 2006, p.149)

Portanto, como observamos na teoria de Kress e Van Leeuwen (2006), a interação acontece através do contato (por exposição ou interpelação), da distância social (através dos planos fechado, médio e geral) e da atitude (subjetiva ou objetiva).

\subsection{Função composicional}

A função composicional une as funções representacional e interacional. Ela averigua como os elementos da função representacional se conectam aos elementos da função interacional. Kress e Van Leeuwen (2006) correlacionam a função composicional à metafunção textual da gramática sistêmico-funcional proposta por 
Halliday (1994[1985]). Segundo esse autor, a metafunção textual fornece elementos para a análise do uso da linguagem na organização do texto oral ou escrito. Desse modo, a função composicional é capaz de analisar os diferentes elementos relacionados em uma imagem. Segundo Kress e Van Leeuwen (2006), a disposição, no texto, dos elementos verbais e não verbais, forma uma integração que eles denominam "multimodalidade".

Para Kress e Van Leeuwen (2006, p.177), os elementos verbais e não verbais possuem uma lógica quando integrados: "the integration of different semiotic modes is the work of an overarching code whose rules and meanings provide the multimodal text with the logic of its integration" $" 18$.

Muitos outros autores também apontam a integração dos elementos verbais e não verbais. Dionísio (2005, p.141) observa, inclusive, que o próprio texto verbal possui aspectos visuais:

"Importante mencionar que ao conceber os gêneros como
multimodais, não estou atrelando aos aspectos visuais
meramente a fotografias, telas de pinturas, desenhos,
caricaturas, por exemplo, mas também à própria disposição
gráfica do texto no papel ou na tela do computador"

A integração entre imagem e texto pode acontecer de duas formas, segundo Kress e Van Leeuwen (2006, p.177): em composição espacial - na qual texto e imagem são copresentes, como anúncios publicitários, pinturas, capas de revistas - e em composição temporal - na qual imagem e tempo são copresentes, como os diversos vídeos, as danças, os filmes. Em nosso caso, analisaremos o anúncio publicitário, ou seja, a imagem fixa, de composição espacial.

Ambas as composições - espacial e temporal - podem ser analisadas através do valor da informação, da saliência e do emolduramento, visto que as imagens não estáticas devem ser pausadas para a análise de cada momento. No caso do valor da informação, ele pode ser centrado - portanto, no centro da imagem, o elemento ou os elementos ganham destaque, sendo ele(s) o centro da informação e deixando os outros elementos que podem ser encontrados nas margens com menor valor. Esses elementos

\footnotetext{
18 "A integração de diferentes modos semióticos é o trabalho de um código abrangente cujas regras e significados fornecem ao texto multimodal a lógica dessa integração" (tradução nossa)
} 
que não estão no centro, são subordinados ao(s) elemento(s) do centro, porém em menor destaque - ou polarizados - ou seja, distribuídos por toda a imagem.

O valor da informação em modo polarizado pode ser analisado da seguinte forma, a partir de Kress e Van Leeuwen (2006): os elementos que aparecem à esquerda da imagem são os elementos dados pelo produtor, mas que já eram de conhecimento dos observadores, trata-se da verdade já conhecida; os elementos apresentados à direita tratam das informações novas, aquelas que os observadores não conheciam. Os elementos também podem ser organizados no alto da imagem, no topo, e, por isso, possuem maior destaque; enquanto que os elementos da base estão em menor destaque e tratam-se das informações técnicas, mais específicas.

A saliência é um fator da função composicional que tem como objetivo atrair o leitor através do realce do texto não verbal. Essa saliência pode ser ressaltada em um grau que vai do máximo ao mínimo ao analisarmos o tamanho dos elementos (elemento grande significa saliência máxima, maior destaque na imagem), a intensidade do foco (precisão de detalhes), o contraste da tonalidade (cor e brilho), a perspectiva de um elemento em primeiro plano (maior relevância), o posicionamento do campo de visão e algum símbolo que possa remeter a um fator cultural.

Por fim, o emolduramento é a maneira como os elementos estão estruturados na imagem, ou seja, os elementos podem estar conectados através da cor, do foco, de outro elemento que os conecte, até mesmo, pela sobreposição de elementos. Estes elementos também podem estar desconectados, quando há um espaço vazio entre eles.

Para melhor ilustrar a função composicional, na figura abaixo observamos que o valor da informação aparece de forma polarizada, pois existem diversos objetos e nenhum aparece em foco central. Observamos que, do lado esquerdo, encontramos aquilo que já conhecemos, a entrada do metrô, o metrô e o trem (RER); enquanto que, do lado direito, o anúncio nos mostra o que pode ser diferente, comparado a outros meios de transportes. No topo, visualizamos o metrô, ou seja, o ideal de transporte e, na base, encontramos o real, ou seja, um quadro com todas as informações verídicas sobre o comércio do metrô parisiense.

A saliência da imagem é máxima, pois o leitor é atraído pela precisão de detalhes e pelas cores que remetem a um símbolo de fator cultural - as cores da entrada do metrô, o art nouveau, a cor do trem do metrô. Finalmente, o emolduramento é máximo, pois os elementos aparecem conectados por um elemento cultural "o art nouveau". 


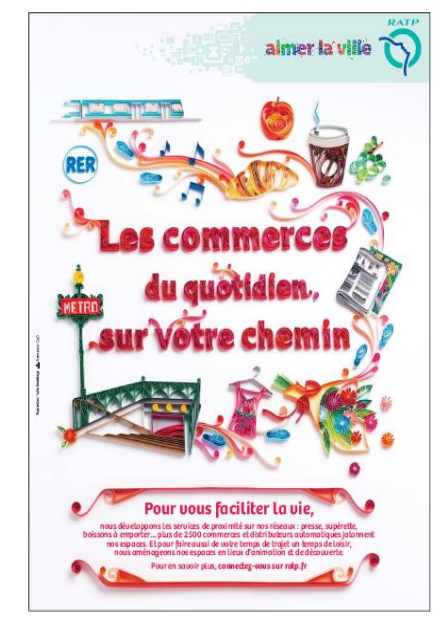

Figura 10: anúncio publicitário da RATP

O quadro a seguir apresenta, em um esquema, a função composicional que é dada através do valor da informação (centrado ou polarizado), da saliência das cores e do emolduramento dos elementos.

Quadro 6: Função composicional

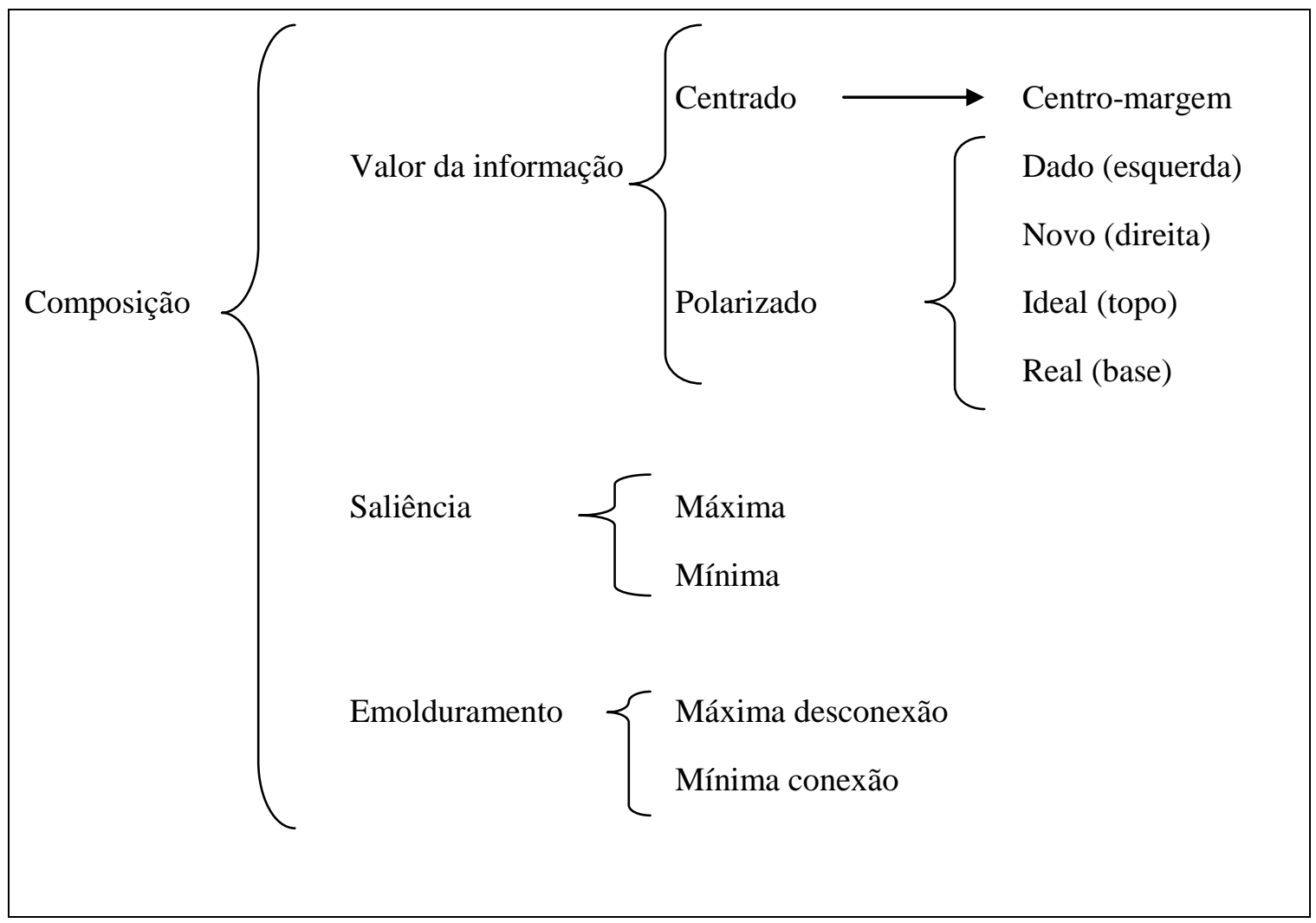

(Adaptado de KRESS; VAN LEEWEN, 2006, p.210) 


\section{União do interacionismo sociodiscursivo e da gramática do design visual}

Até o momento, apresentamos separadamente os modelos de análise do interacionismo sociodiscursivo e da gramática do design visual. Entretanto, como já dissemos, interessa-nos, para dar continuidade ao objetivo proposto nesta pesquisa que é de propor o uso do gênero textual anúncio publicitário para o ensino-aprendizagem do francês como língua estrangeira (FLE), unir as duas teorias. Em nossa opinião, a proposta de trazer elementos da GDV para complementar o ISD, permitindo a análise de textos multimodais, como o texto anúncio publicitário, é bastante enriquecedora e pode contribuir para os estudos baseados no ISD. Como já discutimos na introdução desta dissertação, por um lado, o ISD propõe uma teoria que permite didatizar os gêneros textuais como uma proposta de ensino, mas não apresenta uma teoria para a análise do texto não verbal; por outro lado, a GVD apresenta uma teoria para a análise do texto não verbal, entretanto, não possui essa didatização dos gêneros. Portanto, podemos concluir que ambas são importantes para esta pesquisa, já que precisaremos de conceitos da gramática do design visual (GDV) para analisar a linguagem não verbal presente nos anúncios publicitários, tendo em vista a elaboração de seu modelo didático (SCHNEUWLY ; DOLZ, 2004). Para tanto, nos apoiaremos na união das duas bases teóricas propostas por Leal (2011) em sua tese de doutorado ${ }^{19}$. Segundo Leal (2011, p.201), “a compatibilidade de pressupostos epistemológicos sobre os textos como práticas sociais permitir-nos-á fazer esta aproximação dos quatros teóricometodológicos" por meio da recriação de um modelo metodológico que objetiva responder questões sobre a imagem, ou seja, sobre a linguagem não-verbal e sobre o papel dessa linguagem no funcionamento das atividades humanas de linguagem.

\subsection{Contexto de produção, contexto de recepção e conteúdo temático}

Para o ISD (BRONCKART, 2006), a ação de linguagem pode ser compreendida a partir do contexto de produção, que nada mais é do que a situação de interação constituída por parâmetros objetivos (emissor, co-emissor, e o espaço/tempo de ação) e

\footnotetext{
19 Áudria Leal realizou seu doutorado na Universidade Nova de Lisboa, em 2011, sob orientação da Profa. Dra. Maria Antónia Coutinho, que é uma das grandes estudiosas do ISD em Portugal.
} 
por parâmetros sociossubjetivos (quadro social de interação, papel do enunciador, papel dos destinatários e objetivo), além de outras representações da situação de ação ou dos conhecimentos disponíveis no agente/pessoa.

Esse contexto pode ser levantado a partir de hipóteses que fazemos sobre a situação de produção dos textos, baseando-nos em elementos conhecidos sobre esse contexto, mas, também, em elementos que inferimos a partir dos elementos conhecidos. No entanto, no ISD (BRONCKART, 2006), não levantamos hipóteses sobre o contexto de recepção dos textos. Esse contexto de recepção faz parte da interpretação de quem recebe o gênero textual, de como é reconhecida a atividade do gênero, ou seja, de como o gênero é reconhecido e em que suporte ele é encontrado pois, independentemente de quem recebe o gênero textual, esta pessoa também está inserida em um contexto físico lugar e momento definidos - e ocupa um lugar social - a posição social -, o que pode estabelecer propósitos para a leitura. Portanto, para Leal (2011), o contexto de recepção é composto por quatro categorias: a atividade, o gênero textual, o contexto físico e o contexto sociossubjetivo. A partir dessas reflexões, Leal (2011) propõe um quadro que une as teorias do ISD e da GDV, abordando os contextos de produção e de recepção dos textos, que exemplificamos abaixo.

Quadro 7: Os contextos de produção e de recepção

\begin{tabular}{|c|c|c|c|c|}
\hline \multirow[t]{4}{*}{$\begin{array}{l}\text { Atividade(s) } \\
\text { Relacionada(s) }\end{array}$} & \multirow[t]{4}{*}{$\begin{array}{c}\text { Gênero } \\
\text { escolhido e } \\
\text { suporte } \\
\text { definido }\end{array}$} & \multirow[t]{2}{*}{$\begin{array}{l}\text { Contexto } \\
\text { de } \\
\text { produção }\end{array}$} & Contexto físico & $\begin{array}{l}\text { Lugar de produção } \\
\text { Momento de produção } \\
\text { Produtor e receptor }\end{array}$ \\
\hline & & & $\begin{array}{l}\text { Contexto } \\
\text { sociossubjetivo }\end{array}$ & $\begin{array}{l}\text { Lugar social da produção } \\
\text { Posição social do produtor e } \\
\text { receptor } \\
\text { Objetivo(s) }\end{array}$ \\
\hline & & \multirow[t]{2}{*}{$\begin{array}{l}\text { Contexto } \\
\text { de } \\
\text { recepção }\end{array}$} & Contexto físico & $\begin{array}{l}\text { Lugar de recepção } \\
\text { Momento de recepção } \\
\text { Receptor e produtor }\end{array}$ \\
\hline & & & $\begin{array}{l}\text { Contexto } \\
\text { sociossubjetivo }\end{array}$ & $\begin{array}{l}\text { Lugar social da recepção } \\
\text { Posição social do receptor e }\end{array}$ \\
\hline
\end{tabular}




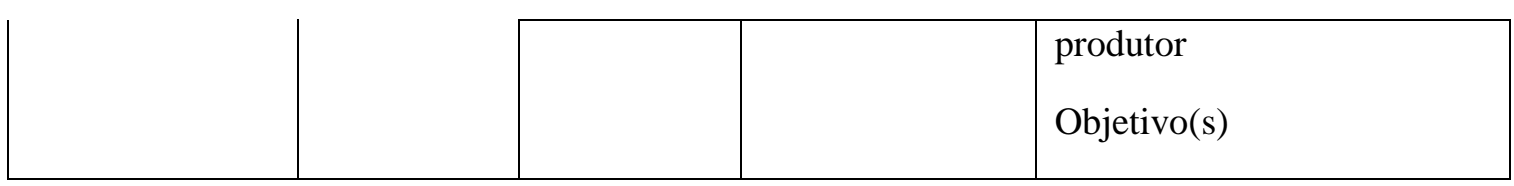

(LEAL, 2011, p.202)

Ainda faz parte do contexto de produção, o conteúdo temático citado no início desta seção. Segundo Leal (2011), o conteúdo temático é referente ao conhecimento do receptor, este por sua vez adquirido no meio social e cultural, e pode ser manifestado no texto. Portanto, par a compreensão de muitos gêneros textuais há a necessidade de um conhecimento prévio para recuperar as representações construídas pelo produtor do texto.

Leal (2011) constata em sua pesquisa que o gênero cartoon tem uma ação de linguagem influenciada pela realidade social. Assim como a autora, também afirmamos, para a nossa pesquisa, que a realidade histórica e social exerce influência no gênero anúncio publicitário e, portanto, necessitamos de um conhecimento prévio sobre ela para ter uma melhor percepção dos conteúdos temáticos presentes nos anúncios publicitários.

Nesse sentido, Leal (2011) afirma que o reconhecimento do conteúdo temático está diretamente relacionado ao contexto e que a compreensão desse conteúdo acontece através de inferências feitas pelo leitor sobre o gênero textual como estrutura e sobre seus contextos de produção e de recepção. Da mesma maneira, Bronckart (2008) afirma que o reconhecimento total da organização do conteúdo temático de um gênero de texto acontecerá através da análise da arquitetura textual do gênero em questão.

\subsection{Arquitetura interna dos textos multimodais}

Com base em Leal (2011, p.205), a aproximação entre a perspectiva do ISD e a perspectiva da GDV torna possível integrar categorias para os textos não verbais na arquitetura interna dos textos de Bronckart (2003, 2006).

Leal (2011) organizou um quadro com a arquitetura geral dos textos proposta pelo ISD e as funções da GDV de Kress e Van Leeuwen (2006) - baseadas nas metafunções da gramática sistêmico-funcional de Halliday (1994) - para, então, criar 
sua proposta: um quadro da "semiótica sociointeracional", como podemos observar no quadro abaixo.

Quadro 8: Formação da semiótica sociointeracional proposta por Leal (2011)

\begin{tabular}{|c|c|c|}
\hline ISD & GVD & Semiótica sociointeracional \\
\hline $\begin{array}{l}\text { Infraestrutura: } \\
\text { a) Organização temática } \\
\text { b) Organização } \\
\text { discursiva }\end{array}$ & $\begin{array}{l}\text { Representacional: } \\
\text { a) Narrativas } \\
\text { b) Conceituais }\end{array}$ & $\begin{array}{l}\text { Organização temático-representacional: } \\
\text { modos de por em discurso as suas } \\
\text { representações sociais: } \\
\text { a) Organização temático verbal } \\
\text { b) Organização temático não verbal }\end{array}$ \\
\hline $\begin{array}{l}\text { Mecanismos } \\
\text { enunciativos: } \\
\text { a) Responsabilidade } \\
\text { enunciativa } \\
\text { b) Distribuição de vozes } \\
\text { c) Modalidade }{ }^{20} \\
\text { modalização }\end{array}$ & $\begin{array}{l}\text { Interativa: } \\
\text { a) Contato } \\
\text { b) Distância social } \\
\text { c) Perspectiva } \\
\text { d) Modalidade }\end{array}$ & $\begin{array}{l}\text { Organização interacional: modos de } \\
\text { manifestação da interação: } \\
\text { a) Manifestação da interação pelo verbal } \\
\text { b) Manifestação da interação pelo não verbal }\end{array}$ \\
\hline $\begin{array}{l}\text { Mecanismos de } \\
\text { textualização: } \\
\text { a) Conexão } \\
\text { b) Coesão nominal }\end{array}$ & $\begin{array}{l}\text { Composicional: } \\
\text { a) Valor da } \\
\text { informação } \\
\text { b) Saliência } \\
\text { c) Estruturação }\end{array}$ & $\begin{array}{l}\text { Organização estrutural: modos de } \\
\text { configuração estruturais. } \\
\text { a) Estruturação verbal } \\
\text { b) Estruturação não verbal }\end{array}$ \\
\hline
\end{tabular}

(LEAL, 2011, p. 205)

Portanto, podemos observar que Leal (2011) dispôs na primeira coluna todos os componentes da arquitetura interna dos textos do quadro do ISD, na segunda coluna as três funções da GDV e na terceira coluna a junção dos modelos de análise. Essa junção também foi dividida em três tipos de organização: a organização temático representacional, a organização interacional e a organização estrutural.

\footnotetext{
${ }^{20}$ Leal (2011) propõe ora o termo modalidade, ora o termo modalização, quando se refere a esse item dos mecanismos enunciativos propostos por Bronckart (1999[2003]). Em nossa pesquisa, optamos por guardar o termo "modalização", quando nos referimos ao ISD, respeitando o que propõe Bronckart (1999[2003]).
} 


\subsection{Organização temático-representacional}

Os organizadores temático-representacionais são as maneiras de colocarmos em discurso as representações sociais de um determinado meio social. Podemos identificálo verbalmente ou não verbalmente em um texto.

Os organizadores temático-representacionais verbais organizam o conteúdo temático do texto, portanto podemos relacioná-los à infraestrutura geral dos textos de Bronckart (1999 [2003]), na qual consideramos os tipos de discurso e a noção de sequência como fatores necessários para a identificação temática durante o processo de leitura.

Os tipos de discurso, como citamos na seção 2.1.2, sobre a infraestrutura geral dos textos, podem ser implicados ou autônomos seja no mundo da conjunção (expor) ou da disjunção (narrar). Já as sequências, como explicamos anteriormente, dizem respeito a planificações locais, organizadas de forma narrativa, argumentativa, dialogal, injuntiva, descritiva ou explicativa.

A imagem também possui organizadores de conteúdo temático, ou seja, trata-se de uma organização temático-representacional não verbal na qual observamos as representações narrativa e conceitual, citadas na seção 3.2 da função representacional de Kress e Van Leeuwen (2006). Através das categorias de representações narrativa e conceitual podemos analisar as representações sociais que são colocadas no texto através do não verbal e identificar qual relação pode ser construída com o verbal. Leal (2011) afirma que a semiotização dos mundos discursivos pode ser feita pelo visual quando a imagem nos fornece algumas informações sobre as coordenadas do contexto de produção, ou seja, o produtor, o lugar de produção, o momento de produção e ainda sua relação com o conteúdo temático. As representações narrativas circunstanciais, por exemplo, podem nos fornecer mais informações sobre o contexto. As circunstâncias são encontradas a partir do cenário, dos seus elementos em primeiro plano ou a partir dos gestos dos participantes ou, ainda, através de outros participantes que podem não fazer parte da ação, mas podem portar algum atributo simbólico. Esse tipo de organização foi esquematizado por Leal (2011, p.208), como podemos ver a seguir: 
Quadro 9: Organização temático-representacional

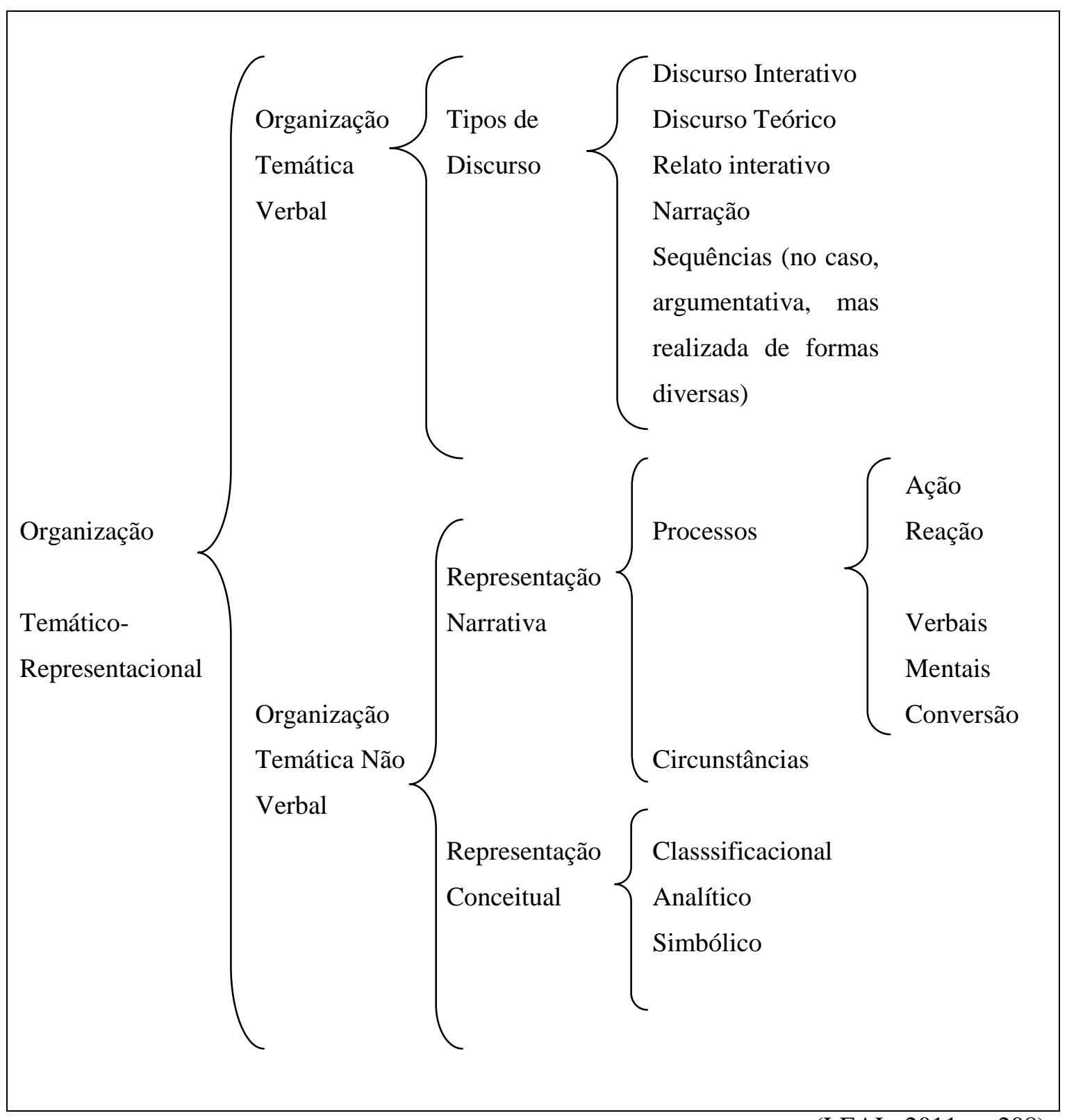

(LEAL, 2011, p. 208)

\subsection{Organização interacional}

A organização interacional, proposta por Leal (2011), corresponde às manifestações verbais e não verbais de interação de um texto. A organização interacional verbal corresponde aos mecanismos de responsabilidade enunciativa, propostos pelo ISD (BRONCKART, 2003), como as vozes do discurso e as modalizações. O uso do "você" e do "eu", por exemplo, é uma marca de interação entre 
o produtor do texto e o seu leitor. Assim como as modalizações (deônticas, lógicas e apreciativas) que avaliam determinado conteúdo. No caso dos anúncios publicitários, percebemos que a interação do produtor do texto com o leitor pode acontecer, até mesmo, através do nome de uma loja, como observamos na figura abaixo.

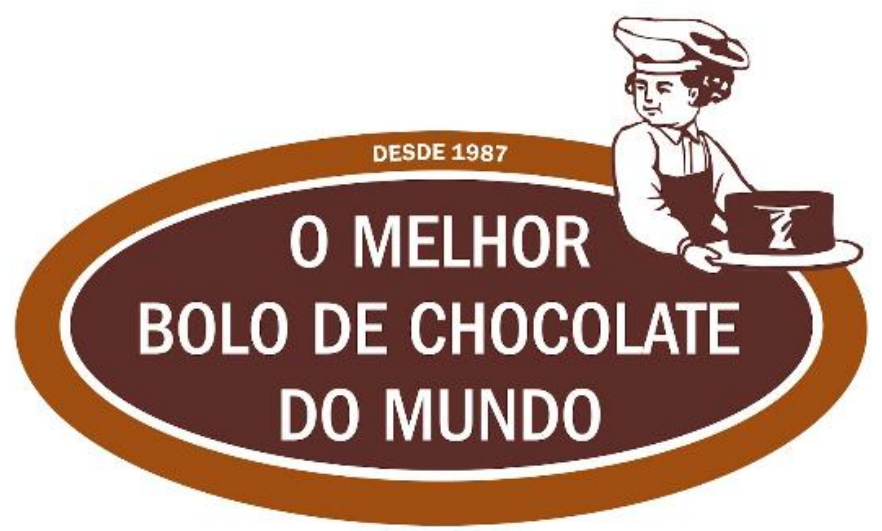

Figura 11: Logotipo com nome da loja "O melhor bolo de chocolate do mundo"

É o que vemos, por exemplo, com o nome da loja de bolos "o melhor bolo de chocolate do mundo", pois a apreciação do produtor do logotipo, qualificando de o "melhor bolo", faz com que o leitor interaja com o nome da loja e se posicione: "seria mesmo o melhor bolo de chocolate do mundo?" Portanto, o próprio nome da loja estabelece uma interação entre o produtor do texto e seu destinatário, o que nos indica que a existência de marcas do autor ou do leitor pode ser considerada como uma interação verbal.

Quanto à organização interacional não verbal, Kress e Van Leeuwen (2006), afirmam que a função interativa tem quatro aspectos principais: o contato, que se refere à interação entre o participante e o leitor; a distância social, que se refere aos elementos semiotizados no texto, por exemplo, quando temos uma visão geral ou close-up; a perspectiva, a partir da qual podemos entender as relações de poder entre o participante e o leitor; e a modalidade que complementa os outros três aspectos, pois analisa o grau de realidade que o texto pretende transmitir ao leitor (através da cor, da contextualização e da representação caricaturada).

Segundo Leal (2011), a organização interacional não verbal pode ser realizada pelas categorias propostas pela GDV (contato, distância social e atitude), pois elas esclarecem o tipo de interação realizado pela imagem, tanto no nível intratextual não 
verbal como na relação entre produtor e observador da imagem. Desta forma, Leal (2011) afirma que a imagem, assim como plano verbal, expõem posicionamentos enunciativos e pontos de vista reveladores quando há a interação entre o verbal e o não verbal e quando se consegue estabelecer um processo de relação entre o autor e o leitor.Essa relação entre a interação verbal do ISD e a interação não verbal da GVD é apresentada no esquema abaixo:

Quadro 10: Organização interacional verbal e não verbal

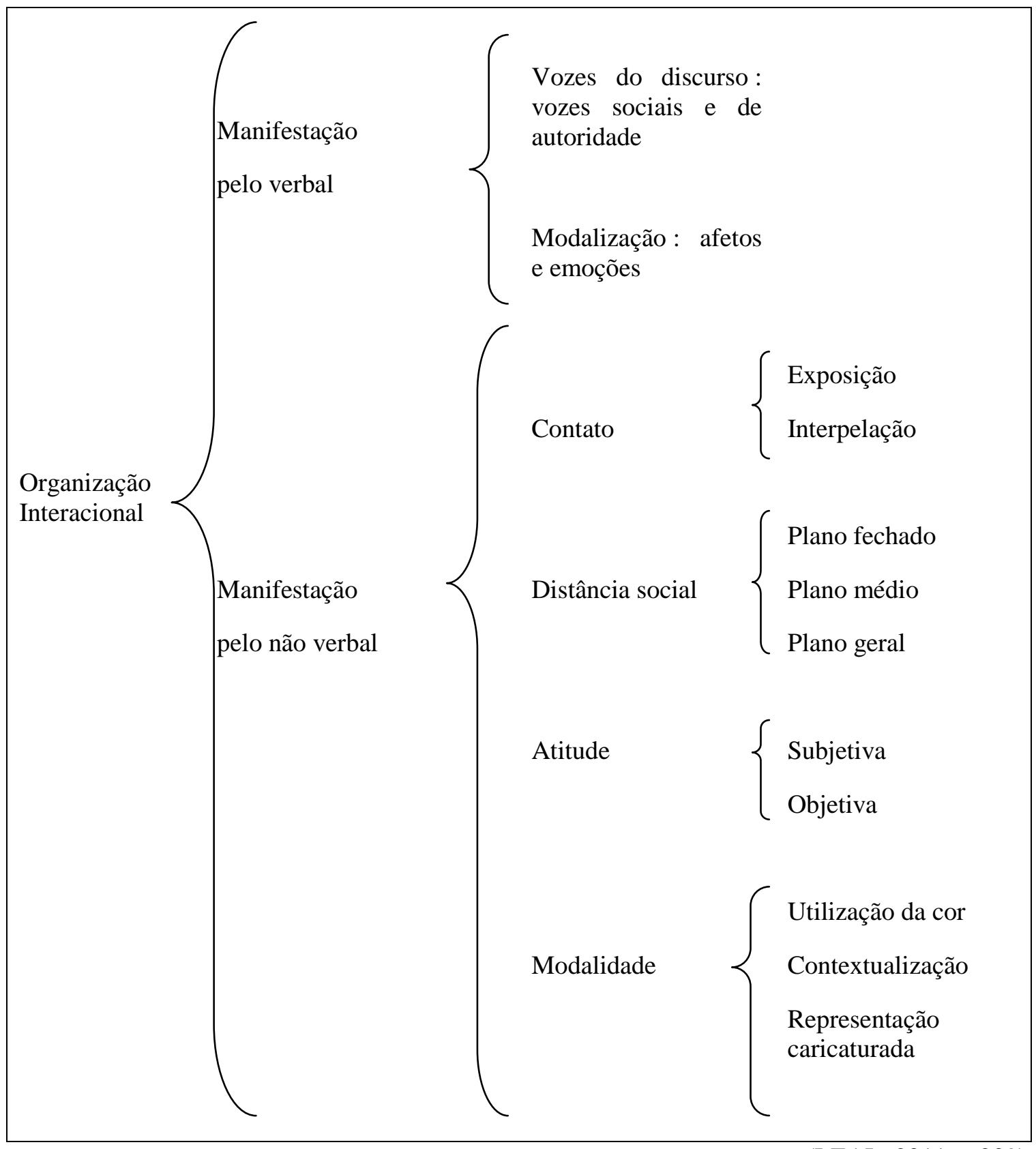

(LEAL, 2011, p.209) 


\subsection{Organização estrutural}

A organização estrutural está diretamente relacionada à forma de apresentação quanto à organização interna do texto. Segundo Leal (2011), a organização estrutural é composta pelas características do gênero textual, ou seja, quando o gênero textual é reconhecido pelo primeiro olhar que consegue captar de imediato a estrutura geral como um todo.

Observamos que, assim como nos itens anteriores, Leal (2011) organiza em duas categorias a organização estrutural. A primeira categoria é a organização estrutural verbal, na qual a autora inclui os mecanismos de textualização do ISD, ou seja, conexão, coesão verbal e nominal. A segunda categoria é a organização estrutural não verbal que reúne, de acordo com a GDV, o valor da informação, a saliência e o emolduramento, conforme apresentado anteriormente.

A seguir, podemos observar o quadro da união da organização estrutural do ISD e da GDV:

Quadro 11: Organização estrutural

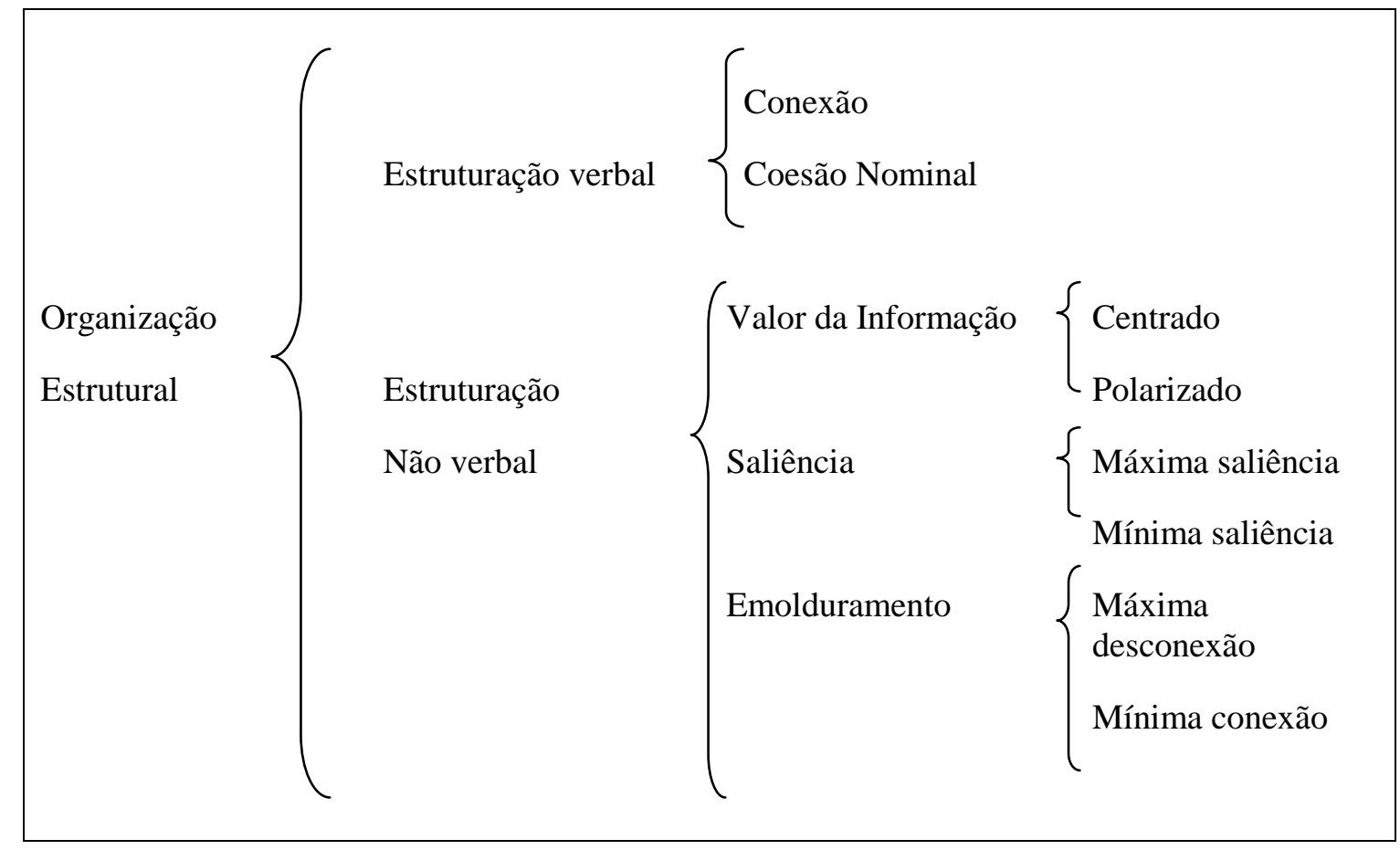

(LEAL, 2011, p. 211) 


\subsection{Quadro da união das teorias}

O quadro da união das teorias do ISD e da GDV foi proposto por Leal (2011) e servirá de base para a nossa análise do gênero textual anúncio publicitário, possibilitando, portanto, o estudo de sua organização textual verbal e não verbal. Para Leal (2011), em seus estudos sobre o gênero textual cartoon, foi essencial levar em conta a intersecção entre imagem e organização textual, por isso, a pesquisadora identificou todas as categorias das teorias do ISD e da GDV e as uniu em um quadro nomeado de semiótica sociointeracional. O mesmo ocorre com o gênero que escolhemos em nossa pesquisa, o anúncio publicitário; daí a pertinência de adotarmos a mesma proposta de união entre as teorias, porém, acrescentando aspectos que permitam compreender o efeito argumentativo provocado pela intersecção entre verbal e não verbal. Em nosso caso, como dissemos, o efeito argumentativo é provocado mais por inserção de vozes e modalizações apreciativas, segundo Plantin (2008) do que pela existência de uma sequência argumentativa propriamente dita.

O quadro abaixo apresenta uma visão de conjunto do modelo de análise Semiótico Sociointeracional, expondo a parte da ação de linguagem bem como a parte da arquitetura interna dos textos. 
Quadro 12: Quadro global de análise da união do ISD com a GDV (Adaptado de LEAL, 2011, p. 212) 21 $^{21}$

\begin{tabular}{|c|c|c|c|c|c|c|}
\hline & & & \multirow{4}{*}{$\begin{array}{l}\text { Capacidade de } \\
\text { ação }\end{array}$} & \multirow[t]{2}{*}{$\begin{array}{l}\text { Contexto de } \\
\text { produção }\end{array}$} & Contexto físico & $\begin{array}{l}\text { Lugar de produção } \\
\text { Momento de produção } \\
\text { Produtor e receptor }\end{array}$ \\
\hline \multirow{3}{*}{$\begin{array}{c}\text { Atividade(s) } \\
\text { Relacionada(s) }\end{array}$} & \multirow{3}{*}{$\begin{array}{c}\text { Gênero } \\
\text { escolhido e } \\
\text { suporte } \\
\text { definido }\end{array}$} & \multirow{3}{*}{$\begin{array}{c}\text { Ação de } \\
\text { linguagem }\end{array}$} & & & Contexto sociossubjetivo & $\begin{array}{l}\text { Lugar social da produção } \\
\text { Posição social do produtor e receptor } \\
\text { Objetivo(s) }\end{array}$ \\
\hline & & & & \multirow{2}{*}{$\begin{array}{l}\text { Contexto de } \\
\text { recepção }\end{array}$} & Contexto físico & $\begin{array}{l}\text { Lugar de recepção } \\
\text { Momento de recepção } \\
\text { Receptor e produtor }\end{array}$ \\
\hline & & & & & Contexto sociossubjetivo & $\begin{array}{l}\text { Lugar social da recepção } \\
\text { Posição social do receptor e produtor }\end{array}$ \\
\hline
\end{tabular}

\footnotetext{
${ }^{21}$ Fizemos algumas adaptações no quadro proposto por Leal (2011), com o objetivo de melhor adequá-lo aos nossos propósitos. Uma das adaptaç̃es diz respeito à inclusão das capacidades de linguagem, na quarta coluna, relacionadas às categorias verbais e não verbais de análise, visando a facilitar a exposição de nossas análises.
} 


\begin{tabular}{|c|c|c|c|c|}
\hline & & & & Objetivo(s) \\
\hline \multirow[b]{3}{*}{$\begin{array}{l}\text { Arquitetura } \\
\text { interna dos } \\
\text { textos }\end{array}$} & \multirow[t]{2}{*}{$\begin{array}{c}\text { Capacidade } \\
\text { discursiva }\end{array}$} & \multirow[t]{2}{*}{$\begin{array}{c}\text { Organização } \\
\text { temático- } \\
\text { representacional }\end{array}$} & $\begin{array}{l}\text { Organização temática } \\
\text { representacional verbal }\end{array}$ & $\begin{array}{l}\text { Conteúdo temático } \\
\text { Tipos de discurso } \\
\text { Sequências (sobretudo a sequência } \\
\text { argumentativa. Em nosso caso, ela se } \\
\text { realiza sobretudo pelo empréstimo ao } \\
\text { intertexto e por categorias como as vozes } \\
\text { e as modalizações, descritas na } \\
\text { organização interacional) }\end{array}$ \\
\hline & & & $\begin{array}{l}\text { Organização temática } \\
\text { representacional não verbal }\end{array}$ & $\begin{array}{l}\text { Tipos de representação } \\
\text { (narrativa/conceitual) }\end{array}$ \\
\hline & $\begin{array}{c}\text { Capacidade } \\
\text { linguístico- } \\
\text { discursiva }\end{array}$ & $\begin{array}{l}\text { Organização } \\
\text { interacional }\end{array}$ & Manifestação pelo verbal & $\begin{array}{l}\text { Vozes do discurso (em nosso caso, } \\
\text { sobretudo voz de autoridade, vozes } \\
\text { sociais) } \\
\text { Modalizações (em nosso caso, sobretudo a } \\
\text { manifestação das emoções e ou dos } \\
\text { afetos) }\end{array}$ \\
\hline
\end{tabular}

${ }^{22}$ Embora Leal (2011) não tenha incluído as sequências em seu quadro de união das teorias, optamos por considerar as eventuais sequências em nosso caso, pois, para a análise dos anúncios publicitários, diferentemente da análise dos cartoons, é importante ter uma categoria que permita analisar a sequência argumentativa, ainda que ela seja realizada de forma diferente do que é apresentado por Bronckart ([1999] 2003). 


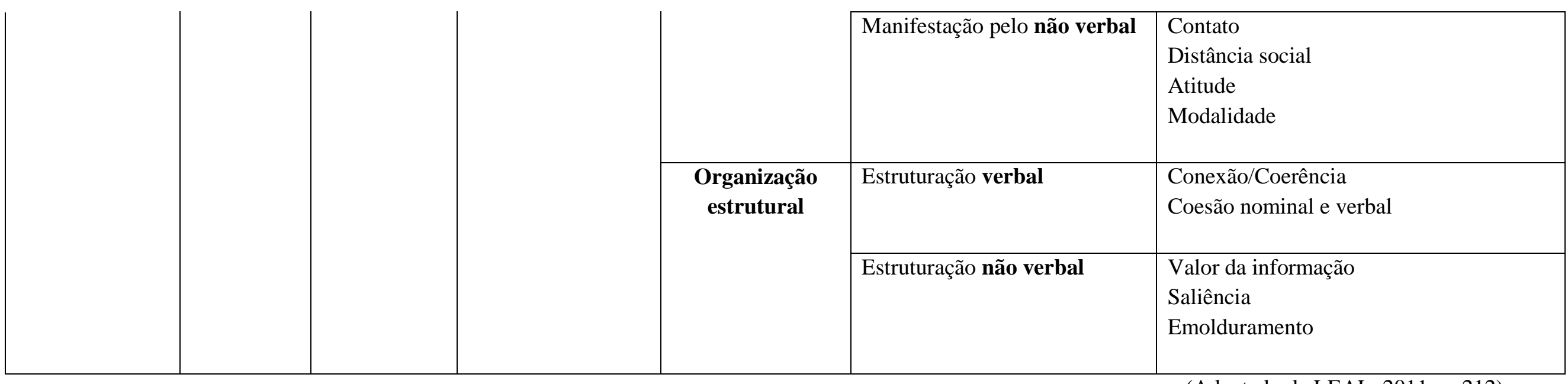

(Adaptado de LEAL, 2011, p. 212) 


\section{Gêneros textuais e ensino}

Do ponto de vista didático, ao refletirmos sobre o ensino-aprendizagem de línguas estrangeiras, que teve início na Antiguidade, percebemos que nem sempre a língua foi vista como um meio de comunicação, menos ainda como um meio de ação no mundo (PUREN, 1988; GERMAIN, 1993). Observamos também que nem sempre os documentos autênticos, encontrados no cotidiano, fizeram parte das aulas de língua. Ao contrário, o material empregado nas aulas de língua, que inicialmente era composto por textos autênticos, porém apenas literários, a textos fabricados com o objetivo de ensinar a língua. A preocupação com o uso de textos autênticos em sala de aula de língua estrangeira surgiu nos anos 70/80, paralelamente ao início da constatação de que uma das funções da linguagem é de ordem comunicativa e, logo, seu ensino deveria buscar esse fim (PUREN,1988; GERMAIN, 1993).

Com o surgimento do Quadro Europeu Comum de Referência (2001), surge a preocupação de levar-se em conta a língua como um meio de ação no mundo, ou seja, ao fazermos uso dela, estamos agindo no mundo e agindo sobre os outros, o que reforça a ideia do caráter social da linguagem. É o que vemos no trecho a seguir: "os utilizadores do Quadro considerarão e, sempre que for apropriado, explicitarão em que domínios o aprendiz necessitará agir ou deverá estar linguisticamente preparado para agir” (Conselho da Europa, 2001, p. 76). Com isso, o QECR reforça não só o caráter social da linguagem como também o fato de que o indivíduo age no mundo através de atividades linguageiras, visando sempre a atingir um resultado (LOUSADA, 2008).

No entanto, a visão da língua como meio de ação já existia no âmbito da filosofia da linguagem (HABERMAS, 1987; VOLOCHINOV, 1977; BAKHTIN, 1997), da linguística, com as teorias da pragmática interacional (AUSTIN e SEARLE, 1990), e foram desenvolvidas inúmeros outros autores, inclusive Bronckart, 1997/1999/2003.

Segundo Habermas (1987), o agir dos indivíduos acontece quando consideradas suas representações em relação ao sistema de mundos, que são classificados em três: mundo objetivo, mundo social e mundo subjetivo. $\mathrm{O}$ mundo objetivo está relacionado aos conhecimentos sobre o determinado meio físico e a história humana. O mundo social está relacionado ao conjunto de normas sociais daquele grupo em particular. E, o 
mundo subjetivo está relacionado ao conjunto dos conhecimentos de si mesmo e da visão dos outros sobre si.

Portanto, o agir acontece sempre relacionado às representações desses mundos, ou seja, segundo Bueno (2007), existe um sistema de representações próprias, do interlocutor, de diferentes grupos sociais, do meio físico etc. São essas representações dos mundos que possibilitam a interação humana, através da qual os indivíduos compartilham conhecimentos que possibilitam a troca verbal. Logo, os mundos exemplificados por Habermas (1987) são os critérios para um agir social.

Bronckart (2006) adota a perspectiva habermasiana e afirma que é através do agir comunicacional que os indivíduos constroem suas representações e se põem de acordo sobre esses três mundos, assumindo, então, a perspectiva de que uma característica específica do agir humano é o fato de ele ser marcado pelo uso da linguagem Dessa forma, como já dissemos, o ISD (BRONCKART, 2003, 2006) interessa-se pelo estudo do desenvolvimento do homem por meio da linguagem e, sobretudo, "pelos textos que comentam as atividades humanas e pelas modalidades escolares ou formais de realização dos sistemas formadores" (BRONCKART, 2005, p. 5). Portanto, as questões ligadas à Didática das Línguas são fundamentais para o ISD, tendo motivado os estudos realizados sobre ensino e aprendizagem da produção escrita e oral por meio das sequências didáticas organizadas em torno dos gêneros textuais (BRONCKART, 2010; SCHNEUWLY ; DOLZ, 2004). Com efeito, Schneuwly e Dolz (2004) partem da hipótese de que "é através dos gêneros que as práticas de linguagem materializam-se nas atividades dos aprendizes" (2004, p.74). Portanto, a introdução do gênero na escola pode "levar o aluno ao domínio do gênero, exatamente como este funciona (realmente) nas práticas de linguagem de referência” (SCHNEUWLY; DOLZ, 2004, p. 79), além de “colocar os alunos em situações de comunicação que sejam o mais próximas possível de verdadeiras situações de comunicação, que tenham um sentido para eles, a fim de melhor dominá-las como realmente são" (2004, p.81).

No entanto, essas afirmações não devem nos levar à ilusão de que todos os gêneros são aprendidos por todos os alunos, em todas as situações: quando falamos em domínio dos gêneros e eficácia em seu uso nas diferentes situações de comunicação, não estamos dizendo que as sequências didáticas baseadas nos gêneros textuais são a solução para todos os problemas de aprendizagem na escola, como afirma Bronckart (2010). Tampouco, estamos afirmando que os gêneros são estáveis e que podem ser ensinados enquanto práticas linguageiras imutáveis. Sabe-se que os gêneros textuais são 
construídos historicamente e se modificam conjuntamente à evolução das questões sociocomunicativas, ou seja, os gêneros não são formas fixas (BRONCKART, 1999 [1997]). Entretanto, apesar de sua maleabilidade, os gêneros textuais possuem certa estabilidade e se observarmos as dimensões partilhadas pelos textos como a estruturação, o acabamento e a relação entre os participantes, vemos que já alguma estabilidade, que pode ser ensinada. No entanto, a estabilidade encontrada nos gêneros textuais não exclui suas evoluções ou até mesmo as variações entre textos de mesmo gênero ao serem produzidos em condições distintas das condições iniciais (SCHNEUWLY ; DOLZ, 2004).

Para compreender como se dá a aprendizagem da língua por meio dos gêneros textuais, é necessário examinar o conceito de capacidades de linguagem. Para Bronckart (2003), o desenvolvimento das capacidades de linguagem ocorre através da realização de ações de linguagem, ou seja, um sistema de ações no âmbito da cooperação e da interação social. Ao admitirmos que o ensino de gêneros textuais pode contribuir para o desenvolvimento das capacidades de linguagem dos alunos, estamos considerando que o gênero textual pode ser entendido como um instrumento, no sentido vigotskiano do termo, e pode ser usado no ensino-aprendizagem de línguas (LOUSADA, 2010).É justamente para a discussão sobre como o professor pode criar instrumentos didáticos (o modelo didático e a sequência didática) que podem contribuir para o desenvolvimento das capacidades dos alunos que se voltam às próximas seções.

\subsection{Artefato e instrumento}

O interacionismo social (SCHNEUWLY, 2004), apoia-se no conceito de atividade mediada exposto por Vigotski (1988), para quem o indivíduo não fica preso às próprias experiências e não possui o mesmo desenvolvimento mental de outro indivíduo. Sendo assim, é a interação social, mediada por um instrumento técnico e/ou semiótico, que permite o desenvolvimento humano. Vigotski (1988, p.127) expõe esse desenvolvimento como interativo, nunca passivo. Podemos mencionar, como exemplo, a relação entre crianças mediada por um brinquedo, pois quando elas veem um objeto, podem agir de maneiras diferentes em relação ao que veem. Ou seja, a criança sozinha pode fazer uso de sua imaginação para mudar o sentido daquele objeto: é o caso de crianças que usam uma vassoura para brincar como se fosse um cavalo. Nas relações 
estabelecidas entre a criança e seus amigos, outros significados serão produzidos além daquele desenvolvido pela imaginação de uma só criança.

Portanto, na perspectiva do interacionismo social, a atividade é necessariamente concebida como tripolar, como aponta Schneuwly (2004, p.23):

\begin{abstract}
"a ação é mediada por objetos específicos, socialmente elaborados, frutos das experiências das gerações precedentes, através dos quais se transmitem e se alargam as experiências possíveis. Os instrumentos encontram-se entre o indivíduo que age e o objeto sobre o qual ou a situação na qual ele age: eles determinam seu comportamento, guiam-no, afinam e diferenciam sua percepção da situação na qual ele é levado a agir. [...] O instrumento torna-se assim, o lugar privilegiado da transformação dos comportamentos [...]" .
\end{abstract}

Partindo do conceito de instrumento encontrado nos trabalhos de Vigotski (1988), Schneuwly e Dolz (2004) afirmam que é possível fundamentar o uso do gênero como instrumento de transformação de uma atividade, inclusive a atividade linguageira. Dessa forma, retomando a perspectiva vigotskiana apresentada por Schneuwly e Dolz (2004) e também por Friedrich (2012), estamos considerando a sequência didática como um instrumento psicológico mediador, que se interpõe entre os aprendizes e o objeto de ensino, o gênero textual, possibilitando o desenvolvimento das capacidades de linguagem.

Vários outros autores adotam essa mesma perspectiva, como, por exemplo, Machado e Lousada (2010), ao afirmarem que, para compreender a metáfora que Schneuwly (2004, p.23) faz ao nos apresentar o gênero como um instrumento ou a sequência didática como um artefato que pode se constituir como instrumento para o trabalho do professor, é necessário entender o conceito de instrumento psicológico, que é internalizado pelo indivíduo. Portanto, trata-se um conceito diferente do conceito de língua como instrumento, utilizado por algumas abordagens que estudam as línguas e seu ensino e que a consideram como exterior aos indivíduos ${ }^{23}$. Na verdade, o conceito de instrumento psicológico, construído por Vigotsky (1988) e retomado por diversos

\footnotetext{
${ }^{23}$ Não é desta forma que adotamos o gênero textual como instrumento, como podemos observar em nossas discussões.
} 
outros pesquisadores (RABARDEL, 1995; FRIEDRICH, 2012), salienta a passagem de algo que tem origem na interação social e é apropriado pelo indivíduo tornando-se constitutivo: de artefato externo, ele passa a ser apropriado e interno, ou seja, um instrumento psicológico recriado pelo psiquismo de cada indivíduo.

Dessa forma, quando usamos a palavra instrumento, não identificamos um objeto que está na natureza - "que existe fora do sujeito" (MACHADO e LOUSADA, 2010, p.625) - e que é palpável, mas algo que é construído pelo sujeito para que ele consiga atingir o objetivo de uma ação. Um instrumento técnico (ou artefato) vai mudar o ambiente físico e social daqueles que ali interagem, ao passo que um instrumento psicológico vai mudar as capacidades psíquicas dos indivíduos, permitindo agir sobre si mesmo e sobre os outros. Nesse sentido, podemos dizer que alguns instrumentos técnicos (ou artefatos), poderão se tornar instrumentos (psicológicos), se forem apropriados pelos sujeitos e servirem para modificar as capacidades psíquicas de si mesmo e dos outros. Essa relação entre instrumento e artefato pode ser visualizada na figura a seguir.

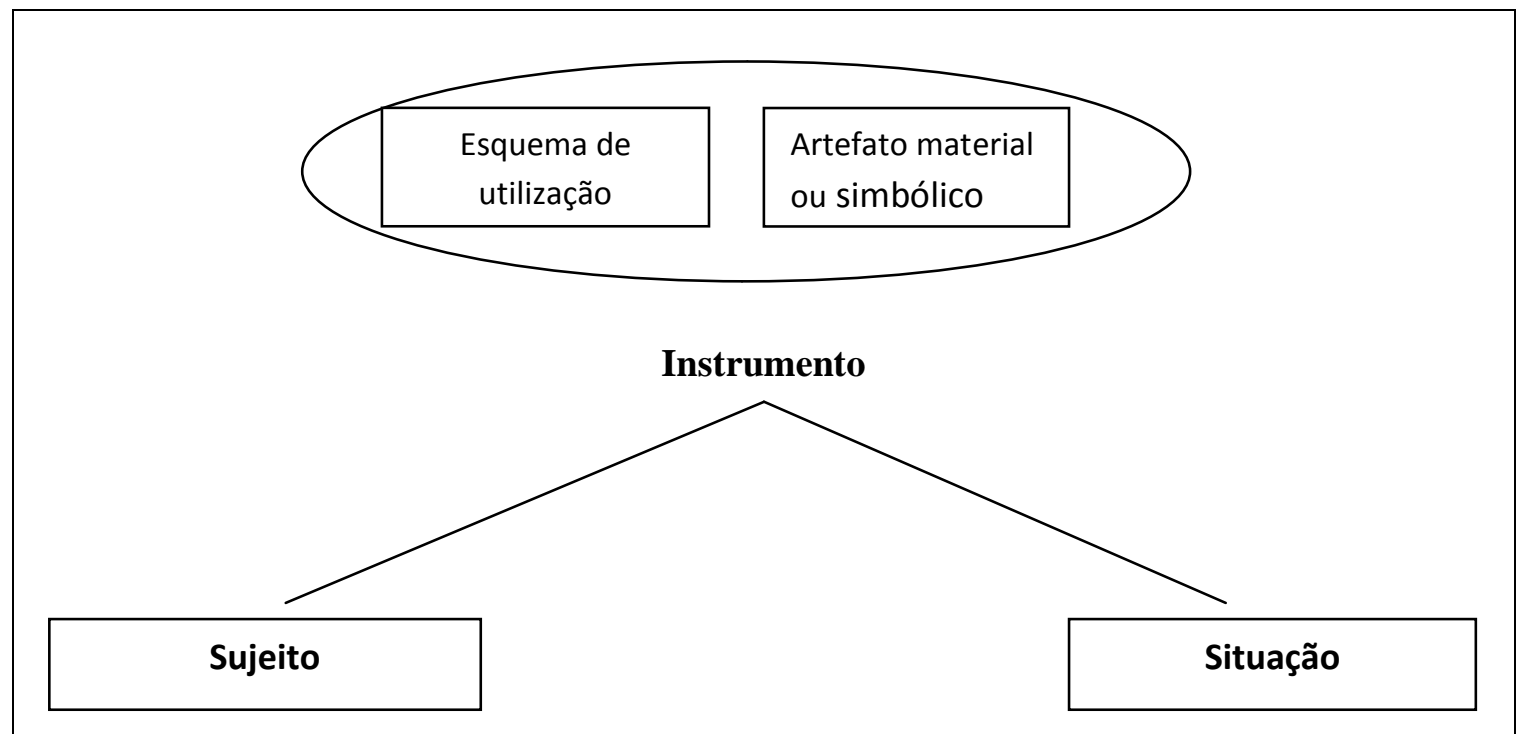

(SCHNEUWLY ; DOLZ, 2004, p.25)

Figura 12: A tripolaridade do instrumento

É dessa forma que podemos considerar os artefatos (RABARDEL, 1995): como os “objetos", ou o brinquedo das crianças, se assim podemos dizer: ao brincar com uma 
boneca, a criança pode estar internalizando, por exemplo, as próprias relações familiares.

Além disso, podemos dizer, citando Machado e Lousada (2010, p. 625) que "só quando algum artefato é apropriado pelo sujeito que ele passa a ser verdadeiro instrumento psicológico". Seguindo a mesma linha de raciocínio, as mesmas autoras (MACHADO e LOUSADA, 2010, p.627) afirmam que o trabalho do professor é uma atividade instrumentada, uma vez que o professor se apropria de artefatos do meio social para assim os utilizar como instrumentos materiais ou simbólicos. Portanto, o gênero textual é um artefato de potencial que só se torna um instrumento psicológico que pode desenvolver as capacidades de linguagem individuais quando apropriado pelo aluno, mas, também, pelo professor. Vejamos, a seguir, como compreender a noção de capacidades de linguagem nesta perspectiva.

\subsection{Capacidades de linguagem}

Afirmamos, anteriormente, que independentemente da língua, a capacidade de interação social está diretamente ligada conhecimento, ainda que implícito, que temos de um gênero textual, ou seja, à apropriação desse artefato. Por isso, Schneuwly e Dolz (2004) sustentam que um gênero textual pode ser um instrumento de desenvolvimento das capacidades de linguagem individuais. $\mathrm{O}$ desenvolvimento das capacidades de linguagem é um mecanismo reprodutor dos modelos de práticas de linguagem disponíveis no meio social e acontece quando os membros dessa sociedade dominam esses modelos e adotam estratégias explícitas para que os aprendizes possam também se apropriar deles (SCHNEUWLY ; DOLZ, 2004, p.52).

Para Dolz, Pasquier e Bronckart (1993) e para Schneuwly e Dolz (2004, p.74), as capacidades de linguagem permitem que o sujeito realize as seguintes operações:

\footnotetext{
"adaptar-se às características do contexto e do referente (capacidades de ação), mobilizar modelos discursivos (capacidades discursivas) e dominar as operações psicolinguísticas e as unidades linguísticas (capacidades linguístico-discursivas)".
} 
Cristovão et al (2010, p.194-195) detalharam as três capacidades através de alguns critérios para melhor compreendê-las:

a) Capacidades de ação: diz respeito ao contexto de produção, sua adequação ao contexto e a mobilização dos conteúdos a partir de inferências sobre quem escreveu o texto, para quem ele se dirige, quando o texto foi produzido, onde foi produzido e qual era o seu objetivo; à avaliação do que é necessário pra adequação do texto à situação de comunicação; à compreensão do vocabulário em sua relação com os aspectos sociais e/ou culturais; à compreensão da relação entre textos e a forma de ser, pensar, agir e sentir de quem os produz.

b) Capacidades discursivas: são os conhecimentos relacionados à organização do conteúdo de um texto, além de sua forma de apresentação. Para identificar as capacidades discursivas deve-se reconhecer a organização do texto: layout, a linguagem não verbal, como fotos, gráficos, títulos, entre outros. Deve-se, também, identificar o distanciamento entre o autor e o leitor através das características do texto, entender a função da organização daquele conteúdo no determinado texto e perceber a diferença entre diversas formas de organização.

c) Capacidades linguístico-discursivas: trata-se do domínio das operações psicolinguísticas e das unidades linguísticas; podem estar relacionadas ao conhecimento sobre coesão e coerência, por exemplo. Essas capacidades são desenvolvidas por atividades que permitam ao aluno a compreensão dos elementos que operam na construção de textos, parágrafo, orações; o domínio de operações que colaborem para a coerência do texto - organizadores textuais, por exemplo; o domínio de operações que cooperam para a coesão verbal - o tempo verbal, por exemplo; a expansão do vocabulário que permite uma melhor compreensão e produção dos textos; a compreensão e a produção de unidades linguísticas adequadas às sintaxe, morfologia, fonética, fonologia e semântica da língua; a consciência de diferentes vozes que constroem o texto; a consciência das escolhas lexicais para tratar um determinado conteúdo temático; o reconhecimento das modalizações - ou não - de um texto; e a identificação da relação entre enunciados, frases e parágrafos de um texto, além de muitas outras operações. 
Segundo Schneuwly e Dolz (2004, p.120), para adotar os gêneros textuais como instrumentos que poderão contribuir para o desenvolvimento das capacidades de linguagem dos alunos, há inúmeras possibilidades de uso dos gêneros textuais na escola. Ao pensar em como incluí-los nos currículos escolares, os autores propuseram alguns critérios essenciais para um agrupamento possível, dentre muitos outros, que poderia levar em conta:

1) a correspondência dos gêneros às grandes finalidades sociais atribuídas ao ensino, cobrindo os domínios essenciais de comunicação escrita e oral em nossa sociedade.

2) a retomada, de forma flexível, das distinções tipológicas, da maneira como já funcionam em vários manuais, planejamentos e currículos.

3) a relativa homogeneidade quanto às capacidades de linguagem implicadas no domínio dos gêneros agrupados.

O quadro a seguir (SCHNEUWLY ; DOLZ, 2004, p.121, adaptado) nos apresenta uma ideia de um dos agrupamentos possíveis a partir dos três critérios citados acima:

Quadro 13: Capacidades de linguagem dominantes

\begin{tabular}{|c|c|c|}
\hline $\begin{array}{c}\text { Capacidades de } \\
\text { linguagem dominantes }\end{array}$ & $\begin{array}{l}\text { Domínios sociais de } \\
\text { comunicação }\end{array}$ & Exemplos de gêneros orais e escritos \\
\hline Narrar & Cultura literária ficcional & $\begin{array}{l}\text { Conto maravilhoso, fábula, lenda, } \\
\text { narrativa de aventura, entre outros. }\end{array}$ \\
\hline Relatar & $\begin{array}{l}\text { Documentação } r \\
\text { memorização de ações } \\
\text { humanas }\end{array}$ & $\begin{array}{l}\text { Relato de experiência vivida, relato de } \\
\text { viagem, reportagem, notícia, } \\
\text { Curriculum vitae, entre outros. }\end{array}$ \\
\hline Argumentar & $\begin{array}{l}\text { Discussão de problemas } \\
\text { sociais controversos }\end{array}$ & $\begin{array}{l}\text { Texto de opinião, carta do leitor, } \\
\text { debate regrado, carta de reclamação, } \\
\text { entre outros. }\end{array}$ \\
\hline Expor & $\begin{array}{l}\text { Transmissão e construção } \\
\text { de saberes }\end{array}$ & $\begin{array}{l}\text { Seminário, conferência, resumo, relato } \\
\text { de experiência científica, entre outros. }\end{array}$ \\
\hline Descrever ações & Instruções e prescrições & Instruções de \\
\hline
\end{tabular}




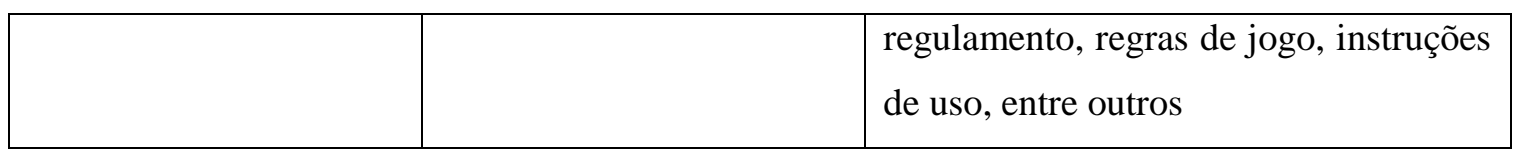

( SCHNEUWLY ; DOLZ, 2004, p.121)

Os critérios de agrupamento propostos por Schneuwly e Dolz (2004) têm fins didáticos e não significam que os gêneros possam ser classificados de maneira absoluta. Exemplificando a partir de dados de nossa pesquisa, por vezes, um gênero textual como o anúncio publicitário pode estar classificado na categoria do expor, mas também na do relatar, ou na do $\operatorname{argumentar}^{24}$. Outros gêneros, pela sua própria situação de produção e definição, são menos maleáveis, como, por exemplo, a instrução de montagem de um móvel, que geralmente será classificada dentro da categoria do “descrever ações”.

O quadro visa portanto a propor apenas sugestões para a escolha dos gêneros textuais que serão objeto de ensino-aprendizagem, pois, antes da construção de uma sequência didática e durante a sua aplicação, deve se levar em conta as capacidades de linguagem que os alunos realmente necessitam desenvolver. Sendo assim, as capacidades de linguagem são analisadas anteriormente à construção da sequência didática a partir de um modelo didático, um instrumento que pode guiar as intervenções dos professores. São justamente os conceitos de modelo didático e de sequência didática, criados pelos estudiosos de Genebra para o ensino de gêneros textuais, que serão apresentados nas próximas seções.

\subsection{Modelo didático}

O modelo didático é um instrumento do professor, ou seja, um objeto "descritivo e operacional, construído para apreender o fenômeno complexo da aprendizagem de um gênero" (DE PIETRO et al, 1996/1997, p.118). Ele está estreitamente relacionado às capacidades de linguagem necessárias para a produção de textos, como citamos

\footnotetext{
${ }^{24}$ Em nossa pesquisa, estamos considerando que o anúncio publicitário se desenvolve sobretudo a partir de uma organização geral da categoria do argumentar, embora possa ter segmentos em que se expõe ou descreve algo.
} 
anteriormente. Esse modelo, de acordo com Cristovão (2005, p.98), pode ser um guia para elaborar um material didático e é destinado a facilitar o aprendizado de língua estrangeira.

Para isso, é necessário basear-se em um conjunto de elementos, como expõem Schneuwly e Dolz (2004, p.180):

\begin{abstract}
"certos resultados de aprendizagem esperados e expressos em diversos documentos oficiais, os conhecimentos existentes; linguísticos (funcionamento dos gêneros para os especialistas) e psicológicos (operações e procedimentos implicados no funcionamento e na apropriação dos gêneros); e a determinação das capacidades mostradas dos aprendizes".
\end{abstract}

Em outras palavras, para a construção do modelo didático, devemos respectivamente: escolher um gênero textual e identificá-lo, selecionar vários textos do mesmo gênero, legitimar as escolhas dos diversos textos através dos especialistas do domínio, analisar os textos segundo o modelo do ISD (BRONCKART, 2003) e observar suas práticas sociais. Segundo Machado e Cristovão (2006, p.558), o modelo didático implica, então, a análise de um conjunto de textos que é considerado como pertencente ao gênero, considerando-se suas características da situação de produção, seus conteúdos típicos, suas formas de mobilizar tais conteúdos, sua construção composicional, seu estilo particular (mecanismos de coesão nominal, verbal, de conexão), entre outros fatores que permitirão a construção das sequências didáticas que serão:

\footnotetext{
"guiadas por um número limitado e preciso de objetivos e serão constituídas por um conjunto de atividades organizadas em um projeto global de apropriação de algumas das dimensões constitutivas de um gênero, de acordo com o nível dos aprendizes.”(MACHADO e CRISTOVÃO, 2006, p.558)
}

Além desses conjuntos de elementos que devem ser levados em consideração para a progressão das capacidades dos alunos, devem-se respeitar alguns princípios para elaborar o "modelo didático" (SCHNEUWLY ; DOLZ, 2004, p.181). Como podemos observar em Cristovão (2005, p.97), para elaborar o MD, devemos levar em conta: "a 
pertinência - respeitando-se as finalidades e os objetivos escolares em função das capacidades dos alunos; a legitimidade - utilizando-se de conhecimentos de experts considerados legítimos pela comunidade a que pertencem; a solidarização: integrandose diferentes dimensões que constituem o gênero".

Com efeito, a construção do modelo didático é essencial, pois guia o trabalho do professor, facilitando a visualização do que pode ser ensinado e aprendido nas práticas escolares, pois é a partir desse modelo que: encontraremos os elementos a serem ensinados, ou seja, o que pode ser objeto de ensino-aprendizagem; delimitaremos os objetivos a serem atingidos em relação às capacidades de linguagem; e identificaremos as capacidades que os alunos já desenvolveram e aquelas que ainda precisam ser desenvolvidas (SCHNEUWLY ; DOLZ, 2004, p180). O modelo didático (MD) revelará, então, aquilo que deve ser ensinado ao aprendiz e se tal modelo deve servir de objeto de ensino-aprendizagem. De fato, as próprias atividades desenvolvidas pelo professor poderão pedir um retorno ao modelo didático para modificá-lo no que for necessário, "considerando-se, assim, que esse modelo jamais é definitivo, mas sim, que se encontra em um processo contínuo de transformação" (2006, p.558).

Finalmente, Cristovão e Machado (2006, p.557) afirmam que "a construção desses 'modelos' não precisa ser teoricamente perfeita', pois, na verdade, existe a preocupação social imediata de trazer subsídios para o trabalho do professor e para a aprendizagem e, além disso, é um modelo construído para "ensinar" a produzir um gênero textual e não um modelo teórico do gênero textual em si. É a partir do MD do gênero textual a ser ensinado que se constrói a sequência didática, como veremos a seguir.

\subsection{Sequência didática}

A sequência didática "é um conjunto de atividades escolares organizadas, de maneira sistemática, em torno de um gênero textual oral ou escrito" (SCHNEUWLY ; DOLZ, 2004, p.97) e, como desenvolvemos na seção anterior, é uma etapa posterior à etapa do modelo didático. 
A sequência didática, segundo Schneuwly e Dolz (2004, p.98), é um esquema que se inicia com a apresentação da situação na qual é explicada de maneira detalhada a tarefa que os alunos deverão produzir. Em seguida, os alunos produzirão uma produção inicial do gênero determinado - etapa esta fundamental, pois é um instrumento de observação em relação ao que os alunos de fato dominam no gênero e embasa todos os módulos posteriores da sequência didática. A produção inicial pode apresentar ao professor quais são as representações dos alunos diante de um determinado gênero textual e não podemos, portanto, considerar os módulos da sequência didática como definitivos. O professor deve adaptar a sequência que tinha previsto baseando-se na produção inicial, ou seja, a partir da análise das produções iniciais, o professor regulará sua sequência didática. O professor pode, também, fazer uma análise dos problemas identificados na produção inicial com a sua turma, mas não deve atribuir nota a essa produção inicial, visto que se trata de uma avaliação diagnóstica.

O esquema da sequência didática proposto por Schneuwly e Dolz (2004) é organizado, portanto, em uma apresentação da situação do projeto, uma produção inicial, alguns módulos - ou atividades criadas de acordo com a necessidade dos alunos para o desenvolvimento de suas capacidades de linguagem - e uma produção final, como podemos observar no esquema a seguir.

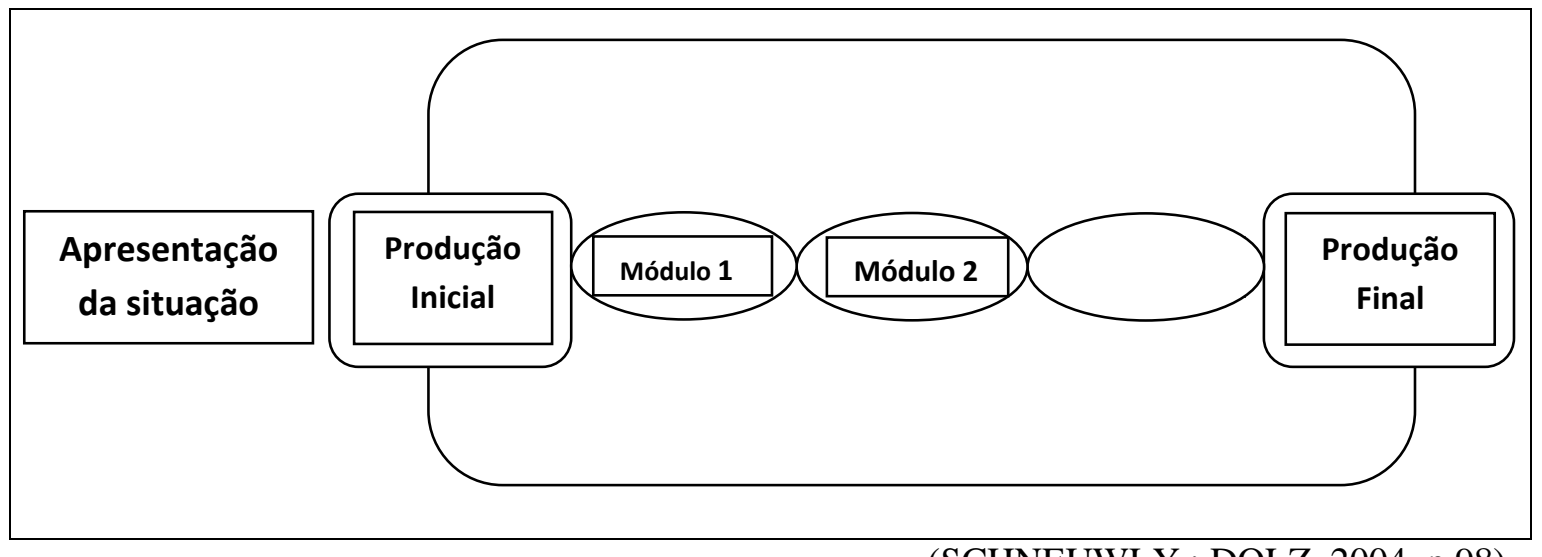

(SCHNEUWLY ; DOLZ, 2004, p.98)

Figura 13: Esquema da sequência didática

A apresentação da situação, proposta por Schneuwly e Dolz (2004), não servirá para uma produção inicial completa, pois somente a produção final será completa. 
Portanto, a produção inicial pode ser simplificada e direcionada a um destinatário fictício. É essa primeira produção que regulará a sequência didática, pois permitirá ao professor descobrir o que os alunos já sabem fazer ou não sabem fazer e definir os módulos de sua sequência didática a fim de desenvolver as capacidades de linguagem dos alunos. Dessa forma, para a construção da sequência didática deve-se, antes de preparar as atividades que servirão de módulos entre uma produção inicial e uma produção final, adaptar os objetivos da sequência às dificuldades do aluno. Para adaptar os objetivos, é necessária uma análise das capacidades de linguagem dos alunos tanto antes, quanto durante o ensino.

Os módulos são, assim, atividades produzidas de acordo com as dificuldades dos alunos e sua quantidade depende dos objetivos de desenvolvimento das capacidades de linguagem. Além disso, os módulos devem propor a variação dos suportes das atividades - orais ou escritas - para dar a oportunidade aos alunos de aprender o gênero por diferentes meios. Por fim, a sequência didática é finalizada com a produção final em que o aluno terá a possibilidade de colocar em prática tudo o que foi aprendido separadamente durante os módulos.

As propostas de Schneuwly e Dolz (2004) incluem algumas estratégias para a sequência didática, como: a adaptação da escolha do gênero às capacidades anteriormente elencadas; a simplificação da complexidade da tarefa de acordo com as capacidades dos alunos; o esclarecimento dos objetivos visados e o itinerário a ser feito; a determinação do tempo que deve ser adequado para que a aprendizagem aconteça; a intervenção de modo que os alunos façam as transformações; a escolha do momento de intervenção entre os alunos; a avaliação de todas as transformações realizadas, entre outras.

Segundo Machado e Cristovão (2006, p.555), a sequência didática é interessante como procedimento didático, pois permite um trabalho global e integrado; sua construção considera tanto os conteúdos de ensino fixados pelas instruções oficiais quanto os objetivos de aprendizagem específicos; contempla a necessidade de um trabalho com atividades e suportes variados; permite integrar as atividades de leitura, de escrita e de conhecimento de uma língua de acordo com um calendário pré-fixado módulos; facilita a construção de programas em continuidade uns com os outros; e propicia a motivação dos alunos, uma vez que os permite observar seu desempenho na maioria das vezes positivo em relação à produção inicial. 
Entretanto, todos esses procedimentos para a construção da sequência didática não impedem que problemas surjam em sala de aula, principalmente pelo fato de não haver tantos estudos sobre o uso de gêneros textuais no ensino-aprendizagem de língua estrangeira, sobretudo o francês, e pela necessidade da rapidez na produção de um material didático. Nesse sentido, Lousada (2005, p.74) explica que "poucos são os livros didáticos que abordam o desenvolvimento da competência para produzir textos de diferentes gêneros, o que é necessário mesmo em LM (língua materna)" e, assim, percebemos a necessidade de um material didático que contemple todas as capacidades de linguagem dos alunos, pois "certos gêneros em LM (menos frequentes ou aos quais estamos menos expostos) têm que ser aprendidos, o que prova a importância e a necessidade de ensiná-los de maneira formal/institucional quando trata de LE (língua estrangeira)". 


\section{Capítulo II - Procedimentos Metodológicos}

“"A principal meta da educação é criar homens que sejam capazes de fazer coisas novas, não simplesmente repetir o que outras gerações já fizeram. Homens que sejam criadores, inventores, descobridores. A segunda meta da educação é formar mentes que estejam em condições de criticar, verificar e não aceitar tudo que a elas se propõe." (Jean Piaget) 
Neste capítulo, temos como objetivo apresentar os procedimentos metodológicos para a realização da pesquisa. Para tanto, apresentamos, primeiramente, as etapas que seguimos para realizar nossa pesquisa; em seguida, descreveremos o contexto em que ela foi aplicada para, logo após, explicar como o modelo didático do gênero anúncio publicitário foi elaborado. Para isso, iniciaremos com uma explicação sobre a escolha do gênero anúncio publicitário e sobre a coleta dos textos autênticos que o compuseram. Dando continuidade, explicitaremos como elaboramos a sequência didática, como a aplicamos em uma experiência piloto e de que forma isso deu origem à sequência didática que permitiu a produção final dos dados. Terminaremos expondo como os dados para a análise foram produzidos e quais foram os procedimentos para analisá-los.

Em resumo, as etapas envolvidas na coleta e análise dos dados desta pesquisa são:

I. Etapas preliminares: coleta de dados para elaboração do MD

- escolha do gênero textual;

- escolha dos jornais;

- levantamento do gênero textual anúncio publicitário;

- escolha dos anúncios publicitários;

II. Elaboração do modelo didático e da sequência didática

- elaboração do modelo didático dos diferentes tipos de anúncios publicitários, com base na união do ISD com a GVD feita por Leal (2011);

- elaboração da sequência didática, com base nos procedimentos de Schneuwly e Dolz (2004) e das categorias da GDV e do ISD;

III. Aplicação da SD e coleta das produções dos alunos

- os problemas relacionados à aplicação da sequência didática piloto;

- aplicação da sequência didática reformulada

- coleta das produções textuais iniciais e finais dos alunos;

IV. Análise dos dados

- análise das produções dos alunos seguindo o modelo do ISD e da GDV;

- comparação das produções textuais com o modelo didático do gênero;

- discussão dos resultados obtidos através da comparação das produções iniciais e finais. 


\section{Contexto da pesquisa}

Nesta seção, exporemos o contexto dos Cursos Extracurriculares da Faculdade de Filosofia, Letras e Ciências Humanas da Universidade de São Paulo - FFLCH-USP onde foi aplicada a sequência didática para a coleta de dados e, também, apresentaremos os alunos participantes da nossa pesquisa.

\subsection{Cursos Extracurriculares da FFLCH-USP}

Esta pesquisa foi realizada junto a um grupo de alunos dos Cursos Extracurriculares de Francês, oferecidos pelo Serviço de Cultura e Extensão da Faculdade de Filosofia, Letras e Ciências Humanas, da Universidade de São Paulo, e pela área de Estudos Linguísticos, Literários e Tradutológicos em Francês, do Departamento de Línguas Modernas.

Esses cursos têm como objetivo desenvolver as habilidades orais e escritas em língua francesa em práticas do cotidiano e tem como público-alvo graduandos e pósgraduandos da USP, professores da rede pública e particular, funcionários da USP, estudantes e demais interessados com o pré-requisito do segundo grau completo.

O curso de francês é dividido em catorze níveis, sendo que cada um possui um programa em que é previsto o ensino-aprendizagem das habilidades comunicativas em francês e também seus elementos gramaticais, lexicais, culturais e fonológicos. Em todos os níveis, um livro didático é adotado para auxiliar o trabalho do professormonitor. Dos níveis $I$ ao IX, o material adotado é o Alter Ego, da editora Hachette. Cada livro Alter Ego é dividido em três níveis - do dossiê um ao três, do quatro ao seis e do sete ao nove - logo, os cursos usam o Alter Ego I, Alter Ego II e Alter Ego III. Dos níveis X ao XII, temos como método o livro Le Nouvel Édito da editora Didier.

Os cursos extracurriculares acontecem no prédio da faculdade de Letras da FFLCH-USP e cada curso tem a carga horária de 45 horas. Os cursos podem ser extensivos - de março a junho ou de agosto a novembro - ou intensivos - mês de julho, mês de janeiro e algumas vezes no mês de fevereiro.Os cursos extensivos são divididos de duas maneiras, em 15 aulas distribuídas em uma aula de três horas de duração por semana e em 30 aulas distribuídas em duas aulas semanais de uma hora e meia, totalizando 45 horas. Diferentemente dos cursos extensivos, as aulas dos cursos 
intensivos são distribuídas em quatro (ou cinco) aulas semanais que, normalmente, acontecem de segunda-feira à quinta-feira (ou sexta-feira), ou seja, são ministradas aulas diárias de três horas de duração, contabilizando 45 horas.

Geralmente, as inscrições para o nível I acontecem através da ordem de chegada e, posteriormente, através de listas de espera, pois a procura é sempre maior do que o número de grupos disponíveis para o primeiro nível, visto que o número máximo de matriculados por grupo é de 20 alunos. Para os demais níveis, o aluno inscreve-se segundo aprovação no nível anterior ou, no caso de alunos novos, é realizado um teste de nível, duas vezes por ano.

Para receber o certificado de extensão, o aluno deve ter uma nota acima de 7,0 e no mínimo $85 \%$ de presença. Cada curso pode ter no mínimo 10 alunos pagantes e no máximo 20, incluindo nesse caso os alunos não pagantes, ou bolsistas. Em cada grupo pode haver um docente, um discente, um funcionário da USP e três pessoas da terceira idade que são beneficiados por uma bolsa de estudos através de um sorteio feito antes do início de cada curso ${ }^{25}$.

Os Cursos Extracurriculares de Francês da FFLCH tiveram um grande crescimento nos últimos anos. Não se pode supor que o aumento tenha acontecido somente por causa do preço acessível, se comparado a outras escolas de idiomas, pois o preço sempre foi acessível. Sendo assim, supomos que parte desse crescimento tenha acontecido pela junção de três fatores: preço, crescimento geral pela busca de outras línguas estrangeiras e uma boa coordenação e administração dos cursos.

Para dar uma ideia da dimensão do crescimento dos cursos, segundo Guimarães Santos (2012), em três anos houve um aumento de alunos e de turmas de mais de $70 \%$. No início de 2009, existiam 22 turmas e 349 alunos; e no final de 2011, os números eram de 38 turmas e 604 alunos. Esta análise não levou em conta os cursos de intensivos que acontecem sempre nos níveis iniciais e, também, proporcionam o aumento do número de alunos nos níveis II, III e, por vezes, IV.

Baseando-nos nas estatísticas de Guimarães Santos (2012, p.125), fizemos um levantamento de 2012 até o segundo semestre de 2013. Percebe-se que o aumento continua, pois do segundo semestre de 2011 ao segundo semestre de 2012 houve um crescimento de cinco turmas, com um total de 43 turmas e houve um aumento de 88

\footnotetext{
${ }^{25}$ Todas as informações são encontradas no seguinte site: http://sce.fflch.usp.br/
} 
alunos, contabilizando 692 alunos. E, do segundo semestre de 2012 ao segundo semestre de 2013, mais 10 turmas foram criadas com um total de 53 turmas e mais 78 alunos entraram para os cursos contabilizando 770 alunos.

Portanto, se compararmos o ano de 2009 ao ano de 2013, observamos o aumento de 22 turmas para 53 turmas e de 349 alunos para 770 alunos, e encontramos um crescimento de mais de $120 \%$ em cinco anos.

A evolução anual pode ser observada no gráfico abaixo:

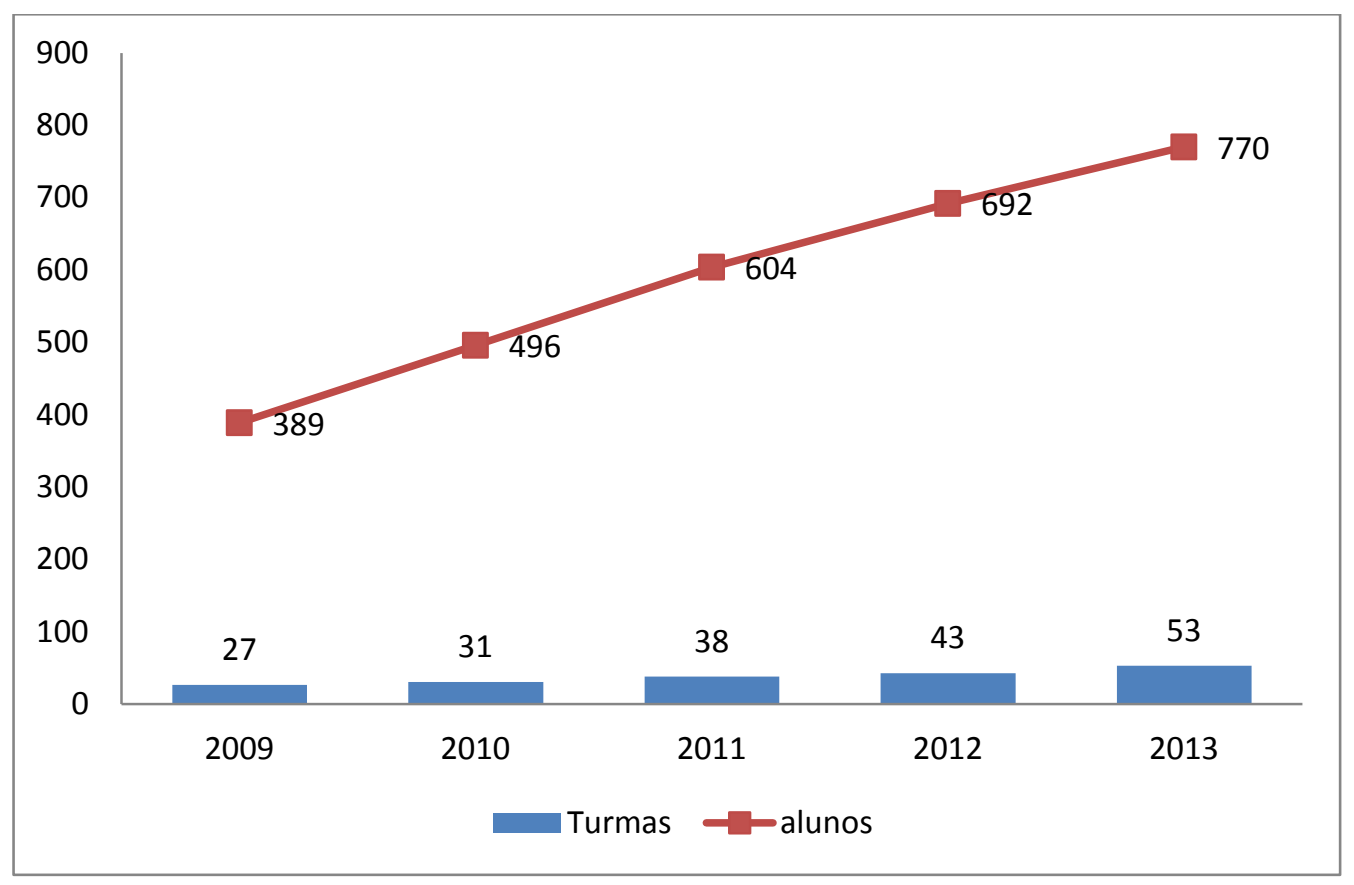

(Adaptado de GUIMARAES SANTOS, 2012, p. 125)

Figura 14: gráfico do crescimento anual de turmas e alunos dos cursos extracurriculares de francês

Além dos objetivos para com os alunos, esse curso tem como característica a formação contínua de professores e a aplicação de pesquisas desenvolvidas nos projetos desses monitores. Os professores são chamados, nesse contexto, de monitores, porque esses professores ainda são alunos da Universidade de São Paulo e não possuem vínculo empregatício com a Faculdade. Para se tornar um monitor nos Cursos Extracurriculares de Francês, deve-se estar vinculado à Universidade de São Paulo e já ter concluído o bacharelado, por isso, o monitor pode estar na licenciatura ou na pós-graduação. Todo semestre o processo de seleção para novos monitores é divulgado em edital. O número de monitores a serem selecionados varia a cada seleção, pois depende da qualificação dos candidatos e da necessidade de novos monitores combinada à procura pelo curso de francês. Existe portanto um processo seletivo, em que o monitor deve ser aprovado na 
análise de currículo, em uma prova escrita específica, realizada em francês, sobre fundamentos básicos da didática de línguas e em uma entrevista, também em francês, com três professores doutores da Faculdade de Letras da FFLCH-USP.

Ao serem aprovados no processo seletivo, os monitores-professores podem ministrar suas aulas por seis meses e, automaticamente, renovar o processo por mais seis meses. No final de dois semestres, caso o monitor queira continuar a exercer a monitoria, pode se candidatar novamente para o processo de seleção.

Em 2012, 20 alunos da Universidade de São Paulo atuavam como monitoresprofessores dos cursos extracurriculares de francês. Desses, 5 eram alunos da licenciatura e 15 eram alunos de mestrado. A maioria dos monitores era constituída por mulheres, sendo 2 monitores homens. Os monitores-professores são remunerados por meio de uma bolsa, por hora trabalhada, e exercem as atividades técnicas e didáticas. Nessas horas trabalhadas estão inclusas as horas de reuniões pedagógicas que acontecem uma vez por mês, durante as quais são abordadas: i) questões administrativas; ii) apresentação de atividades aplicadas nos cursos; iii) discussão de textos sobre a didática de línguas; iv) e experiências vividas em sala de aula. Durante a primeira reunião de cada semestre, são organizadas as apresentações das atividades dos monitores e as lideranças das discussões dos textos sobre o ensino-aprendizagem que são escolhidos pelos monitores em função dos temas de seu maior interesse.

Além de todo o desenvolvimento das reuniões e do trabalho em sala de aula, para a continuidade da formação dos professores-monitores, foram criadas pela coordenadora, as jornadas de formação dos Cursos Extracurriculares de Francês. Semestralmente, uma jornada de formação é organizada pela coordenação e pelos monitores, e os temas também são escolhidos a partir das dificuldades dos monitores em sala de aula. Por essa razão, já aconteceram jornadas sobre as habilidades orais, a arte no ensino do FLE, a multimodalidade no ensino de línguas, o intercultural, a avaliação, entre outras.

As jornadas acontecem durante a manhã e a tarde de uma sexta-feira, em que os professores-monitores apresentam suas oficinas à comunidade USP e ao público externo. O evento é divulgado pela Associação de Professores de Francês de São Paulo, por isso, conta-se com a presença de professores de francês de todo o estado de São Paulo. O último evento teve a presença de mais de 60 participantes.

Por fim, é importante salientar que o contexto dos cursos extracurriculares de francês não visa a nenhum objetivo comercial, e tem como anseio formar professores 
de francês que possam ensinar a língua francesa aos alunos que aumentam gradativamente.

\subsection{Os alunos participantes dos Cursos Extracurriculares da FFLCH-USP}

Os alunos participantes são, como mencionamos na seção anterior, alunos dos cursos extracurriculares de francês. Nesses cursos, os alunos deve ter a idade mínima de 18 anos, pois um dos pré-requisitos para a inscrição é a conclusão do ensino médio, não existindo limite máximo de idade.

A partir do pré-requisito da idade, percebe-se que os grupos são heterogêneos, pois ela varia entre 18 e 80 anos. Além da idade, o que comprova a heterogeneidade do grupo é a diversidade profissional, pois encontramos alunos das diversas áreas da Universidade de São Paulo e alunos de outras universidades, além de profissionais de todas as áreas, como: médicos, psicólogos, professores, cabeleireiros, biólogos, entre outros.

Apesar da heterogeneidade, é possível encontrar um grande número de funcionários da Faculdade de Filosofia, Letras e Ciências Humanas da Universidade de São Paulo, pois todos tem o direito de cursar gratuitamente qualquer curso de cultura e extensão da universidade.

Os alunos dos cursos semanais também se diferenciam dos cursos aos sábados, pois, durante a semana, encontra-se um maior número de estudantes da própria universidade, já que, assim, eles conseguem acrescentar o curso de francês às outras atividades acadêmicas. Aos sábados, a maioria dos alunos não possui vínculo com a universidade, pois os cursos que acontecem durante a semana são nos horários de almoço e à tarde, o que dificulta o curso daqueles alunos que trabalham e não moram próximos à região da cidade universitária. Por esse mesmo motivo, os cursos dos sábados sempre geram uma lista de espera, pois atingem rapidamente a capacidade máxima de 20 alunos.

Geralmente, todos os cursos de nível básico atingem o total de 20 alunos e poucos níveis possuem menos de 15 alunos.

Através de questionários feitos nos primeiros dias de aula de cada curso, podemos observar que muitos alunos escolhem a língua francesa por gostar da cultura e da literatura francófonas e também para estarem aptos às provas de proficiência do 
mestrado e do doutorado. Percebe-se que a escolha pelo curso extracurricular de francês não é uma obrigação para a maioria dos alunos e, por isso, a característica predominante em sala de aula é a motivação, aspecto facilitador na aprendizagem.

Entretanto, os pontos expostos no parágrafo anterior como motivadores na aprendizagem da língua estrangeira, podem ser igualmente motivos para o abandono do curso. Não se trata da maioria, mas para uma minoria de alunos dos níveis iniciais, a não obrigatoriedade do estudo do francês e o objetivo do curso que visa a aprendizagem de todas as habilidades e não somente o exame de proficiência, podem ser desestimulantes. Portanto, tendo motivos semelhantes para a continuidade ou não do curso, faz-se importante para o professor a preparação de aulas interessantes aos seus alunos.

A seguir, apresentaremos as características mais específicas referentes à professora-pesquisadora e, posteriormente, à preparação do modelo didático e da sequência didática com o objetivo principal de contribuir para o desenvolvimento das capacidades de linguagem de seus alunos, mas visando também a propor um curso interessante e motivante aos alunos.

\subsection{A professora pesquisadora}

Nasci em São Paulo, estudei Letras - bacharelado e licenciatura, com habilitação em francês, na Faculdade de Filosofia, Letras e Ciências Humanas da Universidade de São Paulo. Durante a graduação, fiz dois intercâmbios, em 2007 e 2008. O primeiro foi em Dublin, na Irlanda, onde fiz um curso de inglês, e o segundo foi em Paris, na França, onde fiz um curso de francês e participei de alguns cursos da Sorbonne, como aluna ouvinte. Nesse período, como já mencionado na Introdução, interessei-me pelos anúncios publicitários para a aprendizagem da língua estrangeira.

Em julho de 2009, ingressei como monitora nos cursos extracurriculares de francês e comecei a ministrar aulas nesse contexto. A atuação como monitora e a experiência vivida com as dificuldades de compreensão dos anúncios publicitários durante minha estadia na França motivaram-me a ingressar no mestrado, justamente para debruçar-me sobre essa questão.

A pesquisa foi portanto aplicada no contexto dos cursos extracurriculares, do qual continuei participando voluntariamente para a aplicação da sequência didática e 
para acompanhamento das atividades de formação. Na verdade, optamos por não pedir para um outro monitor dos cursos aplicar a sequência, pois acreditamos que nosso conhecimento das teorias que embasaram a sua elaboração seria importante para a coleta dos dados. Sendo assim, participei do desenvolvimento da sequência didática desde a sua execução piloto aos ajustes para a segunda turma. Portanto, em fevereiro de 2012 ministrei o curso de produção escrita criativa com a sequência didática piloto e em julho de 2012 a sequência foi adaptada e aplicada no curso de gêneros textuais.

\section{Procedimentos para a elaboração do modelo didático}

Para a elaboração do modelo didático, alguns procedimentos foram organizados e serão explicados nas seções seguintes, como a escolha do gênero textual anúncio publicitário, dos jornais de onde o gênero anúncio publicitário foi retirado e do período estipulado para organizar a coleta do corpus. Em seguida, a seleção dos anúncios publicitários será explicada e apresentaremos a elaboração do modelo didático do gênero.

\subsection{Escolha do gênero textual}

Assim como mencionamos anteriormente na "introdução", a escolha do gênero textual anúncio publicitário, para a elaboração da sequência didática, tem como objetivo desenvolver as capacidades de linguagem dos alunos aprendizes da língua francesa.,Essa escolha encontra apoio no Quadro Europeu Comum de Referência (QECR), que surgiu em 2001 para o ensino de língua estrangeira através da perspectiva acional, na qual a língua passou a ser vista, do ponto de vista didático, como um meio de ação no mundo.

É nesse contexto e com esse objetivo que o uso do anúncio publicitário parecenos um gênero pertinente para o ensino do francês como língua estrangeira.

Além disso, outro fator importante para a escolha do anúncio publicitário foi a sua autenticidade, que possibilita uma grande exploração pedagógica, já que ele permite preencher a lacuna gerada pelo fato de que muitos materiais didáticos contêm material 
fabricado quase que exclusivamente ${ }^{26}$. Além disso, a partir dos anúncios publicitários, pode-se, por exemplo, ampliar o vocabulário dos alunos, tornar mais realista o estudo da sintaxe, possibilitar a compreensão das ambiguidades e, ainda, favorecer a inserção do aluno no cotidiano francófono atual - nos hábitos alimentares, na vida familiar, nos lazeres - estabelecendo um paralelo entre a cultura francófona e a cultura do aluno.

\subsection{Escolha dos jornais Direct Matin e Direct Soir ${ }^{27}$}

Para esta pesquisa, fizemos uso dos jornais Direct Matin e Direct Soir ${ }^{28}$ da cidade de Paris, na França. A escolha dos jornais ${ }^{29}$ se justifica por serem veículos de fácil acesso em contexto francófono, pois são impressos, gratuitos e distribuídos nas entradas dos metrôs de Paris, um local de grande circulação diária. Outro fator importante é a possibilidade de acessá-lo via internet, exatamente da forma como é impresso, portanto, não se trata de um jornal virtual, mas disponibilizado em uma plataforma na qual podemos diariamente consultá-los, horas após sua distribuição.

Outra justificativa pela escolha desses jornais é a quantidade de anúncios publicitários neles encontrados, pois os jornais são financiados exclusivamente pelas propagandas. Apesar de o jornal Direct Soir ter parado de circular desde dezembro de 2010, sem justificativa, o Direct Matin continua em circulação em diversas cidades da França, como: Paris, Aix en Provence, Avignon, Bordeaux, Lille, Lyon, Marseille, Montpellier, Nantes-Rennes, Nice Côte-d'Azur, Strasbourg e Toulouse. Além do jornal Direct Soir, outros jornais pararam de circular em 2011, como o Direct Sport que teve sua última edição em 01 de julho de 2011 e o Direct Femme em 26 de maio de 2011.

De acordo com o quadro teórico que adotamos, baseado em Bronckart (2003), antes de qualquer análise textual ou discursiva, deve-se identificar o contexto de produção dos textos, para melhor compreendermos as escolhas feitas no plano textual e

\footnotetext{
${ }^{26}$ É o caso, por exemplo, dos seguintes materiais publicados atualmente (Echo, 2010) e há alguns anos (Campus, 2002), ou mesmo de alguns materiais que misturam materiais autênticos e fabricados (Alter Ego, 2006).

${ }^{27}$ O corpus foi retirado pelo site do Direct Média de 15 a 22 de novembro de 2010 e, atualmente, o Direct Soir não é mais distribuído, por isso não se encontra disponível na internet desde dezembro de 2010. Contudo, o jornal Direct Matin continua a ser distribuído em diversas cidades da França e encontra-se na internet para ser carregado todos os dias pelo site: http://kiosque.directmatin.fr/

${ }^{28}$ Estes são dois entre diversos jornais do mesmo grupo, os quais também são nomeados como Direct e distribuídos por toda a França.

${ }^{29} \mathrm{Na}$ seção "Histórico da pesquisa" contamos como e quando foi o primeiro contato com os jornais.
} 
discursivo. Segundo esse autor, o contexto de produção dos jornais pode ser dividido em contexto físico e contexto sociossubjetivo. O contexto físico, segundo o que desenvolvemos na seção 2.1 , diz respeito ao conjunto do "comportamento verbal concreto" (2003, p. 93) e é dividido em: lugar de produção - o lugar físico onde o texto é produzido, momento de produção - o período durante o qual o texto é produzido, emissor - o produtor físico do texto e receptor - as pessoas que percebem ou recebem o texto. Já o mundo social e subjetivo ou contexto sociossubjetivo dizem respeito à “interação comunicativa" dividida também em quatro partes: lugar social - o quadro de formação social como, por exemplo, a instituição escola, enunciador - o papel social do emissor, destinatário - o papel social do receptor do texto e objetivo - o ponto de vista do enunciador e os efeitos produzidos pelo texto no destinatário. Vejamos, portanto, as características do contexto de produção dos jornais que são o veículo de divulgação dos anúncios para, em seguida, atermo-nos aos anúncios publicitários.

Os jornais de nomes Direct Soir e Direct Matin, dos quais retiramos o corpus para esta pesquisa, foram lançados pelo grupo Bolloré em 2006 e 2007, respectivamente. O grupo Bolloré é um importante prestador técnico de audiovisual na Europa e detém mais de $18 \%^{30}$ do capital de mídia europeu, além de possuir capitais em transporte e logística internacional, distribuição de energia e indústrias. Mas, para que esses jornais gratuitos circulem na França, o grupo tem a colaboração dos jornais Courrier International e Le Monde em notícias jornalísticas e, como mencionamos“ anteriormente, a colaboração `dos anúncios publicitários que financiam a distribuição.

Apesar da existência dos jornais Direct Matin e Direct Soir impressos, apresentamos, a seguir, o contexto de produção dos jornais virtuais, visto que o corpus foi inteiramente retirado do site do grupo de mídias Direct.

\footnotetext{
${ }^{30}$ Informações encontradas no site : http://www.bollore.com/ - com acesso em 25.09.2012.
} 
Quadro 14: O contexto de produção dos jornais virtuais Direct Matin e Direct Soir Contexto físico Contexto sociossubjetivo

\begin{tabular}{|l|l|}
\hline $\begin{array}{l}\text { Emissor: Direct Matin e Direct Soir - } \\
\text { jornal virtual }\end{array}$ & $\begin{array}{l}\text { Enunciador: Grupo Bolloré - Direct - } \\
\text { com colaboração dos jornais Courrier } \\
\text { International e Le Monde - detentor de } \\
\text { mais de 22\% do capital do "Euro média } \\
\text { Group", um dos primeiros prestadores } \\
\text { técnicos audiovisuais da Europa. }\end{array}$ \\
\hline $\begin{array}{l}\text { Receptor: Internautas do mundo todo que } \\
\text { leem francês }\end{array}$ & $\begin{array}{l}\text { Destinatário: usuários do metrô que não } \\
\text { tiveram acesso ao jornal impresso, } \\
\text { telespectadores do canal digital Direct 8, } \\
\text { outros internautas }\end{array}$ \\
\hline Local Físico: França/Paris & $\begin{array}{l}\text { Local Social: site do jornal na internet } \\
\text { (http://kiosque.directmatin.fr/) }\end{array}$ \\
\hline Momento: Manhã e final da tarde & $\begin{array}{l}\text { Objetivo: Transmitir as atualidades do dia, } \\
\text { ampliar a divulgação das publicidades } \\
\text { financiadoras adaptando-se ao ritmo de } \\
\text { vida dos leitores e sua mobilidade. }\end{array}$ \\
\hline
\end{tabular}

Ao observarmos o contexto físico do contexto de produção dos jornais virtuais, encontramos: como receptores, os internautas do mundo todo, ou seja, aqueles que têm habilidade de compreensão escrita em língua francesa; e, como momento de produção, um período variável, visto que o jornal virtual é colocado no site após a distribuição do jornal impresso, ou seja, o Direct Matin é posto no site, para seus receptores, no período da manhã, entretanto, sem um horário fixo; o mesmo acontece com o Direct Soir.

Em relação ao contexto sociossubjetivo, temos: como enunciador, o grupo Bolloré, uma empresa familiar criada em 1822, sob a direção de Vincent Bolloré. Esse grupo é detentor de mais de $22 \%$ do capital do "Euro média Group", um dos primeiros prestadores técnicos audiovisuais da Europa e está, atualmente, entre as 500 grandes companhias do mundo e iniciou seu trabalho com os polos transporte, logística e energia. Nos anos 2000, o grupo Bolloré passou a se desenvolver no polo mídia e telecomunicação e, em 2005, a empresa lançou o canal Direct 8. Em 2006, o grupo lançou o jornal gratuito Direct Soir $^{31}$ e, em 2007, o Direct Matin, concorrentes dos jornais gratuitos Métro e 20 minutes. Em 2010, comprou o canal Virgin 17 e o renomeou Direct Star.

Desde o início, os jornais Direct Matin e Direct Soir recebem as reportagens e as notícias, colaborativamente, através dos jornais Le monde e Courrier International.

\footnotetext{
${ }^{31}$ O jornal Direct Soir foi distribuído de 2006 a 2010 com esse nome e, a partir de 2011, foi dividido em Direct Sport, direcionado a um público majoritariamente masculino, e Direct Femme, destinado às mulheres. Isso reitera o interesse da população pelo jornal, que foi dividido por público, e a força do grupo Bolloré, na França.
} 
Ainda sobre o contexto sociossubjetivo, como local social temos o site dos jornais (http://kiosque.directmatin.fr/); e, como destinatário, identificamos o usuário de metrô que não se serviu do transporte em um determinado dia e, por isso, buscou o jornal no site; o telespectador do canal digital Direct 8, local onde os jornais são divulgados; outros destinatários internautas que moraram na França e conheceram o jornal; entre outros internautas que conhecem o jornal por algum motivo e que possuem a habilidade de compreensão escrita em língua francesa; interessados em geral.

Ao observarmos as características dos jornais, percebemos que a disposição dos elementos que os compõem, como as notícias, os anúncios publicitários e as imagens, possuem uma entrada de leitura visual chamada leitura zapping ou modo de leitura hipertextual, ou seja, um modo de leitura rápido e não linear como a leitura que acontece no computador. De maneira geral, não estamos restringindo o hipertexto ao suporte eletrônico, pois da mesma forma que a leitura em suporte eletrônico não é linear, a cognição humana também não é.

Coscarelli (2012, p.121), por exemplo, apresenta-nos o hipertexto sob duas perspectivas: a primeira "que vê o hipertexto como um formato textual que possibilita o estabelecimento de uma rede de relações por meio de inúmeras conexões entre os blocos de texto" e a segunda que "entende o hipertexto, ou a hipertextualidade, como condição enunciativa e cognitiva da produção de conhecimento". A primeira perspectiva pode explicar o layout do jornal e a segunda perspectiva, a mente humana durante a leitura, ou seja, a associação de pensamentos, a condição da enunciação e da cognição humana.

Ainda sobre a disposição dos elementos do jornal Direct Matin e Direct Soir, Koch (2002, p.61) afirma que "todo texto constitui uma proposta de sentidos múltiplos e não de um único sentido", ou seja, "todo texto é plurilinear na sua construção" e é essa opção linear do leitor que faz do texto um hipertexto. E, ainda, o conceito mais próximo à hipertextualidade dos jornais é encontrado em Marcuschi (1999, p.29), ao afirmar que o "hipertexto não é um texto fisicamente realizado, mas uma virtualidade", ou seja, a leitura desses jornais é uma leitura semelhante à de uma página da internet, com diversos boxes onde podemos zapear as notícias de acordo com o nosso interesse.

Os dois jornais possuem informações gerais e as informações são colocadas em cadernos, assim como encontramos as informações nos grandes jornais (não gratuitos), entretanto, nesses jornais gratuitos, não há uma ordem fixa diária para os cadernos. Portanto, encontramos aleatoriamente, nos jornais Direct Matin e Direct Soir, os 
seguintes cadernos: Paris, França, Mundo, Esporte, Cultura, Televisão, Programação Televisiva, Turismo, Automóvel e Diversão.

Com relação ao tamanho dos jornais e à quantidade de anúncios publicitários do período analisado, o jornal Direct Matin possui de 30 a 40 páginas e de 15 a 20 anúncios publicitários; enquanto o jornal Direct Soir possui de 15 a 25 páginas e de 05 a 10 anúncios publicitários. Logo, ambos os jornais possuem de $20 \%$ a $65 \%$ das páginas com pelo menos um anúncio publicitário.

O período para a seleção dos jornais foi escolhido de forma a não pegar nenhum feriado ou data comemorativa de incentivo ao consumo, para que isso não influenciasse os anúncios publicitários. Por isso, o período de coleta dos jornais foi de duas semanas, do dia 15 de novembro de 2010 ao dia 26 de novembro de 2010, ressaltando que os jornais eram divulgados de segunda à sexta. Portanto, dez jornais Direct Matin e dez Direct soir foram coletados nesse período, para serem, posteriormente, analisados.

Dos 20 jornais coletados, escolhemos seis anúncios publicitários relacionados à televisão e cinema, ao governo e ao transporte, totalizando 18 anúncios, dos quais analisamos as características, com base em Bronckart (2003, 2006) e Kress e Van Leeuwen (2006), visando à construção do modelo didático. Através do modelo didático, pudemos organizar atividades escolares para construção de uma sequência didática a fim de contribuir para a aprendizagem do francês e de desenvolver as capacidades de linguagem dos alunos.

\subsection{Escolha dos anúncios publicitários}

A escolha dos anúncios publicitários foi feita após uma análise geral dos anúncios publicitários encontrados nos 20 jornais referentes ao período do dia 15 de novembro de 2010 ao dia 26 de novembro de 2010. Ao fazer um levantamento dos anúncios publicitários, encontramos anúncios sobre filmes, emissões de televisão, peças de teatro, shows, aparelhos tecnológicos, lojas, passagens aéreas e de trem, carros, livros, bebidas, produtos de beleza, bancos, empregos, além de anúncios relacionados ao governo.

O gênero anúncio publicitário, como citamos na seção 2.2, aparece em até $65 \%$ das páginas dos jornais do período selecionado e podemos observar a proporção dos diferentes anúncios, além de suas quantidades na leitura do gráfico abaixo. 


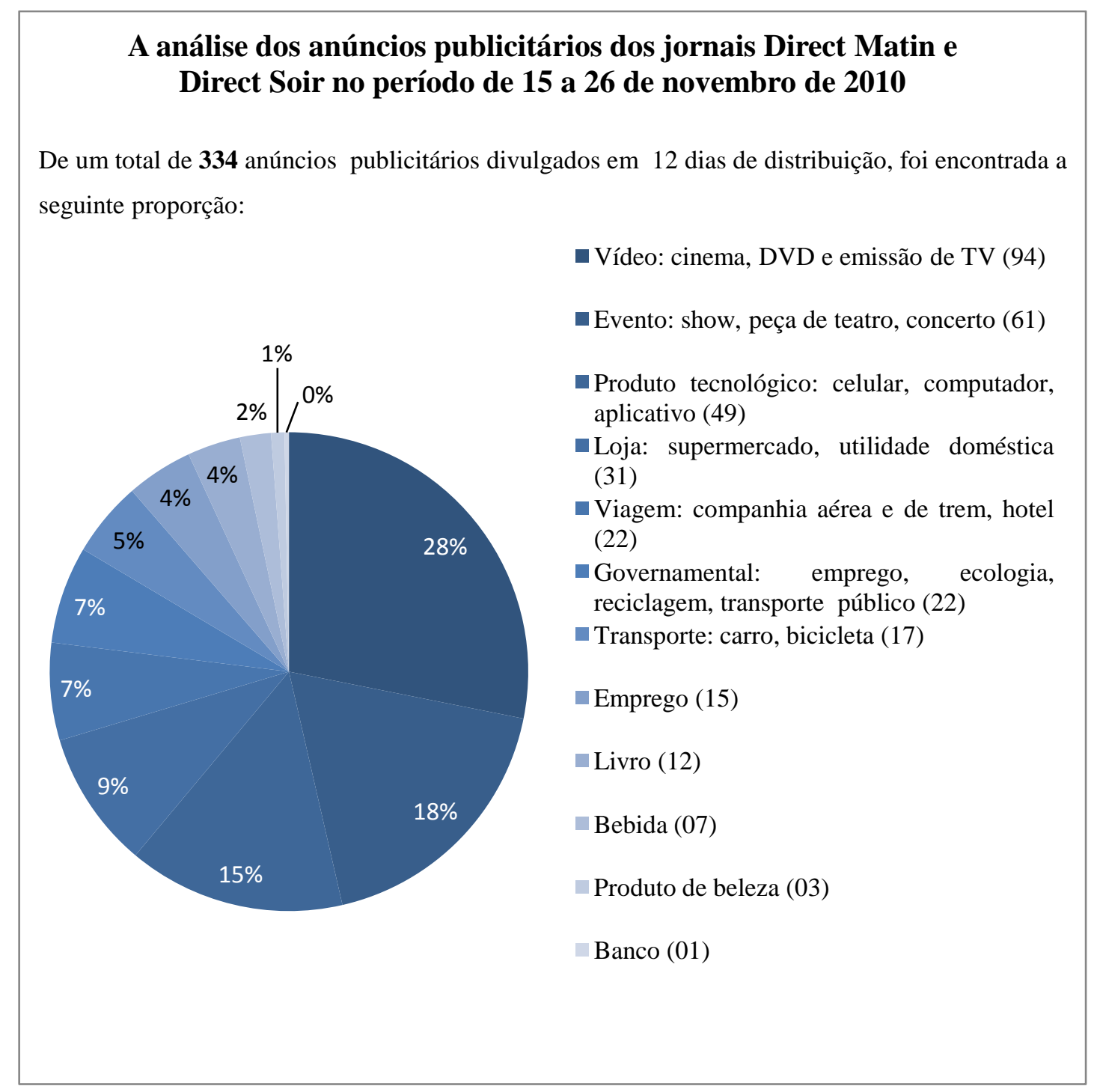

Figura 15: A proporção dos diferentes anúncios publicitários

Para a elaboração do modelo didático do gênero textual anúncio publicitário, escolhemos, através do critério de frequência diária, seis anúncios de cada tipo. Observamos a análise da proporção dos diferentes anúncios publicitários, apresentada na figura 15, mas também a quantidade de um tipo específico de anúncio por dia, ou seja, fizemos um levantamento geral dos dez dias de jornais e um levantamento diário. Os anúncio que foram mais recorrentes diariamente foram escolhidos.

Após observar os tipos de anúncios que apareceram pelo menos uma vez ao dia, durante as duas semanas de distribuição dos jornais, encontramos: vídeo, evento, produto tecnológico, loja e viagem como os mais recorrentes, ou seja, ao menos um anúncio desse tipo aparece uma vez ao dia, seguido dos tipos governamental, que foi encontrado em nove dos dez dias e transporte, encontrado em sete dos dez dias de distribuição. 


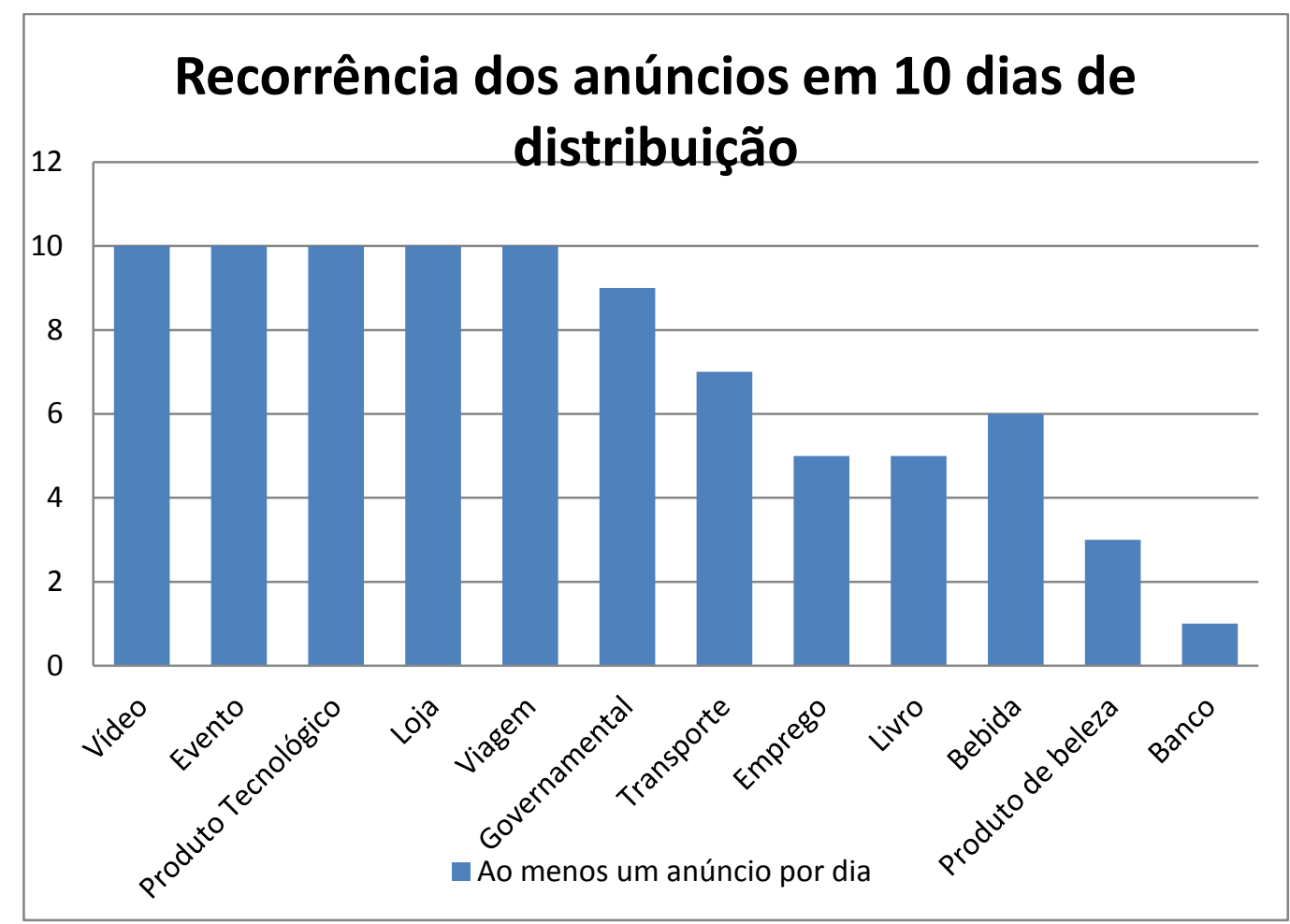

Figura 16: A recorrência dos tipos de anúncios publicitários dos jornais Direct Matin e Direct Soir no período de 15 a 26 de novembro de 2010.

A partir dessa relação, consideramos como critério os conceitos de Schneuwly e Dolz (2004) nos quais nos baseamos, no que diz respeito ao modelo didático e à organização da sequência didática. Sendo assim, procuramos dividir os cinco dias de aula segundo os módulos propostos pelos autores.

Preparamos, primeiramente, um curso piloto que tinha a duração geral de 45 horas, como todos os cursos extracurriculares de francês, e os dias eram organizados e divididos com outros monitores-professores que também fizeram seus ateliês. Portanto, no curso piloto tivemos 3 aulas para o desenvolvimento da sequência didática, sendo 4 ateliês diferentes e dividimos as outras três aulas que totalizavam as 45 horas em uma aula para a apresentação inicial e produção inicial de todos os gêneros do curso, e as outras duas aulas para a produção final de todos os gêneros. Já no segundo curso, tivemos três ateliês e pudemos dividir em 5 aulas para cada ateliê, da seguinte forma: uma aula para a apresentação inicial e para a produção inicial; três aulas divididas em três módulos de atividades e uma última aula para as produções finais.Para organizar o conteúdo a ser trabalhado, escolhemos os quatro tipos mais recorrentes de anúncio para a sequência didática piloto e, após uma reformulação de atividades necessária para um 
melhor desenvolvimento das capacidades de linguagem dos alunos, escolhemos três tipos de anúncios publicitários para a segunda sequência didática. Retomando a escolha pelos tipos de anúncios, ao analisar os textos que seriam coletados para a elaboração do modelo didático e, posteriormente, para a elaboração das atividades que compuseram a sequência didática, percebemos que dos 31 anúncios do tipo loja, apenas dois eram de lojas diferentes e todos os outros eram iguais, porém com a variação do produto a ser vendido.

Já os anúncios do tipo evento eram todos de eventos diferentes, mas não variavam em sua estrutura, ou seja, todos possuíam uma imagem central referente ao evento, a data do evento e endereço, sem nenhum vetor que pudesse produzir uma interação com o leitor e sem um texto verbal relevante para a criação das atividades. $\mathrm{O}$ mesmo acontecia com os anúncios do tipo viagem, nos quais observamos imagens como cartões postais e preços, também com pouco texto verbal.

Sendo assim, pudemos determinar alguns critérios para eliminar alguns tipos de anúncio: anúncios publicitários com insuficiência de textos verbais, estrutura invariável para um mesmo tipo de anúncio, falta de vetores das imagens, que servem para interpelar o leitor e transmitir ação para a imagem retratada não foram selecionados, pois os aspectos que mencionamos são importantes para persuadir o leitor. Por essa razão, as próprias categorias fornecidas pelas teorias do ISD e da GDV contribuíram para a seleção dos anúncios . No quadro global de análise, observamos que faz parte da capacidade discursiva do produtor e do receptor perceber o potencial de persuasão do documento que é composto pela intencionalidade do discurso e pela argumentação. Logo, o desenvolvimento das capacidades de linguagem dos alunos está diretamente relacionado à compreensão do poder de persuasão de um anúncio publicitário, como apresentamos no capítulo I. Além disso, dentre os tipos de anúncios escolhidos, analisamos os que poderiam veicular informações culturais, já que, como apresentamos na Introdução, os implícitos culturais despertaram meu interesse pelos anúncios publicitários, quando morava na França, pois eles dificultavam justamente a compreensão dos anúncios. Sendo assim, julgamos que, no ensino aprendizagem de uma língua estrangeira, a cultura deve aparecer em diferentes contextos, sendo esse gênero textual propício para observar essas diferenças culturais.

O anúncio do tipo produto tecnológico, que apareceu ao menos uma vez durante os dez dias de coleta do jornal, era interessante e foi utilizado na sequência didática, porém, na reformulação da sequência, as atividades em que esses anúncios apareciam 
foram retiradas pela necessidade da inserção de novas atividades que pudessem desenvolver as capacidades de linguagem que observamos como necessárias através de análises da sequência didática piloto.

Portanto, após as análises dos tipos de anúncios publicitários, foram escolhidos: vídeo, produtos tecnológicos (somente na SD piloto), governamental e transportes. Para decidirmos os tipos de anúncios, baseamo-nos, primeiramente, na quantidade diária de cada tipo de anúncio, como pudemos observar no gráfico anterior sobre a recorrência dos anúncios por dia de publicação, em que tivemos pelo menos uma recorrência por dia dos tipos: vídeo, evento, tecnológico, loja, viagem; e a recorrência em mais de cinco dias dos tipos: governamental, transporte e bebida.

Contudo, paralelamente ao critério de frequência, ou seja, à análise da quantidade dos tipos de anúncios, utilizamos o critério de pertinência para o trabalho com os alunos, por isso, selecionamos aqueles anúncios com uma estrutura mais aberta ou variada, que pudesse se prestar melhor ao uso com os alunos. Além disso, o efeito argumentativo produzido pelos anúncios publicitários foi um critério importante, visto que o objetivo de desenvolver as capacidades de linguagem dos alunos envolve, principalmente, nesta pesquisa, a capacidade discursiva, através da qual o leitor é capaz de perceber as intenções de quem lhe direciona o discurso, pois sem essa percepção, não existe comunicação (KOCH, 1996). Em um anúncio publicitário, portanto, o leitor deve apreender a intencionalidade do produtor que aparece em texto verbal mas, principalmente, em texto não verbal. Quando os aspectos verbais e não verbais são apreendidos, os textos podem persuadir o leitor. Finalmente, o último critério de escolha foi o fato de o anúncio poder veicular ou não informações culturais.

Logo, a seleção se deu a partir dos anúncios que poderiam melhor desenvolver as capacidades de ação e a discursiva dos alunos, além de permitir o uso de diferentes suportes e/ou o uso de diferentes habilidades para a criação da sequência didática. Podemos citar, como exemplo, a atividade sobre o anúncio da emissão de televisão que faria uma competição entre profissionais, pois utilizamos a publicidade televisiva para desenvolver também a compreensão oral dos alunos do ateliê. Sendo assim, para a escolha dos tipos, dispensamos aqueles que tinham uma estrutura fixa (local da imagem, do texto verbal e do slogan, apenas com a variação do produto), por tipos a partir dos quais pudéssemos criar diferentes atividades para que as produções dos alunos fossem mais livres para o desenvolvimento das capacidades de ação, discursiva e, também, linguístico-discursiva. Por exemplo, os anúncios que não possuem texto verbal não 
permitiriam o desenvolvimento da produção textual verbal dos alunos, por isso foram descartados.

Portanto, como apresentamos nesta seção, escolhemos os anúncios publicitários de vídeo, dentre os quais encontramos os cartazes de filmes a serem estreados no cinema ou transmitidos na televisão e os anúncios de emissões televisivas em geral; os anúncios governamentais, dos quais fazem parte os anúncios sobre os transportes públicos, a reciclagem, a ecologia, as entidades destinadas à busca de um emprego, além de qualquer anúncio destinado a conscientizar a população; e os anúncios de transporte, como carros e bicicletas.

\subsection{O modelo didático do gênero anúncio publicitário}

O modelo didático é a etapa inicial para a elaboração de um material didático e, por isso, pode ser visto como um instrumento do professor (DE PIETRO ET AL, 1996/1997). Para construirmos o modelo didático de um gênero, respeitamos alguns princípios propostos por Schneuwly e Dolz (2004), ou seja: a) a pertinência - os anúncios publicitários devem ser escolhidos e analisados com o objetivo posterior de desenvolver as capacidades de linguagem dos alunos; b) a legitimidade - as análises são baseadas em estudos de pesquisadores pertencentes à comunidade; c) a solidarização a análise das diferentes dimensões que constituem o gênero.

Para construir o MD, seguimos as seguintes etapas: escolhemos o gênero anúncio publicitário, selecionamos seis anúncios de três tipos diferentes, como explicamos na seção anterior, e, com base em estudos sobre linguagem (BRONCKART, 2003/2006; KRESS E VAN LEEUWEN, 2006, LEAL, 2011), analisamos as características do gênero textual e observamos suas práticas sociais (DE PIETRO ET AL, 1997). No que diz respeito à análise da linguagem verbal e não verbal que constitui os anúncios, o MD foi construído através do quadro da união do ISD (BRONCKART, 2003) e da GDV (KRESS E VAN LEEUWEN, 2006) proposto por Leal (2011), que o nomeou de modelo de análise semiótico sociointeracional, como apresentamos na seção 4 do capítulo I.

Escolhemos seis anúncios de cada um dos três tipos de anúncio publicitário selecionado para a criação da sequência didática. Do tipo vídeo escolhemos: dois programas de televisão e quatro anúncios de filmes ou séries em DVD. Do tipo 
governamental, selecionamos seis anúncios com os temas: ecologia, incêndio, emprego, transporte público e eletricidade. Finalmente, selecionamos seis anúncios do tipo transporte: um anúncio publicitário de bicicleta e cinco anúncios de carros.

Para realizar nossa análise, seguimos a proposta de união das teorias que apresentamos no Capítulo I, representada pelas seguintes etapas:
A) análise do contexto de produção e recepção dos textos
B) análise da organização temático-representacional, verbal e não verbal
C) análise da organização interacional, verbal e não verbal
D) análise da organização estrutural, verbal e não verbal

Vejamos, assim, a primeira etapa da elaboração do modelo didático (A), que diz respeito aos contextos. De acordo com o quadro semiótico apresentado por Leal (2011), os contextos de produção e recepção dos anúncios publicitários, que são publicados em jornais, não costumam ser muito diferentes, pois não existe um período temporal distante: em menos de 24 horas os jornais são produzidos e distribuídos, o que nos leva a imaginar que os contextos de produção e recepção não sofrem muitas alterações.

Em nosso corpus, pudemos observar algumas variações entre o contexto de produção e de recepção como, por exemplo, a variação do produtor, pois ao selecionarmos anúncios de diferentes marcas de produtos ou organizações, encontramos diversos produtores em um único jornal (lembrando que o Direct Matin e o Direct Soir são produzidos pelo mesmo grupo de mídia Direct). Também encontramos a variação da posição social do receptor e do produtor desses anúncios publicitários, porque todos os anúncios financiam um mesmo jornal, mas nem todos os receptores que passam pelo metrô de Paris possuem o mesmo perfil ou posição social.

Portanto, não podemos limitar o perfil dos usuários do metrô (local onde os jornais impressos são distribuídos) a uma posição social única. Por exemplo, o anúncio publicitário de um filme de comédia pode ser dirigido a todos os receptores que estão no metrô, mas apenas aos destinatários amantes de comédia. Da mesma forma, os anúncios de emprego são destinados àqueles que o procuram. Mas, mesmo constatando os dois anúncios divulgados no mesmo dia e no mesmo jornal, não podemos generalizar a posição social dos receptores e afirmar que todo usuário do metrô gosta de comédia e está desempregado. Daí o interesse em se trabalhar com os dois conceitos do ISD: contexto físico de produção e contexto sociossubjetivo. 
Ainda, para refletirmos um pouco mais a respeito da variação da posição social dos receptores dos anúncios publicitários do jornal, destacamos que um anúncio publicitário de um carro caro pode se dirigir ao receptor de posição social favorável, ou seja, que tem condições de comprá-lo ou pode se dirigir a um receptor que ainda não tem o dinheiro para comprá-lo, mas que trabalhará muito para essa conquista.

Analisando a organização temático-representacional verbal da arquitetura interna dos textos (B), encontramos diversos conteúdos temáticos nos anúncios sobre vídeos e nos anúncios governamentais, como: cultura, sociedade, humor, profissão, ecologia, entre outros. O mundo discursivo é majoritariamente o do expor implicado, ou seja, o discurso é interativo, pois os anúncios publicitários estão relacionados ao presente conjunto, ao presente do mundo ordinário em que se dialoga com o leitor para alcançar o objetivo dos anúncios.

Como vimos, em relação à organização temático-representacional não verbal, encontramos as representações: i) narrativas e ii) conceituais ou iii) narrativas e conceituais simultaneamente. Baseando-nos nos anúncios selecionados, apresentamos, a seguir, exemplos dos dois tipos de representações:

i) Há representações narrativas quando existem participantes humanos, pois o olhar e os gestos geram um vetor que chamamos de processo de ação transacional. É o caso do anúncio publicitário do programa de televisão "Espoir de l'année" da emissora M6, em que um dos atores olha para a carne e o ator principal olha para o leitor. Essa implicação ao leitor através do vetor olhar ${ }^{32}$ é bastante comum, como vemos abaixo:

\footnotetext{
${ }^{32}$ Como apontamos no Capítulo II, um vetor é uma linha que parte de um olhar e se direciona a um fenômeno que pode estar presente da imagem observada pelo leitor ou não (KRESS E VAN LEEUWEN, 2006).
} 


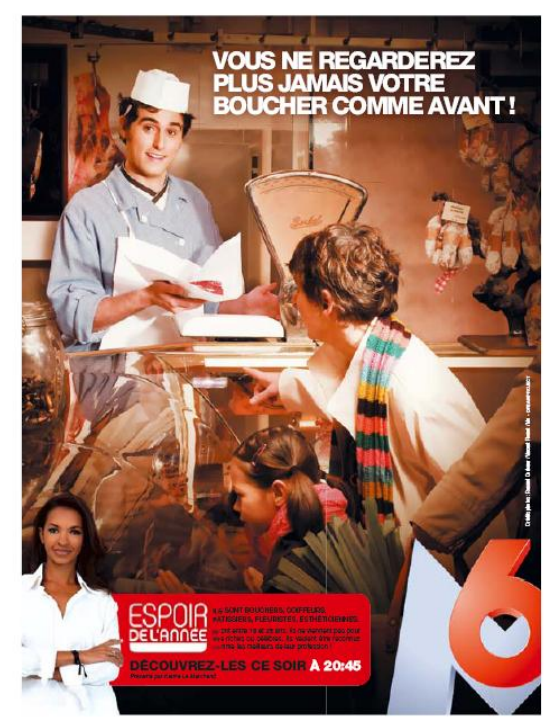

Figura 17: anúncio publicitário de vídeo - M6

Se pensarmos no efeito argumentativo do anúncio que acabamos de observar, veremos que ele acontece por meio da implicação do leitor, através do vetor olhar e do uso do "vous", que criam a impressão de estarmos vendo nosso açougueiro e falando realmente com o produtor do anúncio. O efeito argumentativo também ocorre pelas modalizações apreciativas que indicam a presença de emoções, por meio de dois índices verbais: elementos que indicam que algo é superlativo ("plus jamais") e o ponto de exclamação.

Dentro das representações narrativas, encontramos também a representação do processo de reação não transacional, quando os participantes reagem a algum fenômeno e o observam, mas, apesar de os leitores conseguirem observar a existência de vetores que partem do olhar dos participantes, não conseguem ver o fenômeno ou o evento ao qual os participantes assistem. Um exemplo é o anúncio publicitário do DVD "Toy story 3", em que todos os participantes e personagens do filme aparecem juntos observando algum fenômeno que subentendemos ser o lançamento do DVD, porém, os vetores olhares não observam o DVD. 


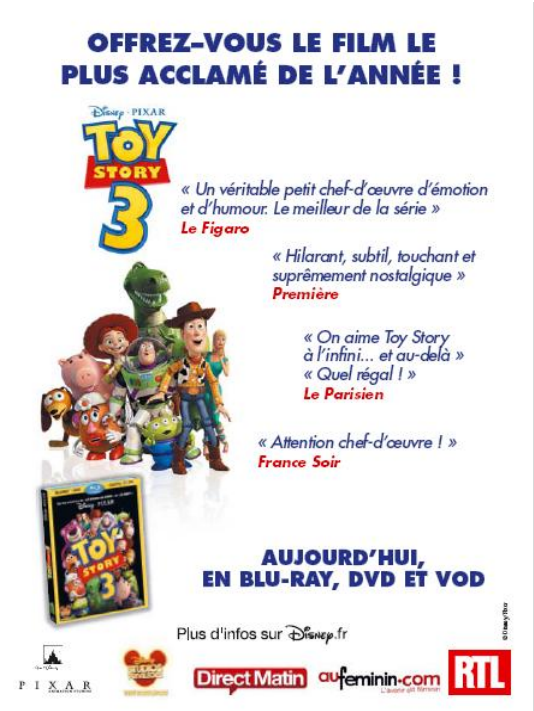

Figura 18: anúncio publicitário de vídeo - Toy Story 3

Um outro exemplo do processo de reação não transacional pode ser visto no anúncio do carro da BMW, no qual seis participantes aparecem em quatro situações diferentes e todos observam algo que subentendemos ser o olhar de alegria exposto no slogan "la joie est irrésistible", de dentro para fora do carro.

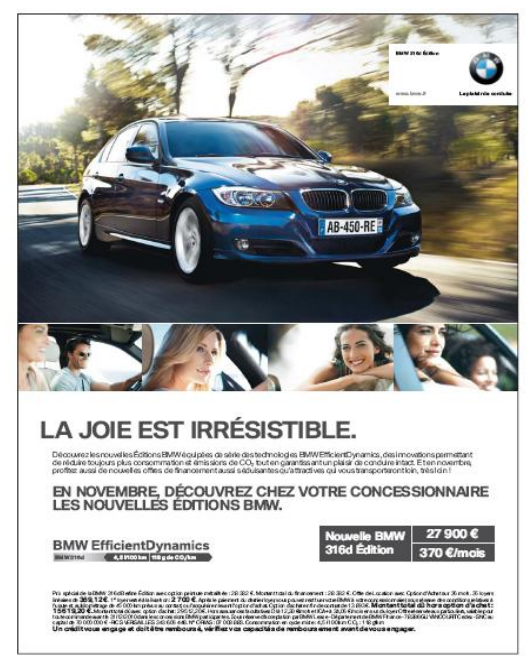

Figura 19: anúncio publicitário de transporte - BMW

ii) Já a organização temático-representacional não verbal conceitual é a representação sem vetor, ou seja, trata-se de participantes ou objetos pertencentes a um grupo específico ou objetos simbólicos que são realçados pelo exagero do tamanho. Essa representação não é muito comum. Um exemplo dessa representação conceitual pode ser encontrado no anúncio publicitário governamental do metrô de Paris, em que 
observamos objetos, sem nenhum vetor, representantes das características socioculturais, pois encontramos um croissant, típico alimento francês, além de um metrô com a típica entrada parisiense em Art Nouveau.

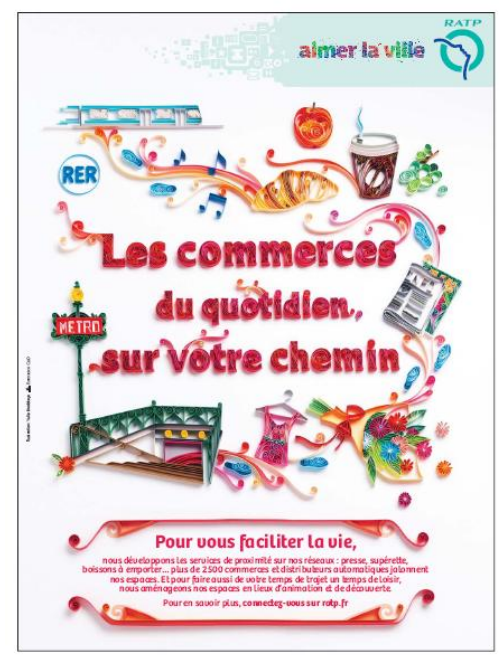

Figura 20: anúncio publicitário de transporte - RATP

iii) É importante afirmar que, no geral, uma representação não anula a outra, pois podemos encontrar um anúncio publicitário com a representação narrativa e a conceitual juntas, como por exemplo, o anúncio do carro da Renault, em que o carro aparece no centro e sozinho, sendo, portanto, o objeto mais importante em cena. E, por não ser humano, o participante não se torna um ator, pois não possui nenhum vetor, sendo esta representação conceitual. Entretanto, na base do anúncio publicitário, podemos encontrar a representação narrativa através de uma foto de um homem de negócios anexada por um clipe, em que encontramos o vetor olhar implicando o leitor.

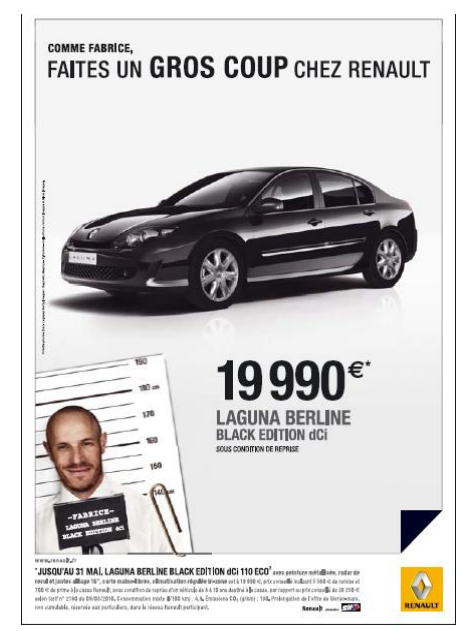

Figura 21: anúncio publicitário de transporte - Renault 
O quadro semiótico sociointeracional, proposto por Leal (2011), apresenta uma organização interacional (C) dividida em verbal - vozes do discurso e modalização - e não verbal - contato, distância social, atitude e modalidade. Passemos, agora, para essa análise.

No que diz respeito ao primeiro item, à organização interacional verbal, como já mencionamos, encontramos uma maior quantidade de discurso interativo implicado da ordem do expor, pois muitos slogans ou textos explicativos dos anúncios publicitários têm como objetivo implicar o leitor na apresentação de algum objeto ou participante. Sendo assim, encontramos várias marcas do pronome pessoal "vous", como em: "Vous ne regarderez plus jamais votre boucher comme avant", no anúncio do programa de televisão Espoir de l'année; Offrez-vous le film le plus acclamé de l'année!", no anúncio do DVD do filme Toy Story 3; "Ne laissez pas la vie de ceux que vous aimez partir em fumée", no anúncio governamental de conscientização dos incêndios domésticos; "votre ancienne voiture vaut encore jusqu'à 5,900 euros", no anúncio dos automóveis Renault.

Em menor quantidade, encontramos a terceira pessoa do plural ou do singular, como, por exemplo, em: "Ils sont bouchers, coiffeurs, pâtissiers, fleuristes, esthéticiennes [...] Decouvrez-les ce soir", encontrado no anúncio do programa de televisão Espoir de l'année.ou em "La joie est irrésistible", no anúncio de automóveis $B M W$.

Ainda na organização interacional verbal, podemos encontrar diversas modalizações, que indicam a atitude do falante em relação ao conteúdo temático. Elas podem apontar: uma constatação ou uma certeza, por exemplo quando o verbo está no modo indicativo; uma ordem, por exemplo, quando o verbo está no modo imperativo ou quando a ordem aparece de forma implícita; ou uma condição, por exemplo quando o verbo se encontra no modo subjuntivo; entre outras. Como já apontamos, segundo Bronckart (2008) e Leal (2011), as modalizações podem ser lógicas ou epistêmicas, quando ligadas aos julgamentos sobre o valor de verdade das proposições enunciadas, ou seja, são expressas por certeza, possibilidade, probabilidade e improbabilidade; podem ser deônticas, quando ligadas aos diferentes graus de obrigatoriedade, como uma necessidade; ou podem ser apreciativas, quando se referem a uma avaliação de aspectos do conteúdo temático.

Os anúncios publicitários que analisamos possuem modalizações variadas, sobretudo lógicas e deônticas. Isso contraria o que observamos frequentemente nos 
livros didáticos, em que se utiliza os anúncios publicitários para a aprendizagem dos verbos no imperativo, como única forma de modalização deôntica. Um exemplo de modalização lógica pode ser encontrado no texto verbal do anúncio publicitário governamental sobre voluntariado, em que encontramos o verbo 'poder' expressando uma possibilidade: “On peut jouer un rôle majeur dans la société dès 16 ans". Também encontramos a modalização deôntica sem requerer verbos no imperativo, mas, através da expressão `avoir besoin`, em “La nature n'a pas besoin de votre vieille TV”, em um anúncio governamental sobre o ecossistema;

Quanto à organização interacional não verbal, podemos analisar sua interação no plano visual em quatro categorias, ou seja, a interação da imagem através do contato do não verbal em relação ao leitor, da distância social do participante ou do ator em relação ao leitor, da atitude objetiva ou subjetiva de acordo com os ângulos da imagem, (trata-se da análise da relação de poder do que é encontrado na imagem), e, por fim, através da modalidade visual, que significa a verdade ou não-verdade representada pela disposição dos participantes da cena.

No que diz respeito ao contato das imagens, encontramos dois tipos de contatos: i) Por demanda ou interpelação, quando existe um vetor olhar direcionado ao leitor da imagem, como o açougueiro e a apresentadora que aparecem no anúncio da emissão "Espoir de l'année", pois ambos atores direcionam seus olhares para o leitor. Encontramos o mesmo contato no anúncio publicitário governamental sobre voluntariado e incêndio; e no anúncio do automóvel da marca Renault.

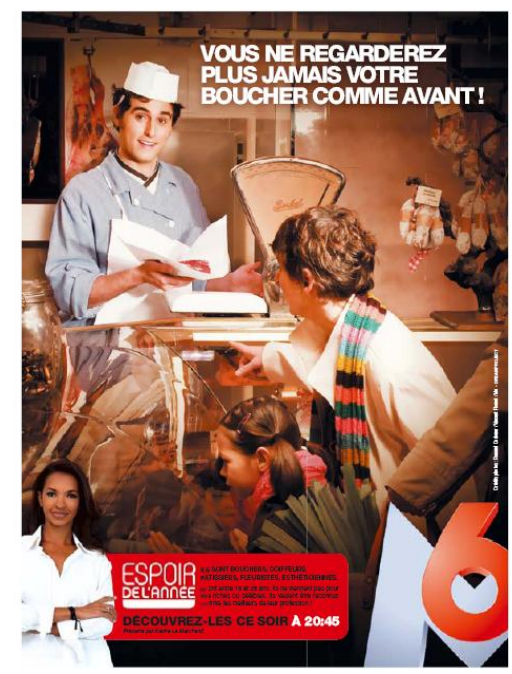

Figura 22: anúncio publicitário de vídeo - M6 
ii) Por oferta ou exposição, no qual o participante não olha para o leitor, como por exemplo, o anúncio publicitário governamental sobre energia elétrica ou o anúncio do automóvel da BMW, nos quais os olhares dos participantes estão direcionados a outros fenômenos.
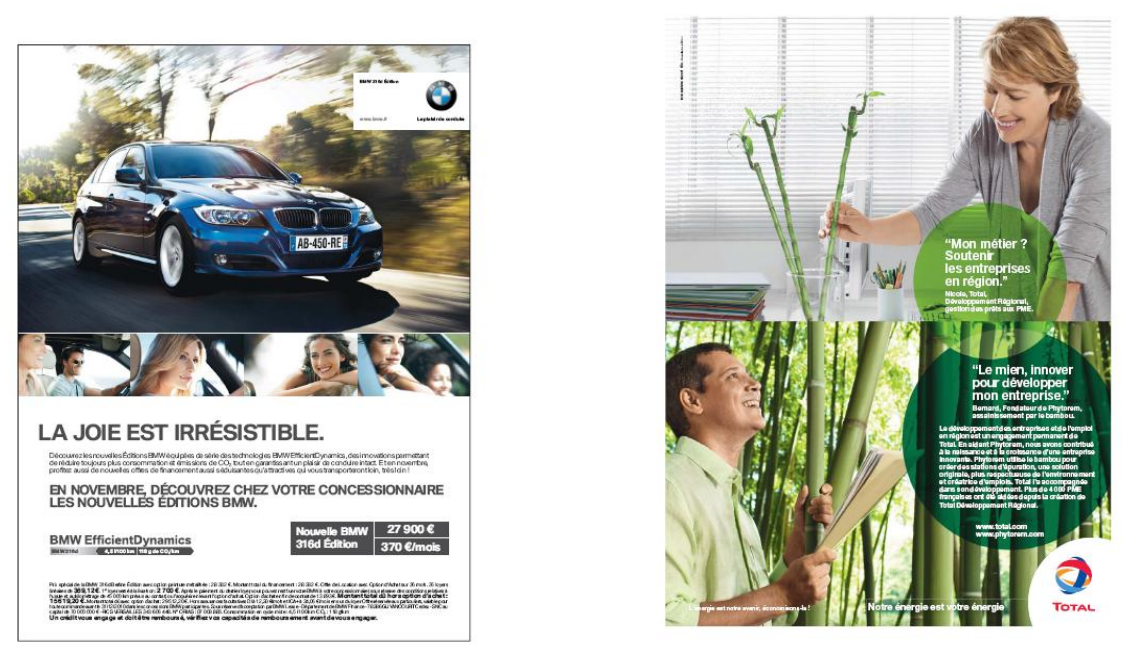

Figura 23: anúncio publicitário de transporte e governamental - BMW e Total

A distância social corresponde aos planos das imagens, ou seja, ao plano fechado, quando o participante aparece em close-up; ao plano médio, quando encontramos o participante do joelho ou da cintura para cima; e ao plano geral, quando o participante aparece de corpo inteiro. Essa distância pessoal parte, portanto, da pessoalidade à impessoalidade. A partir das análises dos anúncios publicitários do nosso corpus, encontramos todos os tipos de distanciamento social. Por exemplo, no anúncio do carro da Renault, em que observamos uma foto em close-up de um homem de negócios, o enunciador tenta aproximar sua importância social à nossa posição social ou à nossa possibilidade de atingir a mesma posição social do participante em questão.

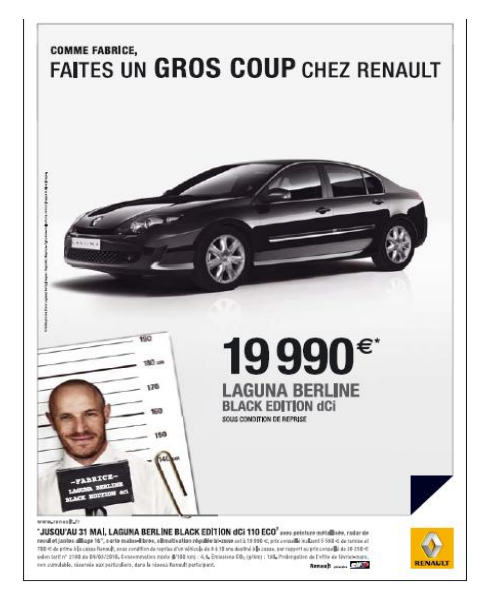

Figura 24: anúncio publicitário de transporte - Renault 
Encontramos um maior distanciamento social nas imagens com cortes, como a apresentadora do programa Espoir de l'année ou o cantor Michael Jackson no anúncio do programa Direct Star, entre outros anúncios dos quais nós, leitores, nos distanciamos socialmente dos participantes.

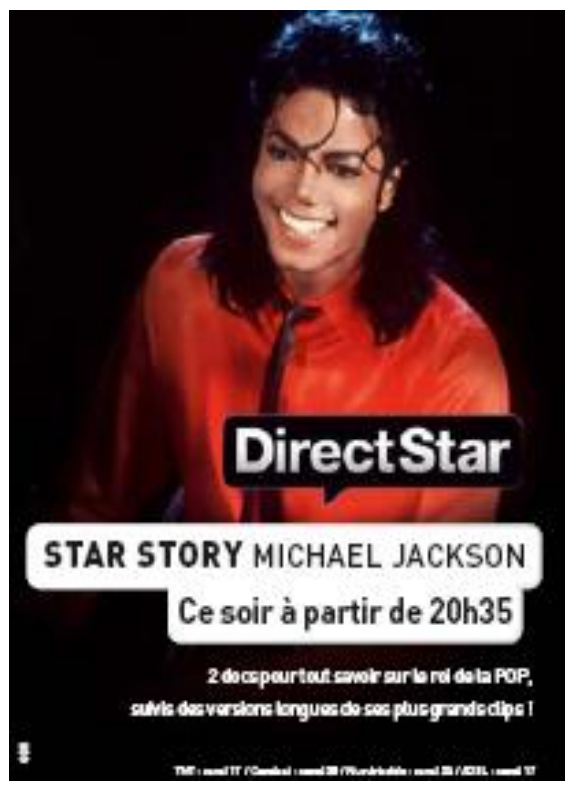

Figura 25: anúncio publicitário de vídeo - Direct Star

Ainda no que diz respeito ao distanciamento social, podemos observar que a figura do participante em um anúncio pode aparecer inteiramente, ou não. Quando o participante aparece inteiramente, dizemos, segundo Kress e Van Leeuwen (2006), que há impessoalidade. Isso não deve ser considerado negativo, visto que as imagens, mesmo impessoais, podem fazer uso de olhares, gestos, cores e os textos podem interpelar o leitor. Isso é uma estratégia empregada nos anúncios, pois não é seu propósito passar despercebido pelo leitor, muito pelo contrário: seu objetivo é persuasivo e isso se realiza sempre de alguma forma. No caso das figuras impessoais, isso pode ocorrer por meio do olhar e do texto verbal. Por exemplo, ao observarmos a figura do participante em um plano geral, como no anúncio governamental sobre voluntariado aos 16 anos de idade, a menina de corpo inteiro é considerada, segundo as categorias de Kress e Van Leeuwen (2006), como representada de forma impessoal. Porém, para interpelar o leitor, a imagem faz uso do olhar, pois ela nos observa e, além disso, o slogan aparece entre aspas, como se fosse a fala dessa garota. Como podemos ver abaixo, ela direciona a sua intenção utilizando o pronome "on", de maneira 
informal, referindo-se a ela e a outros jovens, visto que o anúncio se direciona aos jovens de 16 anos: on peut jouer un rôle majeur dans la société.

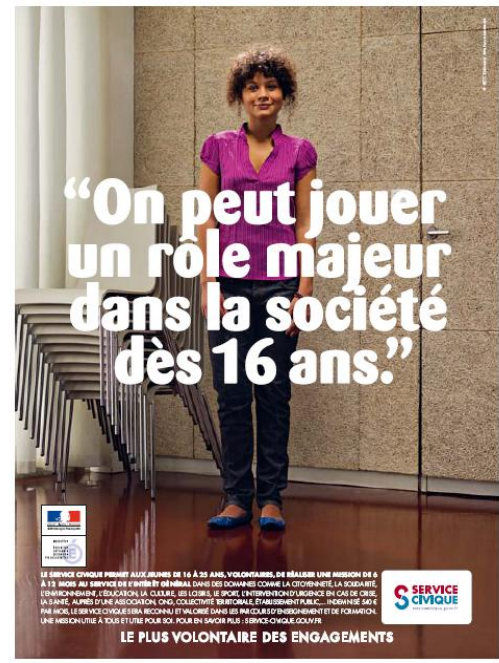

Figura 26: anúncio publicitário governamental - Service Civique

A atitude, terceira categoria da organização interacional não verbal, é outro ponto marcante nos anúncios publicitários e pode ser compreendida a partir dos ângulos dos participantes das imagens, os quais também contribuem para que possamos descobrir a relação de poder entre o participante e o leitor do anúncio. Dependendo do ângulo em que o participante foi fotografado, seu olhar para o leitor muda, assim como muda o seu significado. Portanto, um anúncio publicitário como o da emissão Direct Star, figura 26, em que Michael Jackson olha para cima, ou seja, para nós leitores, pode ter duas compreensões: por um lado, o ângulo alto pode revelar o olhar de Deus, como se observar Michael Jackson de cima nos apresentasse um artista ideal; por outro lado, esse ângulo pode mostrar superioridade por parte do leitor, não como a visão de Deus, mas como se pudéssemos ser melhores do que o participante. Entretanto, se observarmos o contexto, consideramos somente a primeira compreensão, pois se trata de um anúncio publicitário de uma emissão sobre um cantor que é considerado um dos melhores cantores da época. Sendo assim, salientamos a importância da observação do contexto de produção e de recepção, para compreensão dos aspectos verbais e não verbais dos anúncios publicitários.

O ângulo baixo expressa exatamente o contrário do ângulo alto, ou seja, o participante, quando visto de baixo para cima, terá um poder maior do que o leitor. Isso significa que, por exemplo, em um anúncio publicitário no qual o participante possui o 
objeto a ser vendido, expressa a esperteza do participante, em usufruir do objeto antes do leitor. Entretanto, não encontramos esse ângulo no corpus selecionado.

Em todos os anúncios selecionados em que existem participantes humanos, com exceção do anúncio citado sobre o programa Direct Star, o ângulo mais encontrado é o ângulo frontal. Esse ângulo mostra que existe uma relação de igualdade de poder e, portanto, o participante iguala-se ao leitor.

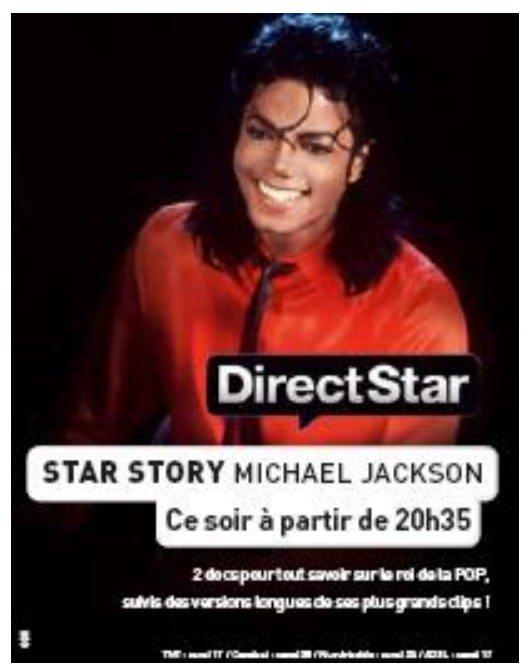

Figura 27: anúncio publicitário de vídeo - Direct Star

De acordo com a quarta categoria a modalidade visual da organização interacional não-verbal, a cor, a contextualização da imagem, a profundidade, além da iluminação e do brilho, são fatores que podem representar a realidade, construir como real um cenário não real ou, simplesmente, destacar o que é relevante em cena. Por exemplo, a luminosidade pode dar maior destaque em um participante, como acontece com o açougueiro do anúncio publicitário do programa Espoir de l'année. As cores podem apresentar o presente ou o passado, como observamos no anúncio do filme que será lançado no cinema "Le nom des gens", em que as imagens em preto e branco nos apresentam como os personagens eram antes de sua união. Além disso, a cor do céu não é real, diferentemente da cor da grama, o que nos faz observar que o que está em terra é a realidade e o que se encontra nas ideias nem sempre é real. 


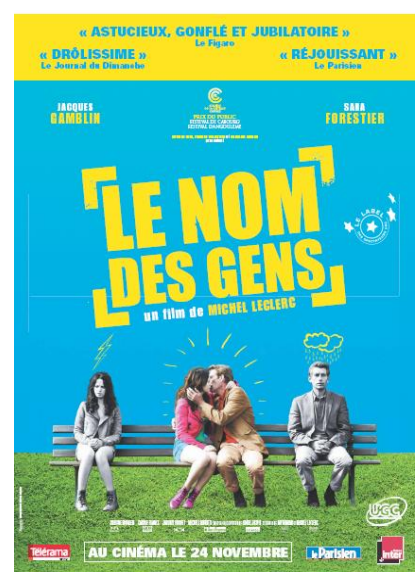

Figura 28: anúncio publicitário de vídeo - Le nom des gens

D) Por fim, para a elaboração do modelo didático, analisamos a organização estrutural verbal, ou seja, as conexões, a coesão nominal e verbal; e a organização estrutural não verbal, em que observamos o valor da informação, a saliência da mesma e o emolduramento.

Os anúncios publicitários, quando não possuem slogan, têm uma caixa de texto na parte inferior da imagem, em que todas as informações de maior importância são apresentadas. Por exemplo, se pensarmos em um automóvel, encontraremos dados como velocidade, emissão de gás, valores, local de venda, consumo de combustível e dados de todos os outros artigos opcionais possíveis para o automóvel do anúncio.

Em anúncios sobre programas de televisão ou filmes em DVD ou que estrearão no cinema, não encontramos muitos textos verbais, mas observamos a presença de datas, locais, patrocinadores e em alguns casos, seleções da crítica, como encontramos no DVD de Toy Story 3,”Attention chef-oeuvre!”, “On aime Toy Story à 1'infini...et audelà. Quel régal!".

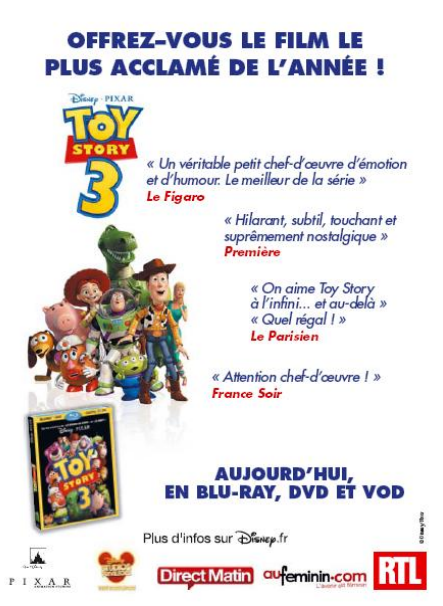

Figura 29: anúncio publicitário de vídeo - Toy Story 3 
No caso acima, vemos que o efeito persuasivo ocorre por meio da inserção de vozes de autoridade, que conferem legitimidade ao anúncio, já que são mencionados elogios de revistas ou jornais importantes, recomendando o filme.

Não encontramos muitos conectores em nosso corpus, provavelmente por não se tratar de um texto longo, mas encontramos, além dos poucos organizadores, preposições e locuções preposicionais que organizam os textos verbais, como: pour, et, en cas de, auprès de, enfin, alors.

Percebemos, também, que para diminuir a quantidade de texto, muitos enunciadores trazem apenas uma parte da citação do jornal, como: "un véritable petit chef d'oeuvre d'émotion et d'humour.", no anúncio do filme Toy Story 3, na figura 29, ou propõem um slogan bastante curto, sem verbo, como em "Toutes leurs meilleures parodies télé enfin en DVD”, no anúncio do DVD de um programa de televisão, na figura 30. Nesses casos, os enunciadores optam por não escrever a frase completa, pois talvez ela parecesse ser menos impactante se colocassem o sujeito e o verbo como "Le dessin est un véritable..." ou "nous avons organisé toutes leurs meilleures..." em lugar de "un véritable chef d'oeuvre d'émotion et d'humour" ou "toutes leurs meilleures parodies télé enfin en DVD".

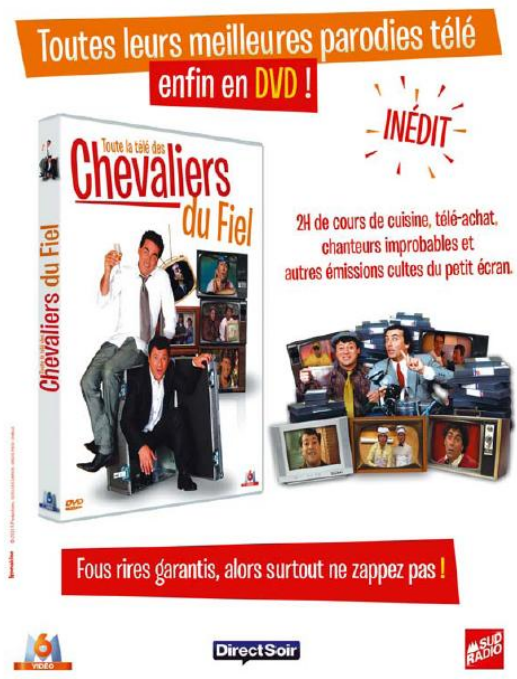

Figura 30: anúncio publicitário de vídeo - Chevaliers du Fiel

O uso de adjetivos é recorrente nos anúncios publicitários de filmes, pois os textos verbais são, frequentemente, construídos através das críticas retiradas de grandes jornais. No caso da figura 31, encontramos adjetivos e também o advérbio "suprêmement" que podem ser considerados modalizações apreciativas sobre o produto 
em questão. Trata-se, portanto, de uma escolha do produtor das críticas de cinema que é assumida também pelo produtor da capa do DVD.

\section{" Hilarant, subtil, touchant et suprêmement nostalgique " Première}

Figura 31: parte do anúncio publicitário de vídeo - Toy Story 3

Encontramos, também, alguns usos dos complementos de objeto direto e indireto, como em "Découvrez-les" ou "Offrez-vous". Mas, no geral, os textos verbais são construídos por substantivos e adjetivos que se repetem através de sinônimos, como no anúncio do filme "Le nom des gens", em que observamos novamente a inserção da voz de autoridade, presente em jornais famosos que recomendam o filme através de adjetivos como "drôlissime", "réjouissant" e "jubilatoire", que são muito semelhantes entre si e foram retomados no mesmo anúncio.

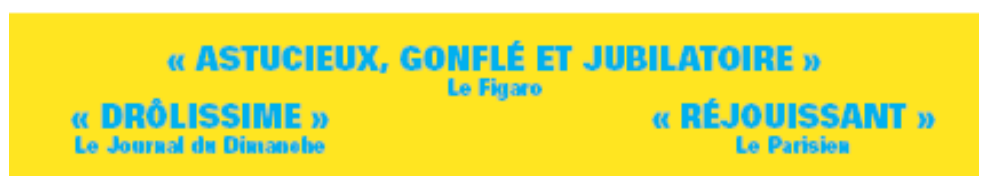

Figura 32: parte do anúncio publicitário de vídeo - Le nom des gens

Com relação aos verbos, observamos que, muitas vezes, o enunciador não faz uso do verbo ou o utiliza no presente do indicativo e no imperativo. Também, encontramos muitas construções negativas e um só uso do verbo no futuro.

Passemos, agora, para a organização estrutural não verbal, que pode ser analisada a partir da localização dos participantes da imagem, pois é a partir dessa disposição que podemos encontrar o valor da informação. Por exemplo, em todos os anúncios publicitários de automóveis, os objetos encontravam-se no centro e em alto grau de destaque. Entretanto, em outros tipos de anúncios, como os anúncios de filmes, podemos encontrar os objetos ou informações de forma polarizada. Lembremos que os elementos encontrados do lado direito são referentes àquilo que é verdadeiro, aquilo que já é conhecido, diferentemente dos elementos do lado esquerdo, analisados por Kress e Van Leeuwen (2006) como informações novas. Por exemplo, no anúncio do filme Toy Story 3, encontramos do lado esquerdo a novidade do lançamento do DVD do desenho, que apesar de ter personagens já conhecidos, corresponde a um novo desenho, pois se trata do terceiro Toy Story. Enquanto que, no lado direito, encontramos a veracidade 
através das críticas retiradas de grandes jornais e da informação relevante na base do anúncio: “Aujourd'hui, en Blu-ray, DVD et VOD”.

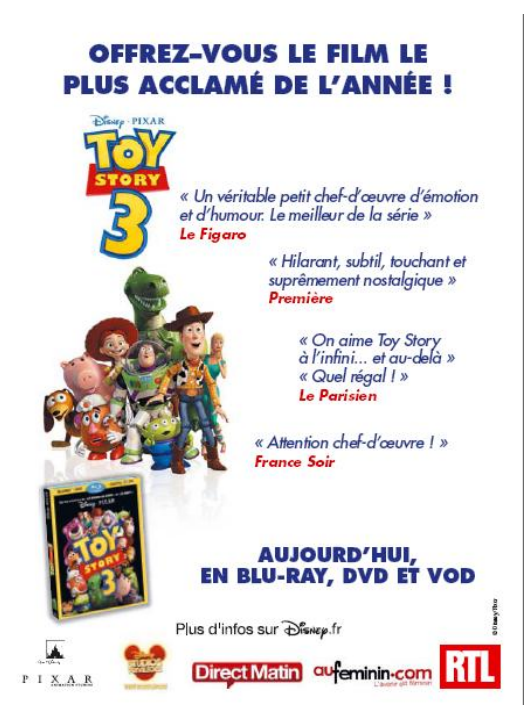

Figura 33: anúncio publicitário de vídeo - Toy Story 3

Kress e Van Leeuwen (2006) também sublinham que suas análises são válidas em línguas ocidentais, pois aquilo que aparece do lado esquerdo também é mais relevante do que os elementos encontrados do lado direito, visto que nossa leitura acontece da esquerda para a direita. Algo diferente ocorre nas línguas orientais, nas quais os anúncios publicitários teriam uma análise invertida desses elementos.

$\mathrm{O}$ valor da informação também é observado quando o texto verbal ou visual aparece no topo ou no rodapé, pois no topo de um anúncio publicitário a visibilidade é maior e, portanto, encontramos as informações de maior prestígio ou de maior emotividade. Enquanto, na base, encontramos as informações técnicas, mais específicas e muitas vezes em tamanho de fonte inferior.

Um bom exemplo para compreender as informações que aparecem no topo e na base é o anúncio publicitário da Peugeot, em que se vê, no topo, o valor do carro e, na base, as informações técnicas do carro. 


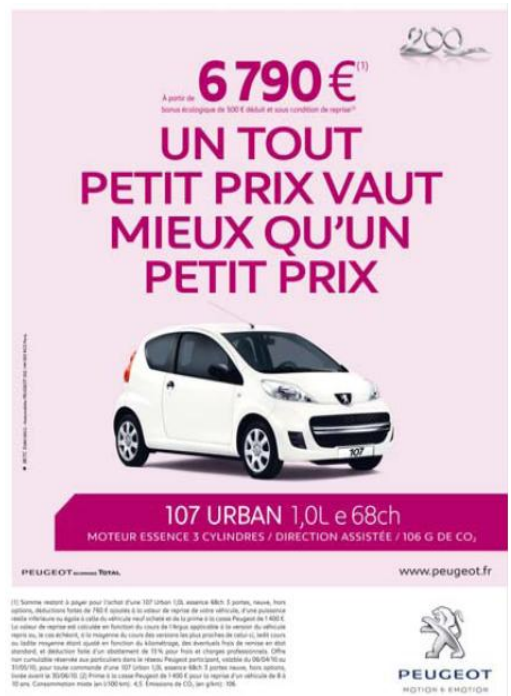

Figura 34: anúncio publicitário de transporte - Peugeot

Outro fator de análise na organização estrutural não verbal é a saliência, ou seja, o foco, os detalhes da imagem, além da tonalidade da cor e do brilho. Ainda como exemplo, no anúncio da Peugeot, encontramos um fundo rosa e o slogan em pink o que salienta um público específico. Outro anúncio interessante que comprova a importância dos detalhes é o anúncio sobre o transporte público metrô, em que diversos elementos estão conectados por galhos de plantas que representam o Art-nouveau, características dos metrôs parisienses.

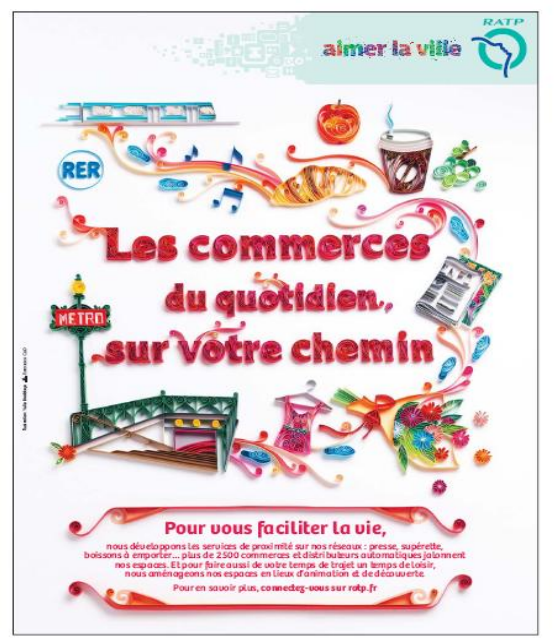

Figura 35: anúncio publicitário de transporte - RATP

Por fim, o emolduramento dos elementos encontrados em um texto não verbal pode ser máximo, ou seja, elementos totalmente conectados ou sem emolduramento. No 
caso dos anúncios publicitários, encontramos conexões máximas entre os elementos dos textos.

Para finalizar, gostaríamos de destacar que o efeito argumentativo do anúncio deve ser compreendido na globalidade do que acabamos de apresentar: texto verbal e texto não verbal contribuem para persuadir o leitor a adquirir o produto. Quanto ao texto verbal, lembramos novamente que não se trata de encontrar uma sequência argumentativa completa, com todas as fases que apresenta Bronckart (1999), mas de perceber que o uso de mecanismos enunciativos, por exemplo, como as vozes e as modalizações, podem contribuir para criar o efeito argumentativo, à semelhança do que nos mostra Plantin (2008).

A partir das análises que apresentamos, pudemos exemplificar o modelo didático do gênero anúncio publicitário para, em seguida, elaborar uma sequência didática para ser aplicada com os alunos. Nesse sentido, parece-nos importante salientar que não temos como objetivo esgotar todas as análises possíveis sobre gênero anúncio publicitário, mas apresentar as características mais recorrentes dentro dos anúncios escolhidos e que, portanto, podem ser consideradas ensináveis. Em outras palavras, nossa intenção foi de elaborar um modelo didático, a partir do qual pudéssemos encontrar os anúncios possíveis de serem trabalhados em sala de aula, no contexto de ensino de FLE, para contribuir para o desenvolvimento das capacidades de linguagem dos alunos. Veremos, a seguir, os procedimentos para elaboração da primeira sequência didática e sua aplicação, que se constituiu em uma experiência piloto e, em seguida, mostraremos a segunda sequência didática que elaboramos, apontado os detalhes de sua aplicação, pois ela contribuiu para a produção de dados desta pesquisa.

\section{Procedimentos de coleta e produção de dados}

Nesta seção, detalharemos as etapas que envolvem a produção das duas sequências didáticas e de sua aplicação. Como dissemos, elaboramos primeiramente uma primeira sequência didática que deu origem a uma experiência piloto em uma turma. A partir dessa experiência, pudemos reelaborar a sequência didática e aplicá-la com outra turma de alunos. Os dados que analisaremos vêm da aplicação dessa segunda sequência didática. 
Apresentaremos primeiramente o perfil das duas turmas e faremos uma reflexão sobre a experiência piloto. A reflexão e a análise da segunda turma serão detalhadas nas próximas seções.

\subsection{Experiência piloto}

Chamamos de experiência piloto o primeiro curso, "Ateliers de escrita criativa em língua francesa". Para a construção desse curso, como apresentaremos no decorrer desta seção, elaboramos a sequência didática piloto que foi aplicada com uma turma de 17 alunos. Essa sequência didática foi dividida em três módulos e aconteceu em três aulas e meia, visto que o curso de 45 horas foi dividido entre quatro monitorasprofessoras. Após a primeira experiência, analisamos as produções dos alunos e pontuamos algumas atividades que poderiam ter sido diferentes para melhor desenvolver algumas capacidades de linguagem pouco desenvolvidas através dessa experiência piloto.

Portanto, abordaremos a elaboração da sequência didática piloto, analisaremos o perfil dos alunos participantes, explicaremos como foi a primeira aplicação da sequência didática e faremos algumas reflexões sobre essa experiência, constatando algumas mudanças necessárias para a produção final de dados, ou seja, para a elaboração da segunda sequência didática.

\subsubsection{Elaboração da sequência didática piloto}

Após analisarmos os anúncios publicitários para a elaboração do modelo didático, organizamos atividades escolares a fim de potencializar a aprendizagem do FLE e de desenvolver as capacidades de linguagem dos alunos. Segundo Schneuwly e Dolz (2004), o sistema que visa a potencializar as capacidades de linguagem dos alunos é a sequência didática.

Ao criarmos as atividades para a SD, tivemos como objetivo a apropriação do gênero anúncio publicitário pelo aluno e, para isso, consideramos as características do gênero escolhido e o conhecimento prévio desses alunos para sua construção. Logo, baseamo-nos nos critérios de Schneuwly e Dolz (2004) para a construção da SD, ou 
seja: criamos uma primeira atividade na qual os alunos produziram o gênero anúncio publicitário de acordo com os seus conhecimentos prévios; posteriormente, criamos três módulos de atividades, que foram trabalhados em três aulas a fim de desenvolver as capacidades de linguagem dos alunos e, por fim, a SD terminou com uma produção final, na qual os alunos tiveram a possibilidade de colocar em prática tudo o que foi aprendido separadamente durante os três módulos.

Essa sequência didática piloto foi aplicada em fevereiro de 2012 e as etapas dessa sequência foram divididas em três aulas de 3 horas e meia, portanto dividimos a primeira aula em 1 hora, para a apresentação e desenvolvimento da produção inicial; 2 horas e 30 minutos para o primeiro módulo da sequência e início do segundo módulo; na segunda aula finalizamos o segundo módulo, com 3 horas e meia de curso; posteriormente, na última aula, iniciamos e finalizamos o terceiro módulo em 2 horas e meia e tivemos em torno de 1 hora para a produção final dos alunos.

Nossa sequência didática foi elaborada em três módulos que totalizaram 40 atividades, com exceção das produções inicial e final.. Para a elaboração das atividades, fizemos uso de anúncios publicitários, mas, também, de propagandas televisivas, de filmes e de outros gêneros textuais como caça-palavras ou textos encontrados em site de pesquisa, como a Wikipédia, para que o curso não fosse cansativo ao trabalhar somente com um único gênero. Nas páginas que seguem, detalharemos as diferentes partes das aulas, explicando cada atividade que foi realizada, apontando os objetivos e fazendo ponderações a respeito da aplicação e da reação dos alunos.

\section{$1^{\text {a }}$ parte da $1^{\text {a }}$ aula: Produção inicial}

A) Iniciamos a aula discutindo sobre o interesse dos alunos em anúncios publicitários, a preferência deles por algum anúncio publicitário e a diferença entre os anúncios brasileiros e franceses, por meio da atividade abaixo: 


\section{I) Echauffement}

\section{Discutez par groupel}

a) Faites-vous attention aux publicités ? Les aimez-vous ? D'habitude, où vous les trouvez ? Avez-vous une pub préférée ? Laquelle ? Et pourquoi ?

b) Quelles pubs sont trouvées sur la presse ? Donnez au moins cinq types.

c) Faites-vous attention aux éléments d'une pub parue dans la presse ? Comment ils sont disposés?

II) Racontez au groupe ce que vous avez découvert par rapport à votre voisin et à la pub.

B) Posteriormente, os alunos fizeram uma atividade sobre as temáticas encontradas nos anúncios publicitários, para facilitar a escolha de um tipo de anúncio ao iniciar a produção inicial:

Les pubs et leurs thématiques

III) Par groupes, faites l'activité proposée.

1) Associez les pubs ou les produits à leurs thématiques. Attention, vous ne saurez pas qui a produit la pub. À la fin, discutez avec votre voisin s'il est possible de trouver plus d'une thématique par pub.
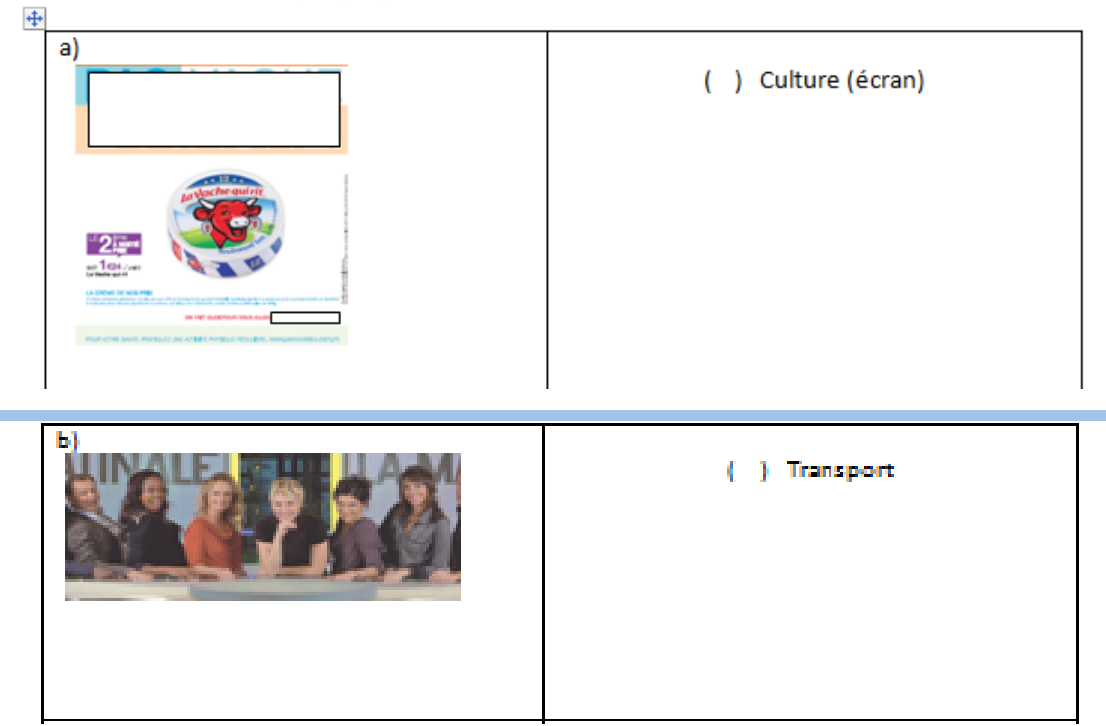


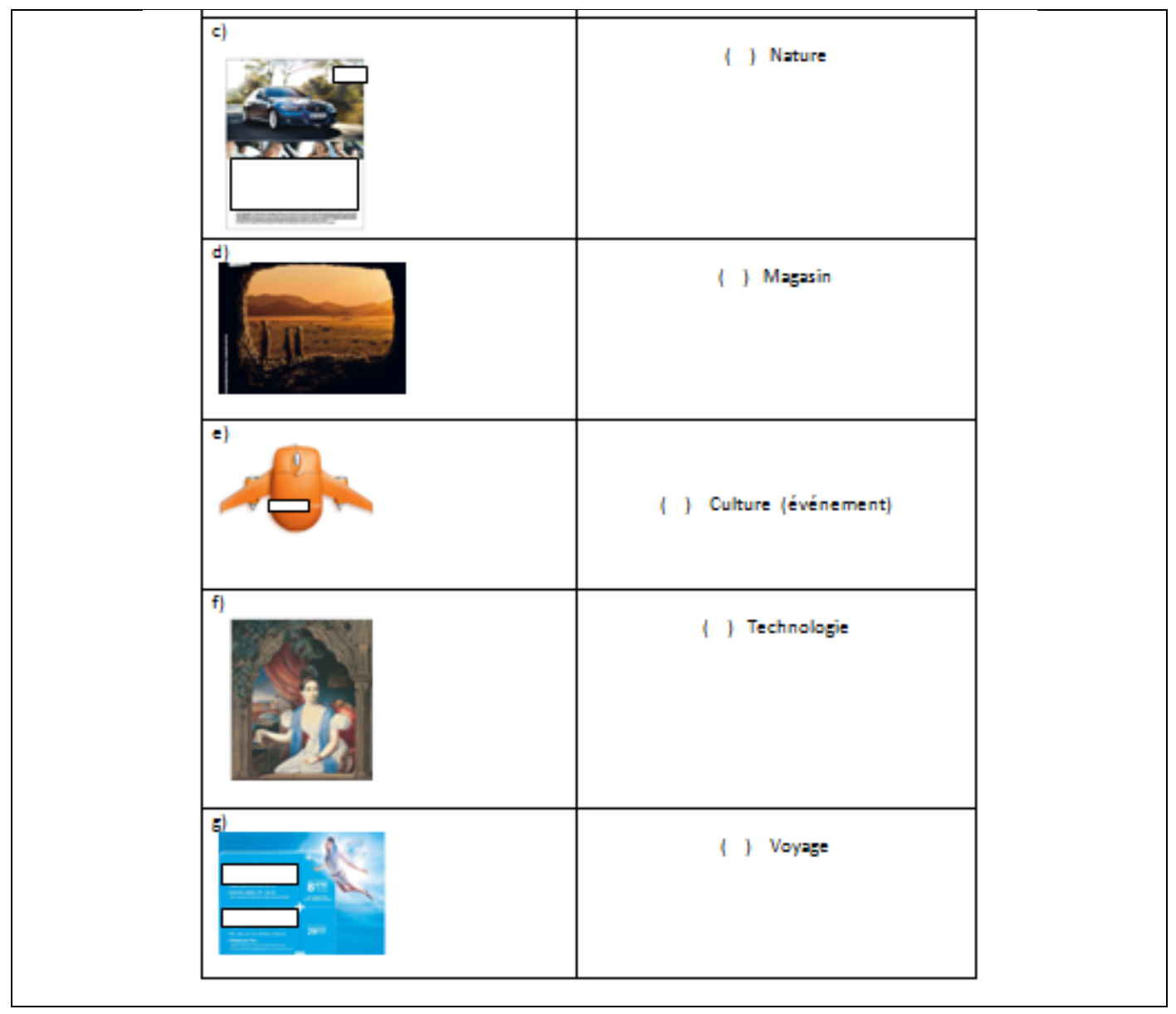

C) Em seguida, os alunos fizeram a escolha por um tipo de anúncio e trabalharam na produção inicial em duplas. É importante lembrar que, apesar de direcionarmos a escolha dos tipos, metade do grupo seguiu o enunciado, nesta sequência piloto.

\section{Le publicitaire - Action 1}

I) Faites Poctivité proposée.

Aujourd'hui wous êtes un publicitaire. Choisissez un produit et construisez une nouvelle pub avec wotre woisin. Vous n'avez pas besoin d'être un dessinateur, mais de définir l'objet, le slogan, Yimage qui apparait au fond de Yobjet, entre autres. (wous pouvez aussi utiliser le vers de la page] 
Ainda na produção inicial, os alunos preencheram uma tabela com a análise do contexto de produção do anúncio criado. Esta atividade pretende desenvolver, nos alunos, um olhar sobre onde estão e para quem se direciona o anúncio, ou seja, a capacidade de ação.

2. Par rapport à votre pub, organisez wos idées en complétant la grille ci-dessous:

\begin{tabular}{|l|l|}
\hline Quelle est la thématique de la pub ? & \\
\hline $\begin{array}{l}\text { Pourquoi avez-wous choisi ce } \\
\text { produit? }\end{array}$ & \\
\hline Oú allez-wous l'annoncer? & \\
\hline Qui a produit cette pub? & \\
\hline $\begin{array}{l}\text { Quiva la recewoir? } \\
\text { Quel est lobjectif du magasin ou de b } \\
\text { marque qui a produit cette pub? }\end{array}$ & \\
\hline $\begin{array}{l}\text { Le slogan choisi reprend une } \\
\text { caractéristique de Yimage? Laquele? }\end{array}$ & \\
\hline $\begin{array}{l}\text { Est-ce que wotre slogan fait sens si } \\
\text { wous ne mettez pas rimage dans la } \\
\text { pub? }\end{array}$ & \\
\hline
\end{tabular}

\section{$2^{\mathrm{a}}$ parte da $1^{\mathrm{a}}$ aula: módulo 1}

A) O módulo 1, iniciou com uma atividade de compreensão verbal e não verbal para selecionar o slogan correspondente a cada anúncio publicitário. Essa atividade tinha como objetivo desmistificar as representações construídas nos livros didáticos de francês, que fazem uso de anúncios publicitários para inserir o ponto linguístico referente ao modo imperativo. Desta forma, os alunos observariam diferentes slogans em diferentes modos verbais. 


\section{Le slogan}

v) Par groupes, faites les activités proposées.

1) Associez les pubs aux slogans.
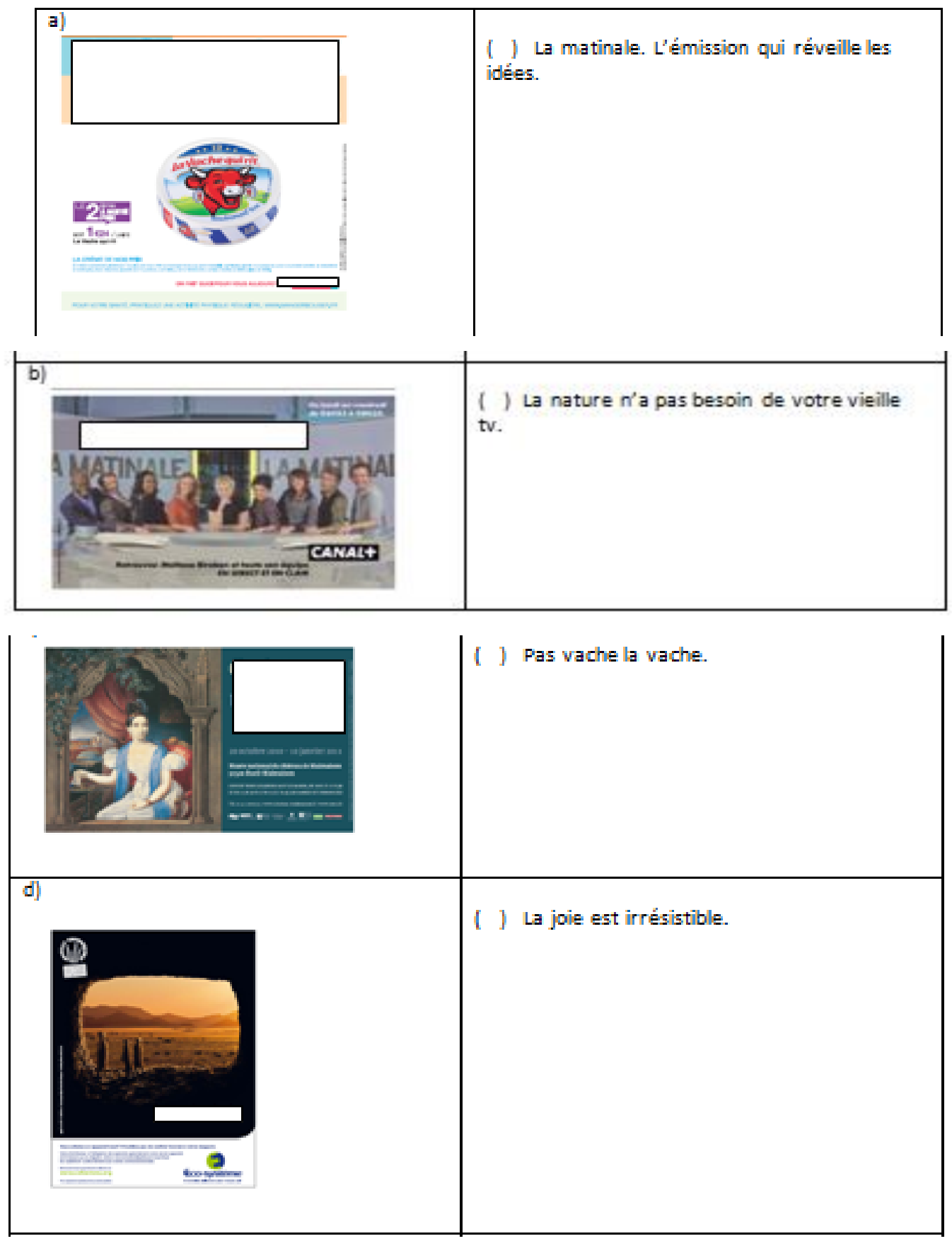


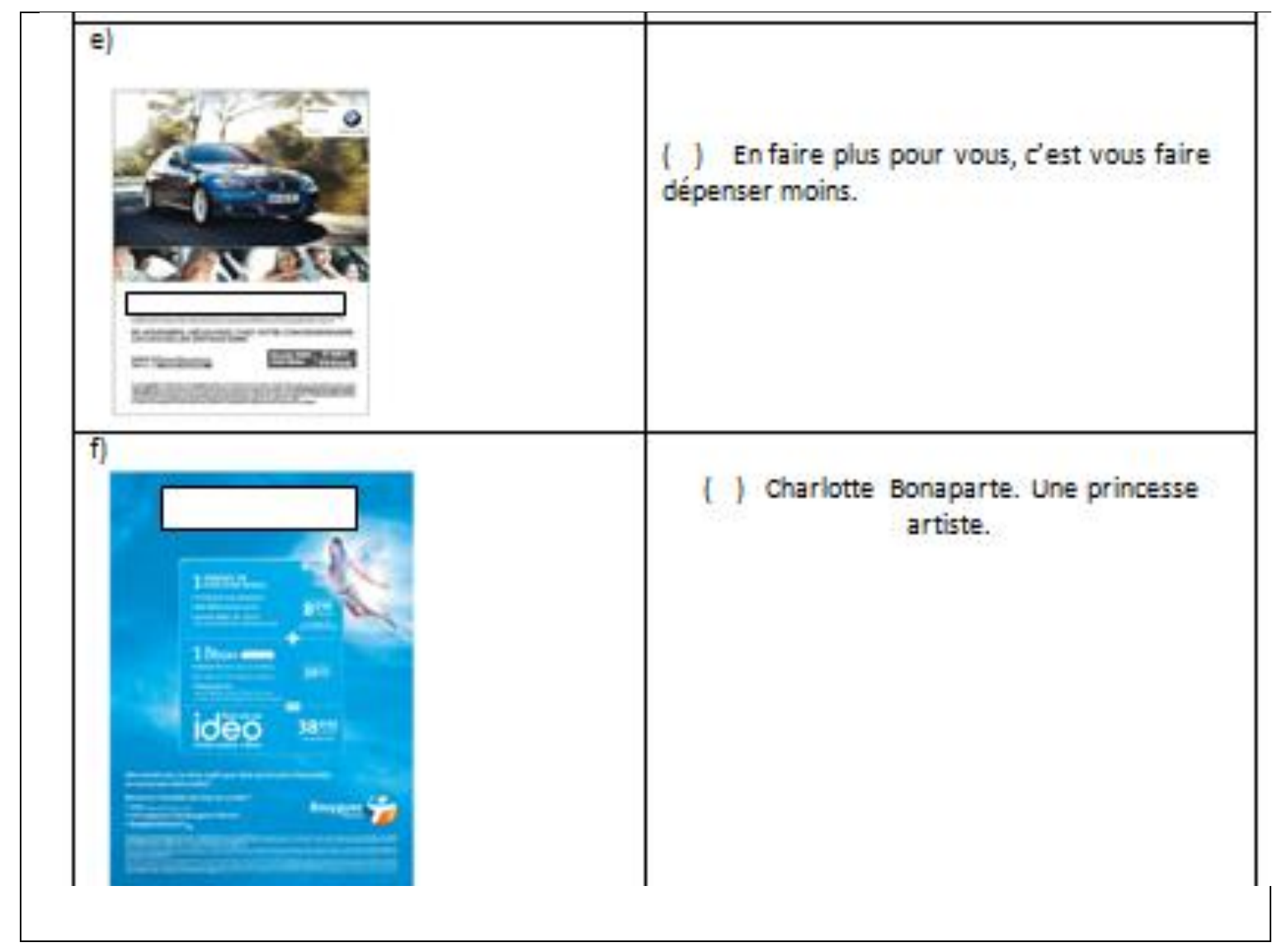

B) Ainda no módulo 1, iniciamos uma atividade através do tipo de anúncio publicitário transporte, com o objetivo de trabalhar a representação das cores que está relacionada diretamente à atitude e à saliência do texto não verbal, ou seja, à capacidade linguísticodiscursiva. Além disso, os alunos deveriam associar expressões referente às cores e discutir sobre a estrutura do anúncio publicitário, observando o conteúdo temáticorepresentacional do objeto, portanto, a capacidade discursiva. 
3. Regardez la pub avec vote woisin et répondez aux questions.

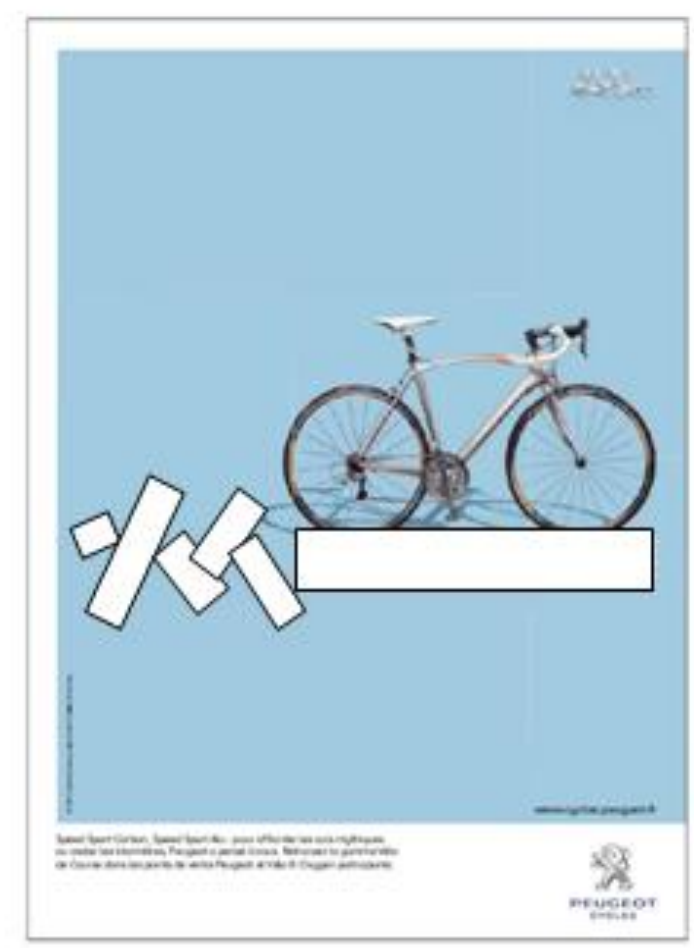

1) Complétez la grille avec votre voisin

\begin{tabular}{|l|l|}
\hline Quel objet voyez-vous sur la pub ? & \\
\hline $\begin{array}{l}\text { Où se trouve-t-il dans Yimage ? En haut, en } \\
\text { bas ou au centre? Imaginez-vous le } \\
\text { pourquoi ? }\end{array}$ & \\
\hline Quelles couleurs voyez-vous ? & \\
\hline Savez-vous le pourquoi de la couleur du vélo ? & \\
\hline Savez-vous le pourquoi de la couleur de fond ? & \\
\hline $\begin{array}{l}\text { Qu'est-ce que vous imaginez en observant la } \\
\text { mise en page du texte verbal effacé? }\end{array}$ & \\
\hline
\end{tabular}


C) A atividade seguinte apresenta um anúncio publicitário televisivo para que os alunos desenvolvam a compreensão oral. No anúncio em questão, diferentes expressões ciclistas são utilizadas na narração de uma corrida com o objetivo de anunciar um aparelho de celular. Em seguida, a atividade explorava a compreensão escrita do dialeto ciclista.

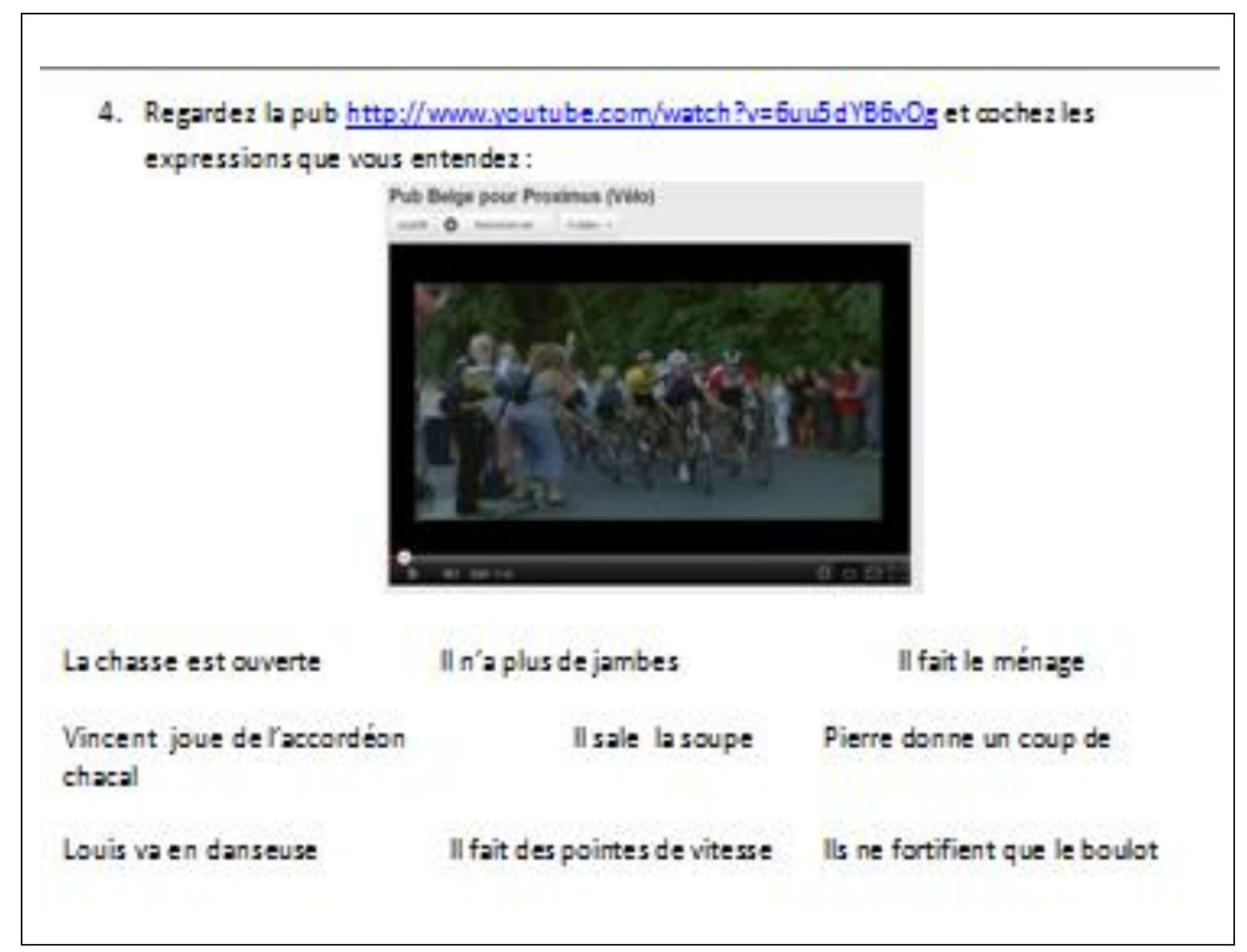

D) Para finalizar o módulo 1, a atividade proposta é de produção escrita, para que os alunos produzam um slogan para a bicicleta da Peugeot, pois retiramos o real slogan para que os alunos utilizassem o vocabulário trabalhado nas últimas três atividades. Após a criação do slogan, a próxima atividade propõe a compreensão do texto descritivo que aparece na base do anúncio. Esse texto descreve o destinatário orientando um contexto de produção para os alunos. Em seguida, modificando o vocabulário do texto descritivo, a atividade pede a reescrita de um texto sobre a bicicleta. 


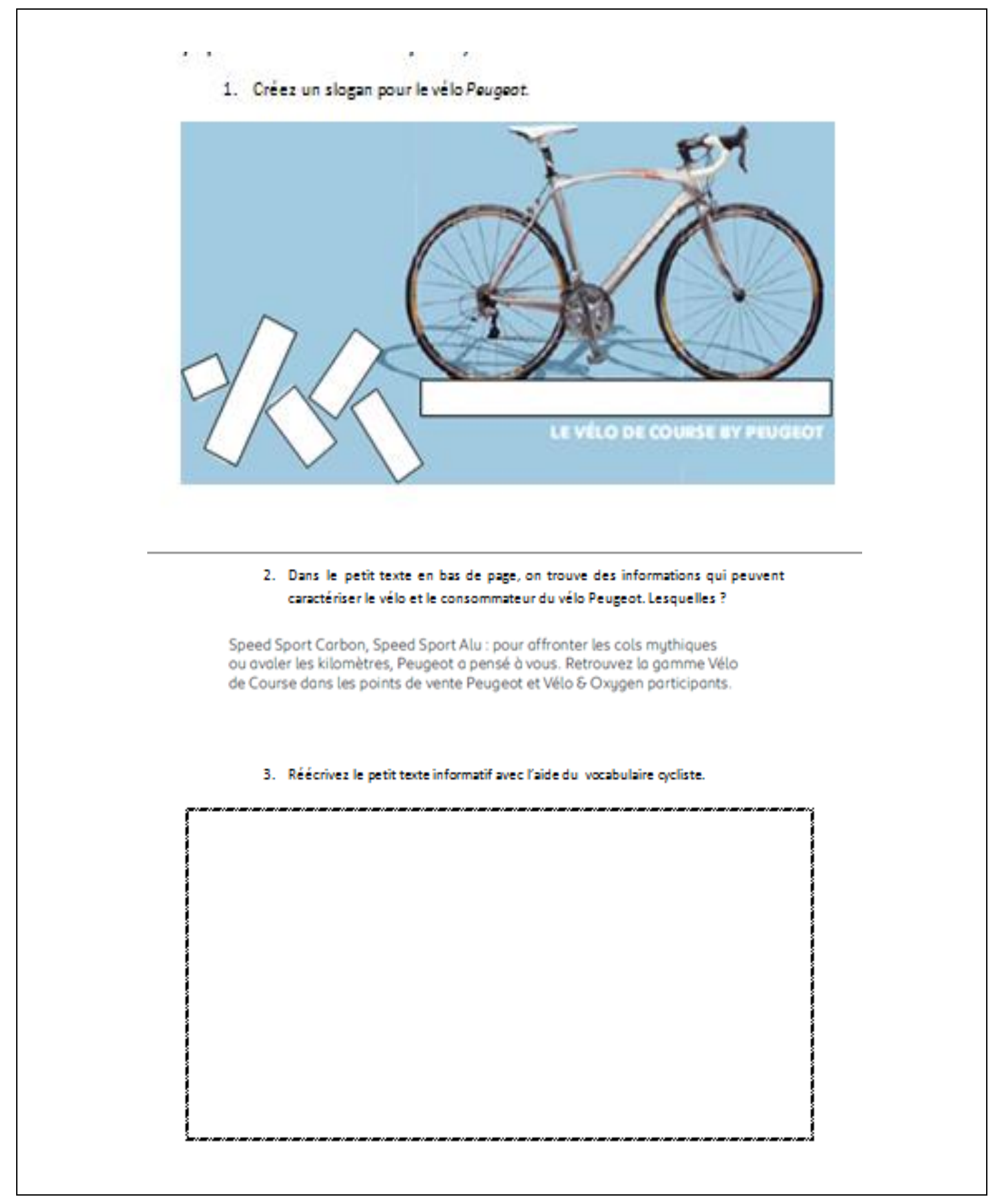

\section{2a aula: Módulo 2}

A) O módulo 2 se iniciou com uma atividade de organização para que os alunos identificassem uma ordem de elementos no anúncio publicitário, como: slogan, imagem central, texto descritivo e logotipo. Entretanto, algumas produções finais desorganizadas e sem logotipo fizeram com que essa atividade fosse modificada na segunda sequência didática. A atividade I tinha como objetivo trabalhar a capacidade de ação e a capacidade discursiva, no que diz respeito à organização e ao objetivo de cada anúncio. 


\section{COURS 02}

I) Regardez les pubs mélangées et discutez les questions avec votre voisin

1) Imaginez l'ordre des pubs et organisez-les.

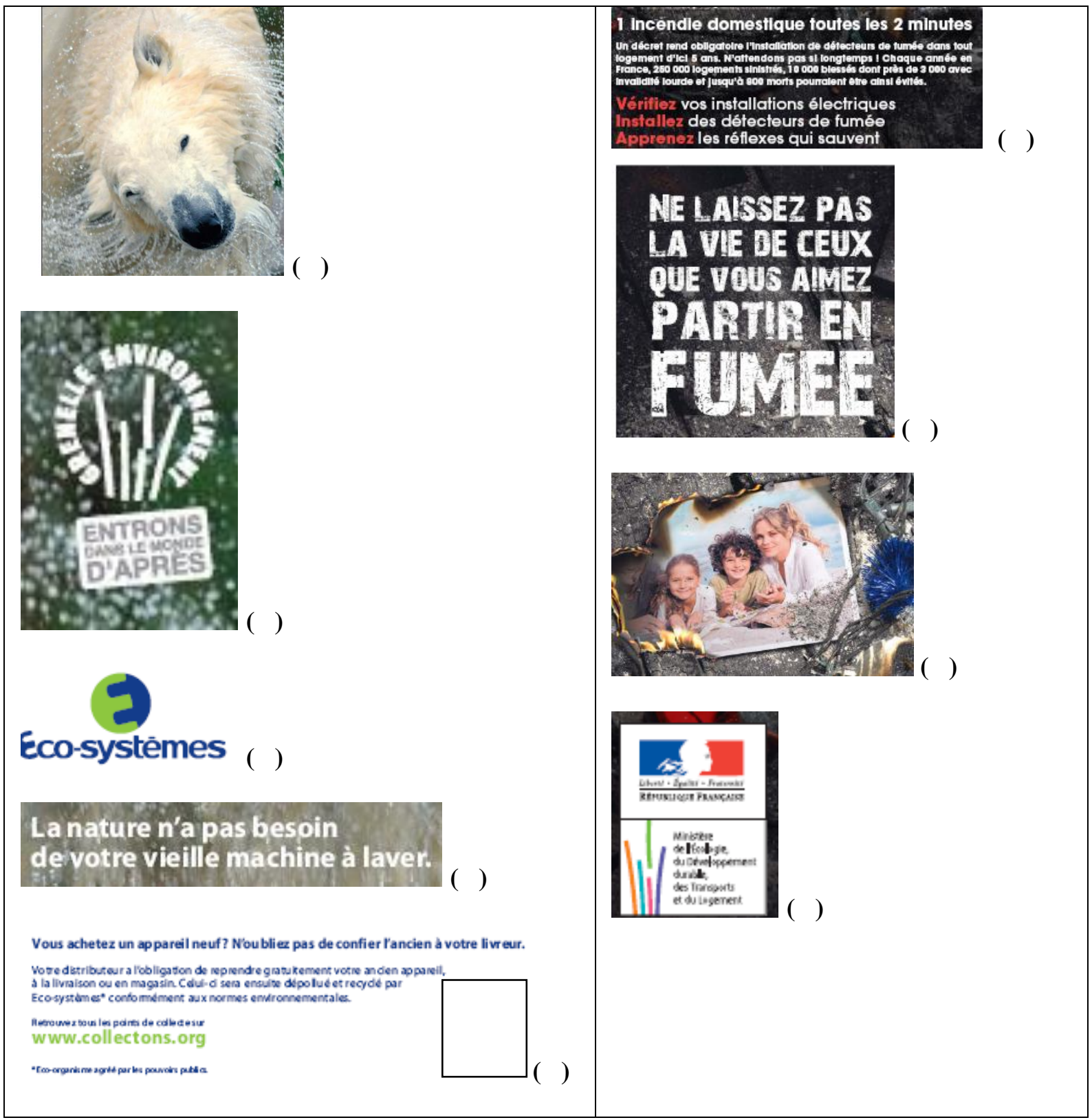

2) Expliquez au groupe le choix de l'ordre.

Pourquoi le texte verbal vient avant l'image ou vice-versa ?

Où vous avez mis la marque de qui a produit la pub ? Et les infos de la pub ? 
3) Regardez les deux pubs et la différence entre les mises en page.

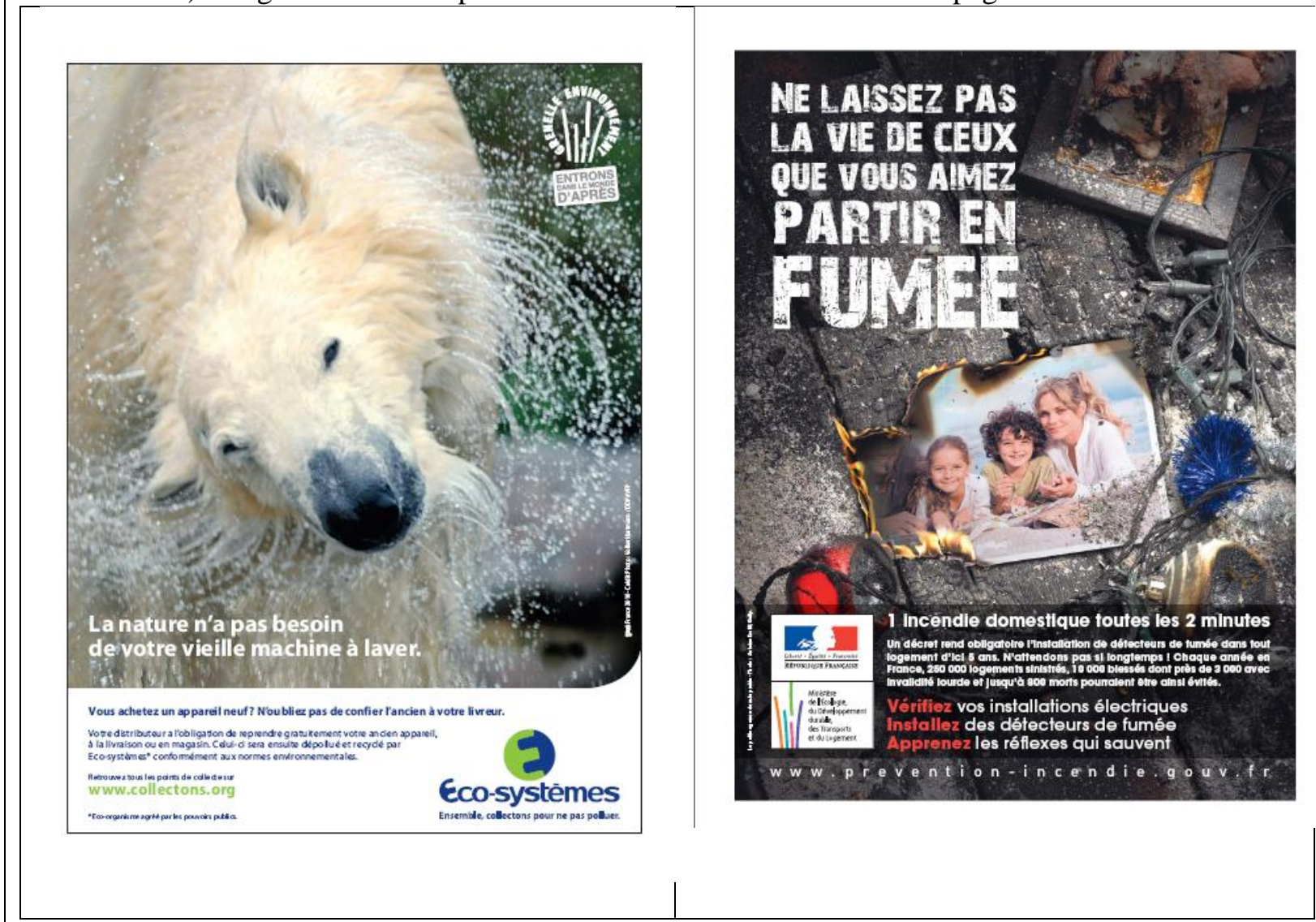

4) Répondez aux questions en réfléchissant toujours aux deux pubs ci-dessus.

-Quelle est la thématique des deux pubs?

- Pour qui elles ont été produites?

- Quels sont les objectifs des pubs?

- Qu'est-ce que vous trouvez de plus important dans chaque une des pubs : l'image ou le texte verbal ? Pourquoi?

-Quelle image peut être modifiée ? Pourquoi ?

-Comprendriez-vous les pubs si on effaçait le texte verbal ou l'image ? Pourquoi ?

- Trouvez-vous des connections entre l'image et le texte verbal ? Lesquelles?

- Quelle contribuition le slogan donne à la pub de l'Eco-systèmes ?

-Comment comprenez-vous l'image de la pub du gouvernement par rapport au texte principal ? 
B) $\mathrm{Na}$ segunda atividade do módulo 2, trabalhamos o anúncio publicitário do tipo tecnológico. A atividade visa o desenvolvimento da capacidade de ação, no que diz respeito ao público destinatário, da capacidade discursiva, através da análise do conteúdo temático e da representação. Além disso, trabalha a conexão e a coerência entre os elementos verbais e o emolduramento não verbal, que estão relacionados à capacidade linguístico-discursiva.

\section{II) Répondez aux questions avec votre voisin.}

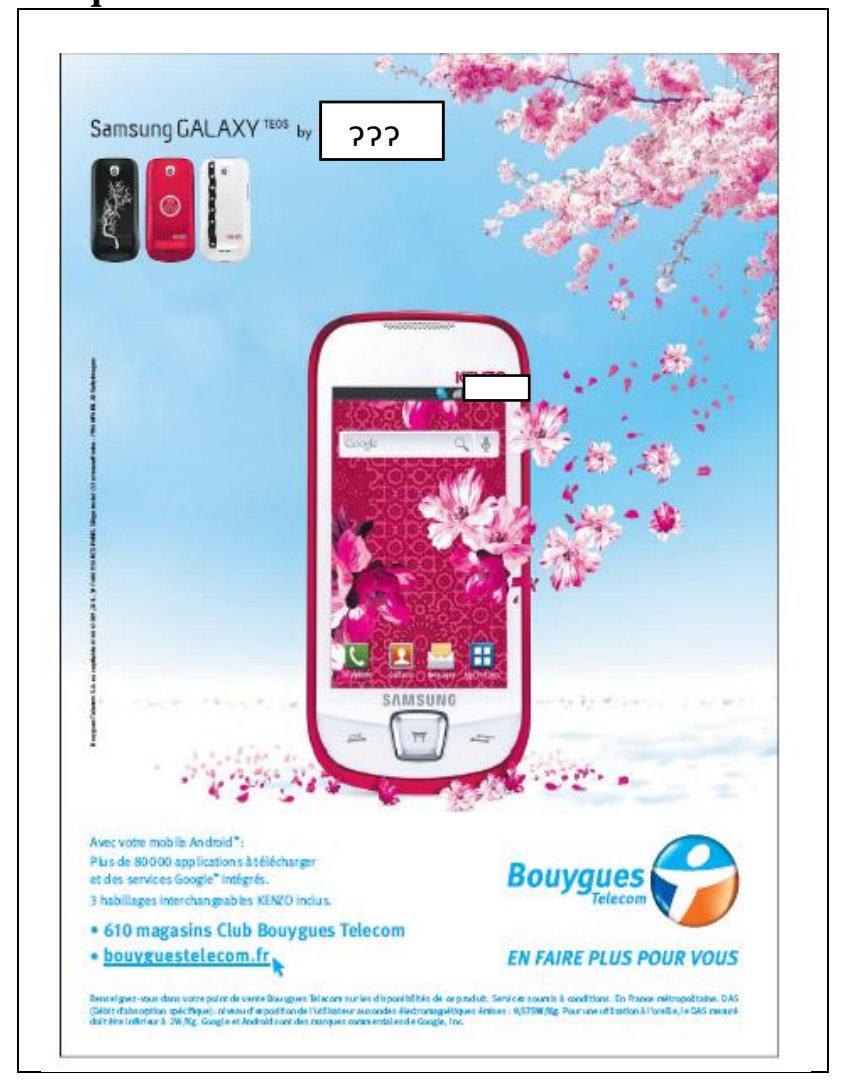

1) Pensez-vous que la pub est intéressante pour vous? Justifiez

2) Acheteriez-vous ce portable ? Justifiez

3) Quelle est l'image la plus importante dans la pub ? Pourquoi ?

4) Le portable est connecté ou deconnecté à d' autres éléments ?

5) A votre avis, qu'est-ce que le bleu, le blanc et le rose signifient dans l'image ?

6) Pensez-vous que la pub est destinée à un public spécifique ? Pourquoi ?

III) Regardez la vidéo (http://www.youtube.com/watch?v=5x9WkggRjnU) et répondez aux questions.

1) De quel genre de document s'agit-il ?

2) Quel est le produit annoncé ?

3) Trouvez-vous des éléments similaires à ceux dela pub Bouygues? Lesquels ?

4) Si vous observez la pub Bouygues, vous trouvez «??? » à la place du modèle du téléphone portable. Quel nom donneriez-vous au portable?

IV) Quel est le slogan de la pub Bouygues?

V) S'il fallait d'un slogan sur la pub, quel serait -il ? Où vous le mettriez? 
C) Ainda no módulo 2, as atividades desenvolvidas visam a discussão sobre o anúncio publicitário do filme "Le nom des gens", sobre o objetivo do anúncio, ou seja, visa o desenvolvimento da capacidade de ação; além disso, as atividades visam um trabalho sobre a organização estrutural verbal, logo, observa-se os adjetivos encontrados em excesso nos comentários críticos e a análise da organização estrutural e interacional não verbal, que fazem parte da capacidade linguístico-discursiva.

D) Além do anúncio publicitário, outro gênero textual é apresentado para a compreensão oral: o trailer do filme.

Por fim, o módulo 2 propõe uma atividade sobre a organização interacional, a saliência das cores no anúncio publicitário, assim como, a produção escrita de um slogan.

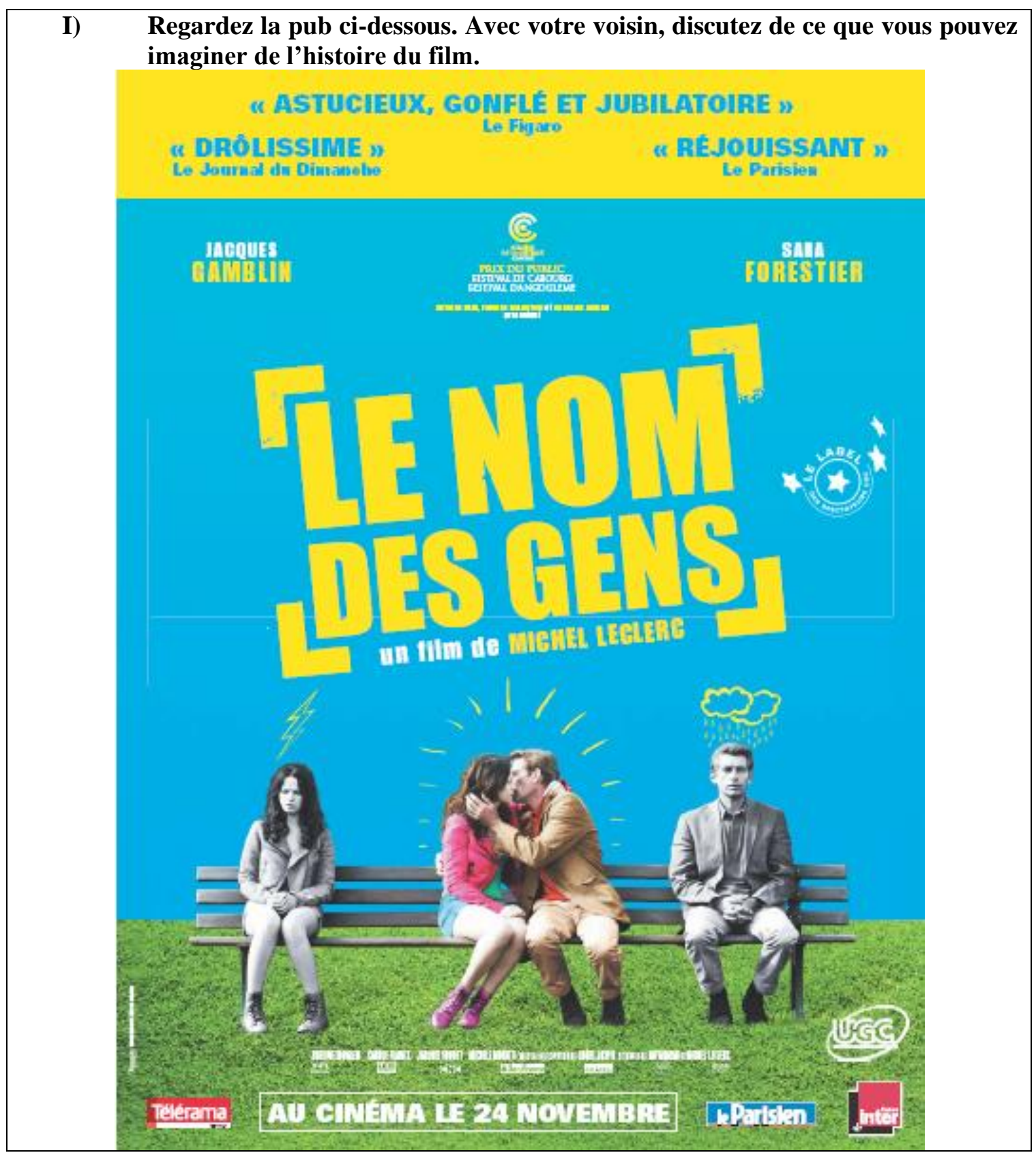


- Regarderiez-vous ce film à cause de la pub? Justifiez

- Pensez-vous qu'il manque un slogan pour avoir plus de spectateurs ou les commentaires de la critique a été suffisante? Pourquoi ?

\section{II) Répondez aux questions suivantes}

1) Trouvez les synonymes correspondants :

\begin{tabular}{l|l} 
( 1 ) gonflé & ( ) ce qui est agréable, contentant. \\
(2) astucieux & ( ) ce qui entraîne une grande joie \\
( 3 ) réjouissant & ( ) ce qui est amusant, comique, bizarre \\
( 4 ) drôle/drôlissime & ( ) ce qui a ou dénote de l'ingéniosité. \\
( 5 ) jubilatoire & ( ) ce qui est audacieux , ballonné
\end{tabular}

2) Qu'est-ce que le symbole «label » veut dire?

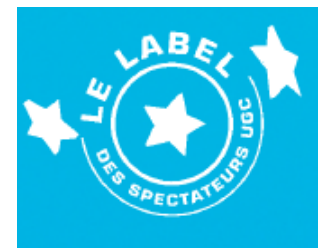

\section{III) Regardez la pub et répondez aux questions}

1) Observez la pub avec votre voisin

\begin{tabular}{|l|l|}
\hline Où sont les personnages? & \\
\hline Qu'est-ce que le bleu signifie dans l'image ? & \\
\hline Qu'est-ce que le vert signifie dans l'image ? & \\
\hline $\begin{array}{l}\text { Trouvez-vous un problème entre le bleu et le } \\
\text { vert? }\end{array}$ & \\
\hline Où se trouve la femme toute seule? & \\
\hline Où se trouve l'homme tout seul ? & \\
\hline Sont-ils heureux ? Pourquoi ? & \\
\hline $\begin{array}{l}\text { Quelle est la différence entre les personnages } \\
\text { seuls et le couple au centre du banc? }\end{array}$ & \\
\hline $\begin{array}{l}\text { Pourquoi une partie de l'image est colorée et } \\
\text { l'autre est blache et noire? }\end{array}$ & \\
\hline $\begin{array}{l}\text { Pouvez-vous donner un mot pour les } \\
\text { symboles sur les têtes des personnages ? }\end{array}$ & \\
\hline $\begin{array}{l}\text { Cette pub reprend un autre genre textuel. } \\
\text { Lequel ? }\end{array}$ & \\
\hline
\end{tabular}




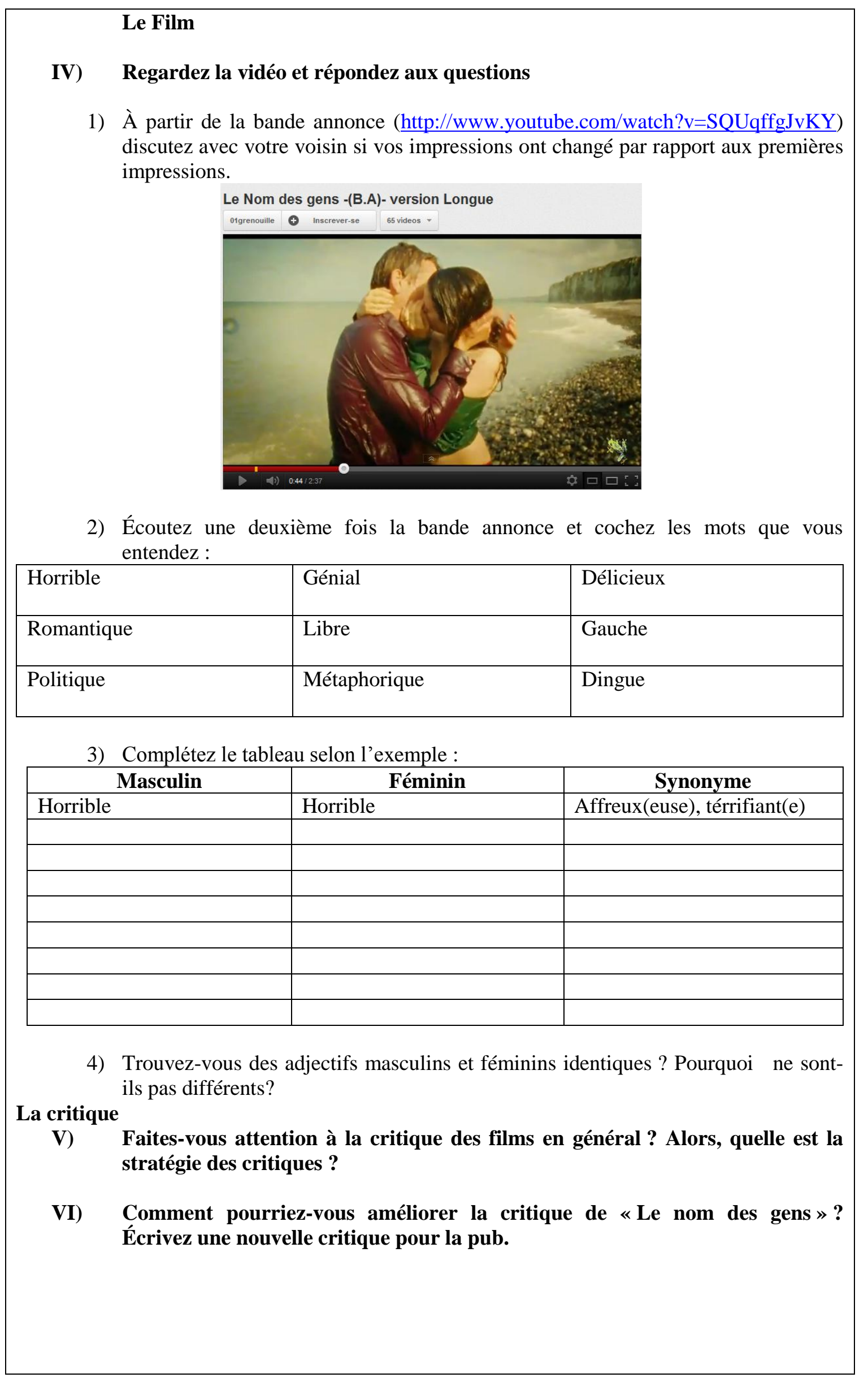




\begin{tabular}{|c|c|c|}
\hline \multicolumn{3}{|c|}{ Le choix du titre } \\
\hline VII) & \multicolumn{2}{|c|}{ ?v=1mYFw6qNF70) et répondez aux questions } \\
\hline \multicolumn{3}{|c|}{$\begin{array}{l}\text { 1) Pensez-vous que la traduction « Os nomes do amor » a été bien choisie en portugais? } \\
\text { Pourquoi? }\end{array}$} \\
\hline \multicolumn{3}{|c|}{ 2) Choisissez un nouveau titre en français. } \\
\hline \multirow{2}{*}{\multicolumn{3}{|c|}{$\begin{array}{l}\text { La réflexion } \\
\text { VIII) } \\
\text { Réfléchissez aux réponses que vous avez données à l'aide de cette petite grille. } \\
\text { Avez-vous trouvé des différences avec la grille précédente ? }\end{array}$}} \\
\hline & & \\
\hline \multicolumn{2}{|c|}{$\begin{array}{l}\text { Pourquoi une partie de l'image est colorée et } \\
\text { l'autre est blache et noire? }\end{array}$} & \\
\hline \multicolumn{3}{|c|}{$\begin{array}{l}\text { Pourquoi les personnages sont disposés à } \\
\text { gauche et à droite? }\end{array}$} \\
\hline $\mathbf{I X})$ & \multicolumn{2}{|c|}{$\begin{array}{l}\text { La création } \\
\text { Si vous pouviez mettre un slogan pour mieux diffuser le film, comment serait- } \\
\text { il? }\end{array}$} \\
\hline
\end{tabular}

\section{$3^{\text {a }}$ aula: módulo 3 e produção final}

A) No módulo 3, do primeiro ao terceiro exercício, tem-se a análise da organização temático representacional conceitual e seus símbolos relacionados aos objetos presentes no anúncio do tipo transporte. Além disso, encontra-se exercícios sobre o vocabulário da cidade e a identificação dos aspectos culturais do anúncio. 


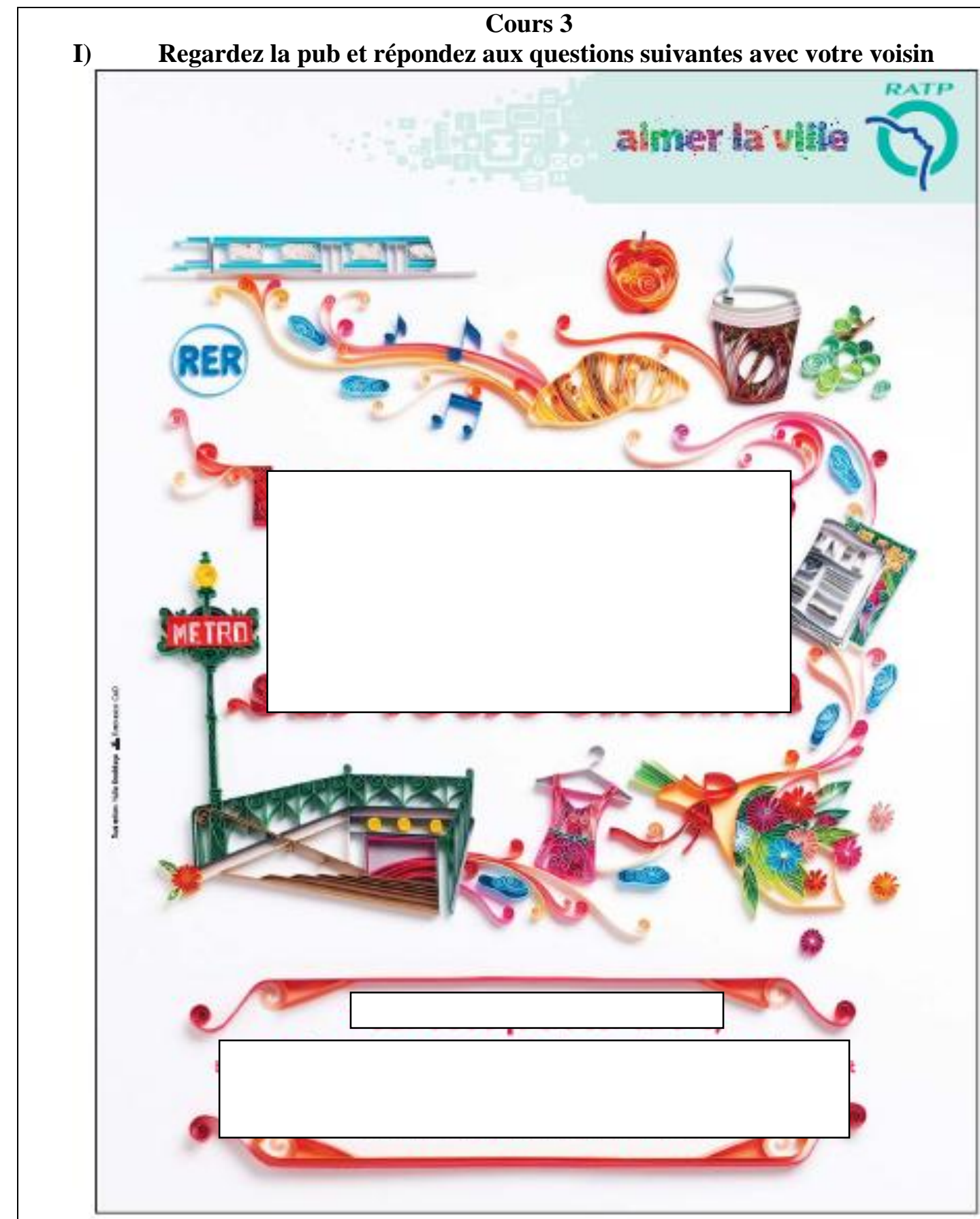

1) Le slogan de la pub a été effacé, comment pouvez-vous la comprendre ?

2) En observant toutes les images, trouvez-vous une image principale ? Laquelle ?

3) Comment les objets apparaîssent sur la pub ? sont-ils connectés ou deconnectés ?

4) Qu'est-ce que voyez-vous au milieu des images ? Où est le début des images? Et la fin?

II) Après avoir observé la pub, créez un slogan pour mettre au centre de la page. 


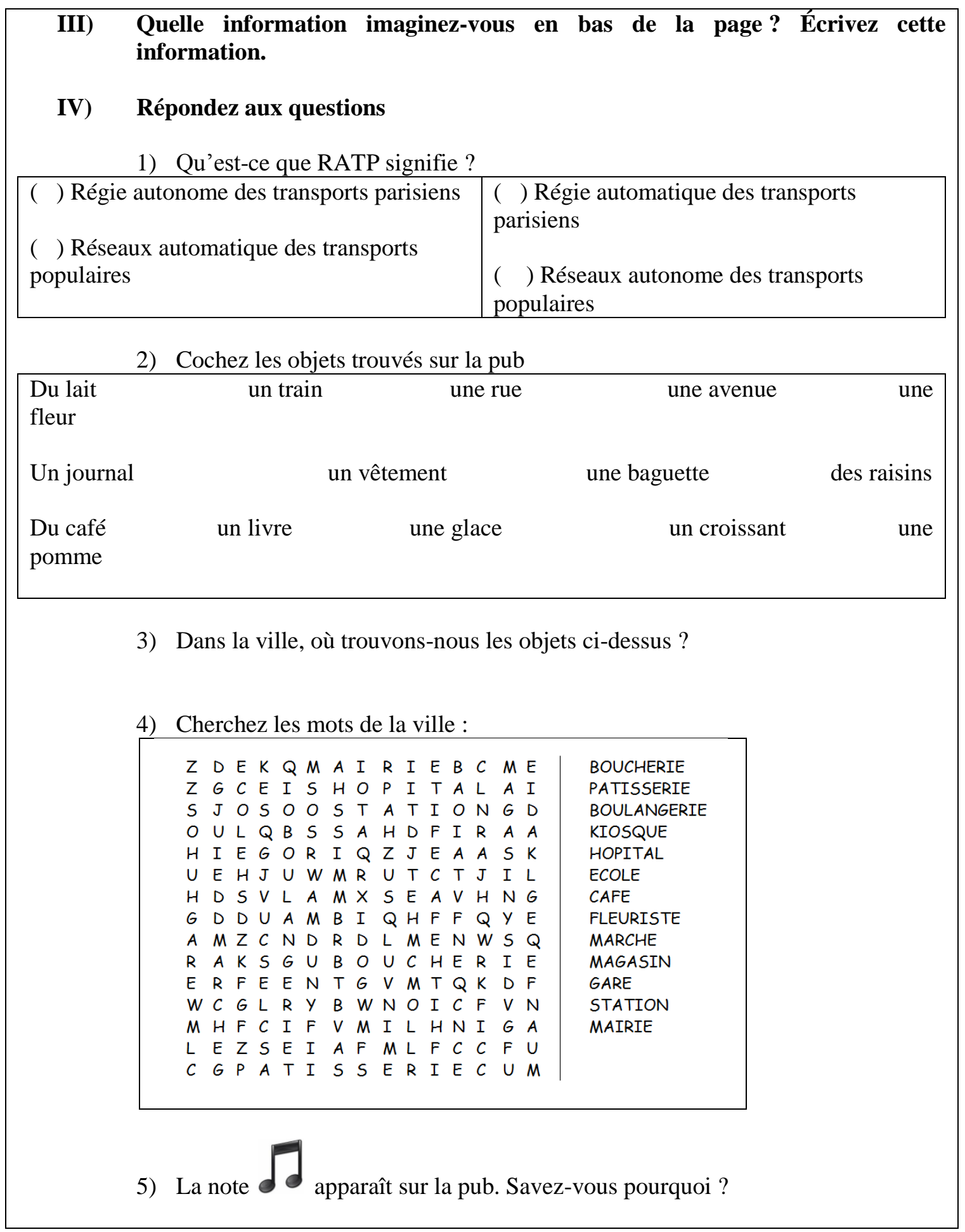

B) O módulo 3 trabalha, também, a compreensão oral do filme "Le fabuleux destin d'Amélie Poulain" e a identificação de semelhanças entre o anúncio do metrô e o caminho de Amélie até o metrô de Paris. Desta forma, elaboramos uma atividade para a discussão sobre os símbolos e o aspecto cultural dos metrôs de Paris. 
V) Regardez l'extrait du film «Le fabuleux destin d'Amélie Poulin » et répondez aux questions. (http://www.youtube.com/watch?v=R3heoAMuyH4\&feature=fvst)

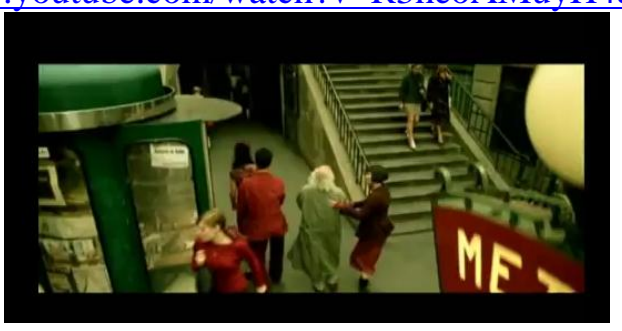

1) Quels commerces voyez-vous sur l'extrait?

2) Où Amélie laisse le monsieur?

3) Qu'est-ce que vous trouvez de différent entre la station de la pub et la station du film?

4) Qu'est-ce que vous trouvez d'identique?

5) Est-ce que l'image ci-dessous vous aide à comprendre le chemin dessiné sur la pub?

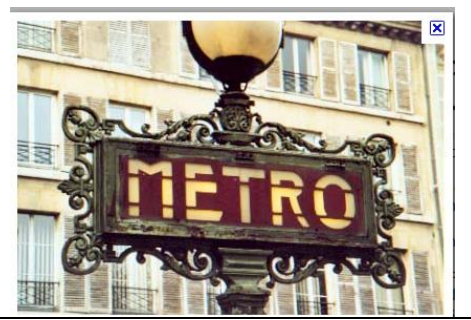

C) O módulo 3 trabalha ainda a compreensão escrita de um texto do site Wikipédia sobre Art nouveau. Para finalizar, o módulo 3, retoma o contexto de produção do anúncio, assim como os aspectos culturais do transporte parisiense. 


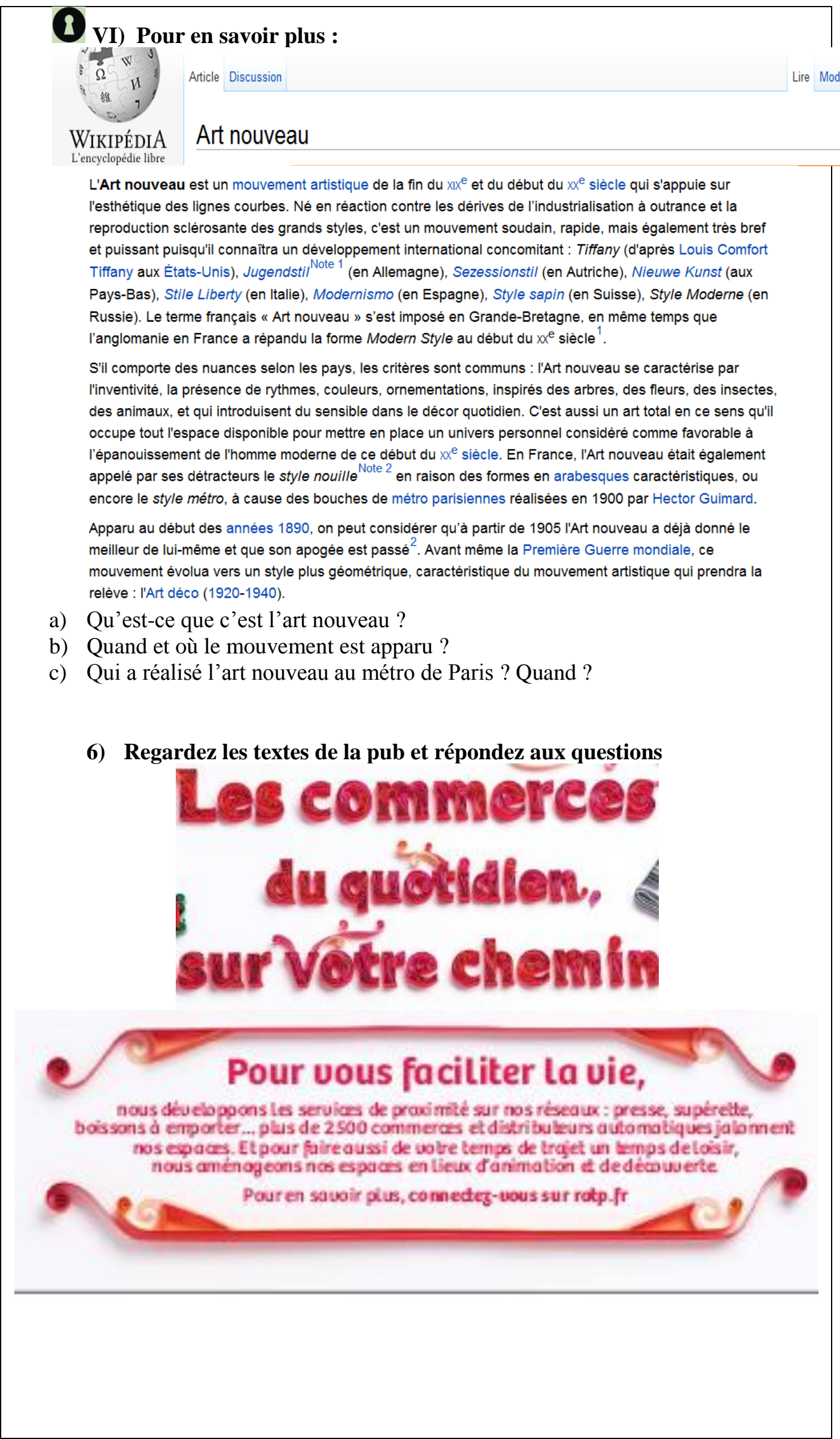


Qui écrit ce message?

À qui ?

Pourquoi?

Quels sont les services disponibles ?

Où vous les trouvez?

Combien de commerces et de distributeurs automatiques il y en a ?

Qu'est-ce que vous comprenez par presse, supérette et distributeur automatique?

Pourquoi la RATP a mis ces commerces dans ses espaces?

\section{3a aula : Produção final}

Após a produção inicial e os três módulos de atividades que visam a desenvolver as capacidades de ação, discursiva e linguístico-discursiva, a sequência didática piloto é finalizada com a produção final de um anúncio publicitário.

\section{VII) Faites l'activité proposée.}

\section{Le publicitaire - Action 2}

Aujourd'hui vous êtes un publicitaire. Choisissez un produit et construisez une nouvelle pub avec votre voisin. Vous n'avez pas besoin d'être un dessinateur, mais de définir l'objet, le slogan, l'image qui apparait au fond de l'objet, entre autres. (vous pouvez aussi utiliser le vers de la page)

\subsubsection{Os alunos participantes da experiência piloto}

A sequência didática que acabamos de apresentar foi aplicada com uma primeira turma de alunos, que cursou os "Ateliers de escrita criativa em língua francesa" no mês de fevereiro de 2012. Para esse grupo, a sequência didática desenvolvida foi aplicada durante três aulas de $3 \mathrm{~h} 30$ cada, ou seja: a produção inicial, a sequência didática e a produção final foram aplicadas em três aulas. 
O grupo era composto por 17 alunos com no mínimo o nível II completo, dos quais 15 alunos eram mulheres e 02 alunos eram homens. No que diz respeito à faixa etária, como citamos anteriormente, os grupos são heterogêneos e, nesse grupo, a aluna mais nova tinha 20 anos enquanto a aluna de mais idade tinha 71 anos.

Com relação ao nível de escolaridade, três alunos haviam concluído a pósgraduação, três cursavam a pós-graduação, um aluno cursava a graduação e 10 alunos tinham o nível superior completo, sendo as áreas de formação muito diversas, como: jornalismo, comunicação, psicologia, letras, geografia, direito, ciências biológicas, entre outras. Desses alunos, nove possuíam vínculo com a Universidade de São Paulo e todos eram residentes da cidade de São Paulo.

Ao analisar o contato dos alunos com outros idiomas, cinco alunas afirmaram não falar outro idioma senão o francês e o português e quatro alunos disseram estudar francês e inglês no período da coleta de dados.

Os motivos pelos quais os alunos estudam o francês variam entre gostar da língua e/ou da cultura francesa (70\%), querer usar a língua em viagens (65\%), querer morar em um país francófono (35\%), ser um sonho (30\%), querer ler textos acadêmicos (24\%), precisar do francês no trabalho $(18 \%)$ e ter amigos ou parentes residentes de um país francófono (18\%).

Depois de termos aplicado a sequência didática com essa turma e termos coletado os textos produzidos pelos alunos, efetuamos uma análise preliminar dos textos e também do curso em si, juntamente com as outras monitoras que o ministraram. Discutindo sobre o tipo de produções que obtivemos e sobre o tipo de curso que realizamos, chegamos à conclusão de que faríamos um novo curso, reelaboraríamos a SD e coletaríamos os dados definitivos para nossa pesquisa a partir de um segundo curso. No entanto, julgamos importante apresentar de que forma essa primeira experiência foi importante para a elaboração de uma outra sequência didática e para sua aplicação em uma segunda turma. Sendo assim, apresentaremos as razões de termos feito um segundo curso com as alterações necessárias na sequência didática, seja por recomendação dos alunos no questionário final, seja pela comparação da produção inicial e da produção final. Em ambos os cursos, as produções iniciais e finais foram feitas em duplas, sendo obrigatória a produção inicial e final com o mesmo par, mas não obrigatório o mesmo par para as diversas atividades desenvolvidas na sequência didática. 


\subsubsection{Aplicação da sequência didática piloto e reflexões}

A sequência didática piloto tinha como objetivo, primeiramente, a coleta de dados para esta pesquisa, sem a necessidade de um segundo curso. Mas, através da análise das produções dos alunos e do questionário final, no qual os alunos avaliam o curso, observamos a necessidade de reorganizar a sequência didática e de trocar algumas atividades para atingir o objetivo do curso que é o desenvolvimento das capacidades de linguagem dos alunos.

O primeiro curso ocorreu em fevereiro de 2012, através do curso intitulado "Ateliers de escrita criativa em língua francesa", no qual quatro gêneros textuais foram trabalhados: itinéraire de Voyage, récit de Voyage, fait divers e o nosso annonce publicitaire. $\mathrm{O}$ curso foi realizado de $1^{\circ}$ a 17 de fevereiro, das $9 \mathrm{~h} 00$ às $12 \mathrm{~h} 30$, com aulas de segunda à sexta-feira.

O curso foi aberto para os interessados pela secretaria de cultura e extensão da FFLCH. Era pré-requisito para se matricular no curso a finalização do nível III dos alunos, estando, portanto, aptos para o nível IV. Além disso, determinamos o número máximo de 20 alunos por turma.

Na primeira aula do curso, fizemos a apresentação das monitoras, realizamos a atividade brise-glace ${ }^{33}$ e a apresentação dos alunos, propusemos o preenchimento do questionário e do termo de consentimento. As 12 aulas seguintes foram divididas entre as quatro monitoras.

Ao término da experiência piloto, comparamos as produções dos alunos e lemos os questionários e as enquetes de satisfação respondidos pelos alunos. Tal fato nos fez pensar em um novo curso, no qual modificaríamos o nome do curso, assim como a sequência didática.

O nome do curso, "Ateliers de escrita criativa em língua francesa", só apareceu como um problema ao analisar os questionários dos alunos, pois o fato de ter a palavra "criativa" no título, fez alguns alunos da Faculdade de Filosofia, Letras e Ciências Humanas da Universidade de São Paulo imaginarem que o curso estaria relacionado à leitura, à criação e ao sistema literário e não à aprendizagem da língua francesa através dos gêneros textuais. Isso aconteceu por influência de uma matéria da graduação que

\footnotetext{
${ }^{33}$ Atividade brise-glace significa atividade quebra-gelo, que serve para aquecer os alunos em língua estrangeira, levando-os se conhecerem melhor e criando uma boa ambientação dos mesmos em sala de aula.
} 
apresentava a escrita criativa relacionada à investigação da gênese de textos literários e não literários e à inclusão do escritor no sistema literário.

Para melhor justificar o imprevisto do nome do curso, coloco alguns recortes da enquete de satisfação, de duas alunas, feita no final do curso, no quadro a seguir:

Quadro 15: trechos da enquete de satisfação do curso "Ateliers de escrita criativa em língua francesa"

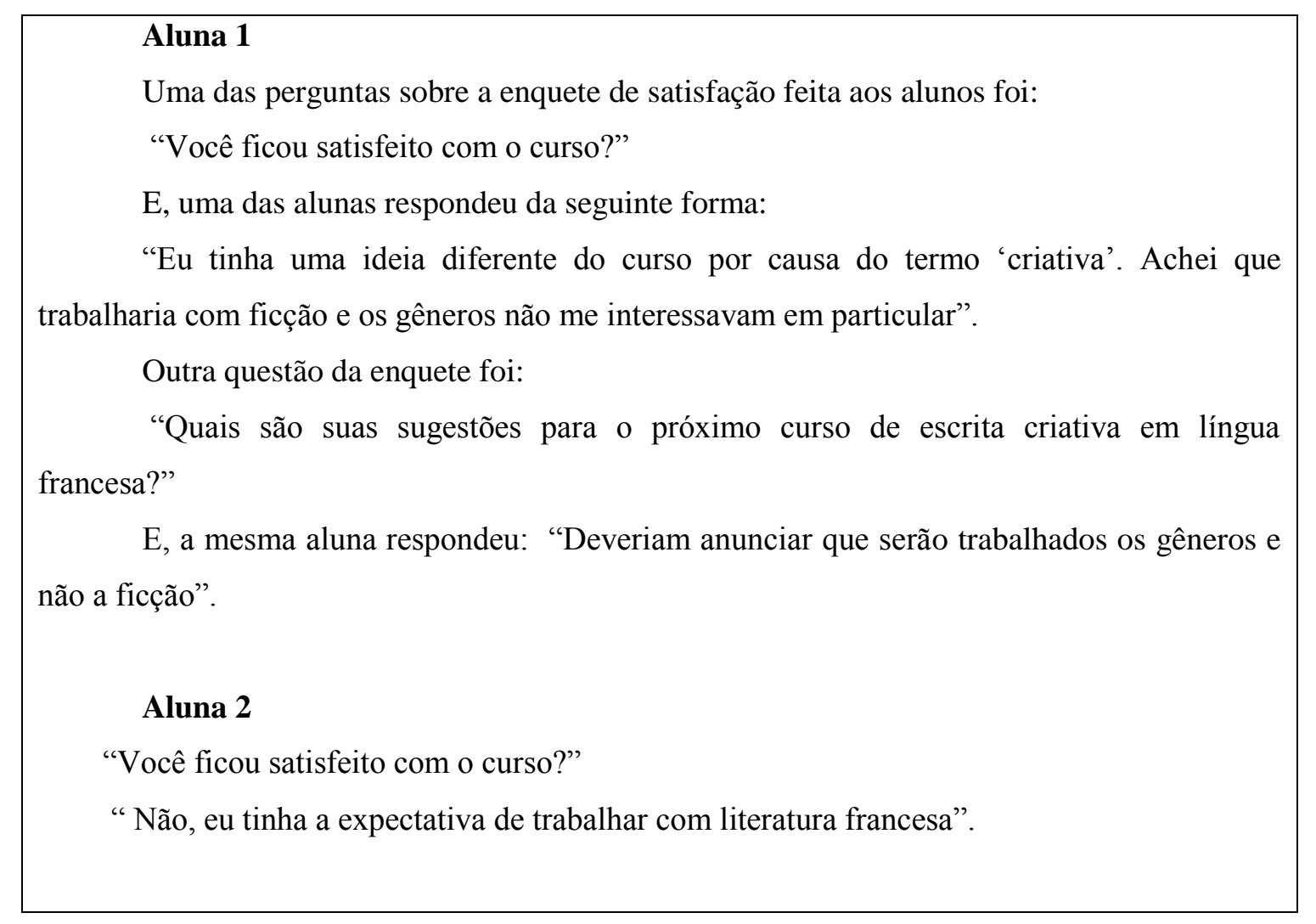

Outro fator importante para a mudança da sequência didática foi a comparação das produções dos alunos, pois percebemos que algumas partes encontradas na elaboração do MD não tinham sido trabalhadas nos módulos que antecediam a produção final, como, por exemplo, a organização estrutural não verbal, ou seja, a saliência, o valor da informação e o emolduramento. Isso também influencia a organização interacional, no que diz respeito aos ângulos da imagem que criam o distanciamento social ou a sequência argumentativa verbal, caso o texto verbal não esteja organizado.

Para trabalhar a saliência, na parte de estruturação do texto não verbal, precisaríamos ter disponibilizado canetinhas coloridas. Esta conclusão se deu através da análise das produções finais, mas também foi o questionamento de uma aluna em sala de aula, pois ela queria colorir e utilizou as canetas esferográficas para concluir seu 
anúncio publicitário. Outro problema, ainda sobre a organização estrutural, foi o emolduramento dos objetos da imagem, ou seja, deveríamos ter trabalhado a posição de alguns elementos, como, por exemplo, a localização do texto verbal descritivo, que se instala na base da imagem, e do logotipo obrigatório em todo anúncio publicitário.

Além disso, ainda analisando as produções finais dos alunos, percebemos que muitas duplas não seguiram a estrutura do gênero anúncio publicitário e usaram a expressão escrita somente na produção do slogan, esquecendo-se do texto explicativo na base desses anúncios.

Abaixo, mostramos um exemplo que demonstra a necessidade de uma reorganização da sequência didática, com base nos problemas citados nos parágrafos anteriores, como, organização temático representacional, interacional e estrutural:

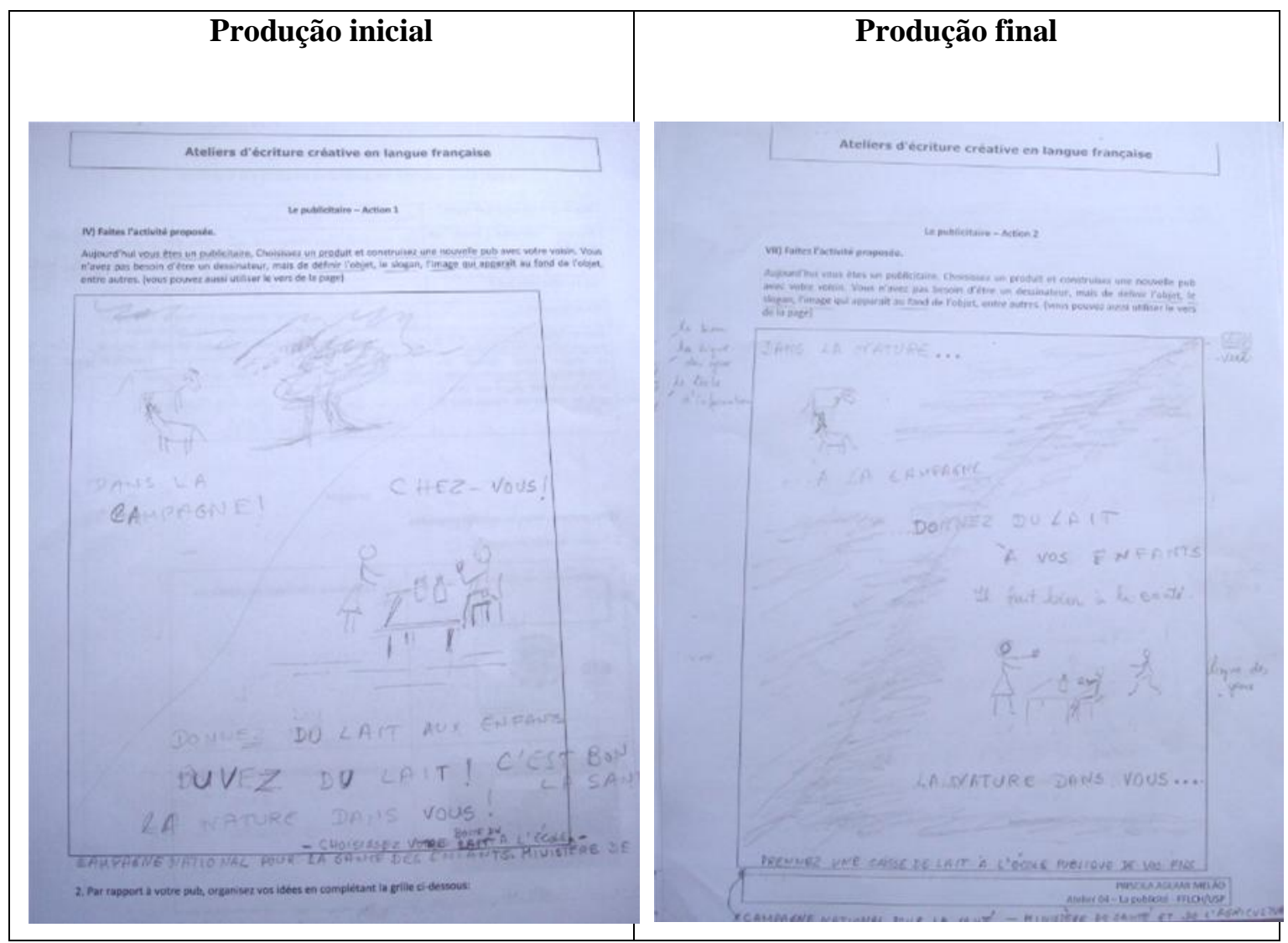

Figura 36: Produção inicial e final de uma das duplas do curso piloto

Ainda, precisamos modificar o nome dado às produções inicial e final: "Le publicitaire - action 1" e "Le publicitaire - action 2", pois o objetivo do curso é desenvolver as capacidades de linguagem dos alunos de forma a compreenderem que a produção inicial e final não os torná-los publicitários. Por outro lado, percebemos que 
os textos produzidos pelos alunos não tinham realmente desenvolvido os aspectos argumentativos e persuasivos, verbalmente e não verbalmente, para agirem em língua estrangeira.

Portanto, todas as constatações apresentadas nesta seção nos levaram a propor uma nova SD que seria aplicada em outro curso, cinco meses depois.

\subsection{A produção final de dados}

Para a produção final de dados, apresentaremos a elaboração da segunda sequência didática, ilustrando as atividades que foram modificadas e detalhando o objetivo das atividades. Apresentaremos, também, os alunos do segundo curso de gêneros, que foi nomeado diferentemente para cada ateliê, portanto: "Ateliers de escrita em francês: descobrir a publicidade". Posteriormente, descreveremos como se desenvolveu o curso, ou seja, a aplicação da segunda sequência didática.

\subsubsection{A elaboração da segunda sequência didática}

Como desenvolvemos nas seções anteriores, foi elaborada, primeiramente, uma primeira $\mathrm{SD}^{34}$, ou seja, uma sequência didática piloto, que foi aplicada em fevereiro de 2012 e, após as reflexões sobre o desenvolvimento das capacidades de linguagem dos alunos, reformulamos algumas de suas atividades e elaboramos, portanto, a segunda SD, que foi aplicada em julho de 2012.

Sendo assim, nessa segunda SD procuramos aperfeiçoar algumas atividades, para atingir alguns objetivos de desenvolvimento das capacidades de linguagem dos alunos. Logo, inserimos uma atividade sobre a organização estrutural dos elementos que caracterizam o gênero anúncio publicitário, além de uma outra atividade sobre o texto verbal descritivo. Inserimos, também, atividades referentes à organização interacional não verbal sobre os ângulos das imagens e sobre as cores, Além disso, nesta aplicação, disponibilizamos canetinhas coloridas para as produções inicial e final dos alunos, de

\footnotetext{
${ }^{34}$ A primeira sequência didática encontra-se em anexo.
} 
forma que eles pudessem usar alguns recursos visuais a mais que contribuissem para ampliar o efeito argumentativo dos textos

Nossa sequência didática, assim como a SD piloto, foi elaborada em três módulos que totalizaram 40 atividades, com exceção das produções inicial e final. Para a elaboração das atividades, fizemos uso de diferentes gêneros textuais, como: anúncios publicitários, propagandas televisivas, caça-palavras ou textos encontrados em site de pesquisa, como a Wikipédia. Utilizamos diferentes gêneros e suportes como recursos para nossa SD, pois sentimos a necessidade de variar as atividades, evitando a monotonia para os alunos.

As etapas da nossa sequência didática foram divididas em duas aulas para as produções iniciais e finais e três módulos de atividades:

\section{$>1^{\text {a }}$ aula: Produção inicial}

Assim como na primeira sequência, houve discussão sobre o interesse dos alunos em anúncios publicitários, a preferência deles por algum anúncio publicitário e a diferença entre os anúncios brasileiros e franceses. Mas, nesta sequência, a orientação sobre a escolha por um tipo de anúncio publicitário: programa de televisão, meio de transporte ou filme, foi melhor desenvolvida em sala.

A produção inicial também aconteceu em dupla, mas não a relacionamos com a profissão do publicitário, visto que nosso objetivo não é formar publicitários, mas desenvolver as capacidades de linguagem dos alunos em língua francesa.

Da mesma forma, após a produção inicial, os alunos analisaram o contexto de produção do anúncio criado.

\section{$2^{a}$ aula: módulo 1}

A) $\mathrm{O}$ módulo 1 foi modificado, pois inserimos uma atividade sobre a disposição e o tamanho do logotipo, assim como, a localização do objeto principal em quatro diferentes anúncios. A atividade foi modificada para que os alunos pudessem observar os anúncios integralmente e, não de forma fragmentada, o que deve ter impedido o desenvolvimento da atividade, ou seja, a observação da estrutura de um anúncio. 
1. Regardez les pubs et répondez Vrai (V) ou Faux(F):
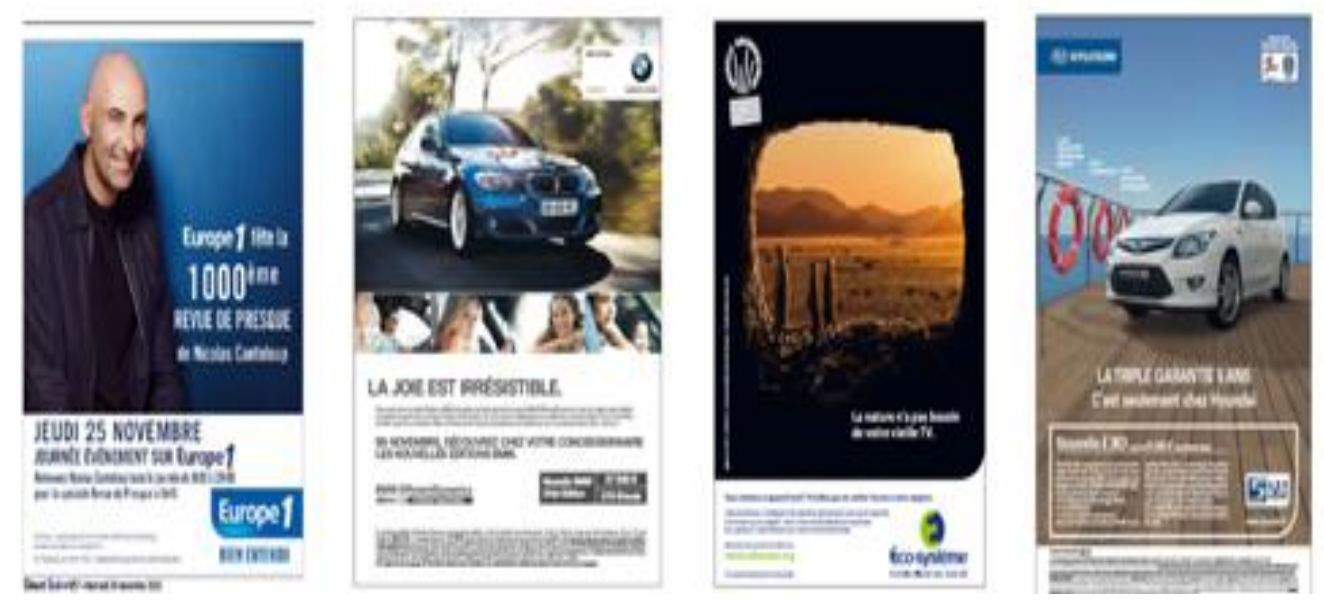

\section{( ) Les pubs annoncent le même type de produit.}

( )Toutes les pubs ont un logo.

( ) les images sont toujours au centre.

( )Les logos sont obligaroirement à droite.

( ) La taille du logo est la même sur toutes les pubs.

2) Análise e organização do texto verbal dos slogans de três anúncios

B) Em seguida, o módulo 1 modificou a abordagem do tipo de anúncio de vídeo através de um anúncio publicitário televisivo do programa "Espoir de l'année". Nessa atividade, os alunos trabalham a compreensão oral sobre as diferentes profissões. Em seguida, relacionamos a emissão com as diferentes emissões brasileiras.

Ainda na mesma atividade, é pedida a produção escrita de slogans para as diferentes profissões encontradas no vídeo "Espoir de l'année". 
III) La publicité vidéo

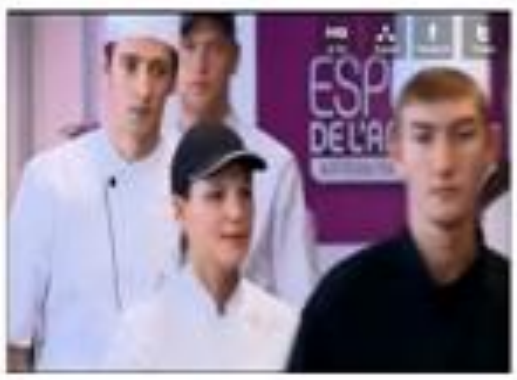

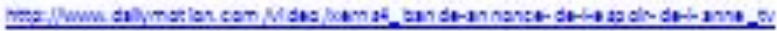

1. Regardez la bande annonce une première fois et cadiez les professions entendues.
( I professeur
1 jooiffeur
( ) facteur
( ) boucher
1 I politicien
1 | fleuriste
1 | Awocat
[ ]pâtissier
( ) concierge

2. Associez les instruments aux professions ci-dessus :

\begin{tabular}{|l|l|l|}
\hline & \\
\hline & & \\
\hline
\end{tabular}




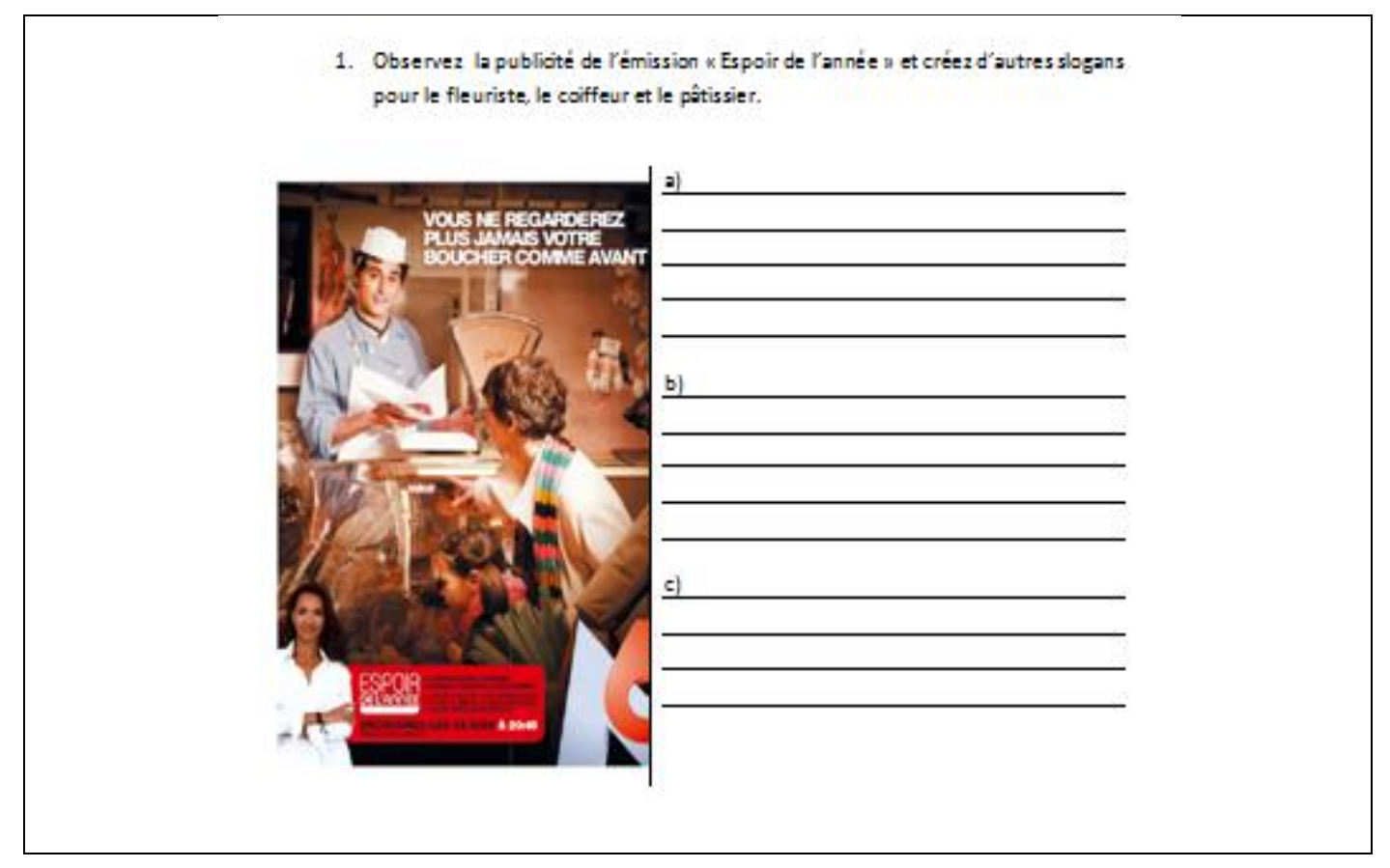

C) Ainda no módulo 1, a atividade a seguir visa a análise da organização temáticorepresentacional, ou seja, para a análise dos vetores representantes narrativos de ações dos participantes do anúncio publicitário. Neste caso, os vetores são trabalhados através do anúncio publicitário "Espoir de l'année" e "Star Story".

D) No anúncio da emissão "Star Story", além do trabalho dos ângulos, tem-se a leitura do texto verbal descritivo e da produção escrita de um novo texto descritivo para um outro tipo de anúncio.

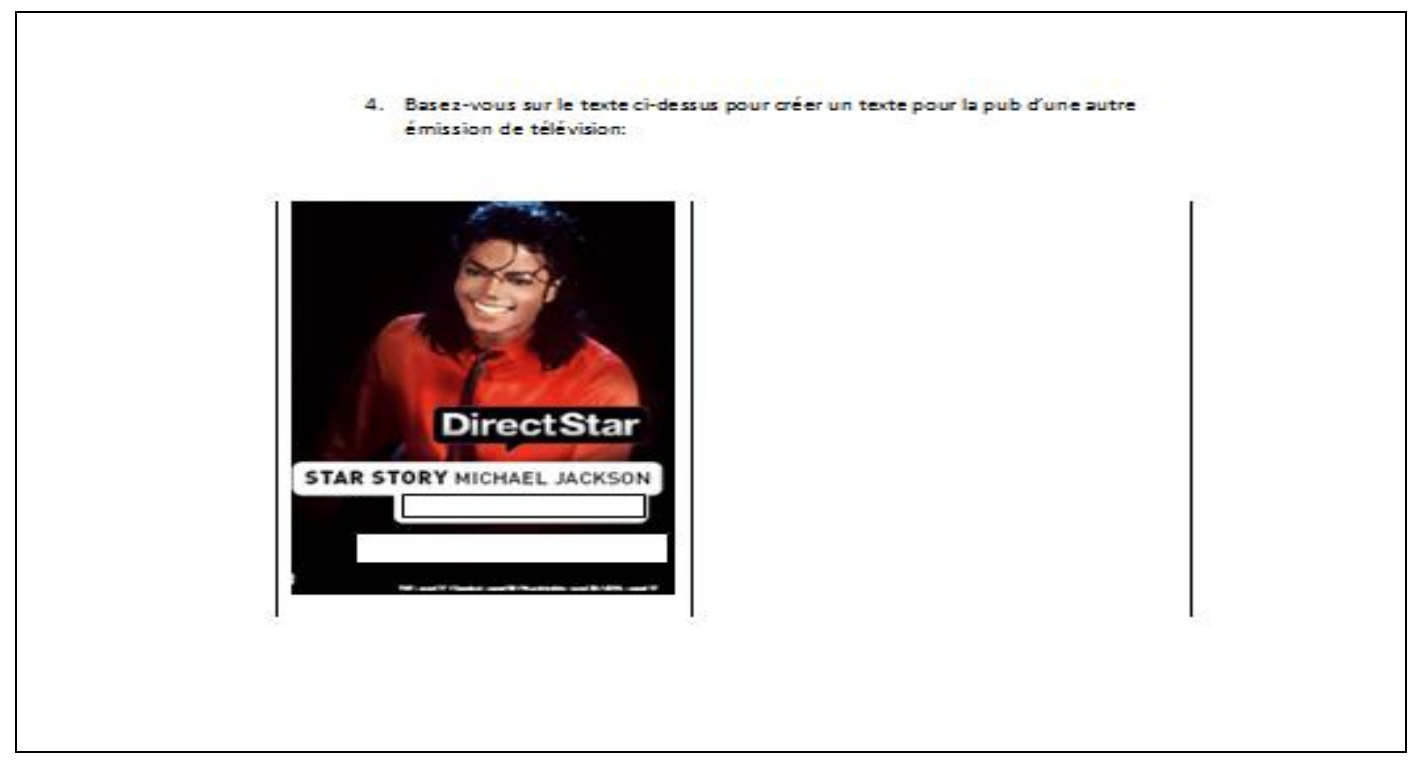

\section{$3^{\text {a }}$ aula: módulo 2}

A) O módulo 2 corresponde à sequência de atividades, proposta no módulo 1 na sequência piloto, sobre o anúncio publicitário do tipo transporte. Portanto, as atividades 
sobre a bicicleta da Peugeot não foram modificadas. Encontra-se, na mesma ordem, a discussão sobre a representação das cores, a associação das citações em referência às cores e a discussão sobre a estrutura do anúncio publicitário da bicicleta Peugeot.

B) Posteriormente, uma atividade de compreensão oral de um anúncio publicitário televisivo desenvolve a capacidade linguístico-discursiva, neste caso, o vocabulário dos ciclistas. Além disso, tem-se a compreensão escrita sobre o dialeto e a produção escrita de um slogan e de um texto descritivo, para o anúncio da bicicleta.

C) Para finalizar o módulo 2, tem-se uma discussão cultural sobre as diferentes corridas do mundo.

\section{$>4^{\text {a }}$ aula: módulo 3.}

A) Para esse terceiro módulo, criamos uma nova atividade sobre os diferentes ângulos de uma imagem e seus significados. Portanto, o módulo 3 inicia com uma reflexão sobre as relações de poder ou de distanciamento entre o leitor e o participante do anúncio publicitário, o que corresponde à organização interacional e visa o desenvolvimento da capacidade linguístico-discursiva.

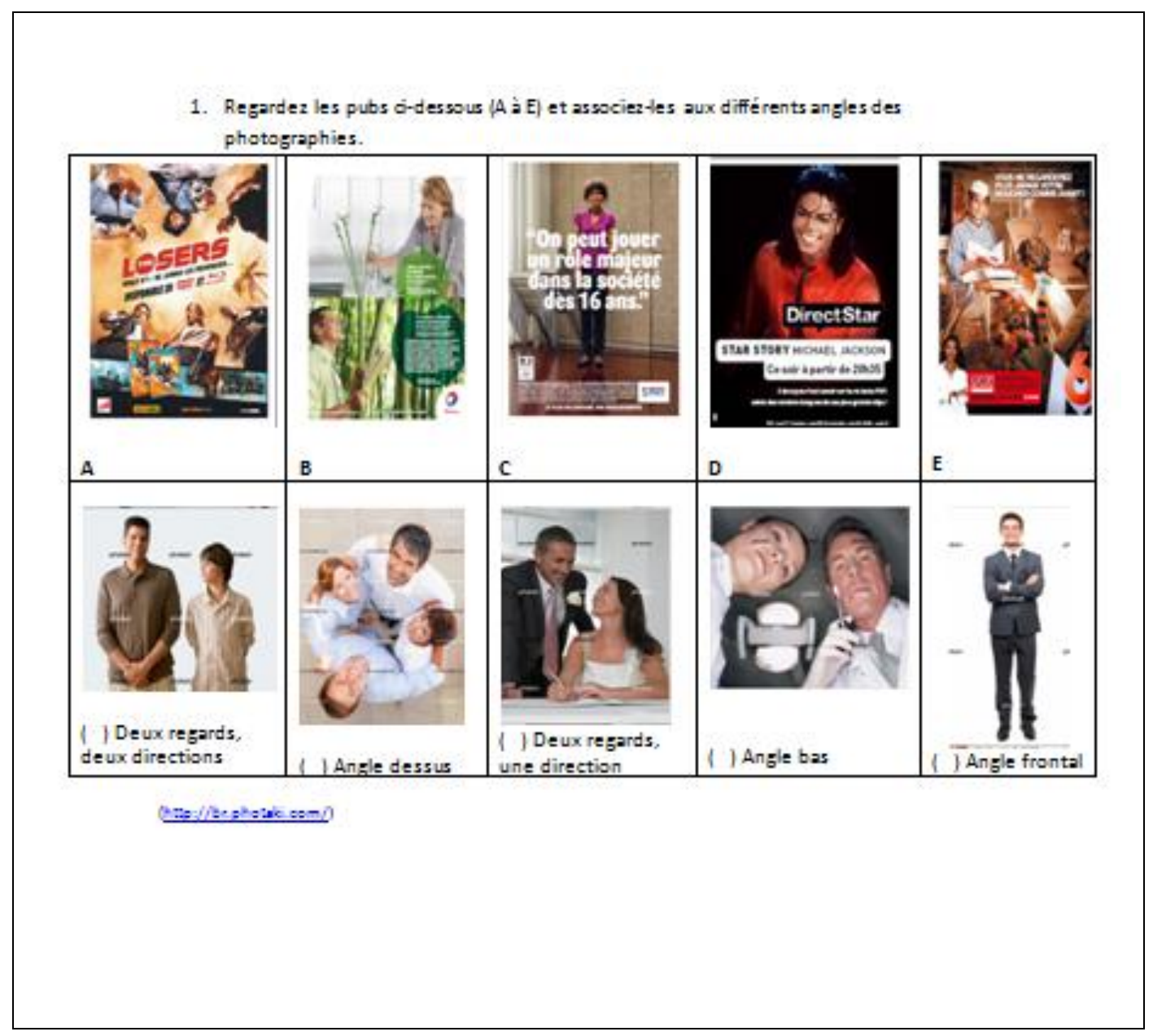




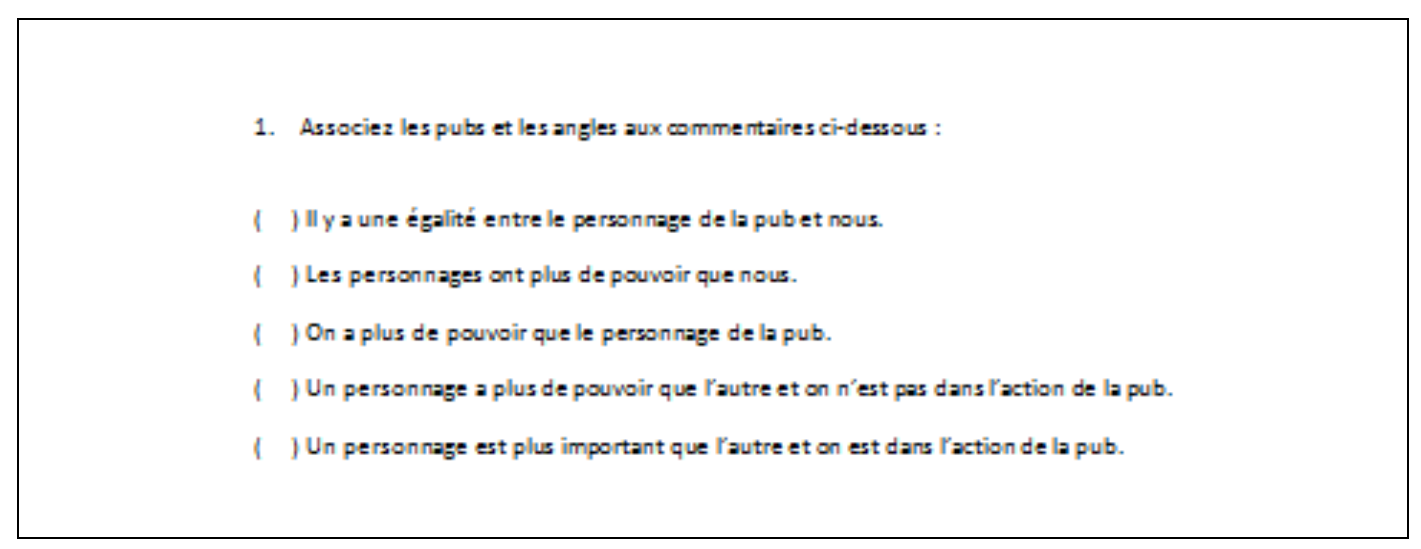

B) Após a atividade sobre os ângulos, o terceiro módulo é composto por atividades que compunham a sequência didática piloto. Portanto, para finalizar o terceiro módulo, selecionamos as atividades sobre o anúncio publicitário do filme "le nom des gens" e sobre o anúncio publicitário do metrô de Paris.

\section{$5^{a}$ aula: Produção final}

Para essa produção final, orientamos uma produção sobre o mesmo tipo de anúncio publicitário realizado na produção inicial e, também, a escolha de um ponto importante da construção e da compreensão dos anúncios publicitários de acordo com a discussão da dupla.

As orientações para desenvolver um mesmo tipo de anúncio e analisar os pontos intencionais do produtor para persuadir o leitor facilitaram as análises e tivemos produções mais criativas, organizadas e bem argumentadas, o que não aconteceu no curso piloto.

Para encerrar esta seção, relembramos que, como citamos no primeiro capítulo desta dissertação, todos esses procedimentos para a construção da sequência didática não impedem que problemas surjam em sala de aula ${ }^{35}$. Contudo, os problemas que surgiram não invalidam a sequência didática elaborada e tampouco as produções dos alunos.

\footnotetext{
${ }^{35}$ Pensamos que, ao restringir as produções iniciais e finais em três tipos de anúncios publicitários, por exemplo, facilitaria a nossa análise das produções, visto que os três módulos da sequência didática tiveram os três tipos de anúncios publicitários em suas atividades. Mas, essa escolha bloquearia o desenvolvimento de alguns alunos que pediram para construir anúncios de acordo com os seus interesses.
} 


\subsubsection{Os alunos participantes da segunda turma}

A segunda turma é referente ao grupo de alunos que cursou os "Ateliers d'écriture en FLE: découvrir la publicité" no mês de julho de 2012. Para esse grupo, a sequência didática desenvolvida foi aplicada da seguinte forma:

Aula 1: produção inicial com uma hora e meia de duração.

Aula 2: Início da Sequência didática com três horas e meia de duração.

Aula 3: Sequência didática com três horas e meia de duração.

Aula 4: Término da sequência didática com três horas e meia de duração.

Aula 5: Produção final com uma hora e meia de duração

O grupo era composto por 14 alunos, dos quais 12 eram mulheres e 02 eram homens. No que diz respeito à faixa etária, a aluna mais nova tinha 21 anos enquanto a aluna de mais idade tinha 66 anos.

Com relação ao nível de escolaridade, 13 alunos tinham o nível superior completo e uma aluna cursava a graduação. Desses alunos de nível superior completo, quatro alunos haviam concluído a pós-graduação e dois cursavam a pós-graduação. Suas áreas de formação são diversas, como: letras, filosofia, história, biotecnologia, ciências biológicas, administração, engenharia, química, psicologia e artes.

Desses alunos, quatro possuíam vínculo com a Universidade de São Paulo; dentre os 14 alunos, onze são residentes da cidade de São Paulo e os outros três são residentes das cidades de Barueri, Osasco e Santana do Parnaíba.

Ao analisar o contato dos alunos com outros idiomas, quatro alunas afirmaram não falar outro idioma senão o francês e o português e três alunas disseram estudar outra língua ou mais línguas no período da coleta de dados do curso "Ateliers d'écriture en FLE". Uma das alunas estudava italiano, inglês e alemão; outra estudava alemão e a terceira aluna estudava italiano no período em que o curso aconteceu.

Os motivos pelos quais os alunos estudam o francês variavam entre: gostar da língua e/ou da cultura francesa (71\%), querer usar a língua em viagens (43\%), querer morar em um país francófono (36\%), ser um sonho (29\%), querer ler textos acadêmicos (29\%), precisar do francês no trabalho (7\%), precisar aprender um novo idioma (7\%) e ter amigos ou parentes residentes de um país francófono (14\%).

Dentre os quatorze alunos, quatro consideraram ter mais dificuldade na habilidade linguística de produção escrita, no entanto todos escolheram o curso para aprimorar a escrita. Na verdade, mesmo aqueles que dizem não terem maiores 
dificuldades escolheram o curso para aperfeiçoar a escrita. Outros pontos interessantes foram a preocupação dos alunos na escolha do curso para não perder o contato com a língua durante o mês de férias $(21 \%)$ e o interesse em aprimorar também a habilidade de produção oral (21\%).

A escolha dos alunos pela produção oral em um curso de escrita em FLE não é inadequada, visto que o pré-requisito para iniciar esse curso era ter o nível IV de francês. Logo, todos os alunos eram capazes de se comunicar entre si somente em língua francesa, contribuindo para desenvolver a habilidade oral dos alunos.

Durante o curso, os alunos que acabamos de apresentar produziram textos em duplas. Para nossas análises, consideramos todos os textos que foram produzidos em duplas, pois nesse segundo curso fizemos as mudanças necessárias pra um melhor desenvolvimento das capacidades de linguagem dos alunos. Porém, o curso por si só não é uma certeza de que todos os alunos desenvolverão suas capacidades de linguagem: podemos dizer que o curso visa a um possível desenvolvimento dessas capacidades. Apresentaremos as análises das produções dos alunos na seção "análise dos dados" e "quadro síntese de análises".

\subsubsection{Aplicação da segunda sequência didática}

Como mencionamos anteriormente, encontramos problemas na sequência didática que nomeamos como piloto, portanto, produzimos uma segunda sequência didática para melhor trabalhar o desenvolvimento das capacidades de linguagem dos alunos.

Sendo assim, aplicamos em julho de 2012 a segunda sequência didática no curso “Atelier d'écriture em FLE: découvrir la publicité, le fait divers et le récit de voyage". Assim como o primeiro curso, a secretaria de cultura e extensão da $\mathrm{FFCH}$ se responsabilizou pelas inscrições. Era pré-requisito para esse curso, diferentemente do primeiro, a finalização do nível IV, ou seja, somente os alunos aptos ao nível V. Optamos por esse nível, pois achamos que alunos de um nível mais avançado poderiam ter um melhor desempenho nas três SDs do curso. Apesar do número máximo de 20 alunos matriculados, tivemos somente 14 alunos nesse grupo. Esse fator não é incomum, visto que o número de alunos diminui nos níveis mais avançados de francês. 
Nesta segunda aplicação, as aulas foram divididas entre três monitorasprofessoras. Logo, o curso ministrado foi dividido em três blocos, pois cada uma foi responsável por um gênero textual. Utilizamos a primeira aula para as atividades de apresentação, o preenchimento dos questionários e do termo de consentimento, além do início das produções iniciais dos alunos de duas monitoras. A segunda aula foi utilizada para uma produção textual e, a partir de então, dividimos três aulas de $3 \mathrm{~h} 30$ para o desenvolvimento dos módulos e o equivalente a 1h45 para a produção final de cada monitora. A última aula foi destinada à entrega das anotações de desenvolvimento dos alunos nas três oficinas.

Como já dissemos, os textos que analisaremos em nossa pesquisa foram produzidos nesse segundo curso, após termos feito modificações nas atividades da sequência didática. Analisaremos, portanto, as produções dos alunos à luz do modelo de análise semiótico sociointeracional, proposto por Leal (2011). Por meio dessas análises, verificaremos:

- o desenvolvimento dos alunos entre as produções iniciais e finais;

- quais as diferenças e semelhanças entre as produções e o modelo didático do gênero, ou seja, ao texto autêntico anúncio publicitário. Também tentaremos explicar por meio de hipóteses as produções que não se adequaram ao gênero.

\section{Procedimentos de análise dos dados}

Para analisarmos as produções iniciais e finais dos alunos, apresentaremos, nesta seção, um plano de análise e os quadros-síntese que estão baseados, basicamente, em Leal (2011), apoiada em Bronckart (2003, 2006) e em Kress e Van Leeuwen (2006), para a criação da semiótica sociointeracional. A esses quadros-síntese, acrescentamos algumas categorias que são pertinentes ao gênero textual anúncio publicitário.

\subsection{Planos de análise}

Assim, a partir da semiótica sociointeracional (LEAL, 2011), analisaremos os textos produzidos em duplas pelos alunos do curso "Ateliers d'écriture en FLE: 
découvrir la publicité". Nas produções iniciais e finais das duplas, analisaremos os contextos de produção e recepção criados pelos alunos, além das organizações dos textos produzidos, ou seja, a organização temático-representacional verbal e não verbal, a organização interacional verbal e não verbal, e a organização estrutural verbal e não verbal. Portanto, faremos as análises em quatro níveis: nível dos contextos, nível temático-representacional, nível interacional e nível estrutural. São esses níveis que apresentamos a seguir:

\subsubsection{Nível dos contextos}

O nível dos contextos das produções dos alunos está diretamente ligado às capacidades de ação (BRONCKART, 2003) e visa a identificar elementos importantes para a criação do gênero textual, como o contexto de produção e de recepção físico e, também, social, elementos propostos por Bronckart (2003) e desenvolvidos por Leal (2011). Assim, as categorias de análise com base nos contextos serão:

1. Contexto físico: emissor, receptor, local de produção e momento de produção.

2. Contexto sociossubjetivo: enunciador (função social do emissor), destinatário (função social do receptor), lugar social, objetivo do enunciador direcionado ao destinatário.

\subsubsection{Nível temático-representacional}

Com a união do ISD com a GDV, o nível temático representacional está relacionado às capacidades discursivas e nos possibilitará analisar o conteúdo temático e os tipos de discurso dos textos verbais, ou seja, poderemos encontrar os conteúdos mobilizados e como eles progridem tematicamente, além dos diferentes tipos de discursos propostos por Bronckart (2003): discurso interativo, discurso teórico, relato interativo e narração. Também analisaremos os tipos de representações construídas nos e pelos textos não verbais: as representações conceituais e as narrativas. Nesse nível, podem ser também analisadas as eventuais sequências, como a argumentativa. Porém, como já dissemos, no gênero anúncio publicitário a argumentação aparece de forma 
diversa, sobretudo através dos mecanismos enunciativos, que fazem parte do próximo nível.

Como explicamos anteriormente, com base em Kress e Van Leeuwen (2006), as representações conceituais não possuem vetores, mas símbolos, classificações de um grupo, estruturas temporais ou estruturas espaciais. Enquanto as representações narrativas aparecem como processos de ação e reação, através de vetores, as representações conceituais aparecem como circunstâncias, ou seja, através de diálogos em balões, gestos ou acompanhamento, todos sem vetores.

\subsubsection{Nível interacional}

O nível interacional se relaciona às capacidades discursivas e engloba os mecanismos enunciativos, portanto, nos textos verbais, analisaremos as vozes do discurso e a as modalizações apreciativa, deôntica ou lógica, baseamo-nos nos estudos de Bronckart (2003, 2006, 2008). São esses mecanismos que possibilitam a criação de um efeito argumentativo no gênero anúncio publicitário, sobretudo por permitirem a expressão dos afetos e emoções e das vozes sociais e de autoridade, como já vimos.

Já nos textos não verbais, os mecanismos enunciativos englobam o contato, a distância social e a modalização do não verbal. Com base em Kress e Van Leeuwen (2006), analisaremos o contato por exposição ou interpelação, a distância social através dos planos das imagens, a perspectiva do envolvimento e a modalidade ${ }^{36}$, todos escolhidos pelos alunos, de acordo com as possibilidades que tiveram de desenvolver as imagens através das cores.

\subsubsection{Nível estrutural}

O nível estrutural também está relacionado às capacidades linguísticodiscursivas e engloba os mecanismos de textualização, ou seja, a conexão, a coerência, a

\footnotetext{
${ }^{36}$ Em nossa dissertação, adotamos o termo modalidade, segundo Kress e Van Leeuwen (2006), que utilizam essa categoria para o texto não verbal. Por outro lado, para analisar o texto verbal, utilizamos o termo modalização, de acordo com Bronckart (1999) e outros autores.
} 
coesão nominal e a coesão verbal do texto verbal, além do valor da informação, a saliência e o emolduramento do texto não verbal.

Para analisar o texto verbal nas produções dos alunos, identificaremos as ocorrências das unidades linguísticas: os organizadores lógico-argumentativos e temporais responsáveis pela conexão, as anáforas nominais (substituição ou repetição) e pronominais (pronomes pessoais, relativos, possessivos, demonstrativos e reflexivos), responsáveis pela coesão nominal e pelos tempos verbais relacionados à coesão verbal.

Para o texto não verbal, analisaremos a composição da imagem, ou seja, o valor da informação a partir do posicionamento dos elementos na imagem (por exemplo, elementos no centro têm alto grau de destaque); a saliência encontrada através do foco, do tamanho, do brilho ou da perspectiva em primeiro plano; e o emolduramento dos elementos que podem estar conectados pela cor, por outros elementos, ou podem estar desconectados.

\subsection{Quadros-síntese das análises}

Utilizaremos dois quadros que visam a facilitar as nossas análises nos capítulos seguintes. O quadro, proposto por Leal (2011), porém adaptado, será utilizado para analisar as produções iniciais e finais dos alunos, assim como analisamos o gênero textual anúncio publicitário para construção do modelo didático. Ao preencher este quadro, compreenderemos as significações da união do texto verbal com o não verbal e conseguiremos observar o desenvolvimento parcial das capacidades de linguagem dos alunos em relação ao gênero textual anúncio publicitário. 
Quadro 16: Quadro-síntese para a análise das produções textuais dos alunos

\begin{tabular}{|c|c|c|c|c|c|}
\hline \multirow{10}{*}{$\begin{array}{l}\text { Atividade(s) } \\
\text { Relacionada(s) }\end{array}$} & \multirow{10}{*}{$\begin{array}{l}\text { Gênero } \\
\text { escolhido } \\
\text { e suporte } \\
\text { definido }\end{array}$} & \multirow{4}{*}{$\begin{array}{c}\text { Ação de } \\
\text { linguagem }\end{array}$} & \multirow[t]{2}{*}{$\begin{array}{l}\text { Contexto de } \\
\text { produção }\end{array}$} & Contexto físico & $\begin{array}{l}\text { Lugar de produção } \\
\text { Momento de } \\
\text { produção } \\
\text { Produtor e receptor }\end{array}$ \\
\hline & & & & $\begin{array}{l}\text { Contexto } \\
\text { sociossubjetivo }\end{array}$ & $\begin{array}{l}\text { Lugar social da } \\
\text { produção } \\
\text { Posição social do } \\
\text { produtor e receptor } \\
\text { Objetivo(s) }\end{array}$ \\
\hline & & & \multirow[t]{2}{*}{$\begin{array}{l}\text { Contexto de } \\
\text { recepção }\end{array}$} & Contexto físico & $\begin{array}{l}\text { Lugar de recepção } \\
\text { Momento de } \\
\text { recepção } \\
\text { Receptor e produtor }\end{array}$ \\
\hline & & & & $\begin{array}{l}\text { Contexto } \\
\text { sociossubjetivo }\end{array}$ & $\begin{array}{l}\text { Lugar social da } \\
\text { recepção } \\
\text { Posição social do } \\
\text { receptor e produtor } \\
\text { Objetivo(s) }\end{array}$ \\
\hline & & \multirow{6}{*}{$\begin{array}{l}\text { Arquitetura } \\
\text { interna dos } \\
\text { textos }\end{array}$} & \multirow[t]{2}{*}{$\begin{array}{l}\text { Organização } \\
\text { temático- } \\
\text { representaci } \\
\text { onal }\end{array}$} & $\begin{array}{l}\text { Organização } \\
\text { temática } \\
\text { representacional } \\
\text { verbal }\end{array}$ & $\begin{array}{l}\text { Conteúdo temático } \\
\text { Tipos de discurso } \\
\text { Sequência } \\
\text { argumentativa }\end{array}$ \\
\hline & & & & $\begin{array}{l}\text { Organização } \\
\text { temática } \\
\text { representacional } \\
\text { não verbal }\end{array}$ & $\begin{array}{l}\text { Tipos de } \\
\text { representação } \\
\text { (narrativa/ } \\
\text { conceitual) }\end{array}$ \\
\hline & & & \multirow[t]{2}{*}{$\begin{array}{l}\text { Organização } \\
\text { interacional }\end{array}$} & $\begin{array}{l}\text { Manifestação } \\
\text { pelo verbal }\end{array}$ & $\begin{array}{l}\text { Vozes do discurso } \\
\text { Modalização }\end{array}$ \\
\hline & & & & $\begin{array}{l}\text { Manifestação } \\
\text { pelo não verbal }\end{array}$ & $\begin{array}{l}\text { Contato } \\
\text { Distância social } \\
\text { Atitude } \\
\text { Modalidade }\end{array}$ \\
\hline & & & \multirow[t]{2}{*}{$\begin{array}{l}\text { Organização } \\
\text { estrutural }\end{array}$} & $\begin{array}{l}\text { Estruturação } \\
\text { verbal }\end{array}$ & $\begin{array}{l}\text { Conexão/Coerência } \\
\text { Coesão nominal e } \\
\text { verbal }\end{array}$ \\
\hline & & & & $\begin{array}{l}\text { Estruturação não } \\
\text { verbal }\end{array}$ & $\begin{array}{l}\text { Valor da informação } \\
\text { Saliência } \\
\text { Emolduramento }\end{array}$ \\
\hline
\end{tabular}


Como dissemos, a partir do contexto de produção podemos analisar o desenvolvimento das capacidades de ação; a partir das organizações temáticorepresentacional e interacional conseguimos analisar as capacidades discursivas e, a partir da organização estrutural, podemos observar o desenvolvimento das capacidades linguístico-discursivas, como apresentamos no quadro a seguir. $\mathrm{O}$ efeito argumentativo acontece através das três capacidades, no plano verbal e não verbal das produções. No entanto, damos destaque, na parte verbal, aos mecanismos enunciativos como responsáveis pelo efeito argumentativo, já que, nos anúncios publicitários, é geralmente nesse nível que o feito argumentativo se consolida.

Quadro 17: Quadro-síntese para a análise das capacidades de linguagem dos alunos

\begin{tabular}{|c|c|}
\hline $\begin{array}{l}\text { Capacidades de } \\
\text { linguagem }\end{array}$ & $\begin{array}{c}\text { Operações de linguagem esperadas na produção do gênero } \\
\text { textual "anúncio publicitário" }\end{array}$ \\
\hline Capacidade de ação & $\begin{array}{l}\text { Identificar as características do contexto de produção e de } \\
\text { recepção: } \\
\text { - enunciador } \\
\text { - destinatário } \\
\text { - Objetivos }\end{array}$ \\
\hline Capacidade discursiva & $\begin{array}{l}\text { Organizar os conteúdos temático-representacionais verbais: } \\
\text { - conteúdo temático } \\
\text { - tipos de discurso } \\
\text { - Sequência argumentativa - mas que se realiza pelas vozes e } \\
\text { modalizações, apresentadas na categoria abaixo } \\
\text { - sequência descritiva } \\
\text { Organizar os conteúdos temático-representacionais não verbais: } \\
\text { - Tipos de representação: narrativa ou conceitual (vetorial ou } \\
\text { simbólica, respectivamente) }\end{array}$ \\
\hline $\begin{array}{l}\text { Capacidade linguístico- } \\
\text { discursiva }\end{array}$ & $\begin{array}{l}\text { Organizar os conteúdos interacionais verbais: } \\
\text { - Discurso interativo implicado da ordem do expor } \\
\text { - Relato interativo implicado da ordem do narrar } \\
\text { - Inserção de vozes sociais e de autoridade } \\
\text { - Modalizações de valor lógico (certeza/verdade) } \\
\text { - Modalizações de valor deôntico (intenção/vontade) } \\
\text { - Modalizações de valor apreciativo } \\
\text { Organizar os conteúdos interacionais não verbais: } \\
\text { - contato (demanda/interpelação ou oferta/exposição) } \\
\text { - distância social (plano fechado, médio ou geral) } \\
\text { - atitude (perspectiva, ângulo da imagem) } \\
\text { - modalidade (cor, brilho, foco) } \\
\text { Organizar os conteúdos estruturais verbais: } \\
\text { - mecanismos de conexão } \\
\text { - mecanismos de coesão nominal (adjetivos qualificativos, } \\
\text { anáforas do pronome pessoal) } \\
\text { - mecanismos de coesão verbal (verbos no presente, futuro ou }\end{array}$ \\
\hline
\end{tabular}




\begin{tabular}{|l|l|}
\hline imperativo) \\
\\
Organizar os conteúdos estruturais não verbais: \\
- valor da informação (topo, base, lado direito e esquerdo da \\
imagem) \\
- Saliência (tamanho da imagem e foco) \\
- Emolduramento (conexão ou desconexão dos elementos da \\
imagem)
\end{tabular}

\section{Credibilidade e aspectos éticos}

O desenvolvimento de uma pesquisa não é uma tarefa simples, pois o pesquisador deve garantir a confiabilidade de sua pesquisa. Para isso, ele pode fazer uso de alguns instrumentos de trabalho que dão credibilidade à investigação, como o apoio em métodos de análises, abordagens teóricas e fontes de dados. Ele pode, ainda, manter o contato com outros pesquisadores para a troca de experiências e para a discussão sobre o trabalho desenvolvido, pois essa troca pode esclarecer o que não está adequado na pesquisa, atingindo, portanto, os objetivos de uma forma clara.

Por isso, é fundamental uma análise crítica do nosso trabalho por pesquisadores que não façam parte do contexto de pesquisa. Para garantir esse aspecto da credibilidade, apresentamos nossa pesquisa em diversas comunicações em eventos científicos, nos quais discutimos o andamento das análises, das elaborações do modelo didático e da elaboração da sequência, assim como, a apresentação de alguns resultados e pudemos agregar importantes contribuições de colegas pesquisadores. Também participamos do grupo de pesquisa ALTER-AGE que nos permitiu e nos permite trocar diferentes análises com colegas da mesma área, enriquecendo o nosso trabalho.

Além dos dados citados, para que a pesquisa fosse construída dentro dos padrões éticos necessários ao se trabalhar com seres humanos, todos os participantes da pesquisa foram informados sobre o estudo, podendo manifestar desinteresse na participação. Para tanto, um termo de consentimento ${ }^{37}$. Também foram esclarecidas quaisquer dúvidas e foi elaborado um termo de consentimento e assinado por todos os participantes desta pesquisa. Esses termos de consentimento estão arquivados e disponíveis para consulta, caso necessário. Com o final da pesquisa, todos os participantes terão acesso aos resultados das análises.

\footnotetext{
${ }^{37}$ Os termos de consentimento devidamente assinados encontram-se em anexo.
} 


\section{Capítulo III - Resultados das análises}

“A teoria sem a prática vira 'verbalismo', assim como a prática sem a teoria, vira ativismo. No entanto, quando se une a prática com a teoria tem-se a práxis, a ação criadora e modificadora da realidade" (Paulo Freire) 
Neste capítulo, apresentaremos as análises das produções dos alunos do curso de gêneros textuais, do "Atelier d'écriture en FLE: découvrir la publicité". Para isso, como explicamos anteriormente, utilizaremos o quadro-síntese da união do ISD com a GDV, adaptado do quadro proposto por Leal (2011) e analisaremos as produções de acordo com as capacidades de linguagem, ou seja, as capacidades de ação, as capacidades discursivas e as capacidades linguístico-discursivas.

Nosso objetivo é observar e comparar as capacidades de linguagem dos alunos na primeira produção e na produção final, para identificar as que foram desenvolvidas. Os critérios para avaliar o desenvolvimento das capacidades partirão de características específicas do gênero anúncio publicitário, que foram apresentadas no modelo didático do gênero. De maneira global, pretendemos verificar como o efeito argumentativo é construído pelos alunos, por meio dos elementos verbais e não verbais mobilizados, como apresentamos anteriormente. O objetivo do produtor de um anúncio publicitário é convencer o seu leitor, fazendo-o adquirir o produto. Portanto, o objetivo do curso de gêneros é fazer os alunos compreenderem a intencionalidade do anúncio para persuadir alguém e desenvolver suas capacidades de linguagem para que consigam fazer o mesmo com seus anúncios. Com isso, esperamos que eles desenvolvam as capacidades de linguagem, em geral, mas especificamente às ligadas à argumentação, de maneira que seus anúncios criem o mesmo efeito de persuasão do interlocutor para adquirir o produto. Porém, ao ter desenvolvido a capacidade de argumentação, esperamos que possam usá-las também em outros gêneros.

Antes de iniciar a análise das produções dos alunos, é importante retomarmos algumas das atividades propostas, sobretudo a produção inicial. A atividade inicial tem como objetivo focar as diferentes opções de anúncios publicitários e facilitar a escolha dos alunos, já que existem inúmeros tipos de anúncios e eles são muito diferentes entre si. Portanto, como a produção livre da sequência didática piloto tinha deixado os alunos confusos com as inúmeras possibilidades, optamos por fazer uma proposta diferente. Sendo assim, partimos da própria proposta da SD, que previa o trabalho com três tipos de anúncios em três módulos diferentes. Sendo assim, colocamos como opção de produção inicial os mesmos três tipos de anúncios dos módulos como facilitadores para essas produções. Dessa forma, os alunos não trabalhariam com tipos diferentes dos que seriam estudados durante o curso.

Com essa opção, na produção final, os alunos não produziriam tipos de anúncio diferentes do escolhido para a produção inicial, o que, em nosso entender, facilitaria a 
nossa análise no que diz respeito ao desenvolvimento das capacidades de linguagem.

Vejamos as duas atividades de produção inicial e final:

\section{Produção Inicial}

1. Choisissez entre:

( ) une émission de télé

( ) un moyen de transport

( ) un film ou dvd

2. Créez une pub pour ce que vous avez choisi avec votre voisin. Vous n'avez pas besoin d'être un dessinateur, mais utilisez des crayons en couleurs et définissez :

- l'objet,

- le slogan,

- l'image qui apparaît au fond de l'objet.

\section{Produção Final}

Construisez une nouvelle pub avec votre voisin. Vous n'avez pas besoin d'être un dessinateur, mais utilisez les crayons en couleurs et définissez : l'objet, le slogan, l'image qui apparaît au fond de l'objet. Vous devez mantenir la thématique choisie dans la première production.

Após as produções inicial e final, todos os alunos fizeram uma atividade através da qual podemos descobrir o contexto de produção escolhido, o que também facilita a nossa análise sobre as capacidades, sobretudo as de ação.

3) Complétez la grille ci-dessous pour organiser vos idées par rapport à la pub que vous avez créée :

\begin{tabular}{|l|l|}
\hline $\begin{array}{l}\text { Pourquoi avez-vous choisi ce } \\
\text { produit? }\end{array}$ & \\
\hline Où allez-vous l'annoncer? & \\
\hline Qui a produit cette pub? & \\
\hline $\begin{array}{l}\text { Qui est votre public ? } \\
\text { Quel est l'objectif du magasin ou de la } \\
\text { marque qui a produit cette pub? }\end{array}$ & \\
\hline $\begin{array}{l}\text { Est-ce que le slogan choisi reprend } \\
\text { une caractéristique de l'image? } \\
\text { Laquelle? }\end{array}$ \\
\hline $\begin{array}{l}\text { Est-ce que votre slogan fait sens si } \\
\text { vous ne mettez pas l'image dans la } \\
\text { pub? }\end{array}$ \\
\hline
\end{tabular}


Parece-nos importante esclarecer, também, que após o término da aplicação da SD e das aulas do curso, foram entregues aos alunos a cópia das produções e um quadro semelhante ao quadro síntese para apresentar o desenvolvimento ou não desenvolvimento em algum elemento de alguma das capacidades de linguagem. Também elaboramos um quadro, no qual apresentamos os problemas linguísticos e as soluções dos mesmos. Ressaltamos, ainda, que o módulo sobre o gênero anúncio publicitário foi o primeiro, pois os alunos também trabalharam os gêneros notícia (fait divers) e relato de viagem (récit de voyage) em sequências didáticas posteriores. Apesar de não termos analisado as produções dos outros ateliês, mas nos baseando em Bronckart (2005c) e no conceito de intertexto, que sustenta a existência de diferentes processos de interação implícita e explícita entre os infinitos textos, podemos considerar que o desenvolvimento alcançado no primeiro módulo foi somente o início, visto que os alunos passaram por mais duas sequências didáticas.

Tendo apresentado uma síntese dos conteúdos trabalhados e das atividades que deram início à nossa $\mathrm{SD}$, passemos à analise das produções textuais dos alunos. Para analisarmos os anúncios, dividiremos este capítulo em quatro seções: a primeira, apresenta as produções dos alunos, colocando lado a lado produção inicial e final; em seguida, temos uma seção para cada capacidade de linguagem e, ao final de cada seção, apresentaremos um quadro-síntese. Neste quadro-síntese teremos uma primeira coluna com os enfoques das capacidades de linguagem, as colunas seguintes com os nomes dos alunos. Nessas colunas, procuraremos demonstrar se houve desenvolvimento das capacidades de linguagem através de um sistema de cores, com uso de: preto, cinza escuro, cinza claro e branco, representando, respectivamente: desenvolvimento das capacidades, desenvolvimento parcial, capacidades desenvolvidas provavelmente anteriormente ao curso e capacidade não desenvolvida. Apresentamos, a seguir, o quadro da legenda das cores que aparecerá nos quadros-síntese das capacidades de linguagem. 
Quadro 18: legenda das cores apresentadas nos quadros-síntese das capacidades de linguagem

Elemento não apareceu na produção inicial e apareceu na produção final: houve desenvolvimento

Elemento apareceu na produção inicial e melhorou na produção final: houve algum desenvolvimento

Apareceu na produção inicial e na produção final da mesma forma : capacidade já desenvolvida

Não apareceu na produção inicial e não apareceu na produção final: não houve desenvolvimento

\section{Produções dos alunos}

Como dissemos, a seguir reproduzimos as produções iniciais e finais dos sete grupos de alunos ${ }^{38}$.

\footnotetext{
${ }^{38}$ Os nomes dos alunos foram modificados a fim de resguardar a identidade dos mesmos.
} 


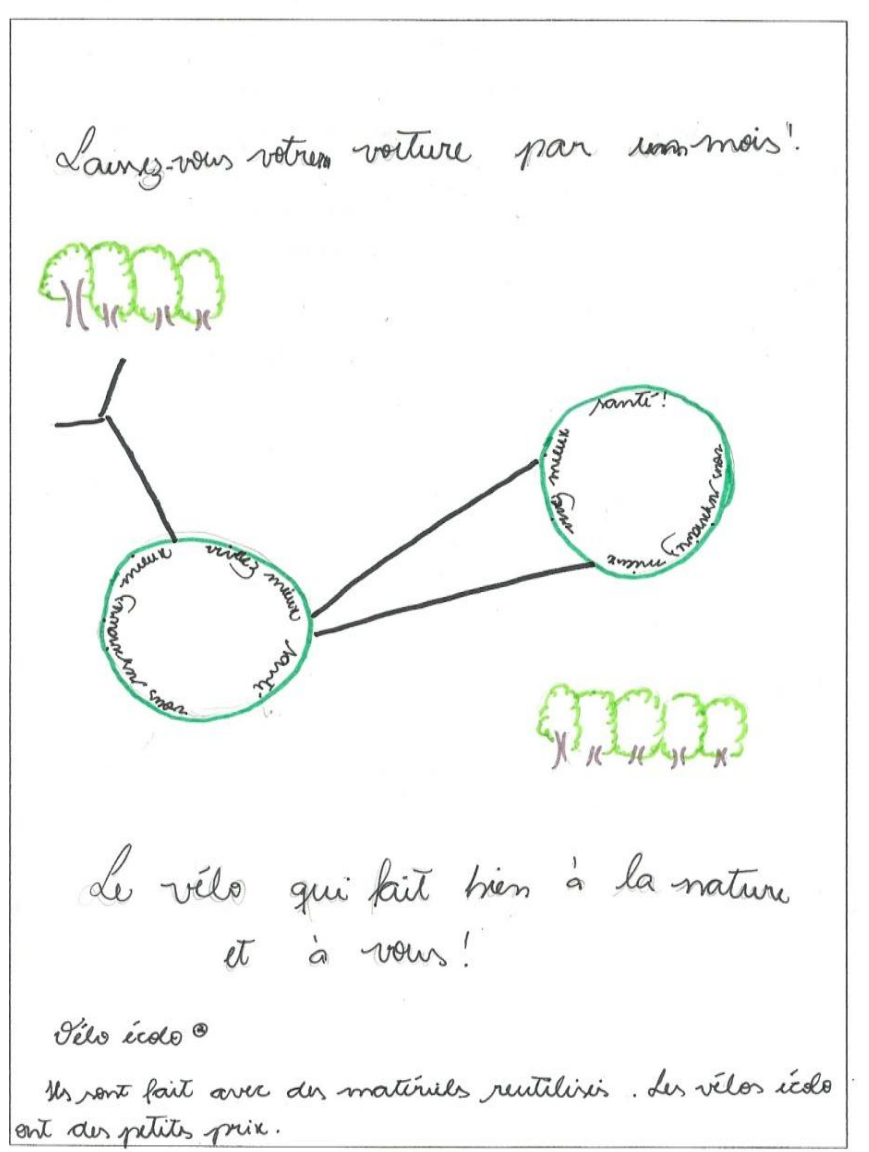

d'écriture em FLE: découvrir la publicité - FFLCH/USP tguiar Melão

Action 2 : la pub

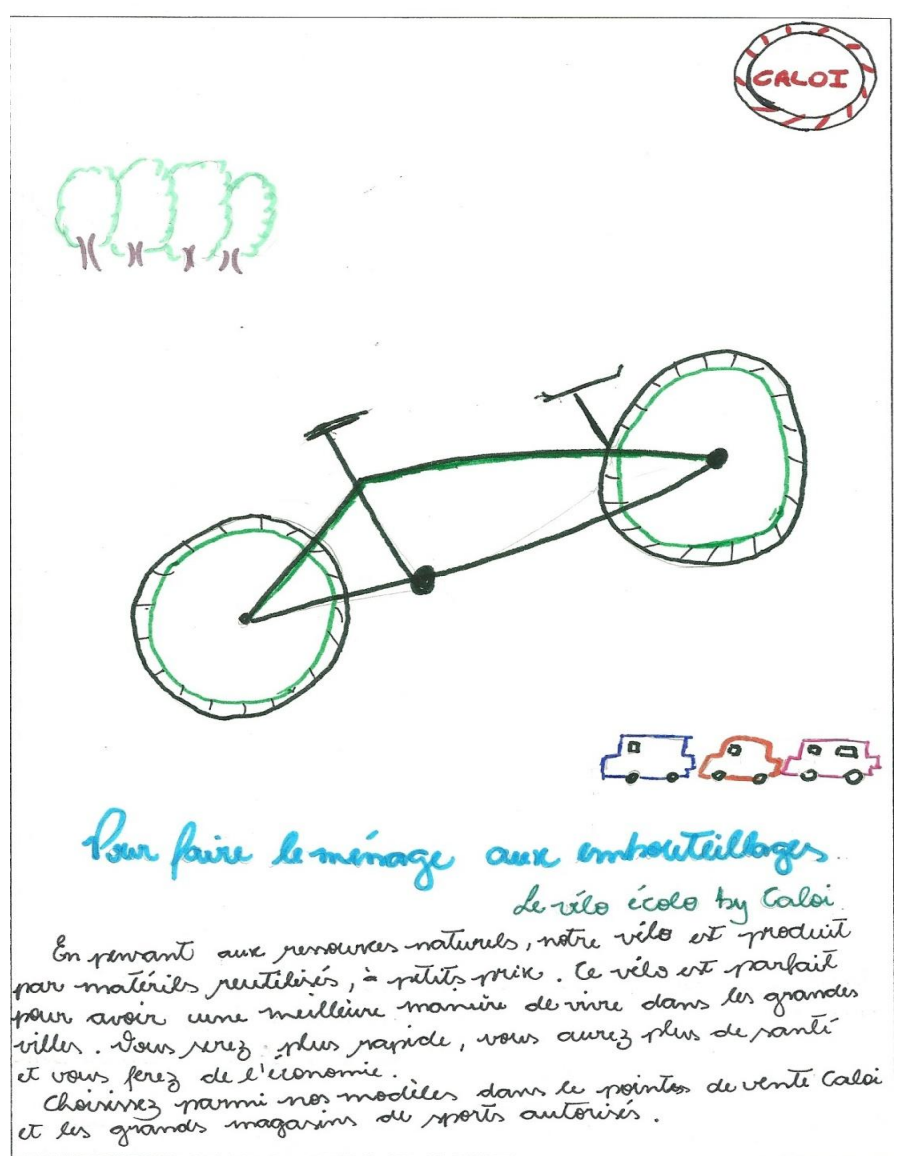


Ateliers d'écriture em FLE: découvrir la publicité - FFLCH/USP Priscila Aguiar Mel

2012

Action 1 : la pub

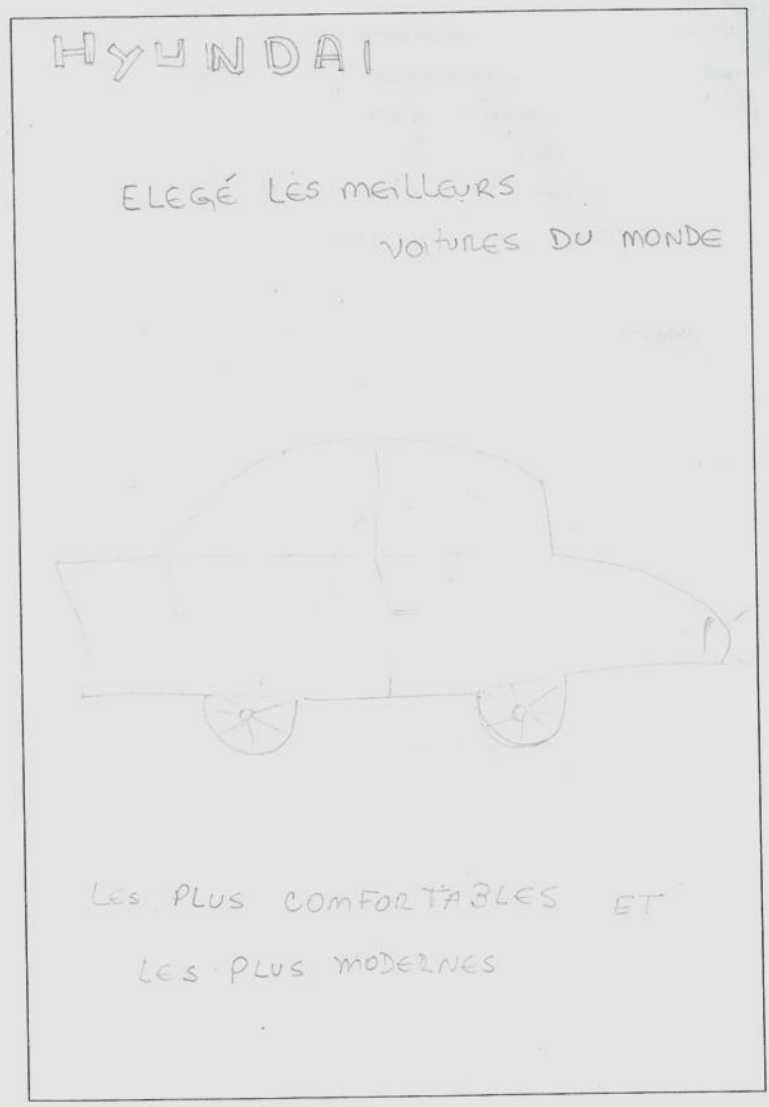

Ateliers d'écriture em FLE: découvrir la publicité - FFLCH/USP Priscila Aguiar Melão

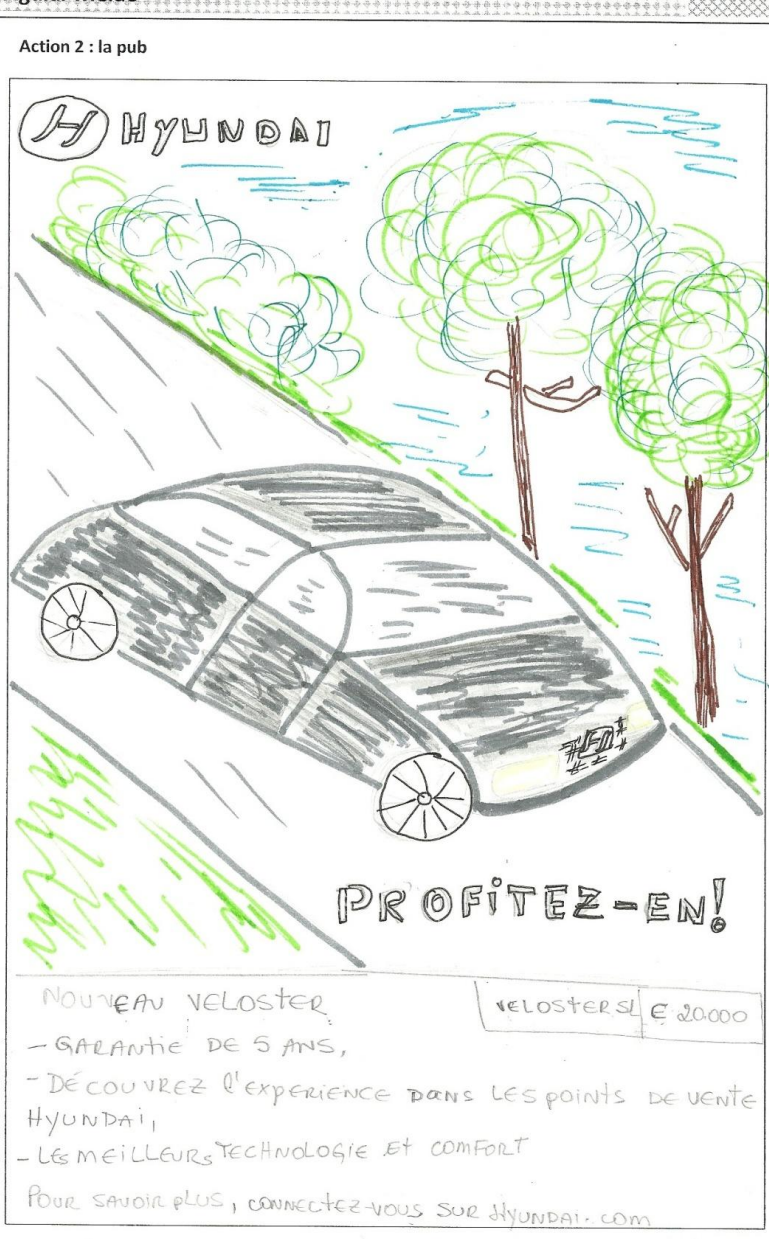


d'écriture em FLE; découvrir la publicité - FFLCH/USP tguiar Melão

2012

Action 1 : la pub

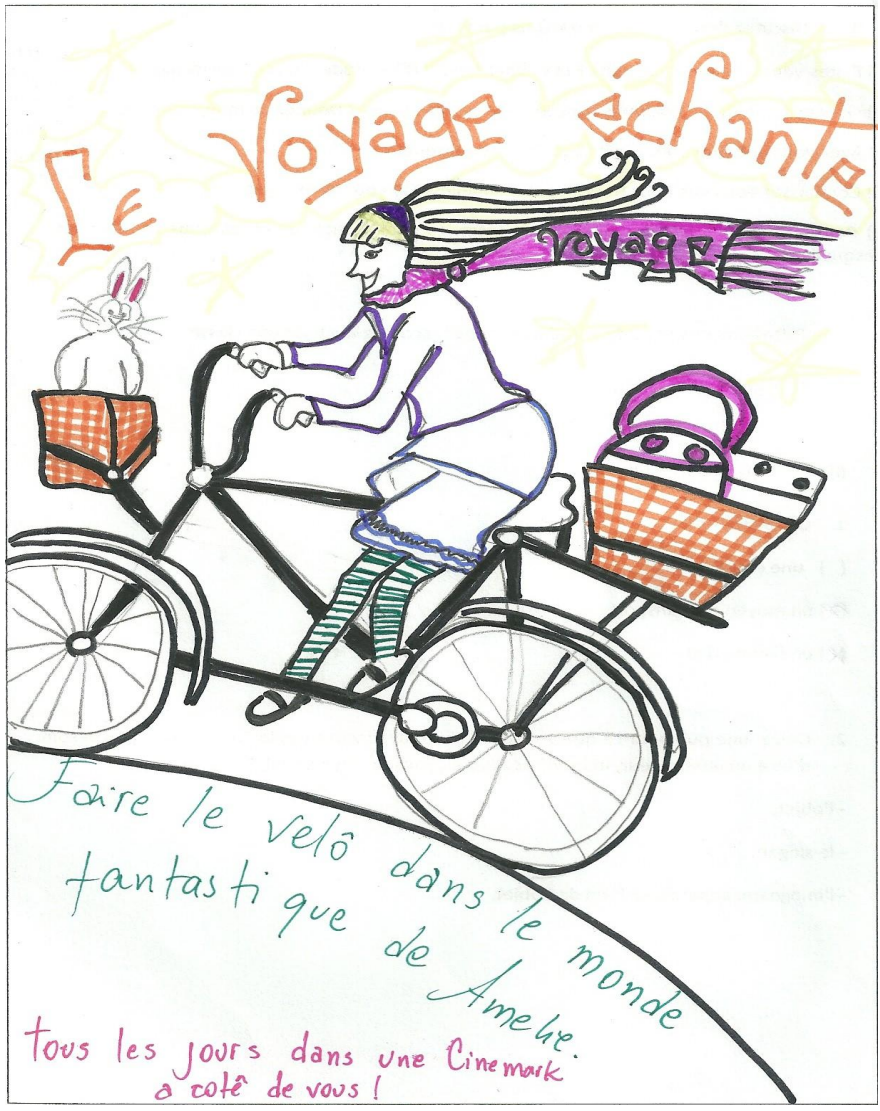

\begin{tabular}{|l} 
Ateliers d'ecriture em FLE: découvrir la publicite - FFLCH/USP \\
Priscila Aguiar Meläo
\end{tabular}

Action 2 : la pub

- Merveillevx c'est fantastique
- Lemonde - Vew boiktines

Le plus belleanimation dianée?

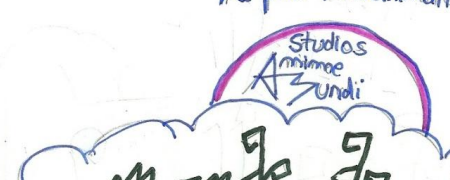

a M

r g a sia

3 (1)

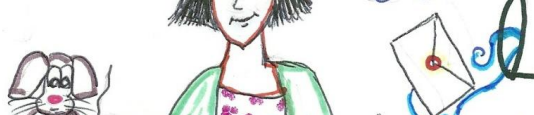

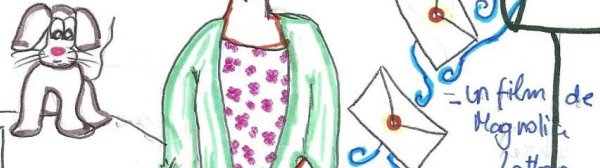

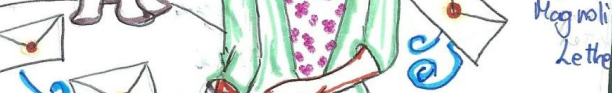

60

Decouvrez le monde de Sophie du Cime Manche de feudi à Dimanche à $15 \mathrm{~h}, 17: 30 \mathrm{het} 19 \mathrm{~h}$

* (4) \$AU CINEMA LE 13 JUUTN

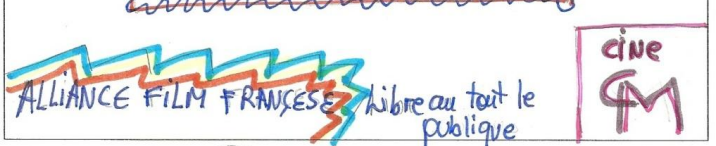


Action 1 : la pub

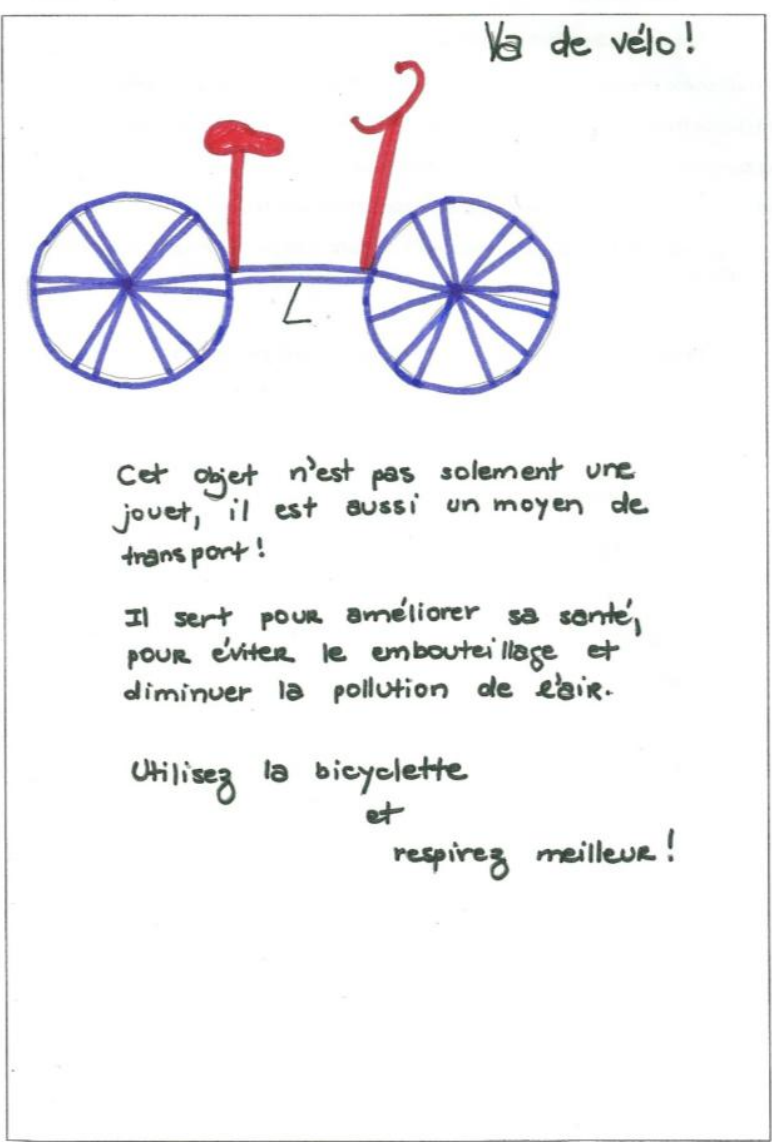

Action 2 : la pub

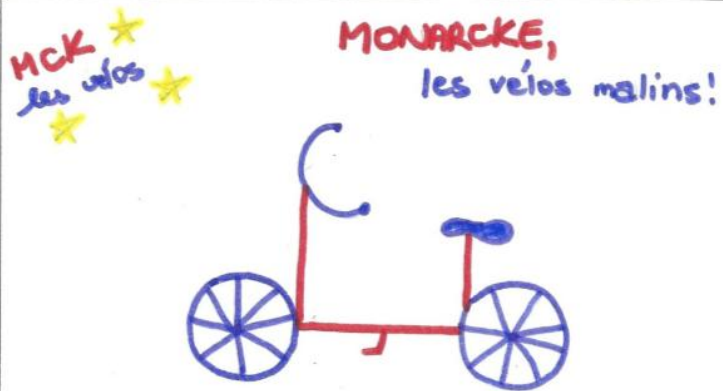

Les vélos Monnrekes sont revenus! maintenant, ils sont propres pour la vie moderne.

Monorcke, c'est un produrt malin: - léger - pliable

- portable - réristant en carbon et alu

monarcke permet que vous allez à toos les rienx avec eni.

Pour en savoir peus: WNW. monarcke. com 
Ateliers d'écriture em FLE: découvrir la publicité - FFLCH/USP Priscila Aguiar Melấ

2012

Action 1 : la pus

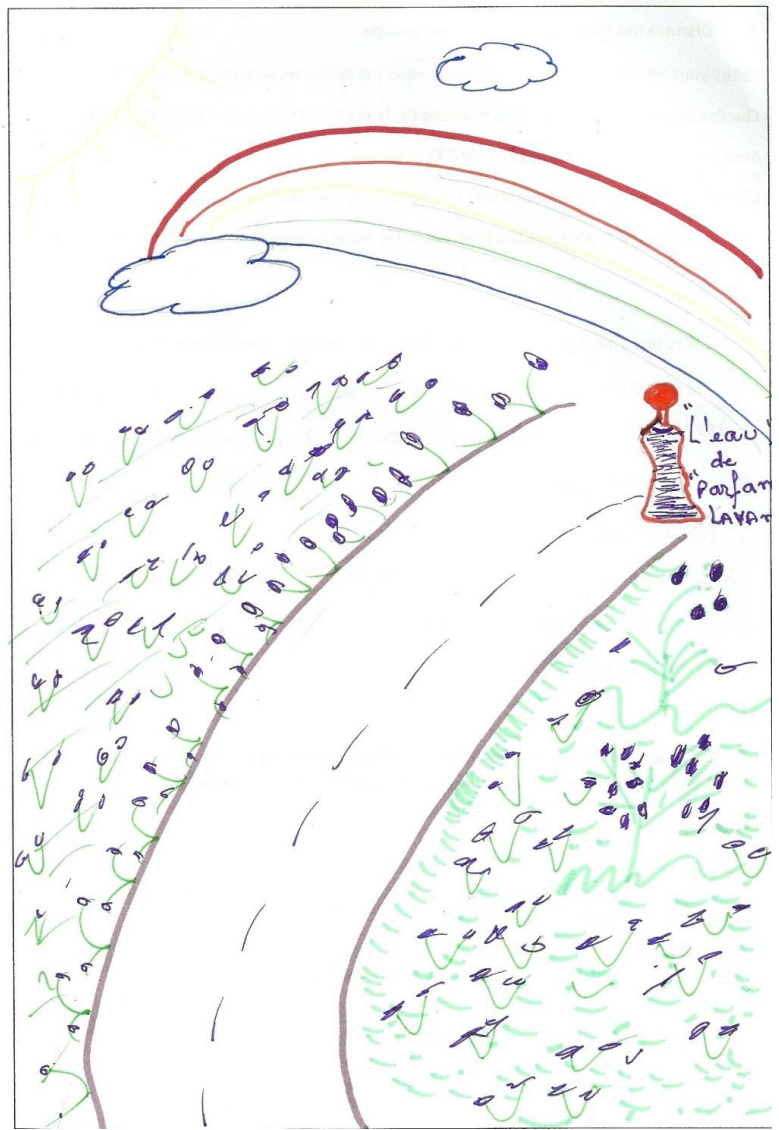

Rosa e Emília - Produção Final

d'écriture em FLE: découvrir la publicité - FFLCH/US

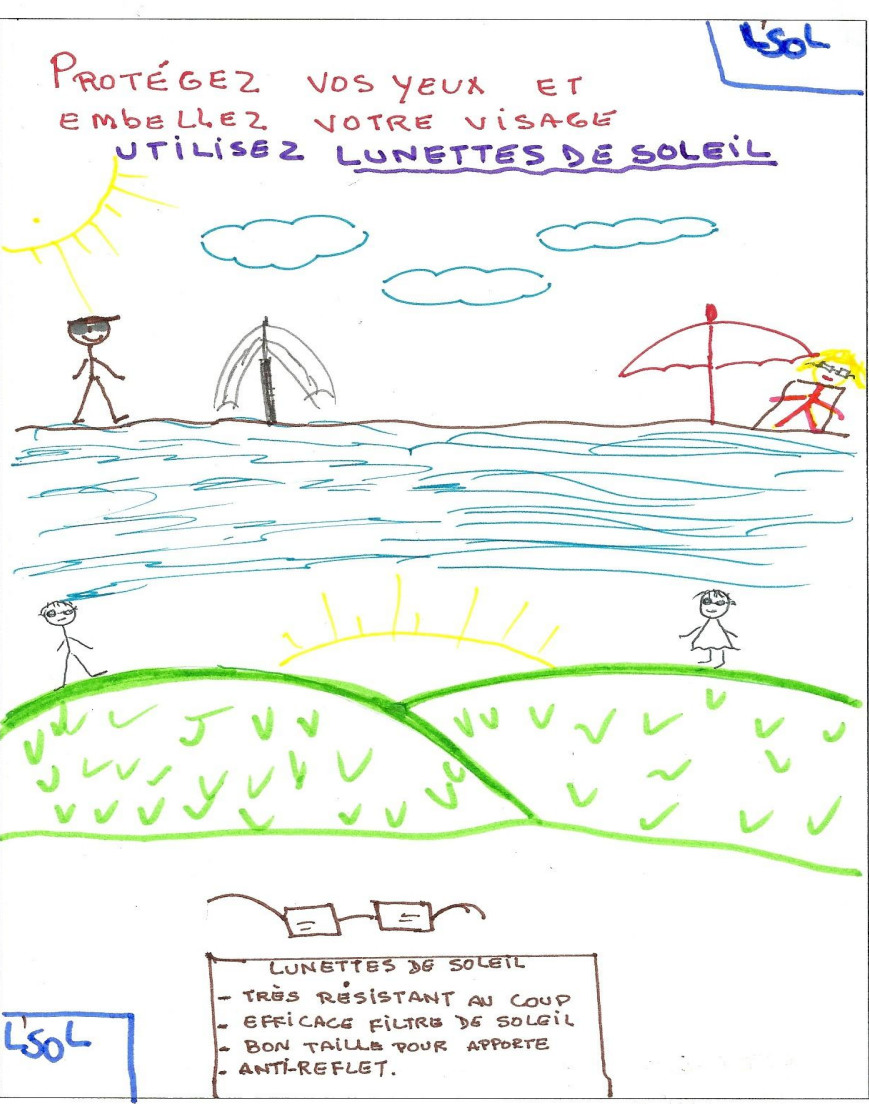


Ateliers d'écriture em FLE: découvvir la publicité $\mathrm{FFLCH/USP}$

Priscila Aguiar Melä́ 2012

Action 1 : la pub

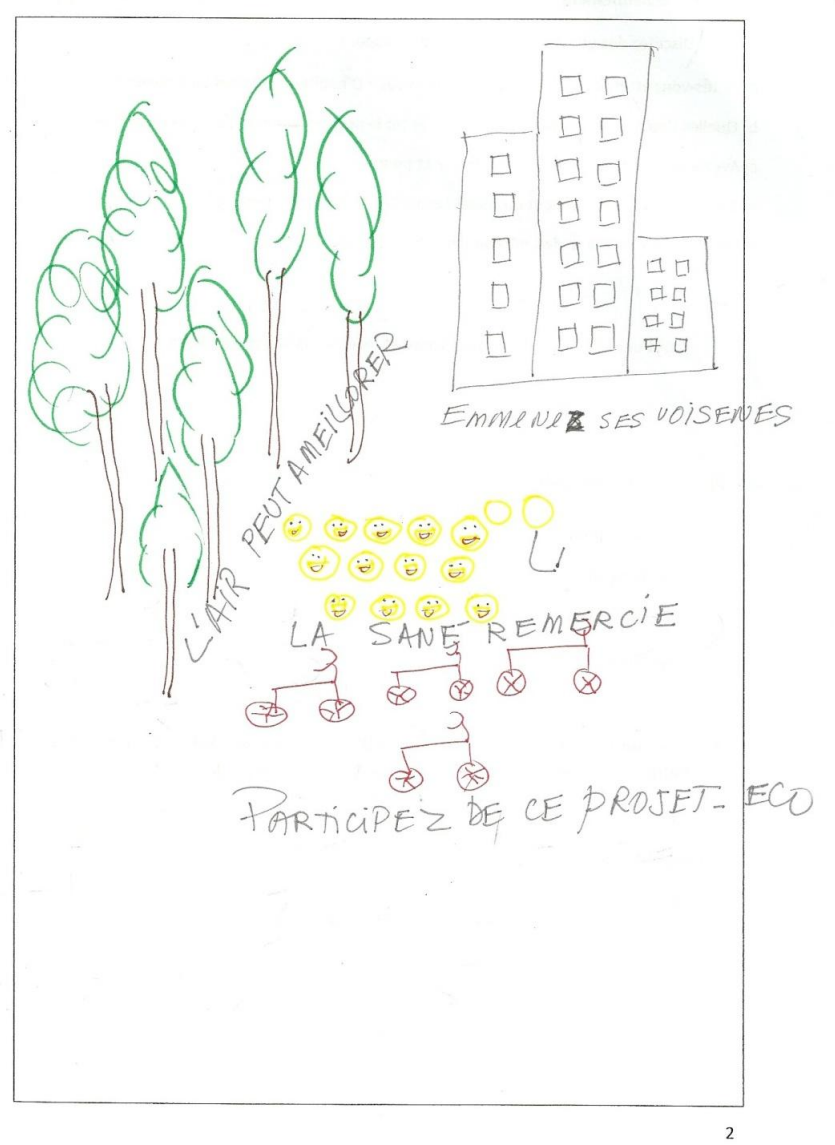

Priscila Aguiar Meláo 2012

Action 2 : la pub

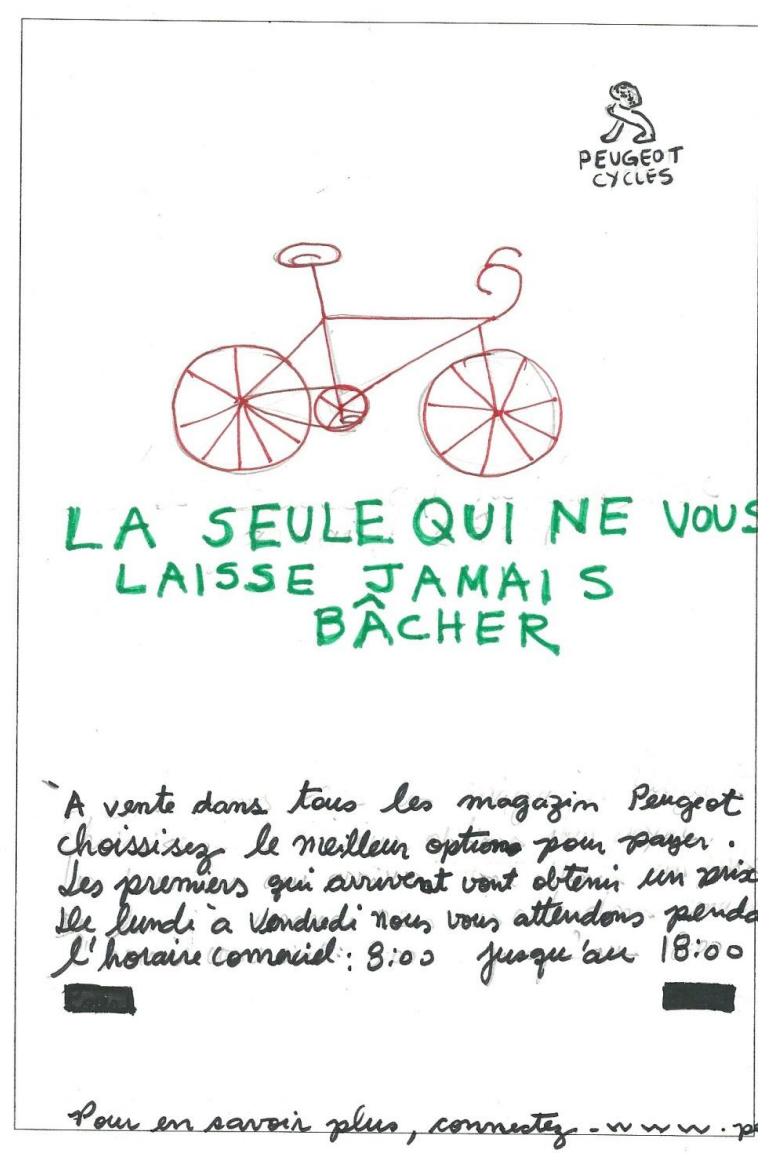


Action 1 : la pub

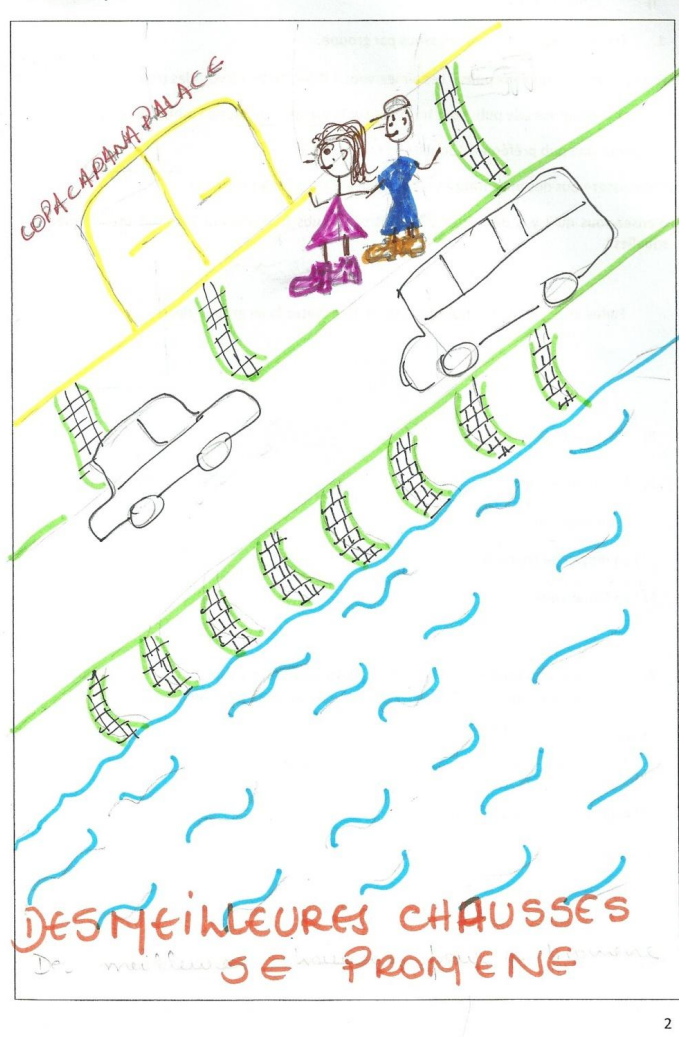

d'écriture em FLE: découvrir la publicité - FFLCH/USP tguiar Melāo

Action 2 : la pub

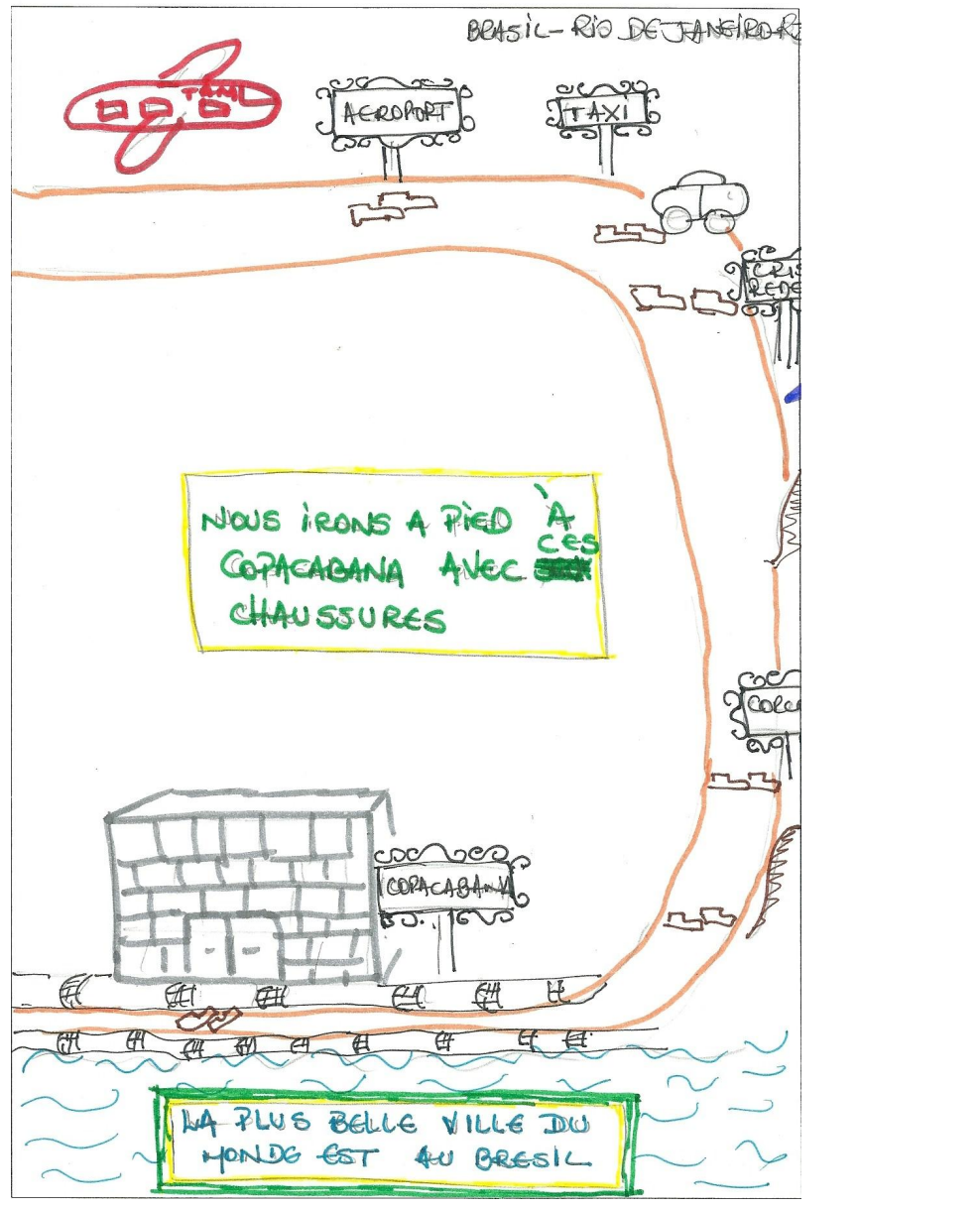




\section{Capacidades de Ação}

Nesta seção, analisaremos, o desenvolvimento das capacidades de ação dos alunos com base no quadro-síntese proposto no capítulo de metodologia (capítulo II). Portanto, serão analisadas as representações do contexto de produção no plano verbal e não verbal das produções inicial e final.

Como já explicamos, as produções foram feitas em duplas, ou seja, temos sete produções iniciais e sete produções finais para esta análise. Dos sete grupos, observamos algum desenvolvimento na produção em seis grupos e nenhum desenvolvimento em apenas um deles. Podemos considerar que cinco duplas tiveram desenvolvimento parcial e uma dupla com grande desenvolvimento no que se refere ao contexto de produção: enunciador, destinatário e objetivos.

Os elementos do contexto de produção são importantes para o desenvolvimento da capacidade de argumentação dos alunos. Se considerarmos que o efeito argumentativo permeia as três capacidades, é necessário iniciar a análise pelo contexto de produção.

Ao analisarmos o plano verbal dos anúncios produzidos, observamos que seis duplas conseguiram se posicionar através de um produto e também direcionar o seu texto a um público, com o objetivo de persuadir o seu leitor. Por exemplo, a produção inicial das alunas Celeste e Diná já tinha os elementos necessários das representações do contexto de produção, ou seja, tinha como enunciador uma marca de bicicleta ecológica (vélo écolo) e vélo écolo também era o nome da marca. Como destinatário, encontramos todos os leitores que possuem carro, pois o slogan nos dá a ordem de largar nosso carro por um mês e o objetivo desse anúncio era fazer bem à natureza e ao leitor. No entanto, podemos considerar que houve algum desenvolvimento na produção final de Celeste e Diná, visto que as alunas atribuíram a marca Caloi à bicicleta ecológica e a colocaram como um produto destinado ao público da cidade grande, não só aos leitores que possuem carro, como podemos identificar no slogan: Pour faire le ménage aux embouteillages (para "limpar" o trânsito). Portanto, o enunciador, o destinatário e o objetivo de venda da bicicleta encontrados no anúncio da produção final são mais claros.

Nas produções de Flora e de Nancy, observamos um grande desenvolvimento quanto ao destinatário e ao objetivo do anúncio publicitário. Na produção inicial de 
Flora e de Nancy, observamos que existe um enunciador (Hyundai), mas não encontramos um destinatário, pois não há nenhuma marca de voz e o discurso é meramente expositivo. Dessa maneira, o objetivo do anúncio é mostrar um carro da Hyundai, sem a interpelação do leitor. Porém, na produção final, Flora e Nancy criaram o anúncio publicitário com o mesmo enunciador e, através do verbo "aproveitar", observamos que o anúncio é destinado aos leitores que gostam de aproveitar a vida ou o carro (profitez-en). Nesse caso o plano não verbal é importante para a compreensão do destinatário, pois podemos ver através do ângulo alto que o carro está em movimento e em meio a natureza. Com isso, como explicamos no capítulo I no que diz respeito aos ângulos de uma imagem, o ângulo alto pode significar o "olhar de Deus", apresentando, portanto, nessa produção o carro perfeito para o destinatário. Além disso, os riscos ou os rabiscos que representam o vento na imagem, mostram-nos um carro veloz, enquanto que o plano de fundo transmite a ideia de que esse carro é apropriado para viajar, ou seja, para sair da cidade, pois o observamos na estrada e em meio à natureza.

Nas produções de Júlia e Janine observamos um grande desenvolvimento quanto à representação do enunciador, pois ele não aparecia na produção inicial. $\mathrm{O}$ anúncio criado na produção inicial parecia ser um anúncio governamental, mas não era possível identificá-lo; já na produção final, as alunas criaram um logotipo para a marca Monarcke de bicicletas. Além da marca, as alunas criaram um slogan que identifica o destinatário: em "Monarcke, les velos malins!" (Monarcke, as bicicletas espertas!) identificamos um destinatário jovem, portanto, ágil e esperto.

O mesmo aconteceu nas produções de Rosa e Emília e nas produções de Valéria e Marta, ou seja, as alunas determinaram melhor o enunciador na produção final e propuseram uma melhor identificação do destinatário e do objetivo do anúncio. $\mathrm{Na}$ produção inicial de Rosa e Emília, observamos um perfume, mas não sabemos a marca, portanto, não sabemos quem é o enunciador. Da mesma forma, na produção inicial de Valéria e Marta, não podemos identificar o enunciador de um projeto ecológico.

Nas produções finais, Rosa e Emília solicitaram permissão para modificar o produto, pois não queriam repeti-lo. Elas escolheram uma marca de óculos que foi inventada e um destinatário vaidoso para a criação do anúncio, pois no slogan, as alunas se referem ao embelezamento do rosto ao utilizar os óculos de sol. Valéria e Marta mantiveram o produto, ou seja, a bicicleta, mas a proposta dos anúncios foi mudada. No primeiro anúncio encontramos um projeto de vida ecológico e, no segundo anúncio, as 
alunas escolheram a bicicleta como objeto de venda, da marca Peugeot, como haviam visto em um dos módulos do curso.

Podemos inferir que Valéria e Marta se basearam em elementos do intertexto, pois utilizam o verbo "bâcher" (que significa cair) do dialeto ciclista, assim como foi apresentado em um dos módulos da nossa sequência didática. Além disso, as alunas organizaram os elementos do anúncio publicitário bem como observaram em um dos módulos da sequência didática, no qual trabalhamos $\mathrm{o}$ mesmo produto (bicicleta).Também podemos dizer que houve recurso ao intertexto no que diz respeito ao conhecimento de mundo (marca Peugeot) das alunas, pois elas apresentaram o logotipo da marca, modificando, portanto, o enunciador do anúncio publicitário. Reveremos esse aspecto nas análises da próxima seção.

As produções da Rosa e da Emília foram as de maior desenvolvimento, no geral, pois não havia texto escrito na produção inicial e, portanto, não havia direcionamento para um destinatário imaginado por elas. Em outras palavras, o texto era apenas um desenho e não realmente um anúncio de um produto, imaginado por um enunciador que quer persuadir seu destinatário a adquiri-lo.

Entretanto, analisando as produções de Carlos e Maria, vemos que as operações de linguagem esperadas para mobilizar representações sobre o contexto de produção não foram desenvolvidas. Apesar das orientações e dos esclarecimentos quanto à produção inicial, os alunos não os seguiram e explicaram que queriam fazer uma publicidade televisiva. Para a produção final, orientei-os sobre a criação do anúncio publicitário e sobre a diferença do gênero se comparado à publicidade televisiva. Apesar de não conseguirem desenvolver as capacidades de ação, conseguiram desenvolver as outras capacidades se observarmos o plano verbal e o intertexto do plano não verbal que serão apresentados nas seções a seguir. Ambas produções deixam subentendida a marca de sapatos que produz o anúncio, assim como a quem ele é destinado. Percebemos, como único elemento, que o destinatário está no Rio de Janeiro.

No plano não verbal, com a exceção das produções de Carlos e Maria, observamos que existe um desenvolvimento das capacidades de ação dos alunos, pois o logotipo, apresentado nas diferentes produções finais, refere-se a um enunciador, uma marca real ou fictícia. Além disso, podemos inferir que a representação das imagens em cores e fundos apresenta um efeito argumentativo maior. Por exemplo, ao visualizarmos a produção final de Flora e Nancy, não encontramos o carro num plano de fundo vazio, 
mas em uma estrada arborizada, em que ele parece adquirir velocidade. Esses elementos visuais aprimoram o tipo de destinatário para quem foi criado o anúncio publicitário.

Na produção final de Celeste e Diná, a bicicleta é real, ou seja, não é o brinquedo apresentado na produção inicial. Além disso, a bicicleta sai do meio das árvores, como visualizamos na produção inicial, ao passo que, na produção final, encontra-se entre as árvores e os carros. Na produção final, o jogo de imagens (árvores e carros) é referente à bicicleta que é feita com recursos naturais para ser utilizada na cidade. Essa imagem da produção final contribui para determinar o destinatário e o objetivo do produto, pois o leitor que se interessará não será o ciclista competidor, visto que o objeto não aparece entre montanhas ou em uma pista de competição. O interesse aparecerá no cidadão que não quer estar em um congestionamento ou dentro de um carro, como podemos observar na imagem. Logo, o objetivo de persuadir um leitor a comprar uma bicicleta Caloi para sair do congestionamento fica mais claro na produção final.

No caso de Eugênia e Bernardo, apesar do plano não verbal ser bem estruturado em ambas produções, somente na produção final o objetivo aparece de forma real. Podemos compreender isso, pois, na produção inicial, o anúncio do filme o disponibiliza em qualquer data no cinema Cinemark, enquanto que, na produção final, a dupla esclarece o objetivo da estreia do filme no dia 13 de junho, assim como o destinatário que só pode assistir às sessões das $15 \mathrm{~h}$, das $17 \mathrm{~h} 30$ e das 19 h de quinta a domingo.

Essas análises podem ser visualizadas e esclarecidas no quadro a seguir, no qual apresentamos a síntese das operações de linguagem que cada dupla conseguiu realizar nos textos. Lembramos que a cor preta é referente ao desenvolvimento de uma operação não existente na produção inicial e a cor branca é referente ao não desenvolvimento, ou seja, tanto na produção inicial, quanto na produção final, a capacidade não foi desenvolvida. A cor cinza escuro indica desenvolvimento parcial na produção final e a cor cinza claro indica capacidade já desenvolvida na produção inicial. 
Quadro 19: Quadro de análise das capacidades de linguagem - capacidade de ação

\begin{tabular}{|c|c|c|c|c|c|c|c|c|}
\hline $\begin{array}{c}\text { Capacidade } \\
\text { s de } \\
\text { linguagem }\end{array}$ & $\begin{array}{l}\text { Operações de } \\
\text { linguagem } \\
\text { esperadas na } \\
\text { produção do } \\
\text { gênero textual } \\
\text { "anúncio } \\
\text { publicitário" }\end{array}$ & $\begin{array}{l}\text { Celeste } \\
\text { e Diná }\end{array}$ & $\begin{array}{l}\text { Flora e } \\
\text { Nancy }\end{array}$ & $\begin{array}{l}\text { Júlia e } \\
\text { Janine }\end{array}$ & $\begin{array}{c}\text { Eugênia } \\
\mathrm{e} \\
\text { Bernardo }\end{array}$ & $\begin{array}{l}\text { Carlos } \\
\text { e Maria }\end{array}$ & $\begin{array}{l}\text { Rosa e } \\
\text { Emília }\end{array}$ & $\begin{array}{l}\text { Valéria } \\
\text { e Marta }\end{array}$ \\
\hline \multirow[t]{4}{*}{$\begin{array}{l}\text { Capacidade } \\
\text { de ação }\end{array}$} & \multicolumn{8}{|c|}{$\begin{array}{l}\text { Identificar as características do contexto de produção e de } \\
\text { recepção: }\end{array}$} \\
\hline & - enunciador & & & & & & & \\
\hline & - destinatário & & & & & & & \\
\hline & - objetivos & & & & & & & \\
\hline
\end{tabular}

\section{Capacidades Discursivas}

Nesta seção, apresentaremos as análises das produções textuais dos alunos, observando o desenvolvimento das operações de linguagem esperadas no gênero textual anúncio publicitário, no que se refere às capacidades discursivas, ou seja, analisaremos o desenvolvimento quanto à mobilização do conteúdo temático, dos tipos de discurso, das sequências descritiva e argumentativa, no que diz respeito ao plano verbal. No que diz respeito ao plano não verbal, analisaremos o desenvolvimento na representação narrativa ou conceitual, no contato, da distância social, na atitude e na modalidade.

No plano verbal, observamos que as operações de linguagem melhor desenvolvidas no grupo foram as relacionas à organização do texto em sequências descritivas e argumentativas e a relação das vozes no discurso interativo implicado da ordem do expor. Também observamos que os alunos selecionaram e organizaram melhor o conteúdo temático, com a exceção da produção de Carlos e Maria, que não esclareceram qual era o produto do anúncio publicitário na produção inicial e, na produção final, criaram uma ambiguidade ao colocar, no primeiro texto, o produto a ser vendido "chaussures" (sapatos) e, no segundo texto, "la plus belle vile du monde est au Bresil" (a cidade mais bonita do mundo está no Brasil). Os textos se confundem e, ao observarmos o plano não verbal, identificamos um anúncio publicitário de viagem. Levantamos a hipótese de que se os alunos tivessem desenvolvido a sequência 
descritiva, teriam talvez esclarecido o mal entendido e facilitaria a descoberta do produto do anúncio.

Apesar de os alunos não terem desenvolvido alguns elementos do plano verbal, observamos que Carlos e Maria desenvolveram a sequência argumentativa no que diz respeito ao intertexto, pois organizaram os textos e se basearam no "art nouveau", assim como viram no anúncio publicitário do metrô de Paris. Ou seja, observamos algum desenvolvimento através do recurso ao intertexto, mas não foi suficiente para a compreensão de sua produção textual.

Ainda no plano verbal, observamos um desenvolvimento nas produções de Celeste e Diná e de Eugênia e Bernardo, pois ambos os grupos inseriram, na produção final, trechos em discurso interativo, enquanto nas produções iniciais os textos não marcavam o destinatário e, portanto, não estavam organizados em discurso interativo. Na produção final de Celeste e Diná encontramos verbos no gerúndio, no futuro e um texto descritivo mais longo, o que não encontrávamos na primeira produção, como podemos observar a seguir.

Ils sont fait avec des matériels reutilisés. Les vélos écolo ont des petits prix.

Celeste e Diná - Produção Inicial

En pensant aux ressources naturels, notre vélo est produit par matériels reutilisés, à petits prix. Ce vélo est parfait pour avoir une meilleure manière de vivre dans les grandes villes. Vous serez plus rapide, vous aurez plus de santé et vous ferez de l'économie. Choisissez parmi nos modèles...

Celeste e Diná - Produção final

O uso de tempos verbais variados, em uma sequência descritiva de maior complexidade, a mobilização de conteúdos temáticos mais variados e a enumeração de verbos (vous serez..., vous aurez..., vous ferez...), terminando com uma sequência injuntiva (choisissez...), ambos possibilitados pelo uso de discurso interativo, contribuem para criar um real efeito argumentativo, o que não acontecia na produção inicial.

Na produção final de Eugênia e Bernardo, o desenvolvimento não aconteceu somente no elemento discurso interativo, mas também nas vozes do discurso e na sequência argumentativa. O discurso interativo, que não aparecia na produção inicial, 
permite a inserção da sequência injuntiva que incita o interlocutor a ver o filme. Vemos, também, a inserção de vozes de autoridade, ou seja, dois jornais importantes, Le monde e New York Times, relatam suas impressões diante do filme. A sequência argumentativa se desenvolve também através do recurso ao intertexto, pois um dos módulos do curso trabalhava um anúncio publicitário de filme e, com isso, os alunos, para persuadir os seus leitores, criaram um anúncio melhor argumentado, com vozes importantes, com data de estreia e local. Também colocaram um carimbo "Le Label" com a intenção de persuadir o leitor através de um argumento de autoridade. Com isso, o efeito argumentativo na produção final é sensivelmente mas bem desenvolvido do que na produção inicial.

Nas produções de Flora e Nancy observamos que, na primeira produção, o discurso das alunas não implicava o leitor, portanto, houve um desenvolvimento, pois na produção final, as alunas desenvolveram as capacidades discursivas através do discurso interativo implicado da ordem do expor, quando utilizaram o pronome "vous".

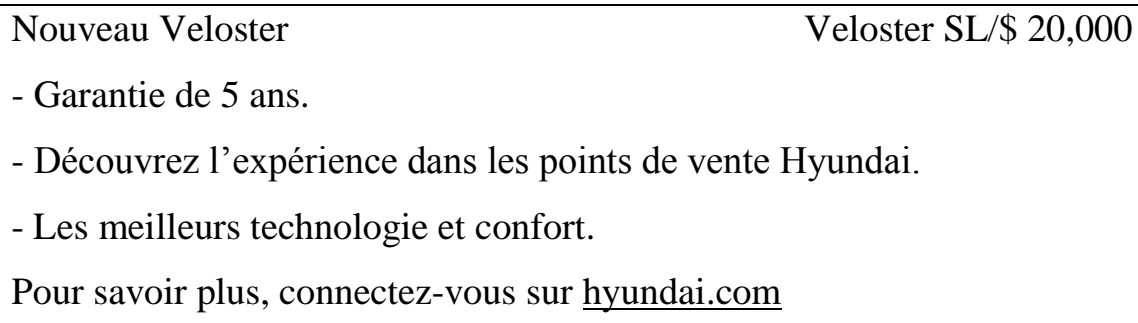

Um elemento, que as alunas poderiam ter desenvolvido melhor, é o detalhamento do texto descritivo, pois elas poderiam ter apresentado a potência e o consumo de combustível do carro, por exemplo. De qualquer forma, o efeito argumentativo da produção final é mais intenso do que na produção inicial, devido ao recurso ao discurso interativo, implicando o leitor e à escolha de conteúdos temáticos mais variados, enumerando qualidades do carro.

Outra dupla que apresentou desenvolvimento quanto ao tipo de discurso, a sequência descritiva e, também, a sequência argumentativa foi a de Rosa e Emília que, na produção inicial, tinham criado um anúncio apenas no plano não verbal. Apesar de terem trocado o conteúdo temático, que era o perfume, na produção inicial, para óculos de sol, na produção final, as alunas organizaram o anúncio, no qual pudemos encontrar uma voz, através de "vous", em uma sequência descritiva que descreve o produto como 
resistente, eficaz, de tamanho adequado e com lente antirreflexo. Além disso, encontramos o efeito argumentativo no slogan que remete os óculos às pessoas que querem proteger os olhos e embelezar o rosto. Portanto, o argumento utilizado para persuadir o leitor não é apenas a proteção aos olhos, mas a capacidade do produto em embelezar.

Nas produções de Valéria e Marta, destacamos a sequência descritiva, pois na produção inicial elas colocaram, de forma desorganizada, quatro slogans ("l'air peut ameillorer, emmenez ses voisenes, la santé remercie, participez de ce projet eco"), enquanto que na produção final, as alunas reorganizaram o anúncio, criaram um único slogan com base no recurso ao intertexto. Na verdade, as alunas utilizaram o dialeto dos ciclistas, visto em um dos módulos do curso e também a frase feita para orientar o leitor em sua pesquisa: "pour en savoir plus". A dupla também desenvolveu um texto descritivo que não existia na produção inicial, para orientar o leitor em sua compra, como podemos ver a seguir.

À vente dans tous les magazins Peugeot. Choisissez le meilleur option pour payer. Les premiers que arrivent, vont obtenir un prix. De lundi à vendredi nous vous attendons pendant l'horaire comerciel: 8:00 jusqu'au 18:00. Pour ne savoir plus, connecte-vous: www.peugeot.com

Valéria e Marta - Produução final

Com esses recursos, as alunas ampliam o efeito argumentativo produzido por seu anúncio na produção final. Na verdade, podemos dizer que a maior parte dos alunos conseguiu ampliar o efeito argumentativo em sua produção final.

No plano não verbal, observamos um desenvolvimento na maioria dos elementos esperados em um anúncio publicitário. $\mathrm{O}$ elemento que teve maior desenvolvimento foi a modalidade, ou seja, o uso das cores, o brilho e o foco do produto do anúncio, pois algumas duplas não capricharam nas cores da produção inicial, como, por exemplo, a produção de Flora e Nancy, que foi feita a lápis. Lembramos que as canetinhas foram disponibilizadas após a realização do curso piloto, pois sentimos a necessidade de os alunos pintarem a imagem para criar uma representação do real. $\mathrm{O}$ objetivo de alcançar uma imagem mais próxima do real aprimora o efeito argumentativo do anúncio e o objetivo de persuadir o leitor. 
Ao analisarmos a modalidade nas produções de Flora e Nancy, observamos que, na produção inicial, o carro aparecia em um fundo branco e em ângulo lateral, criando, dessa forma, um distanciamento com o leitor que, apesar da saliência do carro em destaque, só poderia se aproximar do leitor caso existisse um participante em representação narrativa que pudesse implicar o leitor com um gesto ou com um vetor olhar. Além disso, o anúncio publicitário sem a modalidade das cores e do foco, também não implica o leitor e gera um distanciamento do que é real. Já na produção final, as alunas representaram a realidade, com uma imagem de uma estrada arborizada, com o céu azul e o carro em movimento. Isso mostra que a produção final teve uma interação com o leitor através do ângulo oblíquo do carro que indica um maior envolvimento, assim como o ângulo alto que apresenta um objeto perfeito. Além disso, a modalidade das cores e a saliência conseguem se aproximar da realidade e envolver o leitor na cena.

Outras produções finais nas quais encontramos algum desenvolvimento da modalidade no plano não verbal foram a de Carlos e Maria, pois, diferentemente da produção inicial, a dupla colocou o objeto sapato em diversos locais do anúncio, que recebeu um melhor enfoque.

Valéria e Marta também desenvolveram o anúncio no plano não verbal, pois, na produção inicial, não havia boa organização, pois os elementos da imagem apareciam separadamente: um bloco de árvores, um bloco de prédios, um grupo de pessoas e algumas bicicletas vazias, ou seja, havia uma tentativa de plano geral, que apresenta o ambiente todo, mas os elementos apareciam amontoados, diferentemente da realidade. Mas, na produção final, apesar de não haver um fundo, as alunas que, provavelmente, se basearam em um dos módulos do curso, apresentaram uma bicicleta em primeiro plano, no ângulo horizontal e criaram um desenho para o logotipo da marca. O ângulo horizontal torna-se o melhor ângulo para o objeto bicicleta, pois nele o leitor consegue observar os aros das rodas, a espessura dos canos e o estilo da bicicleta.

Ainda no plano não verbal das capacidades discursivas, destacamos a produção final de Flora e Nancy, no se que refere à atitude, pois no que diz respeito à perspectiva, sua produção final apresentou desenvolvimento, já que o carro aparece através de um ângulo alto, como se fosse visto por um olhar superior (por exemplo, o olhar de Deus) que indicasse aquele carro como o carro "perfeito" ou "único". Além disso, na mesma produção, o uso do ângulo oblíquo também é proposital, assim como observamos com o ângulo horizontal da bicicleta de Valéria e Marta, já que, na maioria dos anúncios 
publicitários de carro, o ângulo é oblíquo para mostrar ao destinatário a lateral e a frente do veículo.

Ainda nas capacidades discursivas, observamos que o item "contato", ou seja, a escolha por um anúncio de interpelação ou de exposição, apesar de já aparecer um pouco nas produções iniciais, desenvolveu-se em cinco duplas: Flora e Nancy, como explicamos anteriormente; Eugênia e Bernardo, que desenvolveram o contato por interpelação; Carlos e Maria, pois a exposição do objeto ficou, de certa forma, mais evidente; Rosa e Emília, que organizaram os planos principais para a exposição dos objetos; e Valéria e Marta, que deixam em evidência qual é o objeto principal do anúncio publicitário.

Vale retomar o desenvolvimento das capacidades de linguagem de Eugênia e Bernardo, pois foram os únicos que representaram os anúncios de forma vetorial e através do contato de interpelação. O contato por exposição é mais simples, pois implica que se escolha um plano para o objeto e o crie de forma real. Mas, o contato por interpelação cria vetores através dos olhares dos participantes do anúncio publicitário e é através deles que conseguimos encontrar uma narrativa na imagem. A produção final abaixo ilustra esse aspecto do contato por interpelação.

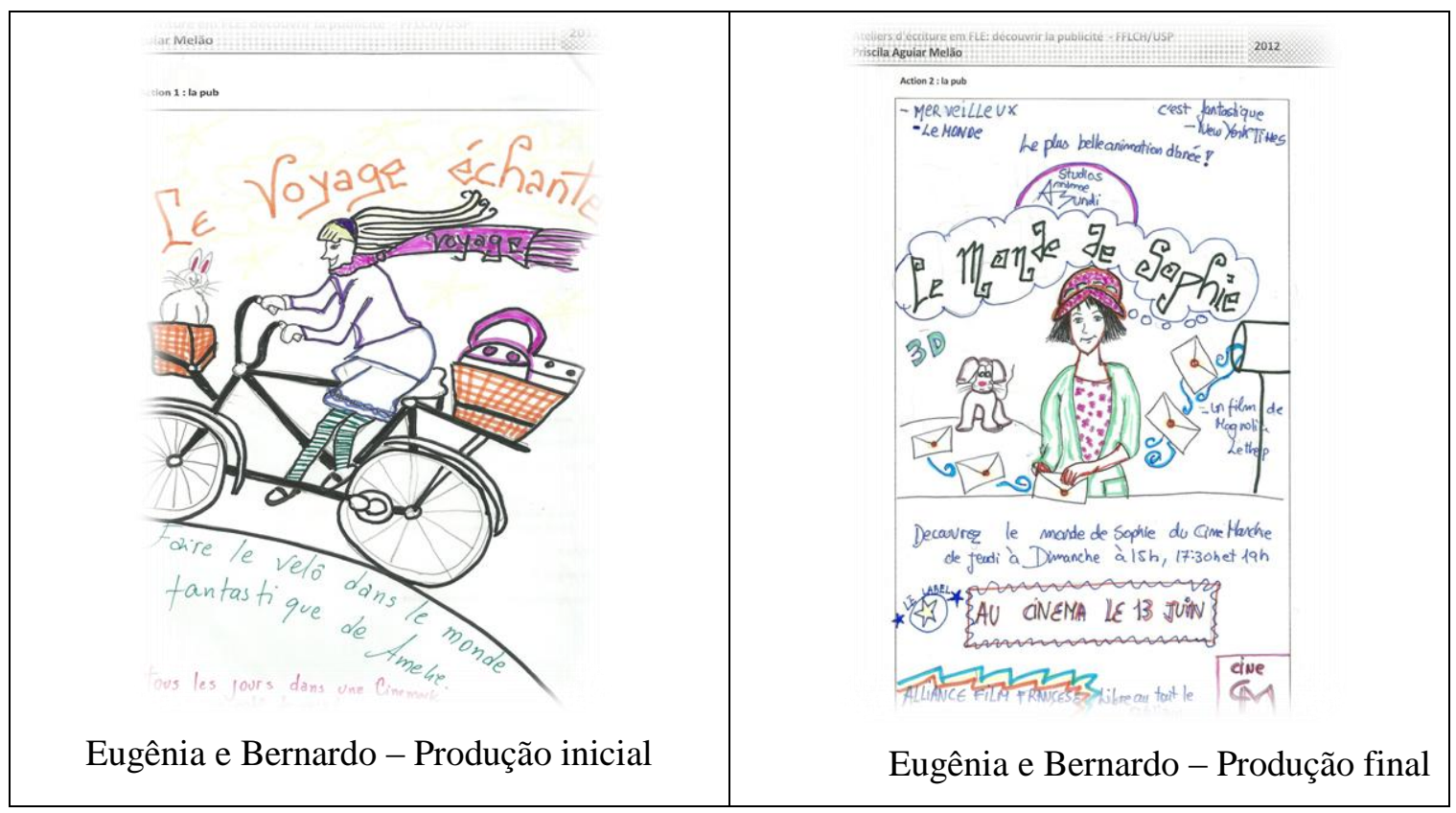

No caso de Eugênia e Bernardo, é interessante observar que, na produção inicial do anúncio publicitário de filme, existe o olhar da menina de bicicleta para o coelho e o olhar do coelho para nós, leitores. Através dos vetores do olhar, podemos imaginar que 
o personagem principal do filme é o coelho. Entretanto, através do texto verbal, descobrimos que se trata de uma viagem no mundo de Amélie. O contato não é expositor, pois o coelho nos chama para a cena e recebe dois olhares: do leitor e da Amélie. Mas, ao analisarmos a produção final, também encontramos um contato de interpelação e uma representação vetorial, ou seja, em primeiro plano, observamos Sophie, personagem principal do filme, que nos olha. Após observarmos a Sophie, encontramos uma carta em sua mão, a carta parece estar em movimento, assim como a dupla viu em um dos módulos sobre a conexão dos elementos da imagem. O movimento das cartas acaba nas patas de um cachorro. Portanto, através do contato, conseguimos identificar a personagem principal e o personagem secundário, além de um elemento que movimenta o filme: as cartas.

Nesse sentido, podemos dizer que a produção final da maioria dos alunos criou um efeito de sentido mais persuasivo, mostrando que se apropriaram em parte das estratégias no plano não verbal para argumentar.

As análises que apresentamos podem ser observadas no quadro a seguir, no qual apresentamos a síntese das operações de linguagem mobilizadas no âmbito das capacidades discursivas necessárias para o desenvolvimento do gênero textual anúncio publicitário. A legenda é a mesma que usamos anteriormente.

Quadro 20: quadro de análise das capacidades de linguagem - capacidade discursiva

\begin{tabular}{|c|c|c|c|c|c|c|c|c|}
\hline $\begin{array}{l}\text { Capacidades } \\
\text { de linguagem }\end{array}$ & $\begin{array}{c}\text { Operações de } \\
\text { linguagem } \\
\text { esperadas na } \\
\text { produção do } \\
\text { gênero textual } \\
\text { “anúncio } \\
\text { publicitário" }\end{array}$ & $\begin{array}{c}\text { Carolina } \\
\text { e Diná }\end{array}$ & $\begin{array}{l}\text { Flora e } \\
\text { Nancy }\end{array}$ & $\begin{array}{l}\text { Júlia e } \\
\text { Janine }\end{array}$ & $\begin{array}{l}\text { Eugênia e } \\
\text { Bernardo }\end{array}$ & $\begin{array}{c}\text { Carlos } \\
\text { e } \\
\text { Maria }\end{array}$ & $\begin{array}{l}\text { Rosa e } \\
\text { Emília }\end{array}$ & $\begin{array}{c}\text { Valéria e } \\
\text { Marta }\end{array}$ \\
\hline \multirow{3}{*}{$\begin{array}{c}\text { Capacidades } \\
\text { discursivas }\end{array}$} & \multicolumn{8}{|c|}{ Organizar os conteúdos temáticos representacionais e interacionais verbal } \\
\hline & $\begin{array}{l}\text { Conteúdo } \\
\text { temático }\end{array}$ & & & & & & & \\
\hline & $\begin{array}{l}\text { Discurso } \\
\text { interativo } \\
\text { implicado da } \\
\text { ordem do expor }\end{array}$ & & & & & & & \\
\hline
\end{tabular}




\begin{tabular}{|l|l|l|l|l|}
\hline $\begin{array}{l}\text { Relato interativo } \\
\text { implicado da } \\
\text { ordem do narrar }\end{array}$ & & & & \\
\hline $\begin{array}{l}\text { Sequência } \\
\text { descritiva }\end{array}$ & & & & \\
\hline $\begin{array}{l}\text { Sequência } \\
\text { argumentativa }\end{array}$
\end{tabular}

\section{Capacidades linguístico-discursivas}

Nesta seção, analisaremos, o desenvolvimento das capacidades linguísticodiscursivas dos alunos, com base no quadro-síntese proposto no capítulo de metodologia (capítulo II). Portanto, da mesma forma que analisamos as capacidades de ação e as capacidades discursivas, analisaremos as produções textuais do gênero textual anúncio publicitário no plano verbal e no plano não verbal. No plano verbal, analisaremos os mecanismos de textualização (conexão, coesão nominal, coesão

\footnotetext{
${ }^{39}$ Consideramos a realização da sequência argumentativa mesmo que ela não seja prototípica e ocorra por recurso ao intertexto ou outro mecanismo.
} 
verbal), os mecanismos enunciativos (vozes e modalizações deônticas e apreciativas). No plano não verbal, analisaremos o valor da informação (organização dos elementos da imagem), a saliência (tamanho e foco) e o emolduramento (mínima conexão ou máxima desconexão dos elementos da imagem).

Se observarmos o quadro-síntese dos elementos das capacidades de linguísticodiscursivas, no final desta seção, veremos que muitas duplas desenvolveram grande parte das operações de linguagem esperadas para o gênero. Mesmo quando já existiam alguns elementos característicos dos anúncios publicitários, na produção inicial, houve um desenvolvimento na produção final. De qualquer forma, parece-nos importante salientar que os problemas apresentados na produção inicial, quanto aos aspectos linguísticos, foram objeto de discussão em sala de aula, no segundo dia do curso. Nossa intenção era apontar alguns problemas, mas sem fazê-lo de forma exaustiva, para que pudessem beneficiar das atividades da SD para melhorar suas produções.

Portanto, analisaremos a seguir o plano verbal e não verbal das capacidades linguístico-discursivas e o seu desenvolvimento após três módulos de sequência didática.

No plano verbal, ao analisarmos os conectores que fazem parte dos mecanismos de textualização, percebemos que poucas duplas apresentaram um desenvolvimento e, com aumento dos trechos com sequências descritivas, poucos conectores ficaram evidentes. No entanto, segundo o MD que apresentamos, esse gênero textual não possui muitos conectores, pois tem textos fragmentados: slogan e texto descritivo. Das sete duplas, observamos um desenvolvimento em três, ou seja, encontramos conectores pertinentes ao gênero textual nas produções finais, por exemplo: “les vélos Monarcke sont revenus! Maintenant, ils sont propres pour la vie moderne" (Júlia e Janine), "protégez vos yeux et embellez votre visage" "(Rosa e Emília), "les premiers qui...jusqu’à $18: 00$ ” (Valéria e Marta).

Com relação aos mecanismos de coesão nominal, todas as duplas apresentaram desenvolvimento, ou seja, encontramos nas produções finais muitos adjetivos e anáforas que pouco apareceram nas produções iniciais como, por exemplo, "merveilleux, fantastique, la plus belle animation" (Eugênia e Bernardo), "léger, pliable, portable, résistant, propres, moderne, malin" (Júlia e Janine), "très résistant, efficace, anti-reflet" (Rosa e Emília), "la seule" (Valéria e Marília), "la plus belle ville" (Carlos e Maria) . Os adjetivos são elementos argumentativos importantes para a valorização do produto em um anúncio publicitário. Nas produções da Celeste e da Diná, como podemos ver a 
seguir, encontramos diferentes adjetivos e anáforas no texto descritivo de base do anúncio publicitário:

Ils sont fait avec des matériels reutilisés. Les vélos écolos ont des petits prix.

Celeste e Diná - Produção inicial

En pensant aux ressources naturels, notre vélo est produit par matériels reutilisés, à petits prix. Ce vélo est parfait pour avoir une meilleure manière de vivre dans les grandes villes. Vous serez plus rapide, vous aurez plus de santé et vous ferez de l'économie. Choisissez parmi nos modèles dans le point de vente Caloi et les grands magasins de sports autorisés.

Celeste e Diná - Produção final

Ao analisarmos os mecanismos de coesão verbal, observamos que, nas produções iniciais, a maioria das duplas utilizou verbos no presente do indicativo e no modo imperativo, enquanto que duas duplas não utilizaram verbos. Dessa maneira, é possível observar um desenvolvimento, pois, nas produções finais, encontramos verbos no indicativo (passado, futuro simples, futuro próximo, presente), no gerúndio, além dos verbos e no modo imperativo.

Ressaltamos que, em muitos livros didáticos de francês como língua estrangeira, o modo imperativo é associado aos anúncios publicitários de forma equivocada, pois aparece como único recurso linguístico causador de um efeito argumentativo. Isso justifica o seu uso na maioria das produções iniciais dos alunos. $\mathrm{Na}$ verdade, o plano verbal dos anúncios publicitários possui outros modos e tempos verbais, além do imperativo, pois a persuasão não aparece somente nesse modo. As duplas parecem ter compreendido o objetivo dos mecanismos de textualização como instrumento argumentativo, como podemos observar a seguir, na tabela que apresenta os modos e tempos verbais encontrados nas produções iniciais e finais das duplas.

\begin{tabular}{|lr|l|l|}
\hline \multicolumn{1}{|c|}{ Duplas } & \multicolumn{2}{c|}{ Produção inicial } & \multicolumn{1}{c|}{ Produção final } \\
\hline $\begin{array}{l}\text { Celeste e } \\
\text { Diná }\end{array}$ & $\begin{array}{l}\text { Verbos no presente do } \\
\text { indicativo e no modo } \\
\text { imperativo }\end{array}$ & $\begin{array}{l}\text { Verbos no infinitivo, nos modos gerúndio e } \\
\text { imperativo e no tempo presente. }\end{array}$ \\
\hline $\begin{array}{l}\text { Flora } \\
\text { Nancy }\end{array}$ & Não há verbo & Verbos no imperativo e no infinitivo. \\
\hline $\begin{array}{l}\text { Júlia } \\
\text { Janine }\end{array}$ & e & $\begin{array}{l}\text { Verbos no tempo presente e } \\
\text { no modo imperativo. }\end{array}$ & $\begin{array}{l}\text { Verbos no infinitivo, nos tempos presente e } \\
\text { passado. }\end{array}$ \\
\hline
\end{tabular}




\begin{tabular}{|lr|l|l|}
\hline $\begin{array}{l}\text { Eugênia } \\
\text { Bernardo }\end{array}$ & Um único verbo no infinitivo & $\begin{array}{l}\text { Verbos no modo imperativo e no tempo } \\
\text { presente. }\end{array}$ \\
\hline $\begin{array}{l}\text { Carlos e } \\
\text { Maria }\end{array}$ & Verbo no tempo presente. & Verbos no tempo presente e no futuro simples \\
\hline $\begin{array}{l}\text { Rosa } \\
\text { Emília }\end{array}$ & e & Não há verbo & Verbos no modo imperativo e no infinitivo. \\
\hline $\begin{array}{l}\text { Valéria } \\
\text { Marta }\end{array}$ & $\begin{array}{l}\text { Verbos no tempo presente e e } \\
\text { no modo imperativo. }\end{array}$ & $\begin{array}{l}\text { Verbos no infinitivo, nos tempos presente e } \\
\text { futuro próximo. }\end{array}$ \\
\hline
\end{tabular}

Nessa tabela, vemos que os alunos apresentaram um uso mais complexo dos modos e tempos verbais, adaptando-os para o que queriam dizer e contribuindo para criar um efeito argumentativo que persuadisse os leitores.

Nas análises sobre os mecanismos enunciativos, observamos as vozes e as modalizações deônticas, apreciativas e até mesmo lógicas nas produções dos alunos. Como já apontamos no MD, essas são as modalizações mais frequentes no gênero.

No geral, as duplas tiveram um bom desempenho e um avanço, principalmente quanto à inserção de vozes, que estabelecem a coerência pragmática do gênero textual e que contribuem para criar o efeito argumentativo, já que dão legitimidade aos argumentos, quando se trata de uma voz de autoridade. Quanto às modalizações apreciativas, também observamos desenvolvimento, já que os alunos aprenderam a manipular as modalizações apreciativas, utilizando comparações e qualificações e deônticas, empregando verbos no imperativo, também ampliando o efeito argumentativo dos anúncios.

Encontramos, em todas as produções finais, com exceção da produção da dupla Carlos e Maria, a voz do enunciador do produto. Além dessa voz que se mostra como responsável pelo produto, encontramos uma voz de autoridade, utilizando uma palavra em língua estrangeira (by), como no anúncio de Celeste e Diná, em que as alunas utilizam a frase "le vélo écolo by Caloi", baseando-se em modelos disponíveis no intertexto, já que o uso de "by" é frequente em anúncios quando se quer dar uma autenticidade aos produtos. Além disso, vemos o uso da voz de autoridade no anúncio de Eugênia e Bernardo, que mencionam "Le Monde" e "New York Times" que apresentam vozes da crítica que aprovam o filme "Le monde de Sophie", dando credibilidade ao anúncio. A mesma função é cumprida pelo carimbo de "le label" como aprovador do filme. 
Ao analisarmos as modalizações, que podem ser uma categoria de efeito argumentativo para a compreensão das emoções no plano verbal, encontramos, no que diz respeito às modalizações deônticas, o uso do imperativo que atribui valor de obrigação, injunção, de alto valor persuasivo, em cinco duplas: "profitez-en" (Flora e Nancy), com o objetivo de fazer aproveitar do carro; "Choisissez parmi nos modeles" (Celeste e Diná), como conselho para ajudar na escolha da bicicleta Caloi; "Découvrez le monde de Sophie" (Eugênia e Bernardo), que aparece como ordem, para que o leitor descubra o mundo de Sophie assistindo ao filme; "Protégez vos yeux...embellez...utilisez..." (Rosa e Emília), aparecem de modo a ordenar e aconselhar o leitor; "Choisissez le meilleur" (Valéria e Marta), que, assim como fizeram Celeste e Diná, tem o propósito de aconselhar a escolha da bicicleta Peugeot.

Vejamos as modalizações apreciativas, que consistem em julgamentos subjetivos sobre algo ou alguém e que podem aparecer através de verbos de sentimento, advérbios ou adjetivos que acompanham substantivos ou adjetivos com grau comparativo ou superlativo. Nas análises, encontramos o aumento dos adjetivos e adjetivos com grau superlativo absoluto analítico, que são adjetivos acompanhados por outro adjetivo ou advérbio (muito, melhor, por exemplo). Nas produções de Celeste e da Diná, por exemplo, observamos um notável avanço, pois, na produção inicial, as alunas tinham usado um único advérbio "le vélo qui fait bien à la nature et à vous", como argumento para o leitor abandonar o seu carro, e na produção final, as alunas desenvolveram um texto com diversos adjetivos: "Ce vélo est parfait...une meilleure manière de vivre...plus rapide...plus de santé...les grands magasins" (Celeste e Diná), com o objetivo de persuadir o leitor a comprar uma bicicleta "perfeita", para ter uma "melhor" qualidade de vida, para ser "mais rápido" e ter mais saúde.

Júlia e Janine também progrediram no que diz respeito às modalizações, pois, na produção inicial, elas haviam criado um panfleto ou um anúncio publicitário governamental, porém, sem enunciador. O texto descritivo da produção inicial mostra uma explicação do que era o objeto bicicleta e para que servia e faz uso de modalizadores apreciativos em "respirez meilleur". Na produção final, as alunas utilizaram diversos adjetivos, demonstrando um bom uso das modalizações apreciativas e mostrando que o recurso às emoções para persuadir o interlocutor foi bem internalizado pelas alunas. Além disso, observamos um jogo de palavras para persuadir o seu leitor à comprar a bicicleta Monarcke, que foi um objeto clássico dos anos 80 , no Brasil, e que estava de volta, como podemos observar a seguir. 
Les vélos Monarcke sont revenus!

Maintenant, ils sont propres pour la vie moderne.

Monarcke, c'est un produit malin :

-léger

-portable

-pliable

- résistant, en carbon et alu

Monarck permet que vous allez à tous les lieux avec lui.

Pour en savoir plus : $\underline{w w w . m o n a r c k e . c o m}$

Júlia e Janine - Produção final

Identificamos, portanto, o jogo de palavras na frase "ils sont propres pour la vie moderne", pois as bicicletas podem ser apropriadas para a vida moderna ou podem ser limpas para a vida moderna (não poluente). Podemos considerar que o uso do jogo de palavras demonstra o recurso ao intertexto e, dessa forma, a inserção de vozes, pois elas baseiam-se no que conhecem tanto sobre anúncios, quanto sobre frases já prontas em sua LM, para criar um efeito argumentativo no anúncio em francês. Dessa forma, ao criar um jogo de palavras, as alunas demonstram um uso avançado dos recursos da língua estrangeira, pois o apelo às vozes para criar mais de um efeito de sentido é um recurso complexo mesmo em língua materna. Ainda, se observarmos todas as palavras sublinhadas no quadro acima e se observarmos a pontuação, encontraremos um texto melhor argumentado através dos adjetivos e, também, através do vocativo Monarcke, da locução adverbial e das exclamações.

Rosa e Emília também desenvolveram o recurso às modalizações apreciativas, visto que, na produção inicial, não havia texto verbal. Na produção final, elas utilizaram "très résistant", "efficace", "bon taille", "anti-reflet" no texto descritivo dos óculos de sol, ou seja, a dupla apresentou variadas características do objeto com o objetivo de vendê-lo. Como dissemos no Capítulo I, o uso desses adjetivos mostra uma capacidade a mobilizar as emoções do leitor, o que tem grande efeito argumentativo.

Ressaltamos, também, que a organização estrutural da produção final de Valéria e Marta foi desenvolvida, pois, na produção inicial da dupla, havia a modalização lógica com o sentido de possibilidade no anúncio publicitário: “l'air peut améillorer”, ou seja, 
a dupla coloca como possibilidade algo que deveria ser uma certeza. Esse uso não é adequado, pois se o objetivo do anúncio é fazer o leitor entrar em um projeto ecológico e andar de bicicleta, não poderia haver a possibilidade, a afirmação deveria aparecer como certa. No entanto, na produção final, as alunas desenvolveram as modalizações apreciativas, como podemos observar a seguir, através de adjetivo, advérbio, superlativo que geram subentendidos.

La seule que ne vous laisse jamais bâcher.

A vente dans tous les magazins Peugeot. Choisissez le meilleur option pour payer. Les premiers qui arrivent, vont obtenir un prix. De lundi à vendredi nous vous attendons pendant l'horaire comerciel : $8: 00$ jusqu'au $18: 00$

Pour en savoir plus, connectez : $\underline{\text { www.peugeot.com }}$

Valéria e Marta - Produção final

No slogan "la seule que ne vous laisse jamais bâcher" (A única que nunca te deixa cair), as alunas conseguiram adjetivar o objeto, ou seja, através de um jogo de palavras e do vocabulário ciclista estudado em um dos módulos do curso, as alunas apresentaram a bicicleta como um instrumento forte, pois ela é a única que não nos deixa cair. Além disso, encontramos a modalização apreciativa na palavra "prix", ou seja, se o consumidor for rápido e um dos primeiros a chegar nos postos de venda, ele ganhará um prêmio ("les premiers qui arrivent vont obtenir un prix"). Ambos artifícios, o jogo de palavras do slogan e o recebimento de um prêmio possuem grande efeito argumentativo persuasivo diante do seu destinatário.

No plano não verbal, observamos maior desenvolvimento no valor da informação, ou seja, na organização da imagem e dos quadros verbais, consequentemente, houve desenvolvimento da saliência, que corresponde ao tamanho e ao foco da imagem. No entanto, o emolduramento não teve grande desenvolvimento, pois os elementos da imagem podem estar conectados ou desconectados, mas, com base em Kress e Van Leeuwen (2006), um bom produtor do texto não verbal é aquele que consegue, através da desconexão máxima dos elementos, chegar a um significado. 
Todas as duplas organizaram a imagem e, dessa forma, valorizaram a informação. Os anúncios, com a exceção da dupla Carlos e Maria, apresentaram um logotipo no topo ou na base, do lado direito ou esquerdo, o qual não encontrávamos em nenhuma produção inicial. Além do logotipo, todas as produções apresentaram um slogan acima ou abaixo do produto, dependendo de sua importância. Por exemplo, Flora e Nancy, preferiram colocar o slogan abaixo do carro, dando maior importância ou saliência à imagem. O mesmo foi proposto pelas alunas Celeste e Diná, para salientar a bicicleta e por Valéria e Marta, também para salientar o objeto bicicleta.

Todas as duplas reservaram um espaço na base das produções finais para o texto descritivo e a maioria completou o espaço de forma correta. No caso de Eugênia e Bernardo, o texto descritivo é curto por se tratar de um anúncio publicitário de filme. Logo, o texto descritivo é composto pela data, local, patrocinadores e produtores. $\mathrm{Na}$ produção de Carlos e Maria, apesar de terem reservado um espaço para o texto descritivo, não houve o preenchimento correto e o texto verbal confunde o leitor se relacionado ao slogan que aparece ao centro da imagem.

Quanto à característica "emolduramento" dos elementos, proposta pela GVD (KRESS E VAN LEEUWEN, 2006), observamos que não houve um grande desenvolvimento, pois a maioria das produções finais apresentaram alguma conexão entre os elementos da imagem, ou seja, as produções mostram que os alunos construíram imagens mais simples.

A relação de conexão ou desconexão dos elementos de um texto visual pode ser facilmente explicada, pois, se imaginarmos uma imagem na qual encontramos como participantes um jogador e uma bola de futebol, logo constatamos que existe uma conexão de sentido entre os elementos. Mas, se imaginarmos uma imagem na qual encontramos um jogador de futebol e um automóvel, afirmamos que existe uma desconexão dos elementos, visto que o jogador não é um piloto, por isso não se justifica que ele seja representado ao lado de um automóvel.

A produção de Celeste e Diná, por exemplo, possui algum tipo de conexão, pois a bicicleta entre árvores e carros faz o leitor imaginar que esse objeto é próprio para os dois ambientes: campo e cidade. Na produção final de Flora e Nancy, o texto visual também aparece conectado, pois o carro está em uma estrada, o que parece ser de fácil compreensão ao leitor. Eugênia e Bernardo conectam os elementos da imagem de forma mais elaborada, ou seja, se não houvesse linhas que conectassem as cartas à Sophie e ao cachorro, não poderíamos afirmar que as cartas têm como destinatário Sophie. 
Da mesma forma, na produção de Rosa e Emília encontramos conexão, pois os óculos de sol são os produtos anunciados e eles aparecem em contextos de fácil compreensão sobre seu uso, ou seja, a imagem de uma praia e de um campo ensolarado remetem ao uso dos óculos.

No caso das produções finais de Júlia e Janine, Valéria e Marta, que apresentam um único objeto em um plano de fundo vazio, não é possível afirmar a existência de conexão ou desconexão, pois para haver conexão no texto visual, é necessária a representação de mais de um elemento na imagem. Portanto, não podemos afirmar que existe o desenvolvimento quanto à característica "emolduramento" do plano não verbal dessas produções.

Entretanto, se unirmos o texto verbal e o texto visual, podemos também dizer que o emolduramento pode acontecer entre imagem e slogan, ou seja, se o slogan retomar algum elemento da imagem, chamamos de emolduramento de conexão e se o slogan não retomar a imagem, chamamos de desconexão. Quando não há conexão, Kress e Van Leeuwen (2006) consideram que se trata de uma produção mais elaborada.

Valéria e Marta não criaram um fundo para a bicicleta da produção final. Portanto, como objeto único, ele não pode estar conectado ou desconectado a outro elemento. Mas, ao relacionarmos o plano não verbal ao plano verbal, observamos a desconexão, pois o slogan, lido literalmente, não se relaciona à bicicleta. $\mathrm{O}$ verbo "bâcher" que no dialeto ciclista significa cair, literalmente, significa cobrir com uma capa (bâche). Portanto, vemos na produção de Valéria e Marta que o plano verbal e não verbal são elementos desconectados que criam um sentido quando juntos.

Podemos afirmar a mesma relação entre os textos verbal e visual na produção de Flora e Nancy, pois encontramos uma desconexão total entre plano não verbal e plano verbal, pois o slogan "profitez-en”, fora do contexto da imagem, pode se referir a outro objeto.

A produção final de Eugênia e Bernardo apresenta o emolduramento de conexão, mas também apresenta o emolduramento de desconexão entre o plano verbal e não verbal, pois o texto verbal que, é representado pelo nome do filme "Le monde de Sophie" (O mundo de Sophie), pode fazer o leitor remeter ao livro O mundo de Sofia, de Jostein Gaarder, através do recurso ao intertexto.. A dupla relação de conexão e desconexão pode ser explicada da seguinte forma: existe uma conexão através das cartas que visualizamos no texto não verbal e que relacionamos com o que acontece no livro, ao mobilizarmos o recurso ao intertexto. Por outro lado, ao vermos o cachorro, 
encontramos uma relação de desconexão, pois, se conhecemos o livro, sabemos que o animal de estimação da personagem de Jostein Gaarder é um gato e não um cachorro.

Nesse sentido, podemos dizer que a produção final da maioria dos alunos criou um efeito de sentido mais persuasivo, mostrando que se apropriaram, principalmente, no plano verbal, dos mecanismos enunciativos: vozes e modalizações apreciativas, e, no plano não verbal, do valor da informação como estratégias de argumentação.

No quadro a seguir, podemos visualizar as conclusões das análises que mostramos nesta seção, no que diz respeito às capacidades linguístico-discursivas do plano verbal e não verbal.

Quadro 21: quadro de análise das capacidades de linguagem - capacidade linguísticodiscursiva

\begin{tabular}{|c|c|c|c|c|c|c|c|c|}
\hline & $\begin{array}{c}\text { Operações de } \\
\text { linguagem } \\
\text { esperadas na } \\
\text { produção do } \\
\text { gênero textual } \\
\text { "anúncio } \\
\text { publicitário" }\end{array}$ & $\begin{array}{l}\text { Celeste } \\
\text { e Diná }\end{array}$ & $\begin{array}{l}\text { Flora e } \\
\text { Nancy }\end{array}$ & $\begin{array}{l}\text { Júlia e } \\
\text { Janine }\end{array}$ & $\begin{array}{l}\text { Eugênia e } \\
\text { Bernardo }\end{array}$ & $\begin{array}{l}\text { Carlos } \\
\text { e Maria }\end{array}$ & $\begin{array}{l}\text { Rosa e } \\
\text { Emília }\end{array}$ & $\begin{array}{l}\text { Valéria } \\
\text { e } \\
\text { Marta }\end{array}$ \\
\hline \multirow{4}{*}{$\begin{array}{l}\text { Capacidades } \\
\text { linguístico- } \\
\text { discursivas }\end{array}$} & \multicolumn{8}{|c|}{ Organização estrutural do verbal: } \\
\hline & $\begin{array}{l}\text { - mecanismos } \\
\text { de } \\
\text { textualização: } \\
\text { conexão }\end{array}$ & & & & & & & \\
\hline & $\begin{array}{l}\text { - mecanismos } \\
\text { de } \\
\text { textualização: } \\
\text { coesão nominal } \\
\text { (adjetivos } \\
\text { qualificativos, } \\
\text { anáforas do } \\
\text { pronome } \\
\text { pessoal) }\end{array}$ & & & & & & & \\
\hline & $\begin{array}{l}\text { - mecanismos } \\
\text { de } \\
\text { textualização: }\end{array}$ & & & & & & & \\
\hline
\end{tabular}




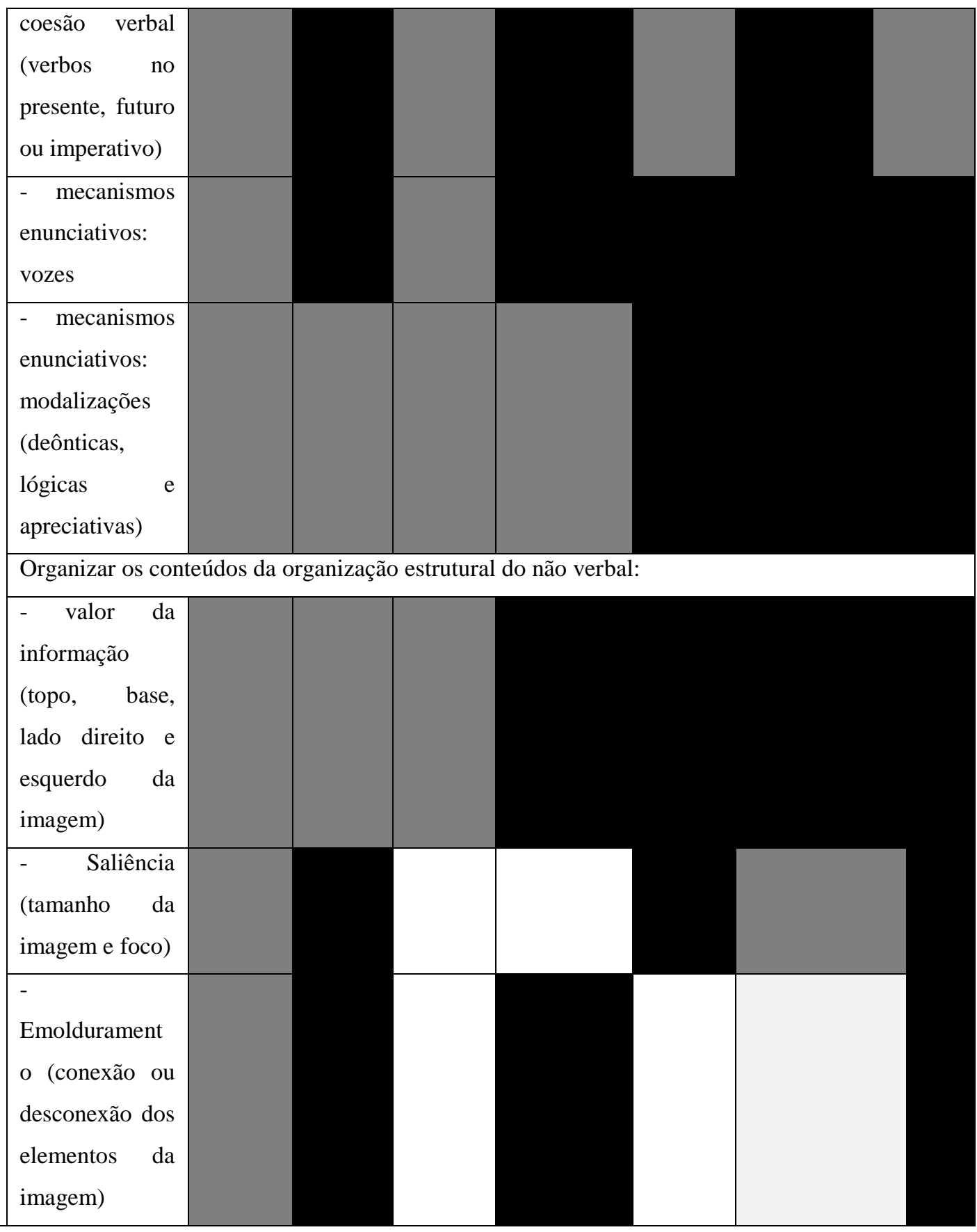

\section{Síntese das análises e o efeito argumentativo das produções}

Nesta seção, faremos uma síntese para facilitar nossa compreensão do desenvolvimento das capacidades de linguagem dos alunos ao produzirem os anúncios publicitários. Para isto, criamos uma categoria geral, que sintetiza vários parâmetros e que diz respeito à capacidade de criar sentidos com a finalidade de persuadir o destinatário a adquirir o produto ou serviço: o efeito argumentativo global do anúncio. 
Essa categoria compreende: o texto visual, o texto verbal com o recurso ao intertexto, a inserção de vozes para reforçar o efeito argumentativo, a presença de modalizações deônticas e apreciativas, enfim, tudo o que confere ao texto uma maior argumentatividade. Trata-se, portanto, de uma síntese que será apresentada em um único quadro, como podemos observar a seguir.

Quadro 22: síntese geral do desenvolvimento da argumentatividade.

\begin{tabular}{|l|c|c|c|c|c|c|c|}
\hline & $\begin{array}{c}\text { Celeste } \\
\text { e Diná }\end{array}$ & $\begin{array}{c}\text { Flora e } \\
\text { Nancy }\end{array}$ & $\begin{array}{c}\text { Júlia e } \\
\text { Janine }\end{array}$ & $\begin{array}{c}\text { Eugênia } \\
\mathrm{e} \\
\text { Bernardo }\end{array}$ & $\begin{array}{c}\text { Carlos e } \\
\text { Maria }\end{array}$ & $\begin{array}{c}\text { Rosa e } \\
\text { Emília }\end{array}$ & $\begin{array}{c}\text { Valéria } \\
\mathrm{e} \\
\text { Marta }\end{array}$ \\
\hline $\begin{array}{l}\text { Efeito } \\
\text { argumentativo } \\
\text { Global }\end{array}$ & & & & & & & \\
\hline
\end{tabular}

Quando pensamos na produção de um anúncio publicitário, tínhamos como objetivo descobrir as características do gênero textual anúncio publicitário que podiam ser ensinadas, elaborar uma sequência didática adequada e, através dela, aprimorar a capacidade de argumentar dos alunos em língua francesa, visto que o gênero textual escolhido tem a persuasão como sua característica principal.

Das sete duplas analisadas nas seções deste capítulo, observamos que as produções iniciais dos grupos Flora e Nancy, Rosa e Emília e Valéria e Marta não tinham alguns elementos necessários para a criação do efeito argumentativo que acabou sendo desenvolvido na produção final. Outras duplas já tinham alguns elementos que produziam efeito argumentativo em sua produção inicial, mas os aprimoraram na produção final, como é o caso das duplas: Celeste e Diná, Júlia e Janine e Eugênia e Bernardo. Somente a dupla de Carlos e da Maria, apesar de recorrerem ao intertexto na produção final, confundiram o tipo de gênero textual e, consequentemente, os elementos das capacidades de ação.

Avançando na reflexão sobre o desenvolvimento dos alunos entre a produção inicial e final, observemos a criação do efeito argumentativo global do grupo de Celeste e Diná. Podemos dizer que, indo desde o logotipo de uma marca conhecida "Caloi", que é reconhecida e, portanto, podemos chamar de voz de autoridade (é a voz de uma das melhores marcas de bicicleta, no Brasil) até o slogan, que recorre ao intertexto (o dialeto ciclista) para persuadir um destinatário que compreenda essa variedade linguística, as 
alunas demonstram grande desenvolvimento no que diz respeito a como criar um efeito argumentativo que persuada o leitor a adquirir o produto. Ao relacionarmos os planos verbal e não verbal, visualizamos uma bicicleta que é potente, pois ela não aparece em uma descida como na produção inicial, mas aparece na subida, o que expressa força. Além disso o objeto aparece entre a natureza e a cidade, deixando para trás os carros da cidade, como expressa o slogan: "Pour faire le ménage aux embouteillages". A certeza de que a bicicleta nos fará mais rápidos, nos dará maior saúde e nos fará economizar, aparece nos verbos do tempo futuro e tem um grande efeito argumentativo, pois traz o uso de uma hipótese de grande probabilidade de realização: se você comprar esta bicicleta da Caloi, com certeza você terá agilidade, dinheiro e saúde. Outro fator persuasivo desenvolvido no plano não verbal é a realidade da imagem, pois na produção inicial a bicicleta aparece como um desenho que possui mensagens nos círculos que representam as rodas. Portanto, uma imagem real, um enunciador real e um texto que faz uso das modalizações e do intertexto têm forte efeito argumentativo.

Na dupla Flora e Nancy, o efeito argumentativo da produção final é grande, se comparado à produção inicial. Na produção inicial, as alunas não usaram cores, o desenho não tinha perspectiva, encontrávamos dois slogans e uma marca. No entanto, a produção final conseguiu responder a algumas das nossas perguntas de pesquisa, pois a sequência didática conseguiu mostrar a importância do ângulo da imagem das cores e do texto verbal que propusesse um slogan desconectado à imagem e, sobretudo, um texto descritivo bem modalizado através de adjetivos. Na produção final, conseguimos visualizar um contexto real, com o vento que mostra a imagem do carro em movimento, o preço do carro, o uso do pronome "en", no slogan, que deixa implícito o tipo de aproveitamento do destinatário.

Nas produções de Júlia e Janine, encontramos um pequeno desenvolvimento do efeito argumentativo no plano não verbal, pois as alunas mantiveram as cores escolhidas na produção inicial e o foco dado ao objeto, mas criaram uma cor para a marca da bicicleta e, desta forma, a marca aparece em destaque pela cor vermelha, e, ainda, colocaram estrelas em volta do logotipo, o que avalia de forma positiva as bicicletas Monarcke. No entanto, no plano verbal, o efeito argumentativo apareceu muito bem estruturado, pois o uso de exclamações remete à emoção do produtor ao destinar o anúncio publicitário ao seu leitor (destinatário). O uso do advérbio "maintenant” (agora) também tem o efeito argumentativo por afirmar que algo será diferente comparado ao passado, ou seja, "maintenant, ils sont propres pour la vie moderne" (agora, elas são 
próprias para a vida moderna), o texto argumenta ao relacionar o passado e o presente, afirmando implicitamente que as bicicletas antigas não acompanhavam a vida moderna, não eram versáteis. Para apresentar explicitamente a mudança das bicicletas Monarcke, o produtor apresenta ao leitor diversas qualidades, como, leve, dobrável, portátil e resistente por ser feita em carbono e alumínio. A generalização em "tous les lieux" para afirmar que essa bicicleta possibilitará ao leitor ir a todos os lugares também é um elemento que cria um efeito argumentativo no texto. Desta maneira, o anúncio deixou de parecer um panfleto de uso da bicicleta, para parecer um anúncio publicitário com muitas características do objeto, uma marca real, um logotipo e esses elementos foram elaborados de forma organizada com o objetivo de persuadir o leitor.

Eugênia e Bernardo demonstraram desenvolvimento nos planos verbal e não verbal, pois no primeiro anúncio, não sabemos qual é o produto destinado aos leitores até ler a última frase na base do anúncio. Os alunos utilizaram o recurso das vozes de autoridade de jornais, de um evento conhecido (animamundi), de modalizadores apreciativos e do contexto de ação para divulgar um filme. Neste anúncio final, os alunos desenvolveram os aspectos linguístico-discursivos, tendo apresentado, além da criação do efeito argumentativo pela mobilização de vozes e modalizações apreciativas, um desenvolvimento quanto a aspectos puramente linguísticos. Sendo assim, a ortografia e a sintaxe que tinham problema na produção inicial tiveram melhora no uso de preposições e de alguns acentos. No plano não verbal, essa dupla foi a única que conseguiu trabalhar através da representação narrativa, ou seja, através de vetores (linha do olhar) que interpelam o leitor e contam uma história. Através dos objetos que aparecem desconectados e a interpelação da produção final, podemos compreender parte do enredo do filme, que pode persuadir o destinatário.

As alunas Rosa e Emília não compreenderam o primeiro enunciado da produção inicial e criaram um anúncio publicitário de perfume. Ao observarmos o anúncio, que aparece sem texto verbal, enxergamos um vidro de perfume enorme, próximo a uma estrada que corta uma plantação de lavanda. Compreendemos que o perfume é de lavanda, mas se com esses elementos o anúncio o aluno não conseguiria convencer o seu leitor a comprar o produto, pois não existe marca ou local para efetuar a compra. Portando, o efeito argumentativo da produção final da dupla Rosa e Emília também apresentou desenvolvimento, principalmente no plano verbal, pois organizaram os elementos de um anúncio e reservaram a base para o texto descritivo que tem a intenção de persuadir o leitor ao apresentar as qualidades do produto. Apesar de haver 
participantes nas imagens, essas pessoas não olham para o leitor, portanto a representação é narrativa, mas expositiva.

Por fim, nas produções da dupla Valéria e Marta, há desenvolvimento do efeito argumentativo, visto que a produção inicial está totalmente desorganizada, apresenta quatro frases, como se fossem quatro slogans e a modalização não está correta, pois cria, através da modalização lógica, a possibilidade e não a certeza do ar menos poluído ao adotar a bicicleta como meio de transporte. Contudo, na produção final, encontramos um anúncio publicitário com forte efeito argumentativo, pois aparece organizado em: logotipo, voz de autoridade real; objeto, em primeiro plano; slogan, com recurso ao intertexto do dialeto ciclista; e texto descritivo, local de venda e site. Esses elementos são os mesmos que identificamos nos anúncios publicitários reais.

Portanto, como visualizamos no quadro de síntese geral, houve desenvolvimento do efeito argumentativo em muitas das produções dos alunos, no plano não verbal, mas, sobretudo, no plano verbal. 


\section{Considerações finais}

"A alegria não chega apenas no encontro do achado, mas faz parte do processo da busca. E ensinar e aprender não pode dar-se fora da procura, fora da boniteza e da alegria.” (Paulo Freire) 
Neste capítulo final, apresentaremos algumas reflexões acerca do estudo realizado sobre o ensino-aprendizagem do francês como língua estrangeira nos cursos extracurriculares da Faculdade de Filosofia, Letras e Ciências Humanas, a partir dos resultados obtidos através das produções textuais de alunos que participaram do curso: Atelier de escrita em francês: descobrir o anúncio publicitário.

Relacionaremos, então, os resultados obtidos com as produções textuais dos alunos aos pressupostos teóricos e metodológicos, buscando responder as perguntas de pesquisa no que diz respeito às características consideradas "ensináveis" a partir do modelo didático, à sequência didática como desenvolvedora das capacidades de linguagem e à aprendizagem da argumentação pelos alunos.

A escolha de nosso objeto de pesquisa "anúncio publicitário" se justifica ao levarmos em consideração que o mundo social é permeado por textos verbais e visuais e, muitas vezes, eles aparecem conjuntamente. Por isso, explicamos durante o estudo que não havia sentido em analisarmos somente os textos verbais se, no caso do anúncio publicitário, na maioria das vezes esse gênero combina o texto verbal e o não verbal.

Logo, para alcançar o objetivo desta pesquisa de estudar o ensino-aprendizagem do francês como língua estrangeira por meio das produções de textos pertencentes ao gênero textual anúncio publicitário, precisamos nos apoiar em duas teorias: o quadro teórico-metodológico do interacionismo sociodiscursivo (BRONCKART, 2003, 2006, 2008) no que diz respeito ao plano verbal, e a gramática do design visual (KRESS E VAN LEEUWEN, 2006), no que diz respeito ao plano não verbal. A união dessas teorias já havia sido feita por Leal (2011), mas adaptamos o quadro teórico proposto pela pesquisadora com o objetivo de melhor adequá-lo aos nossos propósitos. Para tanto, por abordarmos o anúncio publicitário optamos por estudar mais a fundo o efeito argumentativo compreendido e produzido pelos alunos. Portanto, investigamos as sequências argumentativas, como indicadora de desenvolvimento da capacidade discursiva e as vozes, sobretudo as de autoridade, e modalizações, sobretudo as manifestações das emoções e/ou dos afetos, como categorias indicadoras de desenvolvimento da capacidade linguístico-discursiva.

Para realizar nosso estudo, esclarecemos primeiramente que não almejávamos formar alunos publicitários, mas alunos que pudessem argumentar em língua estrangeira, valendo-se de aspectos verbais e visuais. Portanto, acreditamos que uma das contribuições trazidas pelo estudo realizado foi, através do modelo didático do gênero, pois ele permite compreender de que forma o gênero anúncio publicitário persuade o 
leitor. Em outras palavras, contribuímos com a análise da intenção e da argumentação através de um texto multimodal - que, neste caso, significa a coexistência de plano verbal e não verbal - para, então, criar uma sequência didática que desenvolvesse a capacidade de argumentar do aluno de francês.

Observamos, através do modelo didático do gênero, que o anúncio publicitário é um texto que tem como objetivo maior influir sobre o comportamento do leitor, ou seja, persuadi-lo e, para isso, o produtor do gênero textual anúncio publicitário teve certas intenções. No entanto, o destinatário do texto precisa apreender as intenções do produtor para ser capaz de interpretar o objetivo da comunicação e agir socialmente, seja para adquirir o produto, recusá-lo ou adquirir maneiras de agir em relação a ele.

Respondendo a uma das questões de pesquisa, consideramos através do modelo didático que os objetivos do produtor do texto e os efeitos que o texto quer produzir em seu destinatário são o que chamamos de "efeito argumentativo" e que essa característica do gênero textual anúncio publicitário poderia ser "ensinável” em língua estrangeira, devido a sua importância, visto que a interação social acontece por meio da argumentatividade (KOCH,1996).

Descobrimos, assim, que a sequência didática deveria ser construída por meio de atividades que pudessem desenvolver os mecanismos enunciativos no texto verbal, como as vozes e as modalizações, e os tipos de representação no texto não verbal, como a modalidade, o contato e a distância social, para obter, na produção final dos alunos, um desenvolvimento da sequência argumentativa que tivesse realmente um efeito argumentativo persuasivo.

No entanto, no curso de realização de nossa pesquisa, precisamos, a partir do mesmo modelo didático, elaborar duas sequências didáticas. Isso ocorreu, pois precisamos adaptar a primeira SD, já que, ao analisarmos as produções textuais do primeiro curso e o questionário final respondido pelos alunos, encontramos falhas no nome dado ao primeiro curso, nos objetos disponibilizados para a criação do gênero textual e percebemos a necessidade de trocar algumas atividades. $\mathrm{O}$ fato de ter a palavra "criativa" no nome do primeiro curso, fez alguns alunos se confundirem e imaginarem que o curso estaria relacionado à leitura, à criação literária e isso correspondeu a um problema motivacional, ou seja, alguns alunos queriam apenas ler e escrever textos literários em língua francesa.

Diante da comparação das produções dos alunos do primeiro curso "Ateliers de escrita criativa em língua francesa", percebemos que a organização estrutural não 
verbal, como a saliência, o valor da informação eram importantes na organização interacional, no que diz respeito à representação através dos ângulos que criam o distanciamento social e não havia sido trabalhada . Também observamos lacunas nas produções dos alunos quanto à sequência argumentativa verbal e sabíamos que era de grande importância que o texto verbal estivesse bem construído e organizado para desenvolver o efeito argumentativo.

Apesar de termos percebido a necessidade de uma segunda sequência didática, a experiência piloto foi essencial para a confirmação da importância do modelo didático do gênero textual, pois através dos elementos que selecionamos como principais no MD, pudemos encontrar as falhas da aplicação da sequência didática.

Assim como detalhamos no capítulo II, adaptamos a sequência didática da experiência piloto e respondendo à outra questão de pesquisa, consideramos a SD como um instrumento pertinente para o desenvolvimento das capacidades de linguagem dos alunos. Acreditamos que o resultado, no que diz respeito à produção do gênero textual anúncio publicitário para o desenvolvimento da capacidade linguístico-discursiva em língua estrangeira, apesar de ter sido bom, poderia ter sido ainda melhor se tivéssemos um curso que não fosse intensivo. Porém, as 45 horas de curso foram ministradas de forma intensiva diante das possibilidades de oferta do curso e das três professorasmonitoras que aplicavam suas sequências didáticas para a coleta das produções dos alunos.

O motivo pelo qual nos questionamos em relação à duração do curso diz respeito a alguns erros gramaticais que apareceram ou reapareceram nas produções finais, pois, apesar de termos corrigidos os erros, na lousa, e de forma coletiva, pudemos observar a recorrência de alguns erros ou a troca de vocábulo, que apareciam de forma incorreta na primeira produção e não apareciam na produção final. Portanto, acreditamos que se houvesse mais tempo entre a produção inicial e o início do primeiro módulo, para que as correções tivessem sido feitas de forma individual, o desenvolvimento da capacidade linguístico-discursiva talvez pudesse ter sido melhor. Entretanto, parece-nos importante salientar que isso não invalida os resultados obtidos, pois o desenvolvimento dos alunos foi bastante perceptível, como já apontamos. Nesse sentido, é importante relembrar que, assim como salientamos no capítulo III, houve uma correção detalhada e comparativa das produções textuais das duplas no término do módulo sobre gênero textual anúncio publicitário, e podemos considerar que o desenvolvimento alcançado no primeiro módulo foi o início do desenvolvimento almejado sobre as capacidades de linguagem 
dos alunos, visto que as duplas passaram por mais duas sequências didáticas sobre o gênero textual notícia (fait divers) e relato de viagem (récit de voyage).

Se retomarmos as análises dos textos dos alunos, encontradas no capítulo III, observamos que, no geral, esses alunos conseguiram mobilizar suas capacidades para produzir um texto do gênero anúncio publicitário. Então, observamos, com a comparação das produções, algum desenvolvimento na produção de seis grupos e nenhum desenvolvimento em apenas um deles. Logo, dos seis grupos com desenvolvimento, consideramos que cinco duplas tiveram desenvolvimento parcial e uma dupla grande desenvolvimento, no que se refere ao contexto de produção, ou seja, enunciador, destinatário e objetivos. Houve, portanto, uma melhor construção do contexto de produção, ou seja, os alunos analisaram melhor o produto que divulgariam e, portanto, classificaram melhor o público destinado àquele produto e, desta forma, através das outras capacidades, discursiva e linguístico-discursiva, os alunos organizaram os elementos que pudessem persuadir o leitor. Assim, parece-nos importante salientar a importância do desenvolvimento dos elementos do contexto de produção que foram essenciais para o desenvolvimento da capacidade de argumentação dos alunos, pois o efeito argumentativo não se restringe a uma única capacidade de linguagem, na verdade, constatamos que a argumentação permeia as três capacidades.

Com a análise, observamos que as operações de linguagem melhor desenvolvidas, foram as que dizem respeito às sequências descritivas e argumentativas, além da relação das vozes no discurso interativo implicado da ordem do expor, que contribuem para o efeito argumentativo. Além disso, encontramos tempos verbais variados,o que fez das sequências descritivas textos mais complexos. Dessa forma, reforçamos que a maioria dos alunos desenvolveu, na produção final, os elementos das capacidades discursivas, sobretudo os elementos que ampliam o efeito argumentativo.

Ainda, sobre a capacidade discursiva, analisamos o todo das produções finais e acreditamos que, se tivéssemos feito uma sequência didática com um maior número de módulos, as duplas desenvolveriam melhor o texto descritivo que se instala na parte inferior do anúncio publicitário. Percebemos que pelo menos três duplas poderiam ter detalhado melhor o produto do anúncio. De qualquer maneira, com a exceção de uma dupla, todas as duplas desenvolveram parcialmente a capacidade discursiva na parte do texto descritivo.

Para finalizar a síntese sobre o desenvolvimento das capacidades de linguagem, assim como analisamos no final do capítulo III, afirmamos que houve desenvolvimento 
das capacidades linguístico-discursivas. Muitas duplas desenvolveram grande parte das operações de linguagem esperadas para o gênero. E. mesmo quando, na produção inicial, já existiam alguns elementos característicos do gênero textual anúncio publicitário, houve algum desenvolvimento na produção final.

Através dessa análise sobre o desenvolvimento das capacidades de linguagem dos alunos, podemos ressaltar a importância da construção do modelo didático de um gênero textual e, por conseguinte, de uma sequência didática que possa servir de instrumento para o ensino. Isso pois, em muitos livros didáticos de língua estrangeira, encontramos o gênero textual sendo utilizado de forma equivocada, ou seja, como modelo de um único recurso linguístico. Por exemplo, no caso do gênero textual anúncio publicitário, encontrados em métodos para o ensino de língua estrangeira e até mesmo língua materna, observamos esse gênero como recurso para o ensino do modo imperativo, ou seja, nos livros, esse gênero, que tem um efeito argumentativo potencial, na maioria das vezes está associado unicamente ao modo verbal que transmite ordem ou conselho, sem propor ao aluno uma atividade que contraponha os diferentes tipos de anúncios publicitários, como, anúncios com diferentes modos verbais ou até mesmo anúncios que não apresentam texto verbal.

Portanto, ousamos dizer que o estudo sobre o ensino-aprendizagem em FLE mostrou-se positivo, pois após as análises das produções pudemos afirmar que a SD foi desenvolvedora das capacidades de linguagem da maioria das duplas de alunos, principalmente, no que se refere à mobilização do efeito argumentativo, que permeou todas as capacidades de linguagem. Sendo assim, nesta pesquisa, parece-nos que o objetivo, de fazer os alunos compreenderem a intencionalidade do anúncio publicitário em persuadir o leitor e de desenvolver suas capacidades de linguagem para que conseguissem fazer o mesmo com seus anúncios, foi alcançado. Através das análises, observamos o desenvolvimento das capacidades de linguagem em geral, mas especificamente o desenvolvimento das características ligadas à argumentação, de maneira que seis produções, das sete, criaram um efeito de persuasão semelhante ao de um anúncio publicitário autêntico. Salientamos que o desenvolvimento da capacidade de argumentação não estará preso à produções de mesmo gênero textual, já que sabemos que o objetivo do ensino dos gêneros textuais não é a aprendizagem do gênero em si, mas das capacidades de linguagem. Portanto, esperamos que os alunos possam usar sua capacidade de argumentar também em outros gêneros. 
Dessa forma, consideramos que respondemos às questões de pesquisa, pois a construção do modelo didático do gênero foi essencial para modificarmos a segunda sequência didática, no que diz respeito às características essenciais do gênero anúncio publicitário. Além disso, para que o curso não fosse monótono ou unicamente trabalhado através do gênero anúncio publicitário, desenvolvemos diversas atividades que partiam de outros gêneros textuais como trailer, publicidade televisiva, textos de sites de pesquisa, fator que enriqueceu as produções textuais finais dos alunos ao encontrarmos a recorrência ao intertexto de textos trabalhados nos diferentes módulos da SD.

Em suma, com esta pesquisa pudemos confirmar, através das análises das produções dos alunos, que a SD foi um desenvolvedor das capacidades de linguagem, em especial da capacidade discursiva, no que se refere ao efeito argumentativo. Porém, acreditamos que a SD poderia ter um potencial maior se fosse trabalhada de forma extensiva, para que pudéssemos diminuir os problemas referentes às capacidades linguístico-discursivas.

Por fim, acreditamos que esta dissertação pode ter contribuído para as reflexões sobre a noção de gênero textual e sobre o seu uso para o ensino de língua estrangeira, propondo o gênero textual como objeto de ensino, assim como, para a importância de uma sequência didática que faça uso desse texto autêntico e que sirva de instrumento para o ensino-aprendizagem, sendo, portanto, a SD facilitadora do agir social em língua estrangeira. Outro aspecto que contribui para as reflexões do uso do gênero textual no ensino é a importância do gênero multimodal tanto para a compreensão do aluno quanto para a construção do gênero, pois apresentamos a compreensão e a produção do gênero textual como forma de desenvolvimento do efeito argumentativo. Em outras palavras, mostramos que a apreensão da intencionalidade do gênero textual passa pela compreensão dos elementos do plano verbal e do plano visual no que diz respeito à persuasão, o que se encontra em qualquer atividade de linguagem. Nesse sentido, nossa pesquisa tem grande importância, pois, como mostram outros autores (ROJO, 2009; ADAMI, 2011), em um mundo constantemente permeado pela linguagem multimodal, não podemos continuar a ensinar práticas linguageiras que se limitem aos textos verbais.

Finalmente, não esgotamos os modos de análise do gênero, nem construímos uma sequência didática que ensinasse a sequência argumentativa tal qual é apresentada por Bronckart ([1999] 2003), mas construímos uma SD que pudesse desenvolver algumas categorias recorrentes no gênero textual anúncio publicitário, 
como o recurso ao intertexto e as categorias de vozes e modalizações que são os elementos principais do "efeito argumentativo". Nesse sentido, acreditamos que contribuímos para o próprio modelo de análise do ISD, pois pudemos mostrar que a argumentação não pode ser estudada apenas a partir da sequência argumentativa canônica, mas necessita outros referenciais de análise, como o que utilizamos. Ainda quanto às contribuições para o modelo de análise do ISD, mostramos serem produtivas as pesquisas sobre a união entre o ISD e a GDV, para a análise de textos verbais e visuais, assim como as pesquisas sobre o ensino que se apoiam nesses quadros teóricos e são aplicadas com o objetivo de desenvolver as capacidades de linguagem do aluno para que ele possa agir socialmente.

Por último, acreditamos que o nosso trabalho não esgota o estudo do agir social através do gênero textual anúncio publicitário ou o estudo da análise do desenvolvimento das capacidades de linguagem dos alunos. Esperamos motivar novas pesquisas que aprimorem o estudo dos gêneros textuais para o ensino-aprendizagem de FLE, por meio de outras sequências didáticas a partir do gênero anúncio publicitário, explorando como o efeito argumentativo é criado a partir dos textos verbais e visuais.Nesse sentido, as pesquisas contribuiriam para investigar as relações possíveis entre o ISD e a GDV, propondo um modelo de análise que explore melhor os textos multimodais. Este estudo também suscita a realização de pesquisas comparativas sobre os diferentes gêneros textuais que têm o mesmo objetivo, como por exemplo a publicidade televisiva ou o panfleto, ou seja, sobre os gêneros que chegam ao destinatário através de diferentes veículos, como: virtual, impresso, televisivo, e poderiam fazer parte do instrumento "sequência didática" para o ensino aprendizagem do FLE. Finalmente, nossa pesquisa toca em uma questão importante, sem, no entanto, realmente explorá-la: o trabalho do professor ao aplicá-la, o que certamente contribuiu para os resultados dos alunos. Nesse sentido, parece-nos fundamental que pesquisas futuras investiguem o procedimento das sequências didáticas baseadas em gêneros textuais, mas também do ponto de vista do professor. 


\section{Referências Bibliográficas}

-ADAM, Jean-Michel. Élements de linguistique textuelle. Liège: Mardaga, 1990.

Les textes: types et prototypes. Paris : Nathan, 1992.

- ADAMI, Elisabetta. Mashing genres up, breaking them down: Semiotic practices and literacy in the age of copy-and-paste. In: VI Simpósio Internacional sobre Gêneros textuais na Universidade Federal do Rio Grande do Norte. Rio Grande do Norte, 2011.

-ARISTÓTELES, Rhétorique. Trad. : M. Dufour, Paris: Les Belles Lettres [livro 1, 1932; livro 2, 1931; livro 3, 1931)

-AUSTIN, John L. Quando dizer é fazer - Trad. Danilo Marcondes de Souza Filho. Porto Alegre: Artes Médica, 1990.

-BAKHTIN, Mikhail. Estética da criação verbal. São Paulo: Martins Fontes, 1997.

- BARTHES, Roland. Euvres Complètes II. Livres, textes, entretiens 1962-1967. «Mythologie de l'automobile». Nouvelle édition revue, corrigée et présentée par Éric Marty. Paris : Seuil, 2002.

- BENVENISTE, Émile. Les relations de temps dans le verbe français. Problèmes de linguistique générale. Paris: Gallimard, 1959[1966], pp.237-250.

- BRAIT, Beth. Literatura e Outras Linguagens. São Paulo : Contexto, 2010.

- BRASIL, MEC. Secretaria de Educação Fundamental. Parâmetros curriculares nacionais de língua portuguesa - Terceiro e quarto ciclos do ensino fundamental. Brasília: MEC/SEF, 1998a.

- Secretaria de Educação Fundamental. Parâmetros curriculares nacionais de língua estrangeira - Terceiro e quarto ciclos do ensino fundamental. Brasília : MEC/SEF, 1998b.

-BRONCKART, Jean-Paul. Atividade de linguagem, textos e discursos. Por um interacionismo sócio-discursivo. São Paulo: EDUC, 1997/1999/[2003].

Les différentes facettes de l'interactionnisme sócio

discursif. Congresso Internacional Linguagem e Interação, Unisinos, 2005a. 
- Restrições e liberdades textuais, inserção social e

cidadania. Anpoll, 2005b. (número 19, p.229)

Os gêneros de textos e os tipos de discurso como

formatos das interacções em desenvolvimento. Actas do Seminário Internacional de Análise do Discurso da Universidade Nova de Lisboa. Lisboa: Centro de Linguística da Universidade Nova de Lisboa, p.39-79, 2005c.

- Atividade de linguagem, discurso e desenvolvimento

humano. São Paulo: Mercado das Letras, 2006.

O agir nos discursos: das concepções teóricas às concepções dos trabalhadores. Campinas: Mercado de letras, 2008.

BULEA, Ecaterina \& BOTA, Christian. Le projet de

Ferdinand de Saussure. Genève: Librairire Droz, 2010.

- CHARAUDEAU, Patrick. Discurso das Mídias. São Paulo : Contexto, 2007.

- CÍCERO. De l'orateur, livro II. Texto estabelecido e traduzido por E. Courbaud.

Paris: Les Belles Lettres, 1928.

-CONSEIL DE L'EUROPE. Cadre Européen Commun de Référence pour les Langues Apprendre, Enseigner, Evaluer. Paris : Les Editions Didier, 2001.

- COSCARELli, Carla Viana. Hipertextos na teoria e na prática. Belo Horizonte: Autêntica, 2012.

-CRISTOVÃO, Vera Lúcia Lopes. O gênero quarta-capa no ensino de inglês. In: DIONISIO, Angela Paiva; MACHADO, Anna Rachel; BEZERRA, Maria Auxiliadora (org). Gêneros Textuais \& Ensino. Rio de Janeiro: Editora Lucerna, 2005.

- Entrevista: o interacionismo sociodiscursivo em discussão. Concedida a Alessandra Augusta Pereira da Silva e Maria Izabel Rodrigues Tognato. Revista NUPEM, Campo Mourão, v. 2, n. 3, ago./dez, 2010

; BEATO-CANATO, A. P. M.; PETRECHE, C. R. C.; FERRARINI, M.; ANJOS-SANTOS, L. M. Uma proposta de planejamento de ensino de língua inglesa em torno de gêneros textuais. Letras (UFSM), v. 20, p. 191-215, 2010

- CULIOLI, Antoine. Pour une linguistique de l'énonciation. Paris: Ophrys, 1990. 
- DOLZ, Joaquim; PASQUIER, Gustave ; BRONCKART, Jean.-Paul. L'acquisition des discours : émergence d'une compétence ou apprentissage de capacités langagières diverses ? Etudes de Linguistique appliquée, Paris, n. 89, p. 25-35, 1993.

- DOURY, Marianne. Le débat immobile. Analyse de l'argumentation dans le débat médiatique sur les parasciences. Paris : Kimé, 1997.

- DUCROT, Oswald. Polifonía y argumentación. Cali: Universidad del Valle, 1990.

- FRIEDRICH, Janette (2012). Lev Vigotski - Mediação, aprendizagem e desenvolvimento - uma leitura filosófica e epistemológica. São Paulo: Mercado de Letras, 2012.

-GERMAIN, Claude. Evolution de l'enseignement des langues: 5000 ans d'histoire. Paris: Clé International,1993.

- GUIMARÃES SANTOS, Luiza. O ensino-aprendizagem do FLE: pensando o agir social a partir do gênero itinéraire de Voyage. Dissertação ((Mestrado em Língua e Literatura Francesa) - Faculdade de Filosofia, Letras e Ciências Humanas, Universidade de São Paulo, São Paulo, 2013. Disponível em: HTTP://www.teses.usp.br/teses/disponiveis/8/8146/tde-26102012-122158/. Acesso em: 2014-02-01.

-GRIZE, Jean-Blase. De la logique à l'argumentation. Genève : Droz, 1982[1990].

- HABERMAS, Jürgen. Théorie de l'agir communicationnel, t. I et II., Paris : Fayard, 1987.

- HALliDAY, Michael A. K. An introduction to Functional Grammar (2a ed.). London: Edward Arnold, 1985 [1994].

- HEGEL, Georg W. F . Phénoménologie de l'Esprit. Paris: Aubier, 1947.

- KOCH, Ingedori G.Villaça. Desvendando os segredos do texto. São Paulo: Cortez, 2002.

-KRESS, Gunther, VAN LEEUWEN, Theo R. Reading images: the Grammar of visual design/Gunther Kress and Theo van Leeuwen. New York: Routledge, 2006.

-KRESS, Gunther, VAN LEEUWEN, Theo R. Multimodal Discourse. The modes and media of contemporary communication. London: Arnold, 2001. 
-LEAL, Audria Albuquerque. A ORGANIZAÇÃO TEXTUAL DO GÊNERO CARTOON: ASPECTOS LINGUÍSTICOS E CONDICIONAMENTOS NÃO LINGUÍSTICOS. Tese (Doutorado) - Universidade Nova de Lisboa, Lisboa, 2011.

-LIBERALI, Fernanda. Educação de Jovens e Adultos. Em: Célia Maria Carolino Pires; Miriam Orensztejn; Roberta Leite Panico; Sandra Mayumi Murakami Medrano. (Org.). Educação de Jovens e Adultos. Brasília: Ministério da Educação e Cultura, 2002, v. 2, p. 67-97.

- LONGHI, Simone Maria Dantas. Como os jogos podem revelar outras dimensões do trabalho do professor de língua estrangeira?. 2013. Dissertação (Mestrado em Língua e Literatura Francesa) - Faculdade de Filosofia, Letras e Ciências Humanas, Universidade de São Paulo, São Paulo, 2013. Disponível em: HTTP://www.teses.usp.br/teses/disponiveis/8/8146/tde-30072013-103516/. Acesso em: 2014-02-01

-LOUSADA, Eliane Gouvêa. Elaboração de material didático para o ensino de francês. In: DIONISIO, Angela Paiva; MACHADO, Anna Rachel; BEZERRA, Maria Auxiliadora (org). Gêneros Textuais \& Ensino. Rio de Janeiro: Editora Lucerna, 2005.

Utiliser les genres textuels dans une perspective actionnelle. Revista de Lenguas Modernas. No. 8-9, p. 211-218. 2008.

-MACHADO, Anna Rachel. Revisitando o conceito de resumos. In: DIONISIO, Angela Paiva; MACHADO, Anna Rachel; BEZERRA, Maria Auxiliadora (org). Gêneros Textuais \& Ensino. Rio de Janeiro: Editora Lucerna, 2005.

; LOUSADA, Eliane Gouvêa. A apropriação de gêneros textuais pelo professor: em direção ao desenvolvimento pessoal e à evolução do "métier". Linguagem em (Dis)curso, v. 10, n. 3,p. 619-633, 2010.

-MAINGUENEAU, Dominique. Analyser les textes de communication. Paris: Armand Colin, 2007.

- MARCUSCHI, Luiz Antônio. Linearização, Cognição e Referência: o desafio do hipertexto. In: Línguas e Instrumentos Linguísticos, $\mathrm{N}^{\circ}$ 3, Campinas/SP: Pontes, 1999.

- Gêneros textuais: definição e funcionalidade. In:

DIONISIO, Angela Paiva; MACHADO, Anna Rachel; BEZERRA, Maria Auxiliadora (org). Gêneros Textuais \& Ensino. Rio de Janeiro: Editora Lucerna, 2005.

-MARX,Karl ; ENGELS, Friedrich. Études philosophiques. Paris : Editions Sociales, 1951. 
-MEURER, José Luiz. MOTTA-ROTH, Désirée. Gêneros textuais e práticas discursivas. Bauru: EDUSC, 2002.

-PLATIN, Christian. A argumentação. História, teorias, perspectivas. São Paulo ; Parábola editorial, 2008.

-PUREN, Christian. Histoire des méthodologies. Paris: Nathan; Clé International, 1988.

-QUINTILIANO. Institution oratoire. Texto estabelecido e traduzido por J. Cousin. Paris : Les Belles Lettres, 1977.

- RABARDEL, Pierre. Les hommes et les technologies. Paris: Armand Colin, 1995.

- ROJO, Roxane. Letramentos Multiplos: Escola e Inclusão Social. São Paulo: Parábola, 2009.

- SAUSSURE, Ferdinand de. Curso de Linguística Geral. Trad. Antônio Chelini, José Paulo e Izidoro Beinkstein. São Paulo; Cultrix, 1975.

-SCHNEUWLY, Bernard. DOLZ, Joaquim. Gêneros Orais e Escritos na Escola. Campinas: Mercado de Letras, 2004.

-SEARLE, John Roger. Os actos de fala. Coimbra: Almedina, 1987.

-TOULMIN, Stephen Edelston. Os usos do argumento. São Paulo : Martins Fontes, 1958[2006].

-VOLOCHINOV, Valentin. Le marxisme et La philosophie Du langage. Paris : Les Éditions de Minuit, 1977.

-VIGOTSKI, Lev Semenovitch. A formação social da mente. São Paulo: Martins Fontes, 1988.

Pensamento e linguagem. Tradução de Jefferson Luiz Camargo. 2a ed. Martins Fontes: São Paulo, 1987 [1998].

- WEINRICH, Harald. Tempus - Besprochene und erzählte Welt Le temps. Paris: Seuil, 1964 [1973]. 


\section{Apêndices}

Apêndice A: Anúncios publicitários do tipo vídeo e suas análises.............................252

Apêndice B : Anúncios publicitários do tipo governamental e suas análises...............244

Apêndice C: Anúncios publicitários do tipo transporte e suas análises.......................256

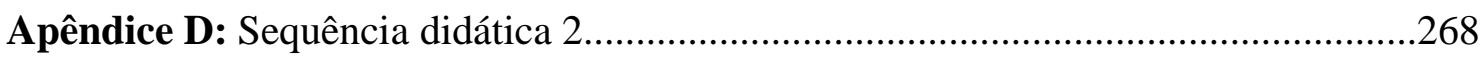

Apêndice E: Produção inicial e final dos alunos...........................................................290

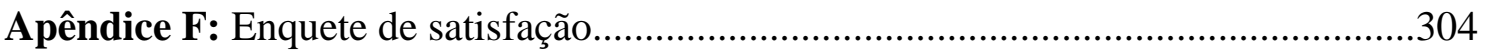

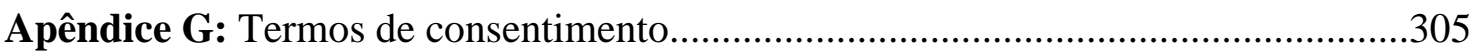

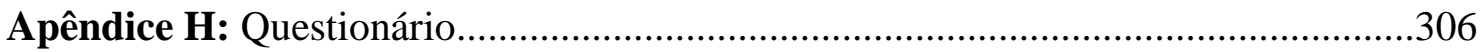

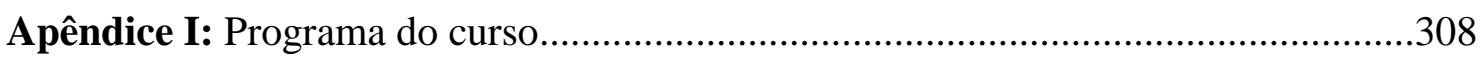

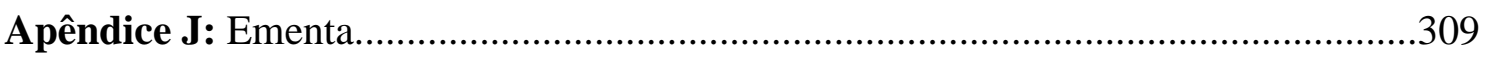

Apêndice K: Sequência Didática Piloto (CD-ROM) 
Apêndice A: Anúncios publicitários do tipo vídeo e suas análises

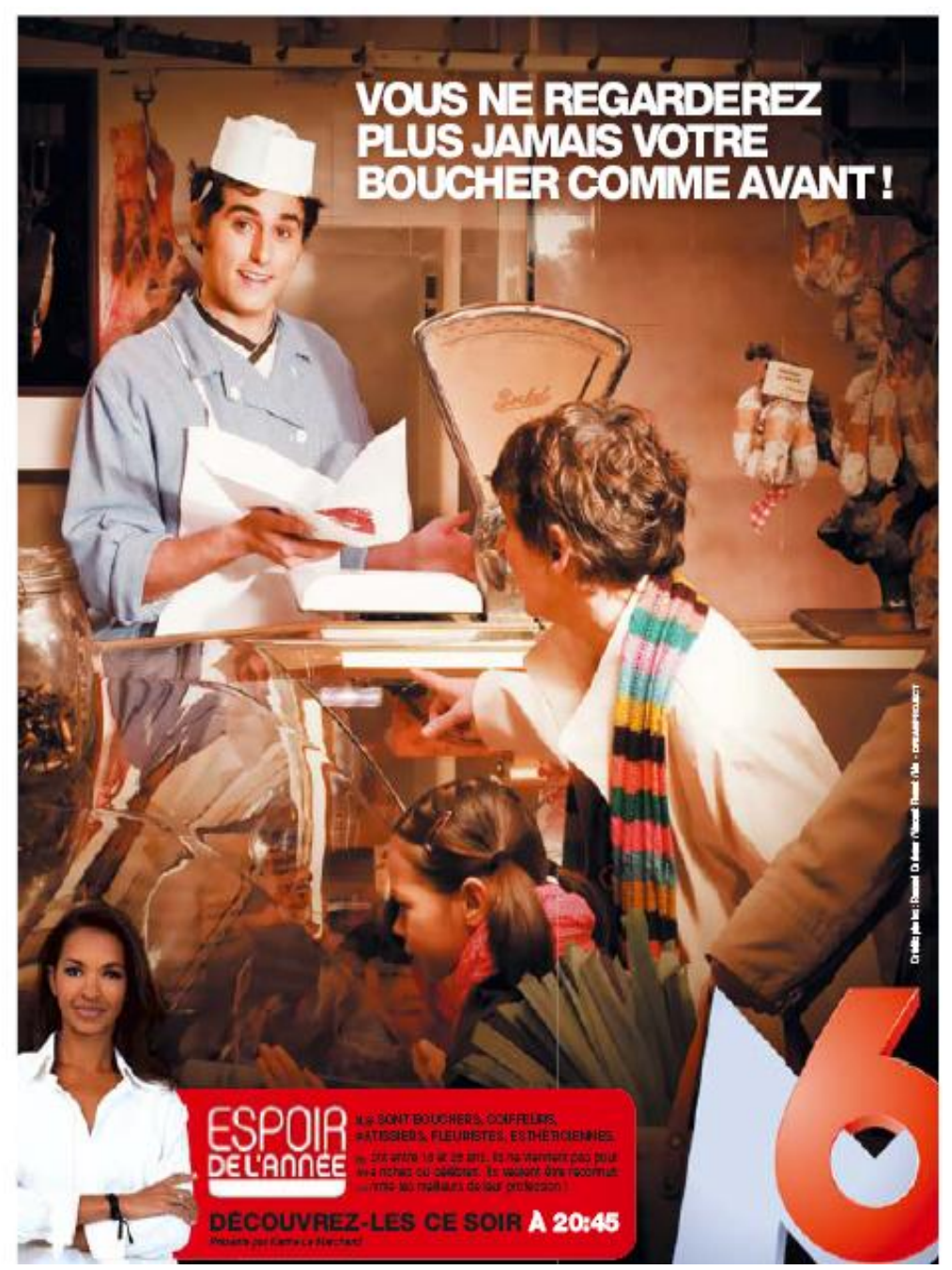

Análises para o modelo didático

Contexto de produção e recepcão:

Enunciador - M6: "Espoir de l'année"

Destinatário - Telespectador do canal usuário do metrô

Lugar social - metrô de Paris

Objetivo - Persuadir o leitor usuário do metrô a assistir ao programa

Organizacão temático-representacional:

Tipos de discurso - interativo implicado

Tipos de representação - transacional: processo de reação vetorial quando $\mathrm{o}$ ator olha para o produto e o participante olha para o leitor. Não transacional: menina que olha a vitrine. Não podemos visualizar o fenômeno

\section{Organização interacional:}

Vozes do discurso - vous - discurso interativo implicado da ordem do expor e ils -interativo implicado da ordem do expor. Dito popular: efeito argumentativo (vous ne...plus jamais...comme avant).

Modalizaçao - epistêmica "vou NE regarderez plus jamais", "ils veulent être reconnus comme »

Contato - demanda/interpelação

Distância social - plano médio

Atitude - perspectiva subjetiva através do ângulo oblíquo e representação da igualdade através do ângulo no nível do olhar.

Modalidade - cores fortes, contexto real, imagem naturalista A verdade representada na imagem: Cores fortes em tons marrom e vermelho que contextualizam o açougue, logo a imagem se torna naturalista - contexto real - a iluminação e o brilho tem foco sobre o profissional - luz atrás da cabeça do açougueiro e sob a balança, também na altura do participante. 


\section{Organizacão estrutural:}

Conexão e coesões - ponto final, "ou" como alternativa, anáfora do pronome "ils", Profissões no plural e o "boucher" no singular. Verbo no futuro.

Valor da informação - polarizado , primeiro plano, à direita temos informação nova, informações reais na base, nas informações técnicas.

Saliência - máxima saliência, foco no açougueiro, açougueiro em um plano superior. Imagem grande mostra a máxima saliência. $\mathrm{O}$ foco está no açougueiro e é percebido pelo brilho da imagem. Além de aparecer em um plano superior ao das clientes. O tamanho das letras também dão importância como : "decouvrez-les CE soir"

Emolduramento - estabelece o percurso da leitura. De forma polarizada, a cliente, o açougueiro e o açougue fazem parte da mesma cena. Mas existe uma desconexão marcada pela imagem da apresentadora na parte inferior do anúncio, o que desconecta o tema do dia-a-dia em um açougue para uma programação televisiva. 


\section{OFFREZ-VOUS LE FILM LE PLUS ACCLAMÉ dE L'ANNÉE !}

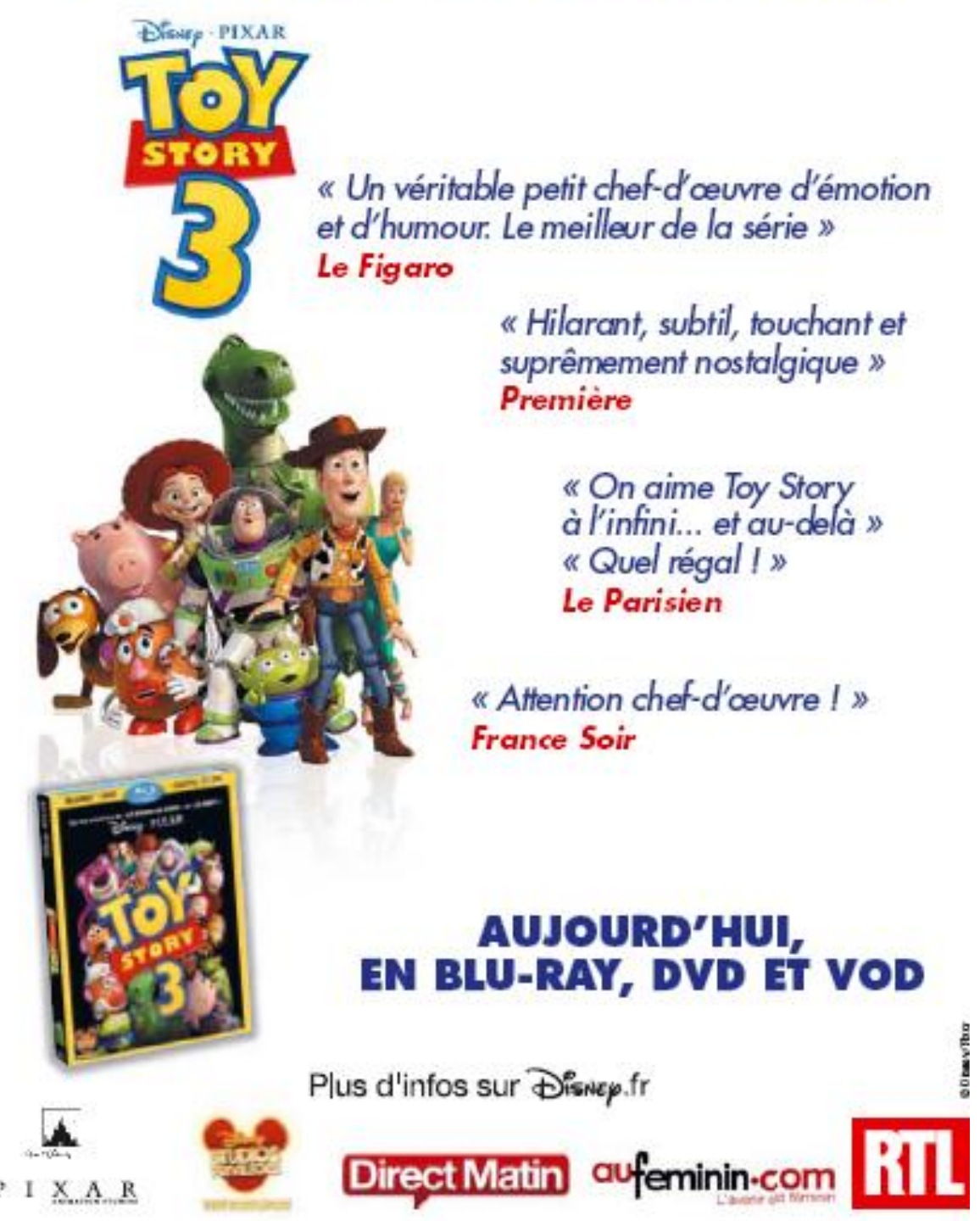

Contexto de producão e recepcão:

Enunciador - Disney Pixar

Destinatário - Público que gostaria de comprar uma animação

Lugar social - metrô de Paris

Objetivo - Persuadir o leitor usuário do metrô a comprar o dvd

Organizacão temático-representacional:

Tipos de discurso - interativo implicado da ordem do expor

Tipos de representação - Processo de reação não transacional: em uma das imagens encontram-se os personagens da animação e seus olhares criam vetores, mas o fenômeno não é visível. Todos olham para a direita na imagem, onde diversas críticas estão dispostas. As imagens foram criadas, por isso não se trata de uma imagem naturalista.

\section{Organização interacional:}

Vozes do discurso - vous; voz de autoridade (jornais) causa efeito de verdade (Charaudeau), argumentativo - Discurso interativo implicado da ordem do expor: "Vous" em "offrez-vous".

Modalizaçao - Indireta de valor deôntico, pois determina um agir através do verbo no imperativo: "Offrez-vous Le film le plus aclamé de l'année". Em uma das críticas expostas em Segundo plano "on aime toy story à l'infini" a modalidade é Indireta de valor apreciativo - "aimer"

Contato - De oferta/exposição, pois na imagem dos personagens o participante não olha para o leitor interpelando-o.

Distância social - Na imagem dos personagens, o plano é geral, o que indica certo distanciamento.

Atitude - Objetiva orientada ao conhecimento, pois revela o que deve ser mostrado sem que exista um ângulo ou perspectiva e apresenta as críticas como base de orientação ao conhecimento da animação.

Como se fosse um dicionário de sinônimos sobre toy story. 
Modalidade - A cena não aparece contextualizada, não existe um fundo, logo a imagem é não naturalista.

Cores fortes e primárias: azul e vermelho. A iluminação privilegia levemente a imagem dos personagens e o DVD (este, por sinal, configura um outro gênero: capa de DVD).

\section{Organizaç̃o estrutural:}

Conexão e coesões - Vírgula, conjunção "et", reticências e exclamações. Apesar de a crítica ser par o mesmo filme, as frases são de diferentes jornais e estão desconectadas através das aspas. "Chef-d'oeuvre" aparece em 2 dos 4 comentários. Essa expressão é utilizada no domínio das artes para destacar a obra mais importante de um artista ou de uma época. Encontram-se muitos adjetivos. Alguns adjetivos podem ser considerados sinônimos: "um petit chef-d'oeuvre d'humour" e "hilariant" ou "um petit chef-d'oeuvre d'émotion" e "touchant". Somenta na crítica do "Le Parisien" encontramos o verbo "aimer" na pessoa "on". Este "on" pode ser o ssujeito jornal, o sujeito "nous" que abrangeria a população total dos receptores do anúncio.

Valor da informação - $\mathrm{O}$ texto é polarizado e o que se encontra do lado direito é informação nova,, as críticas dos jornais e do lado esquerdo é o "dado", ou seja, o ponto de partida que mostra uma verdade já conhecida, o filme toy story 3 , os personagens e o DVD. No sistema horizontal ideal = topo $=$ aparece $u m$ texto verbal $\mathrm{E}$ no sistema horizontal real $=$ embaixo $=$ vemos o site para informações e os logotipos de todos produtores do anúncio.

Saliência - Saliência mínima por causa do tamanho das imagens.Além disso, o foco também é mínimo, pois a imagem dos personagens e o Dvd possuem uma leve sombra, como se existisse alguma luz nessas duas figuras.
Emolduramento $\mathrm{O}$ enquadra dos elementos aparecem separados por um espaço vazio, o que consideramos como emolduramento de desconexão máxima. PS: estruturação escolhida pelo fato das críticas serem de jornais diferentes. 


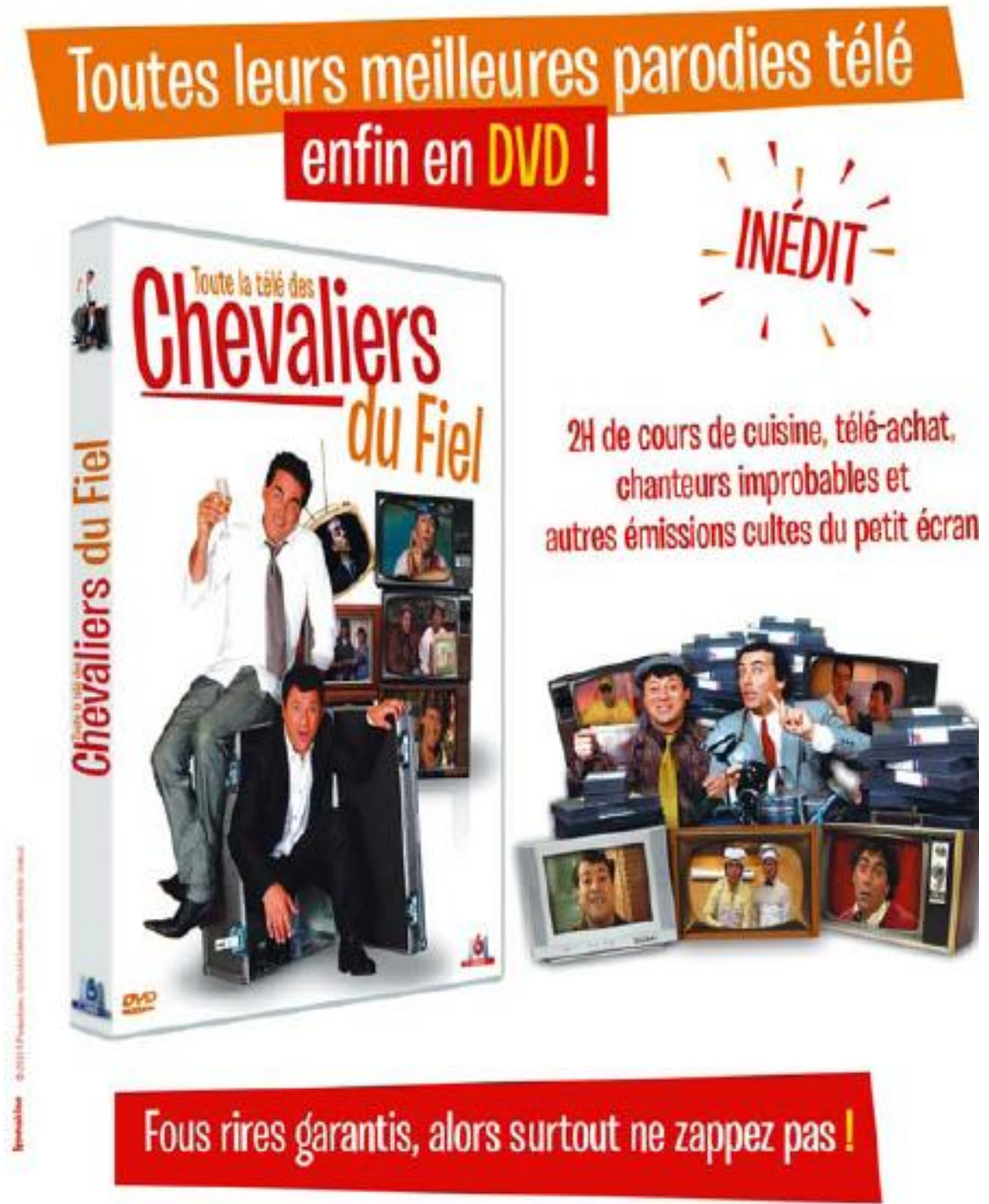

\section{Contexto de producão e recepcão:}

Enunciador - M6, direct soir et sud radio

Destinatário - público usuário de metrô, com interesse em DVD.

Lugar social - metrô de Paris

Objetivo - Persuadir o leitor a comprar o DVD dos humoristas da TV

\section{Organizacão temático-representacional:}

Tipos de discurso - interativo implicado

Tipos de representação - Representação narrativa no sub-gênero capa de DVD. Representação narrativa na outra imagem. Os dois personagens nas duas situações olham para o leitor. Mas existe uma representação conceitual ao observarmos as roupas dos personagens, onde encontramos o papel social dos interlocutores. Na capa do DVD eles aparecem através das roupas sociais como pessoas bem sucedidas, além da taça de champanhe. Na segunda imagem aparecem com uma fita VHS desenrolada na mão e apesar da roupa social, não possuem a postura da outra imagem.Outras pequenas imagens aparecem em TVs. Representação conceitual analítica por sobrecarregar a imagem com atributos, pois cada personagem dentro de cada TV possui um atributo. Efeito argumentativo: "meilleures", "inédit", "cultes", "garantis".

\section{Organizacão interacional:}

Vozes do discurso - vous - Discurso interativo implicado da ordem do expor: "NE zappez pas"

Modalizaçao - Direta (vous) de valor deôntica, com sentido de obrigação através do verbo: "zapper" que aparece no imperativo, na segunda pessoa do plural. O verbo significa trocar de canal. "Fous rires garantis", sentido de certeza, apresenta modalidade indireta epistêmica.Indica o grau de conhecimento do enunciador sobre o assunto. Garantis, faz com que o enunciador assuma inteiramente $\mathrm{o}$ valor 
Contato - Contato de demanda/interpelação pois os humoristas olham para o leitor.

Distância social - Plano geral no gênero capa de DVD, os apresentadores aparecem inteiramente, dando ênfase à cena como um todo, apresentando portanto uma visão de conjunto. Corresponde ao distanciamento social. A outra imagem aparece em plano médio, aproximação social.

Atitude - Perspectiva subjetiva, horizontalmente uma imagem aparece em ângulo obliquo, o que gera um distanciamento no envolvimento. A segunda imagem aparece em ângulo frontal, logo maior envolvimento. Perspectiva objetiva, verticalmente a imagem aparece no nível do olhar, representando a igualdade de poder.

Modalidade - A verdade representada na imagem: cores claras, fundo branco, sem contextualização (ambiente), logo imagem não naturalista. Não existe um foco por iluminação ou brilho, mas o tamanho do DVD aparece em tamanho grande.

\section{Organizacão estrutural:}

Conexão e coesões - Conexões: vírgula, et,exclamação, "alors surtout". Em primeiro plano aparece a frase que introduz o tema do anúncio. Em segundo,"inédit" aparece sem conexão. Em terceiro, texto com informação dos episódios. Em quarto, a certeza do enunciador. Coesões: Petit écran = télé, Adjectif: émissions cultes, fous rires. Coesão verbal: verbo no imperativo. Não há outro verbo, mas em "toutes leurs parodies télé enfin em DVD" e "inédit" dá um valor temporal presente.

Valor da informação - O texto verbal aparece de forma polarizada e em primeiro plano no topo do anúncio. A informação aparece à direita o que propõe alguma nova informação. As informações reais aparecem na base do anúncio, ou seja, as informações técnicas.
Saliência - O DVD mostra maior saliência por ser maior. A palavra "inédit" aparece de forma. O fundo vermelho e laranja no primeiro texto verbal e no último chamam a atenção.

Emolduramento - Polarizado. Os elementos da esquerda são tidos como "verdades" = o DVD inédito. Os elementos da direita introduzem um novo conhecimento, como: "inédit", "2h de cours de cuisine..." 


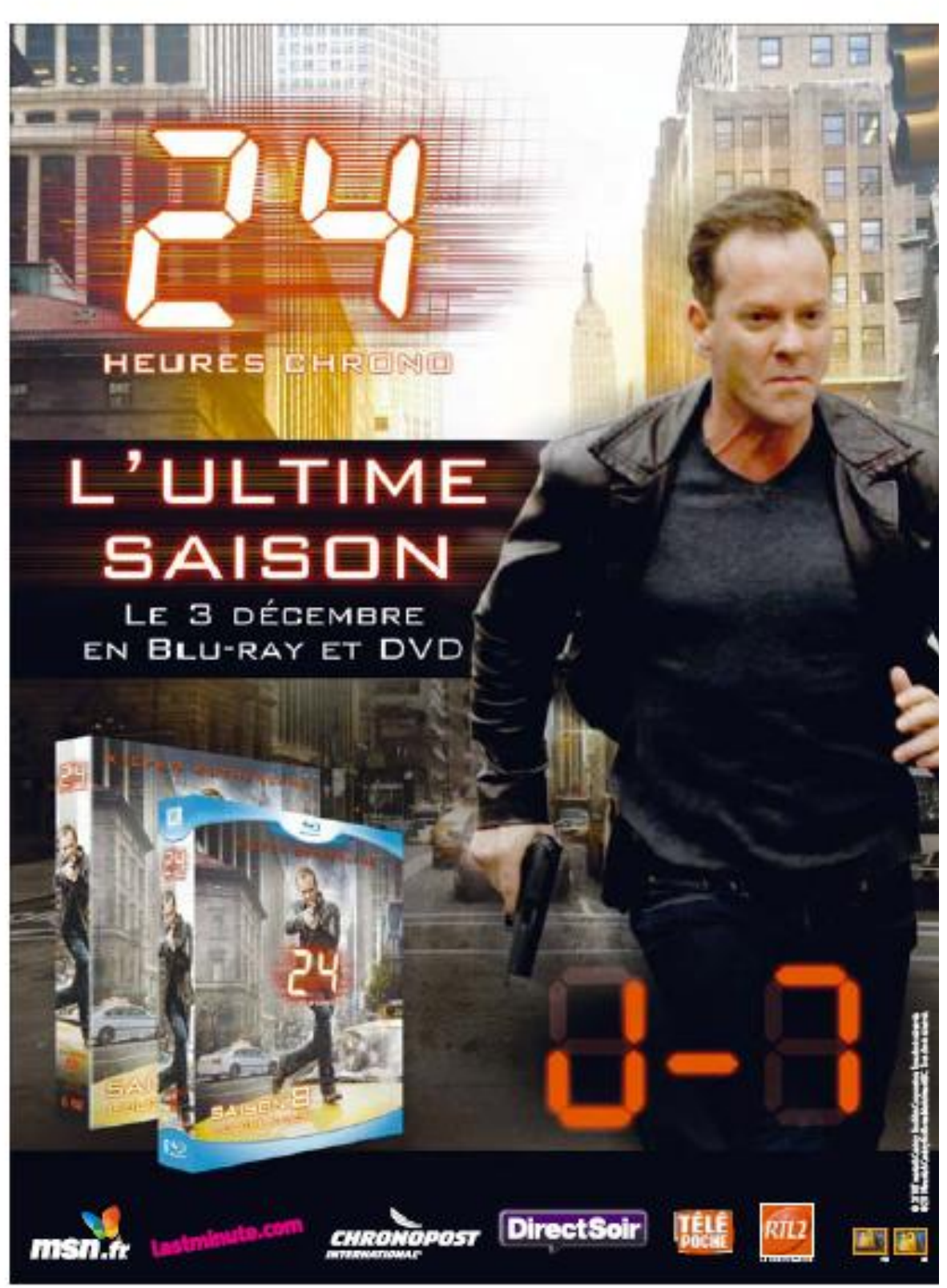

\section{Contexto de producão e recepcão:}

Enunciador - MSN.fr, lastminute.com, chronopost, direct soir, télé poche, RTL2

Destinatário - Usuário do metro com interesse em séries Lugar social - metrô de Paris

Objetivo - Persuadir o leitor a comprar a última temporada da série "24 horas"

\section{Organizacão temático-representacional:}

Tipos de discurso - Mundo do expor: discurso teorico autônomo

Tipos de representação - Representação não transacional : o ator olha adiante, mas não dá para visualizar o fenômeno pelo qual ele está correndo armado.

\section{Organização interacional:}

Vozes do discurso - Não há marca de vozes ou verbos que indiquem tais vozes. Há efeito argumentativo em imagem e texto verbal: "ultime", "em blu-ray et DVD"

Modalizaçao - Não há verbos. Se observarmos o não verbal J-7: podemos imaginar um verbo, como: "Il manque 7 jours pour le DVD être acheté" Mas não há evidência de autor ou receptor.

Contato - Contato de oferta/exposição pois o participante não olha para o leitor. O leitor não é convidado a participar do ato semiótico, seu papel é de um espectador invisível, sendo o participante representado um objeto de contemplação e de informação apresentado de forma impessoal.

Distância social - Geral, pois mostra o ambiente como todo, impessoalidade. O leitor é telespectador.

Atitude - Horizontalmente o ator foi fotografado em ângulo frontal ao observarmos seu posicionamento com relação à cidade, por isso um maior envolvimento, a cidade faz parte do nosso mundo, mas seu olhar não é para 
o leitor. Observando verticalmente, a foto está no nível do olhar, representando a igualdade.

Modalidade - A verdade representada na imagem: Foto naturalista, fundo real, cores não dão foco para o ator ou a acidade, mas para o nome da série e a contagem regressiva para o DVD na loja. O tamanho do ator, bem próximo na foto, dá importância ao personagem. O Box da série no lado esquerdo apresenta a novidade.

\section{Organização estrutural:}

Conexão e coesões - Não há conectores entre os elementos do texto escrito, não há verbo, ponto, virgula. Em « 03 décembre em blu-ray ET DVD » encontramos uma conjunção "e" para adicionar um elemento. Não há repetições. Faz uso de "l'ultime" em vez de "dernier". Ultime tem um sentido de não ter mais volta. 24 Heures chrono = sentido de um dia cronometrado. J-7 = jour $07-\mathrm{n}$ úmeros de um cronômetro identificam a contagem regressiva para a saída do DVD.

Valor da informação - O texto verbal aparece de forma polarizada. A informação que aparece à esquerda trata-se de uma verdade já conhecida, pois a série não é nova, está na última temporada e será lançada em DVD como as temporadas anteriores. À direita o que propõe alguma nova informação, no caso a imagem que consegue ser decifrada do lado direito, é de Nova York - pois grande parte das temporadas se passou em Los Angeles. E quantidade de dias em número digital.

Saliência - Imagem grande mostra a máxima saliência. O ator aparece em tamanho grande. O número 24 aparece com muito brilho.

Emolduramento - Estabelece o percurso da leitura. O nome da série, a cidade em que se passa a nova temporada e o ator, a última temporada com data prevista, o ator protagonista de todas as temporadas, o DVD e a contagem regressiva aparecem de forma polarizada e existe conexão entre os elementos, o fundo não é branco, estão todos sobre a imagem de NY. Leve desconexão do tema da série para da data de lançamento que se conecta ao J-7. 


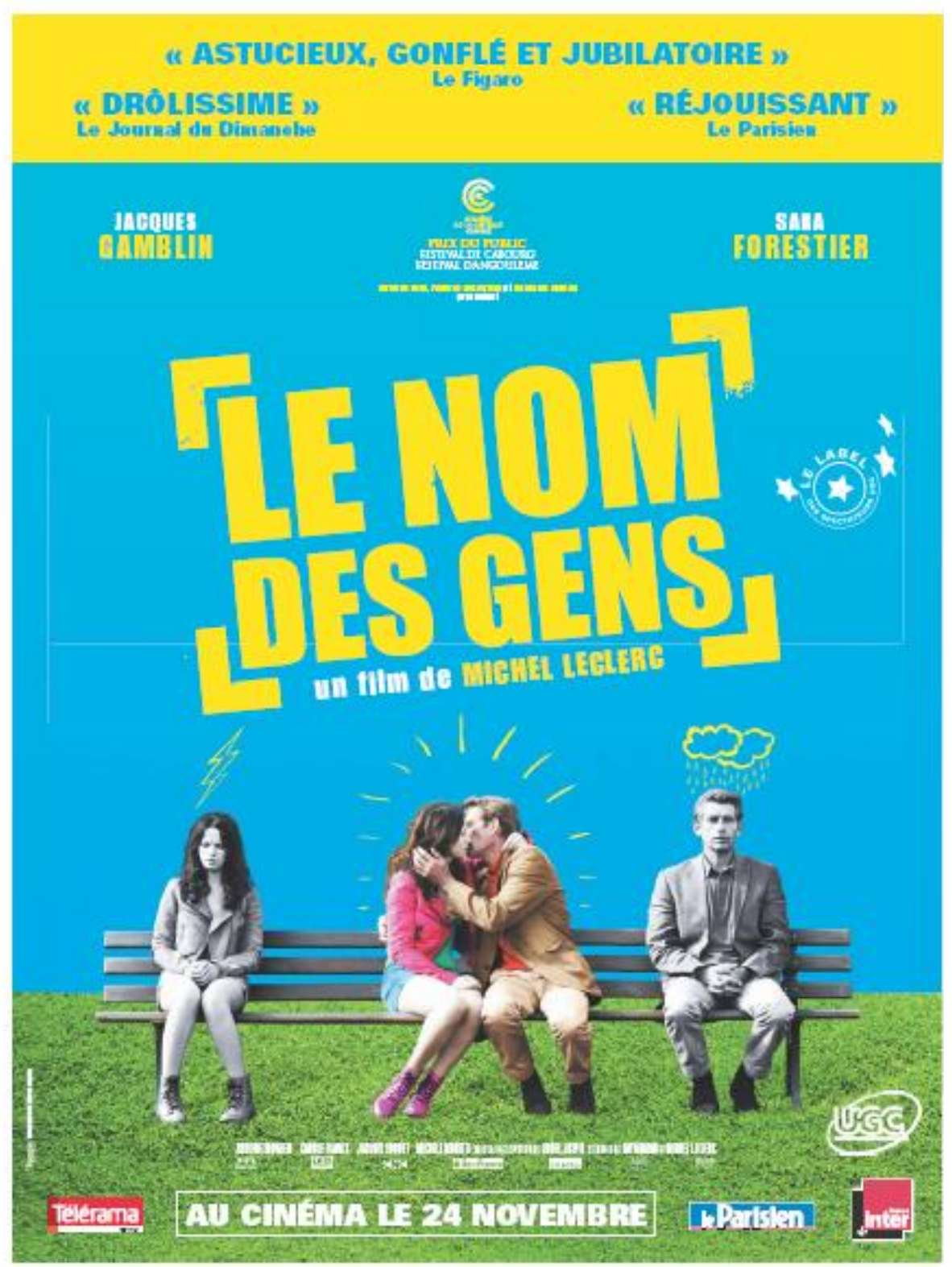

\section{Contexto de producão e recepcão:}

Enunciador - UGC, télérama, Le parisien,france inter

Destinatário - Usuário do metro que costuma assistir aos filmes no cinema. Lugar social - metrô de Paris

Objetivo - Persuadir o leitor a ir ao cinema para assistir ao filme

\section{Organizacão temático-representacional:}

Tipos de discurso - Discurso teórico autônomo

Tipos de representação - Representação aparece através de um outro gênero, pois o anúncio foi feito através da capa do filme e que posteriormente virou DVD. Representação narrativa de processo mental (em preto e branco), os observadores pensam em "raio" e "chuva", o que representa de uma relação turbulenta. A imagem central colorida é representação conceitual simbólica, pois os participantes não possuem vetor e a forma que aparecem juntos simboliza o amor.

\section{Organização interacional:}

Vozes do discurso - Mundo do expor: discurso teórico autônomo. Voz de autoridade: nomes dos jornais, causam efeito argumentativo (o filme deve ser visto).

Modalizaçao - Não há verbos. Relações predicativas indiretas de valor epistêmico - o texto verbal apresenta com a certeza as críticas de jornal através da adjetivação positiva fazendo, por exemplo, o uso do superlativo "issímo". Se a crítica estivesse completa apareceria, por exemplo, como:"Le film est drôlissime", Fazendo uso do verbo "ser" no presente, na forma afirmativa. É a certeza dos críticos. O carimbo "Le label dês espectateurs ugc" valida as críticas que aparecem no topo do anúncio..

Contato - Contato de oferta/exposição, pois os participantes não olham para o leitor. 
O papel do leitor é de um espectador invisível, como acontece nos filmes Distância social - Geral, pois mostra o parque como um ambiente como todo, impessoalidade. O leitor é telespectador.

Atitude - Horizontalmente os atores que estão em um banco foram fotografados em ângulo frontal apesar de não olharem para o leitor, logo o envolvimento é parcial.

Verticalmente, o ângulo no nível do olhar representa igualdade ente o observador-leitor e os atores, ninguém é superior. Poderíamos pensar em um amor ordinário.

Modalidade - A foto não é naturalista, pois apesar de ser um banco em um gramado, não existe fundo. Ele é pintado de azul como um desenho infantil. O céu é de mentira e as imagens em preto e branco trazem um valor de passado, antes de se unirem ou de imaginação, como se ela fosse o pensamento da atriz colorida no momento do beijo e como se ele em preto e branco fosse o pensamento do ator no momento do beijo. As cores amarelo, verde e azul aparecem em uma tonalidade de gibi. A cor em contraste com o preto e branco dá destaque ao casal.

\section{Organizacão estrutural:}

Conexão e coesões -5 adjetivos em 3 críticas. 5 adjetivos: astucieux, gonflé (inflado, bouffant, mangeant, dévorant) ET jubilatoire (provoca alegria expansiva e viva). Drôlissime (engraçadíssimo) Réjouissant (qui amuse- diverte). Encontra-se, também, vírgula e "et" em uma das críticas. Todas as críticas estão entre aspas.

Valor da informação - Polarizada: topo estão as críticas=emotividade. Embaixo: informação da data "au cinema le 23 novembre" = informação sobre o produto

Saliência - As cores dão saliência ao casal unido. O tamanho da fonte dá maior peso ao nome do filme.
Emolduramento - Possui desconexão máxima pelo espaço vazio: crítica positiva, o nome do filme em forma de carimbo de correio no centro, outro carimbo redondo do lado direito, mas a imagem do banco existe conexão. 


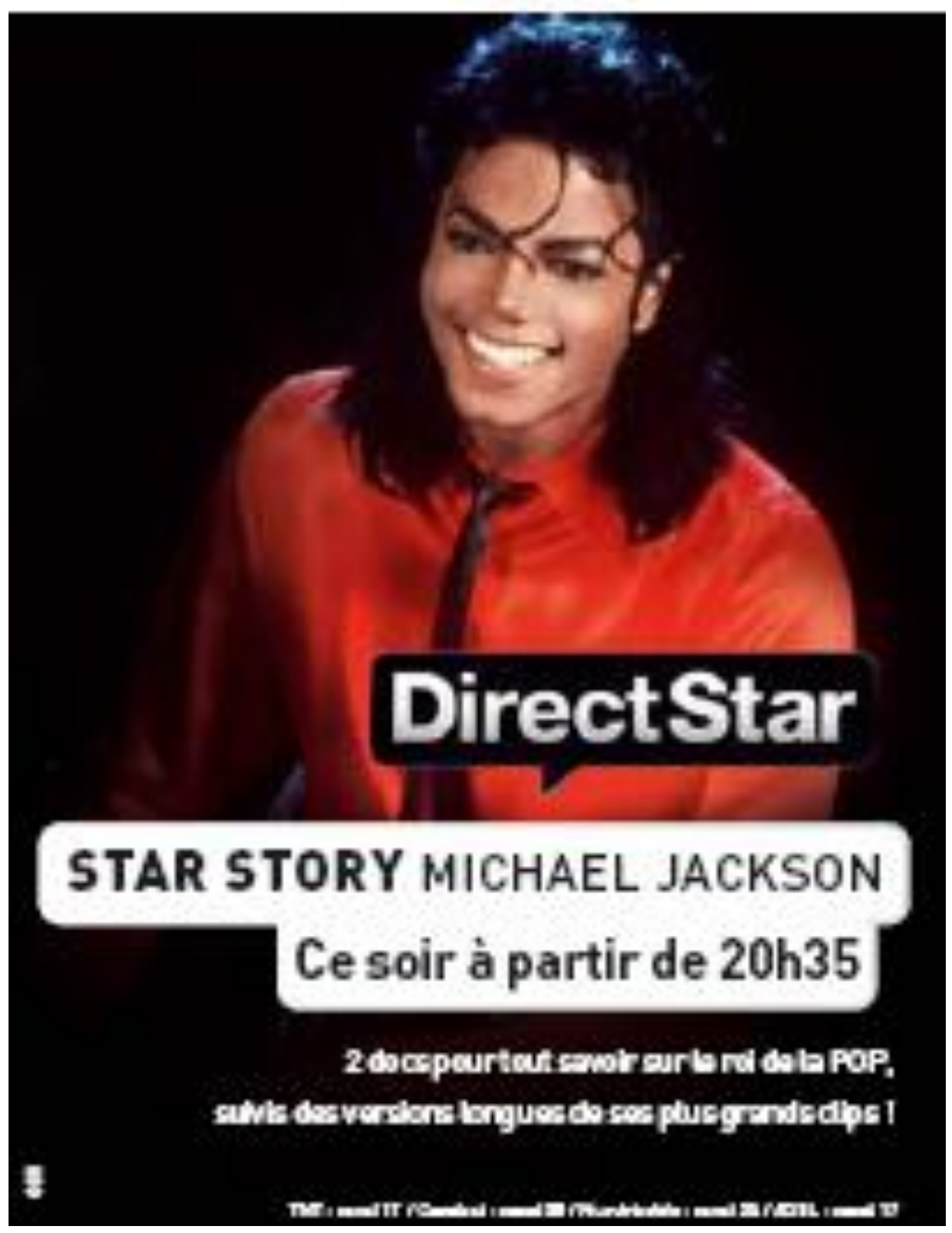

Contexto de produção e recepcão:

Enunciador - Direct Star

Destinatário - Telespectadores amantes do POP e do cantor

Lugar social - metrô de Paris

Objetivo - Persuadir o leitor a assistir o programa ou talvez persuadir novos telespectadores para o canal.

\section{Organizacão temático-representacional:}

Tipos de discurso - Mundo do expor: discurso teórico autônomo.

Tipos de representação - Representação conceitual simbólica, não há vetor, por isso não é narrativa. Simbólica por portar um atributo sugestivo através da cor de pele do Michael Jackson que retoma a ideia encontrada no texto verbal de contar a história do cantor que nasceu negro.

\section{Organizacão interacional:}

Vozes do discurso - Mundo do expor: discurso teorico autônomo. Não há marca de vozes ou verbos que indiquem tais vozes. Efeito argumentativo em: "roi du pop", "versions longues".

Modalização - Sem a marca do sujeito , o verbo "saber" no infinitivo, não é modal. Acredito que seja modalidade predicativa direta por não ter verbo modalizador como: poder, querer, ter.

Contato - Contato de oferta/exposição pois o participante não olha para o leitor.

Distância social - Plano médio - com corte - apresenta um grau de distância moderada com aproximação social, mas sem grande intimidade.

Atitude - Perspectiva subjetiva. Horizontalmente o ângulo é obliquo e nos distancia do participante. Verticalmente a foto foi tirada de um ângulo alto, um olhar de Deus. 
Modalidade - A cena não aparece contextualizada, pois o fundo é preto. A iluminação e o brilho coloca o foco sobre o cantor.

As cores fortes são vermelho e preto.

\section{Organizacão estrutural:}

Conexão e coesões - O primeiro texto aparece sem nenhum conector: "Star story Michael Jackson", nome do programa e do cantor. Em "2 docs pour tout savoir sur le roi de La pop, suivis des versions longues de ses plus grands clips! » Encontramos vírgula, ponto, «pour», «sur». Não há anáforas, $\mathrm{O}$ texto verbal é curto, não interfere na imagem. "2 docs" aparece abreviado provando não dar muitos detalhes ou explicações. No roda-pé do anúncio encontramos os canais correspondentes do direct 8 . Existe uma progressão temática em: Michael Jackson, le roi de la pop. « Ce soir à partir de $20 \mathrm{~h} 35$ » pode ser considerado como futuro próximo, encontrando uma temporalidade.

Valor da informação - A imagem aparece de forma centrada, as outras informações não são mais importantes do que a imagem central, mas são subordinados a ela. As informações reais (técnicas) aparecem na base do anúncio e estão em segundo plano. PS: um ano de morte do cantor

Saliência - A foto do cantor é apresentada em máxima saliência. O foco está no cantor e aparece superior às outras informações. As letras diminuem gradativamente: Direct star/Star Story Michael Jackson/ 2 docs pour tout savoir.../ TNT canal $17 \ldots$

Emolduramento - De forma centrada e imagem única, não existe conexão ou desconexão entre os elementos da imagem. Mas a imagem tem relação com o texto verbal. 
Apêncice B: Anúncios publicitários do tipo governamental e suas análises

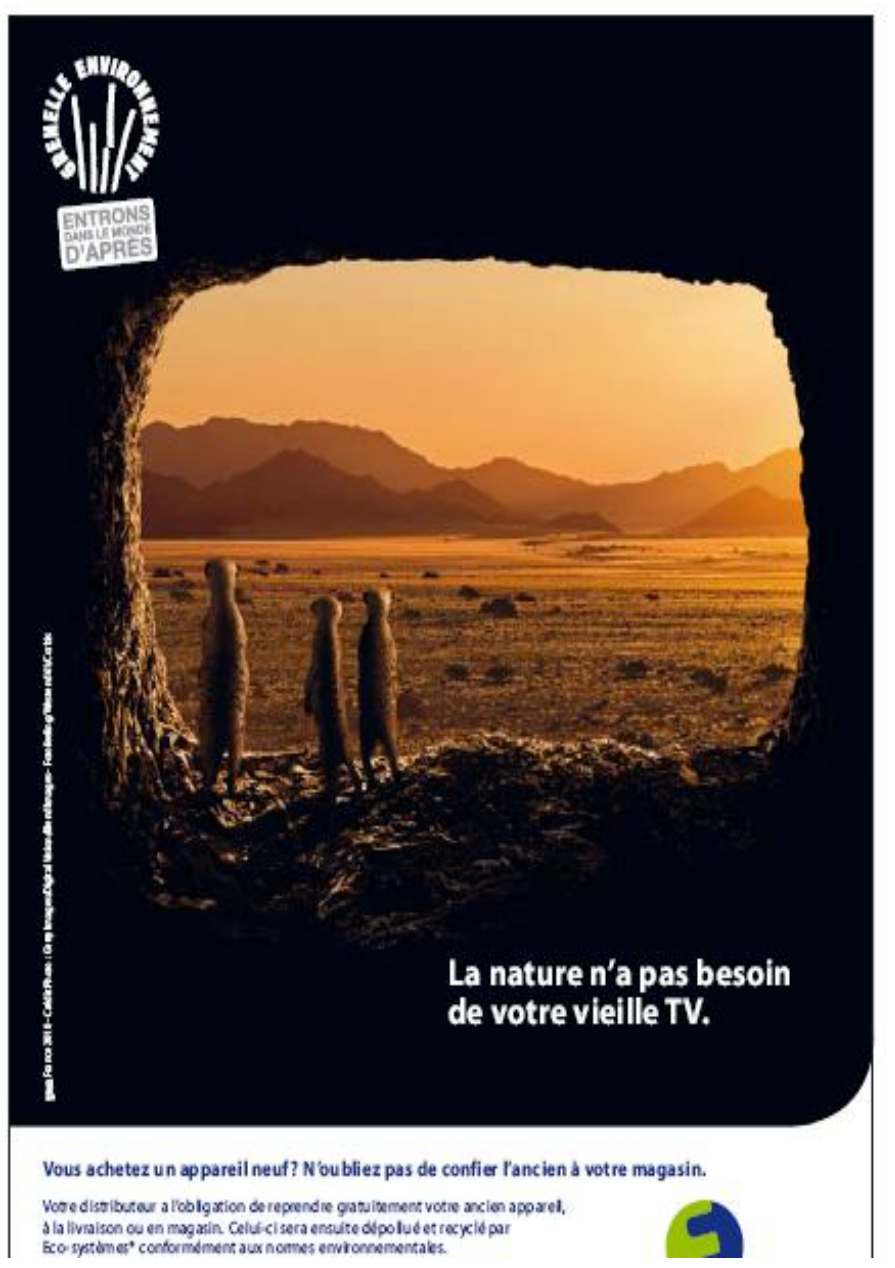

Análises para o modelo didático

Contexto de produção e recepção:
Enunciador - éco-système - collectons pour NE pás poluer Destinatário - usuário do metrô interessado no meio ambiente Lugar social - metrô de Paris

Objetivo - persuadir o público a não jogar o aparelho de TV velho na rua ou no lixo comum. Orientar o consumidor em deixar o velho televisor na loja, pois é parte da obrigação despoluir ou reciclar pelo éco-système.

\section{Organizacão temático-representacional:}

Tipos de discurso - discurso interativo implicado

Tipos de representação -. Representação conceitual analítica por sobrecarregar a imagem com atributos, pois cada personagem da imagem que parece uma TV possui um atributo.

\section{Organização interacional:}

Vozes do discurso - vous - discurso interativo implicado da ordem do expor e elle -discurso autônomo da ordem do expor.

Efeito argumentativo - "obligation", "la nature n'a pas besoin de votre vieille tv », «entrons dans le monde d'après »

Modalizaçao - epistêmica, valor de verdade, "La nature N' a pas besoin de votre vieille TV.»

Contato - demanda/interpelação

Distância social - plano geral, o que cria um distanciamento lógico, visto que os animais e a natureza virgem, não fazem parte do nosso contexto tecnológico.

Atitude - perspectiva objetiva através do ângulo frontal e representação da igualdade através do ângulo no nível do olhar.

Modalidade - cores fortes, contexto real, imagem naturalista A natureza com o objetivo da verdade: Cores fortes em tons marrom e amarelo que contextualizam a natureza intocável, logo a imagem se torna naturalista. A iluminação e o brilho tem foco sobre o que está fora da caverna. 


\section{Organizacão estrutural:}

Conexão e coesões - ponto final, anáfora (vieille, ancien), verbos no imperativo.

Valor da informação - polarizado, primeiro plano, à direita temos informação nova, informações reais na base, nas informações técnicas.

Saliência - máxima saliência, foco na natureza, ângulo no nível do olhar apresenta a igualdade, o tamanho do mundo diante das três criaturas e o convite do logotipo: "entrons dans le monde d'après"

Emolduramento - estabelece o percurso da leitura. De forma polarizada, o convite, seguido da natureza, como se fosse uma televisão e o slogan se conectam para dar o sentido total. 


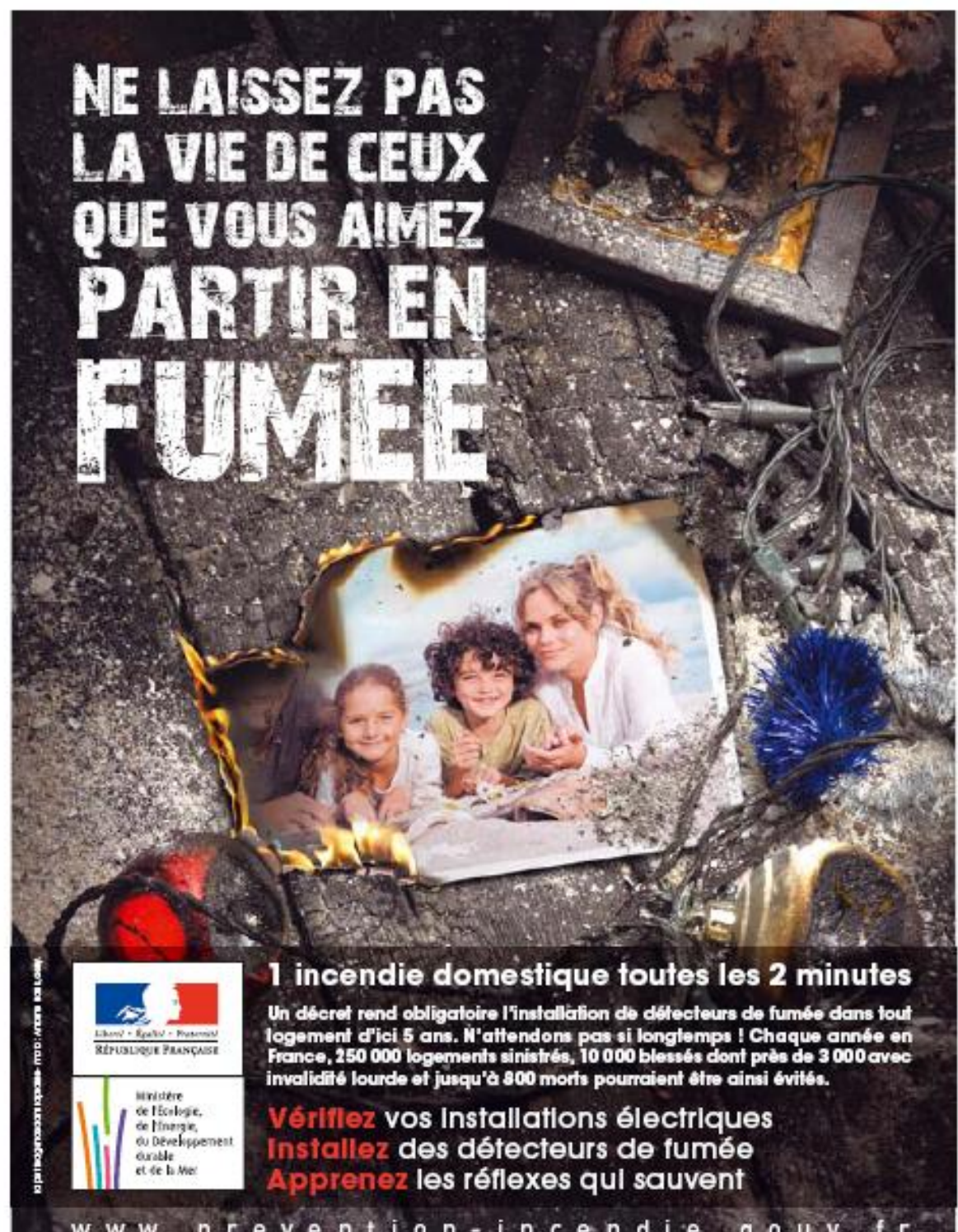

Contexto de producão e recepcão:

Enunciador - o governo francês

Destinatário - usuário do metrô e habitante de qualquer região da França

Lugar social - metrô de Paris

Objetivo - conscientizar a população de que os incêndios domésticos são comuns e que convencer os destinatários a verificar as instalações elétricas.

\section{Organizacão temático-representacional:}

Tipos de discurso - discurso interativo implicado da ordem do expor: vous. E autônomo da ordem do expor, "un décret..."

Tipos de representação -. Processo de reação transacional, visto que os integrantes da família da foto queimada lançam seus olhares para o leitor. Também existe a representação conceitual analítica por sobrecarregar a imagem com atributos, pois a imagem de uma família na foto e os fios de um pisca-pisca natalino nos apresenta uma cena comum familiar, o natal. E talvez seja a época de maior índice de incêndio.

\section{Organizacão interacional:}

Vozes do discurso - vous - discurso interativo implicado da ordem do expor e terceira pessoa em "un décret rend obligatoire" discurso autônomo da ordem do expor. Efeito argumentativo - jogo de palavras "partir en fumée". Além dos objetos incendiados, no plano não verbal.

Modalizaçao - epistêmica "Un décret rend obligatoire... » e deôntica, determinando, através do verbo no imperativo, as ações do cidadão francês « installez », « vérifiez », « apprenez »

Contato - demanda/interpelação

Distância social - se tivermos como base a fotografia, o plano é quase close-up, o que aproxima a cena do incêndio do leitor. 
Atitude - perspectiva objetiva através do ângulo frontal da fotografia e, apesar do ângulo alto pra a fotografia do chão, a família nos observa como em um ângulo no nível do olhar, mostrando maior envolvimento com o leitor.

Modalidade - cores fortes, contexto real, imagem naturalista Existe maior foco na fotografia que ainda queima e no objeto de natal de cor azul que não foi queimado.

\section{Organização estrutural:}

Conexão e coesões - ponto final, anáfora (incendie, fumez; ceux que vous aimez, domestique), verbos no imperativo.

Valor da informação - o texto verbal aparece de forma polarizada, em primeiro plano, no topo do anúncio. As informações reais e as obrigações dos cidadãos aparecem no texto descritivo.

Saliência - máxima saliência para o texto verbal que aparece no canto esquerdo e implica o leitor ao falar daqueles que eles amam. Em segundo plano encontramos a fotografia com o enfoque do fogo.

Emolduramento - polarizado. Máxima conexão entre os elementos: porta retrato, fios de um pisca-pisca, pedaço de objeto natalino e a fotografia ainda em fogo, estabelecem o percurso da leitura. 


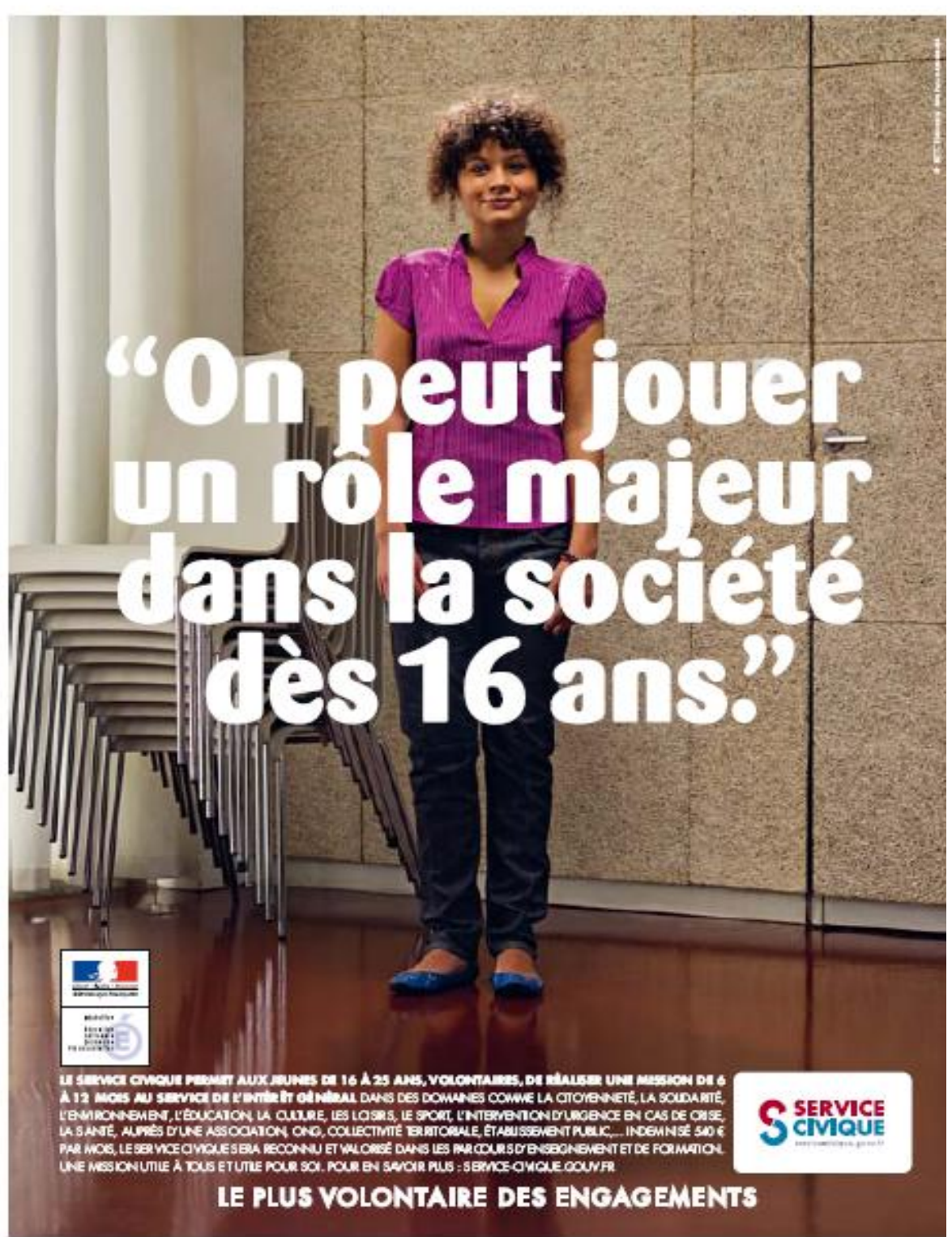

Contexto de producão e recepcão:

Enunciador - o governo e o serviço cívico

Destinatário - Público a partir dos 16 anos até os 25 anos

Lugar social - metrô de Paris

Objetivo - Persuadir o leitor usuário do metrô a fazer voluntariado.

\section{Organizacão temático-representacional:}

Tipos de discurso - relato interativo implicado da ordem do expor

Tipos de representação - Processo de reação transacional: pois o olhar da personagem se dirige ao leitor.

\section{Organizacão interacional:}

Vozes do discurso - on - Discurso interativo implicado da ordem do expor. A própria jovem fala, pois o slogan aparece entre aspas.

Efeito argumentativo: "plus volontaire".

Modalização - Indireta de valor deôntico, pois determina um agir em conjunto através do pronome "on". "On peut jouer un rôle majeur dans la société dès 16 ans »

Contato - De interpelação, pois a personagem olha pra o leitor implicando-o na ação.

Distância social - Na imagem a personagem aparece em plano geral, o que indica certo distanciamento por conta de toda a imagem. Talvez esse distanciamento seja proposital, pois o texto verbal objetiva a uma aproximação a partir do pronome.

Atitude - Horizontalmente a participante foi fotografada em ângulo frontal, o que, apesar do plano geral da distância social, indica um envolvimento ao observarmos seu posicionamento com relação ao seu dever de cidadã. 
Observando verticalmente, a foto está no nível do olhar, representando a igualdade entre o leitor e a participante.

Modalidade - A cena está contextualizada, a garota parece estar em uma sala, observamos a porta, as cadeira, a cortina, mas não conseguimos descobrir se é uma sala de alguma organização ou uma sala de reunião. A imagem é naturalista, apesar de não termos certeza da localização. Cores reais em grande foco, visto que a participante aparece em um plano equivalente ao plano do texto verbal, ocorrendo uma disputa ou talvez uma união daquela voz àquela menina.

\section{Organização estrutural:}

Conexão e coesões - um slogan, como uma fala, está entre aspas. O texto descritivo possui vírgula para conectar as informações. E "auprès de" e "dans" deixam o texto coeso em relação aos lugares indicados para procurar o voluntariado.

Valor da informação - O texto central e mais importante é o slogan. E, apesar de conter informações interessantes como o valor que o voluntário pode receber do governo, o mais importante é servir voluntariamente. E no sistema horizontal real $=$ embaixo $=$ vemos o site para informações e os logotipos de todos produtores do anúncio.

Saliência - Saliência máxima por causa do tamanho da participante conectada ao slogan que compete o espaço. O foco também é mínimo pois não existe outro elemento que dispute a atenção, observamos a sombra da menina no chão, o que nos indica luminosidade.

Emolduramento - existe conexão entre o slogan e a imagem, mas não podemos dizer que o emolduramento é máximo. 


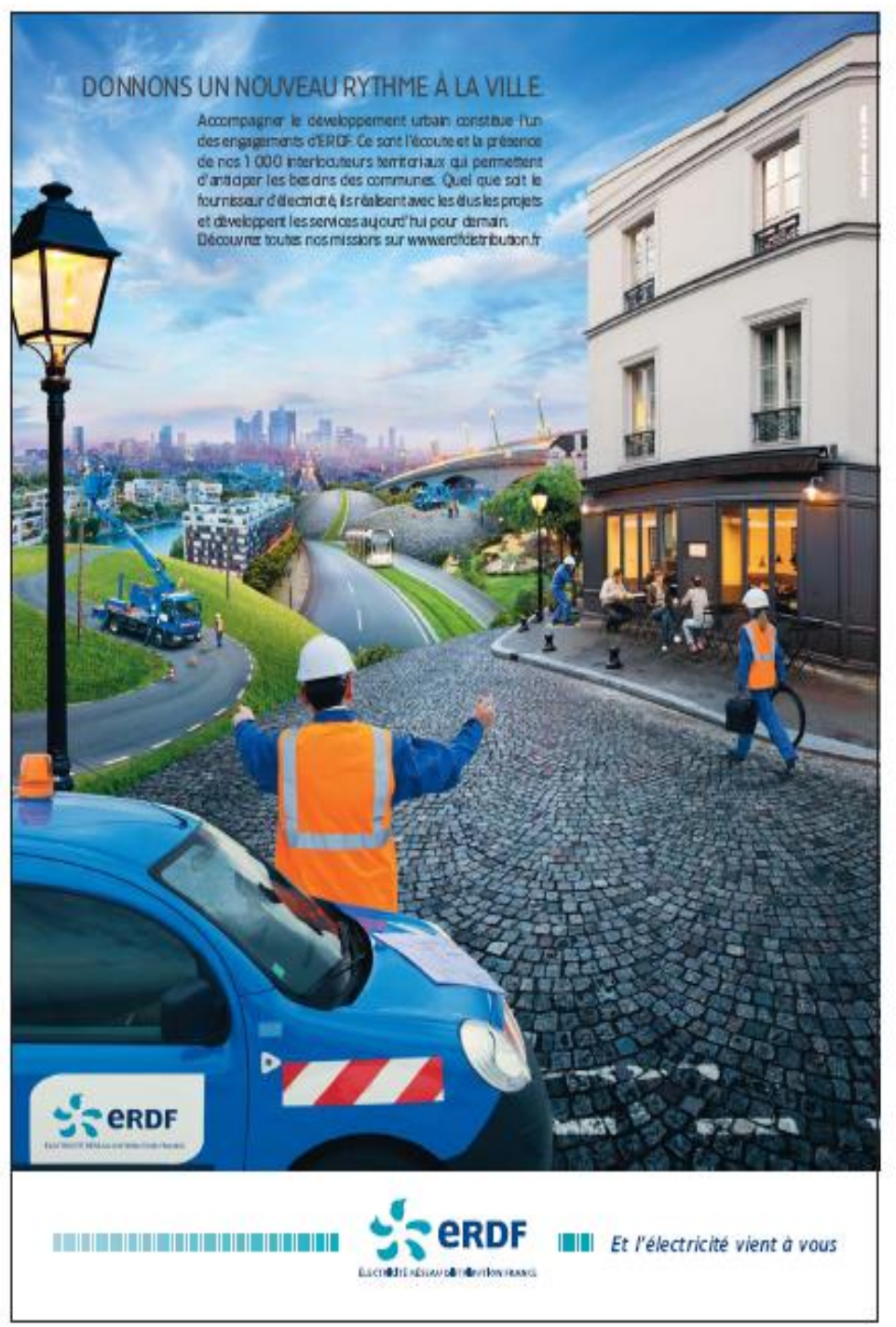

\section{Contexto de produção e recepcão:}

Enunciador - ERDF

Destinatário - usuário do metrô interessado no meio ambiente

Lugar social - metrô de Paris

Objetivo - apresentar o desenvolvimento urbano. O objetivo é informar.

\section{Organizacão temático-representacional:}

Tipos de discurso - Discurso interativo implicado (vous, nous)

Tipos de representação -. Representação conceitual simbólica por sobrecarregar a imagem com atributos, pois cada personagem com uniforme simboliza a ERDF. O uniforme é um atributo simbólico daquele trabalho. Além disso o caminhão também pode fazer essa representação. Também há representação narrativa circunstancial por causa dos gestos do trabalhador mais próximo do nosso campo de visão, pois ele gesticula para os dois lados para mostrar o trabalho de seus colegas.

\section{Organização interacional:}

Vozes do discurso - vous e nous - discurso interativo implicado da ordem do expor. Implica o leitor através do imperativo.

Efeito argumentativo - "l'éléctricité vient à vous" (intertextualidade religiosa)

Modalizaçao - deôntica, valor de obrigação,"donnons", "découvrez"

Contato - demanda/interpelação

Distância social - plano geral, o que cria um distanciamento lógico, visto que nos apresenta uma parte da cidade.

Atitude - perspectiva objetiva e representação da igualdade através do ângulo no nível do olhar.

Modalidade - cores fortes, cidade fictícia que tenta representar o contexto real do desenvolvimento das novas cidades no entorno na grande cidade 
que é vista ao fundo da imagem. Cores reais da empresa tentam apresentar uma imagem naturalista. Iluminação é o foco nos postes de luz.

\section{Organizacão estrutural:}

Conexão e coesões - ponto final, qui, que, et, sur anáfora (ville, urbain), verbos no imperativo e presente do indicativo.

Valor da informação - polarizado, primeiro plano encontramos o slogan seguidos do texto descritivo (o que não é comum nos anúncios), Os elementos

Saliência - cores reais, saliência máxima, Luzes nos postes em evidência.

Emolduramento - o slogan e a imagem se conectam. Mas a imagem sozinha faz com que se crie hipóteses, pois sabemos que se trata da companhia de luz, mas não temos certeza do que a companhia ERDF nos apresenta. 


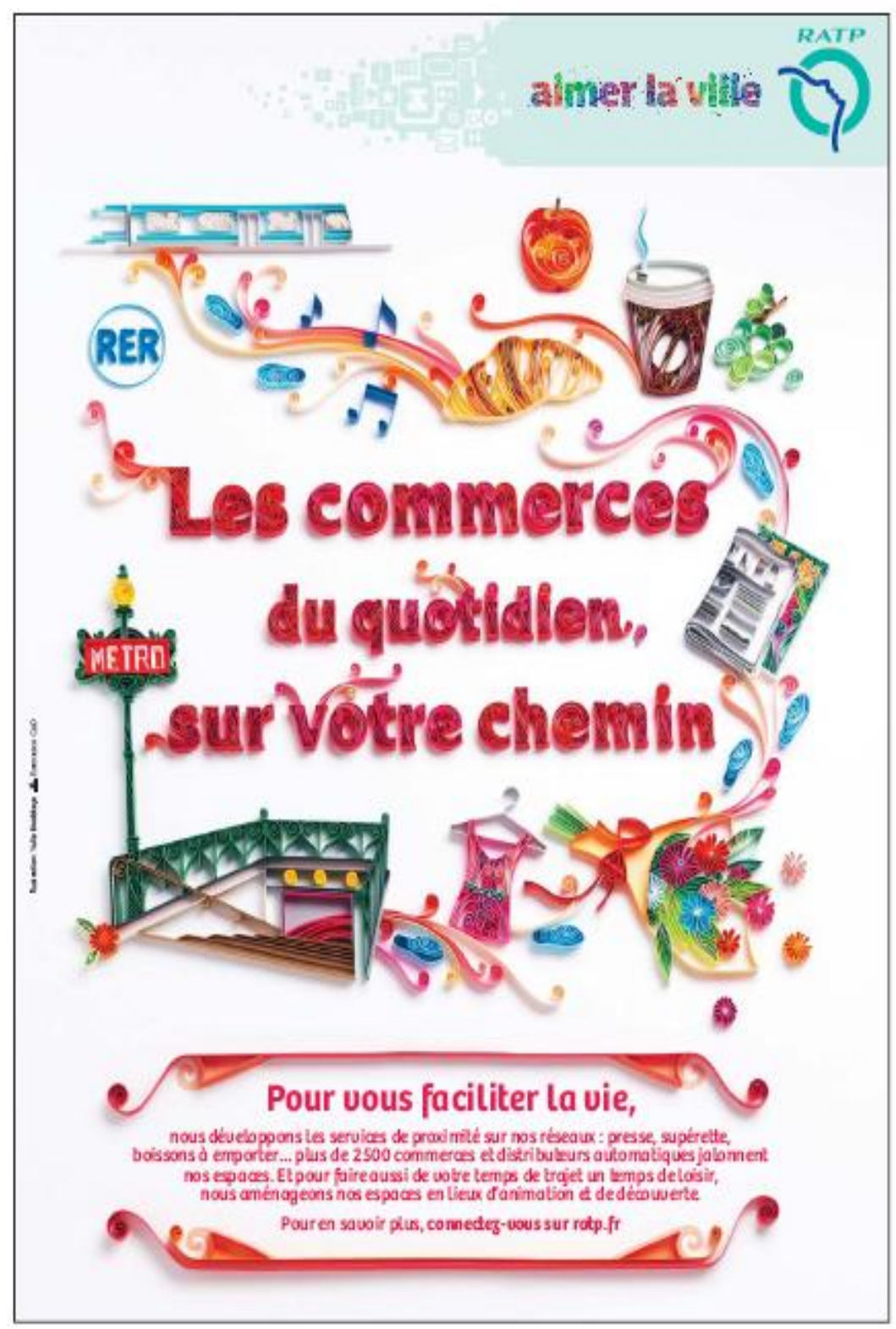

\section{Contexto de producão e recepcão:}

Enunciador - RATP

Destinatário - Público variado que utiliza o metrô de Paris

Lugar social - metrô de Paris

Objetivo - Apresentar os estabelecimentos encontrados nos metrôs e convencer o leitor das facilidades que eles proporcionam.

\section{Organizacão temático-representacional:}

Tipos de discurso - discurso interativo implicado da ordem do expor

Tipos de representação - organização temático-representacional não verbal conceitual é a representação sem vetor, ou seja, trata-se de participantes ou objetos pertencentes a um grupo específico ou objetos simbólicos que são realçados pelo exagero do tamanho.

\section{Organizacão interacional:}

Vozes do discurso - vous - Discurso interativo implicado da ordem do expor. E da ordem do narrar ao explicar o que fizeram no metrô "nous dévéloppons.."

Efeito argumentativo - "plus de 2500 commerces", eficiência do metrô.

Modalização - lógica, pois os comércios estão no metro para facilitar a nossa vida.

Contato - De exposição, pois não existe nenhum personagem que implique o leitor e o slogan apenas apresenta o que podemos encontrar no nosso caminho.

Distância social - Na imagem não há personagem ou algum plano de imagem, Existem diversas figuras espalhadas em um fundo vazio.

Atitude - objetiva, como as placas de trânsito, os elementos aparecem para informar ao usuário da suas existências.

Modalidade - Apesar dos objetos serem desenhos, as cores são reais e o art-nouveau dão destaque e conexão aos elementos da imagem. 


\section{Organização estrutural:}

Conexão e coesões - "et", pour, vírgula. Coesão verbal no presente do indicativo, coesão nominal: anáfora ("chemin", "trajet", "lieu”)

Valor da informação - o slogan é central, mas os elementos estão polarizados e à direita encontramos os objetos que podem ser lidos como novidade, pois à esquerda encontramos elementos já conhecidos: RER e

Metro..

Saliência - cores reais e metro em destaque, maior que os outros elementos salientam o objetivo do anúncios. Não existe saliência por luminosidade, pois os elementos aparecem como em um desenho animado.

Emolduramento - o slogan é central, mas todos os elementos aparecem maximamente conectados pelas folhas do art nouveau, o anúncio consegue esta conexão mesmo sem um fundo real, pois as cores dos elementos são reais e o art nouveau é real. 


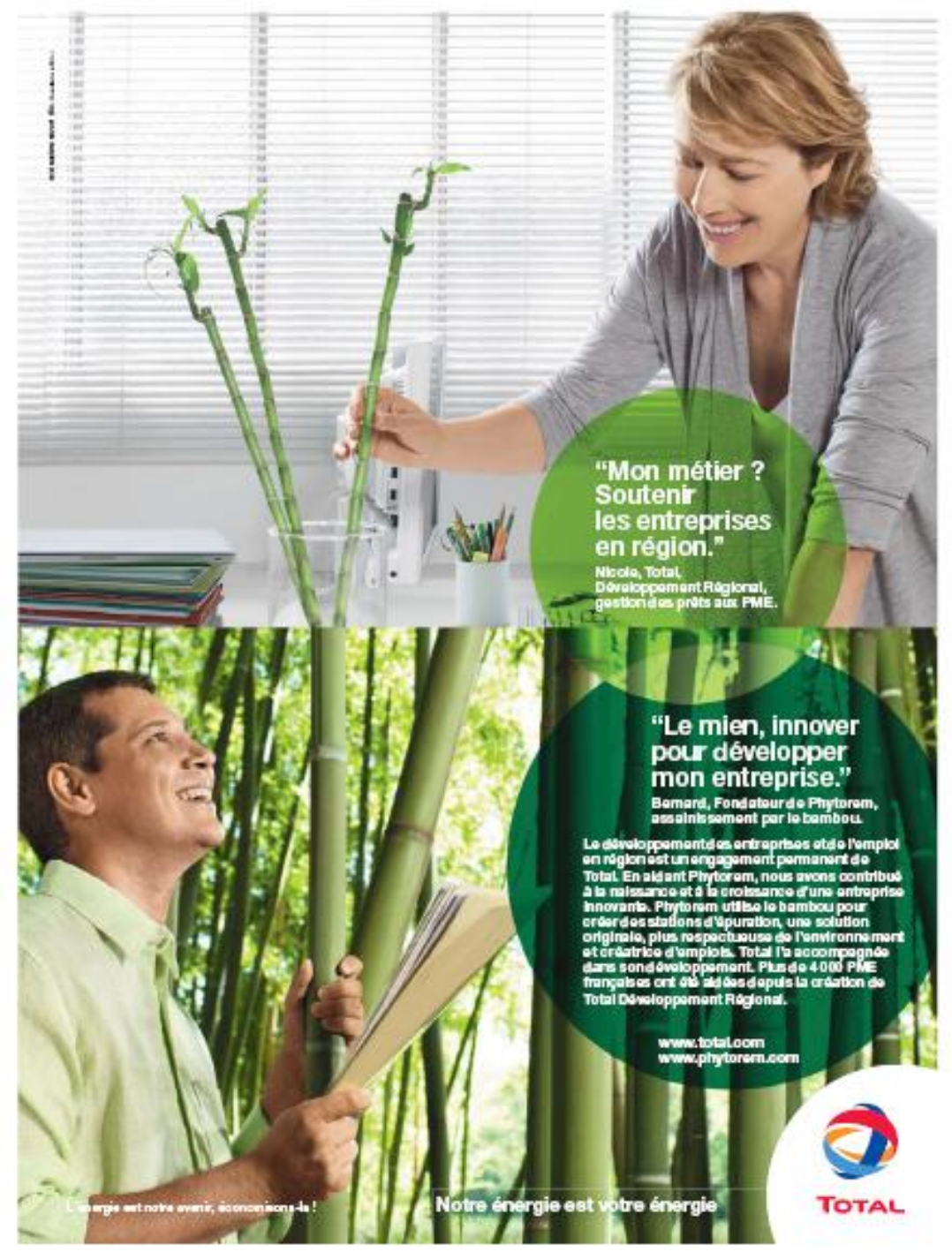

Contexto de producão e recepcão:

Enunciador - Total (energia) e phytorem

Destinatário - a todos que fazem uso da energia e mais especificamente aos donos de empresas

Lugar social - metrô de Paris

Objetivo - Informar o leitor das novas formas de energia em desenvolvimento

\section{Organizacão temático-representacional:}

Tipos de discurso - relato interativo implicado do mundo do narrar

Tipos de representação - transacional: processo de reação vetorial quando um ator olha para outro ator. Transacional, pois apesar de não olharem para o fenômeno, ambos formam vetores com os braços, ao indicar as descobertas da produção de energia. Só conseguimos entender a imagem através do texto verbal

\section{Organizacão interacional:}

Vozes do discurso - jê, relato interativo implicado, E a terceira pessoa, mundo do narrar autônomo. Comprador e empregado interagem na imagem.

Efeito Argumentativo - "notre énergie est votre énergie » (dito popular).

Modalizaçao - epistêmica «mon métier est... »

Contato - exposição

Distância social - plano médio

Atitude - perspectiva subjetiva através do ângulo oblíquo e representação da igualdade através do ângulo no nível do olhar.

Modalidade - cores fortes, contexto real, imagem naturalista A verdade representada na imagem: Cores fortes em tom verde o que evidencia o 
produto primário da energia. A imagem pode ser considerada naturalista contexto real, pois em ambos relatos podemos identificar os personagens que aparecem como se fossem reais.

\section{Organização estrutural:}

Conexão e coesões - ponto final, vírgula, "et", "pour" (finalidade). Anáfora de "mon métier" pelo pronome "mien", repetição de "entreprise", coesão nominal de construção de valor em "soutenir" e "dévélopper".

Valor da informação - foco no lado direito, para informar o leitor sobre as novas energias. No roda-pé da página encontra-se duas frases que incluem o leitor sobre a economia da energia para o nosso futuro e a nossa energia é a sua energia.

Saliência - a saliência não é dada por uma maior luminosidade, mas as cores aparecem de forma real. A mulher aparece primeiramente, de acordo com a linha da leitura, pois a escolha da energia deve começar pelas empresas. Já o homem que aparece na parte inferior, apresenta um trabalho que já está sendo desenvolvido. Basta a empresa fazer uso desta energia, o que é evidenciado pela continuidade do bambu do plano inferior para o plano superior.

Emolduramento - De forma polarizada, todos os elementos estão conectados, mesmo que estejam em outros contextos, é o que acontece som a energia que não fica parada em um só lugar. A imagem deve estar conectada ao verbal para total compreensão. 
Apêndice C: Anúncios publicitários do tipo transporte e suas análises

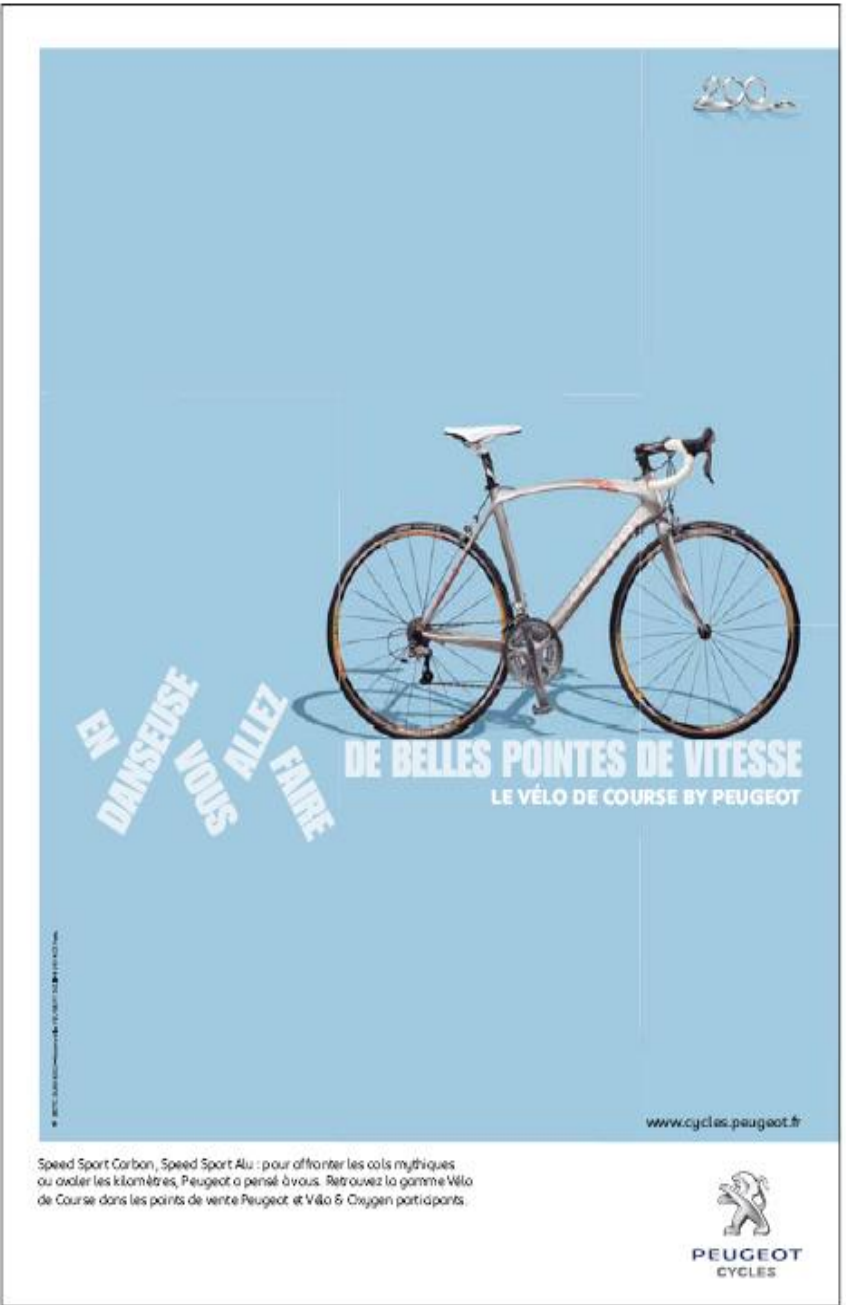

\section{Contexte de production - contexte sociosubjectif}

Enunciador: Peugeot

Destinatario: alguém que se interesse por bicicleta, usuário do metrô..

Objetivo: persuadir « um corredor » a comprar uma bicicleta

Contexto de recepção : o destinatário deve correr em competições, o que só é descoberto através do texto descritivo.

\section{Organizacão temático-representacional:}

Tipos de discurso - discurso interativo implicado do mundo do expor

Tipos de representação - conceitual classificacional, pois não possui um vetor, por isso não pode ser narrativa. $O$ participante possui uma classificação de um grupo, como os ciclistas. (Atenção, pois se pensarmos no que aconteceu antes da foto e conectarmos a bicicleta ao desenho do texto verbal, podemos dizer que houve uma ação: o movimento do guidon)

\section{Organização interacional:}

Vozes do discurso - vous, discurso implicado da ordem do expor.

Efeito Argumentativo - voz da LE (by) e a disposição do texto.

Modalizaçao - epistêmica, lógica: ao ter a certeza em "vous allez faire de belle pointes de vitesse"

Contato - exposição

Distância social - plano geral, menor envolvimento, também não tem um fundo real. Fundo azul $=$ ar puro.

Atitude - impessoalidade, pois a perspectiva é subjetiva e mostra a bicicleta de lado. Mas o objeto está no altura do olhar, o que representa igualdade com o leitor.

Modalidade - cores claras, o fundo não é real. Logo, a imagem não é naturalista. A cor azul pode representar a limpeza, o ar puro. 


\section{Organizacão estrutural:}

Conexão e coesões - não há conector no slogan, mas há no texto descritivo "pour"., "ou" e dois pontos. Uso do infinitivo, verbo no presente, expressão "em danseuse", vocabulário ciclista, por isso adotou várias palavras não compreendidas por quem não pratica o ciclismo/corrida.

Valor da informação - a bicicleta aparece em primeiro plano e sozinha em um fundo azul. Esse fundo azul não é sexista. A bicicleta aparece primeiro, por isso não pode haver a inversão do slogan, ou seja, o slogan foi feito para aquela imagem. Quando o slogan aparece em primeiro plano, quer dizer que poderíamos mudar por outra bicicleta, pois o texto verbal não pertence a imagem.

Saliência - não há jogo de luz, apesar de observarmos a sombra da bicicleta. Como ela é única, sua saliência é máxima e não precisa de brilho. Emolduramento - A imagem precisa se conectar ao texto, mas não há e não precisa de outros elementos para conexão.

\section{Estratégias do produtor:}

A multimodalidade do texto verbal que nos apresenta o movimento do guidão,

Vocabulário de ciclista : .En danseuse vous allez faire de belles pointes de vitesse".

En danseuse $=$ manière de rouler le vélo $\quad$ Pointe de vitesse $=$ vitesse élévée

Detalhes dos destinatários aparecem com mais clareza no texto descritivo.

"Speed Sport Carbon, Speed Sport Alu: Pour affronter les cols mythiques ou avaler les kilomètres $(. .)$.
Affronter $=$ ataque, défi
Cols $=$ passage étroit entre deux

montagnes 


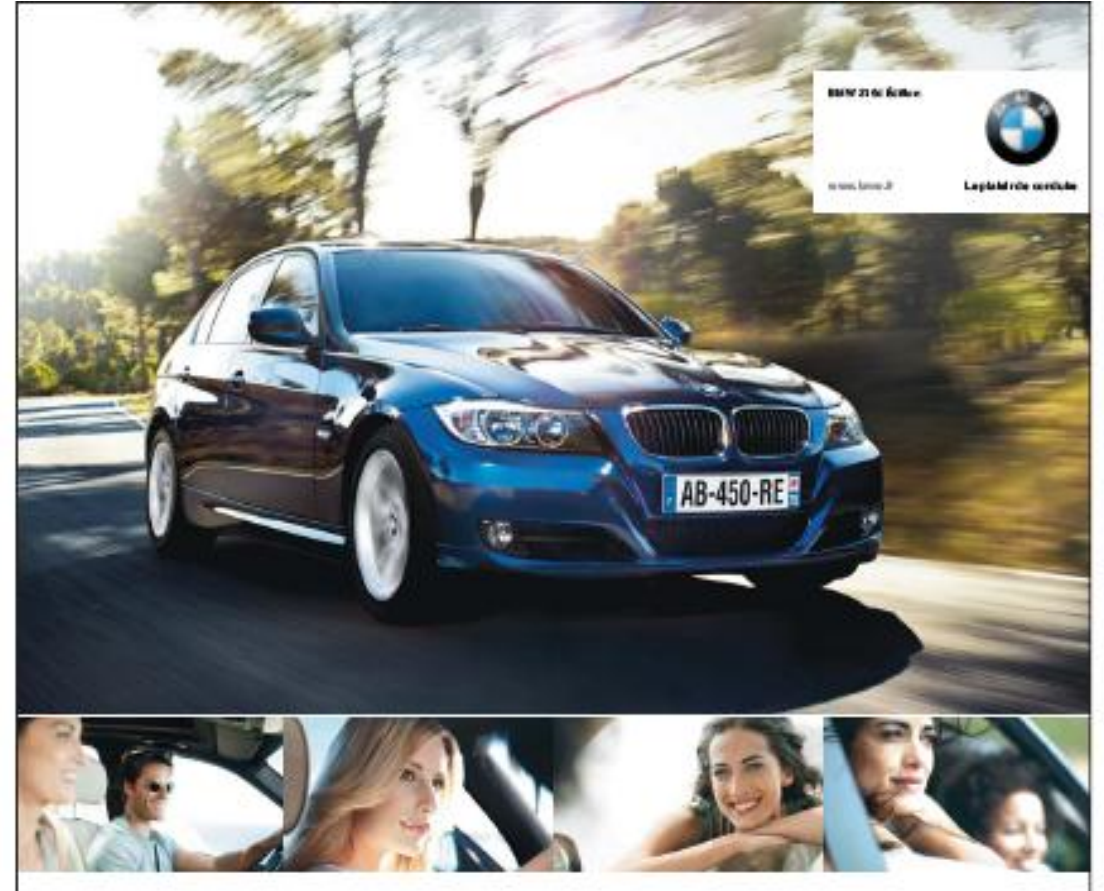

\section{LA JOIE EST IRRÉSISTIBLE.}

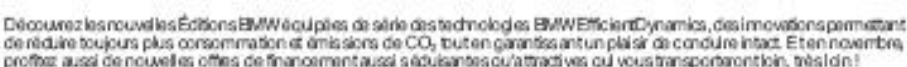
EN NOVEMBRE, DÉCOUVREZ CHEZ VOTRE CONCESSIONNARE EN NOVEMBRE, DECOUVREZ CHE

BMW EfficientDynamics

Nouvelle BMW $27900 \mathrm{C}$ BMW EfficientDynamics

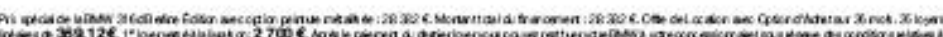

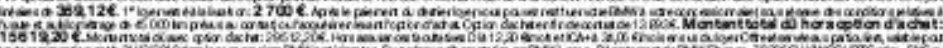

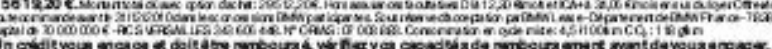

\section{Contexte de production - contexte sociosubjectif}

\section{Enunciador - BMW}

Destinatário - usuário do metrô que possa estar interessado em comprar um carro.

Objetivo - persuadir o leitor a comprar o carro

\section{Organizacão temático-representacional:}

Tipos de discurso - discurso interativo implicado do mundo do expor

Tipos de representação - conceitual, pois não possui um vetor, observamos o carro em uma estrada. Mas também podemos encontrar a representação de reação não transacional, pois os participantes olham algum fenômeno que não podemos identificar.

\section{Organização interacional}

Vozes do discurso - Vous et $3^{\mathrm{a}}$ pessoa, relato implicado da ordem do expor e discurso implicado da ordem do expor.

Efeito argumentativo - "joie", "irrésistible", "nouvelles »

Modalizaçao - apreciativa, deôntica (découvrez)

Contato - oferta/exposição

Distância social - plano geral, menor envolvimento, fundo real. Fotos pequenas, proximidade da foto, rostos.

Atitude - $\mathrm{O}$ carro aparece em primeiro plano, em imagem naturalista (estrada e mata verdadeiras). O ângulo horizontal que mostra o envolvimento está obliquo, o que distancia o carro do leitor. Mostra que o carro faz parte do mundo de outras pessoas. Em seguida, no centro da imagem encontramos 4 fotos estando nelas 5 mulheres e um homem. Somente o homem é identificado como condutor.

Modalidade - cores reais, personagens reais. 


\section{Organização estrutural:}

Conexão e coesões - verbo no presente e no imperativo. Pronome "votre concessionnaire" como se o destinatário já fosse um comprador de BMW. Organizador temporal, vírgulas e ponto final para a coesão. O verbo "découvrez" aparece duas vezes = anáfora. Na parte inferior da imagem encontramos os dados sobre o carro. Estratégias verbais: « la joie est irrésistible » - faz uso da afirmação, como algo lógico e real. Adjetiva a "alegria" como "irresistível". Ou seja, a alegria aparece acima e é irresistível ao mostrar 4 pessoas sorrindo, seja dentro do carro ou apoiadas na janela. As outras duas aparecem com serenidade.

Valor da informação -

Saliência - não há jogo de luz, apesar de observarmos a sombra da bicicleta. Como ela é única, sua saliência é máxima e não precisa de brilho. Emolduramento $\mathrm{O}$ preço aparece em destaque entre os textos verbais pelo fundo cinza. Aqueles que estiverem interessados lerão as letras menores, onde encontramos as opções de financiamento. Os valores estão todos em negrito, dando importância.

\section{Estratégias:}

Em letras pequenas encontramos outras informações do carro. Como o consumo e a emissão de $\operatorname{co} 2$ = conexão com o fundo verde.

No terceiro texto verbal, encontramos o mês em que as novas edições do carro estarão disponíveis. Aparecem em segundo destaque entre os textos verbais.

Ultima frase em negrito " un crédit vous engage ET doit être remboursé, vérifiez vos capacites de remboursement avant de vous engager".

Esta responsabilidade aparece em pequena fonte, não trata da responsabilidade do produtor, mas do destinatário. 


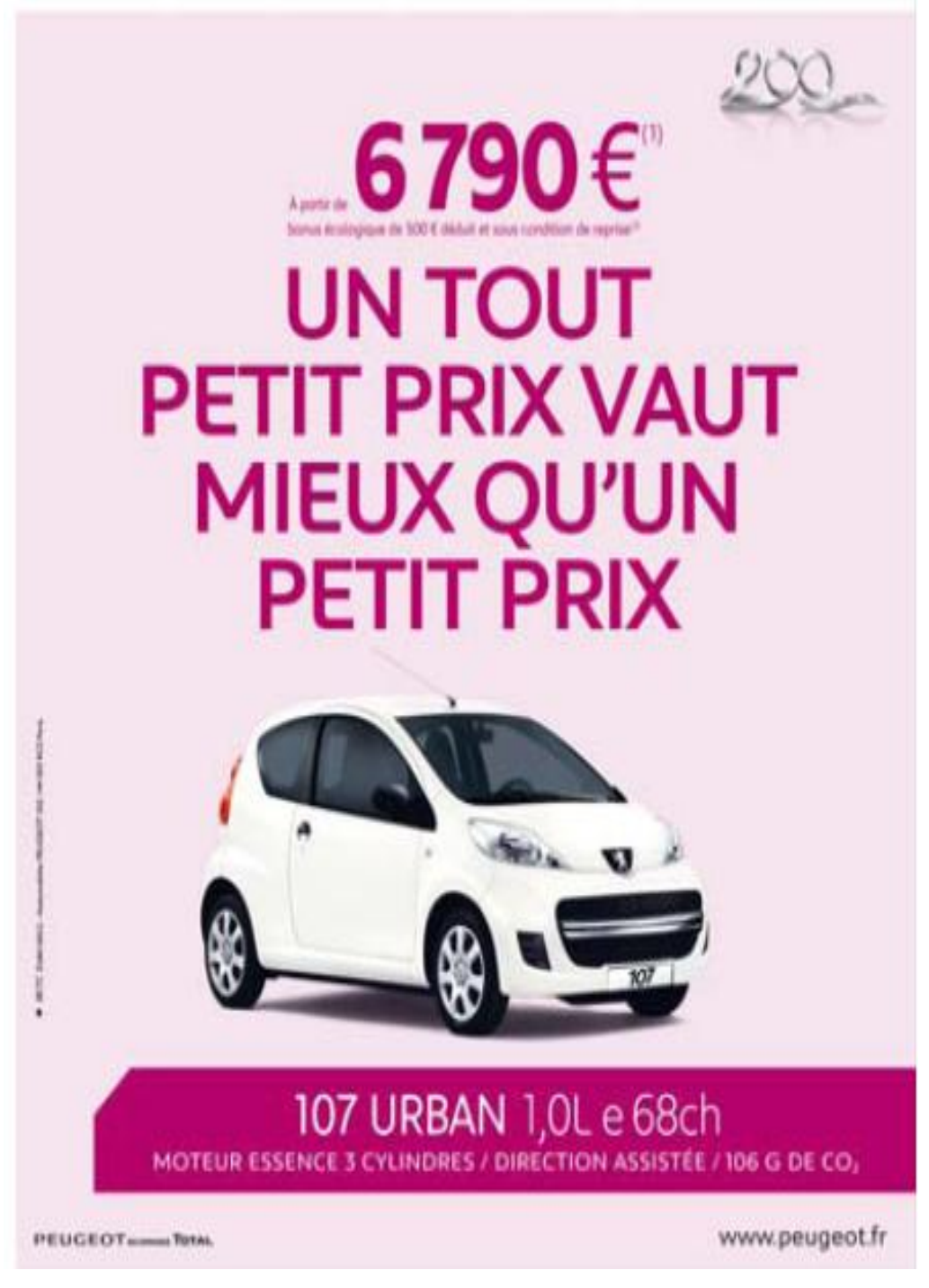

Contexte de production - contexte sociosubjectif

Enunciador - Peugeot

Destinatário - usuário do metrô que possa se interessa em comprar um carro. Em hipóteses, o destinatário é mulher com um salário baixo.

Objetivo - persuadir o leitor a comprar o carro.

\section{Organização temático-representacional:}

Tipos de discurso - discurso interativo implicado do mundo do expor

Tipos de representação - conceitual, pois não possui um vetor, observamos o carro em um fundo cor de rosa. O carro é pequeno e pode portar um atributo - fácil de dirigir.

\section{Organizacão interacional:}

Vozes do discurso $-3^{\text {a }}$ pessoa, relato implicado da ordem do expor.

Efeito argumentativo- jogo de palavras "un tout petit prix vaut mieux.... »

Modalização - apreciativa e epistêmica.

Contato - exposição/oferta. Não há interpelação.

Distância social - plano geral, menor envolvimento, fundo vazio.

Atitude - O preço do carro aparece em primeiro plano, mostrando-se mais importante que o carro. A imagem não é naturalista, mas pode ser sexista.

Modalidade - cores reais, personagens reais.

Organização estrutural:

Conexão e coesões - sem conector, slogan: comparação, repetição/anáfora/gradação: tout petit prix e petit prix.

Valor da informação - slogan em primeiro plano, por isso o valor é mais importante na hora da compra. O carro aparece em segundo plano. Cores rosa e carro pequeno indicam que o destinatário possa ser uma mulher. $\mathrm{O}$ valor inferior a um carro grande pode gerar uma hipótese de que a mulher ganha menos do que o homem.

Saliência - Evidenciar o preço do automóvel - o consumidor pagará pouco "6, 790". O foco está no preço e em seguida no carro. 
Emolduramento $\mathrm{O}$ preço aparece em destaque, as anáforas dos preços podem estar conectadas com a imagem, pois o carro é tão pequeno quanto

o preço. Mas o texto verbal e a imagem separadas não podem fazer sentido, precisam estar unidos. 


\section{COMME FABRICE, FAITES UN GROS COUP CHEZ RENAULT}
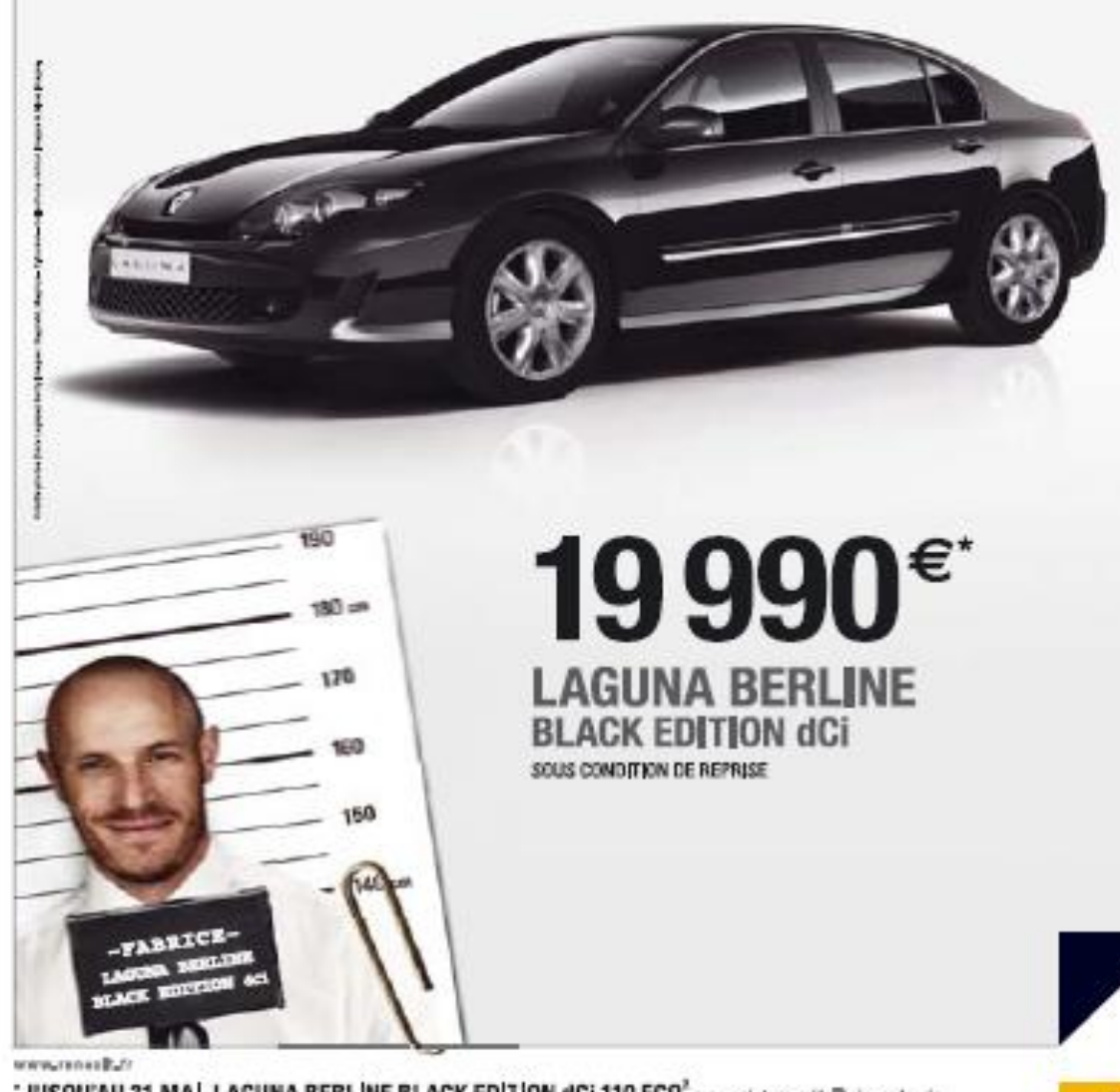

120

150 T

\section{LAGUNA BERLINE}

BLACK EDITION dCi

SOUS CSNOTKN DE RERTISE

\section{Contexte de production - contexte sociosubjectif}

\section{Enunciador: Renault}

Destinatário: usuário do metrô - que poderia se interessar em comprar um carro.

Objetivo: persuadir o leitor a comprar o carro (destinatário masculino)

\section{Organizacão temático-representacional:}

Tipos de discurso - interativo implicado

Tipos de representação - conceitual: carro grande, hipótese de poder. transacional: processo de reação vetorial quando o ator olha para o leitor. O participante implica o leitor nessa documentação (clipe).

\section{Organização interacional:}

Vozes do discurso - vous - discurso interativo implicado da ordem do expor.

Efeito argumentativo - "faites un Gros coup" (frase já dita - intertexto) e traz efeito; "Black edition" retoma LE (inglês).

Modalizaçao - epistêmica : comparação para dar a certeza de que Fabrice fez um bom negócio. Apreciativa: o bom negócio.

Contato - exposição/oferta e, posteriormente, demanda/interpelação

Distância social - plano geral com fundo vazio e não real, na imagem maior. E, na imagem menor, plano fechado (close-up), o que diminui a distância com o leitor.

Atitude - perspectiva subjetiva através do ângulo oblíquo do carro e representação da igualdade através do ângulo no nível do olhar. Pode ser objetiva na parte inferior da imagem pequena, pois o ângulo é frontal, o que implica o leitor. 
Modalidade - cores frias, contexto não real, imagem que tenta ser um documento, mas não é. As cores podem trazes a seriedade (preto, branco, cinza) em um senso comum. Iluminação e brilho sobre o carro (enfoque).

\section{Organizacão estrutural:}

Conexão e coesões - comparação, vírgula, verbo no imperativo. Texto descritivo: temporalidade e conexões entre vírgulas.

Valor da informação - centrado, o elemento mais importante aparece no centro do anúncio. Apesar da foto no canto da página, não considero como polarizado. primeiro plano, à direita temos informação nova, informações reais na base, nas informações técnicas.

Saliência - $\mathrm{O}$ carro aparece em evidência, tamanho grande, único objeto na imagem maior. $\mathrm{O}$ plano superior é o carro, em segundo lugar aparece o preço.

Emolduramento - Conexão marcada pelo clipe - une a foto de um documento pessoal à foto do carro (como se fosse uma compra).

\section{Estratégia do enunciador (Renault X Peugeot):}

Colocar a publicidade em um jornal gratuito de grande circulação, além do mesmo ser publicado na internet. Evidenciar o preço do automóvel - o consumidor pagará "19,900". O título "COMME FABRICE, FAITES UN GROS COUP CHEZ RENAULT" está no topo da publicidade e tenta persuadir a partir de uma comparação entre o leitor e Fabrice, além de salientar o "gros coup", ou seja, o bom negócio a que estão sujeitos.

ângulo da imagem - proposital para a visualização do tamanho do carro

Persuadir um público específico a partir da foto do Fabrice - público masculino - Altura do Fabrice (quase 1m80), gravata (executivo)

A cor predominante do anúncio - preto, branco e cinza - em um senso comum está direcionada à seriedade

Diferença das cores - identificação do consumidor - "implícita"
Diferença dos preços - "diferença de salários"

O momento do valor/preço do carro

Renault: primeiramente, encontra-se a informação do bom negócio de Fabrice (chamada), em seguida encontramos a foto do carro (imagem principal) e, então, o valor (finalização) - relevâncias organizadas: "un tout petit prix" X "un gros coup". 


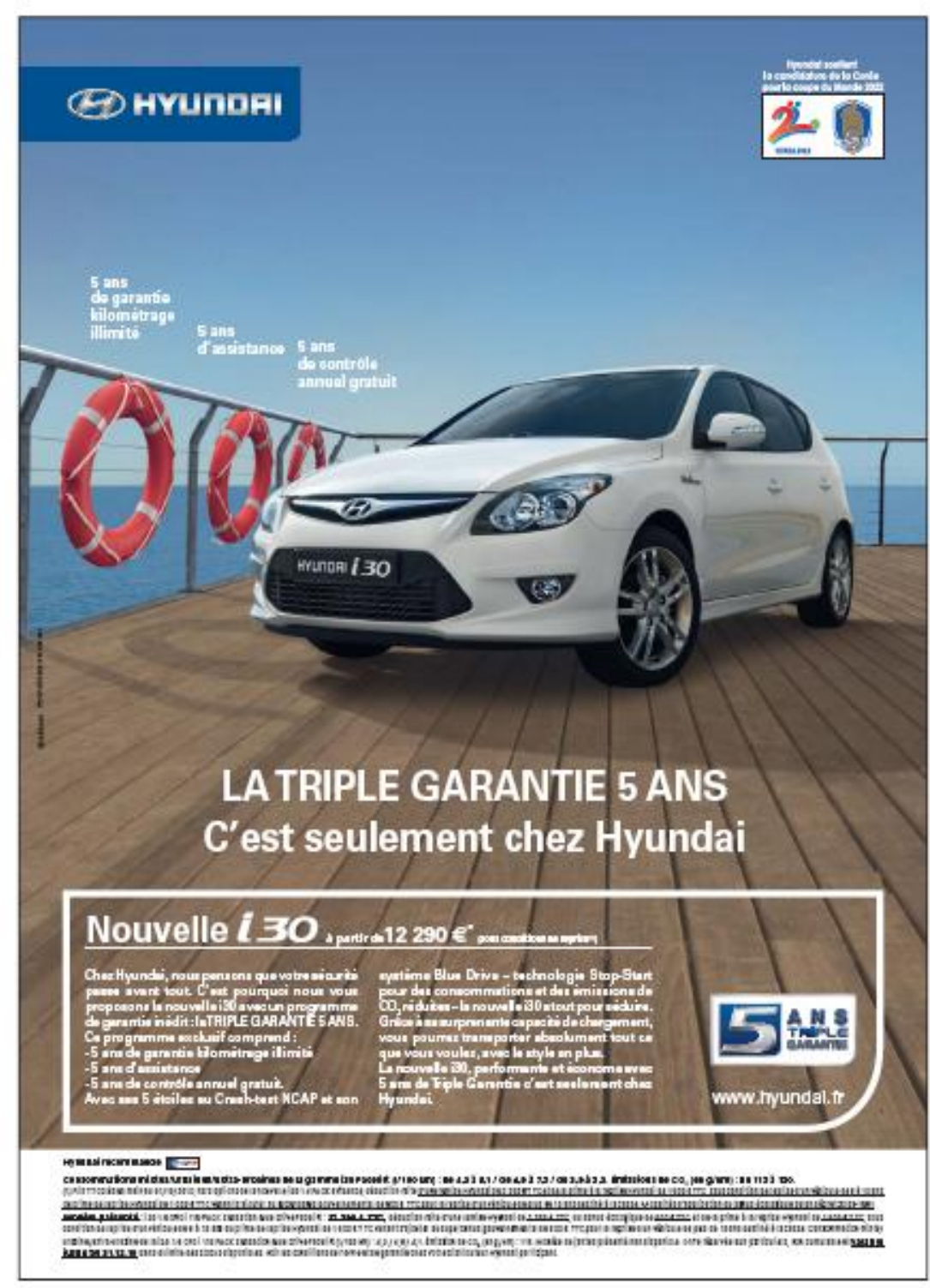

\section{Contexte de production - contexte sociosubjectif}

Enunciador: Hyundai

Destinatário: usuário do metrô - que poderia se interessar em comprar um carro.

Objetivo: persuadir o leitor a comprar o carro

\section{Organização temático-representacional:}

Tipos de discurso - mundo do expor autônomo no slogan. (texto descritivo "nous" e "vous" o que indica um discurso interativo implicado)

Tipos de representação - conceitual: carro, boia, mar. hipótese de férias, segurança e descanso ao pegar a balsa.

\section{Organizacão interacional:}

Vozes do discurso - vous - discurso interativo implicado da ordem do expor.

Efeito argumentativo - gratuit, seulement chez (modalizadores causam efeito).

Modalização: - epistêmica, valor de verdade sobre a tripla garantia que acontece somente na Hyundai.

Contato - exposição/oferta

Distância social - plano geral com fundo real.Carro em ângulo oblíquo, distanciamento. Plano geral, distanciamento.

Atitude - perspectiva subjetiva através do ângulo na altura do olhar, o carro é representação da igualdade.

Modalidade - cores reais, contexto real, iluminação aparentemente real. Mas pode se notar um enfoque na lanterna direita (colada à boia), talvez para evidenciar as três garantias que não aparecem com texto verbal grande. 


\section{Organizacão estrutural:}

Conexão e coesões - sem conectores, verbos no presente. No texto descritivo, em tópicos aparecem as qualidades do carro. Coesão verbal em presente e futuro "vous pourrez apporter tous que vous voulez". O fato de poder levar tudo por causa da capacidade do carro conecta-se à capacidade de transporte de uma balsa - ou indo mais longe, de um navio, onde não temos limite de peso. "La triple" está conectada às boias, pois visualizamos 3 boias. Sobre cada boia encontramos 5 anos de garantia - lembrando que o símbolo da boia é de sobrevivência. Logo, a garantia que tem 5 anos de sobrevivência aborda três pontos:

Valor da informação - centrado, o elemento mais importante aparece no centro do anúncio. Do lado esquerdo encontramos as três garantias, como se trata de um carro oriental, seriam as novidades (que em um carro ocidental, apareceria do lado direito).

Saliência - O carro aparece em evidência, tamanho grande, único objeto na imagem maior. O plano superior é o carro, em segundo lugar aparecem as boias que também são elementos importantes e estão em saliência, não pelo tamanho, mas pela cor vermelha..

Emolduramento - Conexão marcada entre a balsa, a boia e o carro. Como em um contexto real, mas não há participantes. conectados pelo sentido (carro, balsa, sobrevivência)

\section{Estratégia do enunciador:}

Em primeiro plano vemos o carro e em segundo plano a imagem de uma balsa - identificada pelas bóias e pelo solo em madeira, no horizonte vê-se o mar e o céu azul.

O contraste da imagem com a realidade do frio em novembro pode ser um atrativo.

Estutura não verbal :
Carro horizontalmente em ângulo obliquo - envolvimento - não faz parte do seu mundo.

Verticalmente no nível do olhar - poder igualitário. 


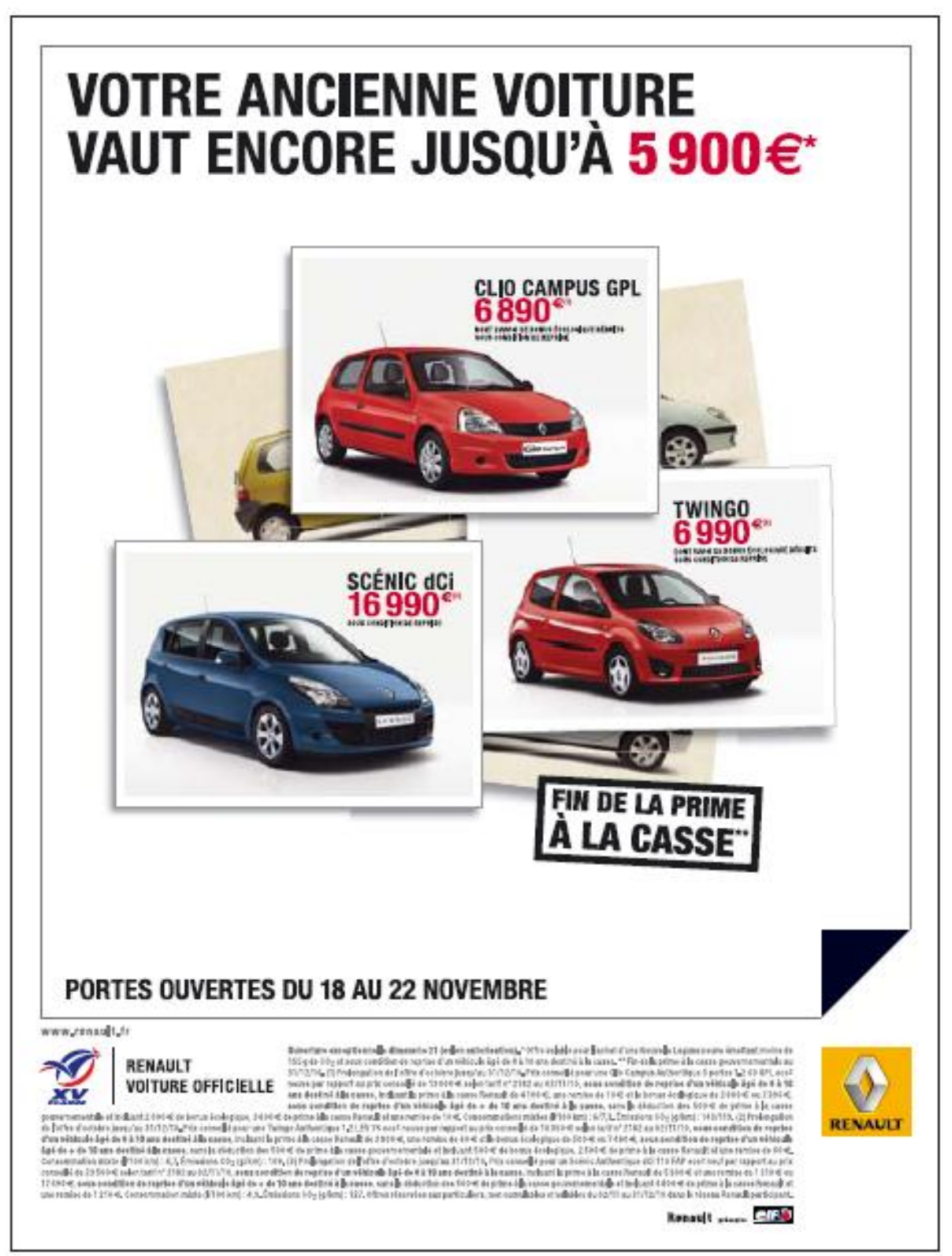

Contexte de production - contexte sociosubjectif

Enunciador - Renault

Destinatário - usuário do metrô interessado em trocar o carro.

Objetivo - persuadir o leitor a trocar de carro.

Lugar social - metrô de Paris

\section{Organização temático-representacional:}

Tipos de discurso - "vous" o que indica um discurso interativo implicado

Tipos de representação - conceitual: várias fotos, não tem uma ação (vetor que indique uma ação, ou participante que indique uma reação com o vetor olhar) - conceitual analítico (esquemas).

\section{Organizacão interacional:}

Vozes do discurso - vous - discurso interativo implicado da ordem do expor.

Efeito argumentativo - "portes ouvertes" (cultural), "fin de la prime à la classe" (cultural) prime significa bônus de final de ano, como o nosso $13^{\circ}$, mas não é obrigatório às empresas.

Modalização: - epistêmica, valor de verdade sobre o valor do seu carro.

Contato - exposição/oferta

Distância social - plano geral de uma pilha de fotos em um fundo não real.

.Carro em ângulo oblíquo, distanciamento.

Atitude - perspectiva subjetiva através do ângulo na altura do olhar, o carro é representação da igualdade.

Modalidade - cores mais fordes para maior evidência.

\section{Organizacão estrutural}

Conexão e coesões - sem conectores, verbos no presente. Temporalidade "encore". 
Valor da informação - polarizado, vários elementos, diferentes informações sobre os carros para troca. Todos aparecem com o valor informação importante. A cor muda também.

Saliência - Os carros aparecem em evidência, apesar de pequenos, não existe outro objeto em cena. O plano superior é do slogan, em que o preço aparece em saliência máxima, em vermelho..

Emolduramento - Conexão marcada entre a balsa, a boia e o carro. Como em um contexto real, mas não há participantes. conectados pelo sentido (carro, balsa, sobrevivência)

\section{Estratégias :}

Verbal: Votre ancienne voiture vaut encore jusqu'à $5900 \$ \$$.. Em seguida encontramos fotos de carros, com nome e valores. Como um carimbo: Fin de La prime à La classe ( la classe = bonne qualité). Ainda na imagem o anúncio de salão em novembro. Em letras minúsculas informações técnicas.

Cada carro possui uma moldura como se fossem cartas ou fotos.

Outras informações:

Do lado direito vemos um outro símbolo do XV de France - equipe de rugby - patrocinador ou parceiro desde 2008. 
Apêndice D: Sequência didática 2

\section{Ateliers d'écriture en FLE: découvrir la publicité - FFLCH/USP} Priscila Aguiar Melão

\section{I) Echauffement}

1. Discutez des questions ci-dessous par groupe.

a) Faites-vous attention aux pubs ? Les aimez-vous ? D'habitude, où vous les trouvez ?

b) Quelles thématiques de pubs sont trouvées sur la presse ? Donnez au moins cinq types.

c) Avez-vous une pub préférée ? Laquelle ? Et pourquoi ?

d) Connaissez-vous des pubs françaises? Lesquelles? Où vous les trouvez?

e) Pensez-vous qu'il y a des différences entre les pubs françaises et les pubs brésiliennes? Lesquelles?

Faites une synthèse de vos discussions et racontez-la au groupe classe.

\section{II) La première pub}

3. Choisissez entre:

( ) une émission

( ) un moyen de transport

( ) un film ou dvd

4. Créez une pub pour ce que vous avez choisi avec votre voisin. Vous n'avez pas besoin d'être un dessinateur, mais utilisez des crayons en couleurs et définissez :

- l'objet,

- le slogan,

- l'image qui apparaît au fond de l'objet.

Action 1 : la pub 
3) Complétez la grille ci-dessous pour organiser vos idées par rapport à la pub que vous avez créée :

\begin{tabular}{|l|l|}
\hline $\begin{array}{l}\text { Pourquoi avez-vous choisi ce } \\
\text { produit? }\end{array}$ & \\
\hline Où allez-vous l'annoncer? & \\
\hline Qui a produit cette pub? & \\
\hline \begin{tabular}{l} 
Qui est votre public? \\
\hline $\begin{array}{l}\text { Quel est l'objectif du magasin ou de la } \\
\text { marque qui a produit cette pub? }\end{array}$
\end{tabular} \\
\hline $\begin{array}{l}\text { Est-ce que le slogan choisi reprend } \\
\text { une caractéristique de l'image? } \\
\text { Laquelle? }\end{array}$ \\
\hline $\begin{array}{l}\text { Est-ce que votre slogan fait sens si } \\
\text { vous ne mettez pas l'image dans la } \\
\text { pub? }\end{array}$ \\
\hline
\end{tabular}

NOM :

NOM :

I) Le logo

1. Regardez les pubs et répondez Vrai (V) ou Faux(F) :
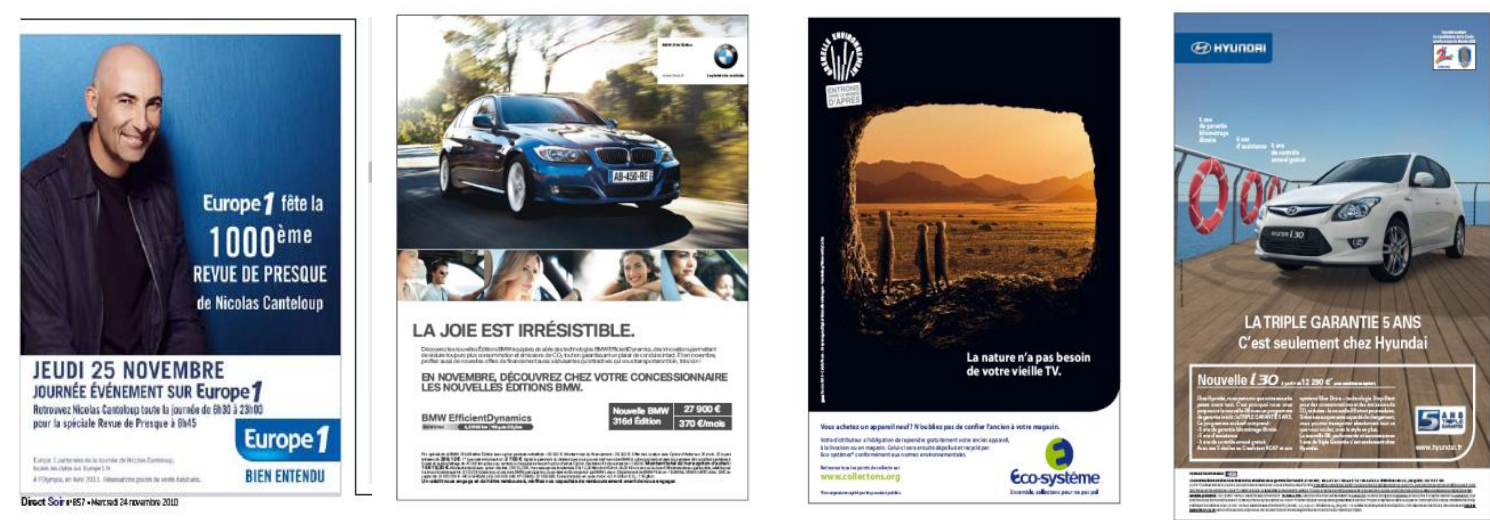

( ) Les pubs annoncent le même type de produit.

( ) Toutes les pubs ont un logo.

( ) Les images sont toujours au centre. 
( ) Les logos sont obligaroirement à droite.

( ) La taille du logo est la même sur toutes les pubs.

\section{II) Le slogan}

1. Mettez les mots dans l'ordre correct, de manière à reconstruire les slogans de quelques pubs :

a)

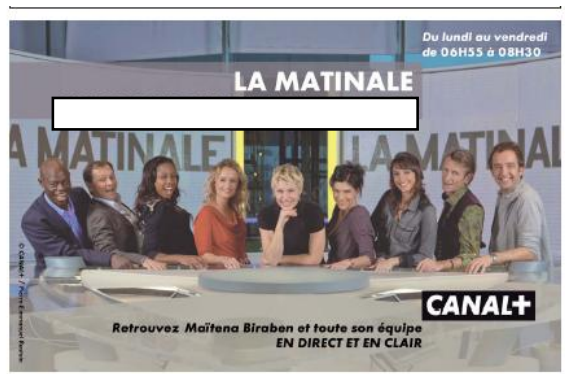

Les matins, réveille, qui, l'émission.

b)

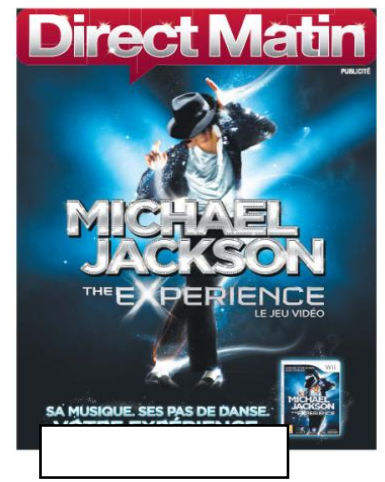

Expérience, musique, pas de danse, sa, votre, ses.

c)

Plus, boucher, votre, ne, vous, comme,

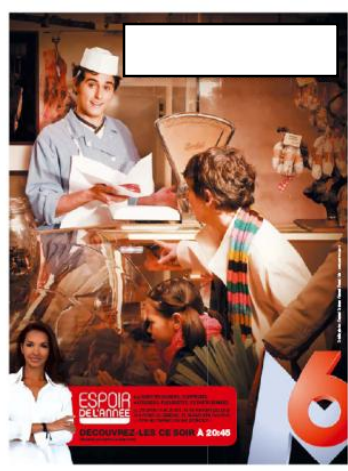
regarderez, avant !, jamais 
5. Regardez les slogans ci-dessus et répondez :

a) Où trouvez-vous les slogans des pubs ? En haut, en bas ou au centre ?

b) Les slogans indiquent tous un ordre ou une obligation ?

c) Que veulent dire les slogans ? Discutez-en.

d) Cochez les caractéristiques des slogans. Ils

( ) sont courts.

( ) contiennent des phrases qui causent un impact.

( ) contiennent toujours des nominalisations. ( ) contiennent toujours des verbes à l'impératif.

( ) se servent de signes de ponctuation (!). ( ) utilisent toujours « vous ».

III) La publicité vidéo

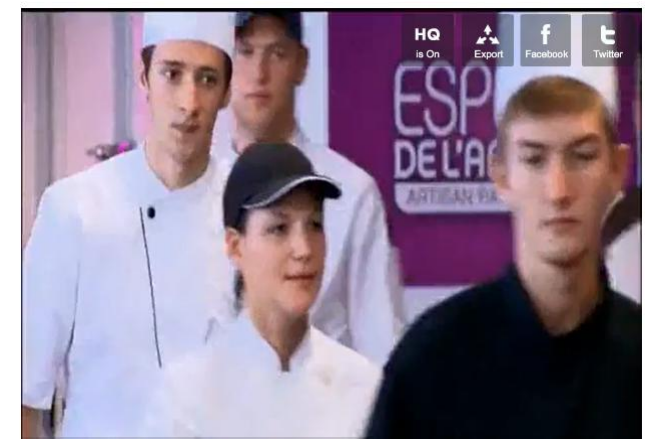

http://www.dailymotion.com/video/xerns4 bande-annonce-de-l-espoir-de-l-anne tv

1. Regardez la bande annonce une première fois et cochez les professions entendues.
( ) professeur
( ) coiffeur
( ) facteur
( ) boucher
( ) politicien
( ) fleuriste
( ) Avocat
( ) pâtissier
( ) concierge

2. Associez les instruments aux professions ci-dessus :

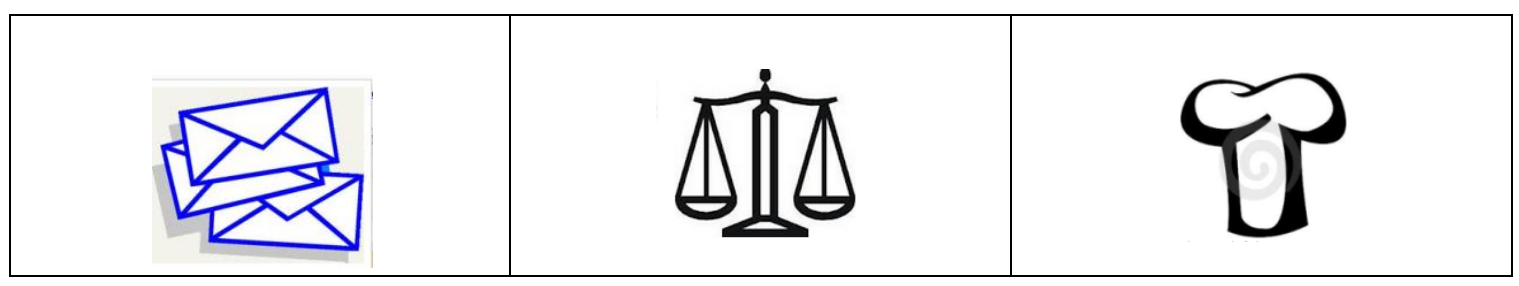




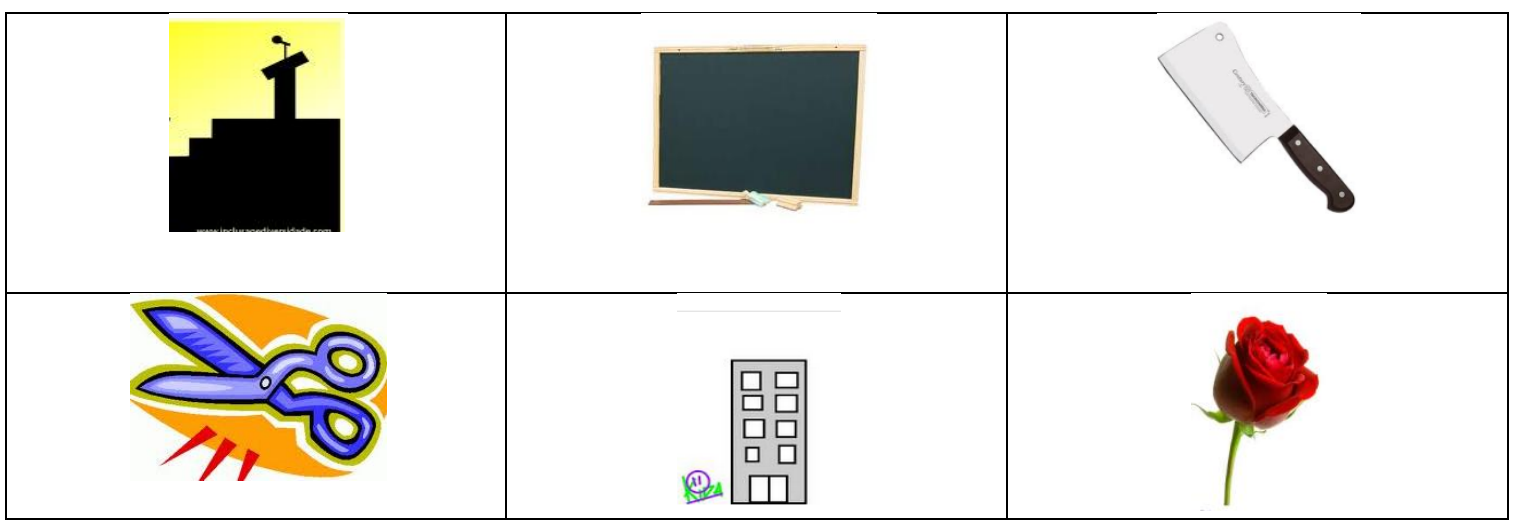

3. Regardez la bande annonce une deuxième fois et répondez vrai (v) ou faux (f).

( ) lls ont entre 18 et 50 ans.

( ) Ils seront évalués par un jury professionnel

( ) Ils veulent gagner un million d'euros.

( ) Ils cherchent la célébrité et la reconnaissance dans leurs métiers.

( ) Ils montrent leur savoir-faire.

4. Discutez avec votre voisin.

a. Avez-vous ces émissions au Brésil ?

b. Trouvez-vous des différences ou des similitudes par rapport à votre pays ? Lesquelles?

\section{IV) La publicité écrite et le slogan}

1. Observez la publicité de l'émission « Espoir de l'année » et créez d'autres slogans pour le fleuriste, le coiffeur et le pâtissier. 


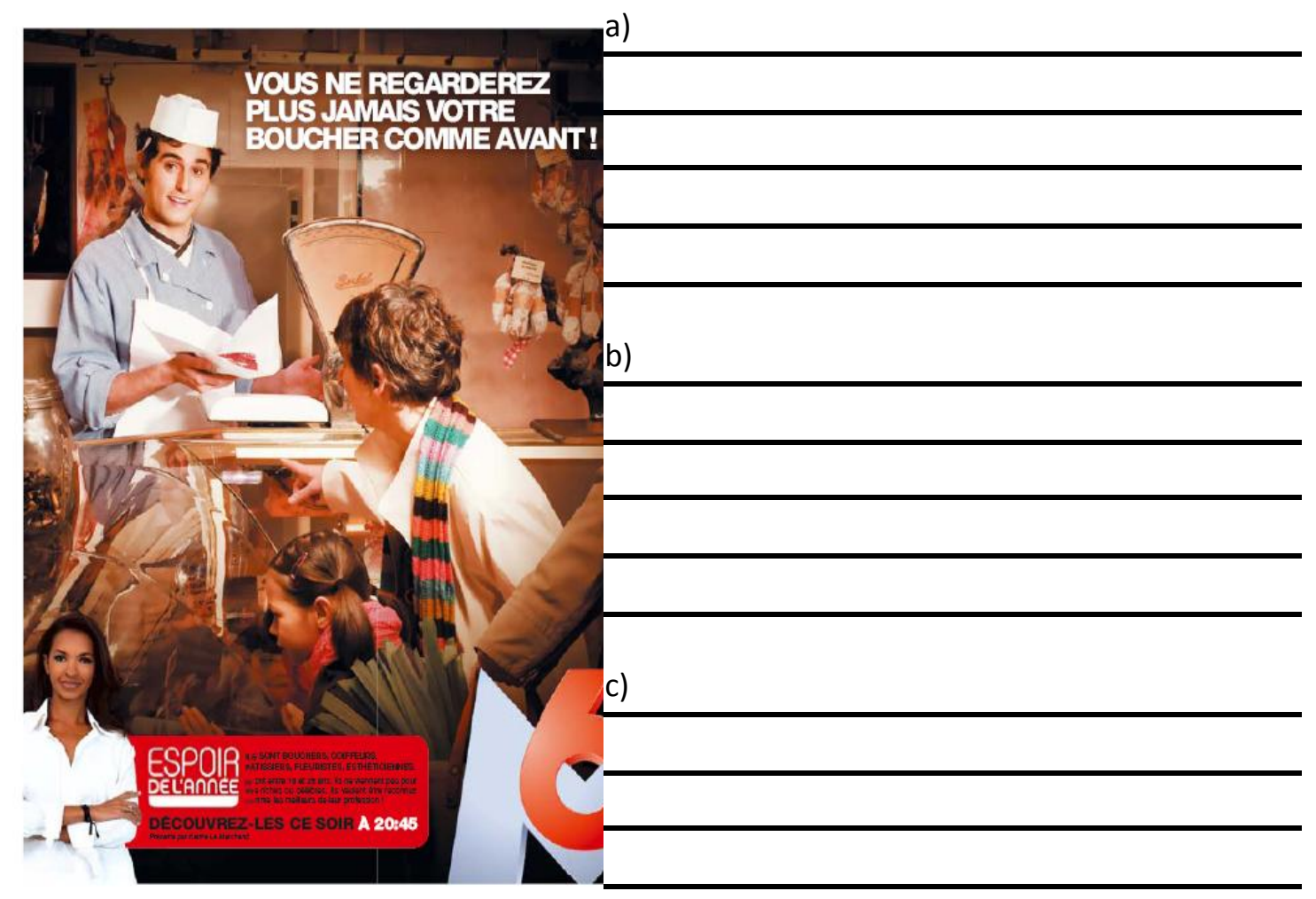

2. À partir de l'organisation de l'image, répondez aux questions avec votre voisin :

- Vers où les personnes de l'image dirigent leur regard?

- Où trouvez-vous plus de lumière ?

- Le centre de l'image nous montre une action. Laquelle ?

- En bas de page vous trouvez d'autres informations par rapport à l'émission.

Lesquelles?

3. Lisez le texte de la pub.

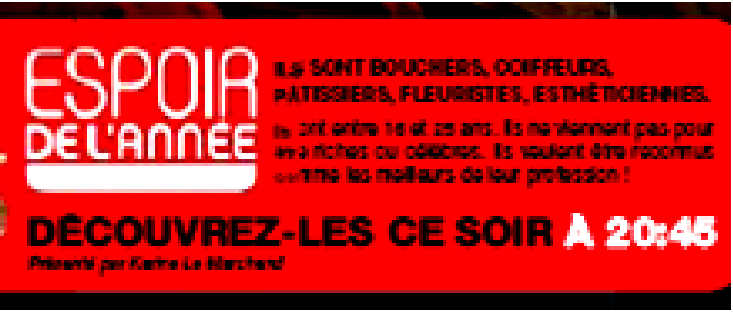

Ils sont bouchers, coiffeurs, pâtissiers, fleuristes, esthéticiennes. Ils ont entre 16 et 25 ans. Ils ne viennent pas pour êtres riches ou célèbres. Ils veulent être reconnus comme les meilleurs de leur profession!

4. Basez-vous sur le texte ci-dessus pour créer un texte pour la pub d'une autre émission de télévision: 


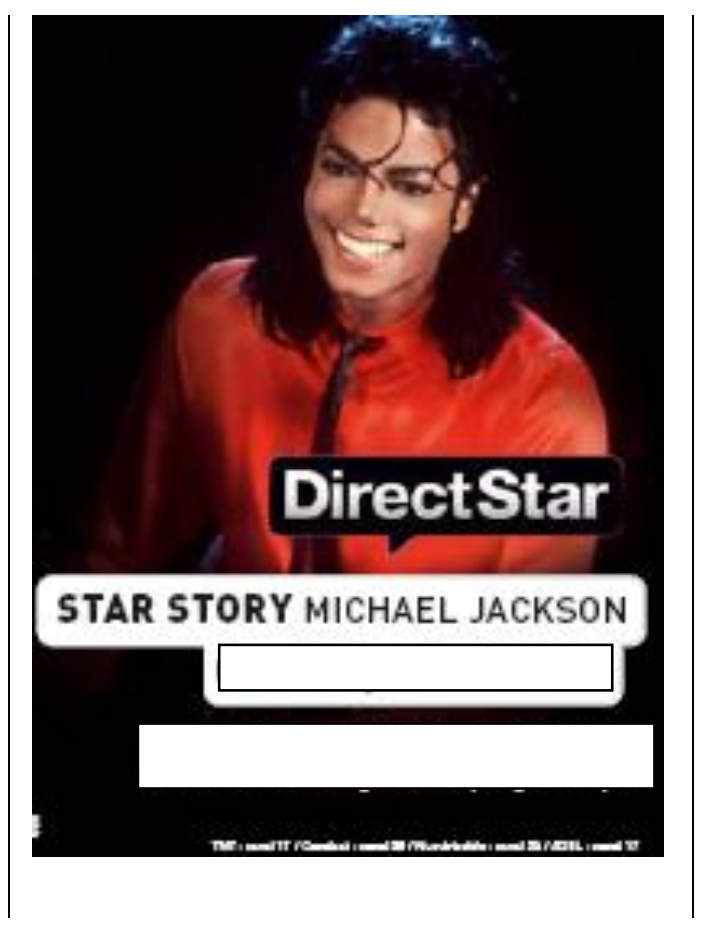

\section{Les couleurs}

1. Les couleurs peuvent nous faire penser aux représentations du monde, d'une culture, $d^{\prime}$ 'une relation sociale ou même de cohésion dans un texte. Quelles représentations avez-vous des couleurs?

\begin{tabular}{l|l} 
Les couleurs & Vos représentations \\
\hline Le Blanc & \\
\hline Le rouge & \\
\hline Le jaune & \\
\hline Le bleu & \\
\hline Le vert & \\
\hline Le noir &
\end{tabular}


2. Associez les citations aux significations

\begin{tabular}{|l|l|}
\hline Les citations & Les explications \\
\hline (a) C'est écrit noir sur blanc & $\begin{array}{l}(\quad) \text { travailler sans être déclaré, sans } \\
\text { payer de taxe. }\end{array}$ \\
\hline (b) Faire travailler sa matière grise & $(\quad$ être en colère tout à coup. \\
\hline (c) Rire jaune & $(\quad)$ être ivre. \\
\hline (d) Travailler au noir & $\begin{array}{l}(\quad) \text { pour insister, dire que c'est écrit en } \\
\text { toutes lettres. }\end{array}$ \\
\hline (e) Un cordon bleu & $(\quad$ être un très bon jardinier. \\
\hline (f) Voir des éléphants roses & $(\quad)$ se forcer à rire. \\
\hline (g) Voir rouge & $(\quad$ ) réfléchir. \\
\hline (h) Avoir la main verte & $(\quad$ ) être un(e) bon(ne) cuisinier(e). \\
\hline
\end{tabular}

Avez-vous des proverbes à partir des couleurs en portugais ? Lesquelles ?

3. Regardez la pub avec votre voisin et répondez aux questions. 


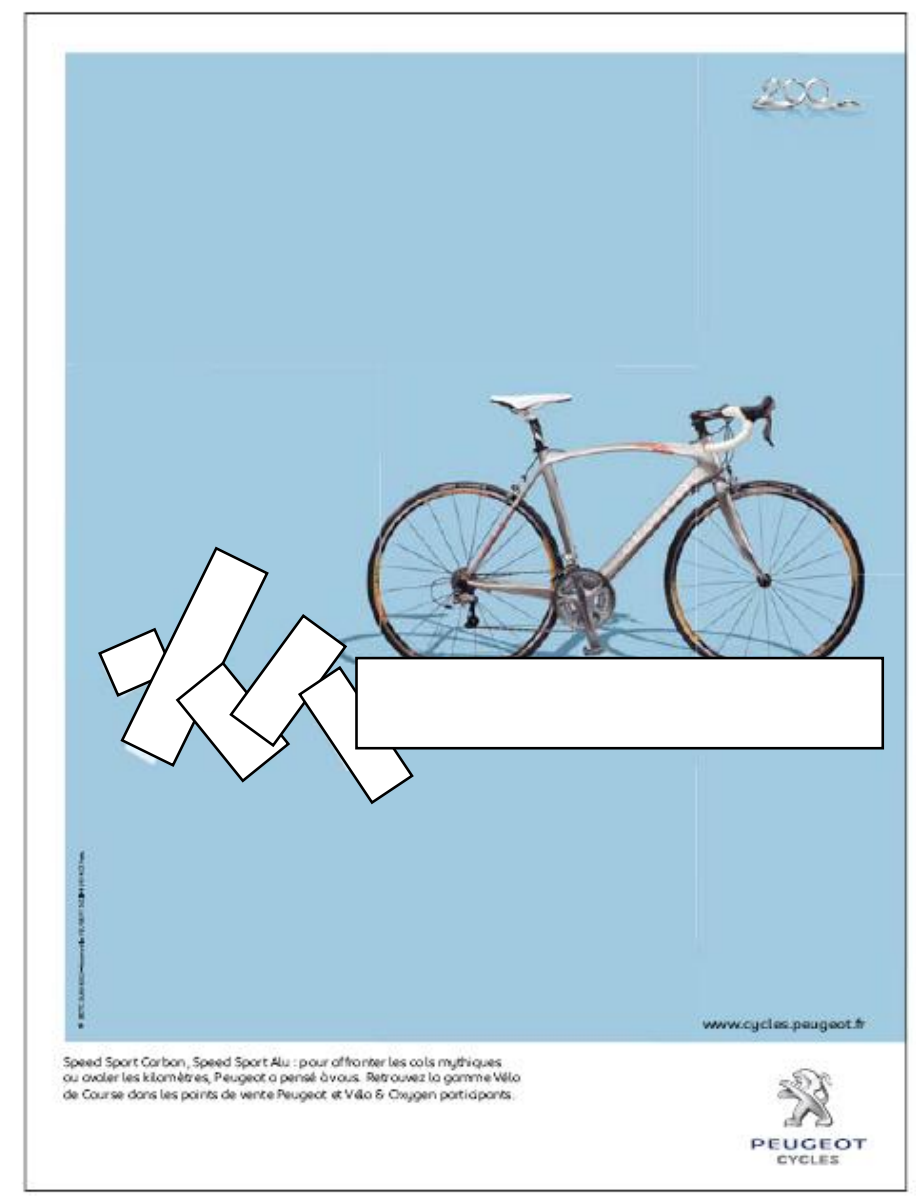

a) Quelles couleurs voyez-vous sur la pub ?

b) Imaginez-vous le pourquoi de la couleur du vélo et de la couleur de fond?

c) Le vélo est tout seul dans la pub? Pourquoi?

d) Pourquoi le slogan vient après l'image ?

e) Qu'est-ce que vous imaginez en observant la mise en page du texte verbal effacé?

4. Regardez la pub http://www.youtube.com/watch?v=6uu5dYB6vOg et cochez les expressions que vous entendez:

Pub Belge pour Proximus (Vélo)

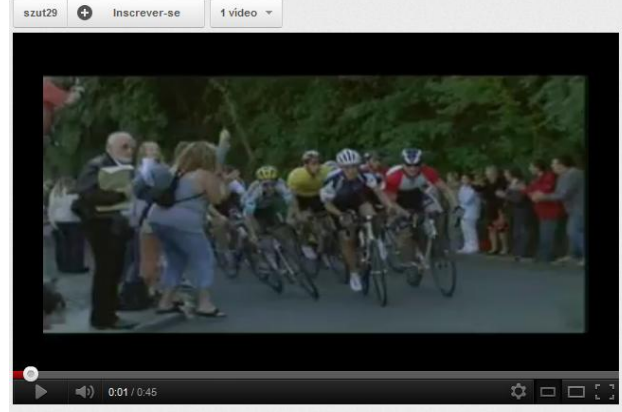


Vincent joue de l'accordéon chacal

Louis va en danseuse
Il sale la soupe

Il fait des pointes de vitesse
Pierre donne un coup de

Ils ne fortifient que le boulot

5. Avez-vous compris ces expressions à partir de la pub ? Discutez avec votre voisin et découvrez leurs sens.

6. Découvrez le vocabulaire des cyclistes en associant les autres expressions aux images.

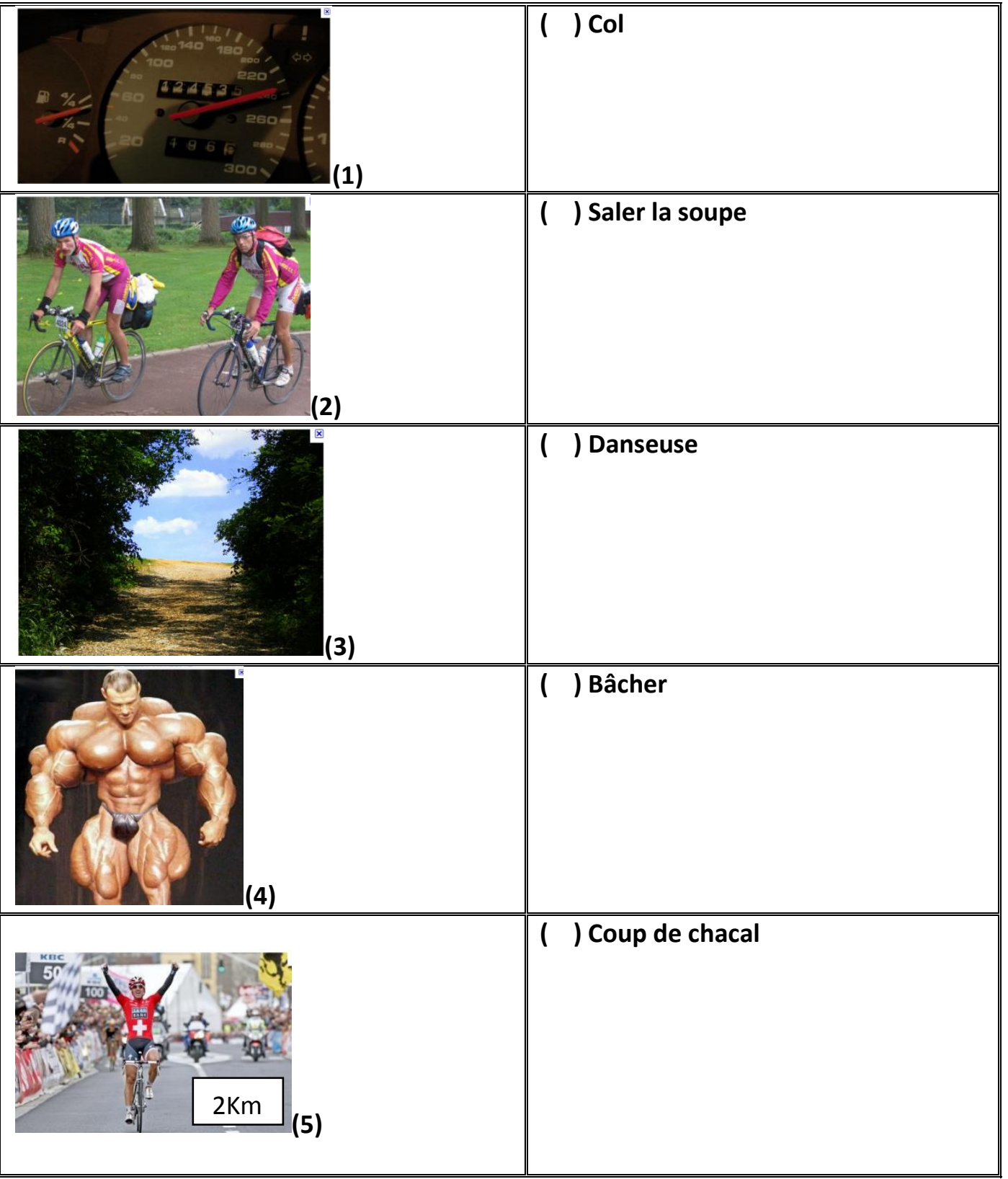




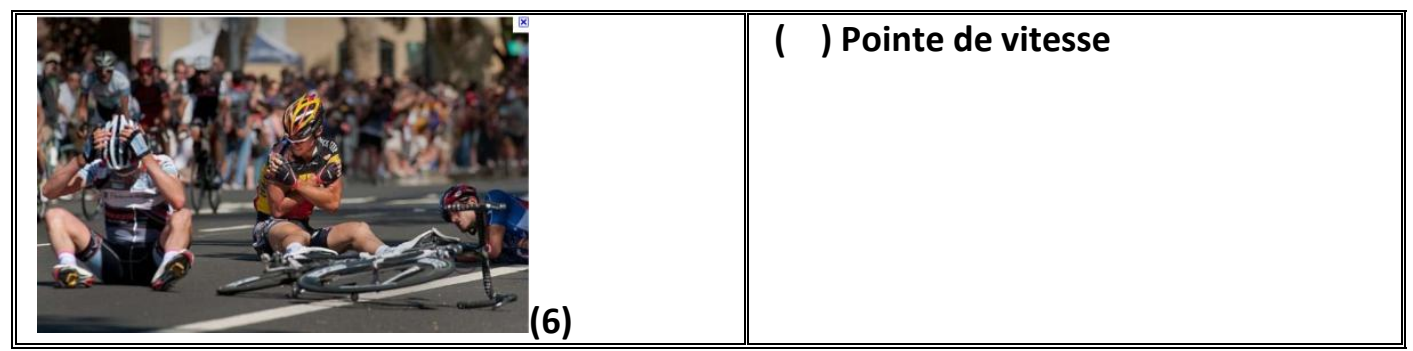

http://fr.wikipedia.org/wiki/Glossaire du cyclisme (consulté le30/01/2012)

VII) À partir du vocabulaire des cyclistes, faites les activités suivantes.

1. Créez un slogan pour le vélo Peugeot.

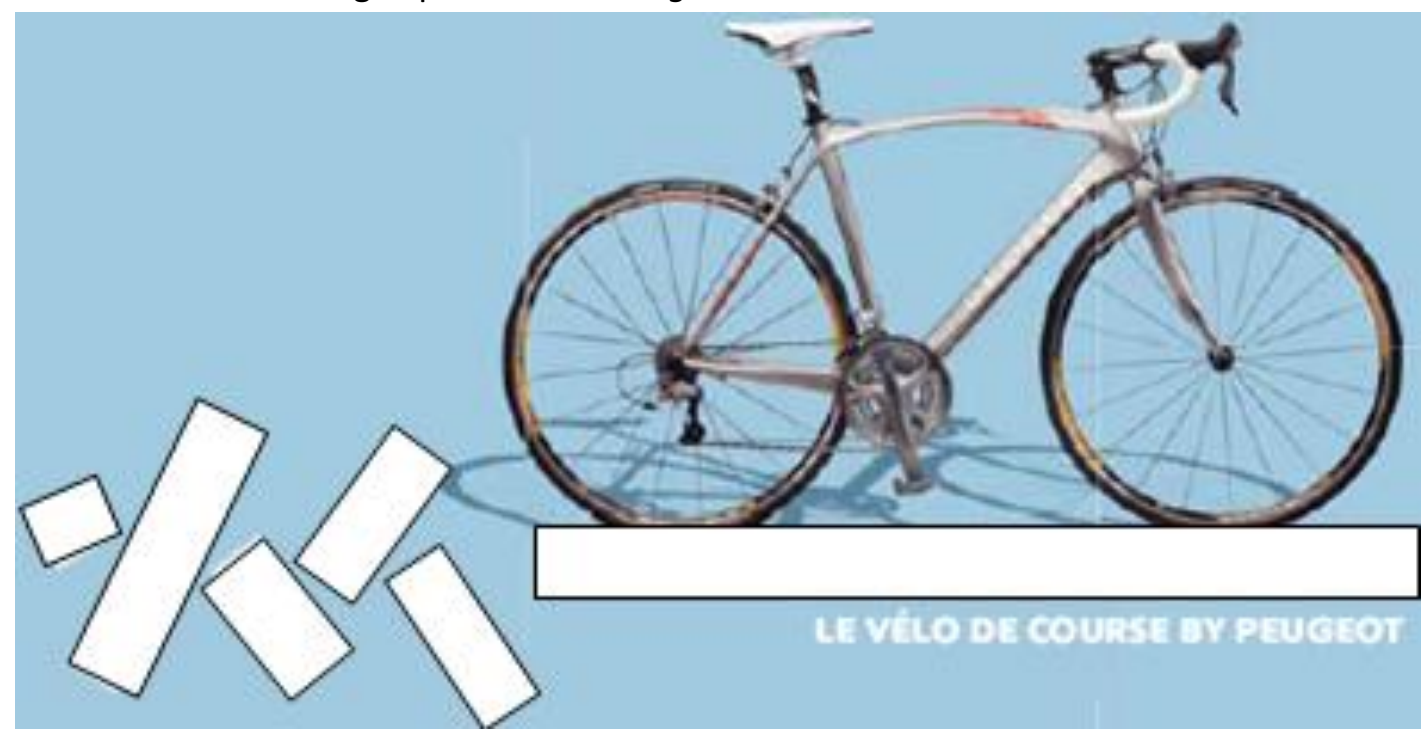

2. Dans le petit texte en bas de page, on trouve des informations qui peuvent caractériser le vélo et le consommateur du vélo Peugeot. Lesquelles ?

Speed Sport Carbon, Speed Sport Alu : pour affronter les cols mythiques ou avaler les kilomètres, Peugeot a pensé à vous. Retrouvez la gamme Vélo de Course dans les points de vente Peugeot et Vélo \& Oxygen participants.

3. Réécrivez le petit texte informatif avec l'aide du vocabulaire cycliste. 


\section{VIII) Discussion en groupe}

1. Aimez-vous la course en vélo?

2. Avez-vous déjà participé à une course?

3. Connaissez-vous les courses: Saint Jacques de Compostelle ou Tour de France? Et la course internationale de la Saint Sylvestre?

4. Dans votre pays, avez-vous une course en vélo très connue?

\section{I) Les angles des images}

1. Regardez les pubs ci-dessous (A à E) et associez-les aux différents angles des photographies.

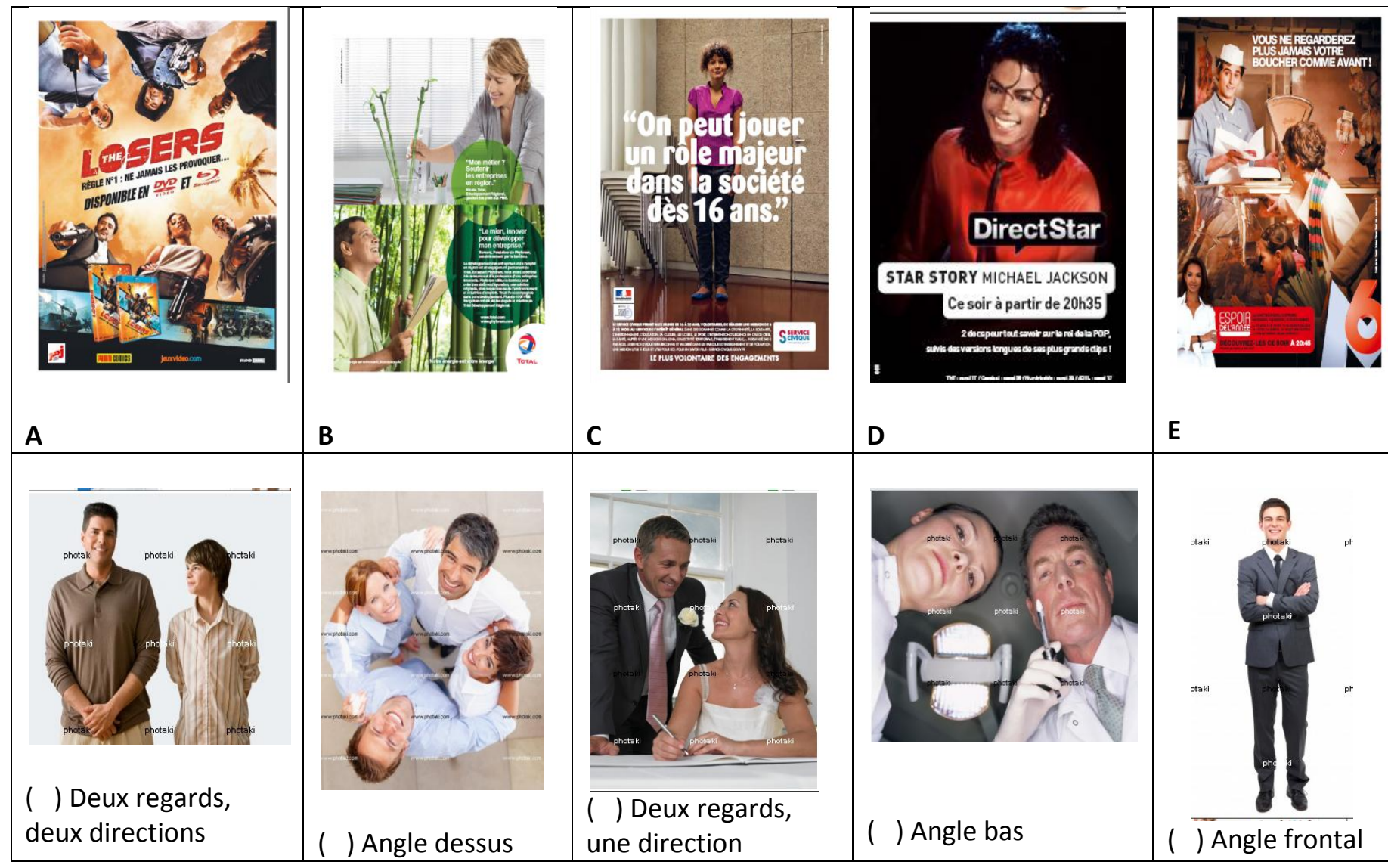

(http://br.photaki.com/)

1. Associez les pubs et les angles aux commentaires ci-dessous :

( ) Il y a une égalité entre le personnage de la pub et nous.

( ) Les personnages ont plus de pouvoir que nous.

( ) On a plus de pouvoir que le personnage de la pub.

( ) Un personnage a plus de pouvoir que l'autre et on n'est pas dans l'action de la pub.

( ) Un personnage est plus important que l'autre et on est dans l'action de la pub. 
1. Regardez la pub ci-dessous et faites les activités proposées.

a) Avec votre voisin, discutez de ce que vous pouvez imaginer de l'histoire du film.

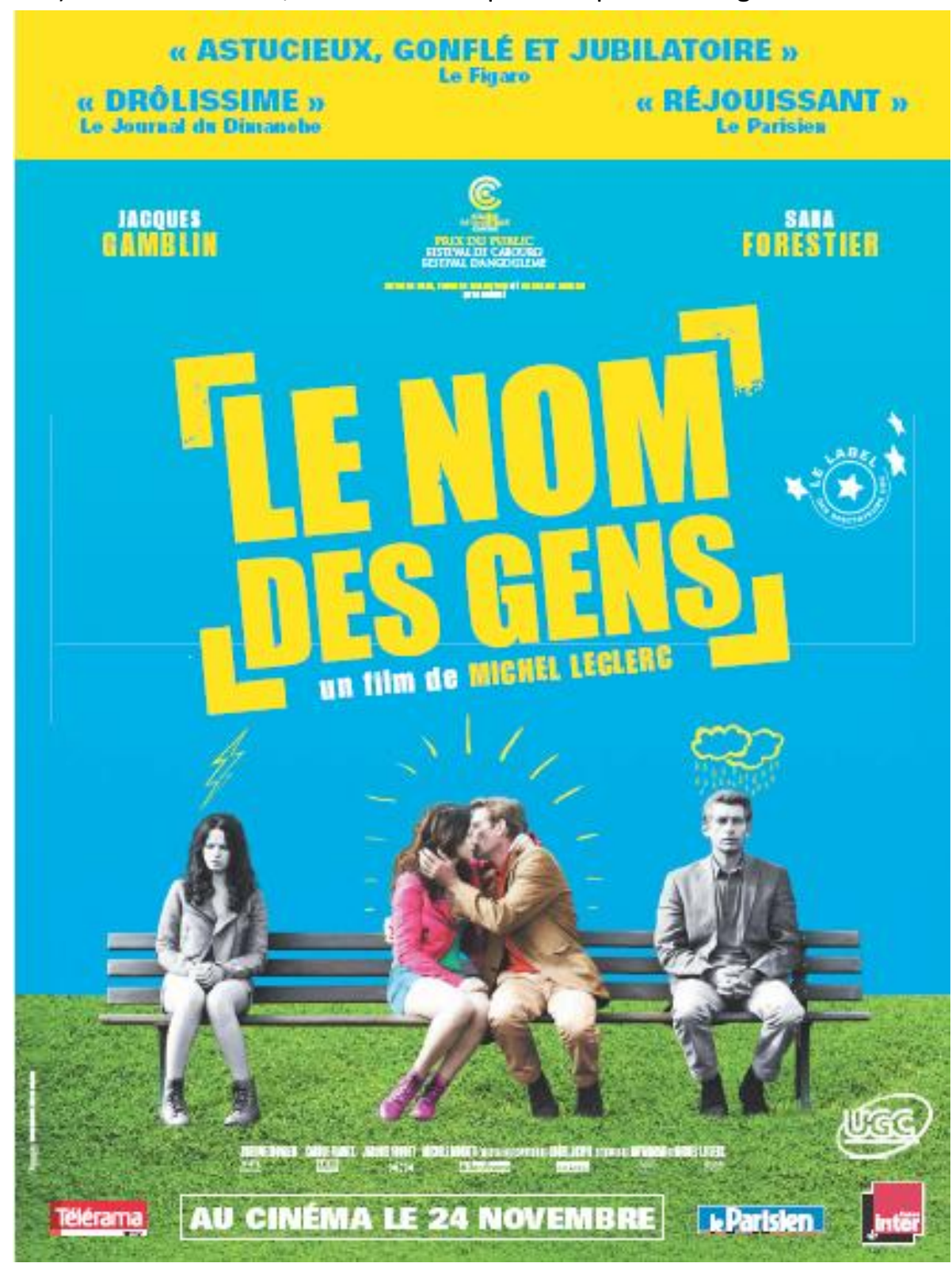

b) Regarderiez-vous le film après avoir vu cette pub? Justifiez

c) Pensez-vous qu'il manque un slogan pour avoir plus de spectateurs ou bien les commentaires de la critique ont été suffisants? Pourquoi ? 
2. Répondez aux questions suivantes.

a) Trouvez les synonymes correspondants :

\begin{tabular}{|c|c|}
\hline ( 1 ) gonflé & ( ) ce qui est agréable, contentant. \\
\hline ( 2 ) astucieux & ( ) ce qui entraîne une grande joie \\
\hline ( 3 ) réjouissant & ( ) ce qui est amusant, comique, bizarre \\
\hline ( 4 ) drôle/drôlissime & ( ) ce qui a a ou dénote de l'ingéniosité. \\
\hline ( 5 ) jubilatoire & ( ) ce qui est audacieux, ballonné \\
\hline
\end{tabular}

b) Qu'est-ce que le symbole « label » veut dire ?

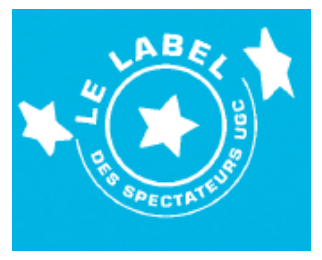

3. Regardez la pub et répondez aux questions

a) Observez la pub avec votre voisin

\begin{tabular}{|l|l|}
\hline Où sont les personnages ? \\
\hline Qu'est-ce que le bleu signifie dans l'image ? & \\
\hline Qu'est-ce que le vert signifie dans l'image ? & \\
\hline $\begin{array}{l}\text { Trouvez-vous un problème entre le bleu et le } \\
\text { vert ? }\end{array}$ & \\
\hline Où se trouve la femme toute seule ? & \\
\hline Où se trouve l'homme tout seul ? \\
\hline \begin{tabular}{l} 
Sont-ils heureux ? Pourquoi ? \\
\hline $\begin{array}{l}\text { Quelle est la différence entre les personnages } \\
\text { seuls et le couple au centre du banc ? }\end{array}$
\end{tabular} \\
\hline $\begin{array}{l}\text { Pourquoi une partie de l'image est en couleur } \\
\text { et l'autre est en noir et blanc? }\end{array}$ \\
\hline $\begin{array}{l}\text { Pouvez-vous donner un mot pour les symboles } \\
\text { sur les têtes des personnages? }\end{array}$ \\
\hline $\begin{array}{l}\text { Cette pub reprend un autre genre textuel. } \\
\text { Lequel ? }\end{array}$ \\
\hline
\end{tabular}


III) Le Film

1. Regardez la vidéo et répondez aux questions

a) À partir de la bande annonce

(http://www.youtube.com/watch?v=SQUqffgJvKY) discutez avec votre voisin si vos impressions ont changé par rapport aux premières impressions.

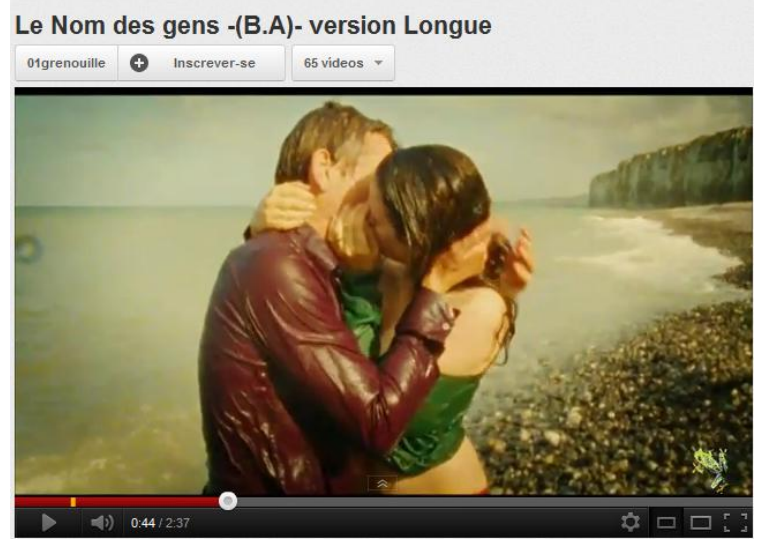

b) Écoutez une deuxième fois la bande annonce et cochez les mots que vous entendez :
( ) Horrible
( ) Génial
( ) Délicieux
( ) Romantique
( ) Libre
( ) Gauche
( ) Politique
( ) Métaphorique
( ) Dingue

c) Complétez le tableau selon l'exemple :

\begin{tabular}{|l|l|l|}
\hline \multicolumn{1}{|c|}{ Masculin } & \multicolumn{1}{c|}{ Féminin } & \multicolumn{1}{c|}{ Synonyme } \\
\hline Horrible & Horrible & Affreux(euse), terrifiant(e) \\
\hline & & \\
\hline & & \\
\hline & & \\
\hline & & \\
\hline & & \\
\hline & & \\
\hline & & \\
\hline
\end{tabular}

d) Trouvez-vous des adjectifs masculin et féminin identiques ? Pourquoi ne sont-ils pas différents? 


\section{IV) La réflexion}

1. Réfléchissez aux réponses que vous avez données à l'aide de cette petite grille. Avezvous trouvé des différences avec la grille précédente?

Pourquoi le ciel et le sol sont différents ?

Pourquoi une partie de l'image est en couleur et l'autre est en noir et blanc?

Pourquoi les personnages sont disposés à gauche et à droite?

2. Si vous pouviez mettre un slogan pour mieux diffuser le film, comment serait-il?

\section{VI) La ville}

1. Regardez la pub et répondez aux questions suivantes avec votre voisin

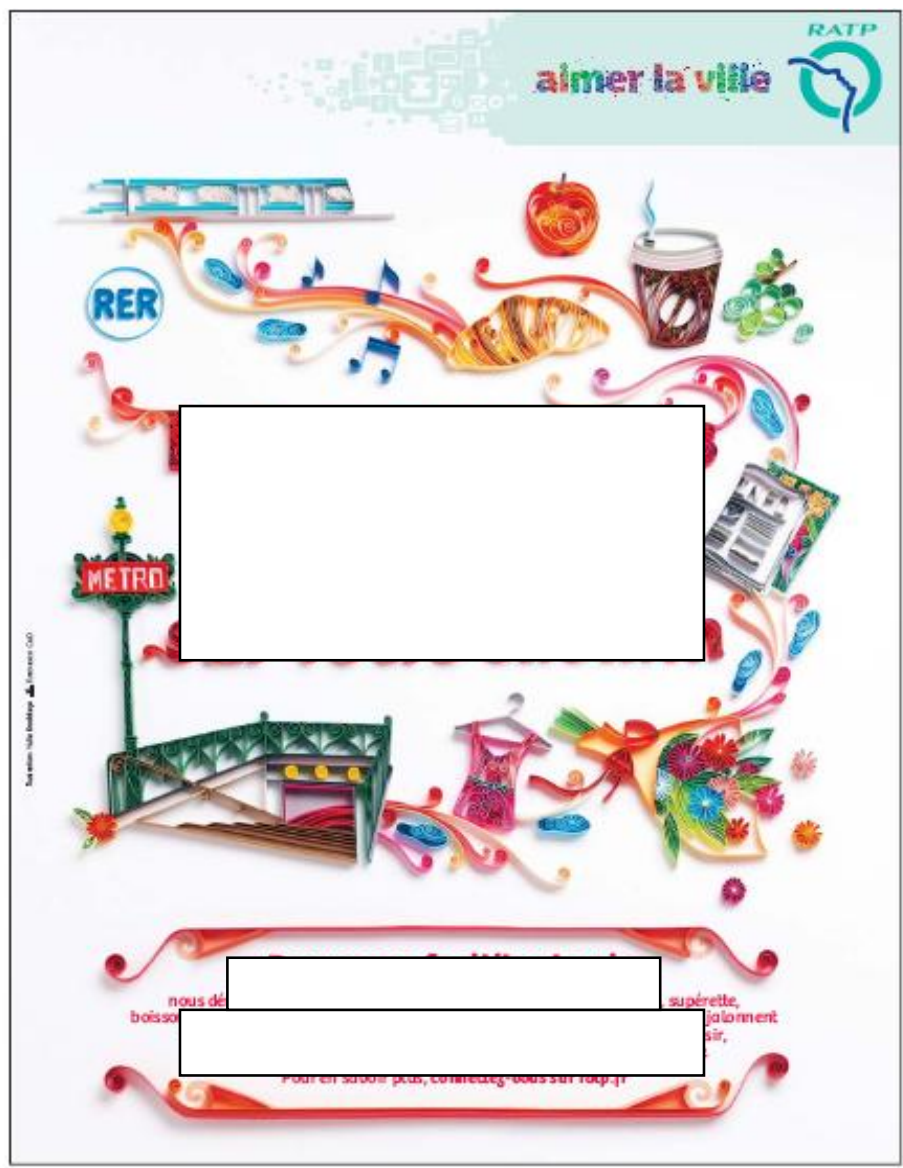



a) Le slogan de la pub a été effacé, comment pouvez-vous la comprendre ?
b) Comment les objets apparaissent-ils sur la pub? Sont-ils connectés ou déconnectés ?
c) Que voyez-vous au milieu des images ? Où est le début des images? Et la fin ?
d) À votre avis, qui a produit cette pub ?
e) Pour quel service et public cette pub a-t-elle été produite?

\section{VII) La création}

1. Après avoir observé la pub, créez un slogan pour mettre au centre de la page.

2. Quelle information imaginez-vous mettre en bas de la page? Écrivez cette information.

\section{VIII) Répondez aux questions}

1. Qu'est-ce que RATP signifie ?

\begin{tabular}{|l||l}
\hline$($ ) Régie autonome des transports parisiens & $\begin{array}{l}(\quad \text { ) Régie automatique des transports } \\
\text { parisiens }\end{array}$ \\
$\begin{array}{l}\text { ( ) Réseaux automatique des transports } \\
\text { populaires }\end{array}$ & $\begin{array}{l}(\quad \text { ) Réseaux autonome des transports } \\
\text { populaires }\end{array}$ \\
\hline
\end{tabular}

2. Cochez les objets trouvés sur la pub

Du lait un train une rue

une avenue

une fleur

Un journal

un vêtement

une baguette

des raisins

Du café

un livre

une glace

un croissant

une pomme 
3. Dans la ville, où trouvons-nous les objets ci-dessus ?

4. Cherchez les mots de la ville :

\begin{tabular}{|lllllllllllllll|l|}
\hline$Z$ & $D$ & $E$ & $K$ & $Q$ & $M$ & $A$ & $I$ & $R$ & $I$ & $E$ & $B$ & $C$ & $M$ & $E$ & BOUCHERIE \\
$Z$ & $G$ & $C$ & $E$ & $I$ & $S$ & $H$ & $O$ & $P$ & $I$ & $T$ & $A$ & $L$ & $A$ & $I$ & PATISSERIE \\
$S$ & $J$ & $O$ & $S$ & $O$ & $O$ & $S$ & $T$ & $A$ & $T$ & $I$ & $O$ & $N$ & $G$ & $D$ & BOULANGERIE \\
$O$ & $U$ & $L$ & $Q$ & $B$ & $S$ & $S$ & $A$ & $H$ & $D$ & $F$ & $I$ & $R$ & $A$ & $A$ & KIOSQUE \\
$H$ & $I$ & $E$ & $G$ & $O$ & $R$ & $I$ & $Q$ & $Z$ & $J$ & $E$ & $A$ & $A$ & $S$ & $K$ & HOPITAL \\
$U$ & $E$ & $H$ & $J$ & $U$ & $W$ & $M$ & $R$ & $U$ & $T$ & $C$ & $T$ & $J$ & $I$ & $L$ & ECOLE \\
$H$ & $D$ & $S$ & $V$ & $L$ & $A$ & $M$ & $X$ & $S$ & $E$ & $A$ & $V$ & $H$ & $N$ & $G$ & CAFE \\
$G$ & $D$ & $D$ & $U$ & $A$ & $M$ & $B$ & $I$ & $Q$ & $H$ & $F$ & $F$ & $Q$ & $Y$ & $E$ & FLEURISTE \\
$A$ & $M$ & $Z$ & $C$ & $N$ & $D$ & $R$ & $D$ & $L$ & $M$ & $E$ & $N$ & $W$ & $S$ & $Q$ & MARCHE \\
$R$ & $A$ & $K$ & $S$ & $G$ & $U$ & $B$ & $O$ & $U$ & $C$ & $H$ & $E$ & $R$ & $I$ & $E$ & MAGASIN \\
$E$ & $R$ & $F$ & $E$ & $E$ & $N$ & $T$ & $G$ & $V$ & $M$ & $T$ & $Q$ & $K$ & $D$ & $F$ & GARE \\
W & $C$ & $G$ & $L$ & $R$ & $Y$ & $B$ & $W$ & $N$ & $O$ & $I$ & $C$ & $F$ & $V$ & $N$ & STATION \\
$M$ & $H$ & $F$ & $C$ & $I$ & $F$ & $V$ & $M$ & $I$ & $L$ & $H$ & $N$ & $I$ & $G$ & $A$ & MAIRIE \\
$L$ & $E$ & $Z$ & $S$ & $E$ & $I$ & $A$ & $F$ & $M$ & $L$ & $F$ & $C$ & $C$ & $F$ & $U$ & \\
$C$ & $G$ & $P$ & $A$ & $T$ & $I$ & $S$ & $S$ & $E$ & $R$ & $I$ & $E$ & $C$ & $U$ & $M$ & \\
& & & & & & & & & & & & \\
& & & &
\end{tabular}

5. La note $\varnothing$ apparaît sur la pub. Savez-vous pourquoi ?

6. Regardez l'extrait du film " Le fabuleux destin d'Amélie Poulain " et répondez aux questions. (http://www.youtube.com/watch?v=R3heoAMuyH4\&feature=fvst)

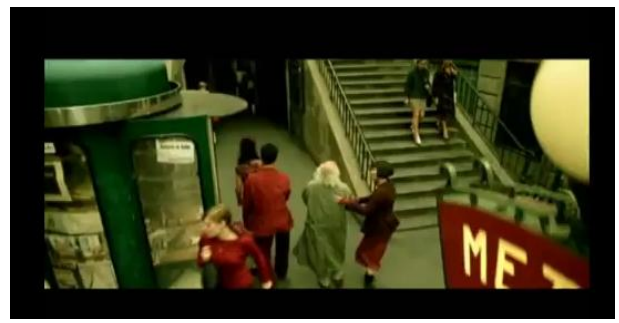

a) Quels commerces voyez-vous sur l'extrait?

b) Où Amélie laisse le monsieur ?

c) Qu'est-ce que vous trouvez de différent entre la station de la pub et la station du film ?

d) Qu'est-ce que vous trouvez d'identique ?

e) Est-ce que l'image ci-dessous vous aide à comprendre le chemin dessiné sur la pub ? 


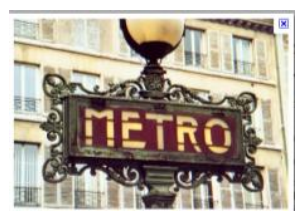

2 III) Pour en savoir plus :

1. Lisez le texte ci-dessous et répondez aux questions :<smiles>c1ccccc1</smiles>

Article Discussion

WiKIPÉDIA Art nouveau

L'Art nouveau est un mouvement artistique de la fin du $x x^{e}$ et du début du $x x^{e}$ siècle qui s'appuie sur l'esthétique des lignes courbes. Né en réaction contre les dérives de l'industrialisation à outrance et la reproduction sclérosante des grands styles, c'est un mouvement soudain, rapide, mais également très bref et puissant puisqu'il connaîtra un développement international concomitant: Tiffany (d'après Louis Comfort Tiffany aux États-Unis), Jugendstil ${ }^{\text {Note } 1}$ (en Allemagne), Sezessionstil (en Autriche), Nieuwe Kunst (aux Pays-Bas), Stile Liberty (en Italie), Modernismo (en Espagne), Style sapin (en Suisse), Style Moderne (en Russie). Le terme français " Art nouveau » s'est imposé en Grande-Bretagne, en même temps que l'anglomanie en France a répandu la forme Modern Style au début du xx ${ }^{\mathrm{e}}$ siècle ${ }^{1}$.

S'il comporte des nuances selon les pays, les critères sont communs : I'Art nouveau se caractérise par l'inventivité, la présence de rythmes, couleurs, ornementations, inspirés des arbres, des fleurs, des insectes, des animaux, et qui introduisent du sensible dans le décor quotidien. C'est aussi un art total en ce sens qu'il occupe tout l'espace disponible pour mettre en place un univers personnel considéré comme favorable à l'épanouissement de l'homme moderne de ce début du $x x^{e}$ siècle. En France, l'Art nouveau était également appelé par ses détracteurs le style nouille $e^{\text {Note } 2}$ en raison des formes en arabesques caractéristiques, ou encore le style métro, à cause des bouches de métro parisiennes réalisées en 1900 par Hector Guimard.

Apparu au début des années 1890, on peut considérer qu'à partir de 1905 l'Art nouveau a déjà donné le meilleur de lui-même et que son apogée est passé ${ }^{2}$. Avant même la Première Guerre mondiale, ce mouvement évolua vers un style plus géométrique, caractéristique du mouvement artistique qui prendra la relève : l'Art déco (1920-1940).

d) Qu'est-ce que c'est l'art nouveau ?

e) Quand et où le mouvement est apparu ?

f) Qui a réalisé l'art nouveau au métro de Paris ? Quand ?

\section{Regardez les textes de la pub et répondez aux questions}

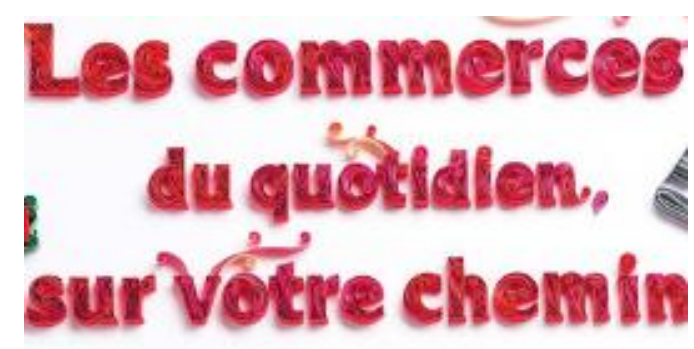




\section{Pour vous faciliter la vie,}

nous dévelopocns les serulias de pravimite sur nos réseaux: presse, supérelte, boissons à emporter... plas de 2500 commeras et distribuleurs autama tiques jalament. nos eqpacs. Et pour faireaussi de volre temps de trajet un temps deloisir. nous amenogeons nos espacss en tieux danimation at dedecauverte.

Pour en savoir plus, co mecteg-vous sur rotp.fr

Qui écrit ce message?

À qui ?

Pourquoi ?

Quels sont les services disponibles?

Où vous les trouvez?

Combien de commerces et de distributeurs automatiques il y en a?

Qu'est-ce que vous comprenez par: presse, supérette et distributeur automatique?

Pourquoi la RATP a mis ces commerces dans ses espaces?

\section{I) La deuxième pub}

1. Cochez les aspects les plus importants, à votre avis, pour créer une bonne pub. Justifiez vos choix.

( ) Penser à l'organisation de la pub sur la page : où placer le logo, le slogan, l'image et le texte informatif.

( ) Avoir un slogan qui cause un impact.

( ) Organiser les images de la pub à partir du regard des personnages et de la direction des objets. 
( ) Choisir un angle de l'image qui montre le pouvoir du personnage ou de celui qui regarde la pub.

( ) choisir les couleurs de l'image et du texte qui représentent les idées que la pub veut transmettre

2. Reprenez la pub que l'un de groupes a créée au début de la séquence. Analysez-la selon la grille ci-dessous. Présentez votre analyse au groupe-classe.

\begin{tabular}{|l|l|}
\hline Pourquoi avez-vous choisi ce produit ? & \\
\hline Où allez-vous l'annoncer? & \\
\hline Qui a produit cette pub? & \\
\hline Qui est votre public? & \\
\hline $\begin{array}{l}\text { Quel est l'objectif du magasin ou de la } \\
\text { marque qui a produit cette pub? }\end{array}$ & \\
\hline $\begin{array}{l}\text { Est-ce que le slogan choisi reprendra une } \\
\text { caractéristique de l'image ? Laquelle? }\end{array}$ & \\
\hline $\begin{array}{l}\text { Est-ce que votre slogan fera sens même si } \\
\text { vous ne le mettez pas avec une image? }\end{array}$ & \\
\hline
\end{tabular}


3.Construisez une nouvelle pub avec votre voisin. Vous n'avez pas besoin d'être un dessinateur, mais utilisez les crayons en couleurs et définissez : l'objet, le slogan, l'image qui apparaît au fond de l'objet. Vous devez mantenir la thématique choisie dans la première production.

Action 2 : la pub

Nom :

Nom : 
Apêndice E: Produção inicial e final dos alunos

Ateliers d'écriture em FLE: découvrir la publicité - FFLCH/USP

Action 1 : la pub

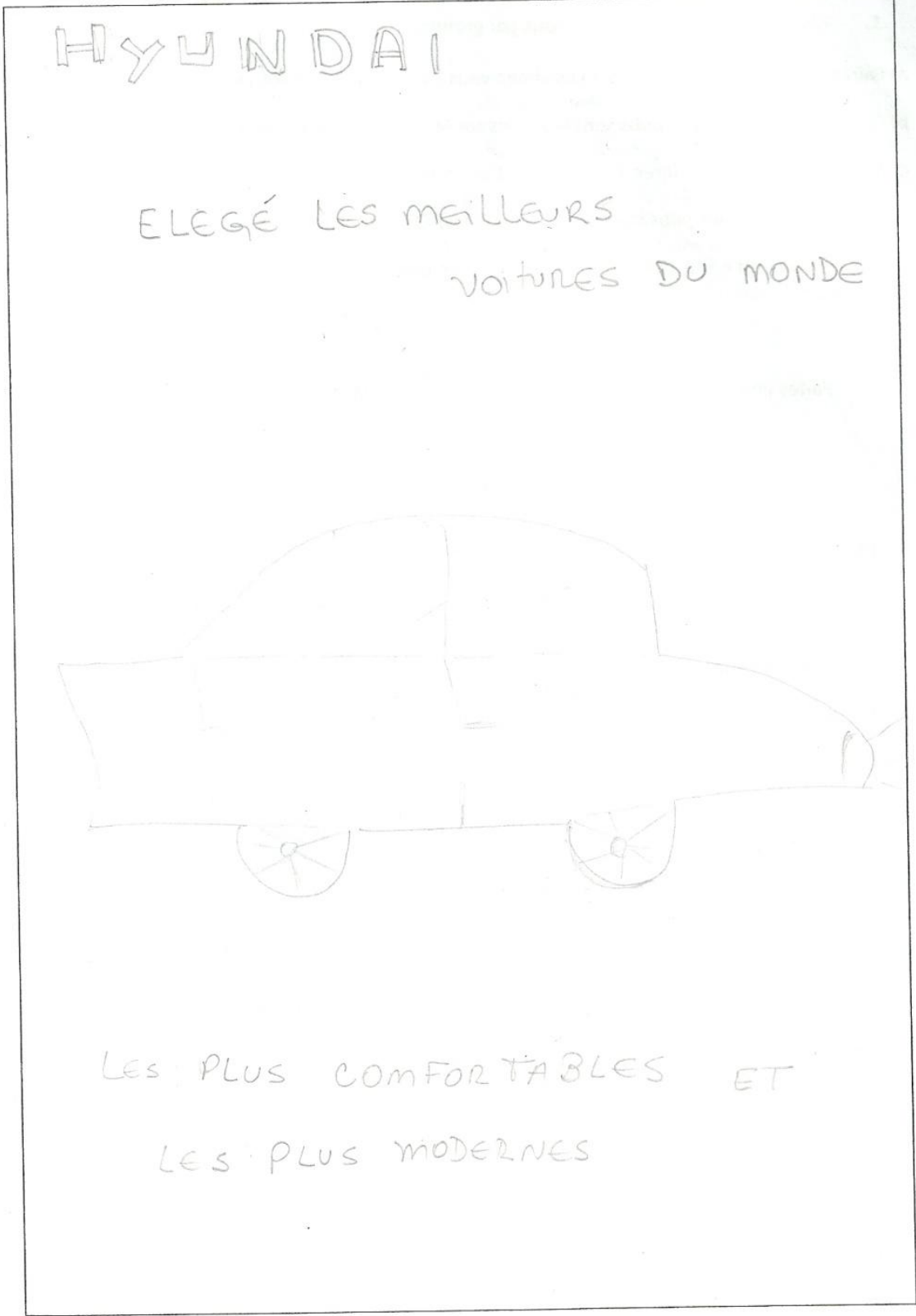




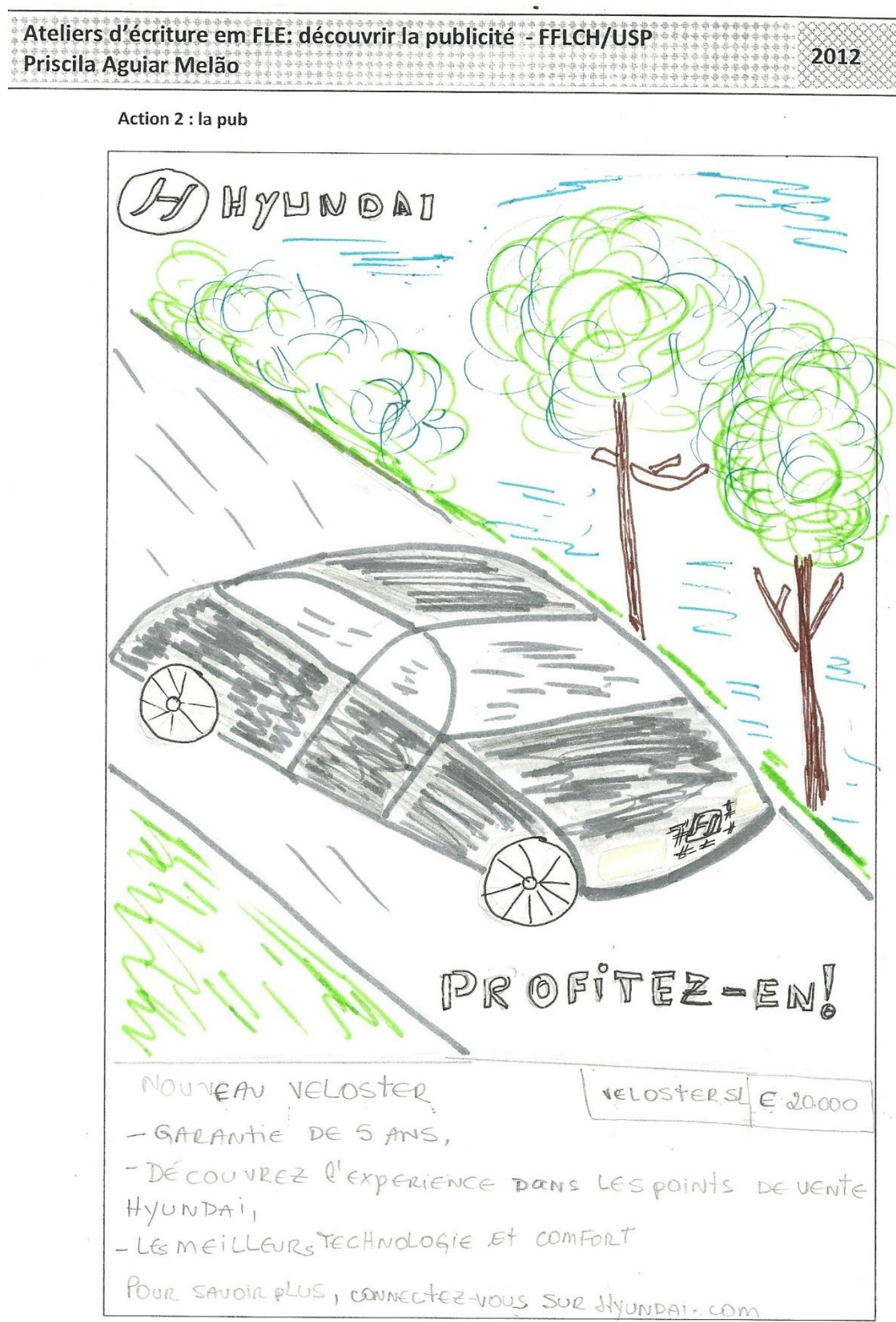


Action 1 : la pub

Lainez-wus votrem voiture par unmois!
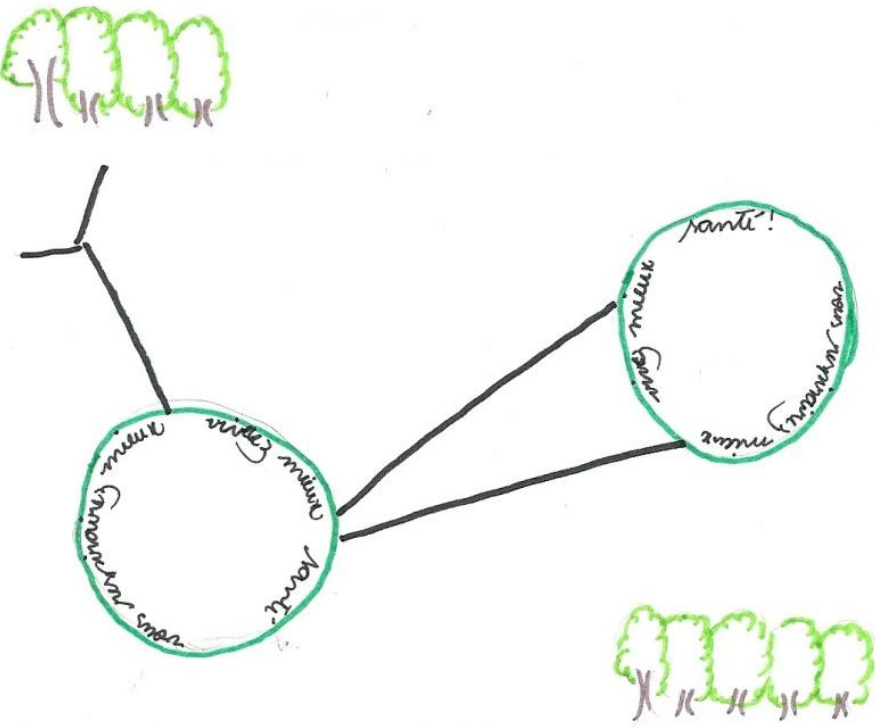

$$
\begin{aligned}
& \text { Le vélo qui bail bien à la nature } \\
& \text { et à vous! }
\end{aligned}
$$

Vélo écolo ${ }^{\circ}$

Is sent fait aver des matíriels rentilisis. Les vélos ícolo ont des petits prix. 

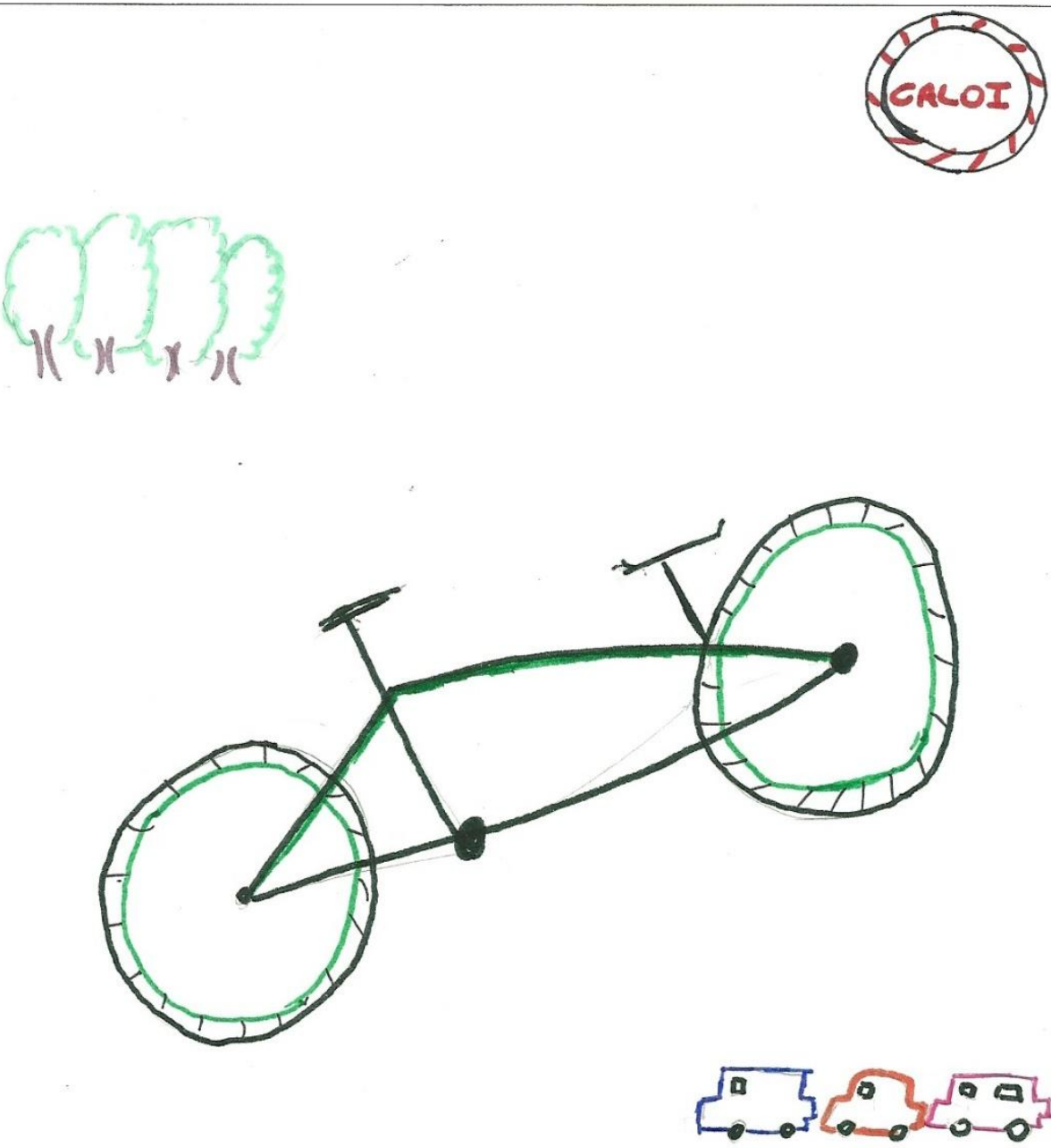

Pser foire le minage ave enhortilloges. Le vélo écolo by caloi

En pewant aure ressources naturuls, notre vilo est produit par matérils pentilisés, a setits prik. Te vélo est parfait pour avoir une melleiure manine de vive dans les grandes villes. Vous serez phlus rapide, wous aurez phus de santé et vous ferez de l'économie. iles dans le pointes de vente Calai Choisissez parmi nos modiles dans antorisés. 
d'écriture em FLE découvrir la publicité - FFLCH/USP tguiar Melão

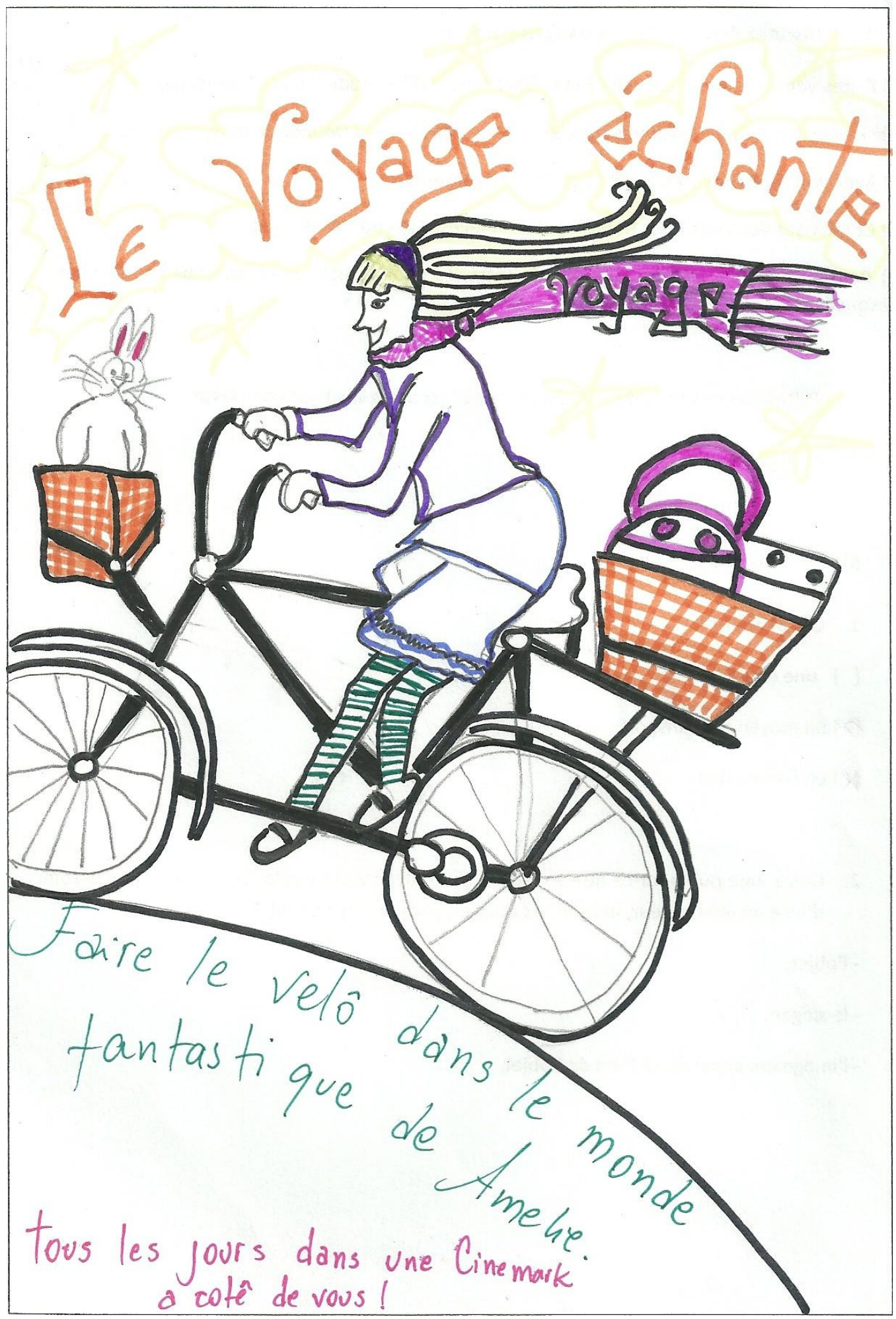


Action 2 : la pub

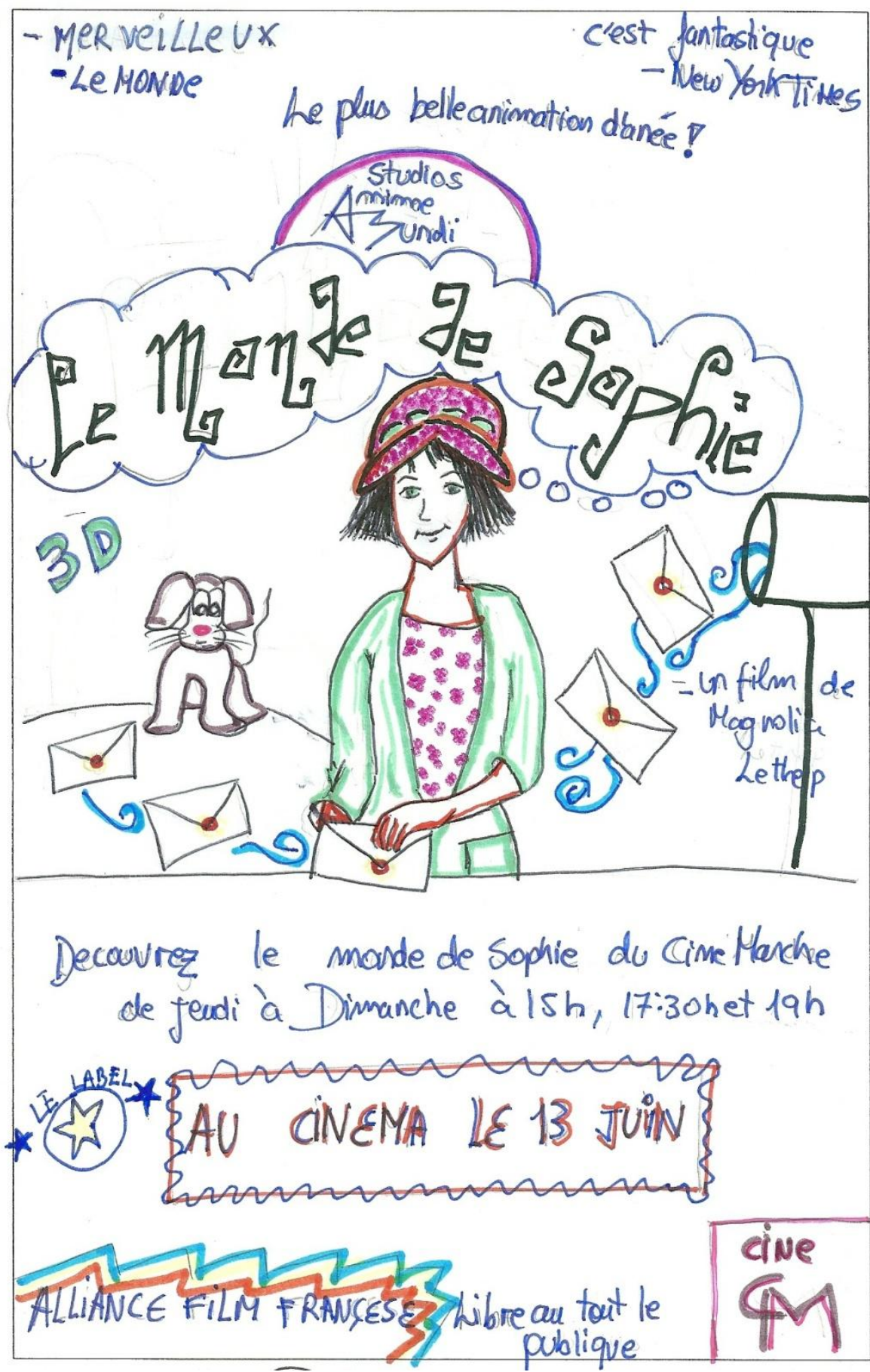




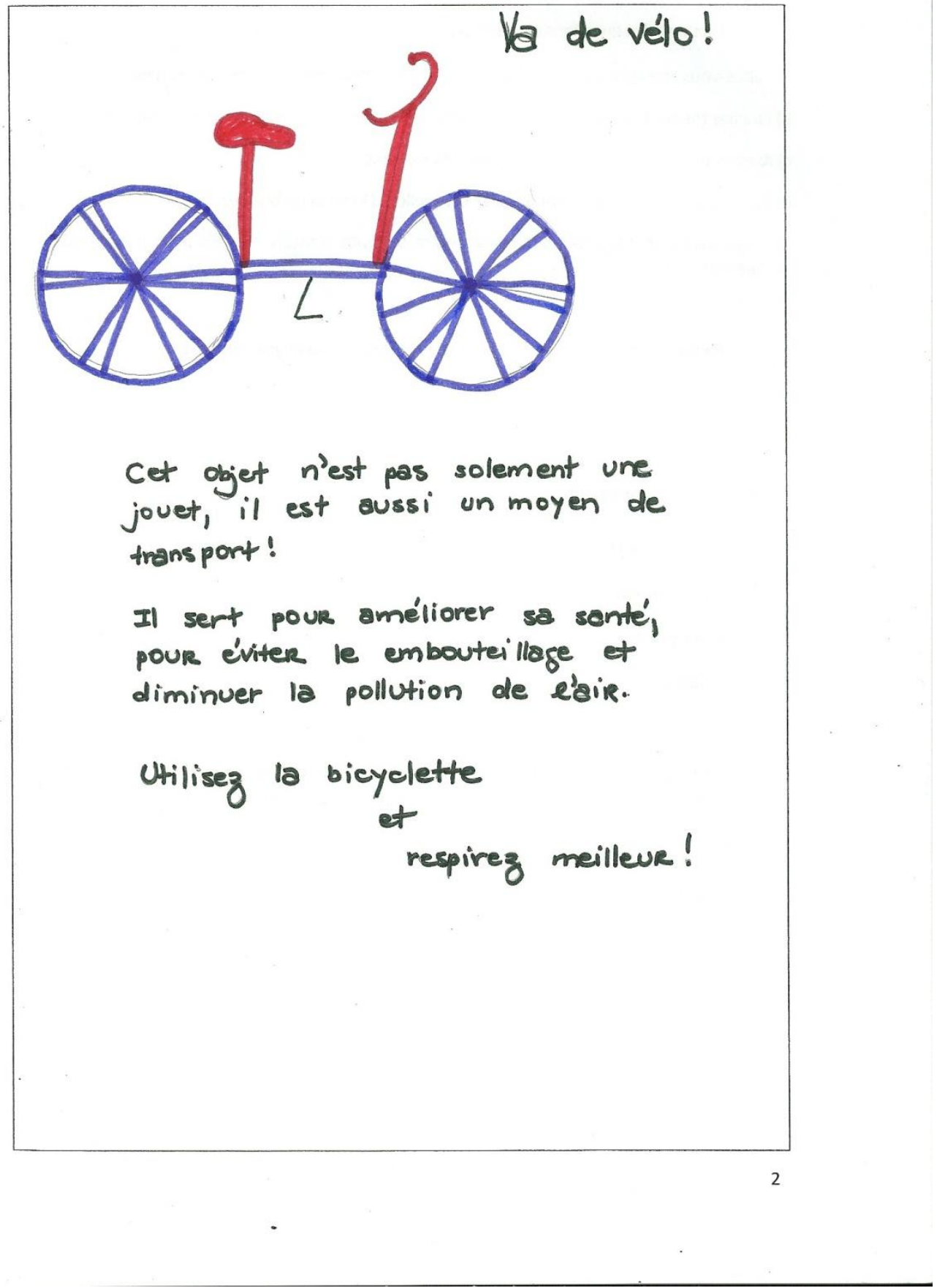


Action 2 : la pub

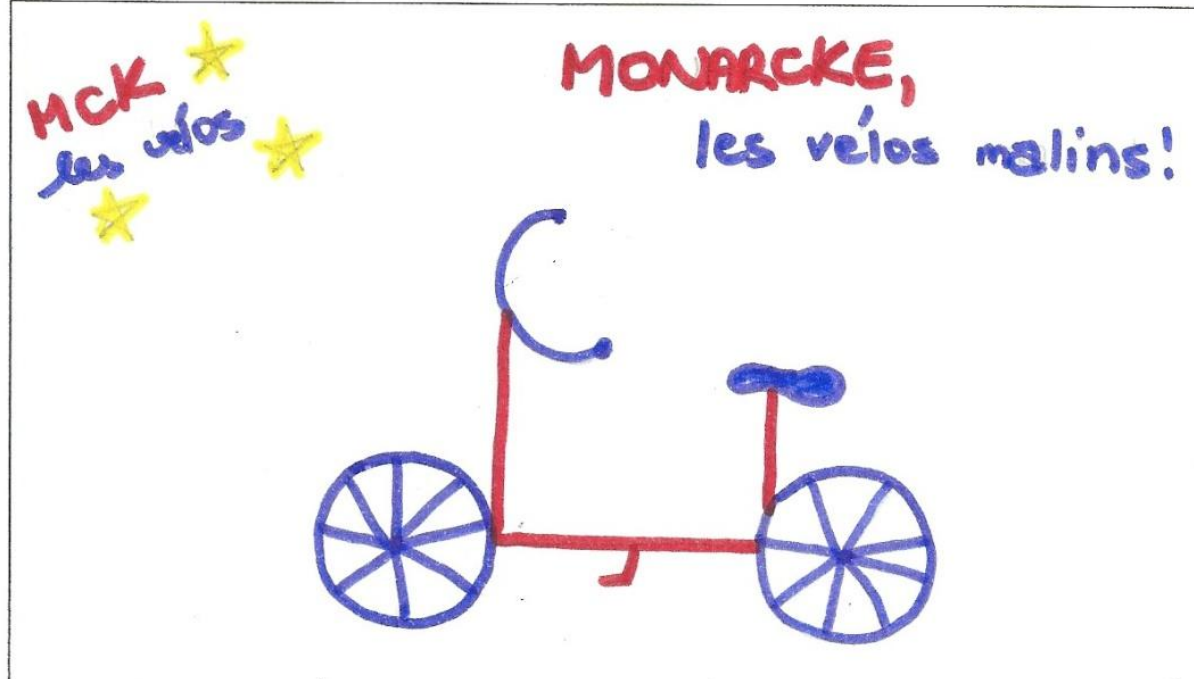

Les vélos Monmpcke sont revenus! mointenant, ils sont propres pour la vie moderne.

Monarcle, c'est un product malin:

- léger

- pliable

- portable

- réristant en carbon et alu

Monarcke permet que vous alleg à tous les lienx ave eni.

Pour en savoir plus:

wun. monarcke. com 
Action 1 : la pub

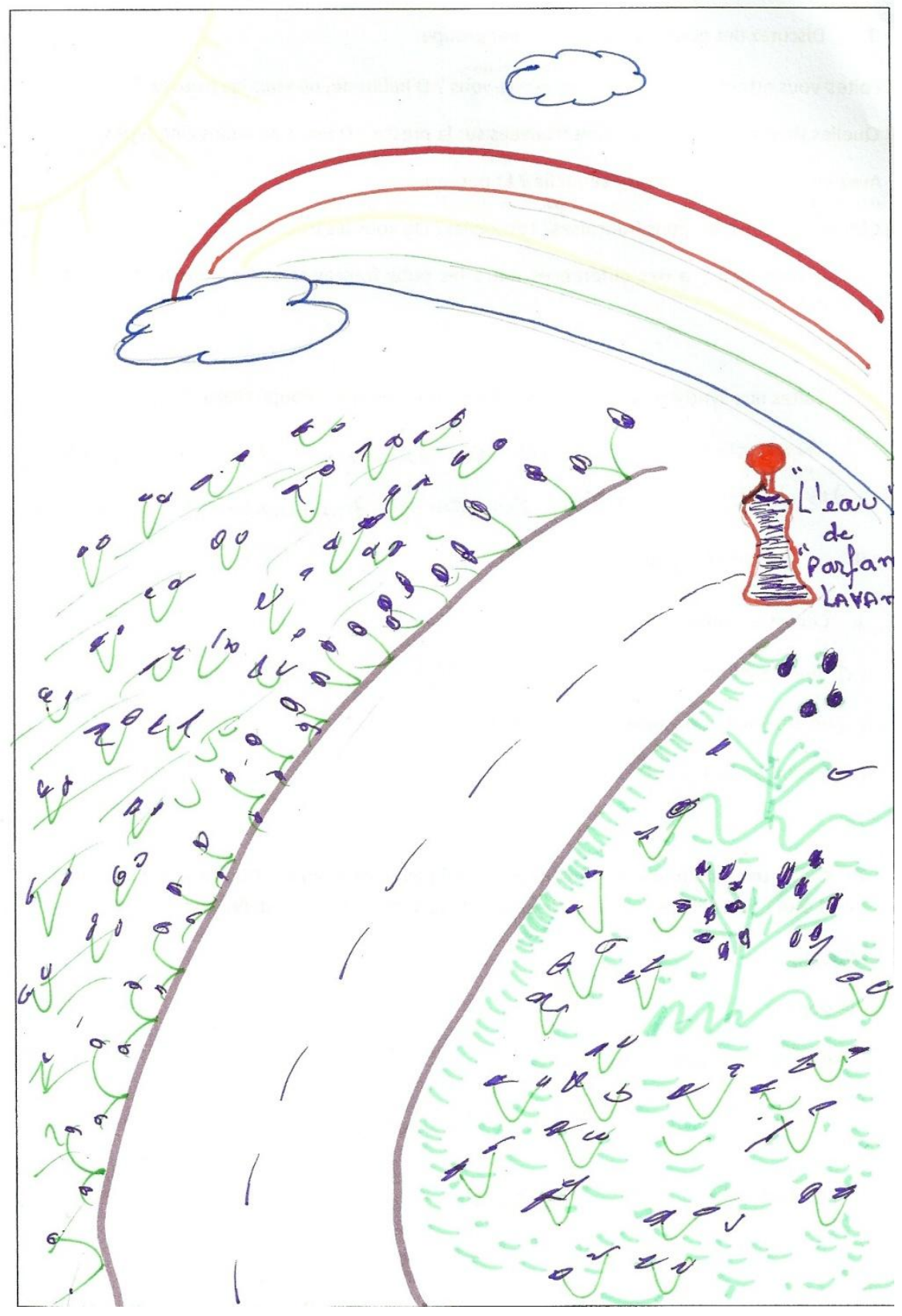


Action 2 : la pub

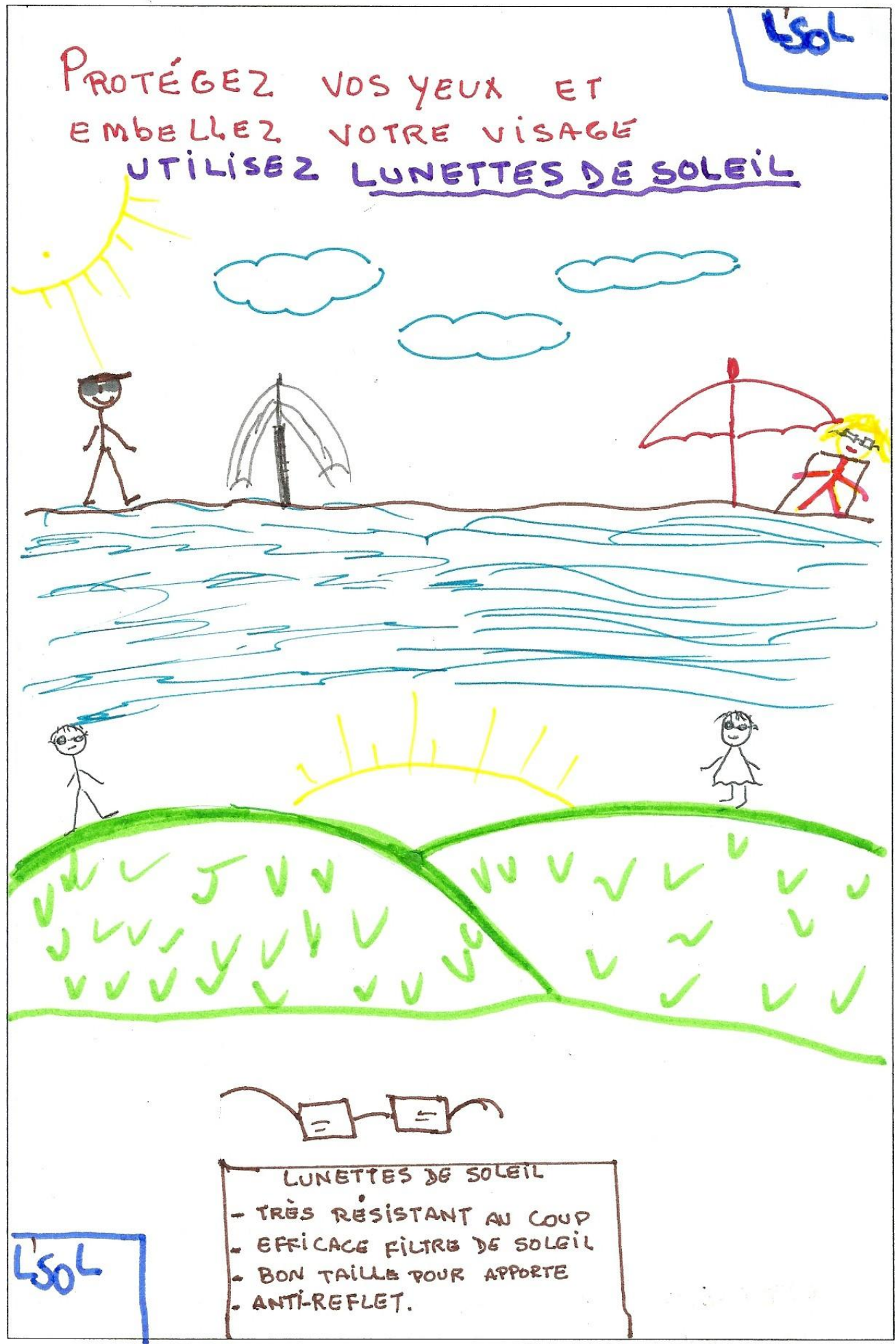




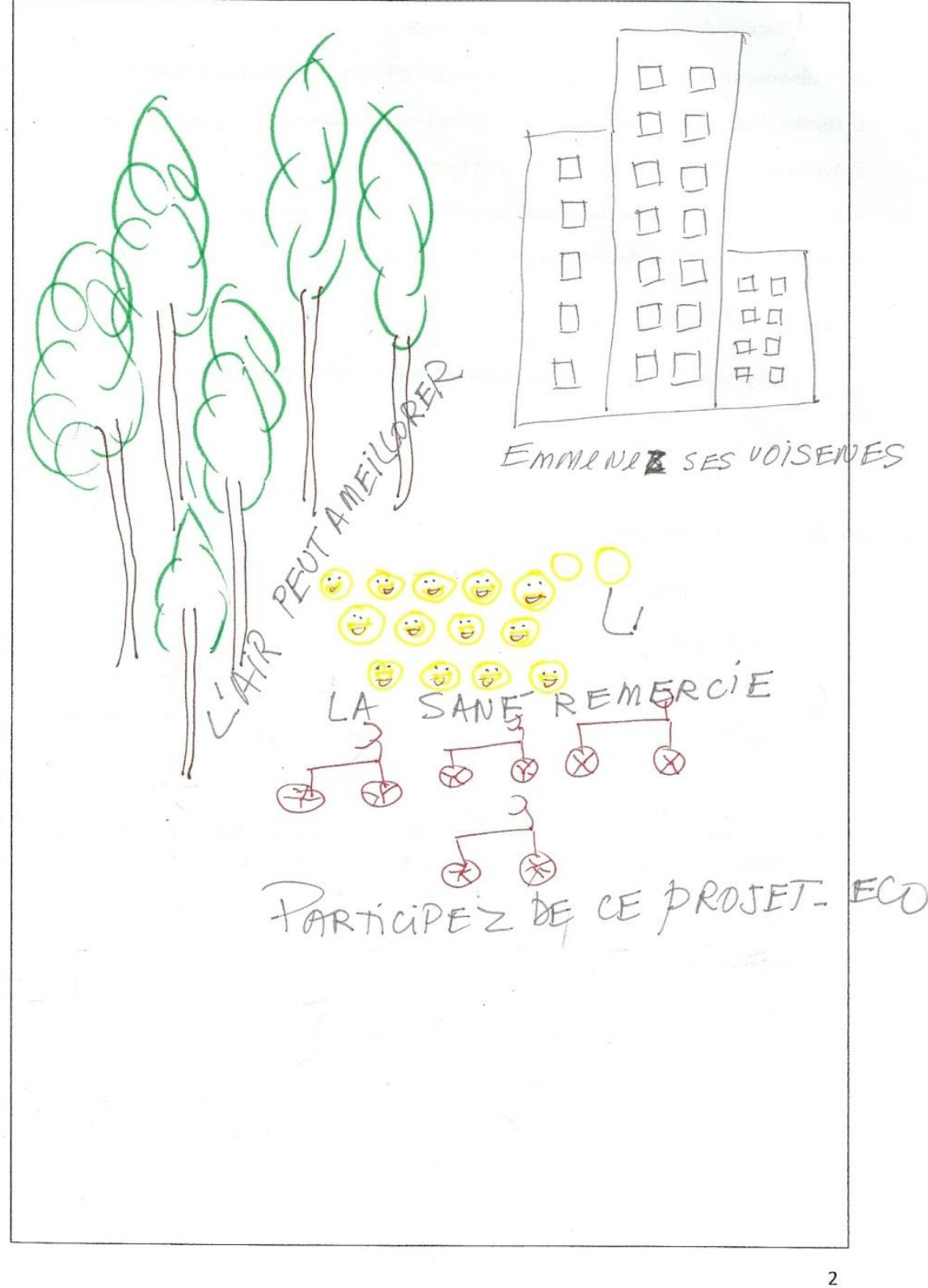


Action 2 : la pub

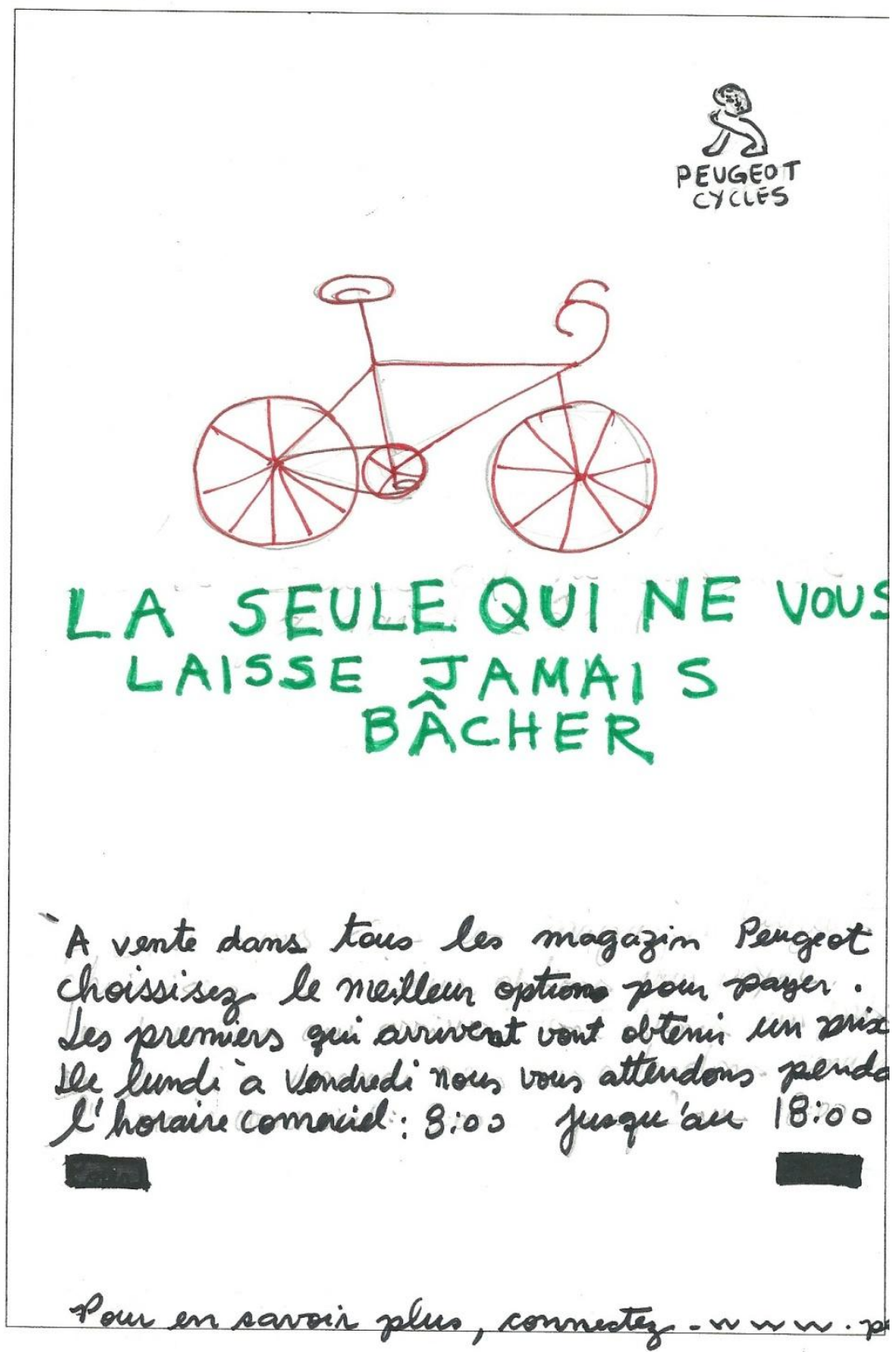


Action 1 : la pub

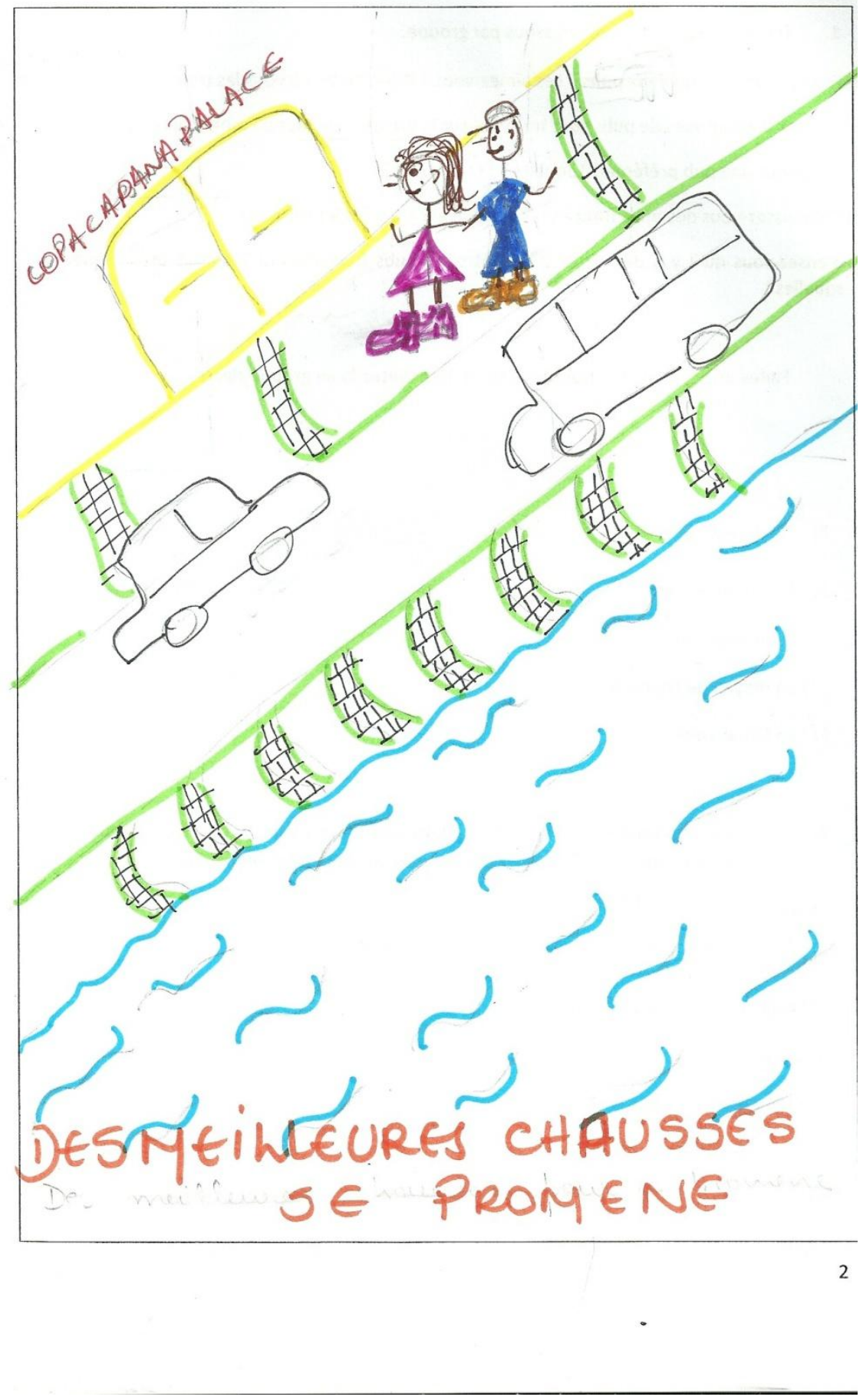


d'écriture em FLE: découvrir la publicité - FFLCH/USP

tguiar Melão

Action 2 : la pub

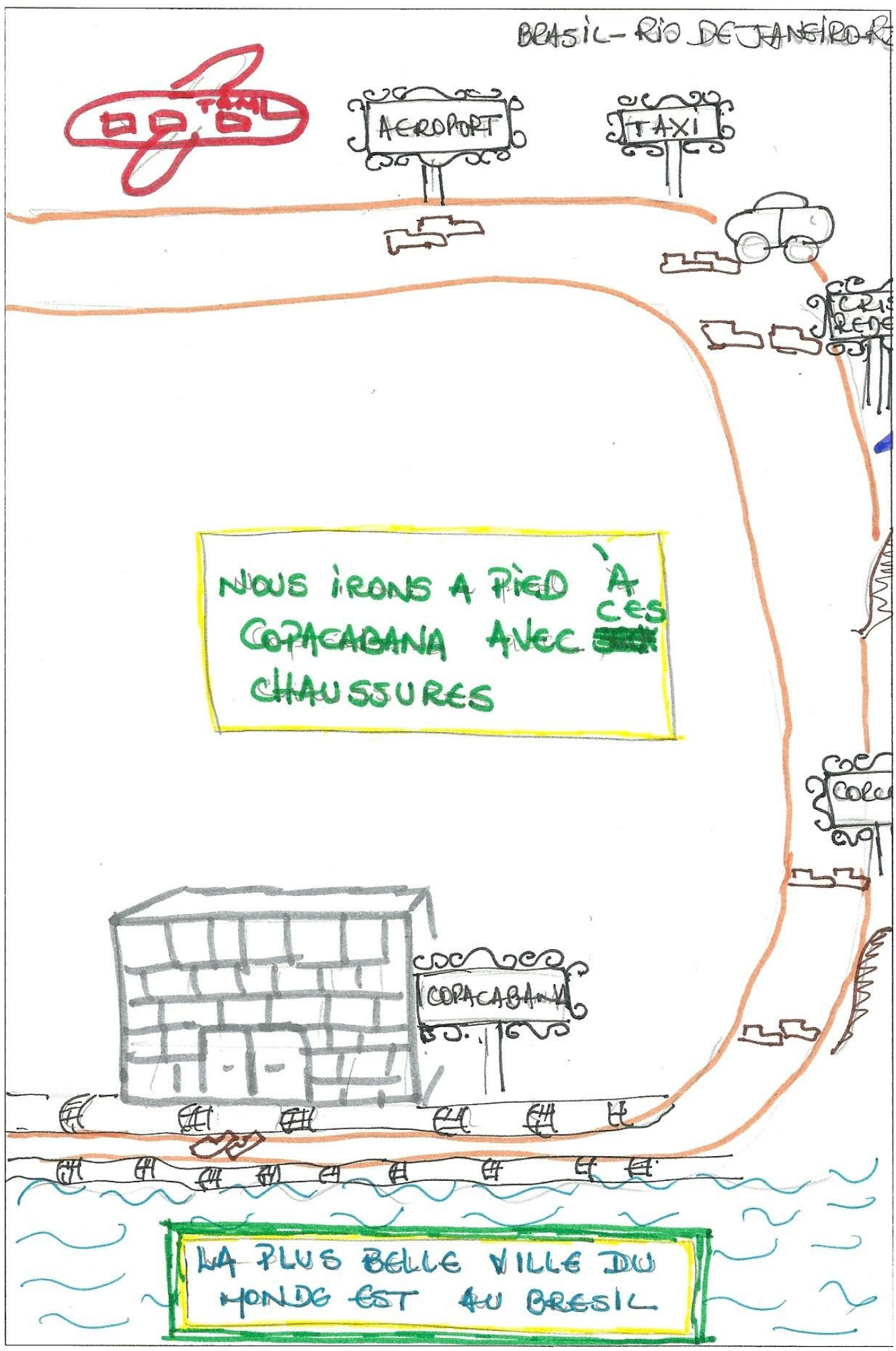


Apêndice F : Enquete de satisfação

Enquête de satisfaction

Nom : (optionnel)

1. Êtes-vous satisfait de l'ensemble du cours ?

2. Cochez la note que vous attribuez aux ateliers que vous avez suivis ( 1 étant peu satisfaisant et 5 étant très satisfaisant):

Atelier 1: Publicité
Atelier 2: Le fait divers
Atelier 3: Le récit de voyage

3. Justifiez vos choix.

4. Quelles sont vos suggestions pour le prochain cours d'atelier d'écriture en langue française?

5. Feriez-vous un autre cours d'atelier d'écriture ?

6. Avez-vous d'autres commentaires à propos du cours ?

Merci de vos réponses! 
Apêndice G: Termo de consentimento

\section{TERMO DE CONSENTIMENTO LIVRE E ESCLARECIDO}

Nome do participante: Data:

Endereço: CEP:

Telefone: RG: CPF:

Nome dos pesquisadores principais: Suélen Maria Rocha (suelen.rocha@usp.br); Renata Añez (renata.anez@gmail.com), Priscila Aguiar Melão (primelao@hotmail.com)

Instituição: Grupo de pesquisa ALTER-AGE (núcleo da USP).

Você está sendo convidado (a) a participar desta pesquisa. Ao integrar este estudo estará permitindo a utilização dos dados aqui fornecidos. Você tem liberdade de se recusar a participar e ainda se recusar a continuar participando em qualquer fase da pesquisa, sem qualquer prejuízo pessoal.

1. Propósito do estudo: estudar os gêneros textuais no ensino e aprendizagem do francês língua estrangeira

2. Procedimentos: coleta de textos escritos pelos participantes.

3. Riscos e desconfortos: nenhum.

4. Benefícios: a participação é voluntária e não trará nenhum benefício direto, mas proporcionará um melhor conhecimento sobre o uso dos gêneros textuais e das sequências didáticas em sala de aula.

5. Direitos dos participantes: o participante pode se retirar deste estudo sem nenhum prejuízo.

6. Compensação financeira: não existem despesas e nem compensação para a participação na pesquisa.

7. Incorporação ao banco de dados do grupo ALTER-AGE. Os dados obtidos com esta participação serão incorporados ao bando de dados do grupo ALTER (núcleo USP), cujos responsáveis zelarão pelo uso e aplicabilidade das amostras unicamente para fins científicos, apenas consentindo o seu uso futuro em projetos que atestem pelo cumprimento dos preceitos éticos em pesquisas envolvendo seres humanos. Algumas amostras poderão ser usadas em publicação, sem que haja identificação do falante e sem que seus direitos sejam atingidos.

8. Confidencialidade: os resultados deste estudo poderão ser publicados em jornais profissionais ou apresentados em congressos profissionais, sem que a identidade dos participantes seja revelada.

Eu compreendo meus direitos como um sujeito de pesquisa e voluntariamente consinto em participar deste estudo e em ceder meus dados para o banco de dados do ALTER. Compreendo sobre o que, como e porque este estudo está sendo feito. Receberei uma cópia assinada deste formulário de consentimento. 
Apêndice H: Questionário

\section{QUESTIONARIO}

\section{A) INFORMAÇÕES GERAIS}

1.Nome:

E-mail:

2. Idade:

3. Sexo:( ) M ( ) F

4. Estado civil:

5. Cidade onde mora:

6. Grau de instrução:

( ) 2 grau-Ensino médio ( ) Superior cursando

( ) Superior completo ( ) Pós-graduação cursando ( ) Pós-graduação completa

7. Área de formação:

8. Possui vinculo com a USP? ( ) Sim （） Não

9. Qual? ( ) Aluno graduação ( ) Aluno pós-graduação ( ) Docente ( ) Funcionário 10. Além do francês você fala outros idiomas? （） Sim （） Não

11. Quais?

12. Atualmente, você está estudando outro idioma? ( ) Sim （） Não

13. Qual?

\section{B) RELACIONAMENTO COM O FRANCÊS}

3. Por que você decidiu estudar francês?

4. Escolha a(s) opção(ões) que melhor representa $(m)$ o motivo pelo qual você decidiu estudar francês :

( ) Adoro a cultura/língua francesa ( ) Era um sonho meu

( ) Tenho amigos/parentes que falam francês ( ) Quero usar o idioma em viagens

( ) Preciso ler textos acadêmicos em francês ( ) Preciso da língua francesa para meu trabalho

( ) Preciso aprender um novo idioma ( ) Quero morar em um país francófono

5. Por que você escolheu estudar nos cursos extracurriculares da FFLCH?

6. Detalhe quando e quais cursos de francês você cursou nos cursos extracurriculares da FFLCH (Ex: "Cursei o nível 1 no primeiro semestre de 2009; fiz o nível 2 nas férias, em julho de 2009; parei de estudar durante 1 ano; cursei o nível 3 no primeiro semestre e o nível 4 no segundo semestre de 2011") 
7. Você já estudou francês em outros lugares? ( ) Sim ( ) Não

8. Em caso positivo, por favor, detalhe as outras vezes em que você estudou francês (quando, onde, por quanto tempo, por que parou)

9. Estudando francês, você já teve alguma reprovação?

( ) Sim, mais de uma vez ( ) Sim, apenas uma

vez ( ) Não

10.Qual foi sua ultima média em um curso de francês?

11.Quantas horas semanais você dedica ao estudo do francês (sem contar as aulas)?

12.Em qual das habilidades linguísticas você considera ter mais facilidade?

( ) Compreensão Oral ( ) Compreensão Escrita ( ) Produção Oral ( )

Produção Escrita

13.Em qual das habilidades linguísticas você considera ter mais dificuldade?

( ) Compreensão Oral ( ) Compreensão Escrita ( ) Produção Oral ( )

Produção Escrita

14. Você gosta de escrever em português? ( ) Sim ( ) Não

15. E em francês? ( ) Sim ( ) Não

16. Que textos você costuma escrever em português?

E em francês?

15. O que você pensa que irá conseguir desenvolver neste curso?

16. Por que você decidiu fazer o curso "Ateliers de escrita em francês" ? 
Apêndice I: Programa do curso

Ateliers d'écriture en FLE_Juillet_2012 Centro de Cultura de Extensão da FFLCH

Calendrier du cours "Ateliers d'écriture en FLE : découvrir la publicité, le fait divers et le récit de voyage" et informations pratiques

Professeures : Suélen M. Rocha (suelen.rocha@usp.br)

Renata Añez (renata.anez@gmail.com)

Priscila_Melão (primelao@hotmail.com)

\begin{tabular}{|c|c|}
\hline $10 / 07$ & $\begin{array}{l}\text { Présentations des professeures, du cours } \\
\text { Activité brise-glace } \\
\text { Remplissage - questionnaire et " termo de consentimento " } \\
\text { Production initiale - Atelier Suélen }\end{array}$ \\
\hline $11 / 07$ & $\begin{array}{l}\text { Production initiale - Atelier Renata } \\
\text { Production initiale - Atelier Priscila }\end{array}$ \\
\hline $\begin{array}{l}12 / 07 \\
16 / 07 \\
17 / 07\end{array}$ & Atelier Priscila \\
\hline $\begin{array}{l}18 / 07 \\
19 / 07 \\
23 / 07\end{array}$ & Atelier Renata \\
\hline $\begin{array}{l}24 / 07 \\
25 / 07 \\
26 / 07\end{array}$ & Atelier Suélen \\
\hline $30 / 07$ & Feedback - ateliers \\
\hline $31 / 07$ & $\begin{array}{l}\text { Remise des notes } \\
\text { Remplissage - enquête de sastisfaction } \\
\text { Fête }\end{array}$ \\
\hline
\end{tabular}

L'heure du cours : $\underline{9 h 00 \text { à } 12 \mathrm{~h} 30}$

\$ Contribution: Votre aide est importante : $\underline{\mathbf{R} \$ 10,00}$ par élève pour les matériels. Merci !

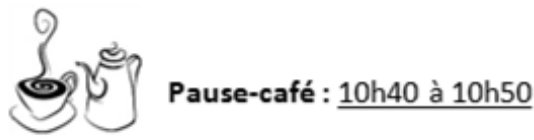




\title{
Apêndice J: Ementa
}

\begin{abstract}
Ateliês de escrita em francês: descobrindo o anúncio publicitário, a notícia e o relato de viagem
Ateliers d'écriture en FLE : découvrir la publicité, le fait divers et le récit de voyage

\section{Programa do curso}

O curso objetiva trabalhar habilidades comunicativas em Língua Francesa que permitam aos alunos dominar a língua em situações variadas, desenvolvendo um comportamento discursivo consciente e elaborando atividades de escrita em situações complexas a partir da perspectiva dos gêneros textuais. Assim, visamos a promover o ensino sistemático da comunicação escrita, por meio de sequências didáticas criadas para melhorar as práticas de linguagem, mas também da comunicação oral, necessária para a comunicação em sala de aula. Três gêneros textuais serão trabalhados nessas sequências, a saber: o anúncio publicitário, notícia e relato de viagem.

Aprender uma língua é aprender a compreender e produzir textos orais e escritos variados. 0 trabalho com os gêneros textuais permite uma compreensão da situação de produção desses textos, gerando não só uma leitura de extração de informações, mas também uma leitura interpretativa, reflexiva e crítica, além de uma produção guiada pelas situações de ação de linguagem, pelos conteúdos mobilizados e pelas finalidades dos textos. Nesse sentido, o curso permitirá que os alunos se apropriem dos gêneros trabalhados, mas também que desenvolvam outras habilidades comunicativas que poderão ser transpostas para outros gêneros textuais e outras situações de escrita.

Os alunos serão confrontados a situações reais durante a aprendizagem para que a linguagem seja usada como uma forma de ação no mundo e aprenderão também a adaptar um gênero textual em função de sua situação de produção particular.

Serão estudados e praticados os elementos lexicais, gramaticais, fonéticos, fonológicos, morfosintáticos e semânticos necessários à expressão escrita e oral que será desenvolvida no curso.

\section{Pré-requisitos para inscrever-se no curso}

Os alunos deverão ter cursado até o nível IV dos cursos extracurriculares, ou devem ter sido aprovados no teste de nível, devendo estar aptos para o nível V.

\section{Bibliografia}

BRONCKART, Jean-Paul. Atividade de linguagem, textos e discursos. Por um interacionismo sociodiscursivo. SP: Educ, 1999.

BRONCKART, Jean-Paul. Atividade de linguagem, discurso e desenvolvimento humano. Campinas : Mercado de letras, 2006.

CHARAUDEAU, Patrick. Grammaire du sens et de l'expression. Paris, Hachette, 1998

CRISTOVÃO, Vera. Lúcia. Lopes. Estudos da Linguagem à luz do interacionismo sociodiscursivo. Londrina: Eduel. 2008. 
DIAS, Reinildes; CRISTOVÃO, Vera Lúcia Lopes. (orgs). O livro didático de língua estrangeira: múltiplas perspectivas. Campinas: Mercado de Letras, 2009.

DIONíSIO, Angela; MACHADO, Anna Rachel; BEZERRA, Maria Auxiliadora (Orgs.) Gêneros Textuais \& Ensino. Rio de Janeiro: Editora Lucerna. 2002. (reedição em 2010 - Parábola editora)

DOLZ, Joaquim; GAGNON, Roxane; TOULOU, Simon. Production écrite et difficultés d'apprentissage. Carnets des Sciences de l'Education, Université de Genève, 2008.

DOLZ, Joaquim; GAGNON, Roxane; DECÂNDIO, Fabrício. Produção escrita e dificuldades de aprendizagem. Campinas: Mercado de letras, 2010.

KARWOSKI, Acir Mário; GAYDECZKA, Beatriz; BRITO, Karim S. Gêneros textuais: reflexões e ensino. São Paulo: Parábola Editora, 2011.

REY-DEBOVE, J. et al. Le petit Robert. Paris, Dictionnaires Le Robert, 1999.

SCHNEUWLY, Bernard.; DOLZ, Joaquim. Gêneros Orais e Escritos na Escola. Campinas: Mercado de Letras. 2004. 